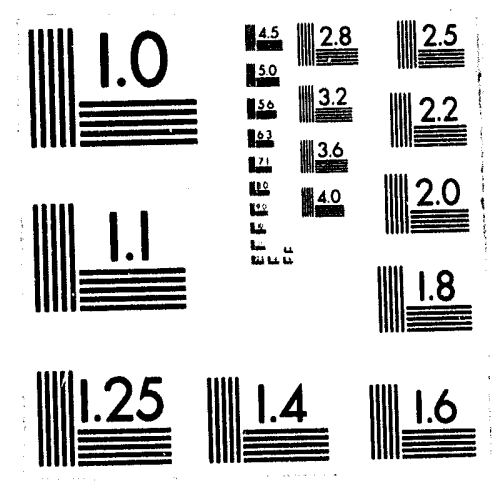




$$
\frac{\vec{\rho}}{\omega}
$$


LBL-34263

UC-000

\title{
Integrated Estimation of Commercial Sector End-Use Load Shapes and Energy Use Intensities in the PG\&E Service Area
}

\author{
H. Akbari, J. Eto, S. Konopacki, A. Afzal, K. Heinemeier, and L. Rainer
}

\author{
Energy Analysis Program \\ Energy and Environment Division \\ Lawrence Berkeley Laboratory \\ University of California \\ Berkeley, California 94720
}

December 1993

This work was jointly supported by Pacific Gas \& Electric (PG\&E), the Califomia Institute for Energy Efficiency (CIEE), and the California Energy Commission (CEC) through the U.S. Department of Energy, under contract DEAC0376SF00098.

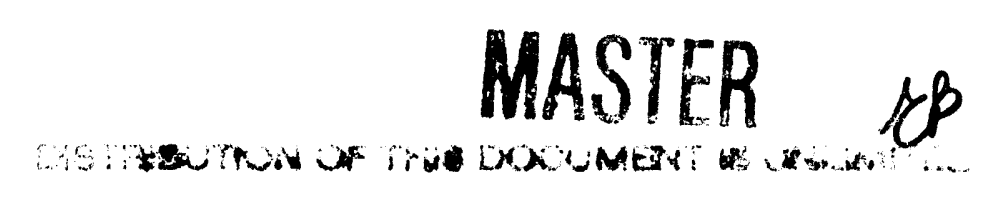




\section{Table of Contents}

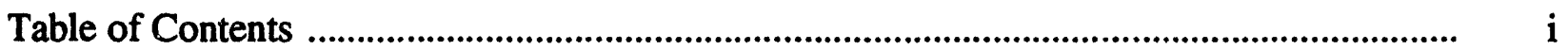

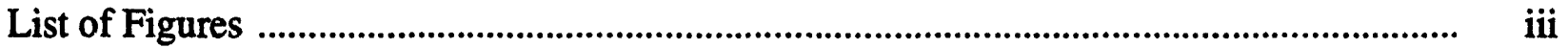

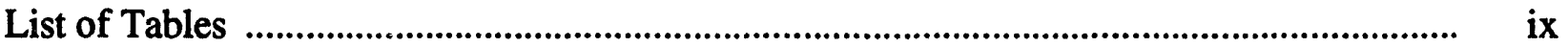

Glossary of HVAC System Types …...........................................................................

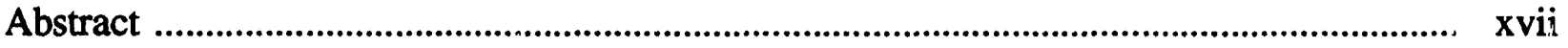

Executive Summary ............................................................................................. xix

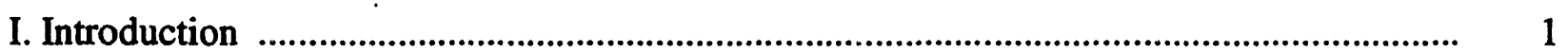

II. Methodology .............................................................................................................. 5

Part 1. Reconciliation Methodology ..................................................................... 5

Initial Estimates of End-Use Load Shapes ………………............................... 5

Average Whole-Building Electricity Use Profiles ............................................... $\quad 8$

Reconciliation of Initial Estimates to Whole-Building Electricity Use

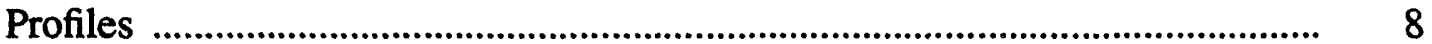

Part 2. Developing PG\&E and CEC Forecasting Model Inputs from Reconciled EUIs

Developing EUIs for Electric Heating, and Non-Electric End Uses ................... 9

Expressing Reconciled EUIs Relative to a 1975 Base Year ............................... 10

Accounting for Fuel Saturation Effects ......................................................... 10

Accounting Separately for Office Equipment EUIs …....................................... 13

Disaggregating Reconciled EUIs by Building and Equipment Vintage ............. $\quad 14$

Non-HVAC End-Uses ............................................................................. 19

Climatic Impacts on Space-Conditioning EUIs ............................................... $\quad 19$

III. Input Data Base Analysis and Integration ................................................................. 21

On-Site Survey Data Base ................................................................................ 21

Load Research Data ......................................................................................... 41

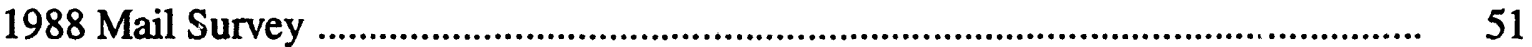

Whole-Building EUIs ...................................................................................... 63

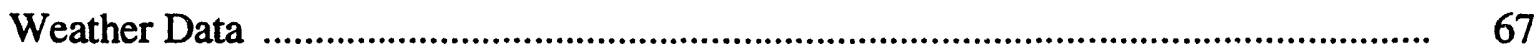




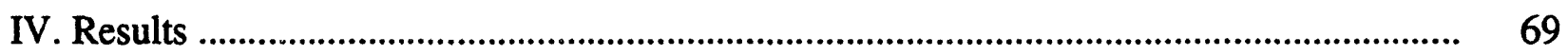

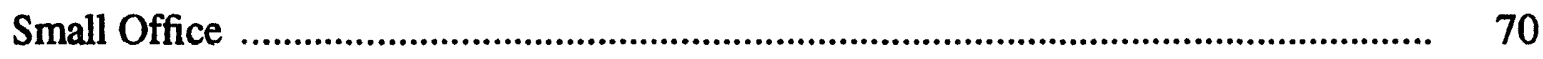

Large Office ..................................................................................................... 81

Retail Store …............................................................................................ 92

Restaurant .................................................................................................. 105

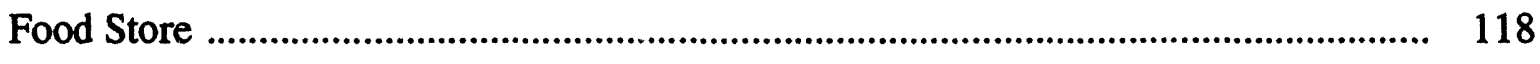

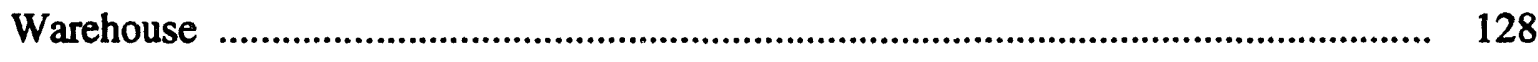

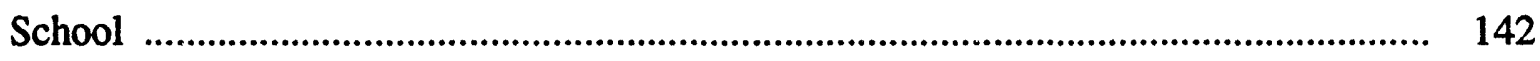

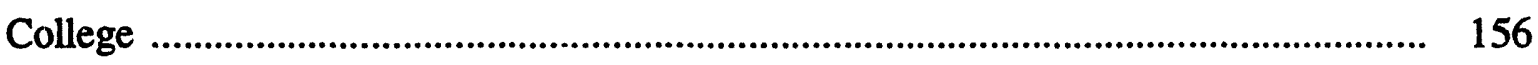

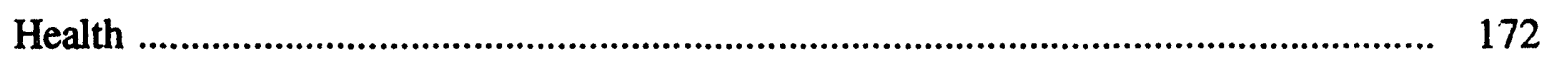

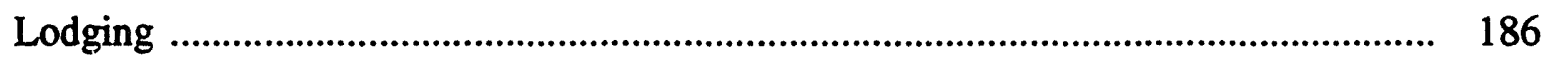

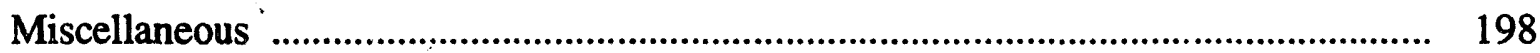

V. Forecasting Model Energy Inputs ............................................................................ 209

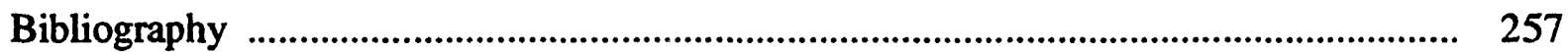




\section{List of Figures}

Figure

Description

Page

Figure 2-1.

Integrated Commercial LS and EUI Estimation Methodology.

Figure 3-1.

Sample Inspection Plot of the Load Research Data.

Figure 3-2.

Weighted Average Load Shape for College Buildings in Coastal

Areas.

Figure 3-3. Three Dimensional Plot of the Weighted Average Load Shape

for Colleges in Coastal Areas.

Figure 3-4. Weighted Average Load Shapes by Type of the Day for

Colleges in Coastal Areas.

Figure 4-1a.

Small Office Simulated Average Standard Day LS - Coastal 73

Figure 4-1b.

Small Office Simulated Average Standard Day LS - Inland 74

Figure 4-2a.

Small Office Whole Building Load vs. Drybulb Temperature for

Standard Day - Coastal

Figure 4-2b. Small Office Whole Building Load vs. Drybulb Temperature for

Standard Day - Inland

Figure 4-3a. Small Office Reconciled Standard Day Annual End-Use

LS - Coastal

Figure 4-3b. Small Office Reconciled Standard Day Annual End-Use

LS - Inland

Figure 4-3c. Small Office Reconciled Nonstandard Day Annual End-Use

LS - Coastal

Figure 4-3d. Small Office Reconciled Nonstandard Day Annual End-Use

LS - Inland

80

Figure 4-4a. Large Office Simulated Average Standard Day

LS - Coastal

Figure 4-4b.

Large Office Simulated Average Standard Day LS - Inland

Figure 4-5a.

Large Office Whole Building Load vs. Drybulb Temperature

for Standard Day - Coastal.

Figure 4-5b. Large Office Whole Building Load vs. Drybulb Temperature for Standard Day - Inland

Figure 4-6a. Large Office Reconciled Standard Day Annual End-Use

LS - Coastal

Figure 4-6b. Large Office Reconciled Standard Day Annual End-Use

LS - Inland 


\section{List of Figures}

Figure

Description

Figure 4-6c. Large Office Reconciled Nonstandard Day Annual End-Use

Page

LS - Coastal

Figure 4-6d. Large Office Reconciled Nonstandard Day Annual End-Use

LS - Inland .

Figure 4-7a.

Retail Store Simulated Average Standard Day LS - Coastal.

97

Figure 4-7b.

Retail Store Sinulated Average Standard Day LS - Inland

98

Figure 4-8a.

Retail Store Whole Building Load vs. Drybulb Temperature

for Standard Day - Coastal.

Figure 4-8b. Retail Store Whole Building Load vs. Drybulb Temperature

for Standard Day - Inland

Figure 4-9a. Retail Store Reconciled Standard Day Annual End-Use

LS - Coastal

Figure 4-9b. Retail Store Reconciled Standard Day Annual End-Use

LS - Inland

Figure 4-9c. Retail Store Reconciled Nonstandard Day Annual End-Use

LS - Coastal

Figure 4-9d. Retail Store Reconciled Nonstandard Day Annual End-Use

LS - Inland

Figure 4-10a.

Restaurant Simulated Average Standard Day LS - Coastal.

Figure 4-10b.

Restaurant Simulated Average Standard Day LS - Inland

Figure 4-11a.

Restaurant Whole Building Load vs. Drybulb Temperature for Standard Day - Coastal.

Figure 4-11b. Restaurant Whole Building Load vs. Drybulb Temperature for Standard Day - Inland

Figure 4-12a. Restaurant Reconciled Standard Day Annual End-Use

LS - Coastal

Figure 4-12b. Restaurant Reconciled Standard Day Annual End-Use

LS - Inland

Figure 4-12c. Restaurant Reconciled Nonstandard Day Annual End-Use

LS - Inland .

Figure 4-13a.

Food Store Simulated Average Standard Day LS - Coastal 122

Figure 4-13b.

Food Store Simulated Average Standard Day LS - Inland 123

Figure 4-14a.

Food Store Whole Building Load vs. Drybulb Temperature for Standard Day - Coastal 


\section{List of Figures}

Figure

Description

Page

Figure 4-14b. Food Store Whole Building Load vs. Drybulb Temperature for Standard Day - Inland

Figure 4-15a. Food Store Reconciled Standard Day Annual End-Use

LS - Coastal

126

Figure 4-15b. Food Store Reconciled Standard Day Annual End-Use

LS - Inland

Figure 4-16a. Warehouse Simulated Average Standard Day LS - Coastal

Figure 4-16b.

Warehouse Simulated Average Standard Day LS - Inland

Figure 4-17a.

Warehouse Whole Building Load vs. Drybulb Temperature for

Standard Day - Coastal

Figure 4-17b. Warehouse Whole Building Load vs. Drybulb Temperature for Standard Day - Inland

Figure 4-18a. Warehouse Reconciled Standard Day Annual End-Use

LS - Coastal

Figure 4-18b. Warehouse Reconciled Standard Day Annual End-Use LS - Inland

Figure 4-18c. Warehouse Reconciled Nonstandard Day Annual End-Use LS - Coastal

Figure 4-18d. Warehouse Reconciled Nonstandard Day Annual End-Use LS - Inland

Figure 4-19a. School Simulated Average Standard Day LS - Coastal. 148

Figure 4-19b.

School Sirnulated Average Standard Day LS - Inland 149

Figure 4-20a. School Whole Building Load vs. Drybulb Temperature for Standard Day - Coastal 150

Figure 4-20b. School Whole Building Load vs. Drybulb Temperature for Standard Day - Inland

Figure 4-21a. School Reconciled Standard Day Annual End-Use LS - Coastal....... 152

Figure 4-21b. School Reconciled Standard Day Annual End-Ust LS - Inland ........ 153

Figure 4-21c. School Reconciled Nonstandard Day Annual End-Use

LS - Coastal

Figure 4-21d. School Reconciled Nonstandard Day Annual End-Use LS - Inland

Figure 4-22a. College Simulated Average Standard Day LS - Coastal 164

Figure 4-22b. College Simulated Average Standard Day LS - Inland 165 


\section{List of Figures}

Figure

Figure 4-23a.

Figure 4-23b.

Figure 4-24a.

Figure 4-24b.

Figure 4-24c.

Figure 4-24d.

Figure 4-25a

Figure 4-25b.

Figure 4-26a.

Figure 4-26b.

Figure 4-27a.

Figure 4-27b.

Figure 4-27c.

Figure 4-27d.

Figure 4-28a.

Figure 4-28b.

Figure 4-29a.

Figure 4-29b.

Figure 4-30a.

Figure 4-30b.

Figure 4-31a.

Figure 4-31b.

Figure 4-32a.
Description

College Whole Building Load vs. Drybulb Temperature for

Standard Day - Coastal 166

167

Standard Day - Inland 168

College Reçonciled Standard Day Annual End-Use LS - Inland 169

College Reconciled Nonstandard Day Annual End-Use

LS - Coastal 170

College Reconciled Nonstandard Day Annual End-Use LS - Inland 171

Health Simulated Average Standard Day LS - Coastal 178

Health Simulated Average Standard Day LS - Inland. 179

Health Whole Building Load vs. Drybulb Temperature for Standard Day - Coastal 180

$\mathrm{P}$, $\mathbf{c}$. Whole Building Load vs. Drybulb Temperature for Standard Day - Inland 181

Health Reconciled Standard Day Annual End-Use LS - Coastal 182

Health Reconciled Standard Day Annual End-Use LS - Inland 183

Health Reconciled Nonstandard Day Annual End-Use

LS - Coastal 184

Health Reconciled Nonstandard Day Annual End-Use

LS - Inland 185

Lodging Simulated Average Standard Day LS - Coastal 192 Lodging Simulated Average Standard Day LS - Inland 193 Lodging Whole Building Load vs. Drybulb Temperature for Standard Day - Coastal

Lodging Whole Building Load vs. Drybulb Temperature for Standard Day - Inland 195

Lodging Reconciled Standard Day Annual End-Use LS - Coastal 196 Lodging Reconciled Standard Day Annual End-Use LS - Inland 197 Miscellaneous Simulated Average Standard Day LS - Coastal. 201 Miscellaneous Simulated Average Standard Day LS - Inland 202 Miscellaneous Whole Building Load vs. Drybulb Temperature for Standard Day - Coastal 203 


\section{List of Figures}

Figure

Description

Page

Figure 4-32b. Miscellaneous Whole Building Load vs. Drybulb Temperature for

Standard Day - Inland

204

Figure 4-33a. Miscellaneous Reconciled Standard Day Annual End-Use

LS - Coastal

205

Figure 4-33b. Miscellaneous Reconciled Standard Day Annual End-Use

LS - Inland

206

Figure 4-33c. Miscellaneous Reconciled Nonstandard Day Annual End-Use

LS - Coastal

207

Figure 4-33d. Miscellaneous Reconciled Nonstandard Day Annual End-Use

LS - Inland 208 


\section{List of Tables}

Table

Description

Page

Table 1-1.

Building Types and End Uses

2

Table 1-2.

Project Tasks...................................................................... 3

Table 1-3.

Input Data

4

Table 2-1.

Prototype Identification by Building Type

7

Table 2-2.

Short-Run Price Elasticity and Price Adjustment Factors -

CEC.

Table 2-3.

Short-Run Price Elasticity and Price Adjustment Factors -

PG\&E

Table 2-4.

Mail Survey Electricity Saturations by End Use - Coastal

Table 2-5.

Mail Survey Electricity Saturations by End Use - Inland

12

Table 2-6.

Office Equipment EUIs [kWh/sqft/yr] and Annual Percentage

Growth

Table 2-7.

Building and Equipment Vintages

Table 2-8.

CEC Energy Conversion Efficiency by Vintage and Energy

Source

Table 2-9.

CEC Equipment Saturations by Fuel Type

Table 2-10.

CEC Weighted Average Energy Conversion Efficiencies by

Fuel and Vintage

Table 2-11.

Weather Stations 20

Table 3-1.

Climate Zone Distribution of 1986 PG\&E Onsite Survey Data.

22

Table 3-2.

Statistics of the 1986 PG\&E On-Site Survey

Table 3-3.

Summary of Building Characteristics in the 1986 PG\&E

On-Site Survey

Table 3-4.

Saturation of Heating, Cooling, System Type, Water Heating

for On-Site Survey Buildings

Table 3-5. Summary of Commercial Building EUIs in the 1986 PG\&E

On-Site Survey.

Table 3-6.

Account Class of 1986 PG\&E Load Research Data.

Table 3-7.

Climate Zone Distribution of 1986 PG\&E Load Research Data.

Table 3-8.

Climate Zone Mapping of Load Research Data by Building

Type

Table 3-9.

Load Research Data Building Summary 50

Table 3-10.

Climate Zone Distribution of 1988 PG\&E Mail Survey Data.

51 


\section{List of Tables}

Table

Table 3-11.

Table 3-12.

Table 3-13.

Table 3-14.

Table 3-15.

Table 3-16.

Table 3-17.

Table 3-18.

Table 4-1.

Table 4-2.

Table 4-3a.

Table 4-3b.

Table 4-4.

Table 4-5.

Table 4-6a.

Table 4-6b.

Table 4-7.

Table 4-8.

Table 4-9.

Table 4-10.

Table 4-11a.

Table 4-11b.

Table 4-12a.

Table 4-12b.

Table 4-13

Table 4-14a.

Table 4-14b.

Table 4-15.
Mapping of the Mail Survey

Dascription

Page

Summary of Building Characteristics in the 1988 PG\&E Mail

Survey

54

1988 PG\&E Mail Survey Statistics on Heating, Cooling, System Type, and Water Heating for PG\&E

Mail Survey Building.

Summary of Whole-building EUIs in the 1988 PG\&E Mail

Survey 62

LBL Analysis of Whole-Building EUIs

65

Mail Survey Floor Area Weighting Factors and Whole Building

EUIs 66

Weather data summary for Oakland and Blue Canyon .. 68

Weather data summary for San Jose, Sacramento, and Fresno .......... 68

Small Office Building Prototype Characteristics............................... 71

Small Office Building Vintage Characteristics................................. 71

Small Office Simulated and EDA-Reconciled EUIs-Coastal .......... 72

Small Office Simulated and EDA-Reconciled EUIs-Inland ............ 72

Large Office Building Prototype Characteristics............................... 82

Large Office Building Vintage Characteristics.................................. 82

Large Office Simulated and EDA-Reconciled EUIs-Coastal .......... 83

Large Office Simulated and EDA-Reconciled EUIs-Inland ............ 83

Small Retail Building Prototype Characteristics .............................. 93

Small Retail Building Vintage Characteristics ................................ 93

Large Retail Building Prototype Characteristics ............................... 94

Large Retail Building Vintage Characteristics ................................. 94

Retail Store Simulated and EDA-Reconciled EUIs - Coastal ........... 95

Retail Store Simulated and EDA-Reconciled EUIs-Inland ............. 96

Sitdown Restaurant Building Prototype Characteristics.................... 106

Sitdown Restaurant Building Prototype Zone Description ................ 106

Sitdown Restaurant Building Vintage Characteristics ...................... 107

Fastfood Restaurant Building Prototype Characteristics ................... 108

Fastfood Restaurant Building Prototype Zone Description ................ 108

Fastfood : :estaurant Building Vintage Characteristics...................... 109 


\section{List of Tables}

Table

Description

Page

Table 4-16a. Restaurant Simulated and EDA-Reconciled EUIs-Coastal 110

Table 4-16b.

Restaurant Simulated and EDA-Reconciled EUIs-Inland 110

Table 4-17a.

Food Store Building Prototype Characteristics 119

Table 4-17b.

Food Store Building Prototype Zone Description 119

Table 4-18.

Food Store Building Vintage Characteristics 120

Table 4-19a.

Food Store Simulated and EDA-Reconciled EUIs - Coastal 121

Table 4-19b.

Food Store Simulated and EDA-Reconciled EUIs-Inland.

Table 4-20a.

Nonrefrigerated Warehouse Building Prototype

Characteristics.....

Table 4-20b. Nonrefrigerated Warehouse Building Prototype Zone

Description

Table 4-21.

Nonrefrigerated Warehouse Building Vintage Characteristics

Table 4-22a.

Refrigerated Warehouse Building Prototype Characteristics

Table 4-22b.

Refrigerated Warehouse Building Prototype Zone

Description

Table 4-23. Refrigerated Warehouse Building Vintage Characteristics.

Table 4-24a.

Warehouse Simulated and EDA-Reconciled EUIs-Coastal.

Table 4-24b.

Warehouse Simulated and EDA-Reconciled EUIs-Inland

Table 4-25a.

Primary School Building Prototype Characteristics.

Table 4-25b.

Primary School Building Prototype Zone Description.

Table 4-26.

Primary School Building Vintage Characteristics

Table 4-27a.

Secondary School Building Prototype Characteristics .

Table 4-27b.

Secondary School Building Prototype Zone Description.

Table 4-28.

Secondary School Building Vintage Characteristics

Table 4-29a.

School Simulated and EDA-Reconciled EUIs-Coastal

Table 4-29b.

School Simulated and EDA-Reconciled EUIs-Inland .

Tabie 4-30a.

Classroom/Lab/Office Building Prototype Characteristics

Table 4-30b.

Classroom/Lab/Office Building Prototype Zone Description

Table 4-31.

Classroom/Lab/Office Building Vintage Characteristics

Table 4-32a.

Dormitory Building Prototype Characteristics

Table 4-32b.

Dormitory Building Prototype Zone Description

Table 4-33.

Dormitory Building Vintage Characteristics. 


\section{List of Tables}

Table

\section{Description}

Table 4-34.

Library Building Prototype Characteristics

Table 4-35.

Library Building Vintage Characteristics

Table 4-36a.

College Simulated and EDA-Reconciled EUIs-Coastal .

Table 4-36b.

College Simulated and EDA-Reconciled EUIs-Inland.

Table 4-37a.

Hospital Building Prototype Characteristics

Table 4-37b.

Hospital Building Prototype Zone Description

Table 4-38.

Hospital Building Vintage Characteristics . 174

Table 4-39a.

Nursing Home Building Prototype Characteristics

Table 4-39b.

Nursing Home Building Prototype Zone Description

Table 4-40.

Nursing Home Building Vintage Characteristics

Table 4-41a.

Health Simulated and EDA-Reconciled EUIs-Coastal.

Table 4-41b.

Health Simulated and EDA-Reconciled EUIs-Inland.

Table 4-42a.

Large Hotel Building Prototype Characteristics

Table 4-42b

Large Hotel Building Prototype Zone Description.

Table 4-43.

Large Hotel Builciing Vintage Characteristics.

Table 4-44a.

Small Hotel Building Prototype Characteristics 189

Table 4-44b.

Small Hotel Building Prototype Zone Description

Table 4-45.

Small Hotel Building Vintage Characteristics.

Table 4-46a.

Lodging Simulated and EDA-Reconciled EUIs - Coastal

Table 4-46b.

Lodging Simulated and EDA-Reconciled EUIs-Inland.

Miscellaneous Building Prototype Characteristics

Miscellaneous Building Vintage Characteristics

Table 4-49a.

Miscellaneous Simulated and EDA-Reconciled EUIs-Coastal 200

Table 4-49b.

Miscellaneous Simulated and EDA-Reconciled EUIs-Inland 200

Table 5-1.

CEC Cooling EUI or 1975 and 1979 Vintages 212

Table 5-2.

CEC Heating EUIs for 1975 and 1979 Vintages 214

Table 5-3. CEC Ventilation EUIs for 1975 and 1979 Vintages 216

Table 5-4. CEC Regional 1986 HVAC EUIs. 217

Table 5-5. PG\&E Cooling EUIs for 1975 and 1979 Vintages 219

Table 5-6.

PG\&E Heating EUIs for 1975 and 1979 Vintages 221

Table 5-7.

PG\&E Ventilation EUIs for 1975 and 1979 Vintages. 223

Table 5.8.

CEC Electric Cooking EUIs for 1975 Vintage 224 


\section{List of Tables}

Table

Table 5-9.

Table 5-10.

Table 5-11.

Table 5-12.

Table 5-13.

Table 5-14.

Table 5-15.

Table 5-16.

Table 5-17.

Table 5-18.

Table 5-19.

Table 5-20.

Table 5-21.

Table 5-22.

Table 5-23.

Table 5-24.

Table 5-25.

Table 5-26.

Table 5-27.

Table 5-28.

Table 5-29.

Table 5-30.

Table 5-31.

Table 5-32.

Table 5-33.

Table 5-34.

Table 5-35.

Table 5-36.

Table 5-37.

Table 5-38.

Table 5-39.
Description

Page

CEC Electric Hot Water EUIs for 1975 Vintage

225

CEC Electric Indoor Lighting EUIs for 1975 Vintage ...................... 226

CEC Electric Outdoor Lighting EUIs for 1975 Vintage ................... 227

CEC Electric Miscellaneous Equipment EUIs for 1975 Vintage ....... 228

CEC Electric Refrigeration EUIs for 1975 Vintage ........................... 229

CEC Gas Cooking EUIs for 1975 Vintage ....................................... 230

CEC Gas Water Heating EUIs for 1975 Vintage .............................. 231

CEC Gas Miscellaneous Equipment for 1975 Vintage ..................... 232

PG\&E Electric Cooking EUIs for 1975 Vintage .............................. 233

PG\&E Electric Hot Water EUIs for 1975 Vintage ............................ 234

PG\&E Electric Indoor Lighting EUIs for 1975 Vintage ................... 235

PG\&E Electric Outdoor Lighting EUIs for 1975 Vintage................... 236

PG\&E Electric Miscellaneous Equipment EUIs for 1975 Vintage .... 237

PG\&E Electric Refrigeration EUIs for 1975 Vintage ....................... 238

PG\&E Gas Cooking EUIs for 1975 Vintage ................................... 239

PG\&E Gas Water Heating EUIs for 1975 Vintage............................ 240

PG\&E Gas Miscellaneous Equipment for 1975 Vintage .................. 241

CEC 1975 EUIs for Region 1 (Rlue Canyon) Climate Zone - U75 ... 242

CEC 1975 EUIs for Region 2 (Sacramento) Climate Zone - U75 .... 243

CEC 1975 EUIs for Region 3 (Fresno) Climate Zone - U75............. 244

CEC 1975 EUIs for Region 4 (San Jose) Climate Zone - U75s ......... 245

CEC 1975 EUIs for Region 5 (Oakland) Climate Zone - U75 ........... 246

CEC 1979 EUIs for Region 1 (Blue Canyon) Climate Zone - EUI79. 247

CEC 1979 EUIs for Region 2 (Sacramento) Climate Zone - EUI79... 248

CEC 1979 EUIs for Region 3 (Fresno) Climate Zone - EUI79 ........... 249

CEC 1979 EUIs for Region 4 (San Jose) Climate Zone - EUI79....... 250

CEC 1979 EUIs for Region 5 (Oakland) Climate Zone - EUI79 ........ 251

PG\&E 1975 EUIs for Coastal (Oakland) Climate Zone..................... 252

PG\&E 1975 EUIs for Inland (Sacramento) Climate Zone ................. 253

PG\&E 1979 EUIs for Coastal (Oakland) Climate Zone..................... 254

PG\&E 1979 EUIs for Inland (Sacramento) Climate Zone ................. 255 
-xiv- 


\section{Glossary of HVAC System Types}

$\begin{array}{ll}\text { Abbreviation } & \text { HVAC System Type } \\ \text { DD } & \text { Dual Duct } \\ \text { FPFC } & \text { Four Pipe Fan Coil } \\ \text { PMZ } & \text { Packaged Multi Zone } \\ \text { PSZ } & \text { Packaged Single Zone } \\ \text { PTAC } & \text { Packaged Terminal Air Conditioner } \\ \text { PVAV } & \text { Packaged Variable Air Volume } \\ \text { RHF } & \text { Reheat Fan } \\ \text { SZRH } & \text { Single Zone Reheat } \\ \text { TPFC } & \text { Two Pipe Fan Coil } \\ \text { VAV } & \text { Variable Air Volume }\end{array}$


-xvi- 


\title{
Integrated Estimation of Commercial Sector End-use Load Shapes and Energy Use Intensities in PG\&E Service Area
}

\author{
H. Akbari, J. Eto, S. Konopacki, A. Afzal, K. Heinemeier, and L. Rainer \\ Energy Analysis Program \\ Lawrence Berkeley Laboratory
}

\begin{abstract}
This project represents a unique research effort to address the commercial sector end-use energy forecasting data needs of the Pacific Gas and Electric Company (PG\&E) and the California Energy Commission (CEC). The object of the project was to develop an updated set of commercial sector end-use energy use intensity (EUI) data that has been fully reconciled with measured data. The research was conducted in two stages. First, we developed reconciled electricity enduse EUIs and load shapes for each of the 11 building types in the inland and coastal regions of the PG\&E service territory using information collected in 1986. Second, we developed procedures to translate these results into a consistent set of commercial sector forecasting model inputs recognizing the separate modeling conventions used by PG\&E and CEC. EUIs have been developed for: 11 commercial building types; up to 10 end uses; up to 3 fuel types; 2 and 5 subservice territory forecasting regions (as specified by the PG\&E and CEC forecasting models, respectively); and up to 2 distinct vintages corresponding to the period prior to and immediately following the adoption of the first generation of California building and equipment standards. For the electricity end uses, 36 sets of daily load shapes have been developed representing average weekday, average weekend, and peak weekday electricity use for each month of the year by building type for both the inland and coastal climate zones.
\end{abstract}


-xviii- 


\section{Executive Summary}

End-use electricity demand forecasts are the critical link between supply- and demand-side planning activities in support of integrated resource planning. End-use information on the suructure of electricity demand is especially important for utility and state planners considering explicit interventions to modify future demands (also known as demand-side management). Yet, historically, the empirical basis to support end-use forecasts and demand-side planning has been weak compared to the information available to support supply-side planning. Not surprisingly, the resulting uncertainties associated with demand-side data have led to significant differences of opinion between utility and state planners regarding the future demand for electricity.

This project represents a unique research effort to address the commercial sector end-use energy forecasting data needs of the Pacific Gas and Electric Company (PG\&E) and the California Energy Commission (CEC) in a cost-effective and coordinated manner.

Cost savings have been achieved through the implementation of a new method for combining information from detailed on-site surveys, mail surveys, and hourly class load research and weather data to develop a consistent set of end-use energy use intensities (EUIs) and load shapes, which have been reconciled to measured loads. Coordination has been achieved through the development of a common base set of end-use EUIs and load shapes that is then adjusted in a transparent fashion for direct incorporation into existing PG\&E and CEC forecasting models.

The object of the research is to develop an updated set of commercial sector end-use energy use forecasting inputs that has been fully reconciled with measured data. The EUIs have been developed to support five stages of disaggregation within the forecasting models (See Table EX-1): 11 commercial building types; up to 10 end uses; up to 3 fuel types; 2 and 5 sub-service territory forecasting regions (as specified by the PG\&E and CEC forecasting models, respectively); and up to 2 distinct vintages corresponding to the period prior to and immediately following the adoption of the first generation of California building and equipment standards. For the electricity end uses, 36 sets of daily load shapes have been developed representing average weekday, average weekend, and peak weekday electricity use for each month of the year by building type for both the inland and coastal climate zones.

The research was conducted in two stages: First, we developed up to 10 reconciled electricity end-use EUIs and load shapes for each of the 11 building types in the inland and coastal regions of the PG\&E service territory using information collected in 1986. Second, we developed procedures to translate these results into a consistent set of commercial sector forecasting model inputs recognizing the separate modeling conventions used by PG\&E and CEC. 
Table EX-1. Summary of Project Scope

\begin{tabular}{|l|l|l|ll|l|}
\hline Building Types & End Uses & Fuels & \multicolumn{2}{|c|}{ Regions } & Vintages \\
& & & PGE & CEC & \\
\hline Large Office & Space Cooling & Electricity & Inland & Region 1 & pre-1979 \\
Small Office & Space Heating & Natural Gas & Coastal & Region 2 & post-1978 \\
Retail & Ventilation & Other & & Region 3 & \\
Foodstore & Indoor Lighting & & Region 4 & \\
Warehouse & Outdoor Lighting & & & Region 5 & \\
Restaurant & Water Heating & & & & \\
School & Cooking & & & & \\
College & Refrigeration & & & & \\
Health & Office Equipment & & & & \\
Lodging & Miscellaneous & & & & \\
Miscellaneous & & & & & \\
\hline
\end{tabular}

The first stage of the research relied on detailed examination of nearly 900 on-site surveys and almost 6,000 mail surveys. The intermediate output of this stage of the research is a set of up to 3 DOE-2 building prototypes ${ }^{1}$ to estimate preliminary end-use hourly electricity load shapes for each of the 11 building types. Next we processed hourly data from over 1,300 class load research accounts to develop whole-building electricity load shapes by building type and climate region. The preliminary end-use load shapes from the simulations are then reconciled by building type for each hour of the year to a whole-building electricity load shapes. Use of the class load research data, therefore, represents an important constraint on the preliminary, engineering-based load shape estimates. End-use EUIs and average load shapes are developed through simple integration of the reconciled hourly end-use load shapes.

At the end of the first stage of the research, we have a set of reconciled end-use EUIs and load shapes that represent aggregate end-use electricity consumption, by building type for the inland and coastal climate region, for 1986. In the second stage of the research, the reconciled data are further disaggregated and transformed into inputs for the PG\&E and CEC end-use forecasting models.

1 Distinct prototypes were used to represent sub-building types for multi-building classes of buildings (e.g., refrigerated and non-refrigerated warehouses, fast-food and sit-down restaurants, large hotel and small motel for lodging) and to represent diverse building functions within a single building category (e.g., lab/office/classroom, library, and dormitory for the college building type). We also specified multiple, function-based zones within the hospital, restaurant, warehouse, foodstore, lodging building types. 
Six distinct effects are treated in this second stage: 1) price effects between 1986 and the 1975 model base year are removed; 2) office equipment energy use is separated from miscellaneous electricity use; 3) fuel saturations are accounted for explicitly; 4) for space-conditioning end uses, the effects of different eras of building and equipment minimum energy efficiency standards are represented ${ }^{2}$; 5) space-conditioning end-use EUIs are developed for all 5 climate regions used by CEC to forecast energy use for the PG\&E service territory; and 6) several EUIs that cannot be estimated directly with our reconciliation methodology, including electric space heating (except for lodging) and all non-electric end uses (space heating, water heating, cooking, and miscellaneous), are developed through direct analysis of the on-site and mail survey data.

The results from this final stage of the research are put into a format according to the forecasting model input data specifications used by PG\&E and CEC. These results, presented in Chapter 5 of the report, are designed to facilitate direct comparison to current model inputs and incorporation of project results into future forecasting efforts.

This project is a unique collaborative research project sponsored jointly by PG\&E and CEC. Its success was based largely on the ability of the sponsors to provide the research team with timely and consensual direction at critical junctures in the project. We believe consensus was achieved because of a shared commitment by all parties to report information in an un-biased fashion and to make joint decisions on this basis. We firmly believe that it provides an important model for future collaborative research in areas where there is a need for better information by the resource planning process. In doing so, it will allow resource planners to focus their attention on areas where there are real differences of opinion, rather than on acknowledged absences of data.

2 The CEC model treats building and equipment efficiency effects separately. 


\section{$\overline{1}$}

章

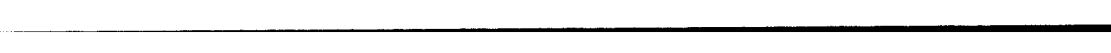




\section{Chapter 1 \\ Introduction}

The Pacific Gas and Electric Company (PG\&E) and California Energy Commission (CEC), through the California Institute for Energy Efficiency (CIEE), have contracted with the Lawrence Berkeley Laboratory (LBL) to develop a set of commercial building sector load shapes (LSs) and energy-use intensities (EUIs) to support PG\&E and CEC forecasts for the PG\&E service territory. The overall objectives of this multi-year CIEE-sponsored project are:

- To apply an end-use load-shape estimation model to develop a common set of hourly enduse load shapes and annual EUIs for commercial buildings by building type, vintage, and climate region. The results will be compatible with PG\&E's and CEC's energy and peak demand forecasting models. Load shapes are developed for typical weekdays, weekend days, and peak days, by month or by season.

- To evaluate the adequacy of the estimated load-shapes and EUIs for the PG\&E and CEC energy and peak demand forecasting models.

- To analyze measured end-use load data in commercial buildings collected by California utilities such as PG\&E and SCE and to validate an end-use load-shape estimation model that was developed at LBL.

The specific goals of the current project are:

- To apply the LBL's end-use load-shape estimation model to obtain a common set of reconciled hourly end-use load shapes and annual EUIs for 11 commercial buildings types.

- To work with PG\&E and CEC to resolve issues related to the transformation of data for application in forecasting models.

Table 1-1 is a matrix of all the building types and end uses of interest to PG\&E and CEC. The project addresses both electric EUIs and electric load shapes, as well as non-electric EUIs. Within these broad categories of EUIs, two further disaggregations are also treated explicitly for the space conditioning end uses (heating, cooling, and ventilation): climate and the effects of the first generation of building and equipment minimum energy performance standards (or vintage). 
Table 1-1. Building Types and End Uses.

End-use EUIs are developed by vintage and climate zone for weather-dependent end uses.

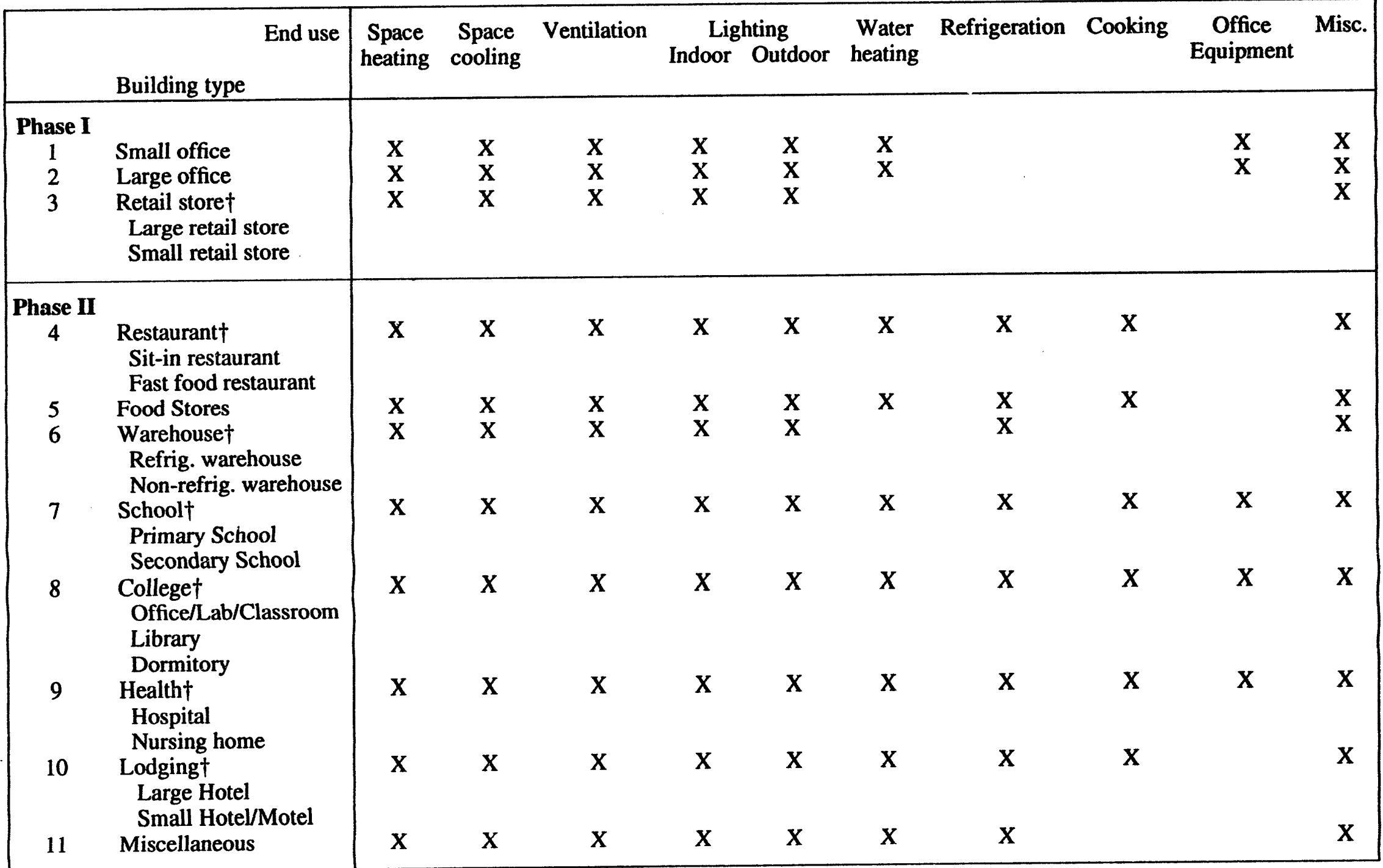

$\dagger \quad$ Initial estimates of end-use EUIs and LSs are developed by weighted average of the component building types. 
The project is organized around the seven tasks, as outlined in Table 1-2.

Table 1-2. Project Tasks

\begin{tabular}{ll}
\hline TASK 1: & Develop detailed work plan \\
TASK 2: & Input Data Analysis \\
TASK 3: & Data Base Integration \\
TASK 4: & DOE-2 Prototype Development \\
TASK 5: & End-Use EUI and Load Shape Estimation \\
TASK 6: & Adjustment to Reconciled EUIS for PG\&E and CEC Forecasting Models \\
TASK 7: & Final Report
\end{tabular}

This report is organized into five chapters. Chapter 2 discusses our methodology, which consists of two major parts: 1) reconciliation of initial end-use load-shape estimates with measured whole-building load data to produce intermediate EUIs and load shapes; and 2) data transfer procedures to transform intermediate outputs into a revised set of inputs for the CEC and PG\&E forecasting models (Part of Task 6). Chapter 2 describes each step involved in both phases of the methodology. Chapter 2 also describes the overall use of data to implement the methodology.

Chapter 3 covers the work performed under Tasks 2 and 3. Task 2 consists of preparing data for use in the project. The core data for the project are outlined in Table 1-3. The primary data for the project are detailed, on-site surveys for a total of 855 buildings in the PG\&E service territory, load research data for 1,374 PG\&E accounts, commercial sector mail survey data, and historical north-coastal and north-central California weather data. Task 3 consists of integrating the various data sets. The objective of this task is not a literal integration of the data sets into one common (and extremely large) data base, but rather identification of important linkages for subsequent analyses. For example, a major component of this task is identifying outlier buildings and creating a clean data base for prototypical building development. The outcome of Task 3 is an overall assessment of the quality of data for use in developing building prototypes and in estimating a preliminary set of EUIs and LSs.

Chapter 4 discusses the intermediate project results consisting of DOE-2 prototype development (Task 4) and end-use EUI and LS estimation (Task 5). In Task 4, we develop prototypes for all building types considered. These prototypes are based primarily on PG\&E's on-site and mail survey data. On those occasions where the PG\&E data were not sufficient to develop prototypes, we modified the existing prototypical building description developed earlier at LBL. Then, using a new method developed by LBL, we reconcile simulation results with whole-building load shapes (Task 5). 
Table 1-3. Input Data

\section{Data Set}

1. PG\&E on-site survey data of 855 buildings including billing data and weights

2. Load research short-interval (30-minute) load data of over 1400 accounts for two years (1985-1986)

3. The 1988 PG\&E commercial sector end-use mail surveys ( -6000 responses)

4. Hourly weather data for five CEC climate zones

The reconciled EUIs are developed for the average stock of the buildings for 1986. The reconciled EUIs must be modified to meet the specification of the PG\&E and CEC forecasting models. Both PG\&E and CEC models separately account for the impact of technologies, vintages, and price changes. In Chapter 5, we use the methodology discussed in Chapter 2 for these modifications to develop a complete set of forecasting model inputs. 


\section{Chapter 2}

\section{Methodology}

The methodology consists of two major parts: 1) reconciliation of initial end-use load-shape estimates with measured whole-building load data to produce intermediate EUIs and load shapes; and 2) data transfer procedures to transform intermediate outputs into a revised set of inputs for CEC and PG\&E forecasting models. This chapter describes the steps involved in each part of the methodology. Chapter 3 describes the development of data to implement the methodology.

\section{Part 1. Reconciliation Methodology}

The major analytical advance of our methodology is the reconciliation of estimated end-use load shape with measured whole-building load shape data. There are three major steps in this process: 1) initial engineering estimates of end-use load shapes; 2) average measured wholebuilding load shapes; and 3) reconciliation of 1 with 2 . Figure 2-1 illustrates the primary data sources and relationships between these steps.

\section{Initial Estimates of End-Use Load Shapes}

In the first step of the reconciliation, we make initial estimates of end-use load shapes for each building type. These estimates are developed using one or more prototypes to represent each building type. For HVAC end uses (heating, cooling, ventilation), the initial estimates result from simulation of the prototype using the DOE-2.1D building energy simulation program (BESG 1990). For non-HVAC end uses (lighting, equipment, cooking, etc.), the estimates result from engineering analysis of data on reported schedules and installed capacities. The schedules and capacities are taken from the on-site and mail surveys, which are used as input to the NonHVAC EUI/LS and DOE-2 Input Generator (NELDIG).

As indicated, due to diversity within some building types, multiple prototypes were sometimes required to represent a single building type. Table 2-1 identifies the prototypes developed for each building type.

The prototypes were developed through an analysis of approximately 850 detailed, on-site surveys, nearly 6000 mail survey responses, and previous prototypes developed by LBL and others for the commercial sector. The analysis of the on-site and mail survey data is described in Chapter 3 , and the final prototype descriptions are presented with the individual building results in Chapter 4.

Initially two simulations of each prototype are performed. The first uses Oakland/Alameda weather to develop an initial estimate of energy use for the Coastal weather zone. The second uses Sacramento weather to develop an initial estimate of energy use for the Inland weather zone. 
Figure 2-1. Integrated Commercial LS and EUI Estimation Methodology. The method consists of three parts: 1) development of preliminary EUIs and LSs using NELDIG and DOE-2, 2) construction of average whole-building type, and 3) reconciliation of the preliminary EUIs and LSs with average whole-building hourly load, using EDA.

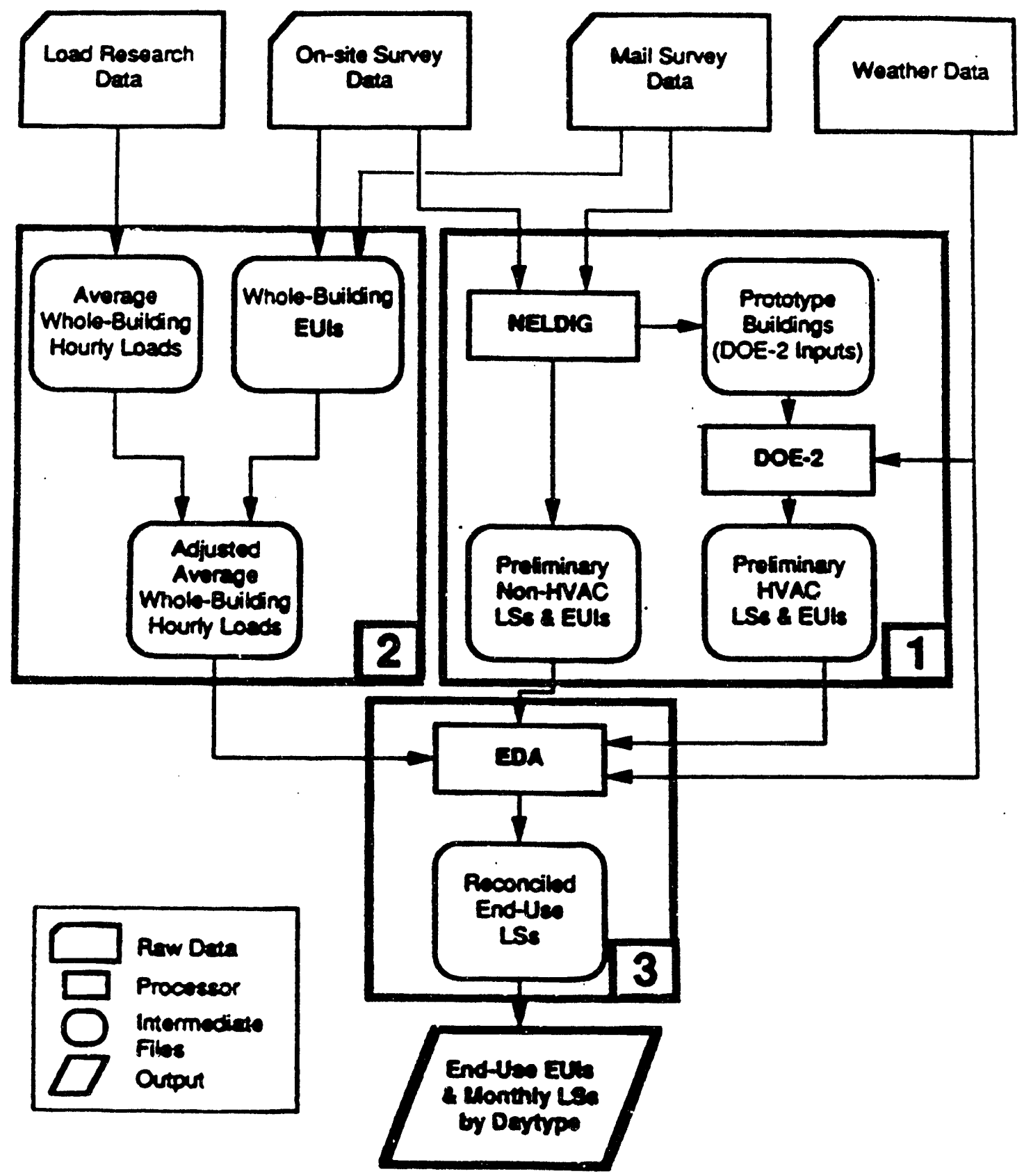


Table 2-1. Prototype Identification by Building Type

\begin{tabular}{|c|c|}
\hline BUILDING TYPE & Prototype(s) \\
\hline SMALL OFFICE & Small Office \\
\hline LARGE OFFICE & Large Office \\
\hline RETAIL & $\begin{array}{l}\text { Large Retail } \\
\text { Small Retail }\end{array}$ \\
\hline RESTAURANT & $\begin{array}{l}\text { Fast Food } \\
\text { Sit-Down }\end{array}$ \\
\hline FOOD STORES & Food Store \\
\hline WAREHOUSE & $\begin{array}{l}\text { Refrigerated } \\
\text { Non-Refrigerated }\end{array}$ \\
\hline SCHOOL & $\begin{array}{l}\text { Primary School } \\
\text { Secondary School }\end{array}$ \\
\hline COLLEGE & $\begin{array}{l}\text { Office/Lab/Classroom } \\
\text { Library } \\
\text { Dormitory }\end{array}$ \\
\hline HEALTH & $\begin{array}{l}\text { Hospital } \\
\text { Nursing Home }\end{array}$ \\
\hline LODGING & $\begin{array}{l}\text { Large Hotel } \\
\text { Small Hotel/Motel }\end{array}$ \\
\hline MISCELLANEOUS & Miscellaneous \\
\hline
\end{tabular}


Average Whole-Building Electricity Use Profiles

In the second step of the reconciliation, we construct average whole-building electricity use profiles for each building type. These profiles provide control totals against which our initial estimates are reconciled. Two sources of data are used: Load research data (LRD) are used to develop the prototypical whole-building load shape, while supplementary data on total commercial sector energy use intensity by building type (also known as whole building EUIs) are used to determine magnitude (which is expressed as a total EUI for the building type or $\mathrm{kWh} / \mathrm{ft}^{2} . \mathrm{yi}^{\mathrm{i}}$ ). The analysis of the LRD to develop whole-building load shapes is described in Chapter 3 . The final whole-building load shapes and EUIs are presented separately for each building in Chapter 4.

The whole-building EUI is used to normalize the whole-building load shapes such that integration of the adjusted $w^{\prime}$ sle-building load shape for the year equals the whole-building EUI. Consequently, the whole-building EUI is an extremely important input to the reconciliation process because it largely determines the magnitude of the reconciled end-use EUIs; thus, the sum of the reconciled EUIs must exactly equal the whole-building EUI. following extensive discussions with the CEC and PG\&E forecasting staff. The basic data used was an in-house analysis by PG\&E. A detailed discussion of the development of these EUIs is presented in Chapter 3 as part of the analysis of data used in the project.

\section{Reconciliation of Initial Estimates to Whole-Building Electricity Use Profiles}

In the third step of the reconciliation, we apply the End-use Disaggregation Algorithm (EDA) to obtain reconciled end-use LSs. Technical aspects of EDA are documented in Akbari, et al. (1988). The corresponding end-use EUIs are simply the integration of the end-use LSs for the entire year. The results of the reconciliations are presented in Chapter 4.

\section{Part 2. Developing PG\&E and CEC Forecasting Model Inputs from Reconciled EUIs}

The end-use LSs and EUIs developed through the reconciliation procedurc: represent a snapshot of 1986 electricity use by building type and end-use for two regions of the PG\&E service territory. For each building type, this snap-shot represents an aggregation over important distinctions that are explicitly represented within CEC and PG\&E forecasting models. These distinctions include price effects between 1986 and the 1975 model base year, office equipment energy use as a distinct element of miscellaneous electricity use, fuel saturations, and, for space conditioning end uses, the effects of different eras of building and equipment minimum energy efficiency standards. The CEC, in addition, models 5 distinct climate regions within the PG\&E service territory, rather than the 2 we examined in Part I. Finally for both models, there are several EUIs that cannot be estimated with our reconciliation methodology, including electric space heating (except for lodging) and all non-electric end uses (space heating, water heating, cooking, and miscellaneous). 
For the second phase of our methodology, we have developed procedures that combine reconciled EUIs (from application of EDA) with additional analysis of the DOE-2 prototypes and additional information from the mail and on-site surveys to specify a complete set of revised energy use inputs for both the CEC and PG\&E models. The basic approach is to start with the reconciled EUIs as a true representation of 1986 energy use and develop adjustment factors that disaggregate these EUIs in a manner that is consistent with CEC's and PG\&E's current forecasting procedures.

It is useful to organize our discussion in a series of sequential steps: 1) Development of 1986 EUIs for end-uses not estimated through application of EDA (electric heating, and all nonelectric end uses); 2) Re-specification of all 1986 EUIs to a 1975 base year through application of the short-run price elasticity of demand and historic energy prices; 3) Removal of fuel saturation effects for all reconciled electric end uses, except those for which, by definition, the saturation is $100 \%$ (indoor and outdoor lighting, and miscellaneous). 4) Incorporate previous LBL work to further disaggregate the electric miscellaneous EUI into distinct categories for office equipment and miscellaneous; 5) For the space conditioning end uses, account explicitly for the effects of the first generation of mandatory minimum building energy efficiency standards; 6) For the space conditioning end use specification used by the CEC model, account separately for the impacts of equipment energy efficiency; 7) Finally, for the space conditioning end use specification used by the CEC model, account separately for the additional variations in energy use for the 5 sub-regions represented by the 2 regions for which explicit reconciliations were performed.

\section{Developing EUIs for Electric Heating, and Non-Electric End Uses}

The first step toward developing revised forecasting model inputs for the CEC and PG\&E models is to complete the development of all EUIs required by the models. There are several classes of EUIs that cannot be estimated using the LBL reconciliation procedure. They include electric space heating, and non-electric space heating, water heating, cooking, and miscellaneous end uses. Electric space heating has a very low saturation in the PG\&E service territory; we did not, for example, detect the presence of electric space heating in our analysis of the LRD (except for the lodging building type). Accordingly, we could not extract profiles for these end uses using our reconciliation procedures. Non-electric space heating, water heating, cooking, and miscellaneous energy use were not estimated using the reconciliation process for the obvious reason that they are not electric end uses.

Our approach for developing EUIs for these end uses is to estimate them directly from the onsite and mail survey data. For the non-electric, non-space conditioning end uses (water heating, cooking, and miscellaneous), this is a straightforward application of various engineering factors to the installed capacity and utilization information reported in the survey data. For the space conditioning end uses (electric and non-electric space heating), we relied on simulations of the same DOE-2 prototypes used to estimate initial conditions for the EDA reconciliations for electric cooling and ventilation. 
It is important to note that EUIs estimated in this fashion, since they are not reconciled to a control total, are $100 \%$ saturation estimates for these EUIs. Therefore, there are no saturation effects to remove, as must be done for the electric EUIs emerging from EDA (to be described below).

\section{Expressing Reconciled EUIs Relative to a 1975 Base Year}

Having now completed the development of a full set of EUIs for all end uses for 1986, we next re-specify these EUIs relative to the 1975 base year used by both CEC and PG\&E in their forecasting models. The re-specification consists of taking into account the effects of energy price changes between 1975 and 1986, which is based on both a measure of the short-run price elasticity of demand and the historic price series. Note that we will account separately for both nonprice impacts on the space conditioning EUIs (i.e., the effects of minimum energy performance standards) and technological change on office equipment EUIs.

CEC and PG\&E currently rely on different estimates of the short-run price elasticity of demand. In order to respect these differences, we have developed separate price adjustment factors. The price elasticities and resulting price adjustment factors are summarized on separate tables for CEC and PG\&E in order to facilitate subsequent modification of the price elasticities by CEC or PG\&E, see Tables 2-2 and 2-3. The price elasticity of demand is a dimensionless number that relates percentage changes in price to percentage changes in demand for a given fuel and building type (in the case of CEC) or for a given fuel and end use (in the case of PG\&E). The price adjustment factors represent the cumulative effect on consumption of these price elasticities and the prices of energy between 1986 and 1975 . When these adjustment factors are multiplied by 1986 energy use, they produce an estimate of 1975 energy use for a given fuel/building type or fuel/end use.

\section{Accounting for Fuel Saturation Effects}

The whole-building EUI or control total used in the reconciliation process reflected the aggregate impact of the various saturations of electricity end uses in the PG\&E service territory. Since the CEC and PG\&E forecasting models account for fuel saturations separately by end use, the effects of the observed aggregate saturations embedded in the reconciled EUIs must be removed. We developed saturation estimates through analysis of the mail survey data See Tables 2-4 and 2-5. (Additional analysis of the mail survey data is presented in Chapter 3.) Saturations for the other end uses are either $100 \%$ (for electric indoor lighting, outdoor lighting, and miscellaneous) or are already accounted for in the estimation process (for heating and all non-electric end uses, see above). 
Table 2-2. Short-Run Price Elasticity and Price Adjustment Factors - CEC

\begin{tabular}{|l|ccc|ccc|}
\hline & \multicolumn{4}{|c|}{} & \multicolumn{3}{c|}{1986 to 1975 } \\
Building Type & Elec & Gas & Othr & Elec & Gas & Othr \\
\hline Small Office & 0.200 & 0.075 & 0.090 & 1.28 & 1.09 & 0.99 \\
Large Office & 0.200 & 0.075 & 0.090 & 1.28 & 1.09 & 0.99 \\
Retail & 0.210 & 0.075 & 0.090 & 1.29 & 1.09 & 0.99 \\
Restaurant & 0.140 & 0.075 & 0.090 & 1.18 & 1.09 & 0.99 \\
Food Store & 0.230 & 0.075 & 0.090 & 1.33 & 1.09 & 0.99 \\
Warehouse & 0.120 & 0.075 & 0.090 & 1.15 & 1.09 & 0.99 \\
School & 0.130 & 0.075 & 0.090 & 1.16 & 1.09 & 0.99 \\
College & 0.170 & 0.075 & 0.090 & 1.23 & 1.09 & 0.99 \\
Health & 0.180 & 0.075 & 0.090 & 1.24 & 1.09 & 0.99 \\
Lodging & 0.110 & 0.075 & 0.090 & 1.14 & 1.09 & 0.99 \\
Miscellaneous & 0.130 & 0.075 & 0.090 & 1.16 & 1.09 & 0.99 \\
\hline
\end{tabular}

Table 2-3. Short-Run Price Elasticity and Price Adjustment Factors - PG\&E

\begin{tabular}{|c|c|c|c|c|}
\hline \multirow[b]{2}{*}{ Building Type } & \multicolumn{2}{|c|}{ Short-Run Price Elasticity } & \multicolumn{2}{|c|}{$\begin{array}{c}\text { 1986-1975 } \\
\text { Price Adjustment Factor }\end{array}$} \\
\hline & Elec & Gas & Elec & Gas \\
\hline Heating & 0.13 & 0.17 & 1.14 & 1.32 \\
\hline Cooling & 0.11 & - & 1.11 & - \\
\hline Ventilation & 0.01 & - & 1.01 & - \\
\hline Hot Water & 0.19 & 0.19 & 1.20 & 1.37 \\
\hline Cooking & 0.01 & 0.01 & 1.01 & 1.01 \\
\hline Refrigeration & 0.01 & - & 1.01 & - \\
\hline In-Lights & 0.01 & - & 1.01 & - \\
\hline Out-Lights & 0.01 & - & 1.01 & - \\
\hline Office Equip & 0.01 & - & 1.01 & - \\
\hline Miscellaneous & 0.01 & 0.19 & 1.01 & 1.37 \\
\hline
\end{tabular}


Table 2-4. Mail Survey Electricity Saturations by End Use [\%] - Coastal (Source: PG\&E 1988 Mail Survey)

\begin{tabular}{|lrccccc|}
\hline & Heat & Cool & Vent & Cook & Refr & HotH2O \\
\hline Small Office & 13.3 & 69.9 & 69.9 & 52.6 & 73.4 & 45.7 \\
Large Office & 7.3 & 86.6 & 86.6 & 61.7 & 79.2 & 20.3 \\
Retail & 18.5 & 59.0 & 59.0 & 60.0 & 75.4 & 24.6 \\
Restaurant & 20.1 & 68.9 & 68.9 & 44.9 & 98.5 & 15.3 \\
Food & 3.7 & 76.0 & 76.0 & 67.5 & 97.8 & 14.5 \\
Warehouse & 14.5 & 47.8 & 47.8 & 66.5 & 89.3 & 52.8 \\
School & 2.2 & 77.2 & 77.7 & 53.3 & 95.5 & 14.0 \\
College & 22.1 & 52.3 & 52.3 & 76.8 & 100.0 & 8.2 \\
Health & 0.3 & 85.4 & 85.4 & 52.8 & 99.8 & 0.9 \\
Lodging & 18.7 & 69.4 & 69.4 & 73.3 & 89.1 & 2.7 \\
Miscellaneous & 2.6 & 27.2 & 27.2 & 70.3 & 96.7 & 21.0 \\
\hline
\end{tabular}

Table 2-5. Mail Survey Electricity Saturations by End Use [\%] - Inland (Source: PG\&E 1988 Mail Survey)

\begin{tabular}{|lrrrrrr|}
\hline & Heat & Cool & Vent & Cook & Refr & HotH2O \\
\hline Small Office & 19.0 & 80.0 & 80.0 & 52.6 & 73.4 & 45.7 \\
Large Office & 1.7 & 91.7 & 91.7 & 61.7 & 79.2 & 20.3 \\
Retail & 9.1 & 76.4 & 76.4 & 60.0 & 75.4 & 24.6 \\
Restaurant & 11.2 & 84.3 & 84.3 & 44.9 & 98.5 & 15.3 \\
Food & 9.7 & 69.5 & 69.5 & 67.5 & 97.8 & 14.5 \\
Warehouse & 7.8 & 51.1 & 51.1 & 66.5 & 92.2 & 52.8 \\
School & 0.0 & 82.8 & 82.8 & 53.3 & 95.5 & 14.0 \\
College & 1.8 & 94.6 & 94.6 & 76.8 & 100.0 & 8.2 \\
Health & 0.9 & 78.3 & 78.3 & 52.8 & 99.8 & 0.9 \\
Lodging & 18.0 & 95.7 & 95.7 & 77.3 & 89.1 & 2.7 \\
Miscellaneous & 3.7 & 77.3 & 77.3 & 70.3 & 96.7 & 21.0 \\
\hline
\end{tabular}




\section{Accounting Separately for Office Equipment EUIs}

Office equipment energy use has been an important new component of commercial sector load growth. Both CEC and PG\&E now explicitly represent this end use in their forecasting models. Previously, it was treated jointly with other miscellaneous electricity use. The data used in our project also reflect this older, more aggregated view of miscellaneous equipment. Accordingly, application of the EDA reconciliation procedure yields only a single EUI for electric miscellaneous.

The importance of the office equipment end use 'ed to CIEE sponsorship (with CEC and PG\&E funding) of a detailed examination of office equipment energy use trends in the PG\&E service territory by LBL (Piette, et. al. 1991). We have taken this work as the current best estimate of the EUI for this end use and subtracted these EUIs from the miscellaneous EUI estimated with EDA. Therefore, the electric miscellaneous EUI represents the residual of the original miscellaneous EUI and LBL's previous analysis of office equipment EUI (all in base year 1975). Table 2-6 presents the 1975 office equipment EUIs derived from the LBL study.

Table 2-6. Office Equipment EUIs [kWh/sqit/yr] and Annual Percentage Growth (Source: Piette et. al. 1991)

\begin{tabular}{|lccc|}
\hline Building & 1983 & Annual \% Growth & 1975 \\
& EUI & $83-86$ & EUI \\
\hline Small Office & 0.66 & 15.4 & 0.21 \\
Large Office & 1.03 & 15.3 & 0.33 \\
Retail & 0.14 & 17.0 & 0.04 \\
Restaurant & 0.05 & 6.6 & 0.03 \\
Food & 0.04 & 9.1 & 0.02 \\
Warehouse & 0.12 & 25.1 & 0.02 \\
School & 0.09 & 14.7 & 0.03 \\
College & 0.13 & 15.9 & 0.04 \\
Health & 0.55 & 13.5 & 0.20 \\
lodging & 0.03 & 14.7 & 0.01 \\
Miscellaneous & 0.10 & 12.1 & 0.04 \\
\hline
\end{tabular}




\section{Disaggregating Reconciled EUIs by Building and Equipment Vintage}

The CEC and PG\&E commercial sector energy demand forecasting models separately tracked energy use by several different vintages for a given building type. These vintages were intended to reflect different eras of building construction practices and equipment choice. For the time period under consideration, the most important vintages correspond to the time immediately prior to and after the enactment of the first generation of mandatory building and appliance minimum efficiency standards by the state of California. Table 2-7 illustrates the relationship between these eras. In this project, we estimate the quantities labeled "U75" and "EUI79," which are the titles used by CEC in their forecasting model for these building and equipment vintages.

Table 2-7. Building and Equipment Vintages

\begin{tabular}{|l|c|c|}
\hline & \multicolumn{2}{|c|}{ Equipment Vintage } \\
Building Vintage & before 1979 & after 1979 \\
\hline before 1979 & U75 & $\begin{array}{l}\text { treated separately } \\
\text { by CEC \& PG\&E }\end{array}$ \\
\hline after 1979 & $\mathrm{n} / \mathrm{a}$ & EU179 \\
\hline
\end{tabular}

Note: U75 is energy-use intensity used by CEC model for the base year 1975. EUI79 is energyuse intensity used by both CEC and PG\&E models for the base year 1979. This project has developed the corresponding vintage prototypes.

The basic idea is to rely on additional DOE-2 simulations to provide ratios that then modify the reconciled EUIs. In this case, the prototypes themselves are modified to reflect conditions unique to each vintage. The challenge for implementing this procedure is the absence of high quality data to support the development of unique prototypes corresponding to each vintage. That is, there are very few buildings represented in either the on-site survey or mail survey built after 1978.

In addition to available on-site and mail survey data, we rely primarily on California's energy performance standards (Titles 24 and 20) and on ASHRAE standards 90/75 and 90.2P. Notably, some aspects of the California standards do not apply to several of the building prototypes examined including nursing homes, both primary and secondary schools, hotels and motels, and colleges.

The resulting prototype modifications are summarized in Chapter 4 following the presentation of the basic (i.e., un-vintaged) prototypes used in the reconciliation. 
The structure of the CEC forecasting model treats building thermal loads separately from equipment energy conversion efficiency. Thus, we adopt CEC's energy conversion equipment shares and efficiencies and work primarily with the ratios of DOE-2 simulations of the loads placed on this equipment. Specifically:

$$
\text { EUI }_{\text {U75 }}=\frac{\text { EUI }_{\text {reconciled }} \times \frac{\text { Price_Effect }}{\text { Electric_Saturation }} \times \frac{\text { Load }_{\text {original_protoype }}}{\text { EUI }_{\text {original_prototype }}} \times \frac{\text { Load }_{\text {U75_prototype }}}{\text { Load }_{\text {original_prototype }}}}{\text { CEC_Energy_Conversion_Equipment_Efficiency } \text { vintage_65-78 }_{\text {_. }}}[1]
$$

or

$$
\text { EUI }_{U 75}=\frac{\text { EUI }_{\text {reconciled }} \times \frac{\text { Price_Effect }}{\text { Electric_Saturation }} \times \frac{\text { Load }_{\text {U75_prototype }}}{\text { EUI }_{\text {original_prototype }}}}{\text { CEC_Energy_Conversion_Equipment_Efficiency } \text { vintage_65-78 }_{\text {_En }}}
$$

The CEC model also expresses EUI79 as a relative percentage of U75 and does not include the effects of HVAC equipment efficiency. Consequently, EUI79-CEC (EUI79 used by CEC model) is calculated using the ratio of loads from the simulations of the prototypes developed to represent U75 and EU179.

$$
\text { EUI79-CEC }=\frac{\text { Load }_{\text {EUI79_prototype }}}{\text { Load U75_prototype }}
$$

The PG\&E model does include the effects of HVAC equipment efficiency in its specification of the equivalent post-standards EUI. Accordingly, EUI79-PG\&E (EUI79 used by PG\&E model) is calculated using EUI79-CEC adjusted for CEC HVAC equipment conversion efficiencies.

$$
\text { EUI79-PG\&E }=\text { EUI }_{\mathrm{U} 75} \times \text { EUI79-CEC } \times \text { CEC_ECEE_RATIO }
$$

where

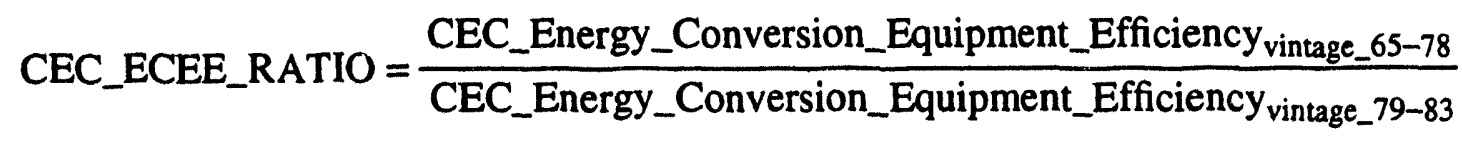

The CEC energy conversion equipment efficiency and shares are presented in Table $\mathbf{2 - 8}$ and Table 2-9. Table 2-10 presents the weighted average energy conversion efficiencies. 
Table 2-8. CEC Energy Conversion Efficiency by Vintage and Energy Source

\begin{tabular}{|l|cccc|cccc|}
\hline & $\begin{array}{c}\text { Boiler } \\
(\eta)\end{array}$ & $\begin{array}{c}\text { Fumace } \\
(\eta)\end{array}$ & $\begin{array}{c}\text { Heat Pump } \\
(\text { COP })\end{array}$ & $\begin{array}{c}\text { Other } \\
(\eta)\end{array}$ & $\begin{array}{c}\text { Chiller } \\
(\text { COP })\end{array}$ & $\begin{array}{c}\text { Pkg. Mult } \\
(\text { COP) }\end{array}$ & $\begin{array}{c}\text { Pkg. Term } \\
\text { (COP) }\end{array}$ & $\begin{array}{c}\text { Heat Pump } \\
\text { (COP) }\end{array}$ \\
\hline Electricity & & & & & & & & \\
Vintage 65-78 & 0.95 & 0.95 & 1.90 & 1.00 & 4.20 & 2.04 & 1.76 & 1.76 \\
Vintage 79-83 & 0.95 & 0.95 & 2.40 & 1.00 & 4.25 & 2.34 & 2.41 & 2.43 \\
Natural Gas & & & & & & & & \\
Vintage 65-78 & 0.66 & 0.66 & 3.00 & 0.66 & 0.59 & 0.36 & 0.20 & 0.20 \\
Vintage 79-83 & 0.75 & 0.75 & 3.00 & 0.66 & 0.75 & 0.65 & 0.20 & 0.20 \\
\hline
\end{tabular}


Table 2-9. CEC Equipment Saturations (\%) by Fuel Type

\begin{tabular}{|c|c|c|c|c|c|c|c|c|}
\hline & \multicolumn{4}{|c|}{ Heating Equipment } & \multicolumn{4}{|c|}{ Cooling Equipment } \\
\hline & Boiler & Furnace & Heat Pump & Other & Chiller & Pkg. Mult & Pkg. Term & Heat Pump \\
\hline SMALL OFFICE & & & & & & & & \\
\hline Electricity & 0.0 & 66.3 & 33.2 & 0.5 & 19.3 & 72.2 & 2.4 & 6.1 \\
\hline Natural Gas & 20.6 & 73.5 & 0.0 & 5.8 & 75.0 & 25.0 & 0.0 & 0.0 \\
\hline Other & 0.0 & 81.0 & 0.0 & 19.0 & 75.0 & 25.0 & 0.0 & 0.0 \\
\hline LARGE OFFICE & & & & & & & & \\
\hline Electricity & 0.0 & 100.0 & 0.0 & 0.0 & 89.6 & 4.9 & 5.5 & 0.0 \\
\hline Natural Gas & 97.5 & 2.5 & 0.0 & 0.0 & 89.6 & 4.9 & 5.5 & 0.0 \\
\hline Other & 100.0 & 0.0 & 0.0 & 0.0 & 89.6 & 4.9 & 5.5 & 0.0 \\
\hline RESTAURANT & & & & & & & & \\
\hline Electricity & 0.0 & 69.9 & 11.5 & 18.6 & 7.2 & 89.4 & 2.0 & 1.4 \\
\hline Natural Gas & 0.7 & 90.5 & 0.0 & 8.8 & 37.0 & 63.0 & 0.0 & 0.0 \\
\hline Other & 0.0 & 0.0 & 0.0 & 100.0 & 37.0 & 63.0 & 0.0 & 0.0 \\
\hline RETAIL & & & & & & & & \\
\hline Electricity & 0.0 & 37.3 & 54.1 & 8.6 & 56.4 & 40.0 & 0.1 & 3.5 \\
\hline Natural Gas & 61.5 & 35.7 & 0.0 & 2.8 & 100.0 & 0.0 & 0.0 & 0.0 \\
\hline Other & 14.0 & 36.0 & 0.0 & 50.0 & 100.0 & 0.0 & 0.0 & 0.0 \\
\hline FOOD STORE & & & & & & & & \\
\hline Electricity & 0.0 & 41.6 & 18.8 & 39.6 & 0.0 & 96.6 & 0.0 & 3.4 \\
\hline Natural Gas & 0.0 & 58.9 & 0.0 & 41.1 & 0.0 & 100.0 & 0.0 & 0.0 \\
\hline Other & 0.0 & 0.1 & 0.0 & 99.9 & 0.0 & 100.0 & 0.0 & 0.0 \\
\hline WAREHOUSE & & & & & & & & \\
\hline Electricity & 0.0 & 0.0 & 0.0 & 100.0 & 6.8 & 93.2 & 0.0 & 0.0 \\
\hline Natural Gas & 0.0 & 62.1 & 0.0 & 37.9 & 30.0 & 70.0 & 0.0 & 0.0 \\
\hline Other & 0.0 & 62.1 & 0.0 & 37.9 & 30.0 & 70.0 & 0.0 & 0.0 \\
\hline SCHOOL & & & & & & & & \\
\hline Electricity & 0.0 & 90.6 & 9.4 & 0.0 & 0.0 & 97.6 & 0.5 & 1.9 \\
\hline Natural Gas & 71.8 & 28.2 & 0.0 & 0.0 & 0.0 & 65.0 & 35.0 & 0.0 \\
\hline Other & 90.0 & 9.0 & 0.0 & 1.0 & 0.0 & 100.0 & 0.0 & 0.0 \\
\hline COLLEGE & & & & & & & & \\
\hline Electricity & 31.0 & 42.0 & 6.0 & 21.0 & 40.0 & 31.0 & 18.0 & 11.0 \\
\hline Natural Gas & 100.0 & 0.0 & 0.0 & 0.0 & 56.0 & 44.0 & 0.0 & 0.0 \\
\hline Other & 100.0 & 0.0 & 0.0 & 0.0 & 56.0 & 44.0 & 0.0 & 0.0 \\
\hline HEALTH & & & & & & & & \\
\hline Electricity & 0.0 & 0.0 & 100.0 & 0.0 & 89.3 & 10.4 & 0.1 & 0.2 \\
\hline Natural Gas & 93.8 & 6.2 & 0.0 & 0.0 & 89.3 & 10.4 & 0.3 & 0.0 \\
\hline Other & 93.8 & 6.2 & 0.0 & 0.0 & 89.3 & 10.4 & 0.3 & 0.0 \\
\hline LODGING & & & & & & & & \\
\hline Electricity & 0.0 & 0.0 & 84.4 & 15.6 & 95.6 & 0.0 & 0.0 & 4.4 \\
\hline Natural Gas & 100.0 & 0.0 & 0.0 & 0.0 & 100.0 & 0.0 & 0.0 & 0.0 \\
\hline Other & 33.0 & 0.0 & 0.0 & 67.0 & 100.0 & 0.0 & 0.0 & 0.0 \\
\hline MISCELLANEOUS & & & & & & & & \\
\hline Electricity & 0.0 & 2.4 & 54.0 & 43.6 & 22.3 & 59.1 & 5.0 & 16.3 \\
\hline Natural Gas & 47.5 & 38.1 & 0.0 & 14.4 & 22.3 & 59.0 & 18.7 & 0.0 \\
\hline Other & 56.0 & 1.0 & 0.0 & 43.0 & 22.3 & 59.0 & 18.7 & 0.0 \\
\hline
\end{tabular}


Table 2-10. CEC Weighted Average Energy Conversion Efficiencies by Fuel and Vintage

\begin{tabular}{|c|c|c|c|c|}
\hline & \multicolumn{2}{|c|}{ Vintage $65-78$} & \multicolumn{2}{|c|}{ Vintage $79-83$} \\
\hline & Heating & Cooling & Heating & Cooling \\
\hline SMALL OFFICE & & & & \\
\hline Electricity & 1.266 & 2.433 & 1.432 & 2.716 \\
\hline Natural Gas & 0.659 & 0.533 & 0.744 & 0.725 \\
\hline Other & 0.660 & 0.533 & 0.733 & 0.725 \\
\hline LARGE OFFICE & & & & \\
\hline Electricity & 0.950 & 3.960 & 0.950 & 4.055 \\
\hline Natural Gas & 0.660 & 0.557 & 0.750 & 0.715 \\
\hline Other & 0.660 & 0.557 & 0.750 & 0.715 \\
\hline RESTAURANT & & & & \\
\hline Electricity & 1.069 & 2.186 & 1.126 & 2.480 \\
\hline Natural Gas & 0.660 & 0.445 & 0.742 & 0.687 \\
\hline Other & 0.660 & 0.445 & 0.660 & 0.687 \\
\hline RETAIL & & & & \\
\hline Electricity & 1.486 & 3.248 & 1.739 & 3.420 \\
\hline Natural Gas & 0.660 & 0.590 & 0.747 & 0.750 \\
\hline Other & 0.660 & 0.590 & 0.705 & 0.750 \\
\hline FOOD STORE & & & & \\
\hline Electricity & 1.148 & 2.030 & 1.242 & 2.343 \\
\hline Natural Gas & 0.660 & 0.360 & 0.713 & 0.650 \\
\hline Other & 0.660 & 0.360 & 0.660 & 0.650 \\
\hline WAREHOUSE & & & & \\
\hline Electricity & 1.000 & 2.187 & 1.000 & 2.470 \\
\hline Natural Gas & 0.660 & 0.429 & 0.716 & 0.680 \\
\hline Other & 0.660 & 0.429 & 0.716 & 0.680 \\
\hline SCHOOL & & & & \\
\hline Electricity & 1.039 & 2.033 & 1.086 & 2.342 \\
\hline Natural Gas & 0.660 & 0.304 & 0.750 & 0.493 \\
\hline Other & 0.660 & 0.360 & 0.749 & 0.650 \\
\hline COLLEGE & & & & \\
\hline Electricity & 1.018 & 2.823 & 1.048 & 3.127 \\
\hline Natural Gas & 0.660 & 0.489 & 0.750 & 0.736 \\
\hline Other & 0.660 & 0.489 & 0.750 & 0.706 \\
\hline HEALTH & & & & \\
\hline Electricity & 1.900 & 3.968 & 2.400 & 4.046 \\
\hline Natural Gas & 0.660 & 0.565 & 0.750 & 0.738 \\
\hline Other & 0.660 & 0.565 & 0.750 & 0.738 \\
\hline LODGING & & & & \\
\hline Electricity & 1.760 & 4.093 & 2.182 & 4.170 \\
\hline Natural Gas & 0.660 & 0.590 & 0.750 & 0.750 \\
\hline Other & 0.660 & 0.590 & 0.690 & 0.750 \\
\hline MISCELLANEOUS & & & & \\
\hline Elertricity & 1.485 & 2.470 & 1.755 & 2.782 \\
\hline Natural Gas & 0.660 & 0.381 & 0.737 & 0.588 \\
\hline Other & 0.660 & 0.381 & 0.737 & 0.588 \\
\hline
\end{tabular}




\section{Non-HVAC End-Uses}

Non-HVAC electric end-uses (cooking, hot water, indoor lighting, outdoor lighting, miscellaneous equipment, and refrigeration) for the 1975 Vintaged EUIs ( U75 ) are calculated by removing the saturation effect from the $1986 \mathrm{EUI}$ and then adjusting this result by the price effect.

$$
\mathrm{U} 75=\frac{\text { EUI } \times \text { Price_Effect }}{\text { Electric_Saturationn }}
$$

Non-HVAC gas end-uses (cooking, hot water, and miscellaneous equipment) for the 1975 Vintaged EUIs are calculated by adjusting the 1986 EUI for the price effect.

$$
\text { U75 = EUI } \times \text { Price_Effect }
$$

\section{Climatic Impacts on Space-Conditioning EUIs}

Space-conditioning EUIs (cooling, ventilation, and heating) are influenced by climate. Within the PG\&E service territory, the CEC forecasts energy use separately for five climatic regions. Generally speaking, different premises of the same building type would experience different heating, cooling, and ventilation loads (and, therefore, EUIs) depending on which of these regions they were located.

In principle, these differences could be estimated directly with separate reconciliations. That is, one can develop unique initial estimates of end-use EUIs and LSs for ech region and reconcile them separately for each region. This approach could not be used because sufficient quantities of LRD were not always available to support the development of unique average whole-building electricity use profiles for each region (see Chapter 3 ).

Instead, a hybrid approach was taken. Separate reconciliations were made for the coastal and inland regions where sufficient data were available. For the remaining $\mathrm{CEC}$ forecasting regions, a separate set of DOE-2 simulations were run for each prototype using weather data from each region. The ratios of simulated energy use for cooling, ventilation, and heating from these simulations to those used in the reconciliations were then used to adjust the reconciled HVAC EUIs to produce a unique value for each region. See equation 8:

$$
\mathrm{EUI}_{\mathrm{CEC}-\text { region }}=\mathrm{EUI}_{\text {original_region }} \times \frac{\text { EUI_prototype_simulation }}{\text { EUE-region }}
$$

Table 2-11 identifies the weather stations used to represent each climate region. 
Table 2-11. Weather Stations

\begin{tabular}{|c|c|c|c|}
\hline PG\&E Climate Region & Weather Station & CEC Climate Region & Weather Station \\
\hline Coastal & Oakland & $\begin{array}{l}\text { Region } 5 \\
\text { Region } 1\end{array}$ & $\begin{array}{l}\text { Oakland } \\
\text { Blue Canyon }\end{array}$ \\
\hline Inland & Sacramento & $\begin{array}{l}\text { Region } 2 \\
\text { Region } 3 \\
\text { Region } 4\end{array}$ & $\begin{array}{l}\text { Sacramento } \\
\text { Fresno } \\
\text { San Jose }\end{array}$ \\
\hline
\end{tabular}




\section{Chapter 3 \\ Input Data Base Analysis and Integration}

The data inputs to this project are of varying quality and come in many different formats. The primary building and load shape data for the project include the on-site surveys of 855 buildings, the whole-building load research data of 1,374 commercial accounts, and PG\&E's 1988 Commercial Energy Use Survey (referred to as the mail survey) of over 6000 accounts (See Table 13).

Tasks 2 and 3 (see Table 1-2) initially assumed that the data had been thoroughly scrutinized and edited. In several cases, however, we have had to perform extensive analyses of the data and remove questionable values. In this section, we discuss this process of data review and database preparation for each of the four input data sets. We also summarize our efforts to review the data for application in developing end-use load shapes and EUTs. The results of these analyses were used in development of prototypical buildings and prototypical whole-building load shapes.

\section{On-Site Survey Data Base}

As part of PG\&E and CEC's on-going efforts to characterize energy end use in the commercial sector, a detailed on-site survey of 855 commercial buildings across the PG\&E service area has been completed (ADM 1987). A summary of the on-site survey buildings is presented in Table 3-1.

We received a computer tape of these data from CEC. Each premise (record) was characterized by 1,135 variables describing the building location, shape, construction, floor-space utilization, indoor and outdoor lighting, HVAC system, electric and non-electric equipment, water heating, cooking equipment, refrigeration systems, and a variety of schedules describing the operation of the premise and its equipment. In addition to building characteristics, the database also contiins a year of utility billing data for most premises. 
Table 3-1. Climate Zone Distribution of 1986 PG\&E On-Site Survey Data (Number of Buildings)

\begin{tabular}{|c|c|c|c|c|c|c|c|}
\hline \multirow{2}{*}{ Premise Type } & \multicolumn{6}{|c|}{ Climate Zone } & \multirow{2}{*}{ Total } \\
\hline & IA & IIA & IIB & III & IV & OTHER & \\
\hline Low Rise Office ${ }^{2}$ & 5 & 4 & 19 & 45 & 43 & 2 & 118 \\
\hline High Rise Office ${ }^{a}$ & 0 & 1 & 2 & 4 & 48 & n & 55 \\
\hline Retail Stores & 8 & 9 & 27 & 42 & 46 & 1 & 133 \\
\hline Food Stores & 3 & 11 & 23 & 21 & 30 & 0 & 88 \\
\hline \multicolumn{8}{|l|}{ Warehouses } \\
\hline Refrigerated & $\mathbf{0}$ & 3 & 3 & 2 & 6 & 0 & 14 \\
\hline Non-Refrigerated & $\mathbf{0}$ & 4 & 4 & 7 & 5 & 2 & 22 \\
\hline School $^{b}$ & 2 & 4 & 12 & 24 & 9 & 2 & 53 \\
\hline College $e^{c}$ & $\mathbf{0}$ & $\mathbf{0}$ & 0 & 0 & 1 & 0 & 1 \\
\hline Health & 3 & 5 & 16 & 32 & 29 & 5 & 90 \\
\hline \multicolumn{8}{|l|}{ Restaurants } \\
\hline Sit-Down & 6 & 3 & 5 & 27 & 19 & 3 & 63 \\
\hline Fast-Food & 1 & 1 & 7 & 4 & 7 & 2 & 22 \\
\hline Lodging & 3 & 2 & 5 & 10 & 14 & 0 & 34 \\
\hline Miscellaneous & 16 & 22 & 32 & 42 & 48 & 2 & 162 \\
\hline Total & 47 & 69 & 155 & 260 & 305 & 19 & 855 \\
\hline
\end{tabular}

a The on-site survey divides the office building into low rises (number of floors $\leq 5$ ) and high rises (Number of Floors $>5$ ).

b All Schools are primary schools; the survey has not compiled data for secondary schools. We used other data sources for prototype development.

c Only one college building was surveyed. We used other data sources for prototype development.

The on-site survey classifies premises by their primary SIC category, but also contains fields which specify the amount of floor space used for various activities such as office, retail, food store, refrigerated and non-refrigerated storage, dining, health cooking, etc. These fields were used to check that premises classified by SIC did in fact use a majority of their floor space for that purpose. We reviewed all of the on-site survey data and constructed a revised data base based on the following two criteria: 
1. Excluded all the buildings from a premise type (as specified by SIC) whose major floor-area activity does not correspond with that premise type ( $<50 \%)$; and

2. Included all the buildings from other other premise types (as specified by SIC) whose major floor-area activity corresponds with that premise type (> 50\%).

With this modification, the number of buildings was changed in almost all the premise types. The revised number of buildings in all the premise types is summarized in Table 3-2.

We performed statistical analysis for several key variables to assess the quality of the data for developing a prototypical building. The primary variables selected for this analysis inclided building size (gross floor area), fraction of heated and cooled floor area, number of floors, window-to-wall ratio, wall and roof R-values, number of standard days per week, number of operating hours on standard days, floor area per person, indoor and outdoor lighting intensities, other equipment usage such as hot water, cooking, refrigeration, and office equipment. Table 3-3 summarizes the result of this analysis for all the buildings. The statistics shown include an overall population average of the variable, the variable mean, median, standard deviation, maximum, and minimum values. The population average values are calculated for intensity variables by summing and dividing by the total population. For example, the population average of the fraction of heated floor area is calculated by dividing the total heated floor area of the population by the total gross floor area of the population, while mean fraction of heated floor area is calculated by taking average of fractions of heated floor area in individual buildings.

Despite our extensive efforts to remove all questionable values from the on-site survey, there are a few outliers. Most noticeable among them are the maximum window-to-wall ratios (office, retail, food store, non-refrigerated warehouse, primary school, health, sit-down restaurants, lodging and miscellaneous buildings) and minimum floor area per person (small office, food store, primary school, sit-down restaurant and miscellaneous buildings). 
Table 3-2. Statistics of the 1986 PG\&E On-Site Survey

(Number of Buildings)

\begin{tabular}{|l|c|c|c|c|}
\hline \multicolumn{5}{|c|}{ Distribution of PG\&E On-Site Survey Data } \\
\hline \hline \multicolumn{1}{|c|}{ Premise Type } & Initial number & \# Dropped Out & \# Moved In & Net Total \\
\hline Office & 173 & 23 & 12 & 162 \\
\hline Retail & 133 & 29 & 13 & 117 \\
\hline Food Stores & 88 & 2 & 4 & 90 \\
\hline Warehouse & 14 & 1 & 0 & 13 \\
Refrigerated & 22 & 2 & 2 & 22 \\
Non-refrigerated & & & & \\
\hline School & 51 & 0 & 0 & 51 \\
Primary Schools & 0 & 0 & 0 & 0 \\
Secondary Schools & 2 & 0 & 0 & 2 \\
Vocational & 1 & 0 & 0 & 1 \\
\hline College & 56 & 2 & 0 & 54 \\
\hline Health* & 9 & 0 & 1 & 10 \\
Hospitals & 63 & 3 & 5 & 65 \\
Nursing Homes & 22 & 0 & 0 & 22 \\
\hline Restaurant & & & & \\
Sit down & 21 & 0 & 0 & 12 \\
Fast food & 12 & 0 & 3 & 155 \\
\hline Lodging & 162 & 10 & 41 & 798 \\
Small Hotel/Motel & 829 & 72 & & \\
Large Hotel & & & & \\
\hline Miscellaneous & & & & \\
\hline Total & & & & \\
\hline
\end{tabular}

* Clinics are included in office buildings. 
Table 3-3. Summary of Building Characteristics in the 1986 PG\&E On-Site Survey

\begin{tabular}{|c|c|c|c|c|c|c|c|}
\hline Type & Population Avg & Mean & Median & Std Dev & $\operatorname{Max}$ & Min & $\mathbf{N}$ \\
\hline \multicolumn{8}{|c|}{ Gross Floor Area $\left(\mathrm{ft}^{2}\right)$} \\
\hline \multicolumn{8}{|l|}{ Office } \\
\hline Small & N/A & 3421.0 & 5855.0 & 5499.0 & 112500.0 & 700.0 & 76 \\
\hline Large & N/A & 98085.0 & 272500.0 & 157128.0 & 1400000.0 & 1325.0 & 72 \\
\hline \multicolumn{8}{|l|}{ Retail } \\
\hline Small & N/A & 3237.0 & 3832.0 & 4315.0 & 44439.0 & 280.0 & 80 \\
\hline Large & N/A & 98351.0 & 80105.0 & 142003.0 & 800800.0 & 4680.0 & 26 \\
\hline $\begin{array}{l}\text { Food Stores } \\
\text { Warehouse }\end{array}$ & N/A & 4431.5 & 3250.0 & 7545.4 & 150000.0 & 124.0 & 90 \\
\hline Refrigerated & N/A & 53200.2 & 34000.0 & 59884.5 & 512258.0 & 2200.0 & 13 \\
\hline Non-Refrigerated & N/A & 6040.2 & 12480.0 & 13219.5 & 96000.0 & 940.0 & 22 \\
\hline Primary Schools & N/A & 6361.7 & 6500.0 & 8292.3 & 46500.0 & 676.0 & 51 \\
\hline College & N/A & 21380.0 & 21380.0 & 0.0 & 21380.0 & 21380.0 & 1 \\
\hline Vocational & $\mathbf{N} / \mathbf{A}$ & 6045.4 & 9554.0 & 3900.1 & 14800.0 & 4308.0 & 2 \\
\hline \multicolumn{8}{|l|}{ Health } \\
\hline Hospitals & N/A & 132036.2 & 192500.0 & 136359.4 & 560211.0 & 7680.0 & 54 \\
\hline \multicolumn{8}{|l|}{ Restaurants } \\
\hline Sit Down & N/A & 3024.6 & 3056.0 & 2166.6 & 21600.0 & 670.0 & 65 \\
\hline Fast Food & N/A & 1649.8 & 1762.5 & 906.8 & 5250.0 & 576.0 & 22 \\
\hline \multicolumn{8}{|l|}{ Lodging } \\
\hline Small Hotel/Motel & N/A & 8304.4 & 15762.0 & 9030.0 & 50900.0 & 1473.0 & 22 \\
\hline Large Hotel & N/A & 205328.6 & 445065.0 & 209996.6 & 1018085.0 & 63000.0 & 12 \\
\hline Miscellaneous & N/A & 8826.0 & 6000.0 & 23147.8 & 945570.0 & 180.0 & 155 \\
\hline \multicolumn{8}{|c|}{ Fraction of Floor Area Heated } \\
\hline \multicolumn{8}{|l|}{ Office } \\
\hline Small & 0.9 & 0.9 & 1.0 & 0.2 & 1.0 & 0.2 & 76 \\
\hline Large & 0.9 & 0.9 & 1.0 & 0.2 & 1.0 & 0.0 & 72 \\
\hline \multicolumn{8}{|l|}{ Retail } \\
\hline Small & 0.8 & 0.8 & 1.0 & 0.3 & 1.0 & 0.0 & 80 \\
\hline Large & 0.9 & 0.9 & 1.0 & 0.3 & 1.0 & 0.0 & 26 \\
\hline Food Stores & 0.7 & 0.7 & 0.8 & 0.4 & 1.0 & 0.0 & 90 \\
\hline \multicolumn{8}{|l|}{ Warehouse } \\
\hline Refrigerated & 0.0 & 0.2 & 0.1 & 0.2 & 0.6 & 0.0 & 13 \\
\hline Non-Refrigerated & 0.5 & 0.7 & 0.3 & 0.4 & 1.0 & 0.0 & 22 \\
\hline Primary Schools & 1.0 & 1.0 & 1.0 & 0.0 & 1.0 & 0.9 & 51 \\
\hline College & 1.0 & 1.0 & 1.0 & 0.0 & 1.0 & 1.0 & 1 \\
\hline Vocational & 1.0 & 1.0 & 1.0 & 0.0 & 1.0 & 1.0 & 2 \\
\hline \multicolumn{8}{|l|}{ Health } \\
\hline Hospitals & 1.0 & 1.0 & 1.0 & 0.0 & 1.0 & 0.8 & 54 \\
\hline Nursing Home & 0.9 & 0.9 & 1.0 & 0.1 & 1.0 & 0.8 & 10 \\
\hline \multicolumn{8}{|l|}{ Restaurants } \\
\hline Sit Down & 0.9 & 0.8 & 1.0 & 0.3 & 1.0 & 0.0 & 65 \\
\hline Fast Food & 0.8 & 0.7 & 1.0 & 0.4 & 1.0 & 0.0 & 22 \\
\hline \multicolumn{8}{|l|}{ Lodging } \\
\hline Small Hotel/Motel & 1.0 & 1.0 & 1.0 & 0.0 & 1.0 & 0.8 & 22 \\
\hline Large Hotel & 1.0 & 1.0 & 1.0 & 0.1 & 1.0 & 0.7 & 12 \\
\hline Miscellaneous & 0.8 & 0.7 & 1.0 & 0.4 & 1.0 & 0.0 & 155 \\
\hline
\end{tabular}


Table 3-3 (Continued). Summary of Building Characteristics in the 1986 PG\&E On-Site Survey

\begin{tabular}{|c|c|c|c|c|c|c|c|}
\hline Type & Population Avg & Mean & Median & Std Dev & Max & Min & $\mathbf{N}$ \\
\hline \multicolumn{8}{|c|}{ Fraction of Floor Area Cooled } \\
\hline \multicolumn{8}{|l|}{ Office } \\
\hline Small & 0.9 & 0.8 & 1.0 & 0.4 & 1.0 & 0.0 & 76 \\
\hline Large & 0.9 & 0.9 & 1.0 & 0.2 & 1.0 & 0.3 & 72 \\
\hline \multicolumn{8}{|l|}{ Retail } \\
\hline Small & 0.7 & 0.7 & 1.0 & 0.5 & 1.0 & 0.0 & 80 \\
\hline Large & 1.0 & 0.9 & 1.0 & 0.2 & 1.0 & 0.0 & 26 \\
\hline \multicolumn{3}{|l|}{ Warehouse } & 0.8 & 0.4 & 1.0 & 0.0 & 90 \\
\hline Refrigerated & 0.0 & 0.2 & 0.1 & 0.2 & 0.6 & 0.0 & 13 \\
\hline Non-Refrigerated & 0.2 & 0.2 & 0.1 & 0.4 & 1.0 & 0.0 & 22 \\
\hline Primary Schools & 0.6 & 0.7 & 1.0 & 0.5 & 1.0 & 0.0 & 51 \\
\hline College & 0.0 & 0.0 & 0.0 & 0.0 & 0.0 & 0.0 & 1 \\
\hline Vocational & 1.0 & 1.0 & 1.0 & 0.0 & 1.0 & 1.0 & 2 \\
\hline \multicolumn{8}{|l|}{ Health } \\
\hline Hospitals & 0.9 & 1.0 & 1.0 & 0.1 & 1.0 & 0.0 & 54 \\
\hline Nursing Home & 0.7 & 0.7 & 0.1 & 0.4 & 1.0 & 0.0 & 10 \\
\hline \multicolumn{8}{|l|}{ Restaurants } \\
\hline Sit Down & 0.7 & 0.7 & 0.9 & 0.4 & 1.0 & 0.0 & 65 \\
\hline \multirow{2}{*}{\multicolumn{8}{|c|}{ Lodging }} \\
\hline & & & & & & & \\
\hline Small Hotel/Motel & 0.4 & 0.4 & 0.5 & 0.5 & 1.0 & 0.0 & 22 \\
\hline Large Hotel & 0.9 & 0.8 & 1.0 & 0.3 & 1.0 & 0.0 & 12 \\
\hline Miscellaneous & 0.5 & 0.4 & 0.5 & 0.4 & 1.0 & 0.0 & 155 \\
\hline \multicolumn{8}{|c|}{ Window to Wall Ratio } \\
\hline \multicolumn{8}{|l|}{ Office } \\
\hline Small & 0.2 & 0.3 & 0.2 & 0.2 & 1.9 & 0.0 & 74 \\
\hline Large & 0.6 & 1.0 & 0.7 & 2.1 & 19.4 & 0.0 & 70 \\
\hline \multicolumn{8}{|l|}{ Retail } \\
\hline Small & 0.2 & 0.4 & 0.2 & 0.5 & 2.5 & 0.0 & 74 \\
\hline Large & 0.3 & 0.2 & 0.1 & 0.2 & 1.1 & 0.0 & 24 \\
\hline \multirow{2}{*}{\multicolumn{8}{|c|}{ Warehouse }} \\
\hline & & & & & & & \\
\hline Refrigerated & 0.0 & 0.1 & 0.1 & 0.1 & 0.6 & 0.0 & 8 \\
\hline Non-Refrigerated & 0.1 & 0.4 & 0.1 & 0.5 & 2.0 & 0.0 & 21 \\
\hline Primary Schools & 0.2 & 0.3 & 0.2 & 0.3 & 2.2 & 0.0 & 49 \\
\hline College & 0.5 & 0.5 & 0.5 & 0.0 & 0.5 & 0.5 & 1 \\
\hline Vocational & 0.3 & \multicolumn{5}{|c|}{ Health } & 2 \\
\hline Hospitals & 0.4 & 0.5 & 0.4 & 0.5 & 4.0 & 0.0 & 52 \\
\hline Nursing Home & 0.2 & 0.3 & 0.3 & 0.2 & 1.0 & 0.0 & 10 \\
\hline \multicolumn{8}{|l|}{ Restaurants } \\
\hline Sit Down & 0.1 & 0.3 & 0.1 & 0.4 & 2.8 & 0.0 & 62 \\
\hline Fast Food & 0.2 & 0.4 & 0.3 & 0.3 & 0.9 & 0.0 & 20 \\
\hline \multicolumn{8}{|l|}{ Lodging } \\
\hline Small Hotel/Motel & 0.1 & 0.1 & 0.1 & 0.2 & 1.2 & 0.0 & 22 \\
\hline Large Hotel & 1.1 & 1.0 & 0.6 & 0.9 & 2.3 & 0.2 & 12 \\
\hline Miscellaneous & 1.3 & 11.9 & 0.1 & 75.9 & 525.0 & 0.0 & 139 \\
\hline
\end{tabular}


Table 3-3 (Continued). Summary of Building Characteristics in the 1986 PG\&E On-Site Survey

\begin{tabular}{|c|c|c|c|c|c|c|c|}
\hline Type & Population Avg & Mean & Median & Std Dev & $\operatorname{Max}$ & Min & $\mathbf{N}$ \\
\hline \multicolumn{8}{|c|}{ Wall R-Value } \\
\hline \multicolumn{8}{|l|}{ Office } \\
\hline Small & N/A & 6.9 & 4.0 & 4.9 & 16.4 & 1.6 & 75 \\
\hline Large & N/A & 6.8 & 5.3 & 5.2 & 23.2 & 1.3 & 70 \\
\hline \multicolumn{8}{|l|}{ Retail } \\
\hline Small & N/A & 4.5 & 3.0 & 4.1 & 20.5 & 1.7 & 75 \\
\hline Large & N/A & 5.0 & 3.6 & 4.3 & 22.5 & 1.7 & 25 \\
\hline \multicolumn{8}{|l|}{ Warehouse } \\
\hline Refrigerated & N/A & 13.6 & 8.0 & 9.2 & 35.6 & 0.8 & 13 \\
\hline Non-Refrigerated & N/A & 4.5 & 3.5 & 2.5 & 16.4 & 1.7 & 22 \\
\hline Primary Schools & N/A & 7.1 & 3.3 & 5.7 & 27.3 & 1.6 & 51 \\
\hline College & N/A & 2.5 & 2.5 & 0.0 & 2.5 & 2.5 & 1 \\
\hline Vocational & N/A & 5.3 & 8.2 & 3.3 & 12.7 & 3.8 & 2 \\
\hline \multicolumn{8}{|l|}{ Health } \\
\hline Nursing Home & $\mathbf{N} / \mathbf{A}$ & 4.9 & 3.6 & 2.6 & 13.6 & 2.6 & 10 \\
\hline \multicolumn{8}{|l|}{ Restaurants } \\
\hline Sit Down & N/A & 4.9 & 3.2 & 3.7 & 14.7 & 1.5 & 65 \\
\hline Fast Food & N/A & 7.1 & 4.1 & 4.5 & 15.2 & 2.0 & 21 \\
\hline \multicolumn{8}{|l|}{ Lodging } \\
\hline Small Hotel/Motel & N/A & 5.3 & 5.2 & 3.1 & 16.4 & 1.5 & 22 \\
\hline Large Hotel & N/A & 7.8 & 4.2 & 7.3 & 18.8 & 2.0 & 12 \\
\hline Miscellaneous & N/A & 5.2 & 3.3 & 4.0 & 28.4 & 0.9 & 151 \\
\hline \multicolumn{8}{|c|}{ Roof R-Value } \\
\hline \multicolumn{8}{|l|}{ Office } \\
\hline Small & N/A & 10.2 & 12.8 & 7.3 & 51.1 & 1.8 & 75 \\
\hline Large & N/A & 9.6 & 10.0 & 7.1 & 27.7 & 1.7 & 69 \\
\hline \multicolumn{8}{|l|}{ Retail } \\
\hline Small & N/A & 8.6 & 8.4 & 7.5 & 37.6 & 1.2 & 74 \\
\hline Large & N/A & 11.7 & 11.2 & 6.5 & 43.5 & 1.2 & 24 \\
\hline Food Stores & N/A & 8.6 & 10.0 & 6.4 & 32.9 & 1.0 & 83 \\
\hline \multicolumn{8}{|l|}{ Warehouse } \\
\hline Refrigerated & N/A & 17.2 & 13.6 & 13.6 & 40.8 & 1.2 & 13 \\
\hline Non-Refrigerated & N/A & 9.5 & 6.9 & 7.0 & 27.4 & 1.8 & 22 \\
\hline Primary Schools & N/A & 24.0 & 6.9 & 75.3 & 380.1 & 1.2 & 50 \\
\hline College & N/A & 13.7 & 13.7 & 0.0 & 13.7 & 13.7 & 1 \\
\hline Vocational & N/A & 4.2 & 7.9 & 4.1 & 13.4 & 2.4 & 2 \\
\hline \multicolumn{8}{|l|}{ Health } \\
\hline Hospitals & N/A & 10.9 & 9.1 & 6.4 & 37.1 & 1.2 & 54 \\
\hline Nursing Home & N/A & 11.4 & 14.2 & 7.5 & 70.8 & 3.1 & 10 \\
\hline \multicolumn{8}{|l|}{ Restaurants } \\
\hline Sit Down & N/A & 9.8 & 8.3 & 7.6 & 26.2 & 1.5 & 59 \\
\hline Fast Food & N/A & 12.2 & 10.2 & 9.1 & 24.4 & 1.9 & 21 \\
\hline \multicolumn{8}{|l|}{ Lodging } \\
\hline Small Hotel/Motel & N/A & 10.2 & 9.4 & 5.9 & 25.1 & 2.3 & 22 \\
\hline Large Hotel & N/A & 17.9 & 9.0 & 11.3 & 29.2 & 3.4 & 12 \\
\hline Miscellaneous & N/A & 9.0 & 5.8 & 7.9 & 28.5 & 0.9 & 149 \\
\hline
\end{tabular}


Table 3-3 (Continued). Summary of Building Characteristics in the 1986 PG\&E On-Site Survey

\begin{tabular}{|c|c|c|c|c|c|c|c|}
\hline Type & Population Avg & Mean & Modian & Sid Dev & Max & Min & $\mathbf{N}$ \\
\hline \multicolumn{8}{|c|}{ No. of Standard Days } \\
\hline $\begin{array}{l}\text { Office } \\
\text { Small } \\
\text { Large }\end{array}$ & $\begin{array}{l}\text { N/A } \\
\text { N/A }\end{array}$ & $\begin{array}{l}5.3 \\
5.3\end{array}$ & $\begin{array}{l}5.0 \\
5.0\end{array}$ & $\begin{array}{l}0.9 \\
0.7\end{array}$ & $\begin{array}{l}7.0 \\
7.0\end{array}$ & $\begin{array}{l}4.0 \\
5.0\end{array}$ & $\begin{array}{l}76 \\
72\end{array}$ \\
\hline $\begin{array}{l}\text { Small } \\
\text { Large } \\
\text { Food Stores } \\
\text { Warehouse }\end{array}$ & $\begin{array}{l}\text { N/A } \\
\text { N/A } \\
\text { N/A }\end{array}$ & $\begin{array}{l}5.3 \\
5.3 \\
6.5\end{array}$ & $\begin{array}{l}5.0 \\
5.0 \\
7.0\end{array}$ & $\begin{array}{l}0.8 \\
0.9 \\
0.7\end{array}$ & $\begin{array}{l}7.0 \\
7.0 \\
7.0\end{array}$ & $\begin{array}{l}3.0 \\
3.0 \\
3.0\end{array}$ & $\begin{array}{l}80 \\
26 \\
90\end{array}$ \\
\hline $\begin{array}{l}\text { Refrigerated } \\
\text { Non-Refrigerated } \\
\text { Primary Schools } \\
\text { College } \\
\text { Vocational } \\
\text { Health }\end{array}$ & $\begin{array}{l}\text { N/A } \\
\text { N/A } \\
\text { N/A } \\
\text { N/A } \\
\text { N/A }\end{array}$ & $\begin{array}{l}5.1 \\
5.4 \\
5.0 \\
5.0 \\
5.0\end{array}$ & $\begin{array}{l}5.0 \\
5.0 \\
5.0 \\
5.0 \\
5.0\end{array}$ & $\begin{array}{l}0.5 \\
1.4 \\
0.1 \\
0.0 \\
0.0\end{array}$ & $\begin{array}{l}7.0 \\
7.0 \\
6.0 \\
5.0 \\
5.0\end{array}$ & $\begin{array}{l}5.0 \\
3.0 \\
5.0 \\
5.0 \\
5.0\end{array}$ & $\begin{array}{r}13 \\
22 \\
51 \\
1 \\
2\end{array}$ \\
\hline $\begin{array}{l}\text { Hospitals } \\
\text { Nursing Home } \\
\text { Restaurants }\end{array}$ & $\begin{array}{l}\text { N/A } \\
\text { N/A }\end{array}$ & $\begin{array}{l}6.9 \\
7.0\end{array}$ & $\begin{array}{l}7.0 \\
7.0\end{array}$ & $\begin{array}{l}0.4 \\
0.0\end{array}$ & $\begin{array}{l}7.0 \\
7.0\end{array}$ & $\begin{array}{l}5.0 \\
7.0\end{array}$ & $\begin{array}{l}54 \\
10\end{array}$ \\
\hline $\begin{array}{l}\text { Sit Down } \\
\text { Fast Food } \\
\text { Lodging }\end{array}$ & $\begin{array}{l}\text { N/A } \\
\text { N/A }\end{array}$ & $\begin{array}{l}6.3 \\
6.2\end{array}$ & $\begin{array}{l}7.0 \\
7.0\end{array}$ & $\begin{array}{l}0.9 \\
0.9\end{array}$ & $\begin{array}{l}7.0 \\
7.0\end{array}$ & $\begin{array}{l}4.0 \\
5.0\end{array}$ & $\begin{array}{l}65 \\
22\end{array}$ \\
\hline $\begin{array}{l}\text { Small Hotel/Motel } \\
\text { Large Hotel } \\
\text { Miscellaneous }\end{array}$ & $\begin{array}{l}\text { N/A } \\
\text { N/A } \\
\text { N/A }\end{array}$ & $\begin{array}{l}7.0 \\
7.0 \\
5.1\end{array}$ & $\begin{array}{l}7.0 \\
7.0 \\
5.0\end{array}$ & $\begin{array}{l}0.0 \\
0.0 \\
1.6\end{array}$ & $\begin{array}{l}7.0 \\
7.0 \\
7.0\end{array}$ & $\begin{array}{l}7.0 \\
7.0 \\
1.0\end{array}$ & $\begin{array}{r}22 \\
12 \\
155\end{array}$ \\
\hline \multicolumn{8}{|c|}{ Standard Day Hours } \\
\hline $\begin{array}{l}\text { Office } \\
\text { Small } \\
\text { Large } \\
\text { Retail }\end{array}$ & $\begin{array}{l}\text { N/A } \\
\text { N/A }\end{array}$ & $\begin{array}{r}9.5 \\
11.9\end{array}$ & $\begin{array}{r}9.0 \\
10.0\end{array}$ & $\begin{array}{l}2.3 \\
5.3\end{array}$ & $\begin{array}{l}18.0 \\
24.0\end{array}$ & $\begin{array}{l}5.0 \\
5.0\end{array}$ & $\begin{array}{l}76 \\
72\end{array}$ \\
\hline $\begin{array}{l}\text { Small } \\
\text { Large } \\
\text { Food Stores } \\
\text { Warehouse }\end{array}$ & $\begin{array}{l}\text { N/A } \\
\text { N/A } \\
\text { N/A }\end{array}$ & $\begin{array}{r}8.9 \\
11.6 \\
13.5\end{array}$ & $\begin{array}{l}10.0 \\
11.0 \\
13.0\end{array}$ & $\begin{array}{l}2.5 \\
1.9 \\
4.1\end{array}$ & $\begin{array}{l}24.0 \\
17.0 \\
24.0\end{array}$ & $\begin{array}{l}1.0 \\
8.0 \\
1.0\end{array}$ & $\begin{array}{l}80 \\
26 \\
90\end{array}$ \\
\hline $\begin{array}{l}\text { Refrigerated } \\
\text { Non-Refrigerated } \\
\text { Primary Schools } \\
\text { College } \\
\text { Vocational } \\
\text { Health }\end{array}$ & $\begin{array}{l}\text { N/A } \\
\text { N/A } \\
\text { N/A } \\
\text { N/A } \\
\text { N/A }\end{array}$ & $\begin{array}{r}9.6 \\
8.1 \\
9.2 \\
9.0 \\
11.5\end{array}$ & $\begin{array}{r}9.0 \\
9.0 \\
9.0 \\
9.0 \\
10.5\end{array}$ & $\begin{array}{l}4.6 \\
3.1 \\
1.6 \\
0.0 \\
1.1\end{array}$ & $\begin{array}{r}24.0 \\
24.0 \\
17.0 \\
9.0 \\
12.0\end{array}$ & $\begin{array}{l}6.0 \\
2.0 \\
7.0 \\
9.0 \\
9.0\end{array}$ & $\begin{array}{r}13 \\
22 \\
51 \\
1 \\
2\end{array}$ \\
\hline $\begin{array}{l}\text { Hospitals } \\
\text { Nursing Home } \\
\text { Restaurants }\end{array}$ & $\begin{array}{l}\text { N/A } \\
\mathbf{N} / \mathbf{A}\end{array}$ & $\begin{array}{l}22.8 \\
24.0\end{array}$ & $\begin{array}{l}24.0 \\
24.0\end{array}$ & $\begin{array}{l}3.8 \\
0.5\end{array}$ & $\begin{array}{l}24.0 \\
24.0\end{array}$ & $\begin{array}{r}8.0 \\
15.0\end{array}$ & $\begin{array}{l}54 \\
10\end{array}$ \\
\hline $\begin{array}{l}\text { Sit Down } \\
\text { Fast Food } \\
\text { Lodging }\end{array}$ & $\begin{array}{l}\text { N/A } \\
\text { N/A }\end{array}$ & $\begin{array}{l}10.3 \\
13.9\end{array}$ & $\begin{array}{l}12.0 \\
12.0\end{array}$ & $\begin{array}{l}4.6 \\
5.0\end{array}$ & $\begin{array}{l}24.0 \\
24.0\end{array}$ & $\begin{array}{l}0.0 \\
8.0\end{array}$ & $\begin{array}{l}64 \\
22\end{array}$ \\
\hline $\begin{array}{l}\text { Small Hotel/Motel } \\
\text { Large Hotel } \\
\text { Miscellaneous }\end{array}$ & $\begin{array}{l}\text { N/A } \\
\text { N/A } \\
\text { N/A }\end{array}$ & $\begin{array}{r}20.0 \\
24.0 \\
9.7\end{array}$ & $\begin{array}{l}24.0 \\
24.0 \\
10.0\end{array}$ & $\begin{array}{l}6.8 \\
0.5 \\
5.2\end{array}$ & $\begin{array}{l}24.0 \\
24.0 \\
24.0\end{array}$ & $\begin{array}{r}8.0 \\
18.0 \\
0.0\end{array}$ & $\begin{array}{r}22 \\
12 \\
154\end{array}$ \\
\hline
\end{tabular}


Table 3-3 (Continued). Summary of Building Characteristics in the 1986 PG\&E On-Site Survey

\begin{tabular}{|c|c|c|c|c|c|c|c|}
\hline Type & Population Avg & Mean & Median & Std Dev & Max & Min & $\mathbf{N}$ \\
\hline \multicolumn{8}{|c|}{ Floor Area per Perron $\left(\mathrm{ft}^{2}\right)$} \\
\hline \multicolumn{8}{|l|}{ Office } \\
\hline $\begin{array}{l}\text { Small } \\
\text { Large } \\
\text { Retail }\end{array}$ & $\begin{array}{r}73.1 \\
198.1\end{array}$ & $\begin{array}{l}209.6 \\
210.2\end{array}$ & $\begin{array}{l}155.7 \\
242.9\end{array}$ & $\begin{array}{l}260.9 \\
140.5\end{array}$ & $\begin{array}{l}1260.0 \\
1145.7\end{array}$ & $\begin{array}{r}3.6 \\
20.7\end{array}$ & $\begin{array}{l}76 \\
72\end{array}$ \\
\hline Small & 102.0 & 180.3 & 175.9 & 211.1 & 1269.7 & 12.7 & 80 \\
\hline Large & 267.6 & 358.5 & 270.4 & 385.0 & 1792.3 & 18.3 & 26 \\
\hline \multicolumn{8}{|l|}{ Warehouse } \\
\hline Refrigerated & 1078.3 & 1152.5 & 1090.9 & 1490.2 & 6500.0 & 184.6 & 13 \\
\hline Non-Refrigerated & 464.5 & 691.2 & 539.7 & 1850.6 & 24000.0 & 67.1 & 22 \\
\hline Primary Schools & 26.9 & 100.9 & 39.2 & 211.8 & 1440.0 & 1.0 & 50 \\
\hline College & 237.6 & 237.6 & 237.6 & 0.0 & 237.6 & 237.6 & 1 \\
\hline $\begin{array}{l}\text { Vocational } \\
\text { Health }\end{array}$ & 39.9 & 37.3 & 50.6 & 14.8 & 70.5 & 30.8 & 2 \\
\hline Hospitals & 190.4 & 250.3 & 234.6 & 196.0 & 1156.1 & 42.4 & 54 \\
\hline Nursing Home & 273.4 & 307.1 & 203.2 & 150.0 & 666.7 & 140.2 & 10 \\
\hline \multicolumn{8}{|l|}{ Restaurants } \\
\hline Sit Down & 38.0 & 57.1 & 43.2 & 53.6 & 290.0 & 6.4 & 65 \\
\hline \multicolumn{7}{|l|}{ Lodging } & 22 \\
\hline Small Hotel/Motel & 212.0 & 408.4 & 218.5 & 440.7 & 1187.5 & 17.0 & 22 \\
\hline Large Hotel & 411.6 & 422.6 & 436.0 & 123.0 & 737.3 & 87.5 & 12 \\
\hline Miscellaneous & 236.3 & 373.2 & 248.9 & 620.2 & 4173.3 & 3.8 & 155 \\
\hline \multicolumn{8}{|c|}{ Indoor Lighting Intensity $\left(\mathrm{W} / \mathrm{ft}^{2}\right)$} \\
\hline \multicolumn{8}{|l|}{ Office } \\
\hline Small & 2.2 & 2.1 & 2.1 & 1.3 & 7.5 & 0.0 & 76 \\
\hline Large & 1.6 & 1.8 & 1.5 & 0.9 & 4.6 & 0.5 & 72 \\
\hline \multicolumn{8}{|l|}{ Retail } \\
\hline Small & 2.2 & 2.4 & 2.1 & 1.4 & 9.5 & 0.5 & 80 \\
\hline Large & 1.8 & 2.0 & 1.8 & 1.1 & 7.1 & 0.8 & 26 \\
\hline Food Stores & 1.7 & 1.6 & 2.0 & 0.9 & 4.3 & 0.4 & 90 \\
\hline \multicolumn{8}{|l|}{ Warehouse } \\
\hline Refrigerated & 0.5 & 0.6 & 0.6 & 0.4 & 1.7 & 0.2 & 13 \\
\hline Non-Refrigerated & 1.0 & 1.0 & 1.1 & 0.5 & 5.5 & 0.1 & 22 \\
\hline Primary Schools & 1.9 & 2.5 & 1.7 & 1.3 & 5.1 & 0.4 & 51 \\
\hline College & 1.5 & 1.5 & 1.5 & 0.0 & 1.5 & 1.5 & 1 \\
\hline Vocational & 1.2 & 1.0 & 1.2 & 0.2 & 1.4 & 1.0 & 2 \\
\hline \multicolumn{8}{|l|}{ Health } \\
\hline Hospitals & 1.8 & 2.0 & 1.3 & 1.2 & 3.9 & 0.4 & 54 \\
\hline Nursing Home & 0.9 & 0.9 & 0.9 & 0.3 & 1.6 & 0.3 & 10 \\
\hline \multicolumn{8}{|l|}{ Restaurants } \\
\hline Sit Down & 1.3 & 1.4 & 1.3 & 1.0 & 6.5 & 0.3 & 65 \\
\hline Fast Food & 2.3 & 2.3 & 2.4 & 1.1 & 4.3 & 0.2 & 22 \\
\hline \multicolumn{8}{|l|}{ Lodging } \\
\hline Small Hotel/Motel & 1.0 & 0.9 & 1.0 & 0.6 & 2.8 & 0.3 & 22 \\
\hline Large Hotel & 0.9 & 1.3 & 1.1 & 0.8 & 2.7 & 0.3 & 12 \\
\hline Miscellaneous & 0.9 & 1.3 & 1.1 & 1.4 & 38.0 & 0.1 & 152 \\
\hline
\end{tabular}


Table 3-3 (Continued). Summary of Building Characteristics in the 1986 PG\&E On-Site Survey

\begin{tabular}{|c|c|c|c|c|c|c|c|}
\hline Type & Population Avg & Mean & Median & Std Dev & Max & Min & $\mathbf{N}$ \\
\hline \multicolumn{8}{|c|}{ Outdoor Lighting Intensity $\left(\mathrm{W} / \mathrm{ft}^{2}\right)$} \\
\hline \multicolumn{8}{|l|}{ Office } \\
\hline $\begin{array}{l}\text { Small } \\
\text { Large }\end{array}$ & 0.3 & 0.4 & 0.2 & 0.4 & 2.0 & 0.0 & 62 \\
\hline & 0.3 & 1.2 & & 55 \\
\hline Small & 0.1 & 0.4 & 0.2 & 0.8 & 7.7 & 0.0 & 51 \\
\hline Large & 0.1 & 0.3 & 0.1 & 0.8 & 3.3 & 0.0 & 19 \\
\hline \multicolumn{7}{|l|}{ Warehouse } & 80 \\
\hline Refrigerated & 0.1 & 0.1 & 0.1 & 0.1 & 0.6 & 0.0 & 12 \\
\hline Non-Refrigerated & 0.1 & 0.1 & 0.1 & 0.1 & 0.5 & 0.0 & 14 \\
\hline Primary Schools & 0.1 & 0.2 & 0.1 & 0.2 & 1.3 & 0.0 & 41 \\
\hline College & 0.0 & 0.0 & 0.0 & 0.0 & 0.0 & 0.0 & .1 \\
\hline Vocational & 0.3 & 0.2 & 0.3 & 0.1 & 0.4 & 0.1 & 2 \\
\hline \multicolumn{8}{|l|}{ Health } \\
\hline Hospitals & 0.1 & 0.1 & 0.1 & 0.1 & 0.4 & 0.0 & 54 \\
\hline Nursing Home & 0.1 & 0.1 & 0.1 & 0.0 & 0.1 & 0.0 & 10 \\
\hline \multicolumn{8}{|l|}{ Restaurants } \\
\hline Sit Down & 0.4 & 0.6 & 0.4 & 0.7 & 4.1 & 0.0 & 51 \\
\hline Fast Food & 0.9 & 1.2 & 1.3 & 1.1 & 3.9 & 0.1 & 17 \\
\hline \multicolumn{5}{|l|}{ Lodging } & & & \\
\hline Large Hotel & 0.1 & 0.2 & 0.0 & 0.2 & 0.5 & 0.0 & 10 \\
\hline Miscellaneous & 0.1 & 0.4 & 0.2 & 0.8 & 8.2 & 0.0 & 136 \\
\hline \multicolumn{8}{|c|}{ Equipment Intensity $\left(\mathrm{W} / \mathrm{ft}^{2}\right)$} \\
\hline \multicolumn{8}{|l|}{ Office } \\
\hline Small & 1.9 & 2.1 & 1.3 & 1.5 & 6.8 & 0.0 & 76 \\
\hline Large & 1.4 & 1.6 & 1.2 & 1.8 & 10.5 & 0.1 & 71 \\
\hline \multicolumn{8}{|l|}{ Retail } \\
\hline Small & 0.8 & 1.4 & 0.5 & 2.4 & 16.8 & 0.0 & 77 \\
\hline Large & 2.1 & 0.7 & 0.4 & 1.2 & 5.1 & 0.1 & 26 \\
\hline \multicolumn{7}{|l|}{ Warehouse } & 89 \\
\hline Refrigerated & 0.5 & 2.0 & 1.2 & 2.0 & 10.7 & 0.0 & 12 \\
\hline Non-Refrigerated & 1.7 & 0.8 & 0.4 & 1.2 & 13.4 & 0.1 & 21 \\
\hline Primary Schools & 0.9 & 1.4 & 0.7 & 1.1 & 5.8 & 0.0 & 47 \\
\hline College & 0.8 & 0.8 & 0.8 & 0.0 & 0.8 & 0.8 & 1 \\
\hline $\begin{array}{l}\text { Vocational } \\
\text { Health }\end{array}$ & 1.0 & \multirow{2}{*}{\multicolumn{5}{|c|}{ Health }} & 2 \\
\hline Hospitals & 2.7 & 3.3 & 1.3 & 3.8 & & & 53 \\
\hline Nursing Home & 1.3 & 1.1 & 0.8 & 0.6 & 1.8 & 0.1 & 10 \\
\hline \multicolumn{8}{|l|}{ Restaurants } \\
\hline Sit Down & 2.3 & 3.1 & 1.9 & 3.0 & 15.1 & 0.1 & 64 \\
\hline Lodging & 3.6 & 4.1 & 2.8 & 1.9 & 6.8 & 0.4 & 21 \\
\hline Small Hotel/Motel & 1.1 & 1.7 & 1.0 & 1.5 & 4.1 & 0.1 & 22 \\
\hline Large Hotel & 1.3 & 1.5 & 1.2 & 0.5 & 2.2 & 0.4 & $\overline{12}$ \\
\hline Miscellaneous & 3.5 & 11.8 & 2.3 & 66.6 & 5023.3 & 0.1 & 153 \\
\hline
\end{tabular}


Table 3-3 (Continued). Summary of Building Characteristics in the 1986 PG\&E On-Site Survey

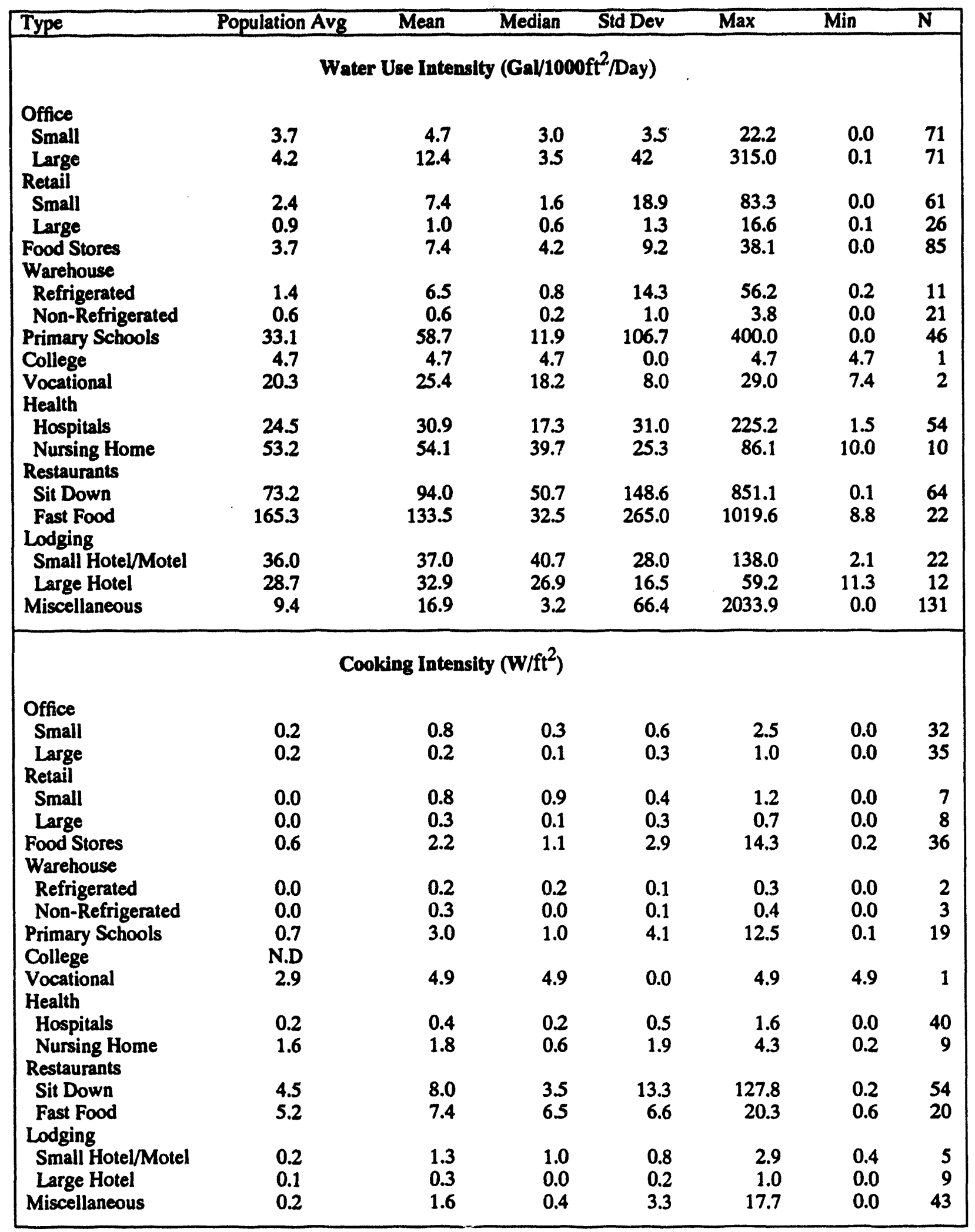


Table 3-3 (Continued). Summary of Building Characteristics in the 1986 PG\&E On-Site Survey

\begin{tabular}{|c|c|c|c|c|c|c|c|}
\hline Type & Population Avg & Mean & Median & Std Dev & Max & Min & $\mathbf{N}$ \\
\hline \multicolumn{8}{|c|}{ Refrigeration Intensity $\left(\mathrm{w} / \mathrm{ft}^{2}\right)$} \\
\hline \multicolumn{8}{|l|}{ Office } \\
\hline Small & 0.1 & 0.3 & 0.2 & 0.2 & 0.8 & 0.0 & 55 \\
\hline Large & 0.1 & 0.1 & 0.0 & 0.1 & 0.5 & 0.0 & 50 \\
\hline \multicolumn{8}{|l|}{ Retail } \\
\hline Small & 0.3 & 1.1 & 0.5 & 1.8 & 13.0 & 0.0 & 48 \\
\hline Large & 0.1 & 0.6 & 0.1 & 1.6 & 6.8 & 0.0 & 18 \\
\hline Food Stores & 5.5 & 6.5 & 5.8 & 4.9 & 23.3 & 0.5 & 90 \\
\hline \multicolumn{8}{|l|}{ Warehouse } \\
\hline Refrigerated & 8.5 & 9.6 & 11.4 & 3.9 & 31.2 & 1.1 & 13 \\
\hline Non-Refrigerated & 0.1 & 0.2 & 0.1 & 0.3 & 2.7 & 0.0 & 11 \\
\hline Primary Schools & 0.3 & 0.7 & 0.2 & 0.7 & 3.5 & 0.0 & 31 \\
\hline College & 0.1 & 0.1 & 0.1 & 0.0 & 0.1 & 0.1 & 1 \\
\hline Vocational & N.D. & & & & & & \\
\hline \multicolumn{8}{|l|}{ Health } \\
\hline Hospitals & 0.1 & 0.4 & 0.2 & 0.5 & 2.0 & 0.0 & 52 \\
\hline \multirow{2}{*}{\multicolumn{8}{|c|}{ Restaurants }} \\
\hline & & & & & & & \\
\hline Sit Down & 2.9 & 3.8 & 3.0 & 2.5 & 11.9 & 0.5 & 64 \\
\hline Fast Food & 4.8 & 6.5 & 4.4 & 5.5 & 20.5 & 2.1 & 22 \\
\hline \multicolumn{8}{|l|}{ Lodging } \\
\hline Small Hotel/Motel & 0.5 & 0.7 & 0.3 & 0.4 & 1.7 & 0.1 & 20 \\
\hline Large Hotel & 0.3 & 0.5 & 0.1 & 0.5 & 1.5 & 0.0 & 12 \\
\hline Miscellaneous & 0.2 & 0.8 & 0.3 & 1.5 & 8.0 & 0.0 & 106 \\
\hline
\end{tabular}

Four aspects of the analysis should be noted in Table 3-3:

1. We have calculated a variety of statistics for each key variable.

2. Several of these variables will directly influence the development of the prototypes.

3. We have partitioned the office and retail on-site survey data $\dagger$ into small and large categories based on the total electricity use of greater or less than $500 \mathrm{MWh} /$ year for offices and $400 \mathrm{MWh} /$ year for retail stores.

4. Lodging was divided into "Large Hotel" and "Small Hotel/Motel" based on the total floor area of greater or less than $60,000 \mathrm{ft}^{2}$.

† In the First Interim Report, we partitioned both office and retail on-site survey data into small and large categories based the following four criteria:

1. Total electricity use of greater or less than $500 \mathrm{MWh} /$ year for offices and $400 \mathrm{MWh} / \mathrm{year}$ for retail stores,

2. Gross floor area of greater or less than $50,000 \mathrm{ft}^{2}$,

3. Gross floor area of greater or less than $30,000 \mathrm{ft}^{2}$, and

4. Number of floors of greater of less than 5 .

The EDA reconciliation for Retail Stores, however, was carried out for the combined large and small retail. We developed prototypes for both large and small retail and combined the simulation results to develop. initial condi- 
The heating and cooling system types, hot water system, and fuel types for the on-site survey buildings are summarized in Table 3-4. As Table 3-4 shows most small offices and fast food restaurants have single zone package systems, while large offices and hospitals have both single and multi-zone package and central systems. Large hotels follow the pattern of large offices and hospitals except that large hotels have predominantly single zone ducting systems. Approximately $20 \%$ of all large offices and large hotels have variable air volume (VAV) air distribution systems. The percentage of buildings having economizers is high in the case of hospitals and large hotels (about 50\%) while in case of small offices/retails, food stores, warehouse (refrigerated and non-refrigerated), primary schools, sit-down/fast food restaurants, and small hotels/motels, percentage of buildings equipped with economizers ranges from $2-10 \%$. The heating fuel is predominantly gas for all the buildings except large hotels; the cooling fuel is electricity. Domestic hot water systems are fueled by both electricity and gas while most large hotels make use of gas and some hotels/motels also use oil.

To a certain extent, HVAC systems for retail stores are similar to those of the offices (Table 34). A major exception is the lower saturation of VAV systems observed in the retail stores.

tions for EDA calculations. We follow the same procedure for Warehouses (Refrigerated and Non-Refrigerated), Schools (Primary and Secondary), Health (Hospitals and Nursing homes), Restaurants (Sit Down and Fast Food), and Lodging (Small Hotel/Motel and Large Hotel). 
Table 3-4. Saturation of Heating, Cooling, System Type, Water Heating for Onsite Survey Buildings

a) Ducted System Type

\begin{tabular}{|c|c|c|c|c|c|c|c|c|c|c|}
\hline & None & Single zone & Multi-zone & Dual duct & 2-pipe & 4-pipe & Induction & VAV single & VAV dual & Other \\
\hline Office & & & & & & & & & & \\
\hline Small & 12.2 & 78.7 & 9.1 & 0.0 & 0.0 & 0.0 & 0.0 & 0.0 & 0.0 & 0.0 \\
\hline Large & 4.4 & 41.9 & 32.0 & 1.0 & 0.5 & 0.0 & 0.82 & 18.1 & 1.2 & 0.0 \\
\hline Retail & & & & & & & & & & \\
\hline Small & 41.5 & 56.0 & 0.3 & 0.0 & 0.0 & 0.3 & 0.0 & 0.0 & 0.0 & 1.9 \\
\hline Large & 4.5 & 52.4 & 35.8 & 0.0 & 0.0 & 0.2 & 0.0 & 7.0 & 0.0 & 0.0 \\
\hline Food Stores & 54.6 & 45.0 & 0.4 & 0.0 & 0.0 & 0.0 & 0.0 & 0.0 & 0.0 & 0.0 \\
\hline $\begin{array}{l}\text { Warehouse } \\
\text { Refrigerated }\end{array}$ & & & & & & & & & no & 00 \\
\hline $\begin{array}{l}\text { Refrigerated } \\
\text { Non-Refrigerated }\end{array}$ & 65.9 & 34.1 & 0.0 & 0.0 & $\begin{array}{l}0.0 \\
0.0\end{array}$ & $\begin{array}{l}0.0 \\
0.0\end{array}$ & $\begin{array}{l}0.0 \\
0.0\end{array}$ & $\begin{array}{l}0.0 \\
0.0\end{array}$ & $\begin{array}{l}0.0 \\
0.0\end{array}$ & 0.0 \\
\hline Schools & 48.9 & I1.1 & 0.0 & 0.0 & & & & & & \\
\hline Primary 20.6 & 69.2 & 7.6 & 2.1 & 0.6 & 0.0 & 0.0 & 0.0 & 0.0 & 0.0 & \\
\hline Vocational & 0.0 & 100.0 & 0.0 & 0.0 & 0.0 & 0.0 & 0.0 & 0.0 & 0.0 & 0.0 \\
\hline College & 0.0 & 100.0 & 0.0 & 0.0 & 0.0 & 0.0 & 0.0 & 0.0 & 0.0 & 0.0 \\
\hline $\begin{array}{l}\text { Health } \\
\text { Hospitals }\end{array}$ & & & $50 ?$ & 57 & 08 & 43 & 05 & 42 & n & ח \\
\hline $\begin{array}{l}\text { Hospitals } \\
\text { Nursing Home }\end{array}$ & $\begin{array}{l}0.0 \\
4.4\end{array}$ & 56.7 & $\begin{array}{r}4.5 \\
4.4\end{array}$ & $\begin{array}{l}0.1 \\
0.0\end{array}$ & 34.5 & 0.0 & 0.0 & 0.0 & 0.0 & 0.0 \\
\hline Restaurants & & & & & & & & & & \\
\hline Sit Down & 30.3 & 65.2 & 2.2 & 0.0 & 2.2 & 0.0 & 0.0 & 0.0 & 0.0 & 0.0 \\
\hline Fast Food & 18.3 & 81.7 & 0.0 & 0.0 & 0.0 & 0.0 & 0.0 & 0.0 & 0.0 & 0.0 \\
\hline Lodging & & & & & & & & & & \\
\hline SmallHotel/Motel & 92.7 & 7.3 & 0.0 & 0.0 & 0.0 & 0.0 & 0.0 & 0.0 & 0.0 & 0.0 \\
\hline LargeHotel & 14.8 & 56.6 & 1.9 & 0.0 & 1.0 & 4.8 & 0.0 & 20.9 & 0.0 & 0.0 \\
\hline Miscellaneous & 45.1 & 51.4 & 3.2 & 0.0 & 0.0 & 0.0 & 0.0 & 0.2 & 0.0 & 0.0 \\
\hline
\end{tabular}


Table 3-4 (Continued). Saturation of Heating, Cooling, System Type, Water Heating for Onsite Survey Buildings

b) Heating Equipment Type

\begin{tabular}{|c|c|c|c|c|c|c|c|c|c|c|}
\hline & None & Furnace & Baseboard & HW Boiler & Steam Boiler & Air to Air HP & Water to Air HP & Unit Heater & Radiant & Other \\
\hline \multicolumn{11}{|l|}{ Office } \\
\hline Small & 0.0 & 71.1 & 0.1 & 0.6 & 0.1 & 11.4 & 0.2 & 12.4 & 4.1 & 0.0 \\
\hline Large & 5.0 & 33.0 & 0.0 & 51.7 & 7.9 & 0.3 & 0.0 & 0.0 & 0.0 & 2.1 \\
\hline \multicolumn{11}{|l|}{$\begin{array}{l}\text { Large } \\
\text { Retail }\end{array}$} \\
\hline Small & 11.4 & 41.3 & 0.2 & 0.3 & 0.0 & 11.2 & 0.0 & 29.2 & 3.5 & 2.9 \\
\hline Large & 7.4 & 57.9 & 0.0 & 0.2 & 17.8 & 5.7 & 0.0 & 11.0 & 0.0 & 0.0 \\
\hline $\begin{array}{l}\text { Food Stores } \\
\text { Warehouse }\end{array}$ & 24.0 & 26.7 & 0.0 & 0.0 & 0.0 & 2.9 & 0.0 & 34.7 & 10.9 & 0.8 \\
\hline Refrigerated & 42.8 & 32.8 & 0.0 & \multicolumn{7}{|c|}{$\begin{array}{l}\text { Food stores } \\
\text { Warehouse }\end{array}$} \\
\hline Non-Refrigerated & 0.9 & 42.2 & $\begin{array}{r}0.0 \\
16.7\end{array}$ & 0.0 & 0.0 & 0.8 & 0.0 & 23.6 & 0.0 & 0.0 \\
\hline \multirow{2}{*}{\multicolumn{11}{|c|}{$\begin{array}{l}\text { Non-kemigerated } \\
\text { Schools }\end{array}$}} \\
\hline Primary 0.0 & 75.3 & 0.0 & 17.1 & & & & & & & \\
\hline Vocational & 0.0 & 83.4 & 0.0 & & 1.8 & $\begin{array}{l}0.0 \\
0.0\end{array}$ & $\begin{array}{l}1.1 \\
0.0\end{array}$ & 0.0 & 0.0 & \\
\hline College & 0.0 & 0.0 & 0.0 & $\begin{array}{r}16.6 \\
100.0\end{array}$ & $\begin{array}{l}0.0 \\
0.0\end{array}$ & $\begin{array}{l}0.0 \\
0.0\end{array}$ & $\begin{array}{l}0.0 \\
0.0\end{array}$ & $\begin{array}{l}0.0 \\
0.0\end{array}$ & 0.0 & 0.0 \\
\hline \multicolumn{8}{|l|}{ Health } & 0.0 & 0.0 & 0.0 \\
\hline Hospitals & 0.6 & 28.3 & 0.0 & 15.3 & 55.7 & 0.0 & 0.0 & 0.0 & 0.0 & 0.0 \\
\hline Nursing Home & 0.0 & 17.5 & 4.4 & 77.8 & 0.3 & 0.0 & 0.0 & 0.0 & 0.0 & 0.0 \\
\hline \multicolumn{11}{|l|}{$\begin{array}{l}\text { Nursing Home } \\
\text { Restaurants }\end{array}$} \\
\hline $\begin{array}{l}\text { Sit Down } \\
\text { Fast Food }\end{array}$ & $\begin{array}{l}10.9 \\
18.4\end{array}$ & $\begin{array}{l}61.8 \\
64.2\end{array}$ & $\begin{array}{l}2.6 \\
0.0\end{array}$ & 2.2 & 0.0 & 2.2 & 0.0 & 15.3 & 2.6 & 2.6 \\
\hline \multirow{2}{*}{\multicolumn{11}{|c|}{$\begin{array}{l}\text { Fast Food } \\
\text { Lodging }\end{array}$}} \\
\hline SmallHotel/Motel & 0.0 & 8.9 & 0.0 & & & & & & & \\
\hline LargeHotel & 0.0 & 20.9 & 0.0 & $\begin{array}{r}7.9 \\
217\end{array}$ & $\begin{array}{r}2.2 \\
10.5\end{array}$ & $\begin{array}{r}3.7 \\
357\end{array}$ & $\begin{array}{l}0.0 \\
0.0\end{array}$ & $\begin{array}{r}77.3 \\
0.0\end{array}$ & $\begin{array}{l}0.0 \\
0.0\end{array}$ & $\begin{array}{l}0.0 \\
2.2\end{array}$ \\
\hline Miscellaneous & 15.8 & 42.9 & 1.1 & $\begin{array}{r}21.7 \\
1.7\end{array}$ & $\begin{array}{r}19.5 \\
1.0\end{array}$ & $\begin{array}{r}35.7 \\
5.2\end{array}$ & 0.0 & 25.2 & 4.5 & 2.6 \\
\hline
\end{tabular}


Table 3-4 (Continued). Saturation of Heating, Cooling, System Type, Water Heating for Onsite Survey Buildings

c) Cooling Equipment Type

\begin{tabular}{|c|c|c|c|c|c|c|c|c|c|c|c|c|c|}
\hline & None & $\begin{array}{c}\text { Window } \\
\text { Unit }\end{array}$ & $\begin{array}{c}\text { Open } \\
\text { Centrif }\end{array}$ & $\begin{array}{c}\text { Hermetic } \\
\text { Centrif }\end{array}$ & $\begin{array}{l}\text { Open } \\
\text { Recip }\end{array}$ & $\begin{array}{c}\text { Hermetic } \\
\text { Recip }\end{array}$ & $\begin{array}{c}\text { One-stage } \\
\text { Absorption }\end{array}$ & $\begin{array}{l}\text { Two-stage } \\
\text { Absorption }\end{array}$ & $\begin{array}{l}\text { Double } \\
\text { Bundle } \\
\end{array}$ & DX & $\begin{array}{l}\text { Direct } \\
\text { Evap }\end{array}$ & $\begin{array}{l}\text { Indirect } \\
\text { Evap }\end{array}$ & Other \\
\hline Office & & & & & & & & & & & & & \\
\hline Small & 22.2 & 4.2 & 0.0 & 0.2 & 0.3 & 0.3 & 0.0 & 0.0 & 0.0 & 72.9 & 0.0 & 0.0 & 0.0 \\
\hline Large & 0.0 & 9.6 & 10.5 & 17.1 & 0.4 & 5.0 & 0.5 & 0.0 & 0.2 & 56.8 & 0.0 & 0.0 & 0.0 \\
\hline Retail & & & & & & & & & & & & & \\
\hline Small & 30.6 & 9.7 & 0.0 & 0.2 & 0.0 & 0.0 & 0.0 & 0.0 & 0.0 & 57.3 & 2.3 & 0.0 & 0.0 \\
\hline Large & 4.5 & 0.0 & 0.0 & 12.7 & 5.7 & 5.7 & 0.2 & 0.0 & 0.0 & 64.9 & 0.0 & 0.0 & 0.4 \\
\hline $\begin{array}{l}\text { Food Stores } \\
\text { Warehouse }\end{array}$ & 31.2 & 8.2 & 0.0 & 0.0 & 0.4 & 0.0 & 0.0 & 0.0 & 0.0 & 41.8 & 18.3 & 0.0 & 0.0 \\
\hline Refrigerated & 41.9 & 32.1 & 0.0 & 0.0 & 0.0 & 0.0 & 0.0 & 0.0 & 0.0 & 25.1 & 0.8 & 0.0 & 0.0 \\
\hline $\begin{array}{l}\text { Non-Refrigerated } \\
\text { Schools }\end{array}$ & 63.4 & 0.0 & 0.0 & 0.0 & 0.0 & 0.6 & 0.0 & 0.0 & 0.0 & 36.1 & 0.0 & 0.0 & 0.0 \\
\hline Primary 30.2 & 1.9 & 0.6 & 0.5 & 0.0 & 0.0 & 0.0 & 0.0 & 0.0 & 66.7 & 0.0 & 0.0 & 0.0 & \\
\hline Vocational & 0.0 & 0.0 & 0.0 & 0.0 & 0.0 & 0.0 & 0.0 & 0.0 & 0.0 & 100.0 & 0.0 & 0.0 & 0.0 \\
\hline $\begin{array}{l}\text { College } \\
\text { Health }\end{array}$ & 100.0 & 0.0 & 0.0 & 0.0 & 0.0 & 0.0 & 0.0 & 0.0 & 0.0 & 0.0 & 0.0 & 0.0 & 0.0 \\
\hline Hospitals & 1.2 & 0.0 & 4.9 & 48.2 & 3.3 & 8.0 & 7.0 & 1.3 & 0.0 & 25.7 & 0.0 & 0.0 & 0.5 \\
\hline $\begin{array}{l}\text { Nursing Home } \\
\text { Restaurants }\end{array}$ & 13.4 & 0.0 & 0.0 & 0.0 & 34.5 & 34.5 & 0.0 & 0.0 & 0.0 & 13.2 & 4.4 & 0.0 & 0.0 \\
\hline Sit Down & 24.9 & 12.5 & 0.0 & 0.0 & 0.0 & 2.8 & 0.0 & 0.0 & 0.0 & 43.1 & 16.8 & 0.0 & 0.0 \\
\hline $\begin{array}{l}\text { Fast Food } \\
\text { Lodging }\end{array}$ & 12.3 & 0.0 & 0.0 & 0.0 & 0.0 & 0.0 & 0.0 & 0.0 & 0.0 & 80.1 & 7.6 & 0.0 & 0.0 \\
\hline SmallHotel/Motel & 64.2 & 28.3 & 0.0 & 0.0 & 0.0 & 0.0 & 0.0 & 0.0 & 0.0 & 6.4 & 1.1 & 0.0 & 0.0 \\
\hline LargeHotel & 0.0 & 14.8 & 0.0 & 6.6 & 20.9 & 0.0 & 1.1 & 0.0 & 0.0 & 56.6 & 0.0 & 0.0 & 0.0 \\
\hline Miscellaneous & 39.0 & 87 & 0.1 & 0.0 & 0.0 & 0.1 & 0.0 & 0.0 & 0.0 & 39.2 & 13.0 & 0.0 & 0.0 \\
\hline
\end{tabular}


Table 3-4 (Continued). Saturation of Heating, Cooling, System Type, Water Heating for On-Site Survey Buildings

d) Distribution System Type (\%)

\begin{tabular}{|lrrrr|}
\hline & None & Package & Built-up & Both \\
\hline Office & & & & \\
Small & 12.2 & 87.0 & 0.4 & 0.3 \\
Large & 0.2 & 50.7 & 28.7 & 20.5 \\
Retail & & & & \\
Small & 41.5 & 57.5 & 0.2 & 0.9 \\
Large & 4.5 & 69.9 & 13.7 & 11.9 \\
Food Stores & 54.6 & 43.0 & 1.6 & .8 \\
Warehouse & & & & \\
Refrigerated & 65.6 & 34.4 & 0.0 & 0.0 \\
$\quad$ Non-Refrigerated & 39.6 & 60.4 & 0.0 & 0.0 \\
Primary Schools & 17.2 & 75.7 & 5.4 & 1.8 \\
College & 0.0 & 0.0 & 100.0 & 0.0 \\
Vocational & 0.0 & 100.0 & 0.0 & 0.0 \\
Health & & & & \\
Hospitals & 1.2 & 21.9 & 23.7 & 53.2 \\
$\quad$ Nursing Hotide & 4.4 & 21.9 & 69.3 & 4.4 \\
Restaurants & & & & \\
Sit Down & 27.8 & 64.6 & 7.6 & 0.0 \\
Fast Food & 18.3 & 81.7 & 0.0 & 0.0 \\
Lodging & & & & \\
SmallHotel/Motel & 87.1 & 12.9 & 0.0 & 0.0 \\
$\quad$ LargeHotel & 14.8 & 35.7 & 27.8 & 21.7 \\
Miscellaneous & 41.0 & 54.8 & 2.1 & 2.1 \\
\hline
\end{tabular}

e) Economizer (\%)

\begin{tabular}{|lrr|}
\hline & No & Yes \\
\hline Office & & \\
Small & 94.2 & 5.8 \\
Large & 67.3 & 32.5 \\
Retail & & \\
Small & 93.6 & 6.3 \\
Large & 68.5 & 31.5 \\
Food Stores & 93.1 & 6.9 \\
Warehouse & & \\
Refrigerated & 92.7 & 7.3 \\
Non-Refrigerated & 99.2 & 0.8 \\
Primary Schools & 94.0 & 5.5 \\
College & 0.0 & 100.0 \\
Vocational & 100.0 & 0.0 \\
Health & & \\
Hospitals & 46.5 & 53.5 \\
Nursing Home & 61.1 & 38.9 \\
Restaurants & & \\
Sit Down & 90.5 & 9.5 \\
Fast Food & 92.4 & 7.6 \\
Lodging & & \\
SmallHotel/Motel & 97.8 & 2.2 \\
LargeHotel & 51.6 & 48.4 \\
Miscellaneous & 93.7 & 6.3 \\
\hline
\end{tabular}


Table 3-4 (Continued). Saturation of Heating, Cooling, System Type, Water Heating for On-Site Survey Buildings

D) Water Heating Equipment Type (\%)

\begin{tabular}{|lrrrrr|}
\hline & None & Central Boiler & Individual & Instantaneous & Other \\
\hline Office & & & & & \\
Small & 14.1 & 0.1 & 85.8 & 0.0 & 0.0 \\
Large & 0.2 & 17.7 & 75.7 & 1.1 & 5.3 \\
Retail & & & & & \\
Small & 57.3 & 0.0 & 42.5 & 0.2 & 0.0 \\
Large & 6.0 & 6.8 & 86.6 & 0.0 & 0.5 \\
Food Stores & 25.8 & 0.0 & 73.8 & 0.4 & 0.0 \\
Warehouse & & & & & \\
Refrigerated & 6.9 & 0.0 & 93.1 & 0.0 & 0.0 \\
Non-Refrigerated & 56.2 & 0.0 & 43.8 & 0.0 & \\
Primary Schools & 33.0 & 10.1 & 56.2 & 0.6 & 0.0 \\
College & 0.0 & 100.0 & 0.0 & 0.0 & 0.0 \\
Vocational & 0.0 & 0.0 & 100.0 & 0.0 & 0.0 \\
Health & & & & & \\
Hospitals & 4.8 & 59.0 & 35.9 & 0.0 & 0.0 \\
Nursing Home & 0.0 & 38.9 & 60.8 & 0.3 & 0.0 \\
Restaurants & & & & \\
Sit Down & 2.6 & 2.2 & 95.2 & 0.0 & 0.0 \\
Fast Food & 0.0 & 1.8 & 98.2 & 0.0 & 0.0 \\
Lodging & & & & & \\
SmallHotel/Motel & 0.0 & 12.2 & 86.7 & 0.0 & 1.1 \\
$\quad$ LargeHotel & 0.0 & 64.3 & 35.7 & 0.0 & 0.0 \\
Miscellaneous & 30.0 & 1.0 & 67.3 & 1.6 & 0.1 \\
\hline
\end{tabular}

g) Heating Equipment Fuel (\%)

\begin{tabular}{|lrrrrrrr|}
\hline & Electric & \multicolumn{1}{c}{ Gas } & Oil & LPG & Wood & Solar & Other \\
\hline Office & & & & & & & \\
Small & 23.8 & 70.3 & 5.9 & 0.0 & 0.0 & 0.0 & 0.0 \\
Large & 6.3 & 92.5 & 0.7 & 0.0 & 0.0 & 0.0 & 0.0 \\
Retail & & & & & & & \\
Small & 27.2 & 70.7 & 0.0 & 2.1 & 0.0 & 0.0 & 0.0 \\
Large & 12.6 & 87.4 & 0.0 & 0.0 & 0.0 & 0.0 & 0.0 \\
Food Stores & 34.3 & 42.4 & 0.0 & 23.3 & 0.0 & 0.0 & 0.0 \\
Warehouse & & & & & & & \\
$\quad$ Refrigerated & 42.7 & 57.3 & 0.0 & 0.0 & 0.0 & 0.0 & 0.0 \\
Non-Refrigerated & 37.4 & 62.6 & 0.0 & 0.0 & 0.0 & 0.0 & 0.0 \\
Primary Schools & 3.0 & 92.2 & 0.0 & 4.9 & 0.0 & 0.0 & 0.0 \\
College & 0.0 & 100.0 & 0.0 & 0.0 & 0.0 & 0.0 & 0.0 \\
Vocational & 0.0 & 100.0 & 0.0 & 0.0 & 0.0 & 0.0 & 0.0 \\
Health & & & & & & & \\
Hospitals & 3.3 & 96.5 & 0.0 & 0.3 & 0.0 & 0.0 & 0.0 \\
$\quad$ Nursing Home & 4.4 & 95.6 & 0.0 & 0.0 & 0.0 & 0.0 & 0.0 \\
Restaurants & & & & & & & \\
$\quad$ Sit Down & 9.6 & 84.5 & 0.2 & 5.7 & 0.0 & 0.0 & 0.0 \\
Fast Food & 11.7 & 86.1 & 0.0 & 2.2 & 0.0 & 0.0 & 0.0 \\
Lodging & & & & & & & \\
SmallHotel/Motel & 34.3 & 41.9 & 0.0 & 23.8 & 0.0 & 0.0 & 0.0 \\
$\quad$ LargeHotel & 56.6 & 41.2 & 0.0 & 0.0 & 0.0 & 0.0 & 0.0 \\
Miscellaneous & 24.2 & 69.4 & 0.4 & 3.1 & 3.0 & 0.0 & 0.0 \\
\hline
\end{tabular}


Table 3-4 (Continued). Saturation of Heating, Cooling, System Type, Water Heating for On-Site Survey Buildings

h) Cooling Equipment Fuel (\%)

\begin{tabular}{|lrlll|}
\hline & Electricity & Gas & Steam & Other \\
\hline Office & 100.0 & 0.0 & 0.0 & 0.0 \\
Small & 98.8 & 0.7 & 0.4 & 0.0 \\
Large & & & & \\
Retail & 100.0 & 0.0 & 0.0 & 0.0 \\
Small & 99.2 & 0.8 & 0.0 & 0.0 \\
Large & 100.0 & 0.0 & 0.0 & 0.0 \\
Food Stores & & & \\
Warehouse & 100.0 & 0.0 & 0.0 & 0.0 \\
Refrigerated & 100.0 & 0.0 & 0.0 & 0.0 \\
Non-Refrigerated & 100.0 & 0.0 & 0.0 & 0.0 \\
Primary Schools & 0.0 & 0.0 & 0.0 & 0.0 \\
College & 100.0 & 0.0 & 0.0 & 0.0 \\
Vocational & & & & \\
Health & 91.3 & 7.7 & 1.0 & 0.0 \\
Hospitals & 100.0 & 0.0 & 0.0 & 0.0 \\
$\quad$ Nursing Home & & & \\
Restaurants & 99.2 & 0.0 & 0.0 & 0.0 \\
Sit Down & 100.0 & 0.0 & 0.0 & 0.0 \\
Fast Food & & & & \\
Lodging & & & \\
SmallHotel/Motel & 100.0 & 0.0 & 0.0 & 0.0 \\
LargeHotel & 98.9 & 0.0 & 0.0 & 0.0 \\
Miscellaneous & 100.0 & 0.0 & 0.0 & 0.0 \\
\hline
\end{tabular}

i) Water Heating Equipment Fuel (\%)

\begin{tabular}{|c|c|c|c|c|c|c|c|}
\hline & Electricity & Gas & Oil & LPG & Solar & Steam & Other \\
\hline \multicolumn{8}{|l|}{ Office } \\
\hline Small & 60.8 & 39.2 & 0.0 & 0.0 & 0.0 & 0.0 & 0.0 \\
\hline Large & 26.7 & 66.3 & 0.4 & 0.0 & 4.8 & 1.7 & 0.0 \\
\hline \multicolumn{8}{|l|}{ Retail } \\
\hline Small & 45.0 & 55.0 & 0.0 & 0.0 & 0.0 & 0.0 & 0.0 \\
\hline Large & 39.3 & 59.8 & 0.0 & 0.0 & 0.5 & 0.4 & 0.0 \\
\hline Food Stores & 54.4 & 40.2 & 0.0 & 5.4 & 0.0 & 0.0 & 0.0 \\
\hline \multicolumn{8}{|l|}{ Warehouse } \\
\hline Refrigerated & 27.2 & 72.8 & 0.0 & 0.0 & 0.0 & 0.0 & 0.0 \\
\hline Non-Refrigerated & 68.7 & 31.3 & 0.0 & 0.0 & 0.0 & 0.0 & 0.0 \\
\hline Primary Schools & 37.3 & 56.9 & 0.0 & 5.8 & 0.0 & 0.0 & 0.0 \\
\hline College & 0.0 & 100.0 & 0.0 & 0.0 & 0.0 & 0.0 & 0.0 \\
\hline Vocational & 83.4 & 16.6 & 0.0 & 0.0 & 0.0 & 0.0 & 0.0 \\
\hline \multicolumn{8}{|l|}{ Health } \\
\hline Hospitals & 1.0 & 85.8 & 3.4 & 0.0 & 0.0 & 9.8 & 0.0 \\
\hline Nursing Home & 0.0 & 100.0 & 0.0 & 0.0 & 0.0 & 0.0 & 0.1 \\
\hline \multicolumn{8}{|l|}{ Restaurants } \\
\hline Sit Down & 7.2 & 85.5 & 0.0 & 7.3 & 0.0 & 0.0 & 0.0 \\
\hline Fast Food & 9.4 & 88.8 & 0.0 & 1.8 & 0.0 & 0.0 & 0.0 \\
\hline \multicolumn{8}{|l|}{ Lodging } \\
\hline SmallHotel/Motel & 3.3 & 49.0 & 23.8 & 23.9 & 0.0 & 0.0 & 0.0 \\
\hline LargeHotel & 0.8 & 98.2 & 0.0 & 0.0 & 0.0 & 0.0 & 0.0 \\
\hline Miscellaneous & 35.1 & 60.7 & 0.0 & 4.1 & 0.0 & 0.1 & 0.0 \\
\hline
\end{tabular}


We conclude our analysis of the on-site survey data by reviewing the statistical results of the whole-building EUIs. Table 3-5 shows the result of this analysis for all building types. Like the statistics of the other on-site survey parameters, for most building types, the population average and mean EUIs are significantly different. Also, the range and standard deviation of EUIs is fairly high, making statistical differences between EUIs insignificant. Since, whole-building EUIs are very critical control measures for EDA reconciliation, they will be discussed in further detail later on this chapter.

Table 3-5. Summary of Commercial Building EUIs in the 1986 PG\&E On-Site Survey

\begin{tabular}{|c|c|c|c|c|c|c|c|}
\hline Type & Population Avg & Mean & Median & Std Dev & $\operatorname{Max}$ & Min & $\mathbf{N}$ \\
\hline \multicolumn{8}{|c|}{ Energy Use Intensity $\left(\mathrm{kWh} / \mathrm{ft}^{2} /\right.$ year $)$} \\
\hline \multicolumn{8}{|l|}{ Office } \\
\hline Small & 13.2 & 12.6 & 14.8 & 9.9 & 91.5 & 1.1 & 68 \\
\hline Large & 16.8 & 23.9 & 18.6 & 21.1 & 174.5 & 4.7 & 53 \\
\hline \multicolumn{8}{|l|}{ Retail } \\
\hline Small & 11.9 & 14.4 & 14.8 & 18.7 & 275.4 & 0.1 & 76 \\
\hline Large & 11.5 & 19.3 & 16.5 & 17.2 & 91.1 & 5.7 & 22 \\
\hline Food Stores & 45.1 & 41.5 & 55.2 & 27.5 & 144.3 & 6.3 & 84 \\
\hline \multicolumn{8}{|l|}{ Warehouse } \\
\hline Refrigerated & 29.0 & 31.3 & 33.9 & 14.3 & 127.4 & 2.9 & 13 \\
\hline Non-Refrigerated & 5.2 & 5.8 & 3.9 & 5.3 & 58.7 & 1.1 & 21 \\
\hline Primary Schoolst & 31.6 & 56.3 & 24.9 & 114.6 & 620.0 & 0.3 & 43 \\
\hline College & 4.3 & 4.3 & 4.3 & 0.0 & 4.3 & 4.3 & 1 \\
\hline Vocational & 22.1 & 13.2 & 25.5 & 13.7 & 44.0 & 7.1 & 2 \\
\hline \multicolumn{8}{|l|}{ Health } \\
\hline Hospitals & 28.8 & 45.3 & 31.6 & 84.9 & 1359.7 & 2.7 & 47 \\
\hline Nursing Home & 11.2 & 10.9 & 9.7 & 8.9 & 171.5 & 4.9 & 10 \\
\hline \multicolumn{8}{|l|}{ Restaurants } \\
\hline Sit Down & 27.8 & 29.4 & 31.7 & 18.0 & 155.5 & 2.6 & 58 \\
\hline Fast Food & 68.7 & 68.1 & 74.2 & 31.9 & 187.7 & 27.2 & 19 \\
\hline \multicolumn{8}{|l|}{ Lodging } \\
\hline Small Hotel/Motel & 11.2 & 12.8 & 9.7 & 29.7 & 282.9 & 2.4 & 21 \\
\hline Large Hotel & 11.3 & 12.2 & 14.2 & 6.2 & 22.2 & 5.5 & 12 \\
\hline Miscellaneous & 6.5 & 11.0 & 11.8 & 22.0 & 1441.7 & 0.0 & 128 \\
\hline
\end{tabular}

$\dagger \quad$ The EUI for the school building is exceptionally high, indicating that the total floor area of all the buildings served by the same meter might not have been surveyed on the 1986 on-site survey. 


\section{Load Research Data}

Load research data (LRD) are routinely collected by PG\&E's load research group for all customer classes for rate making purposes. We used these data to develop whole-building load shapes against which we reconcile our initial estimates of end-use load shapes. For this project, we received a subset of the LRD collected by PG\&E for its commercial accounts. Data collected in both 1985 and 1986 were received, but our initial analysis has focused only on data collected in 1986. The decision to focus on 1986 data is intended to ensure consistency with our other primary source of data, the on-site survey, which was also collected in 1986. The PG\&E load research group also provided us with a data file containing information that would allow us to assign individual accounts to climate zones.

The LRD were transferred to us in two files: 1) a file consisting of an account code, date, 48 fields of half-hourly whole-building electricity consumption, for 365 days and for all LRD accounts; 2) a file consisting of the account code with some additional information such as local weather station, account class, building SIC code, and weighting factor describing each LRD account. The weighting factor indicates the number of buildings the LRD account represents. Prior to our review, we aggregated the half-hourly observations and produced an hourly file of LRD. We then used data from the second file to generate several statistics from the data, including number of accounts by rate class and climate zone for each building type. The LRD were separated into building types based on the assigned SIC codes and building definition.

Offices required a split into large and small sizes. ${ }^{\dagger}$ We examined two methods for making this split. We first reviewed the numbers of accounts by rate class. While commercial customers have some flexibility in the choice of rate class, this choice is often dictated by the amount of electricity consumed, which is a good proxy for building size. The A1 rate class is for small buildings, A12 is for small and medium size buildings with demand meter, and A21 and A22 are large ( $>500 \mathrm{~kW}$ ) time-of-use meters. There is no guarantee that large buildings will only have A21 and A22 time-of-use meters, and small buildings only A1 and A12. Therefore, a second method of splitting the accounts was necessary, where annual electricity use for each account was calculated by integrating the hourly LRD consumption for the entire year.

Table 3-6 summarizes the number of LRD accounts by these rate classes, where the small office is defined as less than $500 \mathrm{~kW}$ and the large office is $500 \mathrm{~kW}$ or greater.

† Retail stores were also split into small and large sizes for the first interim report. The split was made at 400 $\mathrm{kW}$, however the reconciliation was not made at this disaggregated level. Therefore, this information previously included in the first interim report is not reported here. 
Table 3-6. Account Class of 1986 PG\&E Load Research Data (Number of Buildings)

\begin{tabular}{|c|c|c|c|c|c|c|}
\hline \multirow{2}{*}{ Building Type } & \multicolumn{5}{|c|}{ Account Class } & \multirow{2}{*}{ Total } \\
\hline & A1 & A12 & A21 & A22 & PBL & \\
\hline Small office & 75 & 11 & 2 & 2 & 0 & 90 \\
\hline Large office & 19 & 10 & 57 & 159 & 0 & 245 \\
\hline Retail store & 82 & 11 & 45 & 27 & 0 & 165 \\
\hline Restaurant & 33 & 9 & 0 & 1 & 0 & 43 \\
\hline Food store & 18 & 18 & 3 & 1 & 0 & 40 \\
\hline Warehouse & 25 & 14 & 16 & 33 & 0 & 88 \\
\hline School & 19 & 8 & 18 & 6 & 0 & 51 \\
\hline College & 1 & 0 & 12 & 37 & 1 & 51 \\
\hline Health & 3 & 6 & 10 & 43 & 0 & 62 \\
\hline Lodging & 12 & 0 & 15 & 11 & 0 & 38 \\
\hline Miscellaneous & 26 & 7 & 5 & 5 & 0 & 43 \\
\hline Total & 313 & 94 & 183 & 325 & 1 & $\overline{916}$ \\
\hline
\end{tabular}

Notes:

1. A1: Small commercial general service ( $<100,000 \mathrm{kWh} /$ year)

A12: General commercial demand meter

A21: Medium general time-of-use service ( $>500 \mathrm{~kW}$ demand)

A22: Large general time-of-use service ( $>1000 \mathrm{~kW}$ demand)

PBL: Others (not buildings)

2. Some of the current account codes are different from those of 1986 . 
Table 3-7 presents the number of the LRD accounts by building type for each of the five PG\&E climate zones. We used the information presented in Table 3-8 to map the LRD accounts to the five climate zones. Of the 916 LRD there are 335 offices (both large and small) and 165 retails. Of the 335 offices, 294 (88\%) are located in climate zones III and IV (San Francisco bay area). The percentage of retail accounts in climate zones III and IV is somewhat lower (69\% or 114 out of 165). As is the case with offices and retail stores, the majority of accounts for the other building types are located in the San Francisco bay area.

Table 3-7. Climate Zone Distribution of 1986 PG\&E Load Research Data (Number of Buildings)

\begin{tabular}{|l|rrrrr|r|}
\hline \multirow{2}{*}{ Building Type } & \multicolumn{5}{|c|}{ Climate Zone } & \multirow{2}{*}{ Total } \\
& IA & IIA & IIB & III & IV & \\
\hline Small office & 2 & 11 & 11 & 40 & 26 & 90 \\
Large office & 0 & 4 & 13 & 78 & 150 & 245 \\
Retail store & 6 & 19 & 26 & 68 & 46 & 165 \\
Restaurant & 3 & 3 & 8 & 13 & 16 & 43 \\
Food store & 3 & 8 & 4 & 15 & 10 & 40 \\
Warehouse & 4 & 10 & 12 & 37 & 25 & 88 \\
School & 2 & 4 & 17 & 24 & 4 & 51 \\
College & 2 & 3 & 9 & 21 & 16 & 51 \\
Health & 0 & 4 & 13 & 21 & 24 & 62 \\
Lodging & 2 & 3 & 3 & 8 & 22 & 38 \\
Miscellaneous & 2 & 4 & 9 & 20 & 8 & 43 \\
\hline Total & 26 & 73 & 125 & 345 & 347 & 916 \\
\hline
\end{tabular}


Table 3-8. Climate Zone Mapping of Load Research Data by Building Type $\dagger$

\begin{tabular}{|c|c|c|c|c|c|}
\hline CEC Forecasting Zone & IA & IIA & IIB & III & IV \\
\hline $\begin{array}{l}\text { CEC Climate Zone } \\
\text { Energy Weather Station } \\
\text { Peak Weather Station } \\
\text { PG\&E WTHRCITY }\end{array}$ & $\begin{array}{l}\text { CZ01 } \\
\text { Ukiah } \\
\text { Blue Canyon } \\
\text { Angels Camp } \\
\text { Eureka } \\
\text { Ukiah }\end{array}$ & $\begin{array}{l}\text { CZO2 } \\
\text { Sacramento } \\
\text { Sacramento } \\
\text { Auburn } \\
\text { Sacramento } \\
\text { Stockton }\end{array}$ & $\begin{array}{l}\text { CZ03,CZ07 } \\
\text { Fresno } \\
\text { Fresno } \\
\text { Bakersfield } \\
\text { Chico } \\
\text { Fresno } \\
\text { Marysville } \\
\text { Red Bluff }\end{array}$ & $\begin{array}{l}\text { CZO4 } \\
\text { San Jose } \\
\text { San Jose } \\
\text { Concord } \\
\text { Cupertino } \\
\text { Milpitas } \\
\text { Paso Robles } \\
\text { Salinas } \\
\text { San Ramon } \\
\text { Santa Maria } \\
\text { Santa Rosa }\end{array}$ & $\begin{array}{l}\text { CZ05 } \\
\text { SF Airport } \\
\text { SF Airport } \\
\text { Belmont } \\
\text { Colma } \\
\text { Oakland } \\
\text { Potrero } \\
\text { San Rafael } \\
\text { Santa Cruz }\end{array}$ \\
\hline
\end{tabular}

† We are reasonably comfortable with most of the mapping assumptions except for one area: the split between zones III and IV. All the maps we have show that climate zone IV is around the bay area and include Marin and Santa Cruz counties, while climate zone III is inland and southern coastal. The tables we have however map Oakland and Milpitas into climate zone III while we would assume they should be in climate zone IV. We have decided to place Oakland into climate zone IV. 
We identified and deleted questionable records using visual and other analysis of the hourly profiles plotted for each account. Figure 3-1 shows one of these plots. Criteria used in this process included: cross-checks between the reported SIC codes and building definition, spurious load shapes, and excess missing data. The quantity of missing data was determined through a statistical review. In the upper left and right comers of Figure 3-1, we show the key information describing the LRD account. The left uppermost is a seven digit account code, which is unique to each account. Below this is the four digit SIC code. Beneath this is a weighting factor indicating the number of buildings the account represents. To the immediate right is the rate class. In the right uppermost corner is the climate region to which the account belongs. Underneath this is the annual energy consumption. Directly below this is the quantity of missing data expressed as a percentage. The load shape in Figure 3-1 is described by dotted lines which indicate the minimum and maximum values, a solid line which describes the mean average, a dashed line which indicates the median, and solid vertical bars which represent the interquartile range.

The individual LRD accounts were weighted together into a single hourly load shape for each building type and climate region. Figure 3-2 shows an example of a weighted load shape. The LRD accounts had anywhere from 0 to 100 percent of missing data. Accounts in excess of a fixed percentage of missing data were excluded. This upper limit on missing data was determined by visually examining the weighted LRD hourly profiles, which were plotted with varying degrees of missing data $(10 \%, 15 \%, 20 \%, 25 \%, 30 \%)$. We observed that with each increase in missing data the the net effect on the load shape was negligible. Therefore, based on this criteria the upper limit on missing data was set at $30 \%$. Offices and retail stores were excluded if the quantity of missing data exceeded $20 \%$, where phase II building accounts were excluded if it exceeded $30 \%$.

Additionally, 3-dimensional, weighted, yearly load shapes were plotted for each building type and climate region. Figure 3-3 shows an example of a 3-dimensional, weighted, yearly load shape.

Load shapes were also plotted for day types (Monday through Sunday and holidays) and seasons (summer, winter). Figure 3-4 shows an example of a day type-seasonal load shape.

Table 3-9 summarizes the total number of LRD accounts provided and the number actually used. 
Figure 3-1. Sample Inspection Plot of the Load Research Data.

The upper left number is a seven-digit code of the LRD account, followed by four digit SIC code, and a weighting factor indicating the number of buildings the account represents. To the immediate right of weighting factor is the rate class. In the right uppermost corner is the climate region, followed by the annual energy consumption, and percentage of missing data. Hourly minimum, maximum, 25\% quartile, mean (solid continuous line), median, and 75\% quartile are shown.

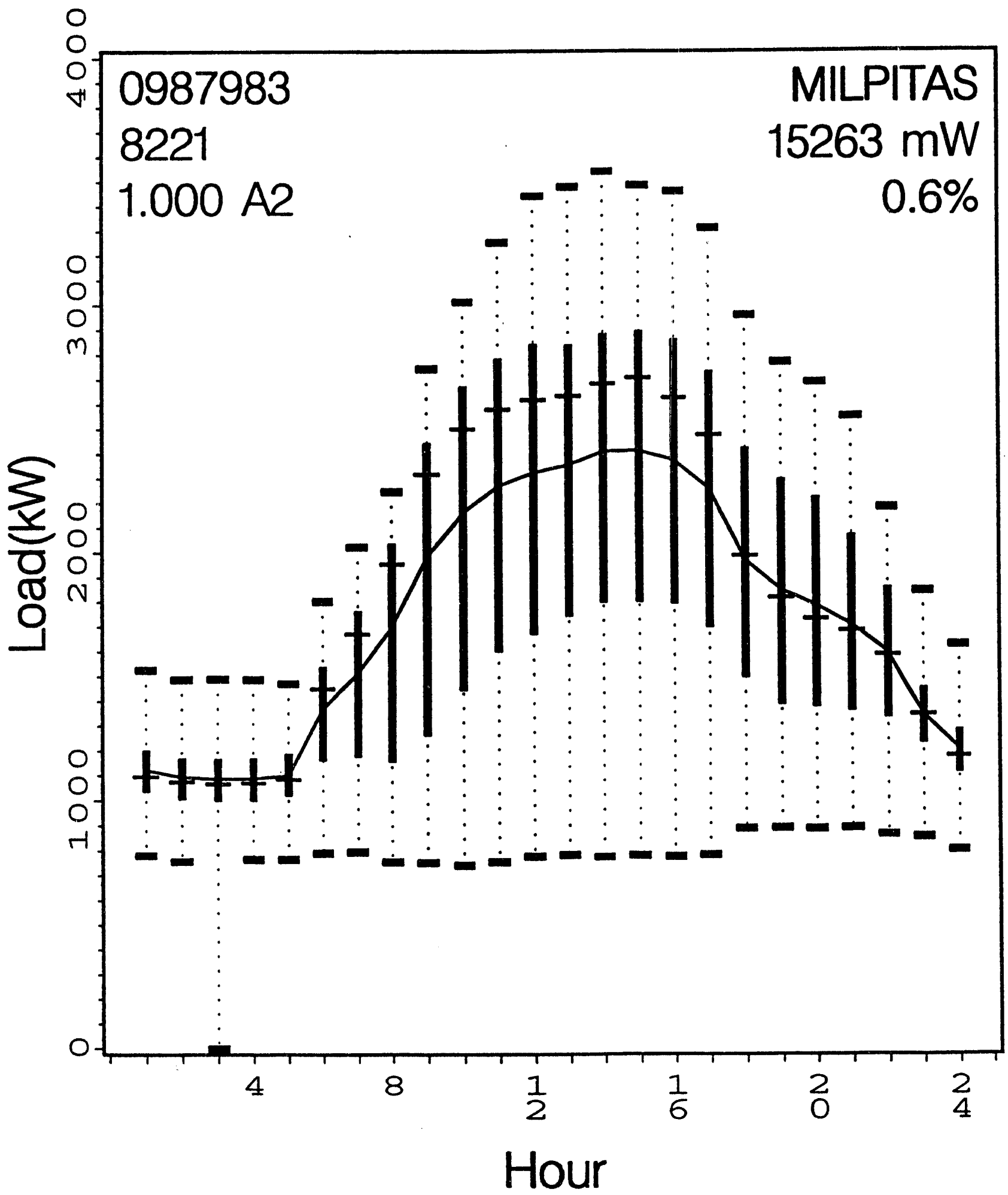


Figure 3-2. Weighted Average Load Shape for College Buildings in Coastal Areas.

Hourly minimum, maximum, 25\% quartile, mean (solid continuous line), median, and 75\% quartile are shown.

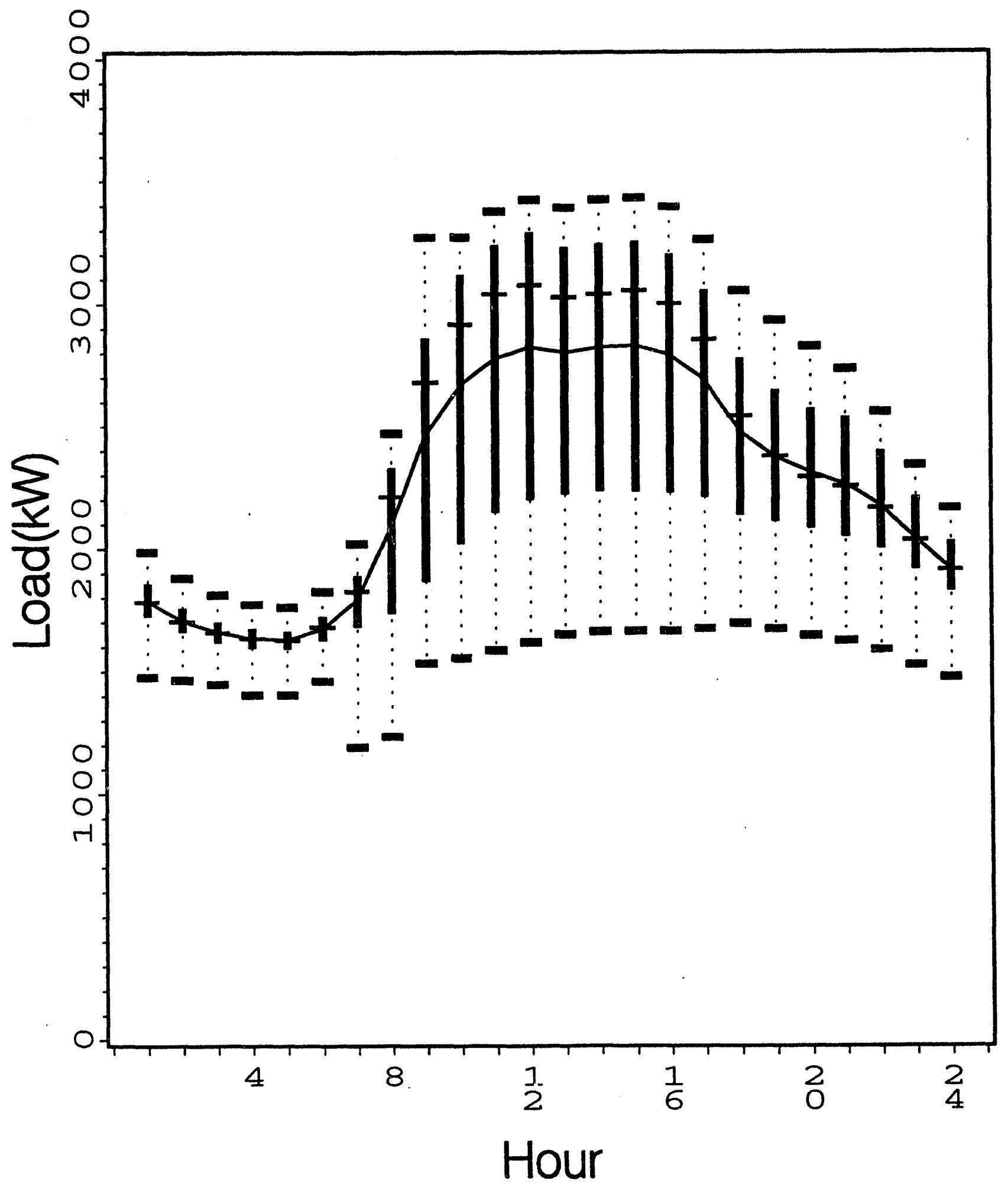




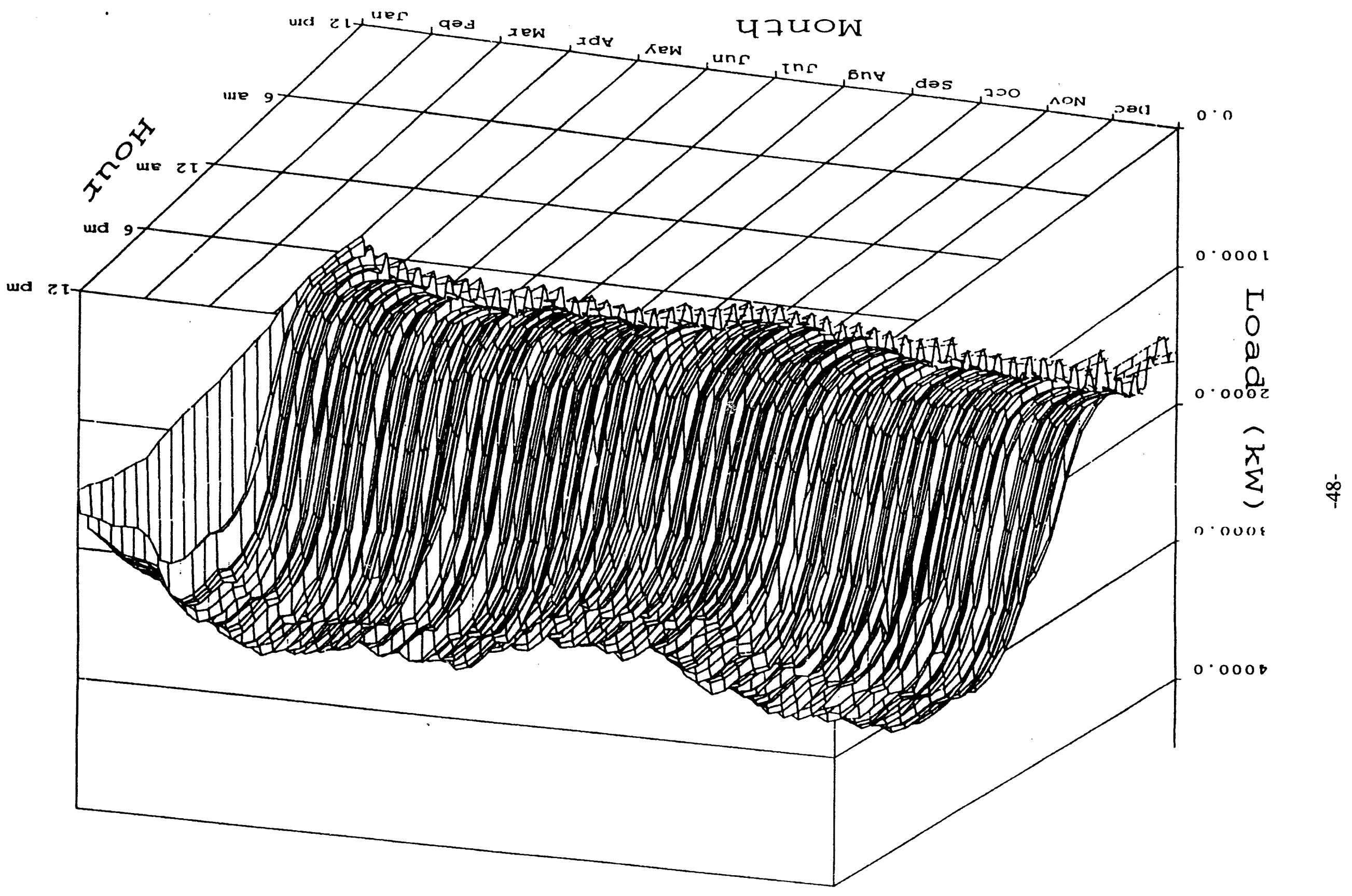

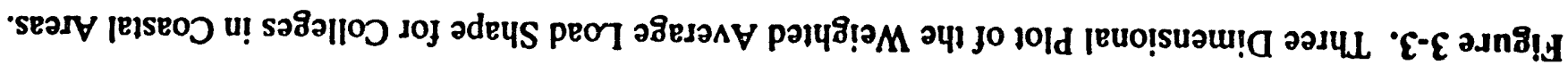


Figure 3-4. Weighted Average Load Shapes by Type of the Day for Colleges in Coastal Areas.

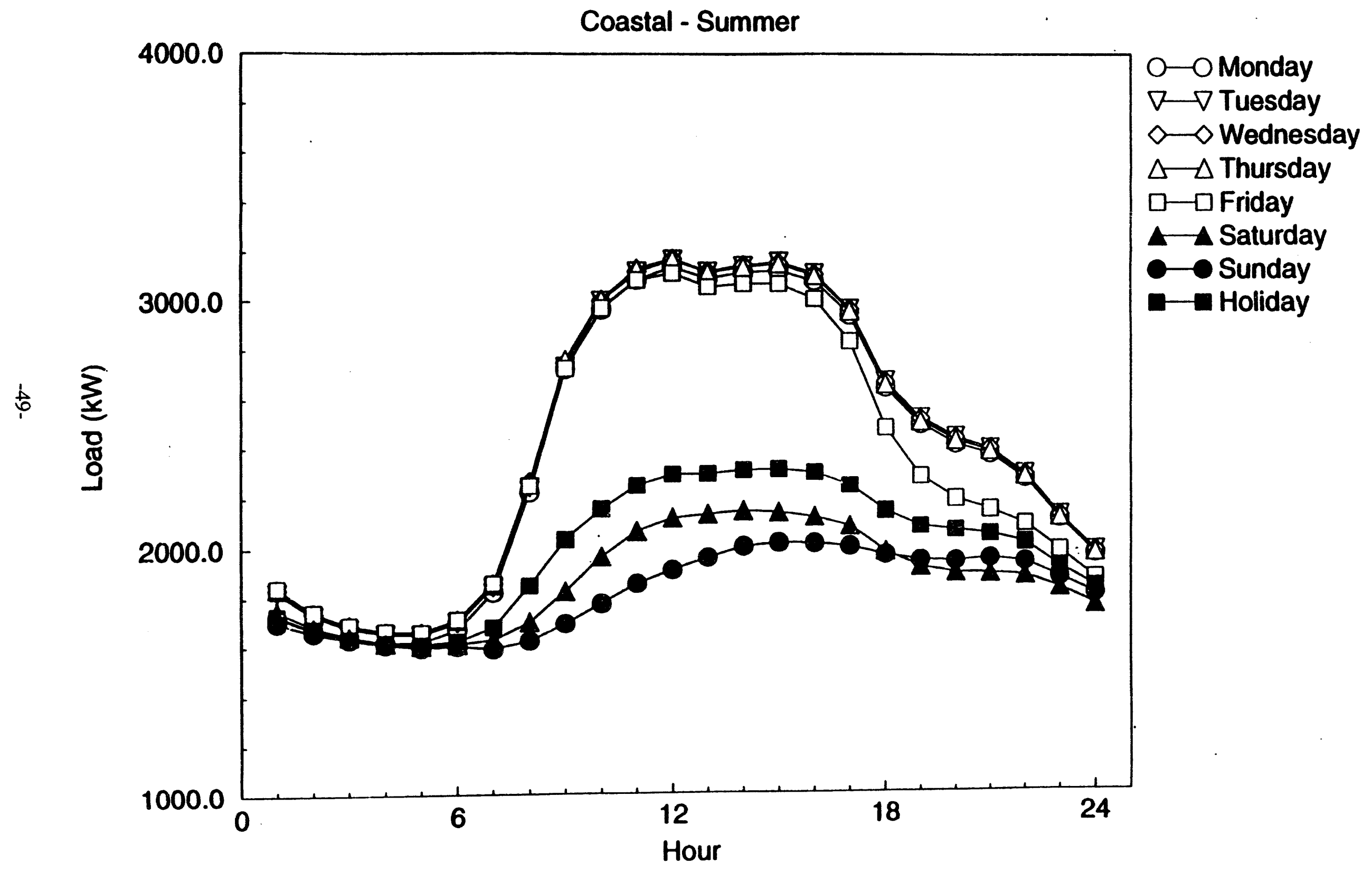


Table 3-9. Load Research Data Building Summary

\begin{tabular}{|l||c|c|c|}
\hline $\begin{array}{l}\text { Building } \\
\text { Type }\end{array}$ & $\begin{array}{c}\text { Climate } \\
\text { Zone }\end{array}$ & $\begin{array}{c}\text { LRD Files } \\
\text { Total }\end{array}$ & $\begin{array}{c}\text { LRD Files } \\
\text { Used }\end{array}$ \\
\hline \hline \multirow{2}{*}{ Small office } & Coastal & 28 & 27 \\
\cline { 2 - 4 } & Inland & 62 & 59 \\
\hline \multirow{2}{*}{ Large office } & Coastal & 150 & 137 \\
\cline { 2 - 4 } & Inland & 95 & 64 \\
\hline \multirow{2}{*}{ Retail store } & Coastal & 52 & 47 \\
\cline { 2 - 4 } & Inland & 113 & 94 \\
\hline \multirow{2}{*}{ Restaurant } & Coastal & 19 & 18 \\
\cline { 2 - 4 } & Inland & 24 & 24 \\
\hline \multirow{2}{*}{ Food store } & Coastal & 13 & 12 \\
\cline { 2 - 4 } & Inland & 27 & 19 \\
\hline \multirow{2}{*}{ Warehouse } & Coastal & 29 & 25 \\
\cline { 2 - 4 } & Inland & 59 & 53 \\
\hline \multirow{2}{*}{ School } & Coastal & 6 & 6 \\
\cline { 2 - 4 } & Inland & 45 & 37 \\
\hline \multirow{2}{*}{ College } & Coastal & 18 & 16 \\
\cline { 2 - 4 } & Inland & 33 & 31 \\
\hline \multirow{2}{*}{ Health } & Coastal & 24 & 22 \\
\cline { 2 - 4 } & Inland & 38 & 34 \\
\hline \multirow{2}{*}{ Lodging } & Coastal & 23 & 23 \\
\cline { 2 - 4 } & Inland & 14 & 12 \\
\hline \multirow{2}{*}{ Miscellaneous } & Coastal & 10 & 6 \\
\cline { 2 - 4 } & Inland & 33 & 24 \\
\hline
\end{tabular}




\section{Mail Survey}

PG\&E routinely collects mail survey data from approximately 6,000 commercial buildings on a three year cycle. We used data from a recent mail survey as an important secondary data source for this project. The mail survey data were used in three ways:

1. To evaluate the representativeness of selected features of the prototypes to be developed;

2. To provide information and guidance on features of the commercial buildings that are poorly represented in the on-site survey data; and

3. To provide another source of estimates for whole-building EUI development.

In this analysis we used the 1988 mail survey. Table 3-10 shows the number of commercial buildings in each climate zone by building type. We found a small number of buildings that could not be unambiguously assigned to one of these zones and have labeled them as "other."

Table 3-10. Climate Zone Distribution of 1988 PG\&E Mail Survey Data

(Number of Buildings)

\begin{tabular}{|c|c|c|c|c|c|c|c|}
\hline \multirow{2}{*}{ Premise Type } & \multicolumn{6}{|c|}{ Climate Zone } & \multirow{2}{*}{ Total } \\
\hline & IA & IIA & IIB & III & IV & OTHER & \\
\hline Office & 56 & 104 & 143 & 395 & 199 & 34 & 931 \\
\hline Nonfood Retail & 53 & 132 & 228 & 470 & 222 & 22 & 1127 \\
\hline Food Retail & 26 & 54 & 68 & 147 & 74 & 6 & 375 \\
\hline Warehouse & 20 & 59 & 83 & 210 & 95 & 30 & 497 \\
\hline Restaurant & 33 & 65 & 98 & 220 & 117 & 11 & 544 \\
\hline Health Services & 31 & 50 & 81 & 179 & 70 & 10 & 421 \\
\hline School & 29 & 42 & 46 & 143 & 58 & 2 & 320 \\
\hline Services & 67 & 132 & 176 & 526 & 237 & 31 & 1169 \\
\hline Comm. Services & 32 & 60 & 100 & 202 & 88 & 15 & 497 \\
\hline Other & 10 & 11 & 22 & 35 & 12 & 2 & 92 \\
\hline Total & 357 & 709 & 1045 & 2527 & 1172 & 163 & 5973 \\
\hline
\end{tabular}


In order to bring the building types of mail survey in conformity with the building types for which we are going to develop prototype modes, we regrouped the buildings according to the functionality of each building. Table 3-11 describes the mapping of the mail survey buildings into the prototype buildings for this study.

Table 3-11. Mapping of the Mail Survey buildings into prototype buildings. The number in parenthesis denotes the number of buildings in the 1988 Mail Survey.

\begin{tabular}{|c|c|c|}
\hline Premise Type & Component Premise & No. of Buildings \\
\hline Office & $\begin{array}{l}\text { OFFICE(Administration/Management(376), Banking/ } \\
\text { Finance(200), Insurance/Real State(111), Legal } \\
\text { /Social(30), City Hall Court(28), Medical Office(7), } \\
\text { Other Offices(85), No response (95)), HEALTH } \\
\text { SERVICES(Medical Offices(102), Medical Lab(20)), } \\
\text { SERVICES(Business Service(40)), COMMUNITY } \\
\text { SERVICE(Post Office (35), Telephone Co.(6), Tran- } \\
\text { sport Office/Terminal(40)) }\end{array}$ & 1175 \\
\hline Fast Food & RESTAURANTS(Fast Food or SS(112)) & 112 \\
\hline Sit-Down & RESTAURANT(Table Service(409), Tavern/Bar(20)) & 429 \\
\hline Retail & $\begin{array}{l}\text { SALES(Non-Food Retail(1128), Non-Food Whole- } \\
\text { sale(3)) }\end{array}$ & 1131 \\
\hline Food Stores & SALES(Food Retail(375), Food Wholesale(0)) & 375 \\
\hline $\begin{array}{l}\text { Refrigerated } \\
\text { Warehouse }\end{array}$ & WAREHOUSE(Refrigerated Warehouse(341)) & 341 \\
\hline $\begin{array}{l}\text { Non-Refrigerated } \\
\text { Warehouse }\end{array}$ & WAREHOUSE(Non-Refrigerated Warehouse(157)) & 157 \\
\hline Primary School & SCHOOL(Elementary(64)) & 64 \\
\hline $\begin{array}{l}\text { Secondary } \\
\text { School }\end{array}$ & SCHOOL(Jr. or Sr. High(124), Trade or Special(24)) & 148 \\
\hline College & SCHOOL(College or university(55)) & 55 \\
\hline Hospital & HEALTH SERVICES(Acute Care Hospital(130)) & 130 \\
\hline Nursing Care & HEALTH SERVICES(Nursing Care(138)) & 138 \\
\hline Lodging & SERVICES(Hotel/Motel(256)) & 256 \\
\hline Miscellaneous & $\begin{array}{l}\text { RESTAURANTS(Not Applicable(3)), HEALTH } \\
\text { SERVICES(Not Applicable(31)), SCHOOL(Not } \\
\text { Applicable(28), Day Care Center(25)) } \\
\text { SERVICES(Entertainment(18), TV or Radio(25), Per- } \\
\text { sonal Service(559), Gas/Auto Repair(117), Other } \\
\text { Repair(30), Funeral/Morgue (53), Lab/Research(1), } \\
\text { Not Applicable(70)), COMMUNITY } \\
\text { SERVICES(Library/ Museum(11), Police or Fire(25), } \\
\text { Church/Civic(248), Outdoor Recreation(46), Indoor } \\
\text { Recreation (83), Not Applicable(3)), OTHER(92) }\end{array}$ & 1468 \\
\hline TOTAL & & 5979 \\
\hline
\end{tabular}


We further grouped the Offices (1175) into Small Office (722) and Large Office (334) based on the total electricity use of greater or less than $500 \mathrm{MW} / \mathrm{year}{ }^{\dagger}$ Similarly, Retail (1131) was grouped into Small(651) and Large Retail(339) based on the total electricity use of greater or less than $400 \mathrm{MW} / \mathrm{year}$. For Lodging(194), we used the basis of gross floor area (greater or less than $\left.60,000 \mathrm{ft}^{2}\right)$ to form Large Hotel(100) and Small Hotel/Motel(94) categories. ${ }^{\dagger}$

As with the on-site survey, we received a computer tape of all the mail survey buildings from CEC. The mail survey characterizes each building (record) by 417 variables describing various characteristics of the building. However, being a mail survey, the quality and depth of the data collected are not as high as those found in the on-site survey.

Since the mail survey data base is used as a secondary data source, we did not review and clean this data base as extensively as we did with the on-site survey. We only performed an analysis of outliers for exclusion from further building characteristic analyses. Table 3-12 (equivalent to Table 3-3 for the on-site survey) summarizes some of the key statistics of the mail survey data for the office and retail buildings.

We observe several potentially important differences between the characteristics of buildings found in the mail survey and those found in the on-site survey. The mean and median floor areas for small offices and small retails are larger than those found in the on-site survey data. Finally, the mail survey's mean and median floor area per occupant, for both retails and offices, are two to three times larger than those of the on-site survey.

Some other useful statistics obtained from the mail survey data are summarized in Table 3-13 (equivalent to Table 3-4 for on-site survey data). The statistics shown in these tables mainly concern the heating and cooling systems, type of domestic water heating, and fuel types.

† Buildings with zero or negative electricity use or zero gross floor were omitted from the data base. 
Table 3-12. Summary of Building Characteristics in the 1988 PG\&E Mail Survey

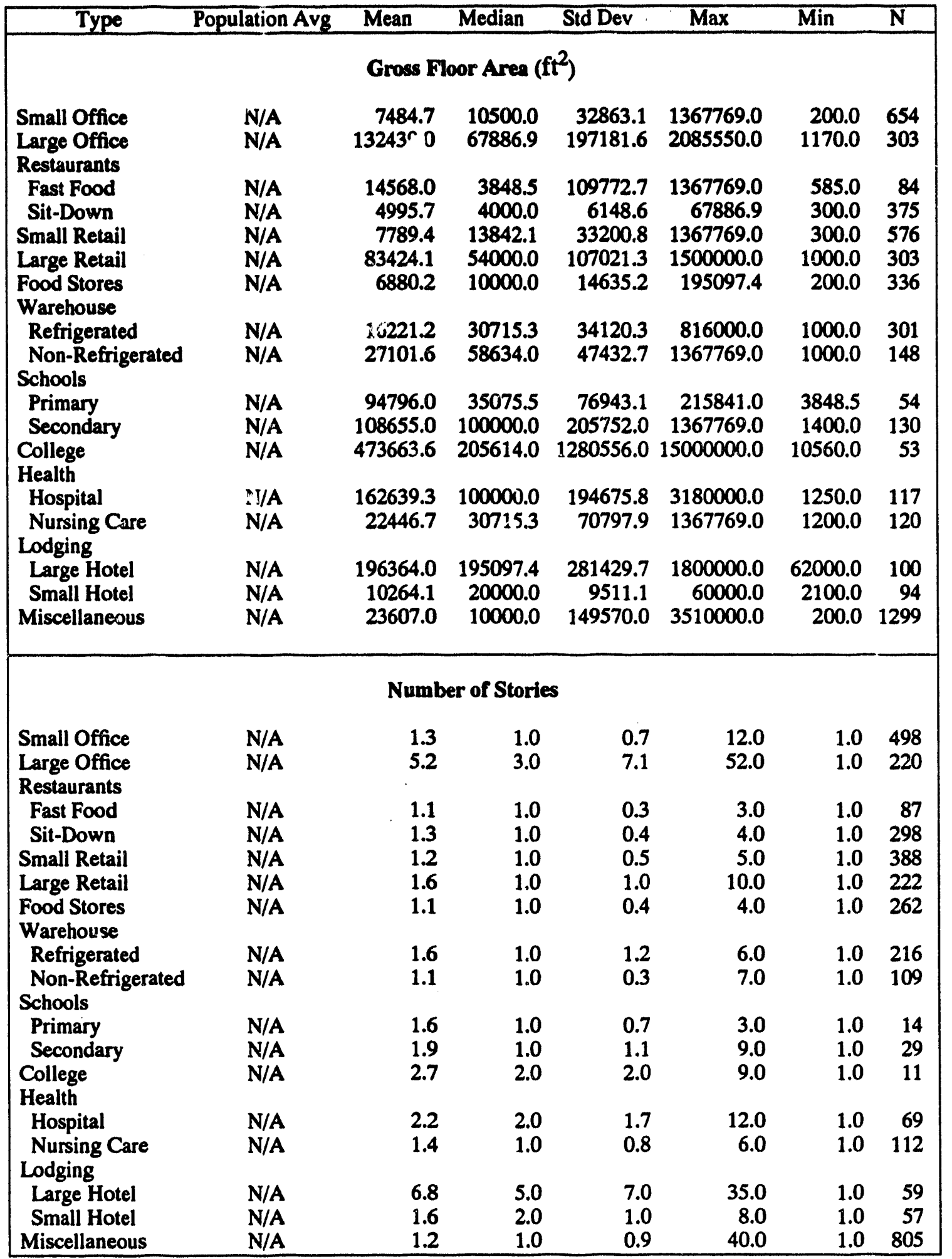


Table 3-12 (Continued). Summary of Building Characteristics in the 1988 PG\&E Mail Survey

\begin{tabular}{|c|c|c|c|c|c|c|c|}
\hline Type & Population Avg & Mean & Median & Std Dev & Max & Min & $\mathbf{N}$ \\
\hline \multicolumn{8}{|c|}{ Number of Bulldings at Facility } \\
\hline Small Office & N/A & 106.2 & 3.0 & 635.8 & 4100.0 & 2.0 & 65 \\
\hline Large Office & N/A & 3.7 & 3.0 & 2.4 & 15.0 & 2.0 & 60 \\
\hline \multicolumn{8}{|l|}{ Restaurants } \\
\hline Fast Food & N/A & 2.7 & 2 & 2.0 & 14 & 2 & 10 \\
\hline Sit-Down & N/A & 3.0 & 2.5 & 0.7 & 6.0 & 2.0 & 4 \\
\hline Small Retail & N/A & 2.6 & 2.0 & 1.0 & 7.0 & 2.0 & 73 \\
\hline Large Retail & N/A & 3.1 & 2.0 & 1.6 & 8.0 & 2.0 & 26 \\
\hline Food Stores & N/A & 2.7 & 2.0 & 2.0 & 14.0 & 2.0 & 10 \\
\hline Warehouse & & & & & & & \\
\hline Refrigerated & $\mathbf{N} / \mathbf{A}$ & 3.3 & 3.0 & 2.2 & 44.0 & 2.0 & 58 \\
\hline $\begin{array}{l}\text { Non-Refrigerated } \\
\text { Schools }\end{array}$ & \multirow{2}{*}{\multicolumn{7}{|c|}{ Schools }} \\
\hline $\begin{array}{l}\text { Schools } \\
\text { Primary }\end{array}$ & & & & & & & 35 \\
\hline Secondary & $\mathbf{N} / \mathbf{A}$ & 10.4 & 9.0 & 11.1 & 90.0 & 2.0 & 86 \\
\hline College & N/A & 40.6 & 20.0 & 100.7 & 600.0 & 2.0 & 32 \\
\hline \multicolumn{8}{|l|}{ Health } \\
\hline Hospital & N/A & 5.2 & 4.0 & 2.5 & 30.0 & 2.0 & 47 \\
\hline Nursing Care & \multirow{2}{*}{\multicolumn{2}{|c|}{ Lodging }} & 4.5 & 4.3 & 14.0 & 2.0 & 16 \\
\hline Large Hotel & N/A & 8.4 & 5.0 & 12.7 & & 20 & 35 \\
\hline Small Hotel & N/A & 8.9 & 3.0 & 6.7 & 17.0 & 2.0 & 22 \\
\hline Miscellaneous & N/A & 7.9 & 4.0 & 27.2 & 720.0 & 2.0 & 234 \\
\hline \multicolumn{8}{|c|}{ Weekday Hours } \\
\hline Small Office & N/A & 10.2 & 9.0 & 4.1 & 24.0 & 0.0 & 358 \\
\hline Large Office & N/A & 12.3 & 10.5 & 4.9 & 24.0 & 6.0 & 183 \\
\hline \multicolumn{8}{|l|}{ Restaurants } \\
\hline Fast Food & N/A & 14.8 & 17.5 & 3.8 & 24.0 & 5.0 & 22 \\
\hline Sit-Down & N/A & 12.5 & 14.5 & 3.7 & 24.0 & 6.0 & 112 \\
\hline Small Retail & N/A & 9.9 & 10.5 & 2.9 & 24.0 & 0.0 & 226 \\
\hline Large Retail & N/A & 13.1 & 12.8 & 3.1 & 24.0 & 7.5 & 128 \\
\hline Food Stores & N/A & 13.6 & 14.0 & 3.8 & 24.0 & 8.5 & 118 \\
\hline \multicolumn{8}{|l|}{ Warehouse } \\
\hline Refrigerated & N/A & 17.0 & 17.0 & 0.5 & 24.0 & 9.0 & 190 \\
\hline Non-Refrigerated & N/A & 17.0 & 17.0 & 0.4 & 17.0 & 9.0 & 94 \\
\hline \multicolumn{8}{|l|}{ Schools } \\
\hline Primary & N/A & 10.3 & 9.0 & 2.0 & 24.0 & 5.5 & 39 \\
\hline Secondary & N/A & 10.1 & 9.2 & 3.1 & 24.0 & 6.5 & 95 \\
\hline \multirow{2}{*}{\multicolumn{8}{|c|}{ Health }} \\
\hline & & & & & & & \\
\hline Hospital & N/A & 23.5 & 24.0 & 2.6 & 24.0 & 8.5 & 91 \\
\hline Nursing Care & N/A & 20.4 & 24.0 & 6.4 & 24.0 & 8.5 & 72 \\
\hline \multicolumn{8}{|l|}{ Lodging } \\
\hline Large Hotel & N/A & 17.0 & 17.0 & 0.0 & 17.0 & 17.0 & 63 \\
\hline Small Hotel & N/A & 17.0 & 17.0 & 0.0 & 17.0 & 17.0 & 47 \\
\hline Miscellaneous & $\mathbf{N} / \mathbf{A}$ & 12.5 & 17.0 & 4.8 & 24.0 & 0.0 & 712 \\
\hline
\end{tabular}


Table 3-12 (Continued). Summary of Building Characteristics in the 1988 PG\&E Mail Survey

\begin{tabular}{|c|c|c|c|c|c|c|c|}
\hline Type & Population Avg & Mean & Median & StdDev & Max & Min & $\mathbf{N}$ \\
\hline \multicolumn{8}{|c|}{ Floor Area per Occupant $\left(\mathrm{ft}^{2}\right)$} \\
\hline $\begin{array}{l}\text { Small Office } \\
\text { Large Office } \\
\text { Restaurants }\end{array}$ & $\begin{array}{l}813.1 \\
605.9\end{array}$ & $\begin{array}{r}623.3 \\
1503.0\end{array}$ & $\begin{array}{l}297.1 \\
318.7\end{array}$ & $\begin{array}{l}1292.7 \\
4906.5\end{array}$ & $\begin{array}{l}13577.4 \\
50350.6\end{array}$ & $\begin{array}{r}28.6 \\
2.2\end{array}$ & $\begin{array}{l}349 \\
176\end{array}$ \\
\hline $\begin{array}{l}\text { Fast Food } \\
\text { Sit-Down } \\
\text { Small Retail } \\
\text { Large Retail } \\
\text { Food Stores } \\
\text { Warehouse }\end{array}$ & \begin{tabular}{r|}
1297.6 \\
216.8 \\
946.2 \\
611.2 \\
313.2
\end{tabular} & $\begin{array}{r}154.3 \\
97.7 \\
584.4 \\
689.0 \\
365.2\end{array}$ & $\begin{array}{r}88.6 \\
57.4 \\
457.1 \\
431.4 \\
360.0\end{array}$ & $\begin{array}{r}187.7 \\
121.9 \\
1563.4 \\
777.8 \\
361.3\end{array}$ & $\begin{array}{r}922.8 \\
2000.0 \\
39019.5 \\
5736.7 \\
2666.7\end{array}$ & $\begin{array}{l}6.3 \\
4.0 \\
2.2 \\
4.6 \\
1.7\end{array}$ & $\begin{array}{r}18 \\
106 \\
221 \\
120 \\
111\end{array}$ \\
\hline $\begin{array}{l}\text { Refrigerated } \\
\text { Non-Refrigerated } \\
\text { Schools }\end{array}$ & $\begin{array}{r}332.6 \\
2007.9\end{array}$ & $\begin{array}{r}861.2 \\
1767.8\end{array}$ & $\begin{array}{r}877.6 \\
1243.3\end{array}$ & $\begin{array}{l}2119.2 \\
2728.7\end{array}$ & $\begin{array}{l}43560.0 \\
39019.5\end{array}$ & $\begin{array}{l}28.6 \\
24.6\end{array}$ & $\begin{array}{r}165 \\
88\end{array}$ \\
\hline $\begin{array}{l}\text { Primary } \\
\text { Secondary } \\
\text { College } \\
\text { Health }\end{array}$ & $\begin{array}{l}362.7 \\
228.7 \\
541.1\end{array}$ & $\begin{array}{l}606.7 \\
330.5 \\
600.2\end{array}$ & $\begin{array}{r}81.9 \\
111.5 \\
248.0\end{array}$ & $\begin{array}{r}511.6 \\
1436.1 \\
936.1\end{array}$ & $\begin{array}{r}1422.8 \\
18236.9 \\
5000.0\end{array}$ & $\begin{array}{l}13.7 \\
22.9 \\
21.4\end{array}$ & $\begin{array}{l}39 \\
92 \\
40\end{array}$ \\
\hline $\begin{array}{l}\text { Hospital } \\
\text { Nursing Care } \\
\text { Lodging }\end{array}$ & $\begin{array}{l}300.4 \\
444.6\end{array}$ & $\begin{array}{l}328.3 \\
302.2\end{array}$ & $\begin{array}{l}364.4 \\
201.5\end{array}$ & $\begin{array}{l}267.5 \\
363.3\end{array}$ & $\begin{array}{l}3000.0 \\
6143.1\end{array}$ & $\begin{array}{l}64.7 \\
22.0\end{array}$ & $\begin{array}{l}89 \\
68\end{array}$ \\
\hline $\begin{array}{l}\text { Large Hotel } \\
\text { Small Hotel } \\
\text { Miscellaneous }\end{array}$ & $\begin{array}{l}891.0 \\
148.9 \\
390.9\end{array}$ & $\begin{array}{r}786.0 \\
445.1 \\
1141.7\end{array}$ & $\begin{array}{l}514.3 \\
184.6 \\
305.5\end{array}$ & $\begin{array}{r}957.7 \\
472.0 \\
9438.8\end{array}$ & $\begin{array}{r}5574.2 \\
2768.4 \\
273553.8\end{array}$ & $\begin{array}{r}65.0 \\
4.6 \\
5.3\end{array}$ & $\begin{array}{r}59 \\
35 \\
607\end{array}$ \\
\hline \multicolumn{8}{|c|}{ Floor Area per Employee $\left(\mathrm{ft}^{2}\right)$} \\
\hline $\begin{array}{l}\text { Small Office } \\
\text { Large Office } \\
\text { Restaurants }\end{array}$ & $\begin{array}{l}1325.3 \\
1399.5\end{array}$ & $\begin{array}{l}1302.4 \\
8788.7\end{array}$ & $\begin{array}{l}389.8 \\
500.0\end{array}$ & $\begin{array}{r}8180.3 \\
21557.7\end{array}$ & $\begin{array}{l}195097.4 \\
283500.0\end{array}$ & $\begin{array}{l}20.1 \\
40.1\end{array}$ & $\begin{array}{l}333 \\
161\end{array}$ \\
\hline $\begin{array}{l}\text { Fast Food } \\
\text { Sit-Down }\end{array}$ & $\begin{array}{r}3562.3 \\
994.4\end{array}$ & $\begin{array}{l}300.9 \\
375.4\end{array}$ & $\begin{array}{l}170.0 \\
176.4\end{array}$ & $\begin{array}{l}372.1 \\
322.8\end{array}$ & $\begin{array}{l}1064.8 \\
4000.0\end{array}$ & $\begin{array}{r}41.9 \\
6.2\end{array}$ & $\begin{array}{r}19 \\
108\end{array}$ \\
\hline Small Retail & $\begin{array}{l}2847.0 \\
1622.9\end{array}$ & $\begin{array}{l}1349.1 \\
2142.8\end{array}$ & $\begin{array}{l}684.1 \\
638.3\end{array}$ & $\begin{array}{l}2214.7 \\
8864.4\end{array}$ & $\begin{array}{l}48774.3 \\
98122.5\end{array}$ & $\begin{array}{l}77.4 \\
80.0\end{array}$ & $\begin{array}{l}214 \\
111\end{array}$ \\
\hline $\begin{array}{l}\text { Food Stores } \\
\text { Warehouse }\end{array}$ & 1725.1 & 674.5 & 541.6 & 550.1 & 4064.5 & 30.0 & 106 \\
\hline $\begin{array}{l}\text { Refrigerated } \\
\text { Non-Refrigerated }\end{array}$ & $\begin{array}{r}332.6 \\
2952.7\end{array}$ & $\begin{array}{l}1079.2 \\
2605.8\end{array}$ & $\begin{array}{r}856.7 \\
1212.5\end{array}$ & $\begin{array}{l}3051.6 \\
2263.4\end{array}$ & $\begin{array}{r}103500.0 \\
24387.2\end{array}$ & $\begin{array}{r}34.5 \\
160.0\end{array}$ & $\begin{array}{r}156 \\
83\end{array}$ \\
\hline $\begin{array}{l}\text { Schools } \\
\text { Primary }\end{array}$ & 4221.7 & 6029.4 & 877.6 & 5193.2 & 11476.3 & 120.0 & 37 \\
\hline Secondary & 2294.6 & 1495.8 & 1357.7 & 1798.5 & 16680.1 & 122.9 & 87 \\
\hline $\begin{array}{l}\text { College } \\
\text { Health }\end{array}$ & 1120.3 & 1870.6 & 805.2 & 3874.0 & 24000.0 & 105.2 & 37 \\
\hline $\begin{array}{l}\text { Hospital } \\
\text { Nursing Cara } \\
\text { Lodging }\end{array}$ & $\begin{array}{l}223.3 \\
817.5\end{array}$ & $\begin{array}{l}284.9 \\
736.1\end{array}$ & $\begin{array}{l}327.3 \\
340.1\end{array}$ & $\begin{array}{l}333.2 \\
864.2\end{array}$ & $\begin{array}{l}2735.5 \\
5419.4\end{array}$ & $\begin{array}{l}76.8 \\
24.0\end{array}$ & $\begin{array}{l}83 \\
64\end{array}$ \\
\hline $\begin{array}{l}\text { Large Hotel } \\
\text { Small Hotel } \\
\text { Miscellaneous }\end{array}$ & $\begin{array}{l}2752.9 \\
3080.2 \\
1194.0\end{array}$ & $\begin{array}{l}5040.6 \\
1588.9 \\
2355.5\end{array}$ & $\begin{array}{r}1625.8 \\
1080.6 \\
772.9\end{array}$ & $\begin{array}{r}12112.6 \\
1644.3 \\
9018.8\end{array}$ & $\begin{array}{r}65032.5 \\
8000.0 \\
227961.5\end{array}$ & $\begin{array}{r}246.2 \\
128.3 \\
3.4\end{array}$ & $\begin{array}{r}59 \\
42 \\
578\end{array}$ \\
\hline
\end{tabular}


Table 3-13. 1988 PG\&E Mail Survey Statistics on Heating, Cooling, System Type, and Water Heating for PG\&E Mail Survey Buildings

a) Percent Buildings by Heated Floor Space

\begin{tabular}{|lrrrrr||c|}
\hline \multicolumn{1}{|c}{ \% floor area } & $25 \%$ & \multicolumn{1}{c}{$50 \%$} & \multicolumn{1}{c}{$75 \%$} & \multicolumn{1}{c|}{ All } & Don't know & \% missing data \\
\hline Small Office & 5.40 & 7.10 & 16.20 & 71.40 & 0.00 & 50.32 \\
Large Office & 5.00 & 4.20 & 16.70 & 74.20 & 0.00 & 47.00 \\
Restaurants & & & & & & \\
Fast Food & 9.40 & 5.10 & 2.00 & 83.50 & 0.00 & 71.90 \\
Sit-Down & 6.50 & 18.20 & 18.30 & 56.90 & 0.00 & 70.80 \\
Small Retail & 4.80 & 27.10 & 21.70 & 46.30 & 0.00 & 62.38 \\
Large Retail & 7.10 & 11.40 & 21.10 & 60.30 & 0.00 & 61.37 \\
Food Stores & 7.70 & 14.60 & 30.70 & 46.90 & 0.00 & 71.77 \\
Warehouse & & & & & & \\
Refrigerated & 39.40 & 11.60 & 13.10 & 35.40 & 0.40 & 49.63 \\
Non-Refrigerated & 14.80 & 1.30 & 50.60 & 28.00 & 5.30 & 36.59 \\
Schools & & & & & & \\
Primary & 0.00 & 0.00 & 54.40 & 45.60 & 0.00 & 60.44 \\
Secondary & 2.40 & 0.00 & 7.60 & 90.10 & 0.00 & 64.52 \\
College & 0.00 & 10.60 & 6.60 & 82.70 & 0.00 & 30.02 \\
Health & & & & & \\
Hospital & 0.00 & 0.00 & 1.40 & 98.60 & 0.00 & 31.58 \\
Nursing Care & 0.00 & 0.50 & 2.40 & 97.00 & 0.00 & 51.88 \\
Lodging & & & & & \\
Large Hotel & 8.30 & 0.00 & 9.80 & 81.90 & 0.00 & 42.16 \\
Small Hotel & 0.80 & 15.60 & 12.60 & 71.00 & 0.00 & 72.02 \\
Miscellaneous & 9.40 & 6.20 & 19.30 & 65.00 & 0.00 & 57.22 \\
\hline
\end{tabular}

b) Percent Buildings by Cooled Floor Space

\begin{tabular}{|lrrrrr||c|}
\hline \multicolumn{1}{|c}{ \% floor area } & \multicolumn{1}{c}{$25 \%$} & \multicolumn{1}{c}{$50 \%$} & \multicolumn{1}{c}{$75 \%$} & \multicolumn{1}{c|}{ All } & Don't know & \% missing data \\
\hline Small Office & 4.70 & 12.60 & 16.90 & 65.80 & 0.00 & 63.71 \\
Large Office & 8.30 & 2.10 & 16.50 & 73.10 & 0.00 & 49.70 \\
Restaurants & & & & & & \\
Fast Food & 0.00 & 22.00 & 2.20 & 75.70 & 0.00 & 78.93 \\
Sit-Down & 14.00 & 15.80 & 20.60 & 49.70 & 0.00 & 76.82 \\
Small Retail & 8.80 & 9.80 & 27.80 & 52.70 & 0.90 & 81.20 \\
Large Retail & 6.00 & 10.00 & 20.90 & 63.10 & 0.00 & 57.21 \\
Food Stores & 8.10 & 8.10 & 40.70 & 43.10 & 0.00 & 80.23 \\
Warehouse & & & & & & \\
Refrigerated & 38.60 & 15.30 & 0.70 & 45.10 & 0.30 & 62.42 \\
Non-Refrigerated & 28.90 & 56.10 & 7.40 & 7.10 & 0.50 & 43.25 \\
Schools & & & & & \\
Primary & 3.50 & 16.20 & 6.70 & 73.60 & 0.00 & 88.39 \\
Secondary & 14.50 & 1.40 & 23.20 & 60.90 & 0.00 & 82.80 \\
College & 6.10 & 17.90 & 2.10 & 73.90 & 0.00 & 44.87 \\
Health & & & & & \\
Hospital & 2.20 & 1.80 & 67.60 & 28.50 & 0.00 & 33.51 \\
Nursing Care & 27.00 & 0.30 & 4.90 & 67.70 & 0.00 & 60.30 \\
Lodging & & & & & & \\
Large Hotel & 8.60 & 0.00 & 30.60 & 57.90 & 2.90 & 47.60 \\
Small Hotel & 0.00 & 4.60 & 4.00 & 91.40 & 0.00 & 85.53 \\
Miscellaneous & 12.60 & 6.20 & 29.20 & 51.60 & 0.50 & 76.22 \\
\hline
\end{tabular}


Table 3-13 (Continued). 1988 PG\&E Mail Survey Statistics on Heating, Cooling, System Type, and Water Heating for PG\&E Mail Survey Buildings

c) Percent Buildings by Glass Cover of Exterior Walls

\begin{tabular}{|c|c|c|c|c|c|c|}
\hline$\%$ glass & 0 To 10\% & 11 To 25\% & 26 To $50 \%$ & 51 To 75\% & $76 \%$ Or More & $\%$ missing data \\
\hline $\begin{array}{l}\text { Small Office } \\
\text { Large Office } \\
\text { Restaurants }\end{array}$ & $\begin{array}{l}45.90 \\
19.00\end{array}$ & $\begin{array}{l}33.40 \\
18.70\end{array}$ & $\begin{array}{l}17.80 \\
34.70\end{array}$ & $\begin{array}{r}2.00 \\
19.70\end{array}$ & $\begin{array}{l}0.90 \\
7.80\end{array}$ & $\begin{array}{l}50.78 \\
46.53\end{array}$ \\
\hline $\begin{array}{l}\text { Fast Food } \\
\text { Sit-Down }\end{array}$ & $\begin{array}{l}34.00 \\
53.60\end{array}$ & $\begin{array}{l}41.50 \\
33.00\end{array}$ & $\begin{array}{r}21.10 \\
9.80\end{array}$ & $\begin{array}{l}3.20 \\
1.80\end{array}$ & $\begin{array}{l}0.30 \\
1.90\end{array}$ & $\begin{array}{l}63.47 \\
70.66\end{array}$ \\
\hline Small Retail & 31.60 & 26.90 & 4.50 & 33.30 & 3.70 & 59.61 \\
\hline $\begin{array}{l}\text { Large Retail } \\
\text { Food Stores }\end{array}$ & $\begin{array}{l}63.50 \\
42.90\end{array}$ & $\begin{array}{l}27.10 \\
30.40\end{array}$ & $\begin{array}{r}6.70 \\
18.30\end{array}$ & $\begin{array}{l}2.70 \\
4.20\end{array}$ & $\begin{array}{l}0.00 \\
4.20\end{array}$ & $\begin{array}{l}54.74 \\
64.68\end{array}$ \\
\hline $\begin{array}{l}\text { Warehouse } \\
\text { Refrigerated } \\
\text { Non-Refrigerated }\end{array}$ & $\begin{array}{l}69.80 \\
97.30\end{array}$ & $\begin{array}{r}14.90 \\
1.40\end{array}$ & $\begin{array}{r}14.90 \\
0.60\end{array}$ & $\begin{array}{l}0.40 \\
0.60\end{array}$ & $\begin{array}{l}0.00 \\
0.00\end{array}$ & $\begin{array}{l}41.49 \\
27.18\end{array}$ \\
\hline Schools & & & & & & \\
\hline $\begin{array}{l}\text { Primary } \\
\text { Secondary }\end{array}$ & $\begin{array}{l}61.90 \\
39.40\end{array}$ & $\begin{array}{l}21.70 \\
37.50\end{array}$ & $\begin{array}{l}16.40 \\
21.70\end{array}$ & $\begin{array}{l}0.00 \\
1.40\end{array}$ & $\begin{array}{l}0.00 \\
0.00\end{array}$ & $\begin{array}{l}59.81 \\
64.93\end{array}$ \\
\hline $\begin{array}{l}\text { College } \\
\text { Health }\end{array}$ & 35.40 & 27.70 & 31.50 & 5.40 & 0.00 & 32.10 \\
\hline $\begin{array}{l}\text { Hospital } \\
\text { Nursing Care } \\
\text { Lodging }\end{array}$ & $\begin{array}{r}5.90 \\
60.80\end{array}$ & $\begin{array}{l}85.40 \\
23.60\end{array}$ & $\begin{array}{r}8.00 \\
11.40\end{array}$ & $\begin{array}{l}0.70 \\
3.40\end{array}$ & $\begin{array}{l}0.00 \\
0.80\end{array}$ & $\begin{array}{l}32.81 \\
53.35\end{array}$ \\
\hline $\begin{array}{l}\text { Large Hotel } \\
\text { Small Hotel } \\
\text { Miscellaneous }\end{array}$ & $\begin{array}{l}32.30 \\
56.00 \\
51.90\end{array}$ & $\begin{array}{l}32.20 \\
22.70 \\
28.40\end{array}$ & $\begin{array}{l}17.00 \\
19.50 \\
10.30\end{array}$ & $\begin{array}{r}13.20 \\
1.30 \\
4.80\end{array}$ & $\begin{array}{l}5.30 \\
0.40 \\
3.20\end{array}$ & $\begin{array}{l}38.81 \\
64.33 \\
53.72\end{array}$ \\
\hline
\end{tabular}

d) Primary Space Heat System Types

\begin{tabular}{|lrrrrrr||c|}
\hline & $\begin{array}{c}\text { Steam/ } \\
\text { Hot Water }\end{array}$ & $\begin{array}{r}\text { Forced Air } \\
\text { Furnace }\end{array}$ & $\begin{array}{c}\text { Rooftop } \\
\text { Units }\end{array}$ & $\begin{array}{c}\text { Wall/Floor } \\
\text { Heaters }\end{array}$ & $\begin{array}{c}\text { Solar } \\
\text { Panels }\end{array}$ & Other & \% missing data \\
\hline Small Office & 5.40 & 40.60 & 29.10 & 21.70 & 0.00 & 3.10 & 57.48 \\
Large Office & 49.70 & 5.80 & 40.60 & 3.20 & 0.00 & 0.70 & 52.56 \\
Restaurants & & & & & & & \\
Fast Food & 22.60 & 0.40 & 35.60 & 38.90 & 0.00 & 2.50 & 71.64 \\
Sit-Down & 12.80 & 29.20 & 30.30 & 24.30 & 0.00 & 3.30 & 73.96 \\
Small Retail & 8.50 & 24.90 & 17.70 & 46.30 & 0.00 & 2.60 & 64.31 \\
Large Retail & 13.90 & 16.70 & 59.50 & 8.90 & 0.00 & 1.90 & 63.54 \\
Food Stores & 9.10 & 27.80 & 33.90 & 26.60 & 0.00 & 2.60 & 72.62 \\
Warehouse & & & & & & \\
Refrigerated & 14.90 & 26.90 & 36.90 & 13.70 & 0.20 & 7.20 & 51.00 \\
Non-Refrigerated & 54.50 & 11.50 & 22.10 & 11.40 & 0.00 & 0.50 & 40.66 \\
Schools & & & & & & & \\
Primary & 23.70 & 54.60 & 17.50 & 4.20 & 0.00 & 0.00 & 59.81 \\
Secondary & 44.90 & 20.80 & 26.30 & 5.50 & 0.00 & 2.50 & 64.53 \\
College & 57.30 & 16.90 & 13.40 & 12.40 & 0.00 & 0.00 & 37.99 \\
Health & & & & & & & \\
Hospital & 93.20 & 1.00 & 5.80 & 0.00 & 0.00 & 0.00 & 32.40 \\
Nursing Care & 22.10 & 18.90 & 38.70 & 20.30 & 0.00 & 0.00 & 52.06 \\
Lodging & & & & & & \\
Large Hotel & 46.20 & 12.40 & 28.20 & 13.20 & 0.00 & 0.00 & 44.41 \\
Small Hotel & 24.70 & 15.30 & 6.40 & 53.70 & 0.00 & 0.00 & 65.69 \\
Miscellaneous & 13.20 & 45.40 & 18.60 & 15.90 & 0.00 & 6.90 & 61.01 \\
\hline
\end{tabular}


Table 3-13 (Continued). 1988 PG\&E Mail Survey Statistics on Heating, Cooling, System Type, and Water Heating for PG\&E Mail Survey Buildings

e) Air Conditioning System (\%)

\begin{tabular}{|lcrrrr||c|}
\hline & $\begin{array}{c}\text { Packaged A-C } \\
\text { with Heating }\end{array}$ & $\begin{array}{r}\text { Packaged A-C } \\
\text { Only }\end{array}$ & $\begin{array}{r}\text { Chilled } \\
\text { Water }\end{array}$ & $\begin{array}{r}\text { Window/Wall } \\
\text { Unit }\end{array}$ & Other & \% missing data \\
\hline Small Office & 67.90 & 19.40 & 1.20 & 10.00 & 1.40 & 69.00 \\
Large Office & 44.70 & 8.40 & 43.80 & 0.00 & 3.00 & 55.04 \\
Restaurants & & & & & & \\
Fast Food & 70.20 & 29.80 & 0.00 & 0.00 & 0.00 & 80.48 \\
Sit-Down & 56.20 & 27.70 & 0.50 & 6.20 & 9.40 & 81.61 \\
Small Retail & 50.30 & 28.70 & 0.30 & 16.10 & 4.70 & 81.77 \\
Large Retail & 61.10 & 20.10 & 18.10 & 0.70 & 0.00 & 61.86 \\
Food Stores & 46.30 & 50.20 & 0.00 & 0.30 & 3.20 & 82.28 \\
Warehouse & & & & & \\
Refrigerated & 58.40 & 14.10 & 11.90 & 4.40 & 11.20 & 64.68 \\
Non-Refrigerated & 91.60 & 7.50 & 0.10 & 0.50 & 0.40 & 46.48 \\
Schools & & & & & & \\
Primary & 53.10 & 19.60 & 4.90 & 0.00 & 22.40 & 89.61 \\
Secondary & 66.70 & 10.20 & 13.90 & 6.00 & 3.30 & 83.26 \\
College & 31.30 & 24.40 & 41.80 & 2.50 & 0.00 & 51.66 \\
Health & & & & & \\
Hospital & 19.20 & 0.90 & 79.90 & 0.00 & 0.00 & 33.91 \\
Nursing Care & 53.70 & 11.20 & 11.10 & 24.10 & 0.00 & 60.67 \\
Lodging & & & & & & \\
Large Hotel & 43.30 & 6.70 & 41.00 & 9.10 & 0.00 & 50.95 \\
Small Hotel & 8.20 & 2.10 & 6.70 & 37.60 & 45.40 & 87.07 \\
Miscellaneous & 42.00 & 32.80 & 4.80 & 10.40 & 9.90 & 77.31 \\
\hline
\end{tabular}

f) Distribution Type for Water/Steam Systems (\%)

\begin{tabular}{|lrrrrrrr||r|}
\hline & $\begin{array}{c}\text { Hydronic } \\
\text { Heat Pump }\end{array}$ & $\begin{array}{r}\text { Fan Coil } \\
\text { Unit }\end{array}$ & $\begin{array}{c}\text { Coils/ } \\
\text { Other }\end{array}$ & $\begin{array}{c}\text { Coils/ } \\
\text { Heat Pump }\end{array}$ & Radiators & $\begin{array}{c}\text { Radiators } \\
\text { Coils }\end{array}$ & Other & $\begin{array}{r}\text { missing } \\
\text { data }\end{array}$ \\
\hline Small Office & 5.20 & 65.30 & 0.00 & 7.00 & 17.60 & 0.50 & 0.50 & 4.40 \\
Large Office & 5.60 & 60.40 & 0.50 & 2.30 & 11.00 & 8.90 & 8.90 & 11.30 \\
Restaurants & & & & & & & & \\
Fast Food & 87.20 & 12.80 & 0.00 & 0.00 & 0.00 & 0.00 & 0.00 & 93.60 \\
Sit-Down & 0.00 & 46.40 & 0.00 & 0.00 & 53.60 & 0.00 & 0.00 & 98.15 \\
Small Retail & 28.00 & 4.10 & 0.00 & 2.10 & 22.90 & 0.00 & 42.90 & 97.50 \\
Large Retail & 0.00 & 69.50 & 0.00 & 0.00 & 9.70 & 9.70 & 11.10 & 95.30 \\
Food Stores & 0.00 & 68.40 & 0.00 & 0.00 & 15.50 & 0.00 & 16.10 & 99.74 \\
Warehouse & & & & & & & & \\
Refrigerated & 1.60 & 48.60 & 0.00 & 0.00 & 0.70 & 46.40 & 2.80 & 92.70 \\
Non-Refrigerated & 0.20 & 1.80 & 0.00 & 0.00 & 97.60 & 0.10 & 0.20 & 67.68 \\
Schools & & & & & & & & \\
Primary & 0.00 & 69.70 & 0.00 & 0.00 & 13.60 & 0.00 & 16.70 & 93.41 \\
Secondary & 5.70 & 49.90 & 0.00 & 0.00 & 40.90 & 0.00 & 3.50 & 84.79 \\
College & 6.70 & 67.20 & 0.00 & 0.00 & 22.80 & 3.30 & 0.00 & 64.49 \\
Health & & & & & & & \\
Hospital & 1.10 & 92.00 & 0.40 & 0.60 & 3.50 & 1.90 & 0.60 & 37.94 \\
Nursing Care & 5.50 & 44.80 & 0.00 & 5.70 & 35.20 & 3.00 & 5.90 & 90.19 \\
Lodging & & & & & & & & \\
Large Hotel & 3.10 & 49.50 & 0.00 & 25.90 & 17.30 & 0.00 & 4.10 & 74.34 \\
Small Hotel & 1.20 & 5.90 & 0.00 & 0.00 & 1.60 & 0.00 & 91.30 & 91.63 \\
Miscellaneous & 5.20 & 29.00 & 0.20 & 0.00 & 32.20 & 1.20 & 32.10 & 95.74 \\
\hline
\end{tabular}


Table 3-13 (Continued). 1988 PG\&E Mail Survey Statistics on Heating, Cooling, System Type, and Water Heating for PG\&E Mail Survey Buildings

\section{g) Water Heating Equipment Type (\%)}

\begin{tabular}{|lrrrr||c|}
\hline & Central Sniler & Water Tank & Instant Heater & Other & \% missing data \\
\hline Small Office & 1.80 & 91.50 & 6.50 & 0.30 & 63.61 \\
Large Office & 18.00 & 76.80 & 3.10 & 2.00 & 53.40 \\
Restaurants & & & & & \\
Fast Food & 7.20 & 90.10 & 0.00 & 2.70 & 74.05 \\
Sit-Down & 14.40 & 84.10 & 1.60 & 0.00 & 73.55 \\
Small Retail & 8.30 & 84.20 & 3.70 & 3.80 & 83.60 \\
Large Retail & 4.30 & 80.60 & 12.70 & 2.40 & 59.62 \\
Food Stores & 6.10 & 89.20 & 4.50 & 0.30 & 71.30 \\
Warehouse & & & & & \\
Refrigerated & 11.90 & 84.20 & 2.90 & 1.10 & 57.54 \\
Non-Refrigerated & 0.60 & 98.10 & 1.20 & 0.10 & 40.20 \\
Schools & & & & \\
Primary & 9.20 & 90.80 & 0.00 & 0.00 & 60.15 \\
Secondary & 22.50 & 77.30 & 0.20 & 0.00 & 67.65 \\
College & 44.70 & 49.20 & 4.00 & 2.00 & 39.65 \\
Health & & & & \\
Hospital & 88.60 & 10.90 & 0.20 & 0.30 & 32.52 \\
Nursing Care & 13.10 & 66.40 & 0.30 & 20.20 & 51.62 \\
Lodging & & & & \\
Large Hotel & 45.90 & 52.20 & 1.30 & 0.70 & 42.88 \\
Small Hotel & 26.70 & 67.00 & 2.30 & 4.00 & 66.35 \\
Miscellaneous & 16.10 & 79.90 & 1.50 & 2.50 & 66.35 \\
\hline
\end{tabular}

h) Space Heating Fuel Type (\%)

\begin{tabular}{|c|c|c|c|c|c|c|c|c|c|}
\hline & $\begin{array}{c}\text { Natural } \\
\text { Gas }\end{array}$ & Electricity & $\begin{array}{l}\text { Fuel Oil } \\
\text { Only }\end{array}$ & $\begin{array}{l}\text { Gas with } \\
\text { Oil Back }\end{array}$ & $\eta$ & $\begin{array}{c}\text { Propane/ } \\
\text { Butane }\end{array}$ & Other & $\begin{array}{l}\text { Don't } \\
\text { Know }\end{array}$ & $\begin{array}{c}\% \text { missing } \\
\text { data }\end{array}$ \\
\hline Small Office & 62.10 & 31.70 & 0.00 & 0.0 & J & 0.00 & 5.30 & 0.80 & 50.69 \\
\hline $\begin{array}{l}\text { Large Office } \\
\text { Restaurants }\end{array}$ & 74.60 & 16.60 & 0.00 & 3.40 & .0 & 0.00 & 1.00 & 1.00 & 48.10 \\
\hline Fast Food & 62.40 & 27.90 & 0.00 & 0.00 & 0.00 & 0.00 & 9.70 & 0.00 & 68.78 \\
\hline Sit-Down & 68.70 & 21.70 & 0.00 & 0.10 & 0.00 & 0.00 & 9.50 & 0.00 & 69.71 \\
\hline Small Retail & 69.70 & 28.30 & 0.30 & 0.00 & 0.00 & 0.00 & 0.60 & 1.10 & 62.32 \\
\hline Large Retail & 67.90 & 27.40 & 0.60 & 0.90 & 1.20 & 0.00 & 1.40 & 0.70 & 61.15 \\
\hline $\begin{array}{l}\text { Food Stores } \\
\text { Warehouse }\end{array}$ & 78.00 & 15.60 & 0.00 & 0.20 & 0.00 & 0.00 & 3.00 & 3.20 & 69.15 \\
\hline Refrigerated & 68.80 & 26.90 & 0.20 & 0.10 & 0.00 & 0.20 & 3.80 & 0.00 & 53.91 \\
\hline $\begin{array}{l}\text { Non-Refrigerated } \\
\text { Schools }\end{array}$ & 82.80 & 16.60 & 0.50 & 0.10 & 0.00 & 0.00 & 0.00 & 0.00 & 36.93 \\
\hline Primary & 88.90 & 1.90 & 1.20 & 0.00 & 5.20 & 0.00 & 2.80 & 0.00 & 59.59 \\
\hline Secondary & 92.20 & 0.70 & 0.40 & 0.80 & 1.70 & 0.00 & 4.20 & 0.00 & 63.90 \\
\hline College & $\mathbf{7 4 . 8 0}$ & 19.50 & 0.00 & 2.60 & 0.00 & 0.00 & 1.30 & 1.70 & 30.02 \\
\hline Health & & & & & & & & & \\
\hline Hospital & 91.50 & 0.40 & 0.50 & 6.40 & 0.80 & 0.00 & 0.40 & 0.00 & 31.58 \\
\hline $\begin{array}{l}\text { Nursing Care } \\
\text { Lodging }\end{array}$ & 72.10 & 22.50 & 0.00 & 0.70 & 1.30 & 0.00 & 3.10 & 0.40 & 52.95 \\
\hline Large Hotel & 72.90 & 17.40 & 0.00 & 2.00 & 5.10 & 0.00 & 2.60 & 0.00 & 41.19 \\
\hline Small Hotel & 61.00 & 13.30 & 0.00 & 0.00 & 0.20 & 0.00 & 12.40 & 13.00 & 64.87 \\
\hline Miscellaneous & 72.40 & 9.40 & 1.10 & 0.40 & 0.60 & 0.00 & 7.20 & 8.80 & 56.80 \\
\hline
\end{tabular}


Table 3-13 (Continued). 1988 PG\&E Mail Survey Statistics on Heating, Cooling, System Type, and Water Heating for PG\&E Mail Survey Buildings

i) Air Conditioning Fuel Type (\%)

\begin{tabular}{|c|c|c|c|c|c|c|c|c|}
\hline & \multicolumn{2}{|r|}{ Electricity } & \multicolumn{2}{|c|}{ Natural Gas } & \multicolumn{2}{|c|}{ Other } & \multicolumn{2}{|c|}{$\%$ missing data } \\
\hline Small Office & & 86.90 & \multirow{2}{*}{\multicolumn{2}{|c|}{$\begin{array}{l}8.60 \\
3.80\end{array}$}} & \multirow{2}{*}{\multicolumn{2}{|c|}{$\begin{array}{l}4.50 \\
1.30\end{array}$}} & \multirow{2}{*}{\multicolumn{2}{|c|}{$\begin{array}{l}63.35 \\
49.66\end{array}$}} \\
\hline Large Office & & 94.90 & & & & & & \\
\hline \multicolumn{9}{|l|}{ Restaurants } \\
\hline Fast Food & & 72.30 & \multirow{2}{*}{\multicolumn{2}{|c|}{$\begin{array}{r}27.70 \\
2.10\end{array}$}} & \multirow{2}{*}{\multicolumn{2}{|c|}{$\begin{array}{l}0.00 \\
0.00\end{array}$}} & \multirow{2}{*}{\multicolumn{2}{|c|}{$\begin{array}{l}77.94 \\
75.05\end{array}$}} \\
\hline Sit-Down & & 97.90 & & & & & & \\
\hline Small Retail & & 92.30 & \multicolumn{2}{|r|}{5.90} & \multicolumn{2}{|r|}{1.80} & \multicolumn{2}{|r|}{81.17} \\
\hline Large Retail & & 94.70 & \multirow{2}{*}{\multicolumn{2}{|c|}{$\begin{array}{r}5.30 \\
14.80\end{array}$}} & \multirow{2}{*}{\multicolumn{2}{|c|}{$\begin{array}{l}0.00 \\
0.00\end{array}$}} & \multirow{2}{*}{\multicolumn{2}{|c|}{$\begin{array}{l}58.73 \\
77.95\end{array}$}} \\
\hline Food Stores & & 85.20 & & & & & & \\
\hline \multicolumn{9}{|l|}{ Warehouse } \\
\hline Refrigerated & & 94.30 & \multirow{2}{*}{\multicolumn{2}{|c|}{$\begin{array}{l}5.70 \\
0.30\end{array}$}} & \multirow{2}{*}{\multicolumn{2}{|c|}{$\begin{array}{l}0.00 \\
0.30\end{array}$}} & \multirow{2}{*}{\multicolumn{2}{|c|}{$\begin{array}{l}63.51 \\
42.80\end{array}$}} \\
\hline Non-Refrigerated & & 99.40 & & & & & & \\
\hline Schools & & & & & & & & \\
\hline Primary & & 80.40 & & 12.40 & & 7.20 & & 88.80 \\
\hline Secondary & & 98.00 & & 2.00 & & 0.00 & & 83.05 \\
\hline College & & 91.50 & & 8.50 & & 0.00 & & 52.59 \\
\hline Health & & & & & & & & \\
\hline Hospital & & 99.50 & & 0.30 & & 0.30 & & 33.36 \\
\hline Nursing Care & & 95.70 & & 4.30 & & 0.00 & & 61.23 \\
\hline Lodging & & & & & & & & \\
\hline Large Hotel & & 90.0 & & 8.60 & & 1.40 & & 47.21 \\
\hline Small Hotel & & 99.30 & & 0.70 & & 0.00 & & 85.47 \\
\hline Miscellaneous & & 89.00 & & 8.00 & & 3.00 & & 76.20 \\
\hline & & j) Wat & r Heating & Fuel Ty! & pe (\%) & & & \\
\hline & $\begin{array}{l}\text { Natural } \\
\text { Gas }\end{array}$ & Electricity & $\begin{array}{l}\text { Purchased } \\
\text { Steam }\end{array}$ & $\begin{array}{l}\text { Fuel } \\
\text { Oil }\end{array}$ & $\begin{array}{c}\text { Propane/ } \\
\text { Butane }\end{array}$ & Solar & Other & $\%$ missing \\
\hline Small Office & 57.20 & 42.30 & 0.00 & 0.00 & 0.30 & 0.20 & 0.00 & 58.55 \\
\hline Large Office & 64.90 & 30.90 & 3.20 & 0.00 & 1.00 & 0.00 & 0.00 & 48.94 \\
\hline Restaurants & & & & & & & & \\
\hline Fast Food & 75.70 & 19.20 & 0.00 & 0.00 & 5.10 & 0.00 & 0.00 & 72.02 \\
\hline Sit-Down & 72.90 & 18.10 & 0.00 & 0.00 & 9.00 & 0.00 & 0.00 & 69.16 \\
\hline Small Retail & 68.60 & 30.20 & 0.00 & 0.00 & 1.20 & 0.00 & 0.00 & 82.09 \\
\hline Large Retail & 55.50 & 42.80 & 0.00 & 0.00 & 0.00 & 1.70 & 0.00 & 57.42 \\
\hline Food Stores & 71.20 & 25.70 & 0.00 & 0.00 & 2.90 & 0.00 & 0.10 & 67.62 \\
\hline Warehouse & & & & & & & & \\
\hline Refrigerated & 53.30 & 41.70 & 0.00 & 0.10 & 4.00 & 0.00 & 0.90 & 56.92 \\
\hline Non-Refrigerated & 31.40 & 68.60 & 0.00 & 0.00 & 0.00 & 0.00 & 0.00 & 39.58 \\
\hline Schools & & & & & & & & \\
\hline Primary & 36.80 & 58.90 & 0.00 & 1.20 & 2.90 & 0.20 & 0.00 & 61.01 \\
\hline Secondary & 81.50 & 18.00 & 0.00 & 0.00 & 0.00 & 0.40 & 0.00 & 66.88 \\
\hline College & 65.70 & 28.90 & 0.00 & 0.00 & 1.50 & 2.00 & 1.90 & 39.39 \\
\hline Health & & & & & & & & \\
\hline Hospital & 97.50 & 0.20 & 0.90 & 0.50 & 0.40 & 0.00 & 0.50 & 31.60 \\
\hline Nursing Care & 75.10 & 23.50 & 0.00 & 0.00 & 0.80 & 0.60 & 0.00 & 50.84 \\
\hline Lodging & & & & & & & & \\
\hline Large Hotel & 91.80 & 2.00 & 3.00 & 0.00 & 2.50 & 0.00 & 0.60 & 38.42 \\
\hline Small Hotel & 65.70 & 5.00 & 0.00 & 0.00 & 28.70 & 0.00 & 0.60 & 64.36 \\
\hline Miscellaneous & 75.50 & 20.00 & 0.00 & 0.10 & 2.60 & 0.00 & 1.80 & 62.81 \\
\hline
\end{tabular}


The whole-building EUIs obtained from the analysis of the mail survey data are presented in Table 3-14.

Table 3-14. Summary of Whole-building EUIs in the 1988 PG\&E Mail Survey

\begin{tabular}{|c|c|c|c|c|c|c|c|}
\hline Type & Population Avg. & Mean & Median & Std. Dev. & $\operatorname{Max}$ & Min & $\mathbf{N}$ \\
\hline \multicolumn{8}{|c|}{ Energy Use Intensity $\left(\mathbf{k W h} / \mathrm{ft}^{2}\right)$} \\
\hline Small Office & 7.3 & 8.3 & 12.5 & 8.4 & 97.9 & 1.0 & 627 \\
\hline Large Office & 16.9 & 22.2 & 19.2 & 14.2 & 93.5 & 1.2 & 294 \\
\hline \multicolumn{8}{|l|}{ Restaurants } \\
\hline Fast Food & 15.6 & 25.5 & 30.3 & 20.9 & 92.1 & 2.1 & 55 \\
\hline Sit-Down & 16.5 & 23.7 & 31.6 & 19.2 & 99.0 & 1.1 & 298 \\
\hline Small Retail & 6.7 & 8.9 & 10.8 & 10.0 & 98.1 & 1.1 & 541 \\
\hline Large Retail & 14.3 & 19.2 & 17.4 & 11.9 & 96.2 & 1.3 & 291 \\
\hline Food Stores & 32.1 & 34.7 & 45.5 & 21.8 & 96.0 & 2.0 & 274 \\
\hline \multicolumn{8}{|l|}{ Warehouse } \\
\hline Refrigerated & 8.2 & 8.3 & 10.1 & 9.3 & 86.7 & 1.1 & 247 \\
\hline Non-Refrigerated & 6.2 & 7.4 & 7.9 & 9.2 & 76.5 & 1.0 & 120 \\
\hline \multicolumn{8}{|l|}{ Schools } \\
\hline Primary & 5.6 & 5.7 & 5.0 & 4.2 & 40.3 & 1.6 & 40 \\
\hline Secondary & 4.8 & 9.3 & 5.3 & 16.9 & 85.9 & 1.0 & 101 \\
\hline College & 8.6 & 10.5 & 10.4 & 7.0 & 49.5 & 1.3 & 40 \\
\hline \multicolumn{8}{|l|}{ Health } \\
\hline Hospital & 42.1 & 36.5 & 23.0 & 20.6 & 82.9 & 1.0 & 91 \\
\hline Nursing Care & 9.4 & 9.1 & 10.2 & 9.3 & 95.4 & 1.3 & 96 \\
\hline \multicolumn{8}{|l|}{ Lodging } \\
\hline Large Hotel & 7.2 & 7.1 & 7.1 & 5.7 & 28.5 & 1.1 & 85 \\
\hline Small Hotel/Motel & 7.1 & 6.9 & 8.6 & 11.7 & 90.3 & 1.2 & 85 \\
\hline Miscellaneous & 5.1 & 8.2 & 9.7 & 12.0 & 9.9 .5 & 1.0 & 1054 \\
\hline
\end{tabular}




\section{Whole-Building EUIs}

Whole-building EUIs play a critical role in LBL's methodology to reconcile simulation and engineering estimates with measured whole-building load research data. Historically, project sponsors (CEC, PG\&E, and, previously, SCE) have participated actively in decisions regarding the development of these data. In Phase I of the project, whole-building EUIs were developed by PG\&E (Mr. J. DeValois's memo dated 4 Feb. 1992) for all of the building types considered by the project. LBL used the whole-building EUIs developed for large office, small office, and retail buildings in completing Phase I project deliverables. Subsequently, discussions were held that led to re-examination of the whole building EUIs. ${ }^{1}$

The goal of the analysis is to develop whole-building EUIs, by building type, for both a coastal and non-coastal climate region for the Phase II buildings. Where appropriate, the wholebuilding EUI is based on a combination of whole-building EUIs from two constituent, subbuilding types (e.g., restaurants are a combination of fast-food and sit-down establishments). For these cases, whole-building EUIs are required both by sub-building type and by climate region. In addition, weighting factors to combine the sub-building type EUIs into a single building type EUI (separately by climate region) are also required.

Our approach was based on several important assumptions. First, the highest quality data for determining whole-building EUIs are those contained in the on-site survey, followed by the mail survey. Second, despite this preference for reliance on the on-site survey, use of the on-site survey may not be appropriate for some building types due to the small number of buildings surveyed. Third, in any case, the mail survey, due its much larger sample size, is a more appropriate source of information for developing weighting factors to combine whole-building EUIs from sub-building types into a single EUI for a building type and region.

1 In conjunction with the filing of PG\&E's preliminary forecast, PG\&E developed a second set of whole-building EUIs for use in the project (J. DeValois's memo dated 2 Jun. 1993). At a meeting held on 2 July 1993 to discuss the second interim report for the project, PG\&E (J. DeValojs) presented the methods used to develop these new EUIs, as well as further modifications leading to a third set of whole-building EUIs.

A second meeting was held on 21 July 1993 to address these issues, as well as to discuss independent work conducted by CEC to develop an alternative (or fourth) set of whole-building EUIs. A basic focus of the discussion was the wisdom of relying on data from the Quarterly Fuels and Electricity Report (QFER) to develop whole-building EUls; QFER data were the basis for both the most recent two PG\&E proposals as well as the CEC proposal. A concern was raised that reliance on these, rather than on an independent set of data, would yield mis-leadingly self-consistent results, since the forecasts are also calibrated to QFER data.

The outcome of the second meeting was agreement on two issues:

(1) LBL would not revisit the three building types already analyzed in Phase I of the project.

(2) LBL would prepare a new set of whole-building EUIs based on more detailed analysis of the on-site and mail survey data. 
Table 3-15 summarizes LBL's analysis of whole-building EUIs, along with information on the underlying values and sources used to develop them. There are three steps in the process. First, develop service area-wide whole-building EUIs for each sub-building type. Second, develop distinct, sub-building type whole-building EUIs for each climate zone, using simulations of the prototypes. Third, combine sub-building type, climate-zone specific whole-building EUIs into a single whole-building EUI for each building type and climate zone.

Step 1: We relied on whole-building EUIs developed from the on-site survey data, whenever the sample size (by sub-building type) exceeded about 15. This was possible for all building types, except secondary school, college, nursing, and lodging. In using the mail survey to develop EUIs for these remaining buildings, we made an effort to address data quality concerns by first eliminating the highest and lowest $5 \%$ of values (10\% total), before calculating the resulting "trimmed" mean. These are labeled on Table 3-15 as "raw EUIs." Their source is indicated as either "on-site" or "mail trim," as is the number of surveyed data contributing to the EUI.

Step 2: We introduced, but bounded the use of, engineering judgement into the development of separate whole-building EUIs for the coastal and non-coastal climate regions. That is, we used simulations of the prototypes, adjusted for the saturation (separately for coastal and non-coastal) of end uses (electric cooling, water heating, and space heating) and relative floor areas (coastal versus non-coastal) to develop coastal and non-coastal adjustment factors, which we then applied to the whole-building EUIs previously developed on a service area wide basis. These are labeled on Table 3-15 as "region adjustments."

Step 3: We combined sub-building type and climate-specific whole-building EUIs, within each climate region, using floor area weights developed from the mail survey. In this case, the weights refer to the relative floor area of sub-building types to a single building category. These are labeled on Table 3-15 as "weights."

Application of this procedure leads to somewhat counter-intuitive results for one whole-building EUI (warehouse) and for one su i-building EUI (primary school). However, we believe both results are well-supported by the data. In the case of Warehouse, a higher proportion of the more energy-intensive, refrigerated warehouses in the coastal region leads to a larger wholebuilding EUI for the warehouse building type for the coastal region than for the non-coastal region. Similarly, in the case of the primary school sub-building type, higher electric saturations for cooling and water heating leads to a higher coastal whole-building EUI than noncoastal EUI. Nevertheless, when combined on a floor-area-weighted basis with the secondary school, the trend is reversed (consistent with intuition); the overall whole-building EUI for the school is larger for non-coastal than for coastal. 
Table 3-16 summarizes the mail survey floor area weights and the whole-building EUIs for each aggregate prototype in the coastal and inland climate regions.

Table 3-15. LBL Analysis of Whole-Building EUIs (kWh/sqft.yr). EUIs for each sub building type and climate region is calculated by multiplying the Raw EUls by the corresponding adjustment factors. The aggregate EUIs are calculated by weight-averaging the component buildings.

\begin{tabular}{|l|ccc|ccc|ccc|}
\hline Building Type & Raw EUI & N & Sourcet & Adj. fact & Weight & Adj. EUI & Adj. fact & Weight & Adj. EUI \\
& & & & & & & & & \\
\hline Restaurant & & & & & & 36.5 & & & 37.2 \\
sitdown & 28.0 & 57 & OS & 1.00 & 0.79 & 28.0 & 1.00 & 0.77 & 28.0 \\
fastfood & 68.7 & 19 & OS & 1.00 & 0.21 & 68.7 & 0.99 & 0.23 & 68.0 \\
Food Store & 45.1 & 84 & OS & 0.98 & 1.00 & 44.2 & 1.03 & 1.00 & 46.5 \\
Warehouse & & & & & & 18.4 & & & 13.5 \\
refrigerated & 29.0 & 13 & OS & 0.99 & 0.57 & 28.7 & 1.01 & 0.34 & 29.3 \\
non-refrigerated & 5.2 & 21 & OS & 0.92 & 0.43 & 4.8 & 1.04 & 0.66 & 5.4 \\
School & & & & & & 4.5 & & & 4.8 \\
primary & 6.2 & 43 & OS & 1.02 & 0.21 & 6.3 & 0.96 & 0.19 & 6.0 \\
secondary & 4.2 & 104 & MS & 0.96 & 0.79 & 4.0 & 1.07 & 0.81 & 4.5 \\
College & 6.0 & 42 & MS & 0.88 & 1.00 & 5.3 & 1.17 & 1.00 & 7.0 \\
Health & & & & & & 25.5 & & & 27.1 \\
hospital & 28.3 & 45 & OS & 0.99 & 0.87 & 28.0 & 1.01 & 0.92 & 28.6 \\
nursing & 9.8 & 90 & MS & 0.91 & 0.13 & 8.9 & 1.08 & 0.08 & 10.5 \\
Lodging & & & & & & 6.4 & & & 7.7 \\
small hotel & 6.6 & 79 & MS & 0.93 & 0.18 & 6.1 & 1.07 & 0.52 & 7.1 \\
large hotel & 6.8 & 80 & MS & 0.95 & 0.82 & 6.5 & 1.23 & 0.48 & 8.4 \\
Miscellaneous & 6.5 & 126 & OS & 0.93 & 1.00 & 6.1 & 1.15 & 1.00 & 7.5 \\
\hline
\end{tabular}

$\dagger \quad$ OS: On-Site Survey; MS: Trimmed Mail Survey 
Table 3-16. Mail Survey Floor Area Weighting Factors and Whole Building EUIs

\begin{tabular}{|c|c|c|c|c|}
\hline \multirow{2}{*}{$\begin{array}{l}\text { BUILDING TYPE } \\
\text { Prototype }\end{array}$} & \multicolumn{2}{|c|}{ Weighting Factors } & \multicolumn{2}{|c|}{ Whole-Building EUIs ${ }^{\dagger}$} \\
\hline & Coastal & Inland & Constal & Inland \\
\hline SMALL OFFICE & 1.0 & 1.0 & 9.7 & 13.1 \\
\hline LARGE OFFICE & 1.0 & 1.0 & 20.4 & 26.4 \\
\hline RETAIL & & & 8.4 & 12.6 \\
\hline Large & 0.24 & 0.19 & & \\
\hline Small. & 0.76 & 0.81 & & \\
\hline RESTAURANT & & & 36.5 & 37.2 \\
\hline Fast Food & 0.21 & 0.23 & & \\
\hline Sit-Down & 0.79 & 0.77 & & \\
\hline FOOD STORES & 1.0 & 1.0 & 44.2 & 46.5 \\
\hline WAREHOUSE & & & 18.4 & 13.5 \\
\hline Refrigerated & 0.57 & 0.34 & & \\
\hline Non-Refrigerated & 0.43 & 0.66 & & \\
\hline SCHOOL & & & 4.5 & 4.8 \\
\hline Primary School & 0.21 & 0.19 & & \\
\hline Secondary School & 0.79 & 0.81 & & \\
\hline COLLEGE & & & 5.3 & 7.0 \\
\hline Office/Lab/Classroom & 0.75 & 0.75 & & \\
\hline Library & 0.05 & 0.05 & & \\
\hline Dormitory & 0.20 & 0.20 & & \\
\hline HEALTH & & & 25.5 & 27.1 \\
\hline Hospital & 0.87 & 0.92 & & \\
\hline Nursing Home & 0.13 & 0.08 & & \\
\hline LODGING & & & 6.4 & 7.7 \\
\hline Large Hotel & 0.82 & 0.48 & & \\
\hline Small Hotel/Motel & 0.18 & 0.52 & & \\
\hline MISCELLANEOUS & 1.0 & 1.0 & 6.0 & 7.5 \\
\hline
\end{tabular}




\section{Weather Data}

The final set of data required for the project was historic weather data for each California climate zone. We obtained a set of historic weather data from the CEC for each representative weather station used by CEC in forecasting.

Two activities were carried out using weather data. The first was assignment of PG\&E load research data to the five climate zones used by the CEC in forecasting. This activity, whose outcome was reported on previously, was completed using supplementary data provided by PG\&E on weather city assignment to each LRD account. A summary of these assignments is presented in Table 3-8.

The second activity has been analysis of the historic weather data. Tables 3-17 and 18 summarize the weather data found for each of the two coastal and three non-coastal weather stations in 1986. The weather parameters summarized include statistics on dry-bulb and wet-bulb temperature and on heating and cooling degree days. These parameters are averaged in two ways. The simple average is the linear average of the weather stations parameters. The weighted average parameters are calculated using the number of LRD small office buildings in each climate zone with weights shown in Table 3-6.

Since the number of LRD accounts in climate zones IA, IIA, and IIM is very small, statistically meaningful prototypical whole-building load shapes cannot be developed for these climate regions. Therefore, it was decided to combine LRD from climate zones IA and IV into a coastal zone, and to combine LRD from zones IIA, IIB, and III into a non-coastal zone. Also, it was decided that the Oakland/Alameda weather station would represent the coastal climate zone. (see memo "Weather Stations for Analysis of Load Research Data", 10/1//1, Akbari). This decision is based on the averages presented in Table 3-17, where both the simple and weighted average parameters are almost identical to those of the Oakland weather station.

Looking at Table 3-18 it is observed that the simple average parameters are usually very close to those of the Sacramento and the weighted average parameters are close to San Jose weather. Having used the number of retail stores as weights, the weighted parameters would still be close to San Jose. Therefore, for all practical purposes, the choice for a "representative" weather station should be between Sacramento and San Jose. Since, San Jose is in the Bay Area and it usually does not reflect the weather characteristics of the interior valley, we recommended Sacramento, out of the three given weather stations, to represent the non-coastal climate. 
Table 3-17. Weather data summary for Oakland and Blue Canyon

\begin{tabular}{|l|c|c|c|c|}
\hline \multicolumn{1}{|c|}{ Parameter } & & & \multicolumn{2}{c|}{ Average } \\
& Oakland & Blue Canyon & Simple & Weighted \\
\hline Avg. Drybulb Temp. (F) & 56 & 51 & 54 & 56 \\
Max. Drybulb Temp. (F) & 90 & 85 & 88 & 90 \\
Min. Drybulb Temp. (F) & 40 & 22 & 31 & 40 \\
Avg. Wetbulb Temp. (F) & 52 & 41 & 47 & 52 \\
Max. Wetbulb Temp. (F) & 67 & 65 & 66 & 67 \\
min. Wetbulb Temp. (F) & 38 & 17 & 28 & 38 \\
Heating Deg. Days (Base 55) & 324 & 2578 & 1451 & 347 \\
Heating Deg. Days (Base 60) & 1120 & 3781 & 2451 & 1147 \\
Heating Deg. Days (Base 65) & 2629 & 5167 & 3898 & 2654 \\
Cooling Deg. Days (Base 55) & 1369 & 1435 & 1402 & 1370 \\
Cooling Deg. Days (Base 60) & 340 & 813 & 577 & 345 \\
Cooling Deg. Days (Base 65) & 24 & 374 & 199 & 28 \\
\hline
\end{tabular}

Table 3-18. Weather data summary for San Jose, Sacramento, and Fresno

\begin{tabular}{|l|c|r|r|r|r|}
\hline \multicolumn{1}{|c|}{ Parameter } & & & \multicolumn{3}{c|}{ Average } \\
& San Jose & Sacramento & Fresno & Simple & Weighted \\
\hline Avg. Drybulb Temp. (F) & 61 & 60 & 65 & 62 & 61 \\
Max. Drybulb Temp. (F) & 97 & 103 & 107 & 102 & 99 \\
Min. Drybulb Temp. (F) & 34 & 32 & 33 & 33 & 34 \\
Avg. Wetbulb Temp. (F) & 54 & 53 & 55 & 54 & 54 \\
Max. Wetbulb Temp. (F) & 75 & 82 & 76 & 78 & 76 \\
min. Wetbulb Temp. (F) & 32 & 31 & 31 & 31 & 32 \\
Heating Deg. Days (Base 55) & 203 & 586 & 447 & 412 & 263 \\
Heating Deg. Days (Base 60) & 683 & 1233 & 974 & 963 & 763 \\
Heating Deg. Days (Base 65) & 1536 & 2237 & 1772 & 1848 & 1621 \\
Cooling Deg. Days (Base 55) & 3015 & 3010 & 4400 & 3475 & 3180 \\
Cooling Deg. Days (Base 60) & 1670 & 1832 & 3102 & 2201 & 1854 \\
Cosling Deg. Days (Base 65) & 698 & 1011 & 2075 & 1261 & 888 \\
\hline
\end{tabular}




\section{Chapter 4}

\section{Results}

This chapter summarizes the results of our analyses in developing end-use EUIs and load shapes for all building types studied, using the methodology discussed in Chapter 2. In the following sections we summarize the results for each building type.

The presentation of the results for each building type are organized in the following order:

1. Table of the building prototype and vintage characreristics,

2. A table of DOE-2 simulated and EDA-reconciled end-use EUIs,

3. Two plots of average standard day DOE-2 simulated end-use LSs for coastal and inland climates,

4. Two scatter plots of hourly whole-building EUIs against drybulb temperature for standard days of coastal and inland climates ("+" sign denotcs winter days and "small square" sign denotes summer days),

5. Four plots of average standard and nonstandard day EDA reconciled end-use LSs for coastal and inland climates.

See the Glossary of HVAC System Types at the beginning of this report for system type definitions. 


\section{Small Office}

The small office prototype is modeled as a $3,900 \mathrm{ft}^{2}$ single zone, single story building. The building is conditioned with a Packaged Single Zone system, and hot water and heating are provided by a.gas furnace.

Major chiaracteristics of the prototypical building are summarized in Table 4-1. The vintage and technology options are summarized in Table 4-2.

Table 4-3 shows the DOE-2 simulation and EDA-reconciled end-use EUI summaries for the Small Office category of the coastal and inland climate regions. DOE-2 simulated average standard day end-use LSs for the coastal and inland climate zones are shown in Figure 4-1. Scatter plots of hourly whole-building EUIs against drybulb temperature for annual standard days of coastal and inland climates are shown in Figure 4-2. The inland plot demonstrates significant summer cooling for during the late morning and afternoon, whereas the coastal plot illustrates a weaker correlation between whole-building-load and dry bulb temperature during the afternoon. EDA reconciled average standard and nonstandard day end-use LSs for coastal and inland climates are shown in Figure 4-3. The LSs indicate that indoor lighting constitutes the majority of the load, and lesser loads of equal magnitude are cooling, ventilation, office equipment, miscellaneous equipment, and outdoor lighting. Peak operation occurs on weekdays during 8 am to 5 pm.

Note: Packaged Single Zone (PSZ) 
Table 4-1. Small Office Building Prototype Characteristics

\begin{tabular}{|c|c|}
\hline Shell & \\
\hline Floor Area $\left(1000 \mathrm{ft}^{2}\right)$ & 3.9 \\
\hline Number of Floors & 1 \\
\hline Ceiling Insulation $\mathbf{R}$-value & 11.5 \\
\hline Wall Insulation R-value & 8.9 \\
\hline Window shading coefficient & 0.69 \\
\hline Window/wall ratio & 0.13 \\
\hline Loads & \\
\hline Occupancy $\left(\mathrm{ft}^{2} /\right.$ person$)$ & 189 \\
\hline Lights $\left(\mathrm{W} / \mathrm{ft}^{2}\right)$ & 2.0 \\
\hline Equipment $\left(\mathrm{W} / \mathrm{ft}^{2}\right)$ & 0.7 \\
\hline Refrigeration $\left(\mathrm{W} / \mathrm{ft}^{2}\right)$ & 0.02 \\
\hline Cooking $\left(\mathrm{W} / \mathrm{ft}^{2}\right)$ & 0.05 \\
\hline Hot Water $\left(B t u / h r / \mathrm{ft}^{2}\right)$ & 0.2 \\
\hline Schedule & \\
\hline Standard Days & 5 \\
\hline Start & 8 \\
\hline Stop & 17 \\
\hline Non-Standard Days & 2 \\
\hline Start & 9 \\
\hline Stop & 18 \\
\hline System & \\
\hline System Type & PSZ \\
\hline COP & 2.4 \\
\hline Supply Air $\left(\mathrm{cfm} / \mathrm{ft}^{2}\right)$ & 0.7 \\
\hline Economizer Limit Temperature & $65^{\circ} \mathrm{F}$ \\
\hline Thermostat Type & Proportional \\
\hline Outside Air Control & Temperature \\
\hline Outside Air / Person (CFM) & 15 \\
\hline Heat Setpoint & $71^{\circ} \mathrm{F}$ \\
\hline Cool Setpoint & $73^{\circ} \mathrm{F}$ \\
\hline Plant & \\
\hline Heating & Gas Furnace \\
\hline Cooling & Direct Expansion \\
\hline Hot Water & Gas Furnace \\
\hline
\end{tabular}

Table 4-2. Small Office Building Vintage Characteristics

\begin{tabular}{|l|rr|}
\hline Technology & Pre-1978 & \multicolumn{1}{c|}{ Post-1978 } \\
\hline Ceiling Insulation R-value & 11.5 & 18.9 \\
Wall Insulation R-value & 8.9 & 9.2 \\
Indoor Lighting (W/ $\mathrm{ft}^{2}$ ) & 2.4 & 2.2 \\
Equipment $\left(\mathrm{W} / \mathrm{ft}^{2}\right.$ ) & 0.5 & 0.5 \\
Thermostat Type & Proportional & Reverse Action \\
Outside Air Control & Fixed & Temperature \\
System Type & PSZ & PSZ \\
\hline
\end{tabular}


Table 4-3a. Small Office Simulated and EDA-Reconciled EUIs-Coastal (kWh/ti $\left.{ }^{2} / \mathrm{yr}\right)$

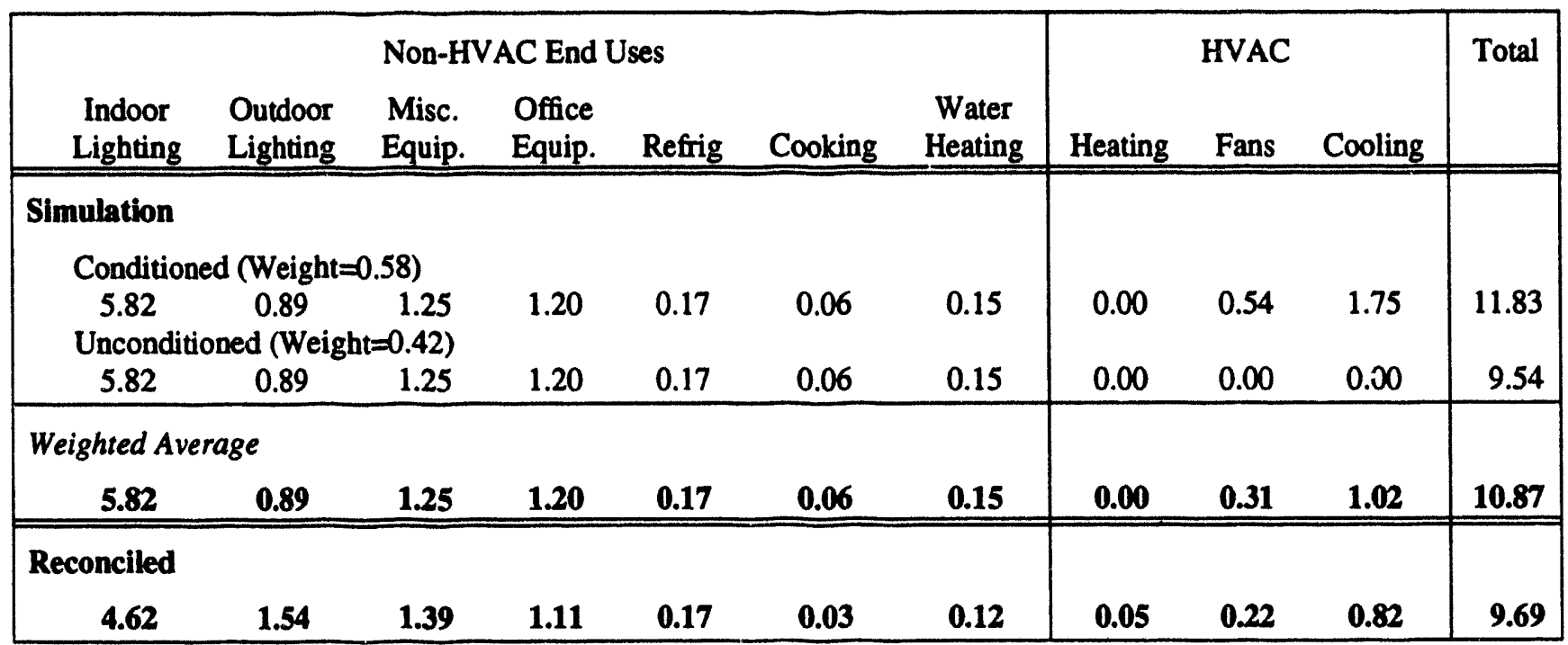

Table 4-3b. Small Office Simulated and EDA-Reconciled EUIs-Inland $\left(\mathrm{kWh} / \mathrm{ft}^{2} / \mathrm{yr}\right)$

\begin{tabular}{|c|c|c|c|c|c|c|c|c|c|c|}
\hline \multicolumn{7}{|c|}{ Non-HVAC End Uses } & \multicolumn{3}{|c|}{ HVAC } & \multirow[t]{2}{*}{ Total } \\
\hline $\begin{array}{c}\text { Indoor } \\
\text { Lighting }\end{array}$ & $\begin{array}{l}\text { Outdoor } \\
\text { Lighting } \\
\end{array}$ & $\begin{array}{l}\text { Misc. } \\
\text { Equip. }\end{array}$ & $\begin{array}{l}\text { Office } \\
\text { Equip. }\end{array}$ & Refrig & Cooking & $\begin{array}{c}\text { Water } \\
\text { Heating } \\
\end{array}$ & Heating & Fans & Cooling & \\
\hline \multicolumn{11}{|l|}{ Simulation } \\
\hline \multicolumn{11}{|c|}{ Conditioned (Weight=0.92) } \\
\hline 5.82 & 0.89 & 1.25 & 1.20 & 0.17 & 0.06 & 0.15 & 0.00 & 0.82 & 3.51 & 13.87 \\
\hline \multicolumn{11}{|c|}{ Unconditioned (Weight $=0.08$ ) } \\
\hline 5.82 & 0.89 & 1.25 & 1.20 & 0.17 & 0.06 & 0.15 & 0.00 & 0.00 & 0.00 & 9.54 \\
\hline \multicolumn{11}{|c|}{ Weighted Average } \\
\hline 5.82 & 0.89 & 1.25 & 1.20 & 0.17 & 0.06 & 0.15 & 0.00 & 0.75 & 3.22 & 13.51 \\
\hline \multicolumn{11}{|l|}{ Reconciled } \\
\hline 4.62 & 1.54 & 1.39 & 1.11 & 0.17 & 0.03 & 0.12 & 0.05 & 0.57 & 3.13 & 13.09 \\
\hline
\end{tabular}


Figure 4-1a. Small Office Simulated Average Standard Day LS - Coastal

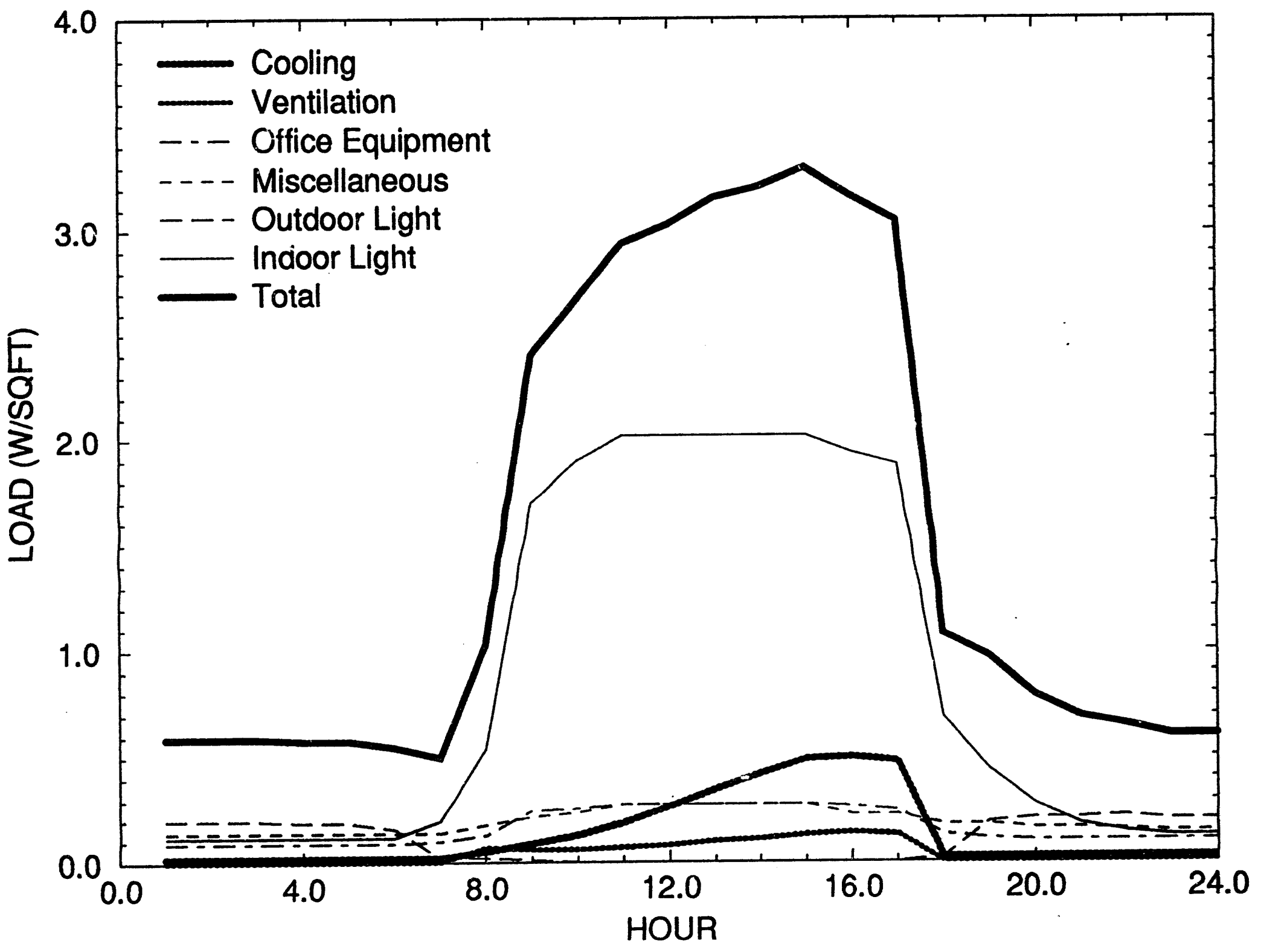




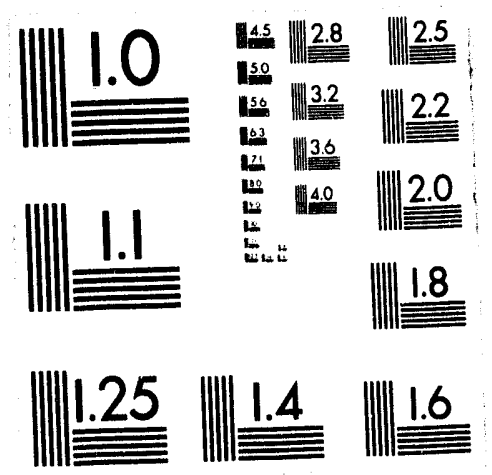



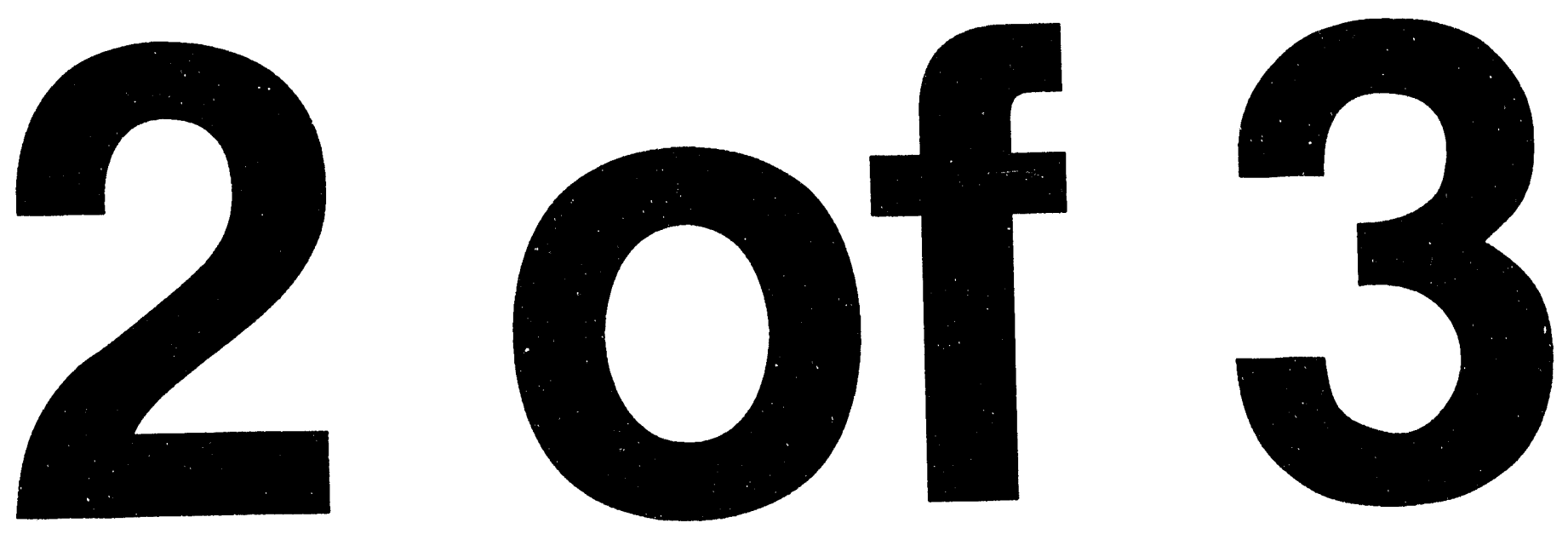
Figure 4-1b. Small Office Simulated Average Standard Day LS - Inland

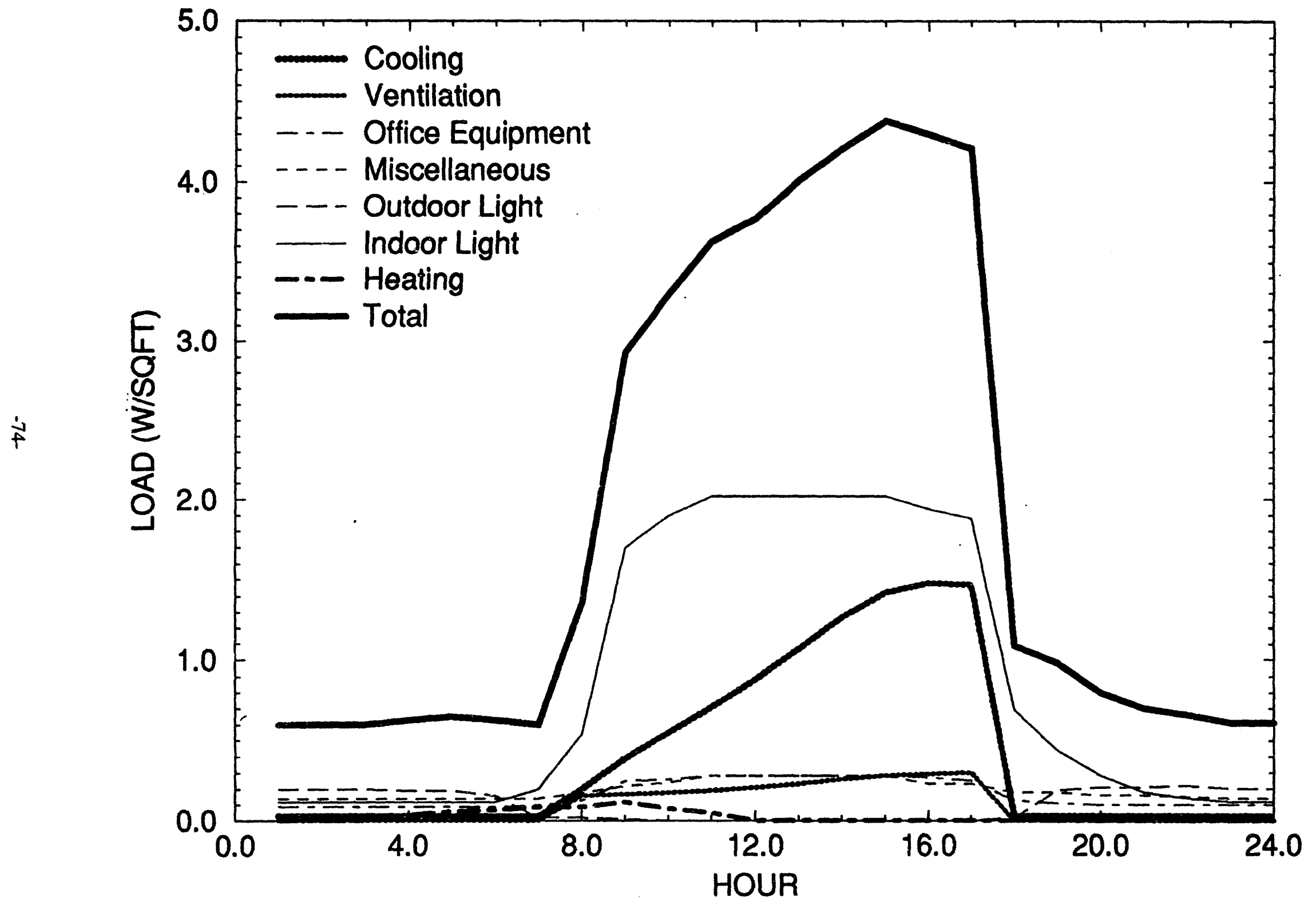


Figure 4-2a. Small Office Whole Building Load vs. Drybulb Temperature for Standard Day - Coastal

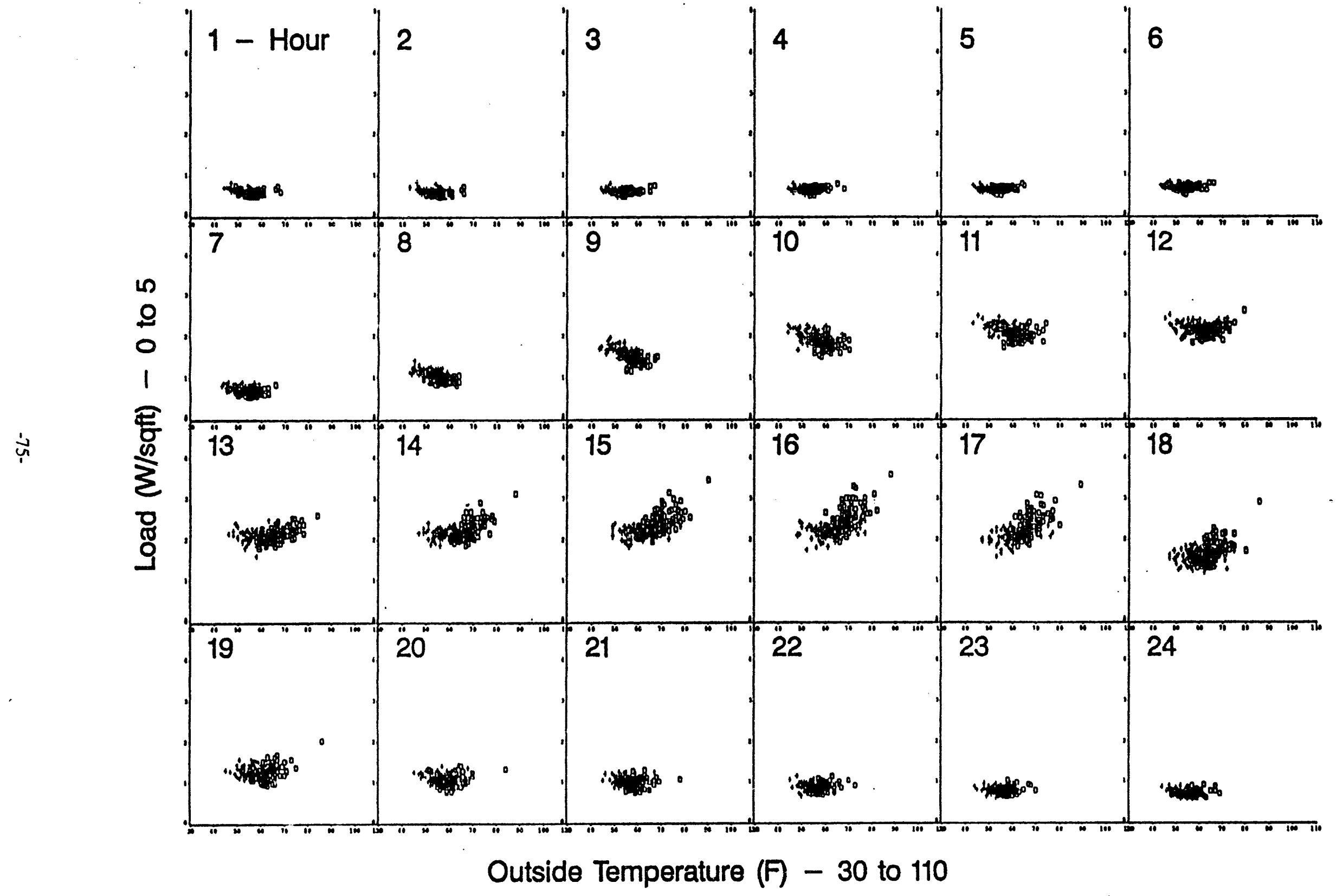


Figure 4-2b. Small Office Whole Building Load vs. Drybulb Temperature for Standard Day - Inland

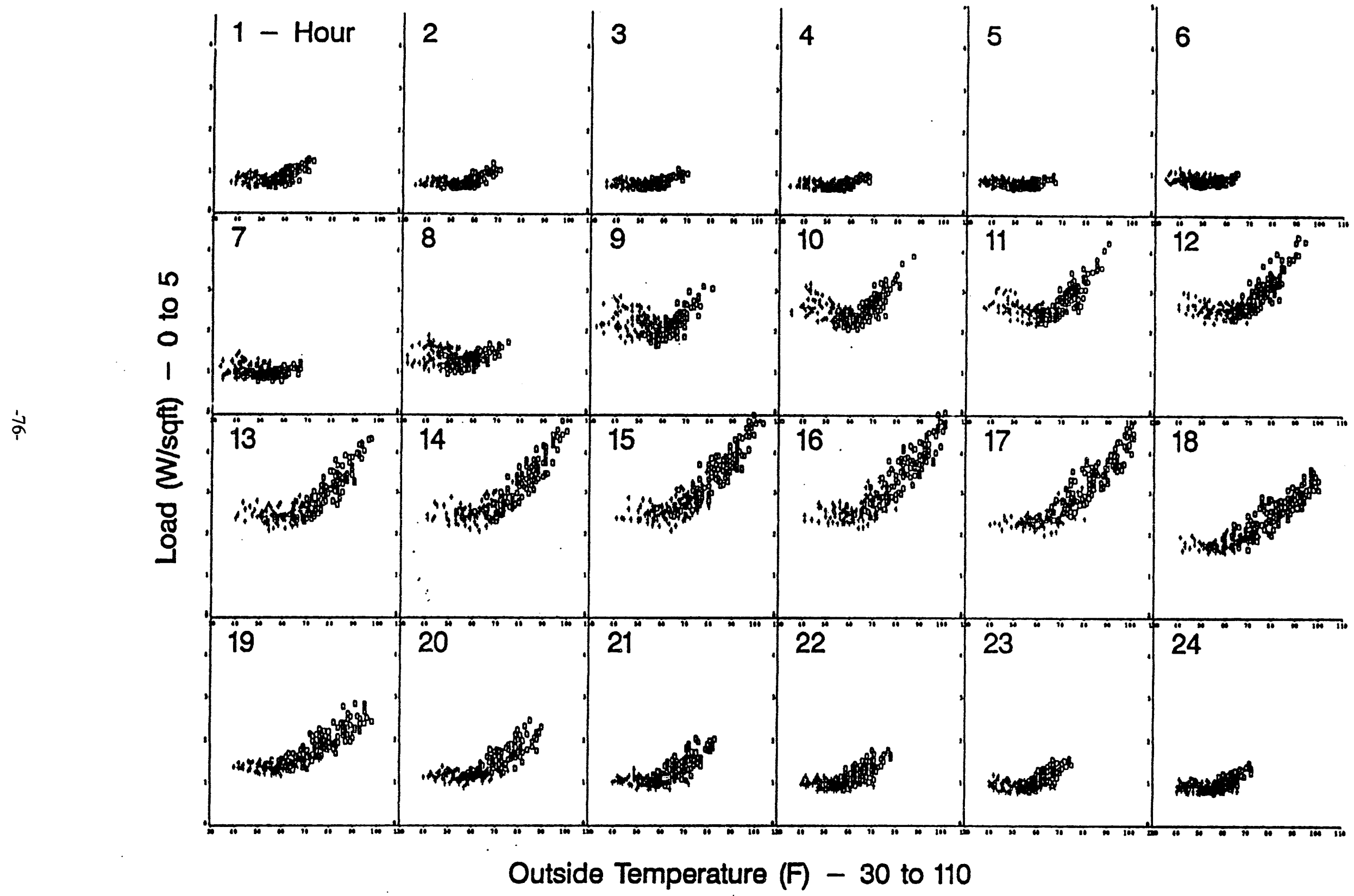


Figure 4-3a. Small Office Reconciled Standard Day Annual End-Use LS - Coastal

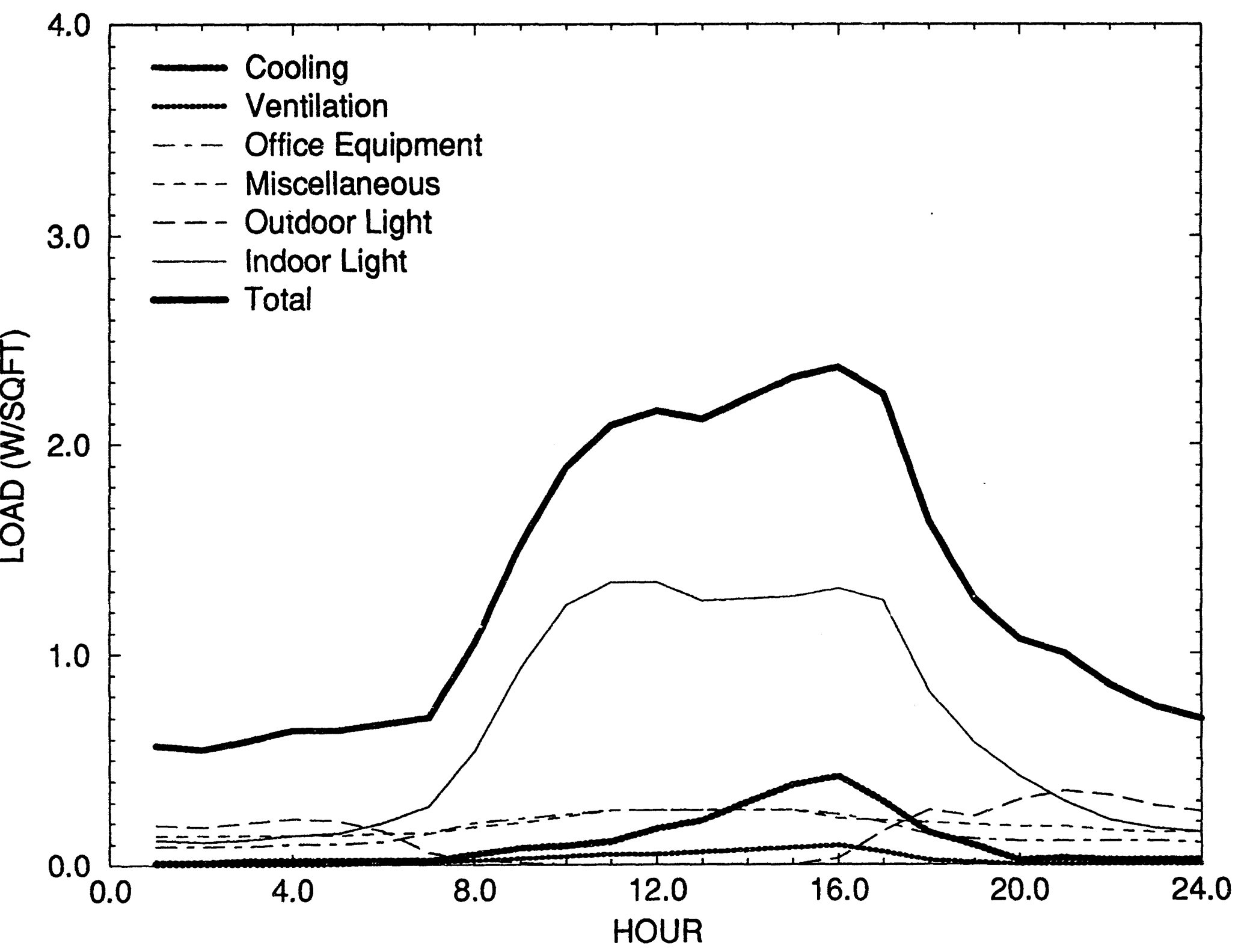


Figure 4-3b. Small Office Reconciled Standard Day Annual End-Use LS - Inland

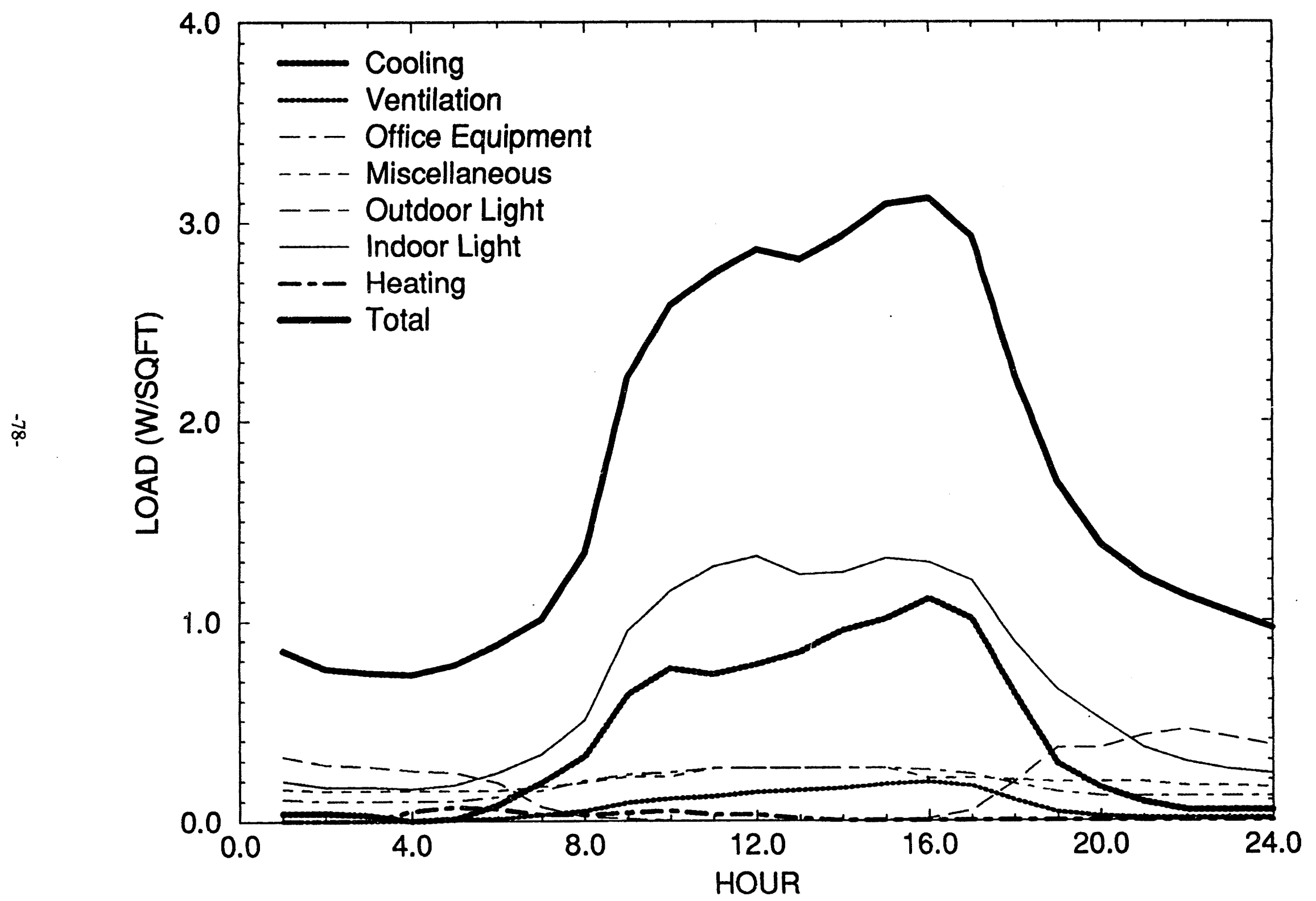


Figure 4-3c. Small Office Reconciled Nonstandard Day Annual End-Use LS - Coastal

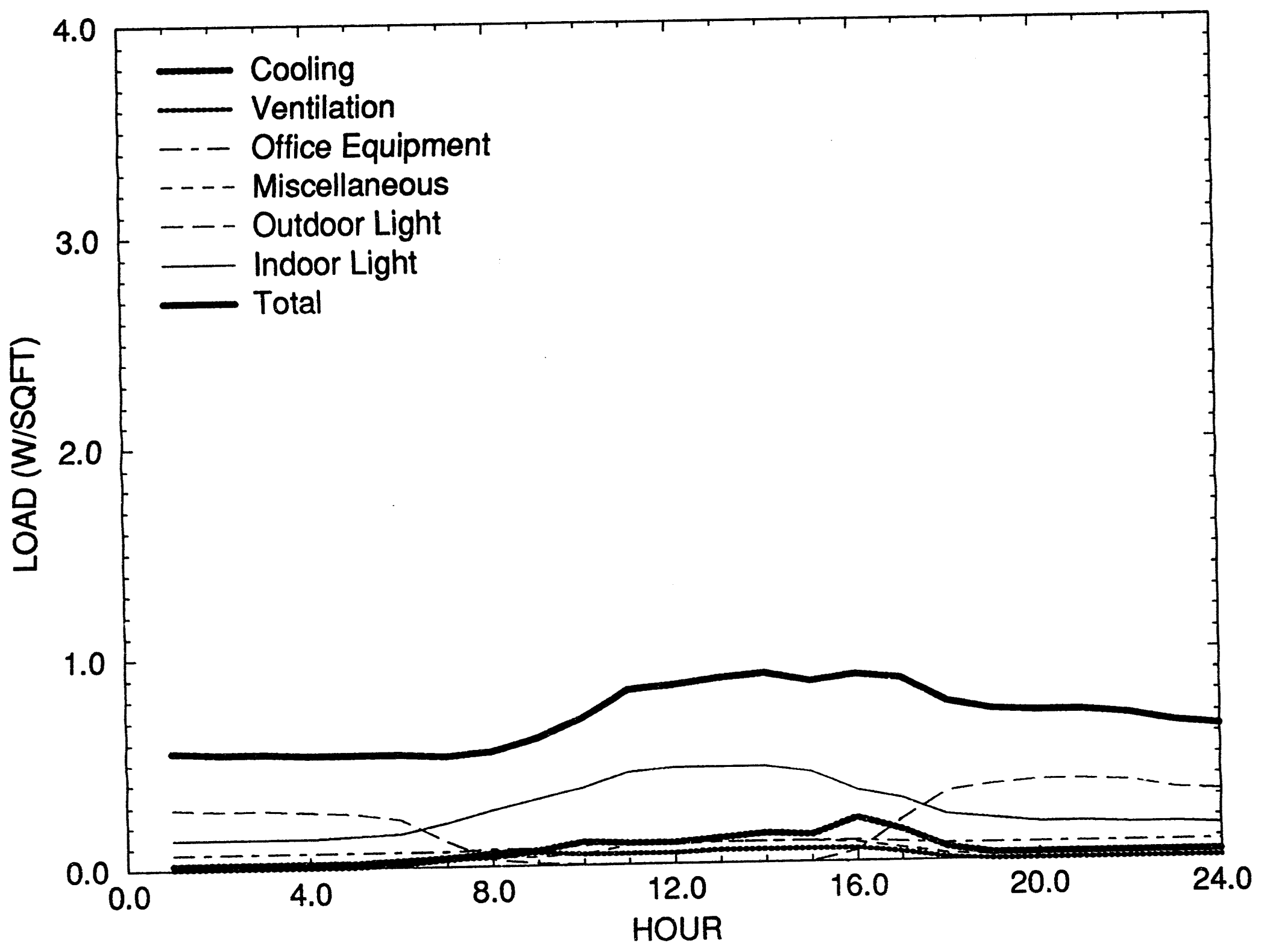


Figure 4-3d. Small Office Reconciled Nonstandard Day Annual End-Use LS - Inland

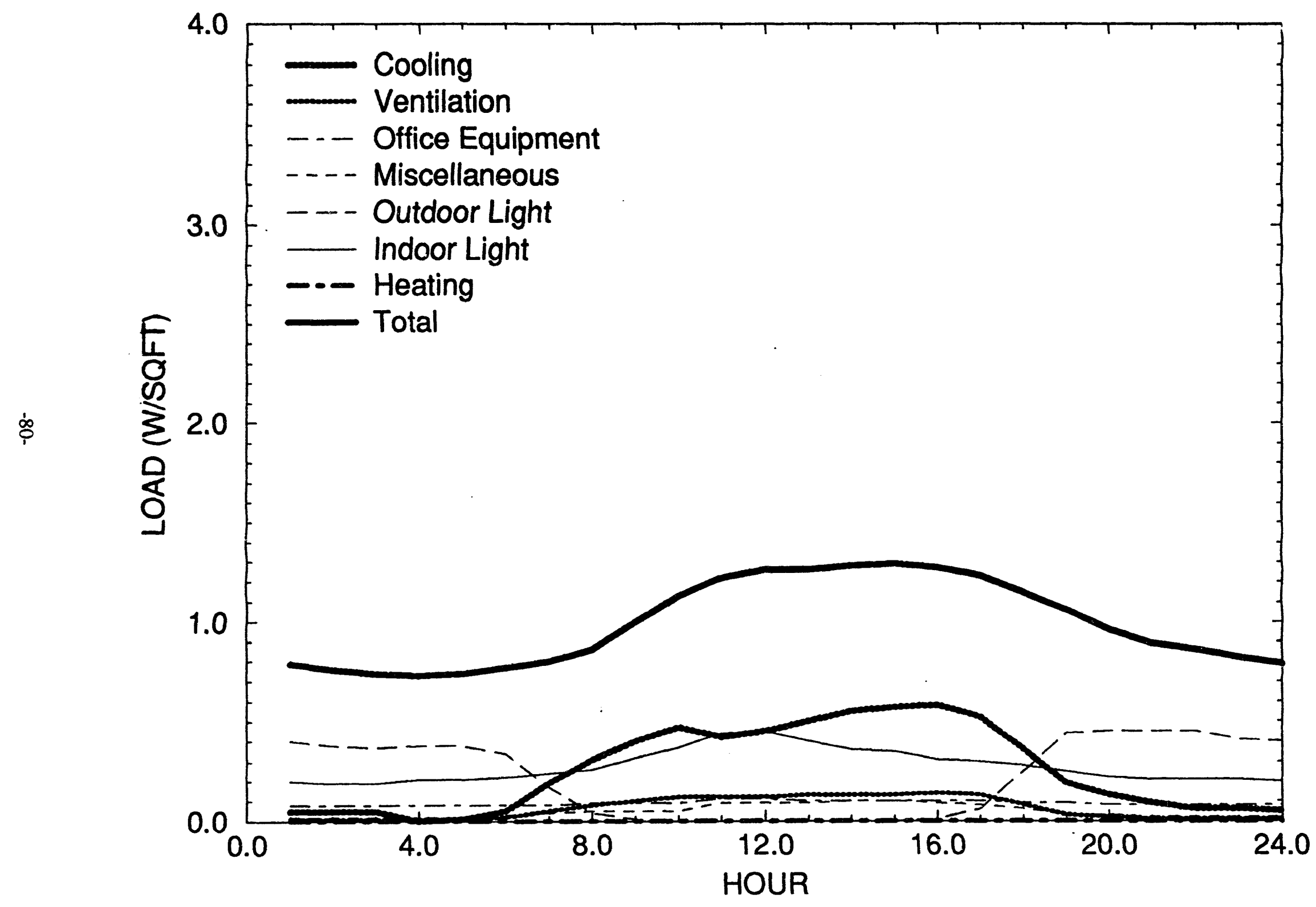




\section{Large Office}

The large office prototype is a $99,600 \mathrm{ft}^{2}$ five story building modeled with five identical zones. The prototype is conditioned with a Single Zone Reheat system for the central system and a Packaged Single Zone system for the packaged system. Hot water is provided by a gas furnace, and heating is provided by a gas boiler. For the central system, cooling is provided by hermetic centrifugal chillers.

Major characteristics of the prototypical building are summarized in Table 4-4. The vintage and technology options are summarized in Table 4-5.

Table 4-6 shows the simulation and EDA-reconciled end-use EUI summaries for the Large Office category of the coastal and inland climate regions. DOE-2 simulated average standard day end-use LSs for the coastal and inland climate zones are shown in Figure 4-4. Indoor lighting account for most of the load. Scatter plots of hourly whole-building EUIs against drybulb temperature for annual standard days of coastal and inland climates are shown in Figure 4-5. These plots reveal a cooling dependent load during business hours. EDA reconciled average standard and nonstandard day end-use LSs for coastal and inland climates are shown in Figure 4-6. The LSs indicate that indoor lighting constitutes the majority of the load, and lesser loads of equal magnitude are cooling, ventilation, office equipment, miscellaneous equipment, and outdoor lighting. Peak operation occurs on weekdays during 8 am to $5 \mathrm{pm}$.

Note: Packaged Single Zone (PSZ)

Packaged Multi Zone (PMZ)

Single Zone Reheat (SZRH)

Variable Air Volume (VAV) 
Table 4-4. Large Office Building Prototype Characteristics

\begin{tabular}{|c|c|}
\hline Shell & \\
\hline Floor Area $\left(1000 \mathrm{ft}^{2}\right)$ & 99.6 \\
\hline Number of Floors & 5 \\
\hline Ceiling Insulation R-value & 12.4 \\
\hline Wall Insulation R-value & 9.0 \\
\hline Window shading coefficient & 0.59 \\
\hline Window/wall ratio & 0.13 \\
\hline \multicolumn{2}{|l|}{ Loads } \\
\hline Occupancy $\left(\mathrm{ft}^{2} /\right.$ person$)$ & 273 \\
\hline Lights $\left(\mathrm{W} / \mathrm{ft}^{2}\right)$ & 1.5 \\
\hline Equipment $\left(\mathrm{W} / \mathrm{ft}^{2}\right)$ & 0.7 \\
\hline Refrigeration $\left(\mathrm{W} / \mathrm{ft}^{2}\right)$ & 0.01 \\
\hline Cooking $\left(\mathrm{W} / \mathrm{ft}^{2}\right)$ & 0.05 \\
\hline Hot Water $\left(\mathrm{Btu} / \mathrm{hr} / \mathrm{ft}^{2}\right)$ & 0.04 \\
\hline \multicolumn{2}{|l|}{ Schedule } \\
\hline Standard Days & 5 \\
\hline Start & 6 \\
\hline Stop & 20 \\
\hline Non-Standard Days & 2 \\
\hline Start & 9 \\
\hline Stop & 19 \\
\hline \multicolumn{2}{|l|}{ System } \\
\hline System Type & $\begin{array}{l}\text { Packaged: PSZ } \\
\text { Central: SZRH }\end{array}$ \\
\hline COP & 2.5 \\
\hline Supply Air $\left(\mathrm{cfm} / \mathrm{ft}^{2}\right)$ & 0.7 \\
\hline Economizer Limit Temperature & $65^{\circ} \mathrm{F}$ \\
\hline Thermostat Type & Proportional \\
\hline Outside Air Control & Temperature \\
\hline Outside Air / Person (CFM) & 15 \\
\hline Heat Setpoint & $70^{\circ} \mathrm{F}$ \\
\hline Cool Setpoint & $72^{\circ} \mathrm{F}$ \\
\hline \multicolumn{2}{|l|}{ Plant } \\
\hline Heating & Gas Boiler \\
\hline Cooling & $\begin{array}{l}\text { Packaged: Direct Expansion } \\
\text { Central: Hermetic Centrifugal Chiller }\end{array}$ \\
\hline Hot Water & Gas Furnace \\
\hline
\end{tabular}

Table 4-5. Large Office Building Vintage Characteristics

\begin{tabular}{|c|c|c|}
\hline Technology & Pre-1978 & Post-1978 \\
\hline Ceiling Insulation R-value & 12.4 & 18.9 \\
\hline Wall Insulation R-value & 6.3 & 9.2 \\
\hline Indoor Lighting $\left(\mathrm{W} / \mathrm{ft}^{2}\right)$ & 1.6 & 1.6 \\
\hline Equipment $\left(\mathrm{W} / \mathrm{ft}^{2}\right)$ & 0.5 & 0.5 \\
\hline Thermostat Type & Proportional & Reverse Action \\
\hline Outside Air Control & Fixed & Temperature \\
\hline System Type & Packaged: PMZ & PSZ \\
\hline & Central: SZRH & VAV \\
\hline
\end{tabular}


Table 4-6a. Large Office Simulated and EDA-Reconciled EUIs-Coastal $\left(\mathrm{kWh} / \mathrm{ft}^{2} / \mathrm{yr}\right)$

\begin{tabular}{|c|c|c|c|c|c|c|c|c|c|c|}
\hline \multicolumn{7}{|c|}{ Non-HVAC End Uses } & \multicolumn{3}{|c|}{ HVAC } & \multirow[t]{2}{*}{ Total } \\
\hline $\begin{array}{c}\text { Indoor } \\
\text { Lighting }\end{array}$ & $\begin{array}{l}\text { Outdoor } \\
\text { Lighting } \\
\end{array}$ & $\begin{array}{l}\text { Misc. } \\
\text { Equip. }\end{array}$ & $\begin{array}{l}\text { Office } \\
\text { Equip. }\end{array}$ & Refrig & Cooking & $\begin{array}{c}\text { Water } \\
\text { Heating }\end{array}$ & Heating & Fans & Cooling & \\
\hline \multicolumn{10}{|l|}{ Simulation } & \\
\hline \multicolumn{11}{|c|}{ Packaged $($ Weight $=0.51)$} \\
\hline 6.77 & 0.23 & 1.57 & 1.21 & 0.08 & 0.09 & 0.04 & 0.00 & 0.87 & 2.71 & 13.57 \\
\hline \multicolumn{11}{|c|}{ Central (Weight $=0.49)$} \\
\hline 6.77 & 0.23 & 1.57 & 1.21 & 0.08 & 0.09 & 0.04 & 0.00 & 3.84 & 2.83 & 16.66 \\
\hline \multicolumn{11}{|c|}{ Weighted Average } \\
\hline 6.77 & 0.23 & 1.57 & 1.21 & 0.08 & 0.09 & 0.04 & 0.00 & 2.33 & 2.77 & 15.09 \\
\hline \multicolumn{11}{|l|}{ Reconciled } \\
\hline 10.48 & 0.44 & 2.14 & 1.73 & 0.09 & 0.15 & 0.05 & 0.00 & 2.98 & 3.88 & 20.40 \\
\hline
\end{tabular}

Table 4-6b. Large Office Simulated and EDA-Reconciled EUIs_-Inland $\left(\mathrm{kWh} / \mathrm{ft}^{2} / \mathrm{yr}\right)$

\begin{tabular}{|c|c|c|c|c|c|c|c|c|c|c|}
\hline \multicolumn{7}{|c|}{ Non-HVAC End Uses } & \multicolumn{3}{|c|}{ HVAC } & \multirow[t]{2}{*}{ Total } \\
\hline $\begin{array}{c}\text { Indoor } \\
\text { Lighting } \\
\end{array}$ & $\begin{array}{l}\text { Outdoor } \\
\text { Lighting } \\
\end{array}$ & $\begin{array}{l}\text { Misc. } \\
\text { Equip. }\end{array}$ & $\begin{array}{l}\text { Office } \\
\text { Equip. }\end{array}$ & Refrig & Cooking & $\begin{array}{c}\text { Water } \\
\text { Heating }\end{array}$ & Heating & Fans & Cooling & \\
\hline \multicolumn{10}{|l|}{ Simulation } & \\
\hline \multicolumn{11}{|c|}{ Packaged $($ Weight $=0.51)$} \\
\hline 6.77 & 0.23 & 1.57 & 1.21 & 0.08 & 0.09 & 0.04 & 0.00 & 1.03 & 3.71 & 14.73 \\
\hline \multicolumn{11}{|c|}{ Central (Weight $=0.49)$} \\
\hline 6.77 & 0.23 & 1.57 & 1.21 & 0.08 & 0.09 & 0.04 & 0.00 & 4.43 & 3.85 & 18.27 \\
\hline \multicolumn{11}{|c|}{ Weighted Average } \\
\hline 6.77 & 0.23 & 1.57 & 1.21 & 0.08 & 0.09 & 0.04 & 0.00 & 2.71 & 3.78 & 16.48 \\
\hline \multicolumn{11}{|l|}{ Reconciled } \\
\hline 10.48 & 0.44 & 2.14 & 1.73 & 0.09 & 0.15 & 0.05 & 0.00 & 4.03 & 5.71 & 26.36 \\
\hline
\end{tabular}


Figure 4-4a. Large Office Simulated Average Standard Day LS - Coastal

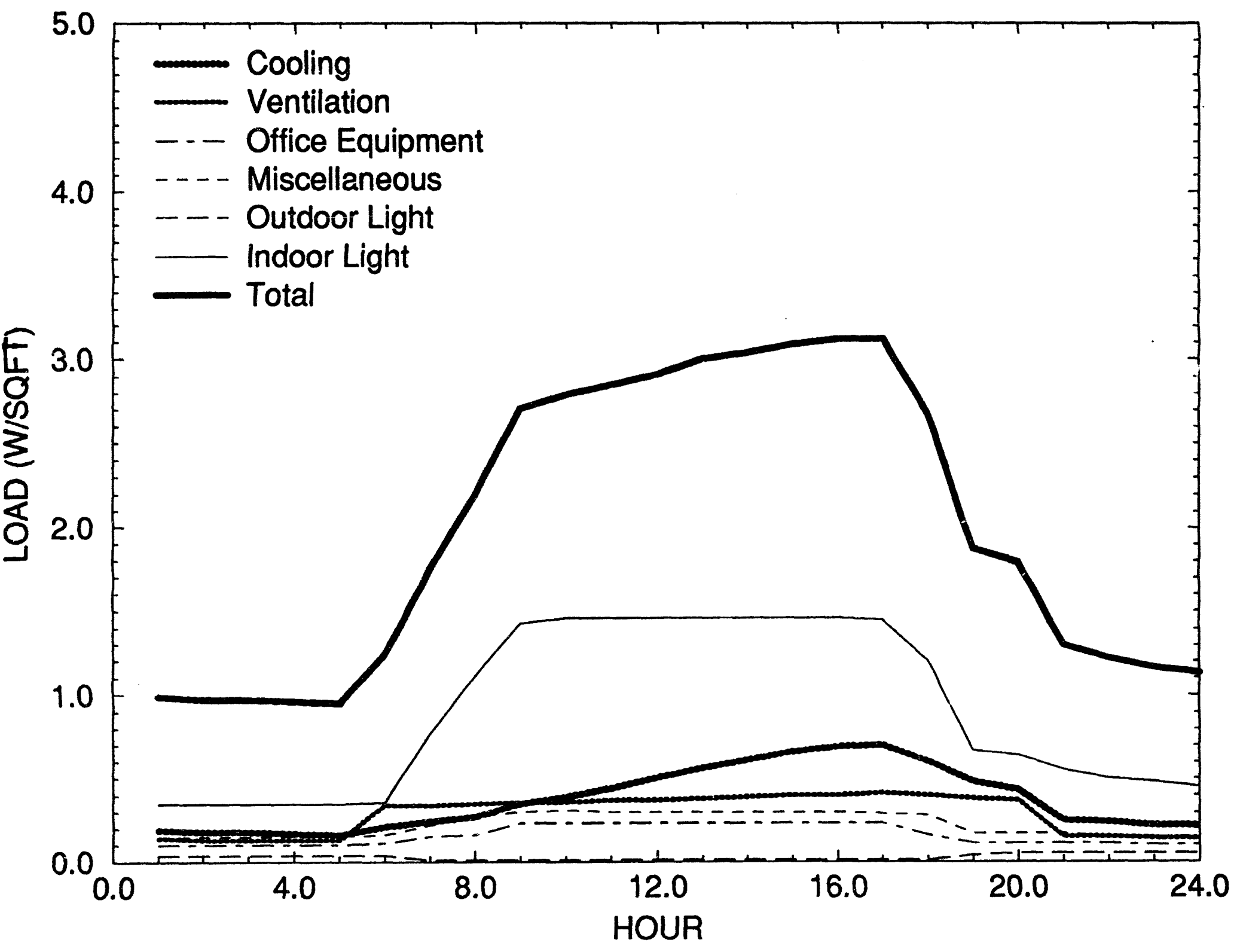


Figure 4-4b. Large Office Simulated Average Standard Day LS - Inland

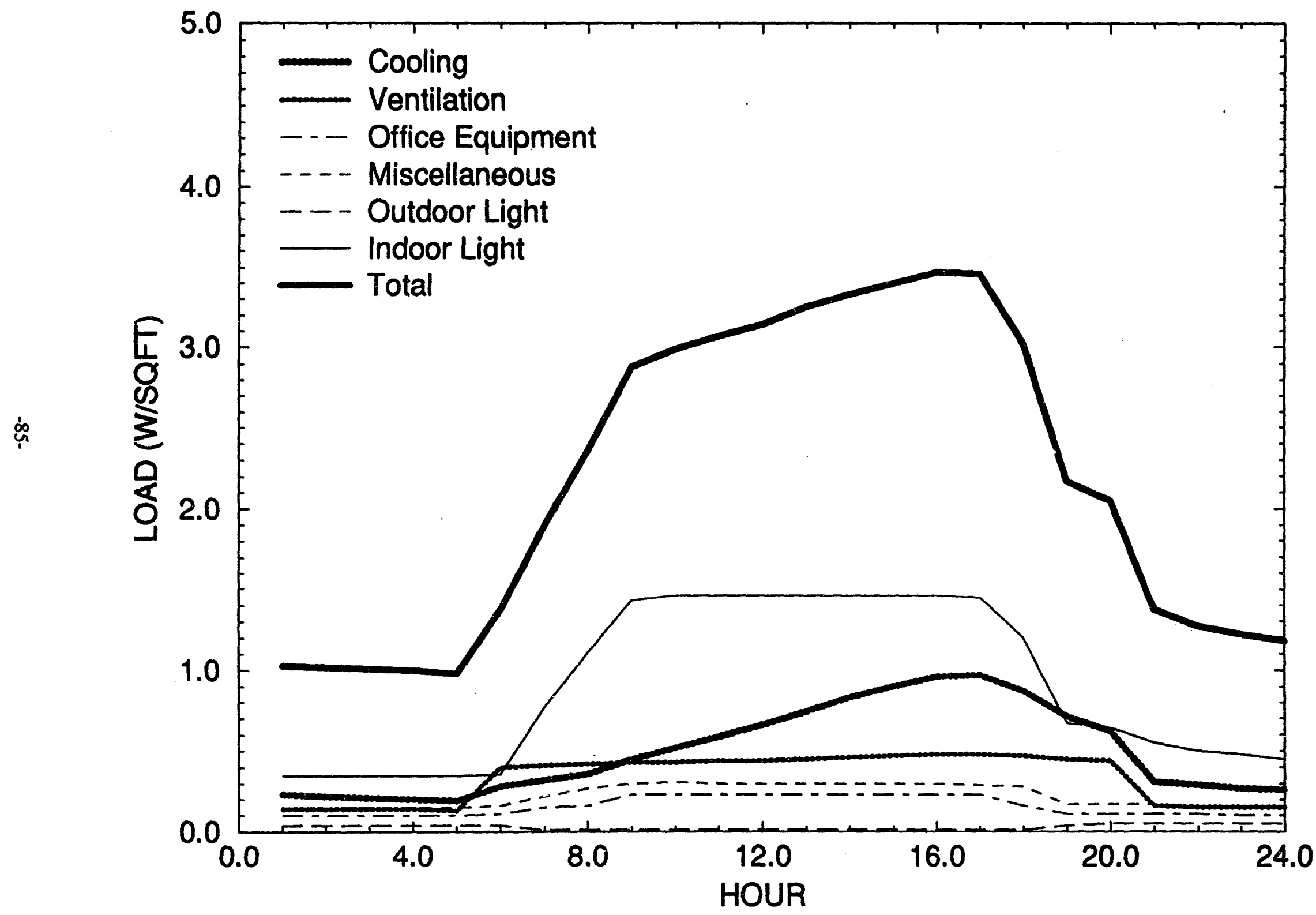


Figure 4-5a. Large Office Whole Building Load vs. Drybulb Temperature for Standard Day - Coastal

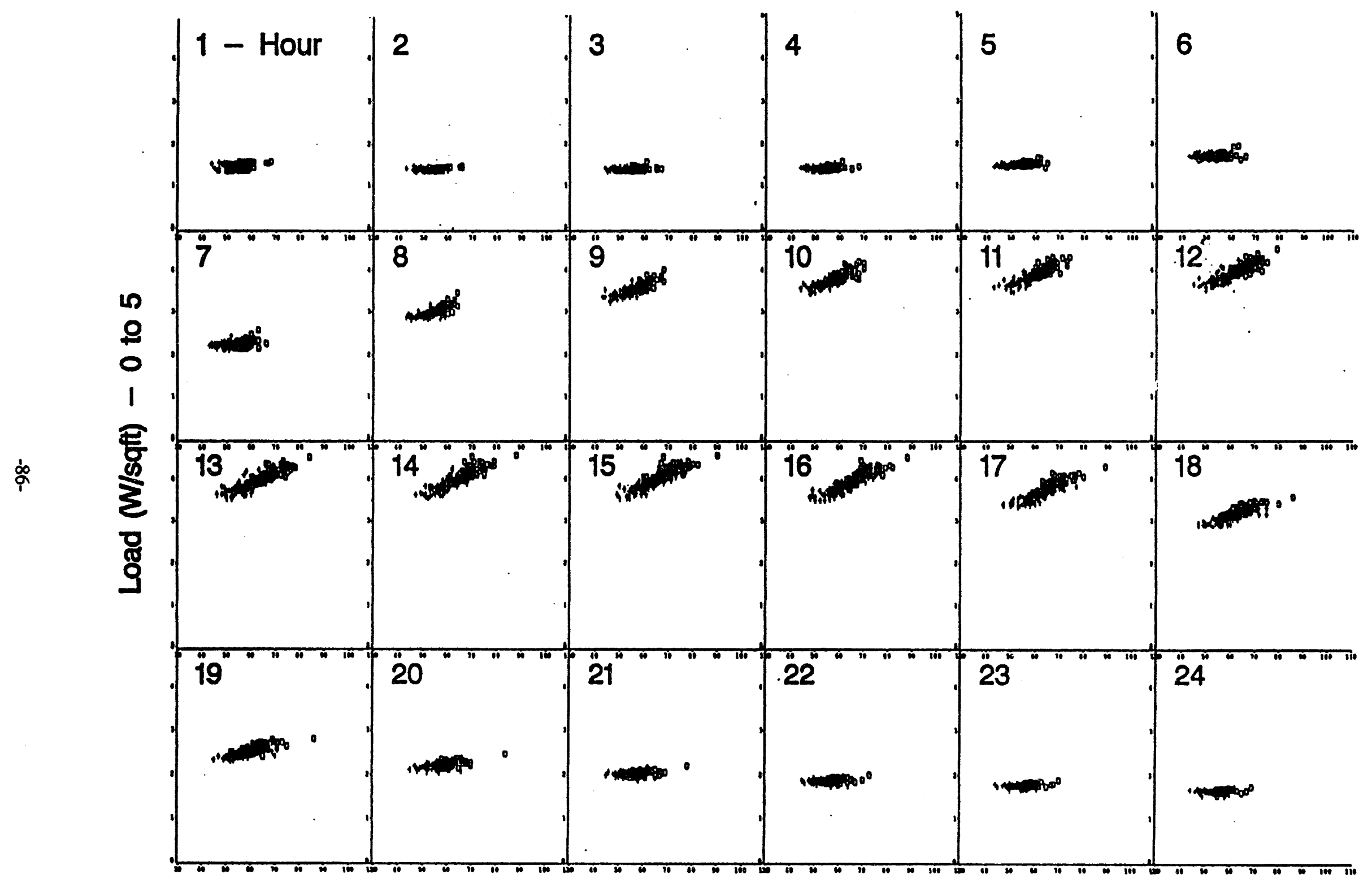

Outside Temperature $(\boldsymbol{F})-30$ to 110 
Figure 4-5b. Large Office Whole Building Load vs. Drybulb Temperature for Standard Day - Inland

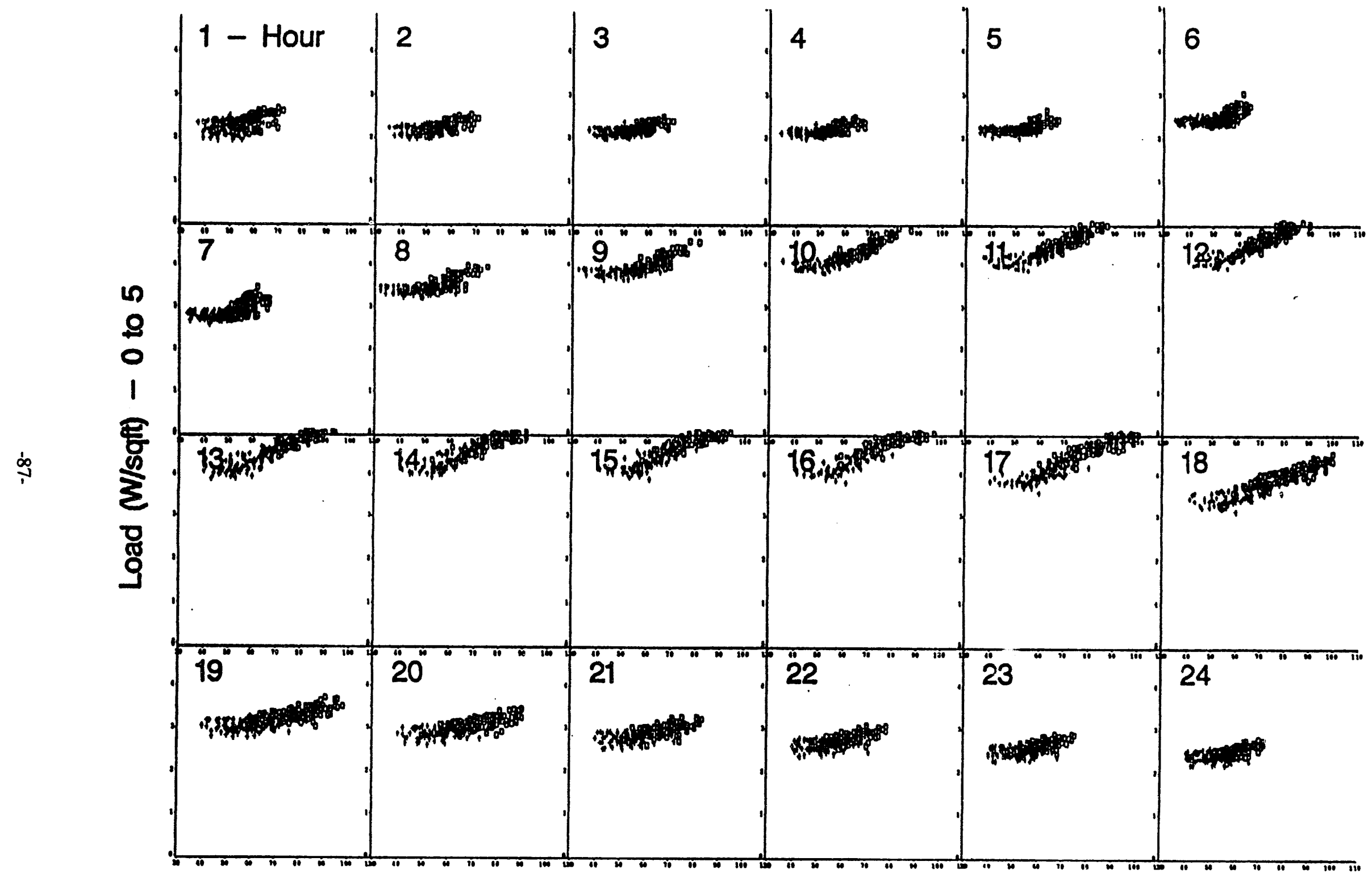

Outside Temperature $(\boldsymbol{F})-30$ to 110 
Figure 4-6a. Large Office Reconciled Standard Day Annual End-Use LS - Coastal

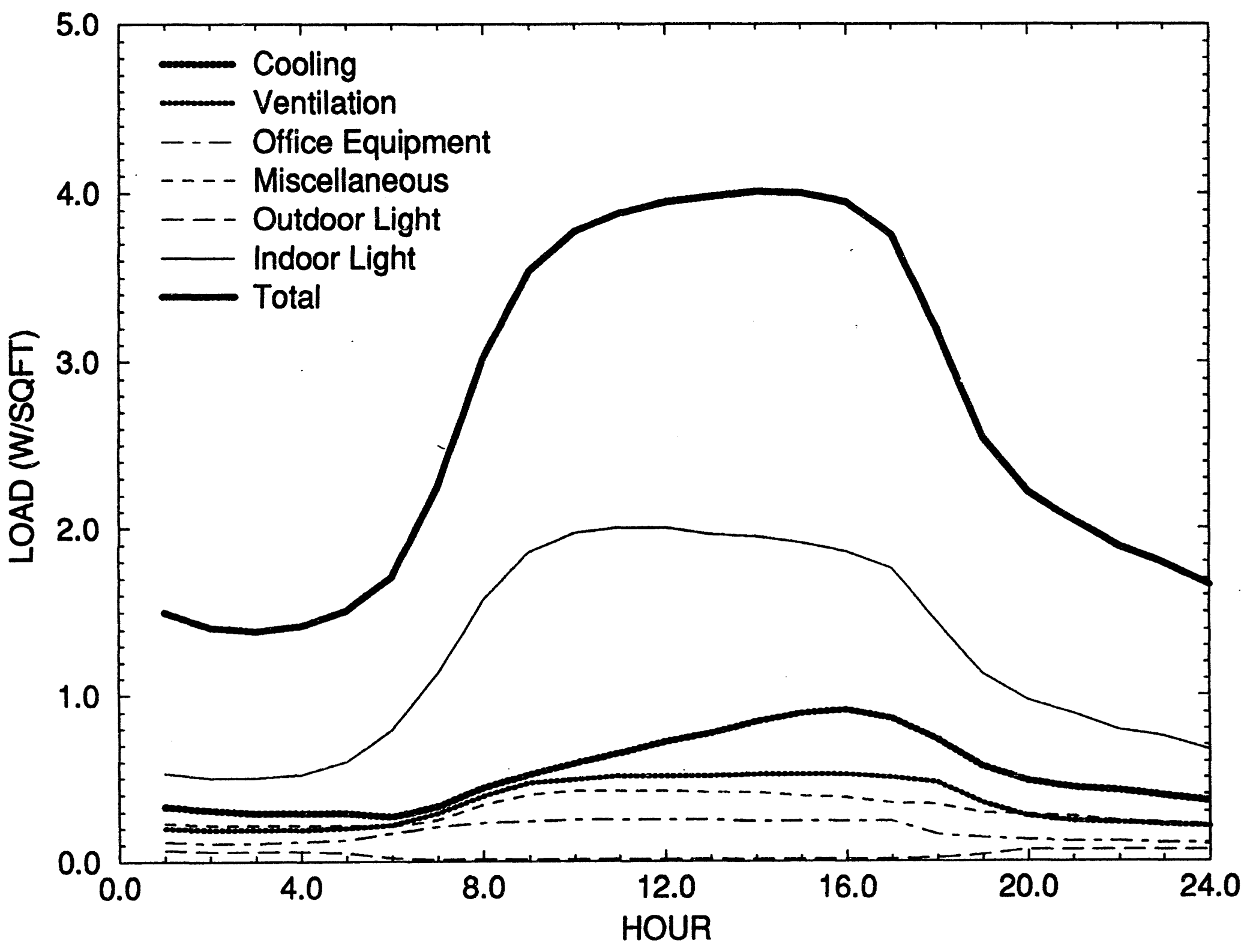


Figure 4-6b. Large Office Reconciled Standard Day Annual End-Use LS - Inland

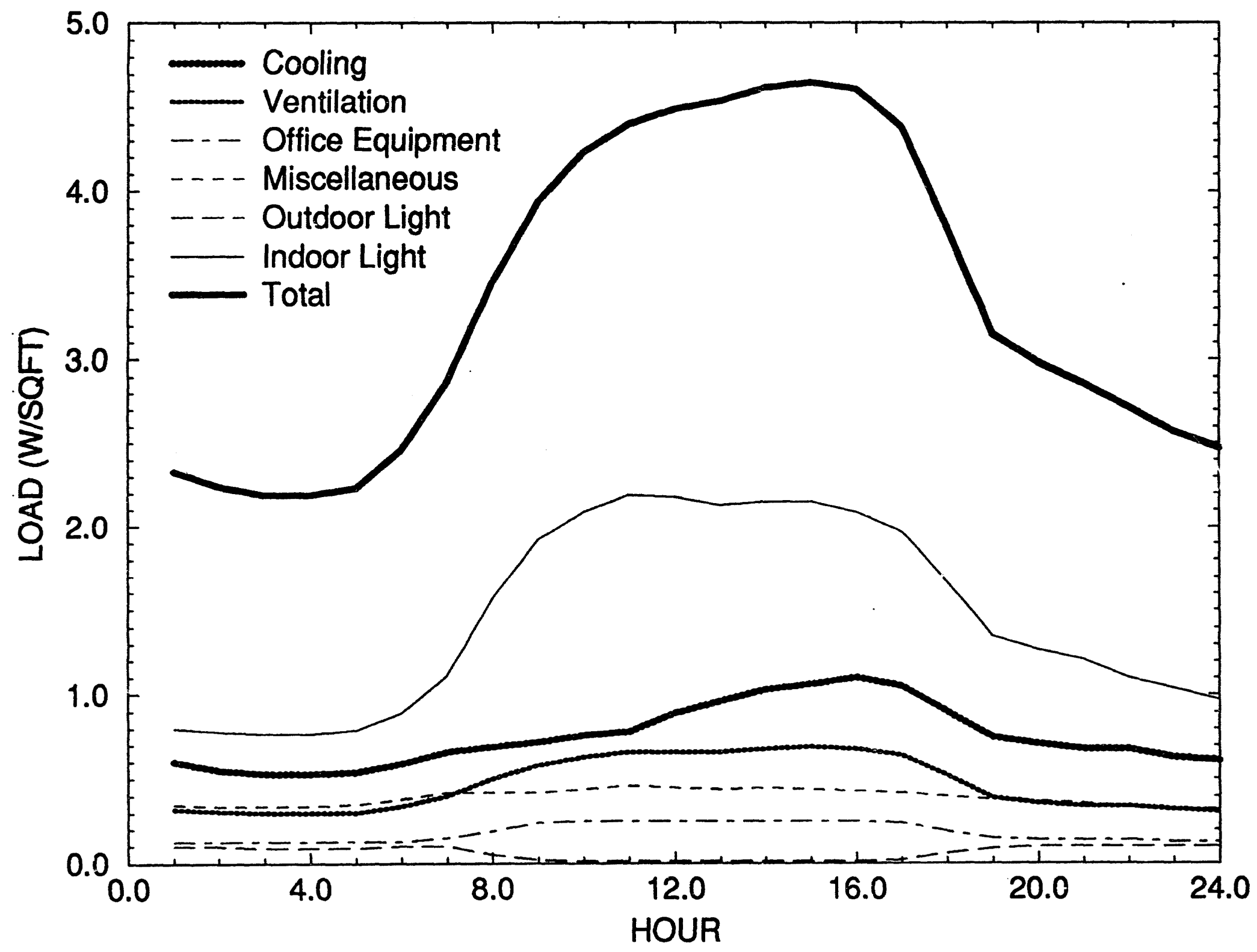


Figure 4-6c. Large Office Reconciled Nonstandard Day Annual End-Use LS - Coastal

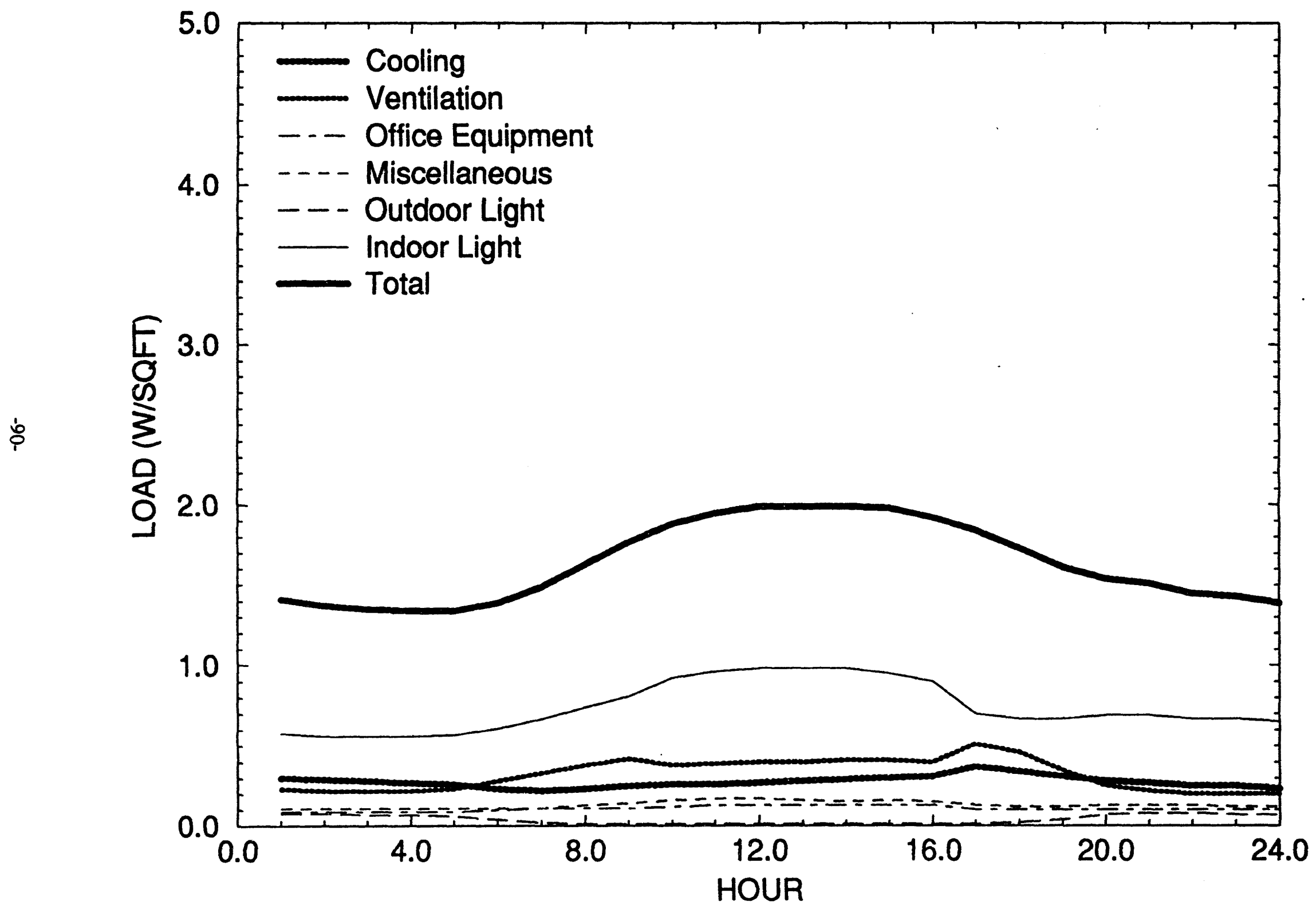


Figure -6d. Large Office Reconciled Nonstandard Day Annual End-Use LS - Inland

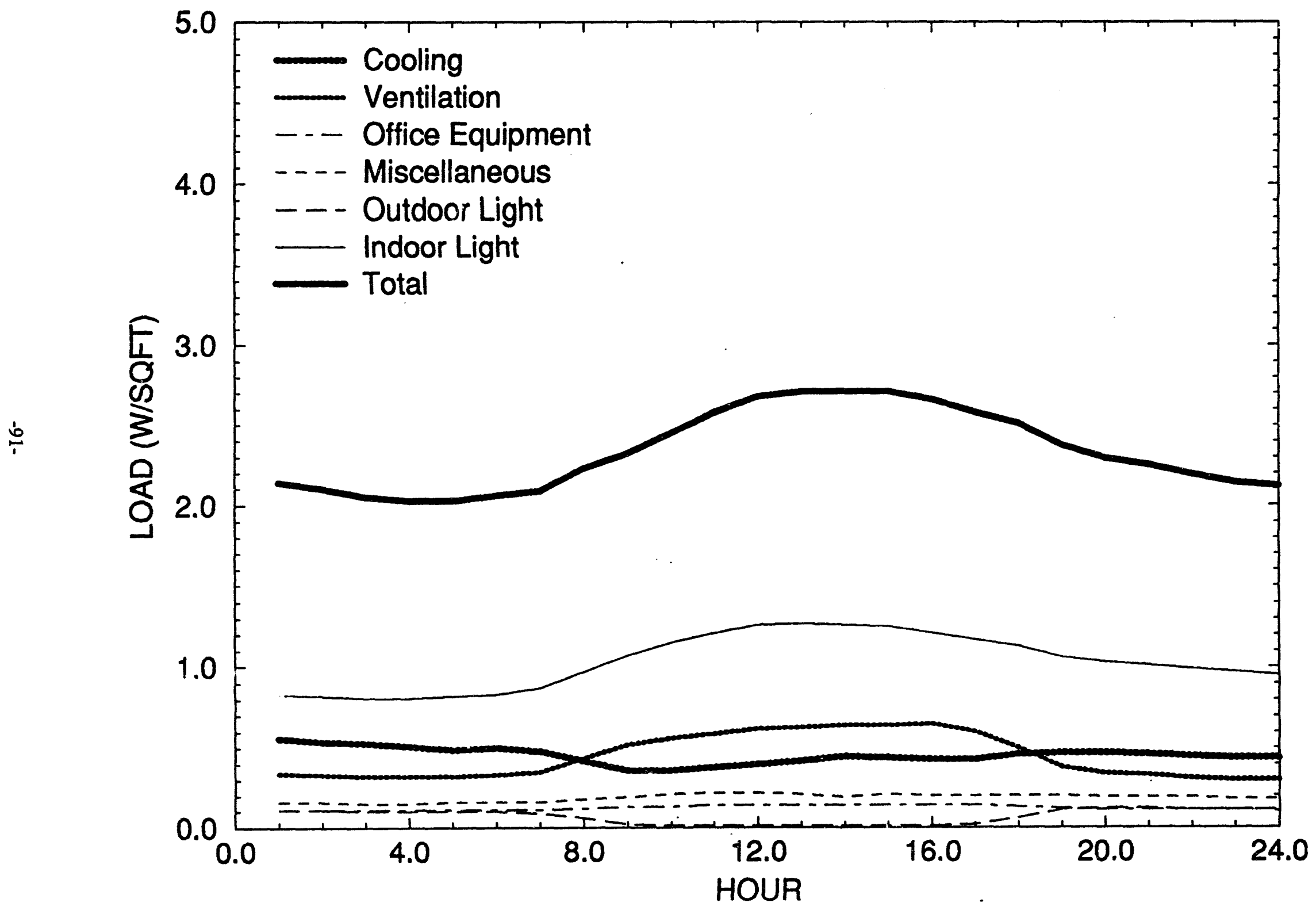




\section{Retail Store}

The retail store prototype is a combination of small and large types.

\section{Small Retail}

The small retail prototype is a $3,100 \mathrm{ft}^{2}$ single story building modeled with a single zone and conditioned with a Packaged Single Zone system. Hot water and heating are provided by a gas furnace.

Major characteristics of the prototypical building are summarized in Table 4-7. The vintage and technology options are summarized in Table 4-8.

\section{Large Retail}

The large retail prototype is a $97,000 \mathrm{ft}^{2}$ single story building modeled with five identical zones. The central version is conditioned with a Single Zone Reheat system and the packaged version is conditioned with a Packaged Single Zone system. Hot water and heating are provided by a gas furnace, and cooling is provided by hermetic centrifugal chillers for the central system.

Major characteristics of the prototypical building are summarized in Table 4-9. The vintage and technology options are summarized in Table 4-10.

\section{Retail Store}

Table 4-11 shows the simulation and EDA-reconciled end-use EUI summaries for the Retail Store of the coastal and inland climate regions. DOE-2 simulated average standard day end-use LSs for the coastal and inland climate zones are shown in Figure 4-7. Scatter plots of hourly whole-building EUIs against drybulb temperature for annual standard days of coastal and inland climates are shown in Figure 4-8. The inland plot demonstrates significant summer cooling during the late morning and afternoon, whereas the coastal plot shows no correlation between whole-building-load and dry bulb temperature. EDA reconciled average standard and nonstandard day end-use LSs for coastal and inland climates are shown in Figure 4-9. The LSs indicate that indoor lighting constitutes the majority of the load, and lesser loads of equal magnitude are cooling, ventilation, miscellaneous equipment, and outdoor lighting (note inland cooling is approximately two times greater than coastal). Peak operation occurs on weekdays during 9 am to $9 \mathrm{pm}$ and on weekends from 10 am to $6 \mathrm{pm}$.

Note: Packaged Single Zone (PSZ)

Single Zone Reheat (SZRH)

Variable Air Volume (VAV) 
Table 4-7. Small Retail Building Prototype Characteristics

\begin{tabular}{|l|r|}
\hline Shell & \\
Floor Area (1000 $\mathrm{ft}^{2}$ ) & 3.1 \\
Number of Floors & 1 \\
Ceiling Insulation R-value & 8.1 \\
Wall Insulation R-value & 6.9 \\
Window shading coefficient & 0.82 \\
Window/wall ratio & 0.08 \\
Loads & \\
Occupancy $\left(\mathrm{ft}^{2} /\right.$ person) & 159 \\
Lights (W/ $\mathrm{ft}^{2}$ ) & 2.0 \\
Equipment $\left(\mathrm{W} / \mathrm{ft}^{2}\right)$ & 0.4 \\
Refrigeration $\left(\mathrm{W} / \mathrm{ft}^{2}\right)$ & 0.06 \\
Cooking (W/ $\left.\mathrm{ft}^{2}\right)$ & 0.01 \\
Hot Water (Btu/hr/ $\left.\mathrm{ft}^{2}\right)$ & 0.02 \\
Schedule & \\
Standard Days & 5 \\
Start & 10 \\
Stop & 17 \\
Non-Standard Days & 2 \\
Start & 10 \\
Stop & 17 \\
System & \\
System Type & PSZ \\
COP & 2.4 \\
Supply Air (cfm/ $\mathrm{ft}^{2}$ ) & 0.7 \\
Economizer Limit Temperature & $65^{\circ} \mathrm{F}$ \\
Thermostat Type & Proportional \\
Outside Air Control & Temperature \\
Outside Air / Person (CFM) & 15 \\
Heat Setpoint & $70^{\circ} \mathrm{F}$ \\
Cool Setpoint & $74^{\circ} \mathrm{F}$ \\
r'lant & \\
Heating & Gas Furnace \\
Cooling & Gas Furnace \\
Hot Water & \\
\hline
\end{tabular}

Table 4-8. Small Retail Building Vintage Characteristics

\begin{tabular}{|l|rr|}
\hline Technology & Pre-1978 & Post-1978 \\
\hline Ceiling Insulation R-value & 8.1 & 18.9 \\
Wall Insulation R-value & 6.9 & 9.2 \\
Indoor Lighting $\left(W / \mathrm{ft}^{2}\right.$ ) & 2.0 & 2.1 \\
Equipment $\left(W / \mathrm{ft}^{2}\right)$ & 0.3 & 0.3 \\
Thermostat Type & Proportional & Reverse Action \\
Outside Air Control & Fixed & Temperature \\
System Type & PSZ & PSZ \\
\hline
\end{tabular}


Table 4-9. Large Retail Building Prototype Characteristics

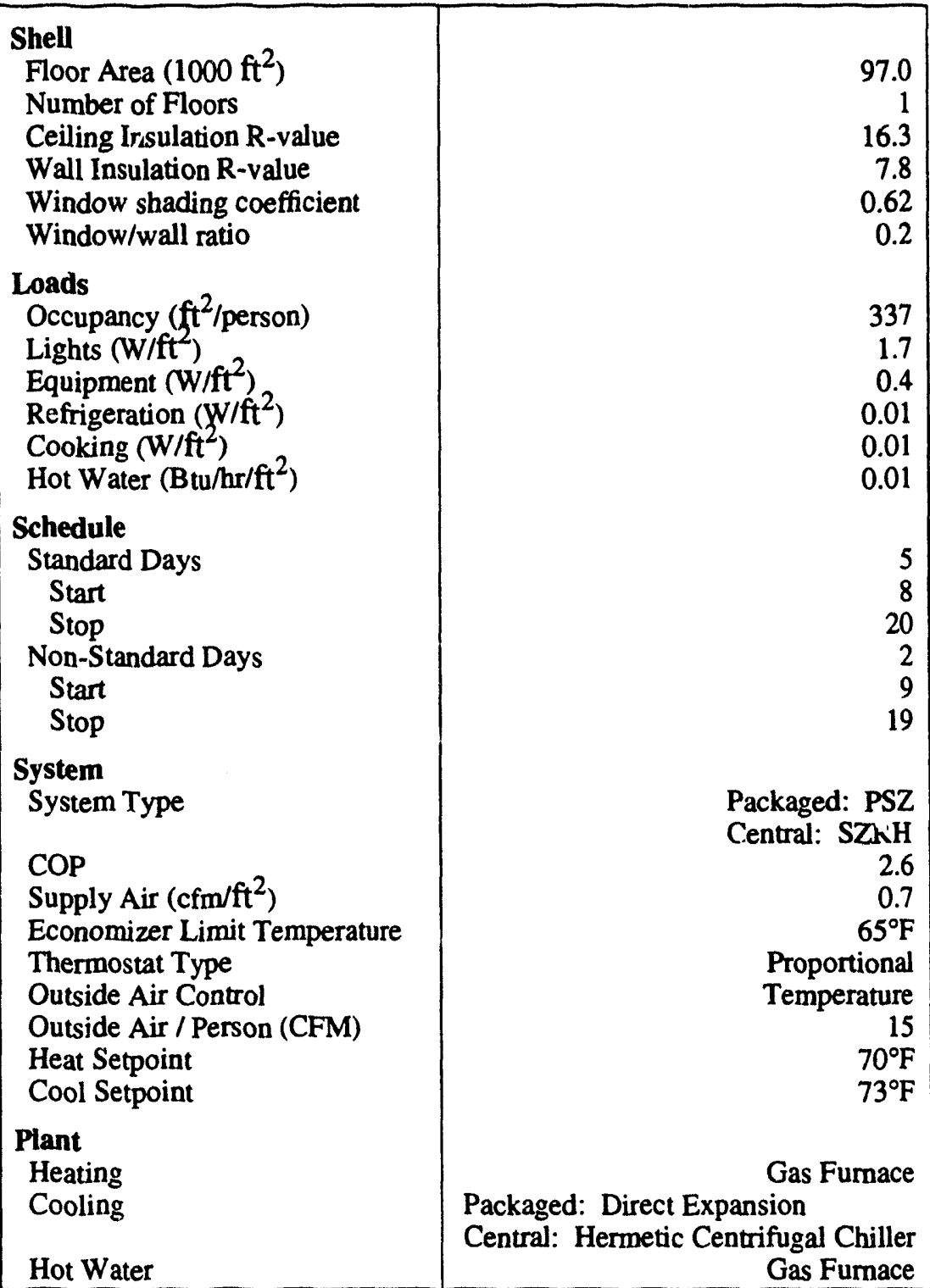

Table 4-10. Large Retail Building Vintage Characteristics

\begin{tabular}{|l|rr|}
\hline Technology & \multicolumn{1}{|c|}{ Pre-1978 } & Post-1978 \\
\hline Ceiling Insulation R-value & 16.3 & 33.3 \\
Wall Insulation R-value & 7.8 & 9.2 \\
Indoor Lighting (WV/ft ${ }^{2}$ ) & 2.1 & 1.9 \\
Equipment (W/ft ${ }^{2}$ ) & 0.3 & 0.3 \\
Thermostat Type & Proportional & Reverse Action \\
Outside Air Control & Fixed & Temperature \\
System Type & Packaged: PSZ & PSZ \\
& Central: SZRH & VAV \\
\hline
\end{tabular}


Table 4-11a. Retail Store Simulated and EDA-Reconciled EUIs-Coastal (kWh/ft $\left.\mathbf{2}^{2} / \mathrm{yr}\right)$

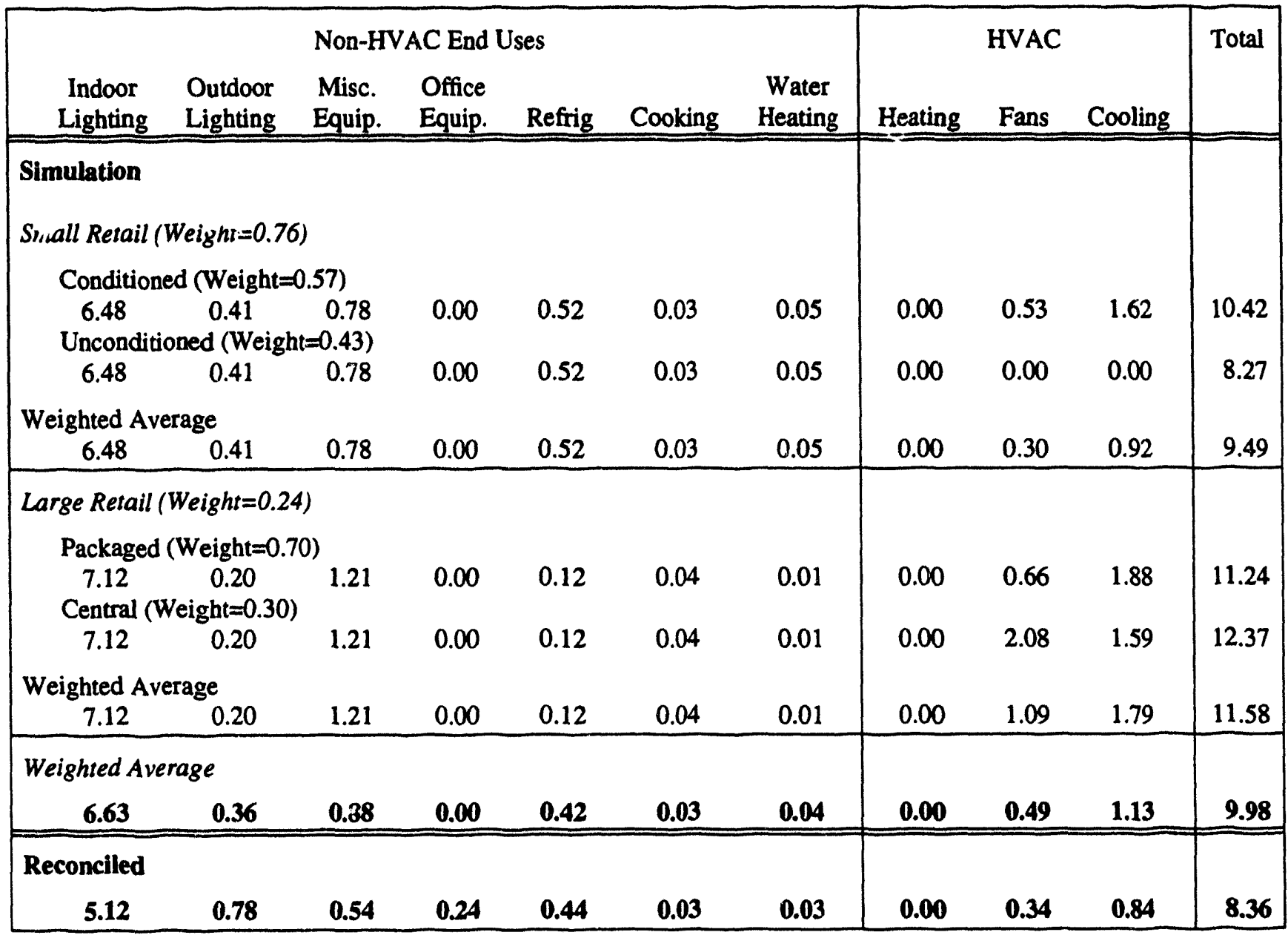


Table 4-11b. Retail Store Simulated and EDA-Reconciled EUIs - Inland $\left(\mathrm{kWh} / \mathrm{ft}^{2} / \mathrm{yr}\right)$

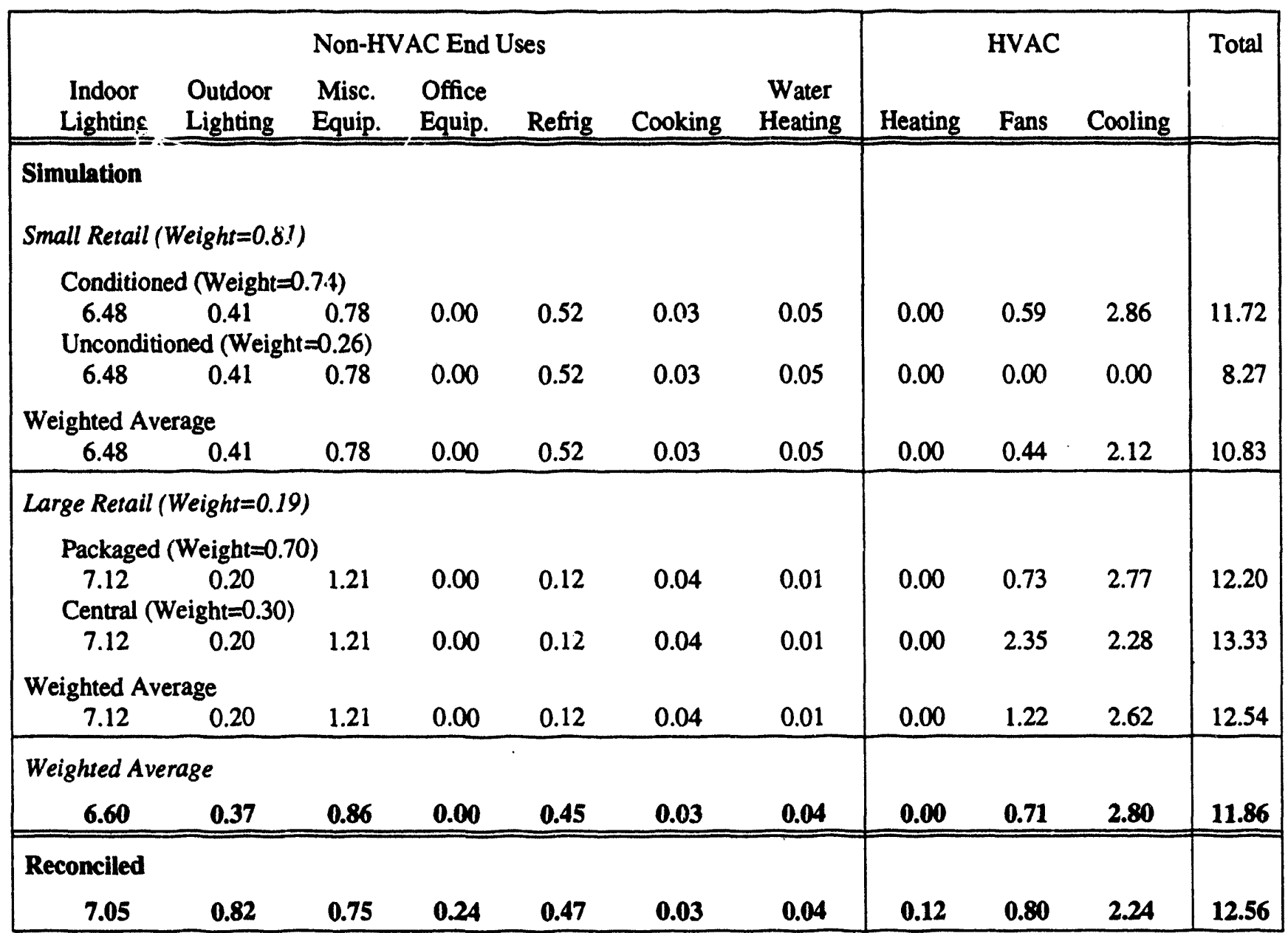


Figure 4-7a. Retail Store Simulated Average Standard Day LS - Coastal

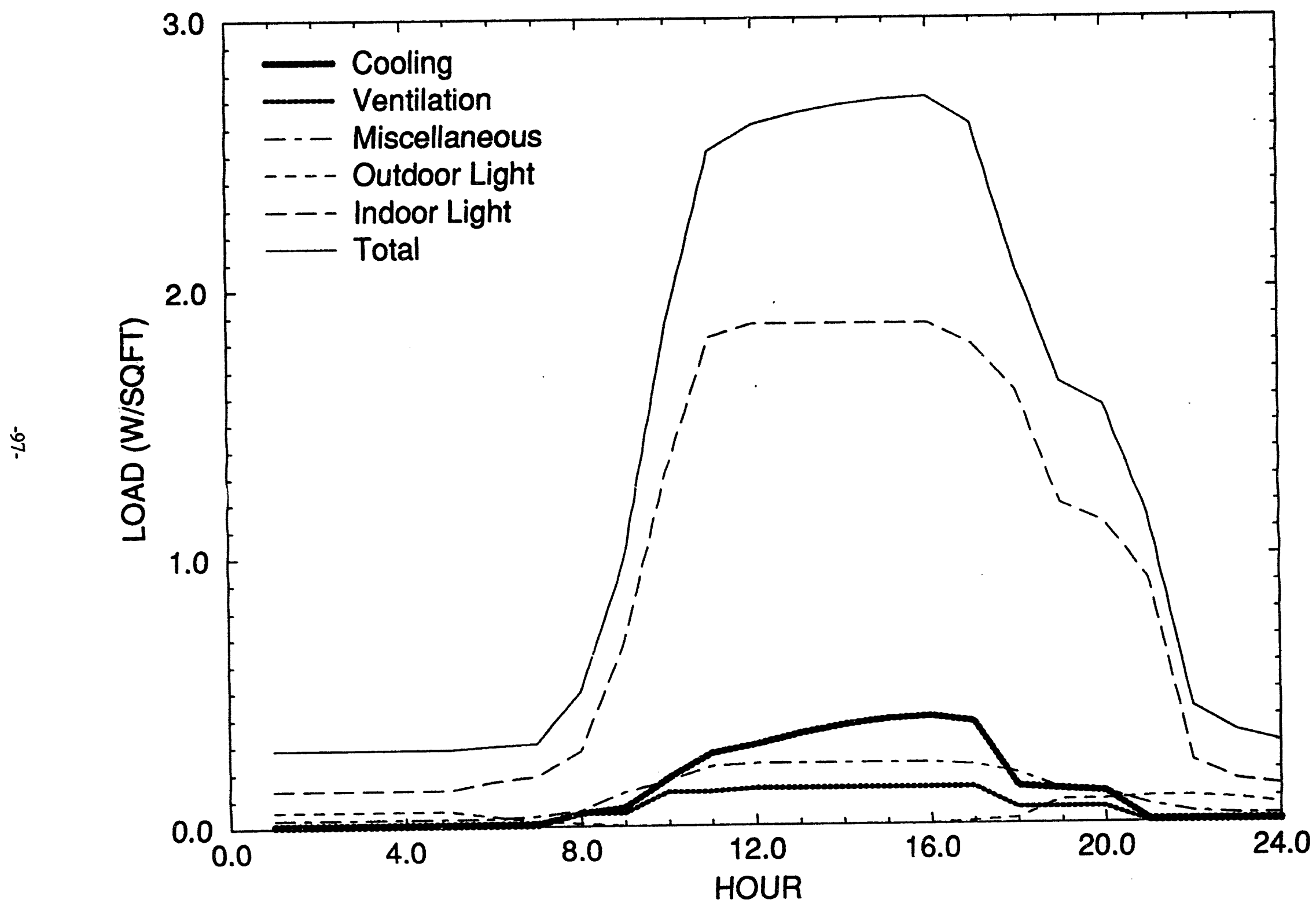


Figure 4.7b. Retail Store Simulated Average Standard Day LS - Inland

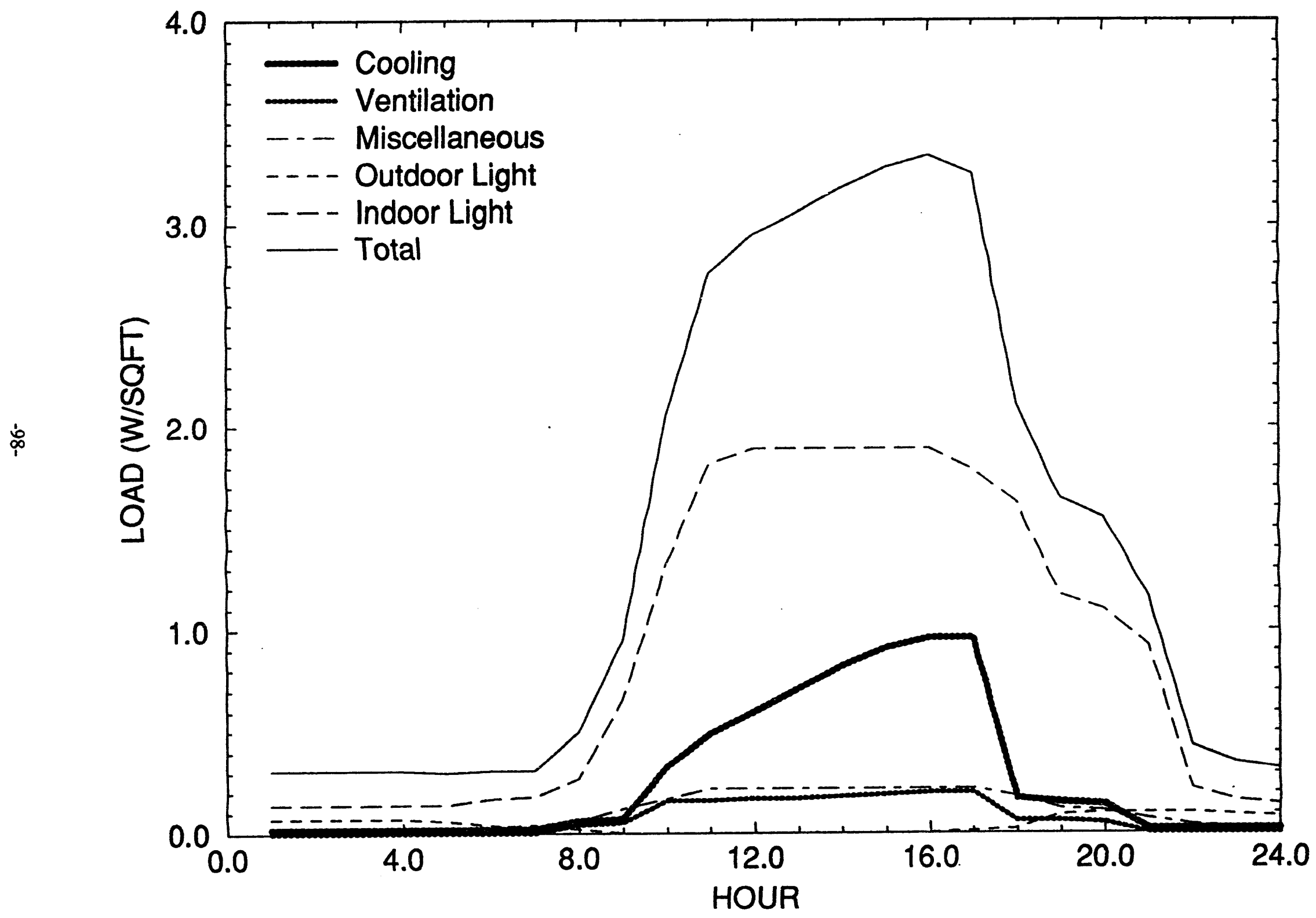


Figure 4-8a. Retail Store Whole Building Load vs. Drybulb Temperature for Standard Day - Coastal

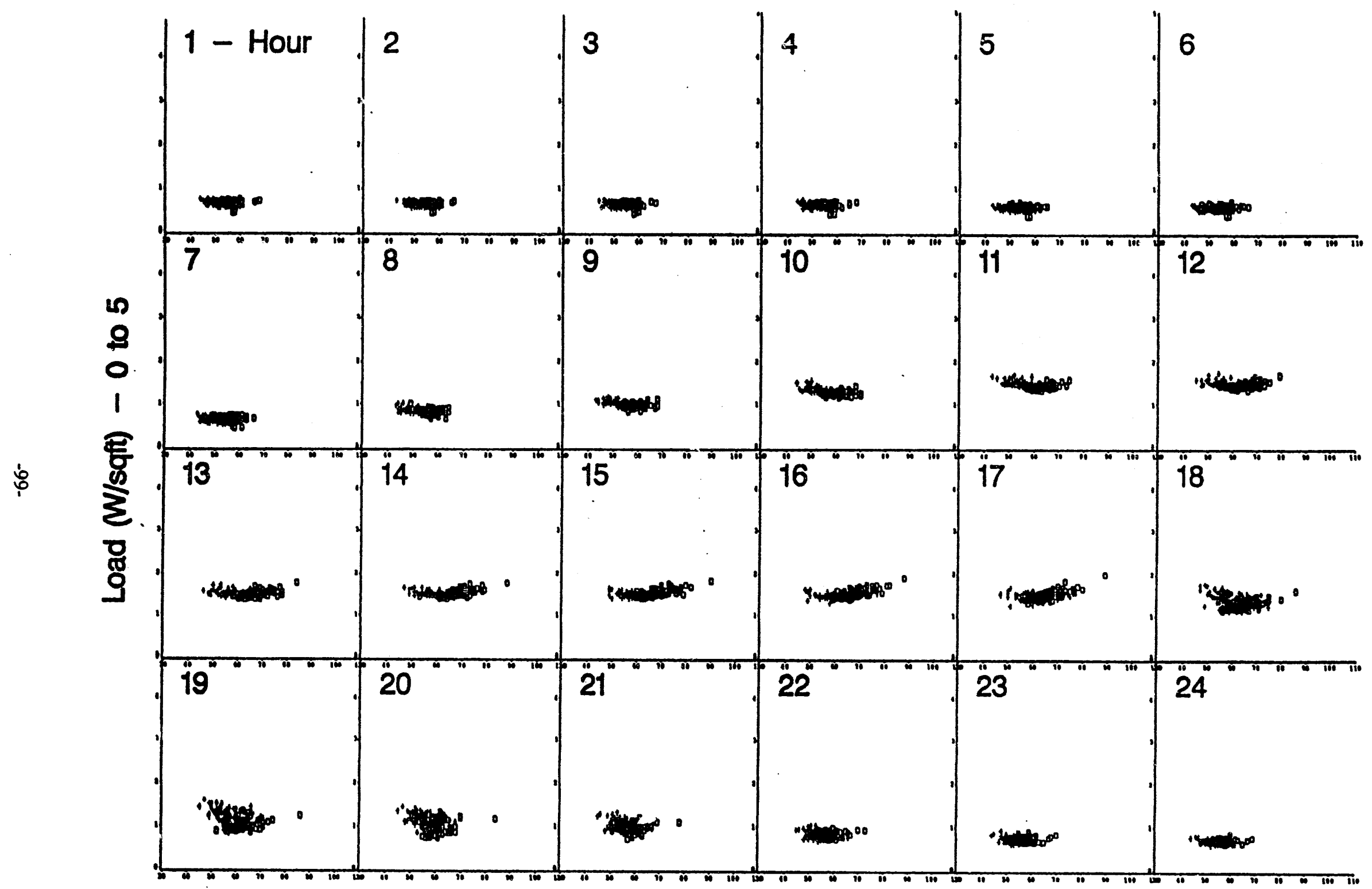

Outside Temperature (F) - 30 to 110 
Figure 4-8b. Retail Store Whole Building Load vs. Drybulb Temperature for Standard Day - Inland

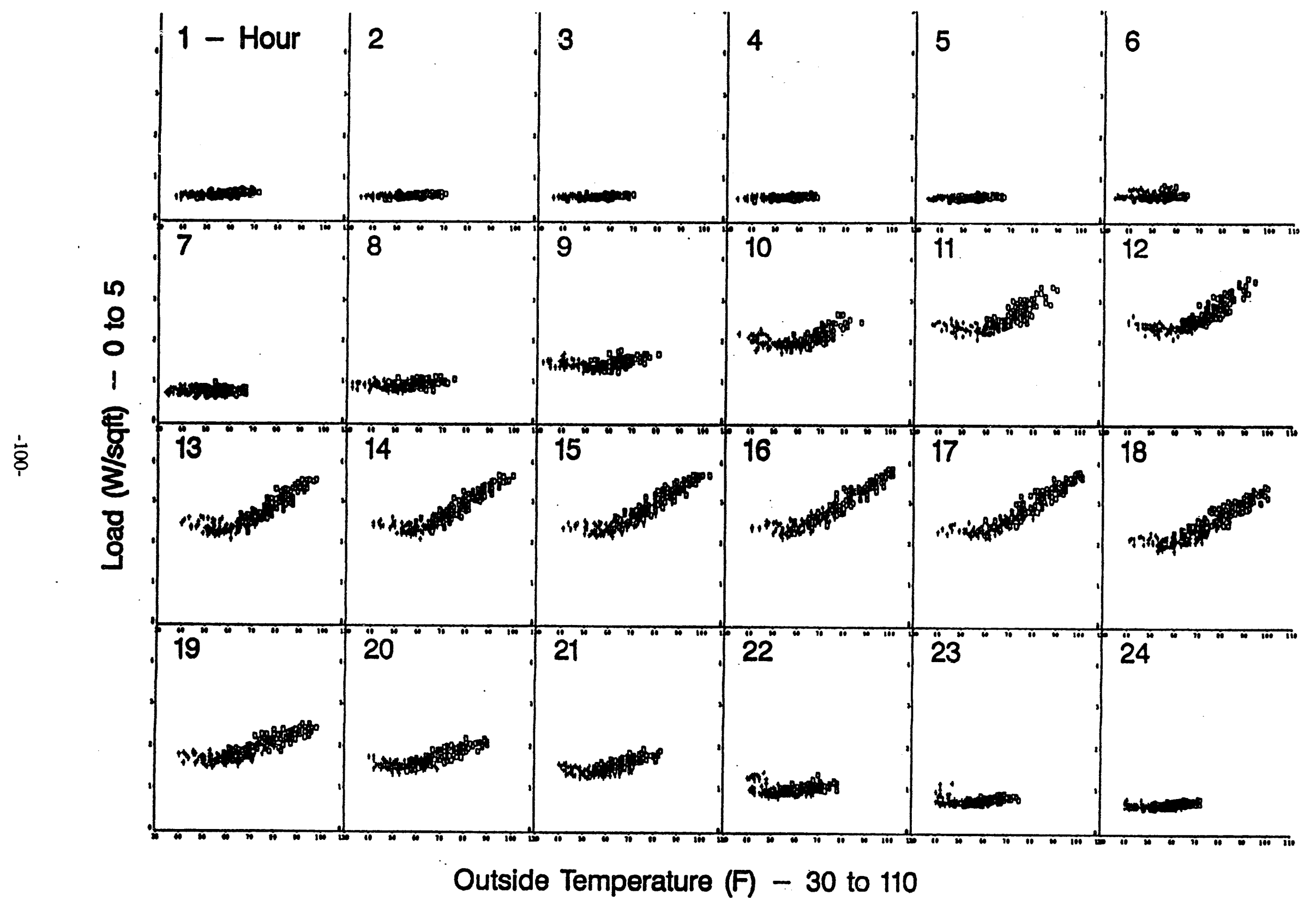


Figure 4-9a. Retail Store Reconciled Standard Day Annual End-Use LS - Coastal

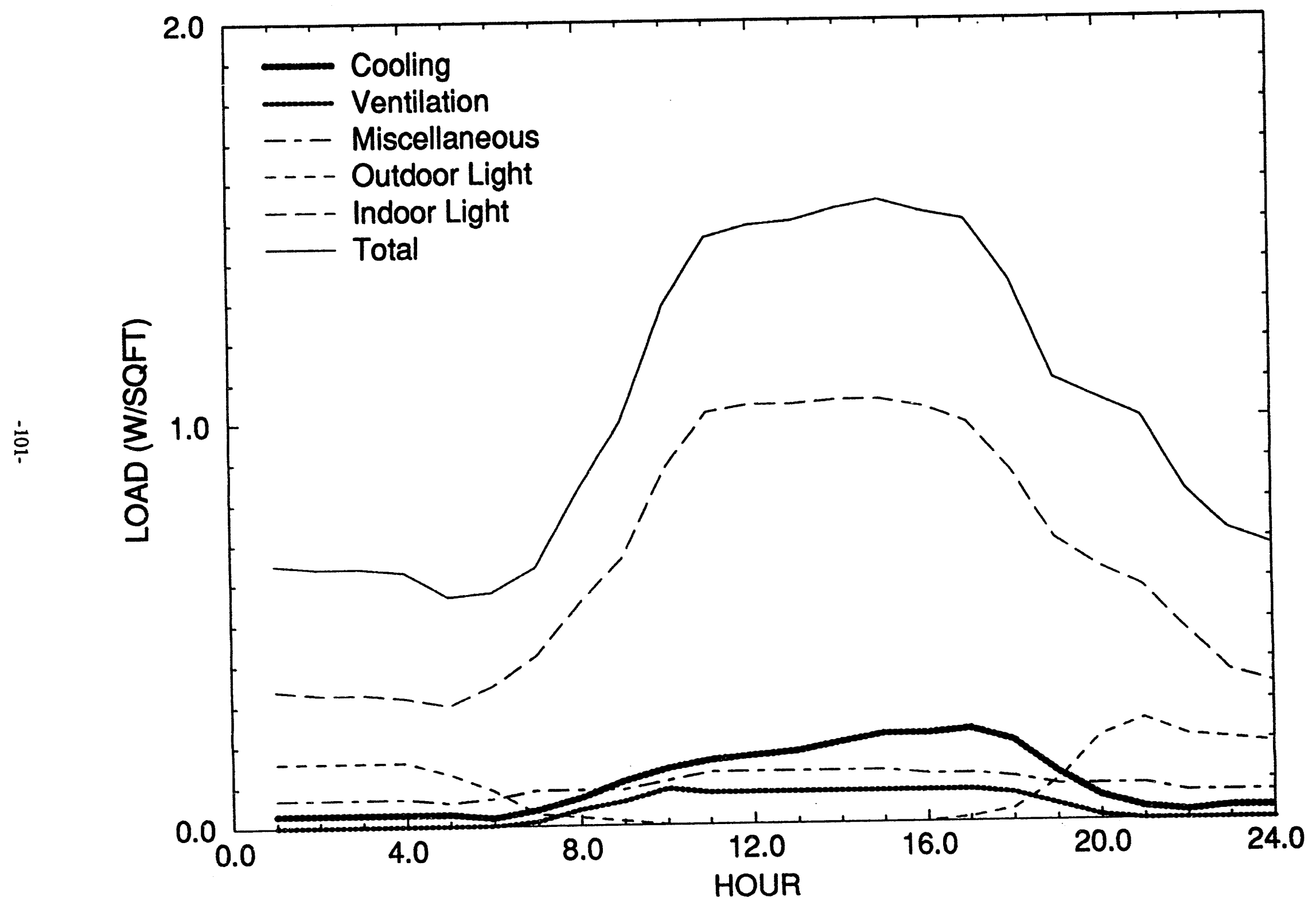


Figure 4-9b. Retail Store Reconciled Standard Day Annual End-Use LS - Inland

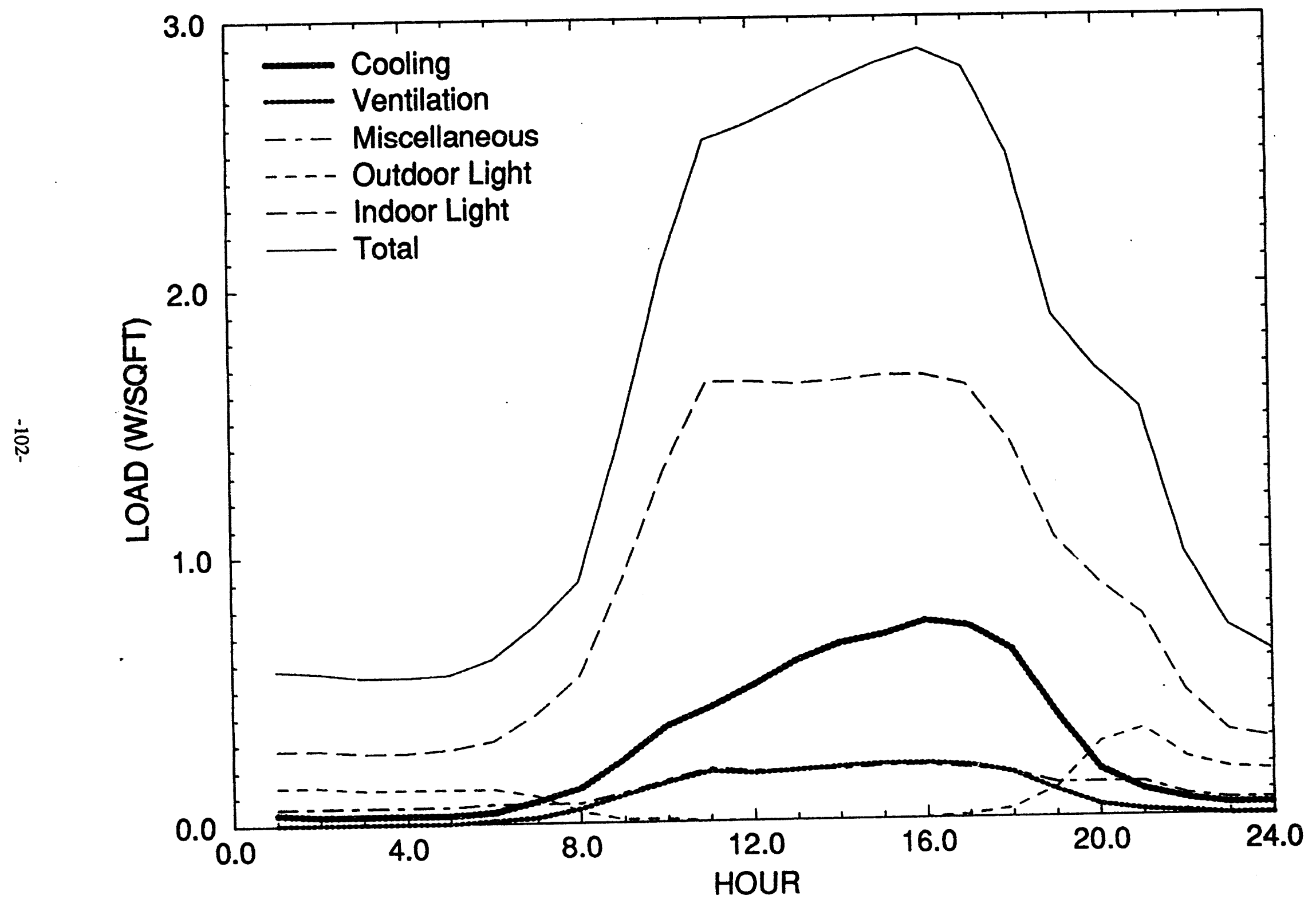




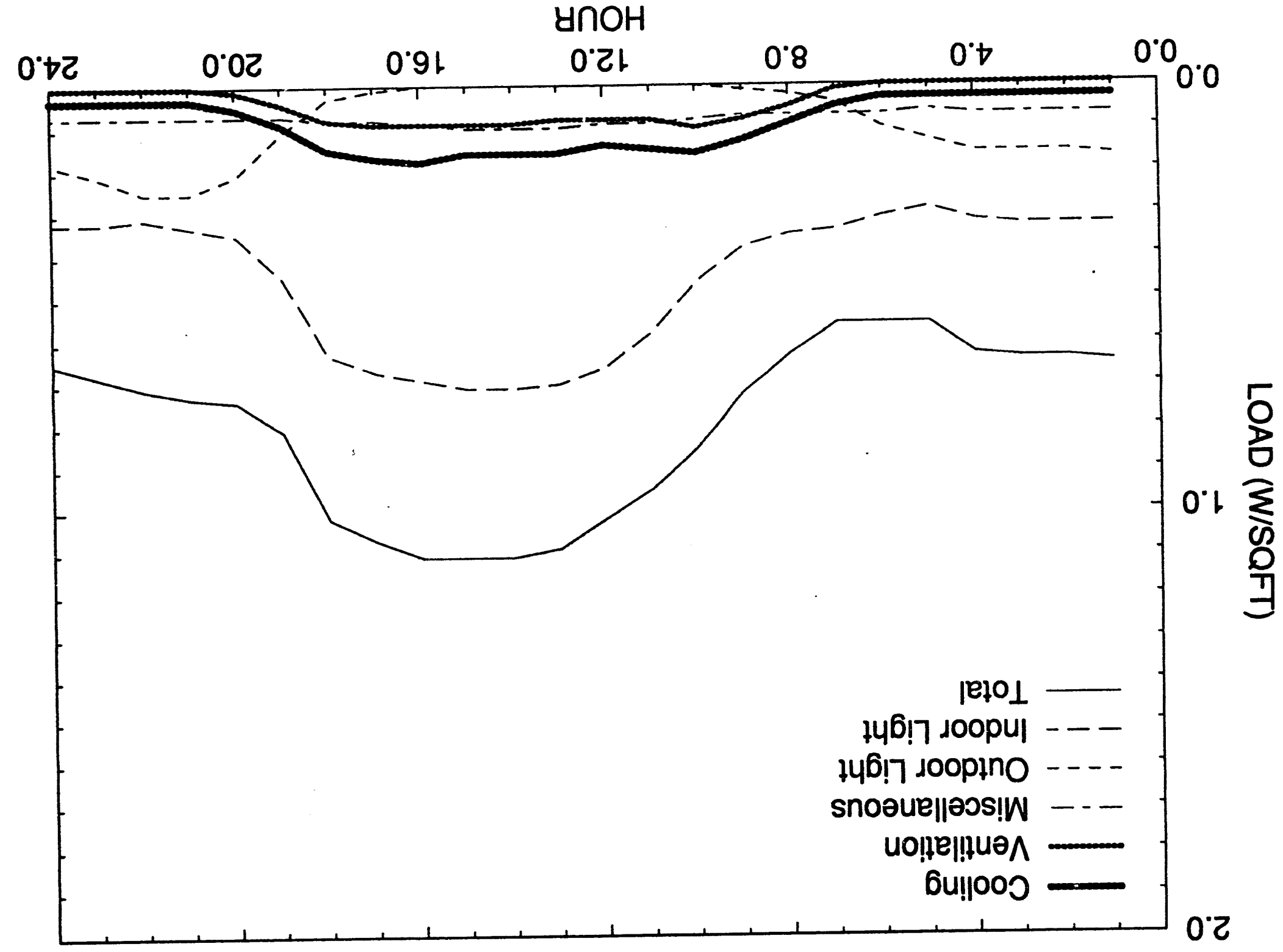

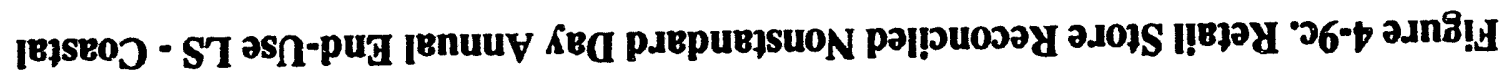


Figure 4-9d. Retail Store Reconciled Nonstandard Day Annual End-Use LS - Inland

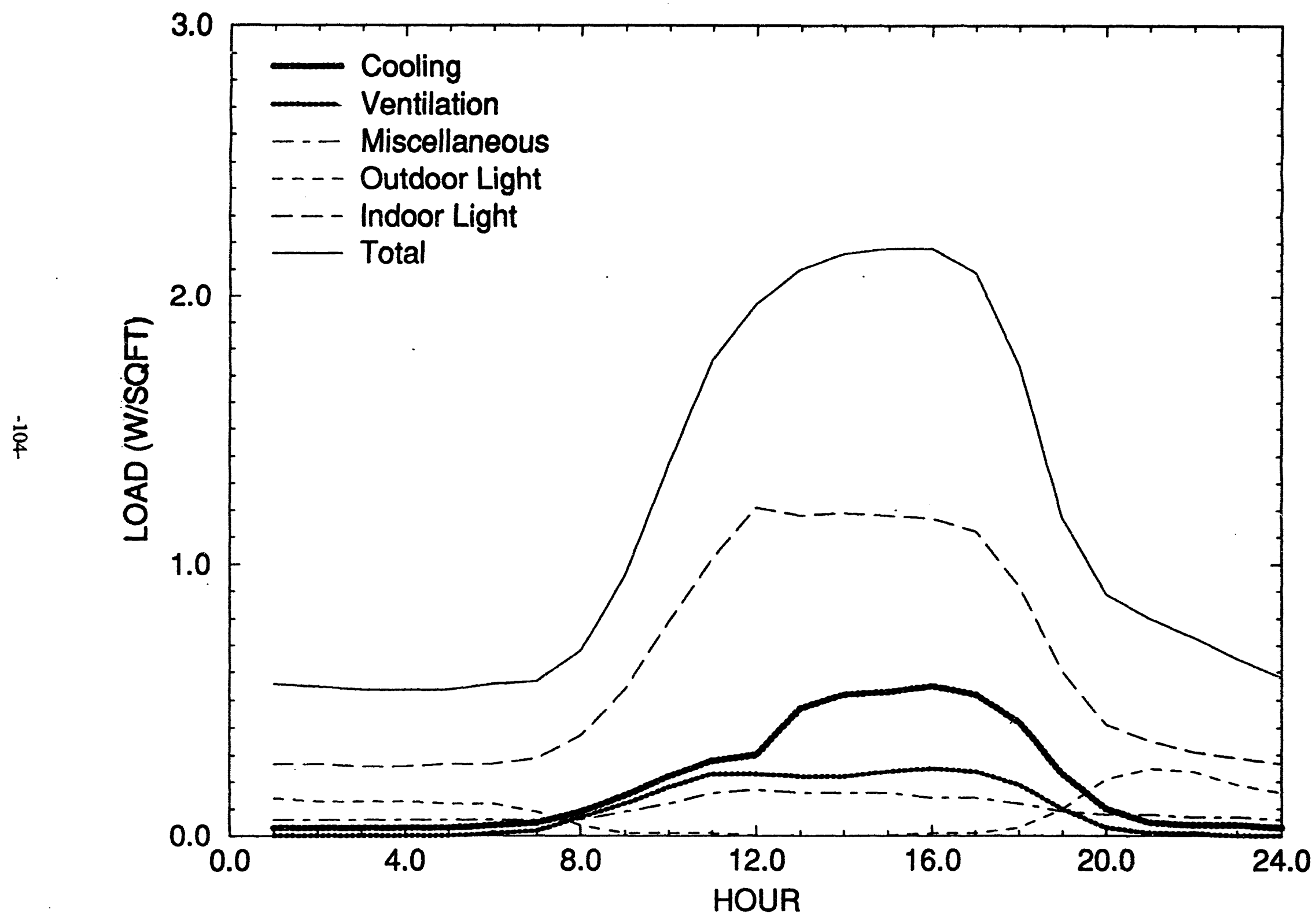




\section{Restaurant}

The Restaurant prototype is a combination of sitdown and fastfood types.

\section{Sitdown Restaurant}

The sitdown restaurant prototype is a 3,000 $\mathrm{ft}^{2}$ single story building modeled with two zones, a $900 \mathrm{ft}^{2}$ kitchen and a 2,100 $\mathrm{ft}^{2}$ dining area. The building is conditioned with a Packaged Single Zone system, where hot water and heating are provided by a gas furnace.

Major characteristics of the prototypical building are summarized in Table 4-12a and Table 412b. The vintage and technology options are summarized in Table 4-13.

\section{Fastfood Restaurant}

The fastfood restaurant prototype is a $1,700 \mathrm{ft}^{2}$ single story building modeled with a kitchen and dining area of equal size. The zones are conditioned with a Packaged Single Zone system and heated with a gas furnace.

Major characteristics of the prototypical building are summarized in Table 4-14a and Table 414b. The vintage and technology options are summarized in Table 4-15.

\section{Restaurant}

Table 4-16 shows the DOE-2 simulation and EDA-reconciled end-use EUI summaries for the Restaurant category of the coastal and inland climate regions. DOE-2 simulated average standard day end-use LSs for the coastal and inland climate zones are shown in Figure 4-10. Scatter plots of hourly whole-building EUIs against drybulb temperature for annual standard days of coastal and inland climates are shown in Figure 4-11. The coastal plots depict no correlation between whole-building-load and dry bulb temperature, however the inland plots illustrate some correlation from late morning through the evening in the summer. EDA reconciled average standard and nonstandard day (Coastal standard day only) end-use LSs for coastal and inland climates are shown in Figure 4-12. The LSs indicate that cooling, ventilation, cooking, refrigeration, miscellaneous equipment, and indoor lighting are of about equal magnitude, where outdoor lighting and electric hot water heating sum to a small percentage. Peak operation occurs on weekdays and weekends from 10 am to $12 \mathrm{am}$.

Note: $\quad$ Packaged Single Zone (PSZ) 
Table 4-12a. Sitdown Restaurant Building Prototype Characteristics

\begin{tabular}{|l|r|}
\hline Shell & \\
Floor Area (1000 $\mathrm{ft}^{2}$ ) & 3.0 \\
Number of Floors & 1 \\
Ceiling Insulation R-value & 7.9 \\
Wall Insulation R-value & 6.3 \\
Window shading coefficient & 0.78 \\
Window/wall ratio & 0.08 \\
Loads & \\
Occupancy ( $\mathrm{ft}^{2} /$ person) & 67 \\
Refrigeration (W/ $\mathrm{ft}^{2}$ ) & 2.9 \\
Schedule & \\
Coastal & \\
Standard Days & \\
Start & 7 \\
Stop & 5 \\
Non-Standard Days & 24 \\
Start & - \\
Stop & - \\
Inland & - \\
Standard Days & \\
Start & 5 \\
Stop & 5 \\
Non-Standard Days & 24 \\
Start & 2 \\
Stop & 5 \\
System & 24 \\
System Type & \\
COP & PSZ \\
Supply Air (cfm/ft ${ }^{2}$ ) & 2.3 \\
Economizer Limit Temperature & 0.7 \\
Thermostat Type & $65^{\circ} \mathrm{F}$ \\
Outside Air Control & $72^{\circ} \mathrm{F}$ \\
Heat Setpoint & \\
Cool Setpoint & Proportional \\
Plant & Gas Furnace \\
Heating & Gas Furnace \\
Cooling & \\
Hot Water & Girect Expansion \\
\hline & \\
\hline
\end{tabular}

Table 4-12b. Sitdown Restaurant Building Prototype Zone Description

\begin{tabular}{|l|rr|}
\hline & Dining & Kitchen \\
\hline Floor Area (\% total) & 70 & 30 \\
Outside Air (ACH) & - & 6.6 \\
Outside Air / Person (CFM) & 15 & - \\
Indoor Lighting (W/ $\left./ \mathrm{ft}^{2}\right)$ & 1.2 & 1.5 \\
Equipment $\left(W / \mathrm{ft}^{2}\right)$ & 0.1 & 7.5 \\
Cooking $\left(W / \mathrm{ft}^{2}\right)$ & - & 15.0 \\
Hot Water $\left(\mathrm{Btu} / \mathrm{hr} / \mathrm{ft}^{2}\right)$ & - & 40 \\
\hline
\end{tabular}


Table 4-13. Sitdown Restaurant Building Vintage Characteristics

\begin{tabular}{|l|rr|}
\hline Techr & Pre-1978 & Post-1978 \\
\hline Ceiling Insulation R-value & 7.3 & 14.6 \\
Wall Insulation R-value & 5.8 & 13.0 \\
Indoor L ghting (W/ft ${ }^{2}$ ) & 1.4 & 1.3 \\
Equipment $\left(W / \mathrm{ft}^{2}\right.$ ) & 1.9 & 2.1 \\
Cooking.(W/ $\mathrm{ft}^{2}$ ) & 12.0 & 13.4 \\
Thermostat Type & Proportional & Reverse Action \\
Outside Air Control & Fixed & Temperature \\
System Type & PSZ & PSZ \\
\hline
\end{tabular}


Table 4-14a. Fastfood Restaurant Building Prototype Characteristics

\begin{tabular}{|l|r|}
\hline Shell & \\
Floor Area $\left(1000 \mathrm{ft}^{2}\right)$ & 1.7 \\
Number of Floors & 1 \\
Ceiling Insulation R-value & 11.8 \\
Wall Insulation R-value & 9.0 \\
Window shading coefficient & 0.79 \\
Window/wall ratio & 0.09 \\
Loads & \\
Refrigeration (W/ft ${ }^{2}$ ) & 4.8 \\
Schedule & \\
Coastal & \\
Standard Days & \\
Start & 7 \\
Stop & 5 \\
Non-Standard Days & 24 \\
Start & - \\
Stop & - \\
Inland & - \\
Standard Days & \\
Start & 5 \\
Stop & 5 \\
Non-Standard Days & 24 \\
Start & 2 \\
Stop & 5 \\
System & 24 \\
System Type & \\
COP & PSZ \\
Supply Air (cfm/ $\mathrm{ft}^{2}$ ) & 2.3 \\
Economizer Limit Temperature & 0.7 \\
Thermostat Type & $65^{\circ} \mathrm{F}$ \\
Outside Air Control & Proportional \\
Heat Setpoint & Temperature \\
Cool Setpoint & $65^{\circ} \mathrm{F}$ \\
Plant & $73^{\circ} \mathrm{F}$ \\
Heating & \\
Cooling & \\
Hot Water & Gas Furnace \\
& Gas Furnace \\
\hline
\end{tabular}

Table 4-14b. Fastfood Restaurant Building Prototype Zone Description

\begin{tabular}{|l|rr|}
\hline & Dining & Kitchen \\
\hline Floor Area (\% total) & 50 & 50 \\
Occupancy $\left(\mathrm{ft}^{2} /\right.$ person) & 34 & 114 \\
Outside Air (ACH) & - & 7.3 \\
Outside Air / Person (CFM) & 15 & - \\
Indoor Lighting (W/ $\mathrm{ft}^{2}$ ) & 1.7 & 2.5 \\
Equipment $\left(\mathrm{W} / \mathrm{ft}^{2}\right)$ & - & 7.2 \\
Cooking $\left(\mathrm{W} / \mathrm{ft}^{2}\right)$ & - & 10.4 \\
Hot Water (Btu/hr/ft & - & 20 \\
\hline
\end{tabular}


Table 4-15. Fastfood Restaurant Bullding Vintage Characteristics

\begin{tabular}{|l|rr|}
\hline Technology & Pre-1978 & \multicolumn{1}{c|}{ Post-1978 } \\
\hline Ceiling Insulation R-value & 9.5 & 14.6 \\
Wall Insulation R-value & 7.7 & 13.0 \\
Indoor Lighting $\left(W / \mathrm{ft}^{2}\right.$ ) & 2.1 & 2.2 \\
Equipment $\left(W / \mathrm{ft}^{2}\right.$ ) & 5.8 & 6.4 \\
Cooking (W/ $/ \mathrm{ft}^{2}$ ) & 8.3 & 9.3 \\
Thermostat Type & Proportional & Reverse Action \\
Outside Air Control & Fixed & Temperature \\
System Type & PSZ & PSZ \\
\hline
\end{tabular}


Table 4-16a. Restaurant Simulated and EDA-Reconcled EUIs-Coastal (kWh/ft $\left.{ }^{2} / \mathrm{yr}\right)$

\begin{tabular}{|c|c|c|c|c|c|c|c|c|c|c|}
\hline \multicolumn{7}{|c|}{ Non-HVAC End Uses } & \multicolumn{3}{|c|}{ HVAC } & \multirow[t]{2}{*}{ Total } \\
\hline $\begin{array}{l}\text { Indoor } \\
\text { Lighting }\end{array}$ & $\begin{array}{l}\text { Outdoor } \\
\text { Lighting }\end{array}$ & $\begin{array}{l}\text { Misc. } \\
\text { Equip. }\end{array}$ & $\begin{array}{l}\text { Office } \\
\text { Equip. }\end{array}$ & Refrig & Cooking & $\begin{array}{l}\text { Water } \\
\text { Heating }\end{array}$ & Heating & Fans & Cooling & \\
\hline \multicolumn{11}{|l|}{ Simulation } \\
\hline \multicolumn{11}{|c|}{ Conditioned (Weight $=0.69$ ) } \\
\hline 6.89 & 1.62 & 5.32 & 0.00 & 6.30 & 3.32 & 0.24 & 0.00 & 2.66 & 3.49 & 29.84 \\
\hline \multicolumn{11}{|c|}{ Unconditioned (Weight $=0.31$ ) } \\
\hline 6.89 & 1.62 & 5.32 & 0.00 & 6.30 & 3.32 & 0.24 & 0.00 & 0.00 & 0.00 & 23.69 \\
\hline \multicolumn{11}{|c|}{ Weighted Average } \\
\hline 6.89 & 1.62 & 5.32 & 0.00 & 6.30 & 3.32 & 0.24 & 0.00 & 1.84 & 2.41 & 27.94 \\
\hline \multicolumn{11}{|l|}{ Reconciled } \\
\hline 8.56 & 2.17 & 6.72 & 0.07 & 7.57 & 4.24 & 0.31 & 0.00 & 4.35 & 2.51 & 36.50 \\
\hline
\end{tabular}

Table 4-16b. Restaurant Simulated and EDA-Reconciled EUIs-Inland (kWh/nt $\left.{ }^{2} / y r\right)$

\begin{tabular}{|c|c|c|c|c|c|c|c|c|c|c|}
\hline \multicolumn{7}{|c|}{ Non-HVAC End Uses } & \multicolumn{3}{|c|}{ HVAC } & \multirow[t]{2}{*}{ Total } \\
\hline $\begin{array}{c}\text { Indoor } \\
\text { Lighting }\end{array}$ & $\begin{array}{l}\text { Outdoor } \\
\text { Lighting }\end{array}$ & $\begin{array}{l}\text { Misc. } \\
\text { Equip. }\end{array}$ & $\begin{array}{l}\text { Office } \\
\text { Equip. }\end{array}$ & Refrig & Cooking & $\begin{array}{l}\text { Water } \\
\text { Heating }\end{array}$ & Heating & Fans & Cooling & \\
\hline \multicolumn{11}{|l|}{ Simulation } \\
\hline \multicolumn{11}{|c|}{ Conditioned (Weight $=0.84$ ) } \\
\hline 7.02 & 1.66 & 5.38 & 0.00 & 6.37 & 3.34 & 0.24 & 0.00 & 3.03 & 8.01 & 35.05 \\
\hline \multicolumn{11}{|c|}{ Unconditioned (Weight $=0.16$ ) } \\
\hline 7.02 & 1.66 & 5.38 & 0.00 & 6.37 & 3.34 & 0.24 & 0.00 & 0.00 & 0.00 & 24.01 \\
\hline \multicolumn{11}{|c|}{ Weighted Average } \\
\hline 7.02 & 1.66 & 5.38 & 0.00 & 6.37 & 3.34 & 0.24 & 0.00 & 2.55 & 6.73 & 33.29 \\
\hline \multicolumn{11}{|l|}{ Reconciled } \\
\hline 7.63 & 1.97 & 5.87 & 0.07 & 6.80 & 3.69 & 0.26 & 0.00 & 5.73 & 5.17 & 37.19 \\
\hline
\end{tabular}


Figure 4-10a. Restaurant Simulated Average Standard Day LS - Coastal

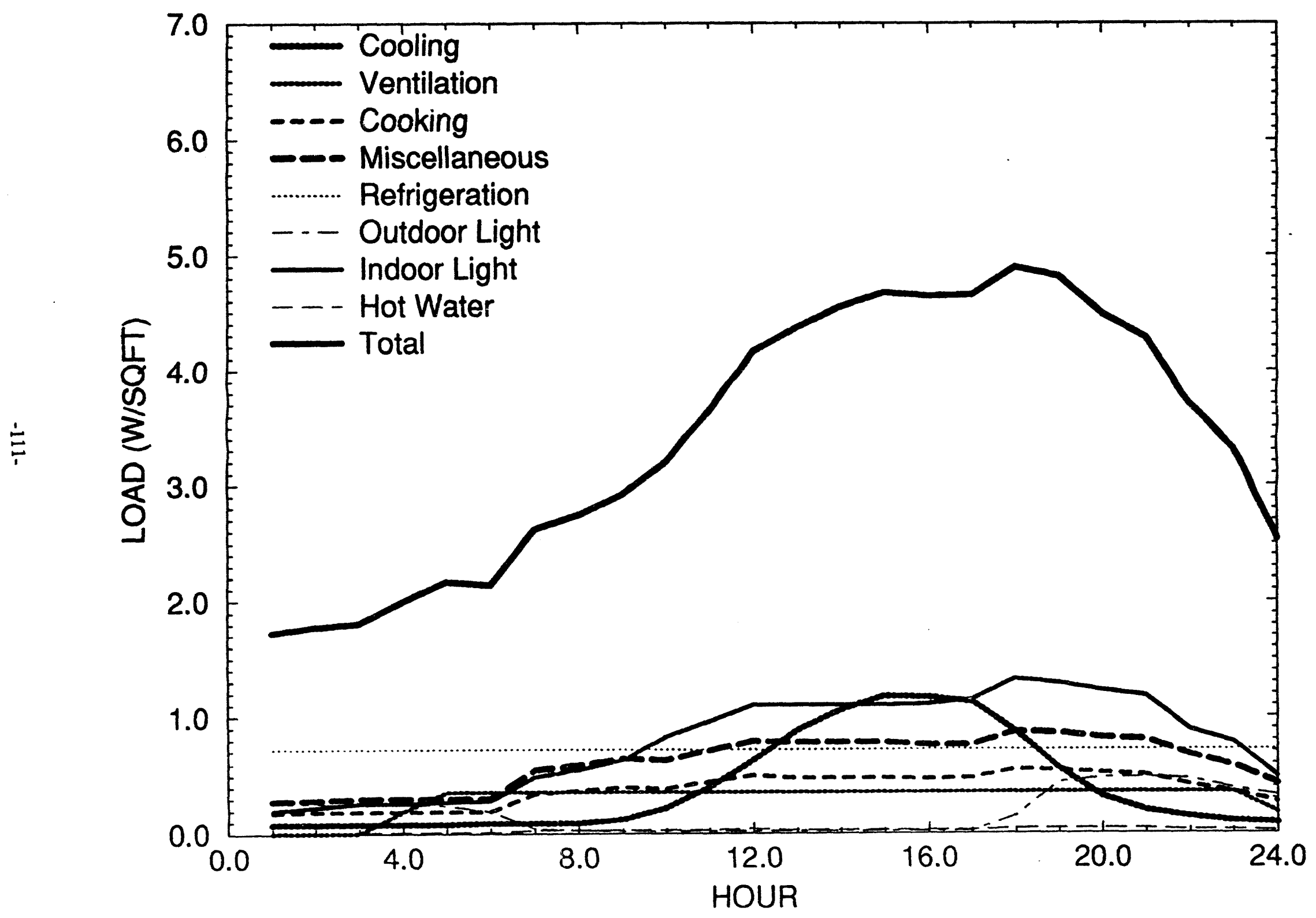


Figure 4-10b. Restaurant Simulated Average Standard Day LS - Inland

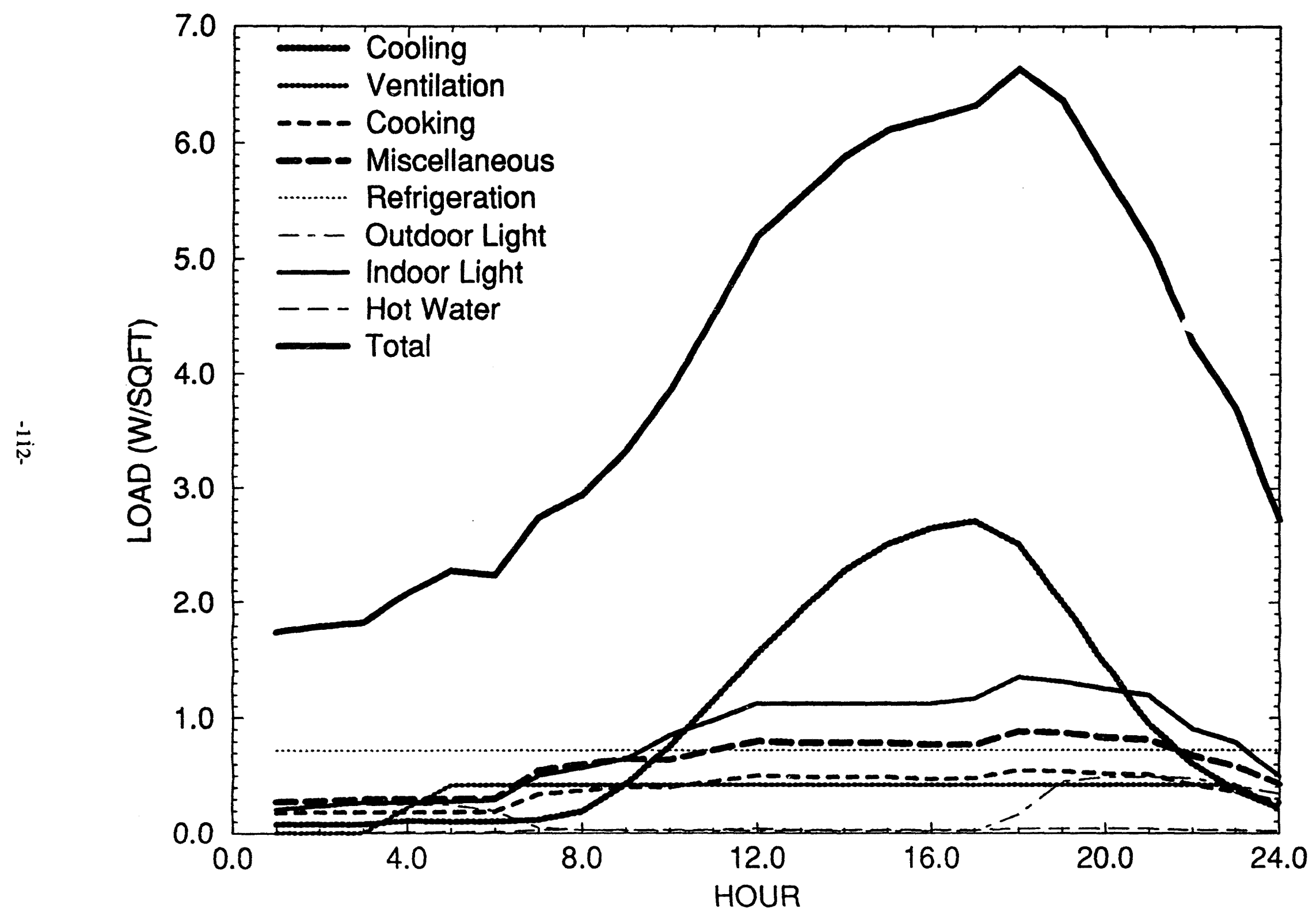




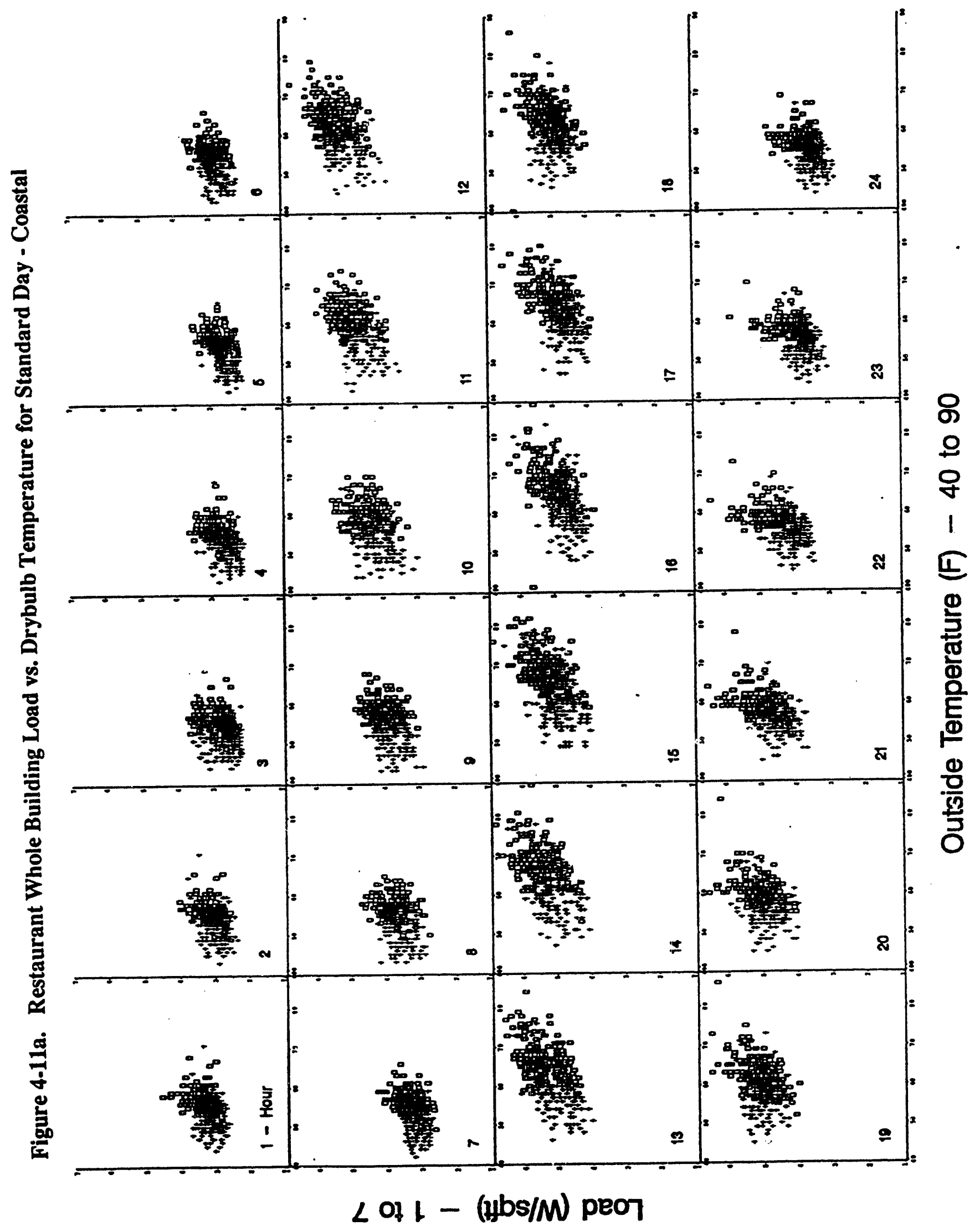


Figure 4-11b. Restaurant Whole Building Load vs. Drybulb Temperature for Standard Day - Inland

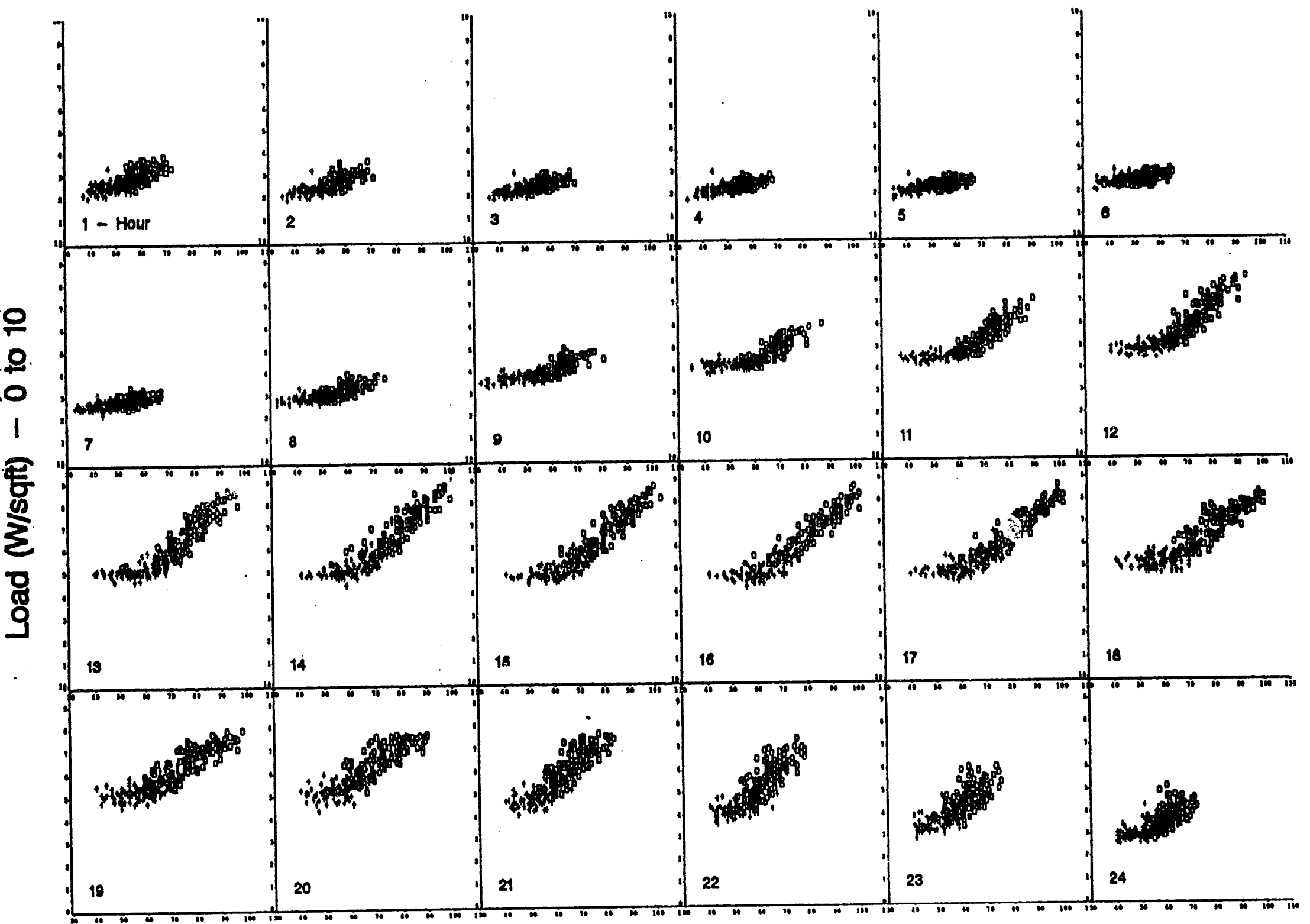

Outside Temperature $(F)-30$ to 110 
Figure 4-12a. Restaurant Reconciled Standard Day Annual End-Use LS - Coastal

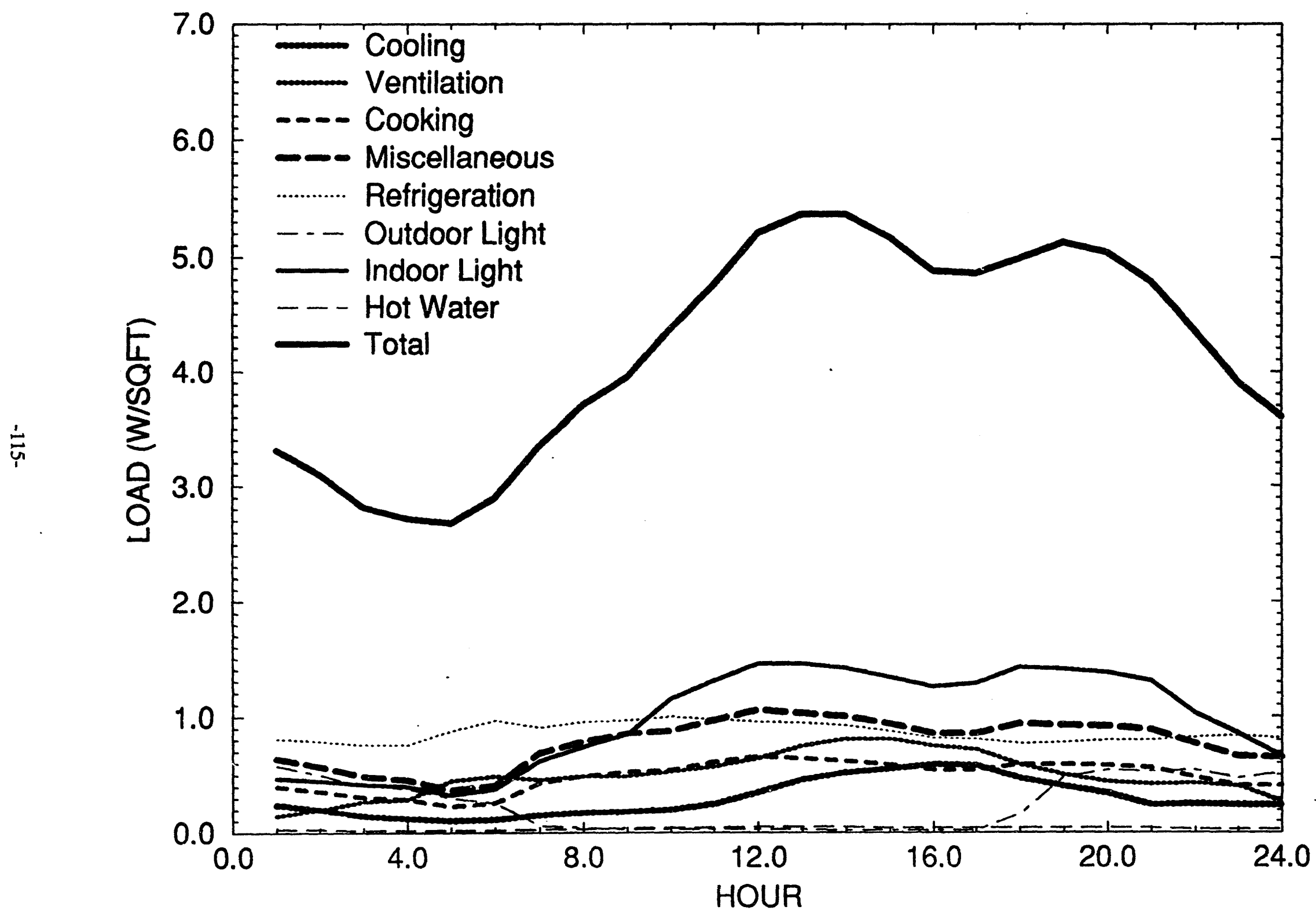


Figure 4-12b. Restaurant Reconciled Standard Day Annual End-Use LS - Inland

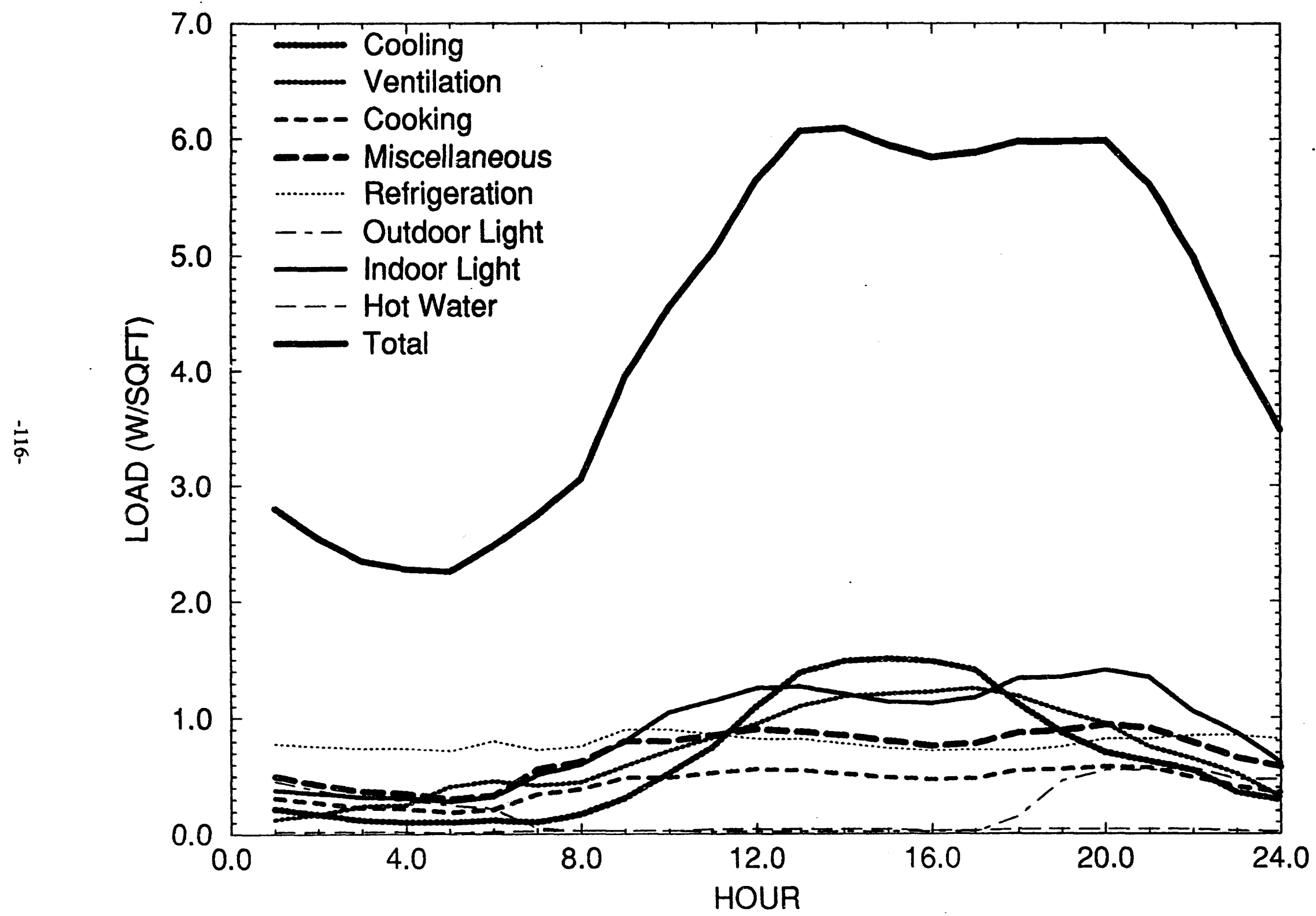


Figure 4-12c. Restaurant Reconciled Nonstandard Day Annual End-Use LS - Inland

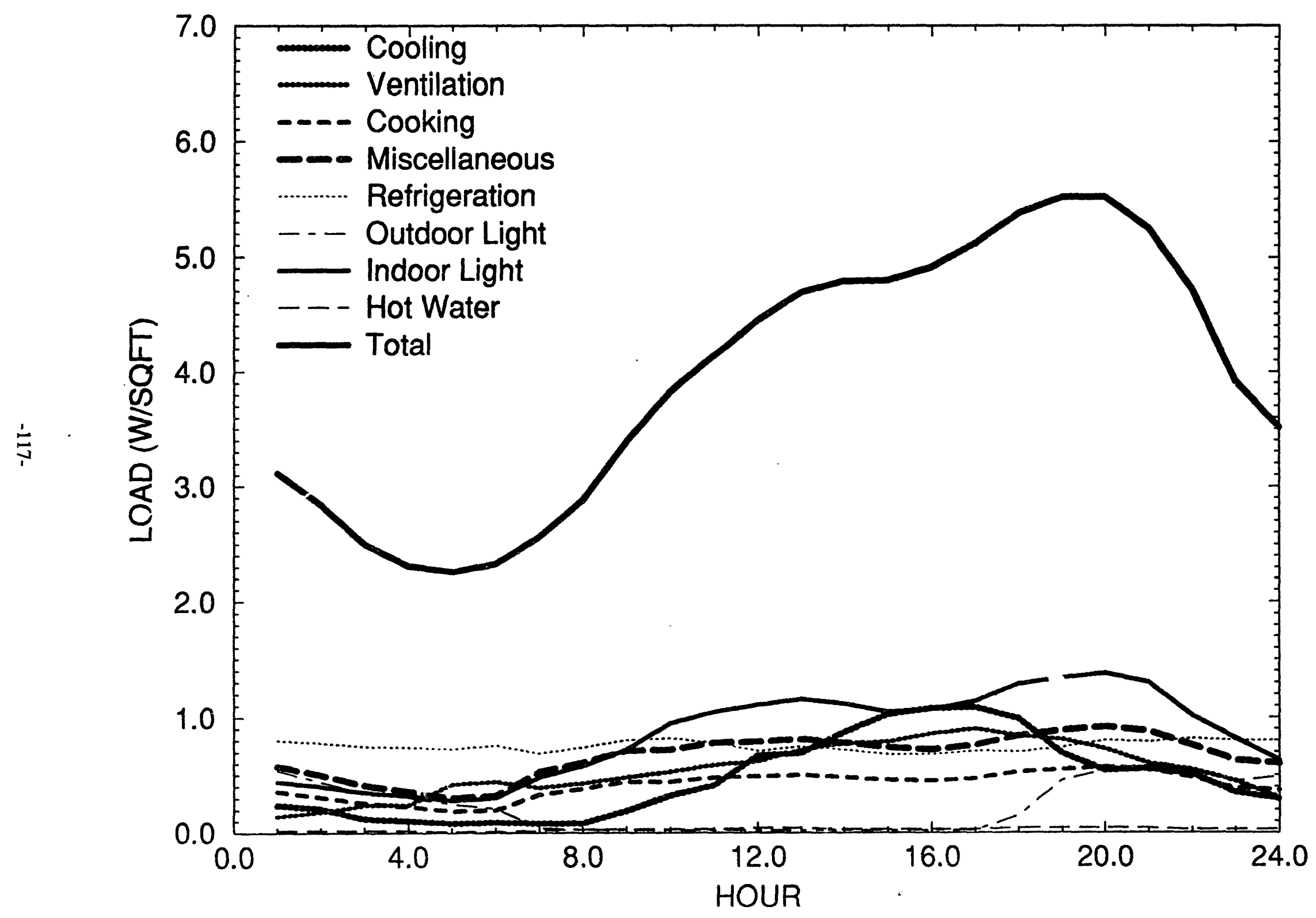




\section{Food Store}

The sood store prototype is a 4,400 $\mathrm{ft}^{2}$ building modeled with five zones, which are $2,700 \mathrm{ft}^{2}$ of sales, $200 \mathrm{ft}^{2}$ of deli, $500 \mathrm{ft}^{2}$ of bakery, $100 \mathrm{ft}^{2}$ of office, and $900 \mathrm{ft}^{2}$ of dry storage. Each are conditioned with a Packaged Single Zone system, hot water and heating are provided by a gas furnace.

Major characteristics of the prototypical building are summarized in Table 4-17a and Table 417b. The vintage and technology options are summarized in Table 4-18.

Table 4-19 shows the DOE-2 simulation and EDA-reconciled end-use EUI summaries for the Food Store category of the coastal and inland climate regions. DOE-2 simulated aveiage standard day end-use LSs for the coastal and inland climate zones are shown in Figure 4-13. Scatter plots of hourly whole-building EUIs against drybulb temperature for annual standard days of coastal and inland climates are shown in Figure 4-14. The inland plot demonstrates a weak correlation during summer between whole-building-load and dry bulb temperature through the entire day, but the coastal plot depicts no correlation. EDA reconciled average standard day end-use LSs for coastal and inland climate regions are shown in Figure 4-15. The LSs indicate that indoor lighting and refrigeration are the largest end-uses, cooling, ventilation, and miscellaneous equipment share the next greatest load, and cooking, outdoor lighting, and hot water heating make up the smallest percentage. Peak operation occurs on weekdays and weekends from 7 am to $9 \mathrm{pm}$.

Note: Packaged Single Zone (PSZ) 
Table 4-17a. Food Store Building Prototype Characteristics

\begin{tabular}{|l|r|}
\hline Shell & \\
Floor Area $\left(1000 \mathrm{ft}^{2}\right)$ & 4.4 \\
Number of Floors & 1 \\
Ceiling Insulation R-value & 10.8 \\
Wall Insulation R-value & 5.8 \\
Window shading coefficient & 0.81 \\
Window/wall ratio & 0.07 \\
Loads & \\
Refrigeration $\left(\mathrm{W} / \mathrm{ft}^{2}\right.$ & \\
Hot Water (Btu/hr/ $\left.\mathrm{ft}^{2}\right)$ & 5.5 \\
Schedule & 4.0 \\
Standard Days & \\
Start & 7 \\
Stop & 6 \\
Non-Standard Days & 2 \\
Start & - \\
Stop & - \\
System & - \\
System Type & \\
COP & PSZ \\
Supply Air (cfm/ $\mathrm{ft}^{2}$ ) & 2.3 \\
Economizer Limit Temperature & 0.7 \\
Thermostat Type & $65^{\circ} \mathrm{F}$ \\
Outside Air Control & Proportional \\
Heat Setpoint & Temperature \\
Cool Setpoint & $70^{\circ} \mathrm{F}$ \\
Plant & $75^{\circ} \mathrm{F}$ \\
Heating & \\
Cooling & Gas Furnace \\
Hot Water & Gas Furnace \\
\hline
\end{tabular}

Table 4-17b. Food Store Building Prototype Zone Description

\begin{tabular}{|l|rrrrr|}
\hline & Office & Dry Storage & Bakery & Deli & Sale \\
\hline Floor Area (\% total) & 3 & 20 & 12 & 5 & \\
Occupancy ( $\mathrm{ft}^{2} /$ person) & 130 & 880 & 220 & 220 & 325 \\
Outside Air (ACH) & - & - & 5.6 & - & - \\
Outside Air / Person (CFM) & 15 & 15 & - & 15 & 15 \\
Indoor Lighting (W/ft ${ }^{2}$ ) & 1.7 & 1.0 & 1.7 & 1.7 & 1.7 \\
Equipment $\left(\mathrm{W} / \mathrm{ft}^{2}\right.$ ) & 0.5 & 0.4 & 7.5 & 3.8 & 0.4 \\
Cooking $\left(\mathrm{W} / \mathrm{ft}^{2}\right.$ ) & - & - & 5.0 & - & - \\
\hline
\end{tabular}


Table 4-18. Food Store Building Vintage Characteristics

\begin{tabular}{|l|rr|}
\hline Technology & Pre-1978 & \multicolumn{1}{c|}{ Post-1978 } \\
\hline Ceiling Insulation R-value & 10.8 & 10.8 \\
Wall Insulation R-value & 5.6 & 8.7 \\
Indoor Lighting $\left(\mathrm{W} / \mathrm{ft}^{2}\right.$ ) & 1.7 & 1.6 \\
Equipment $\left(W / \mathrm{ft}^{2}\right)$ & 1.1 & 1.3 \\
Cooking $\left(W / \mathrm{ft}^{2}\right)$ & .5 & .5 \\
Thermostat Type & Proportional & Reverse Action \\
Outside Air Control & Fixed & Temperature \\
System Type & PSZ & PSZ \\
\hline
\end{tabular}


Table 4-19a. Food Store Simulated and EDA-Reconciled EUIs-Coastal $\left(\mathrm{kWh} / \mathrm{ft}^{2} / \mathrm{yr}\right)$

\begin{tabular}{|c|c|c|c|c|c|c|c|c|c|c|}
\hline \multicolumn{7}{|c|}{ Non-HVAC End Uses } & \multicolumn{3}{|c|}{ HVAC } & \multirow[t]{2}{*}{ Total } \\
\hline $\begin{array}{c}\text { Indoor } \\
\text { Lighting }\end{array}$ & $\begin{array}{l}\text { Outdoor } \\
\text { Lighting }\end{array}$ & $\begin{array}{l}\text { Misc. } \\
\text { Equip. }\end{array}$ & $\begin{array}{l}\text { Office } \\
\text { Equip. }\end{array}$ & Refrig & Cooking & $\begin{array}{l}\text { Water } \\
\text { Heating }\end{array}$ & Heating & Fans & Cooling & \\
\hline \multicolumn{11}{|l|}{ Simulation } \\
\hline \multicolumn{11}{|c|}{ Conditioned (Weight $=0.76)$} \\
\hline 8.88 & 0.91 & 4.57 & 0.00 & 11.49 & 0.37 & 0.07 & 0.00 & 1.92 & 1.17 & 29.38 \\
\hline \multicolumn{11}{|c|}{ Unconditioned (Weight $=0.24)$} \\
\hline 8.88 & 0.91 & 4.57 & 0.00 & 11.49 & 0.37 & 0.07 & 0.00 & 0.00 & 0.00 & 26.29 \\
\hline \multicolumn{11}{|c|}{ Weighted Average } \\
\hline 8.88 & 0.91 & 4.57 & 0.00 & 11.49 & 0.37 & 0.07 & 0.00 & 1.46 & 0.89 & 28.64 \\
\hline \multicolumn{11}{|l|}{ Reconciled } \\
\hline 14.26 & 1.43 & 6.97 & 0.06 & 14.66 & 0.54 & 0.11 & 0.00 & 3.41 & 2.76 & 44.20 \\
\hline
\end{tabular}

Table 4-19b. Food Store Simulated and EDA-Reconciled EUIs-Inland $\left(\mathrm{kWh} / \mathrm{ft}^{2} / \mathrm{yr}\right)$

\begin{tabular}{|c|c|c|c|c|c|c|c|c|c|c|}
\hline \multicolumn{7}{|c|}{ Non-HVAC End Uses } & \multicolumn{3}{|c|}{ HVAC } & \multirow[t]{2}{*}{ Total } \\
\hline $\begin{array}{c}\text { Indoor } \\
\text { Lighting } \\
\end{array}$ & $\begin{array}{l}\text { Outdoor } \\
\text { Lighting }\end{array}$ & $\begin{array}{c}\text { Misc. } \\
\text { Equip. }\end{array}$ & $\begin{array}{l}\text { Office } \\
\text { Equip. }\end{array}$ & Refrig & Cooking & $\begin{array}{c}\text { Water } \\
\text { Heating }\end{array}$ & Heating & Fans & Cooling & \\
\hline \multicolumn{11}{|l|}{ Simulation } \\
\hline \multicolumn{11}{|c|}{ Conditioned (Weight $=0.69)$} \\
\hline 8.88 & 0.91 & 4.57 & 0.00 & 11.49 & 0.37 & 0.07 & 0.00 & 2.38 & 2.70 & 31.37 \\
\hline \multicolumn{11}{|c|}{ Unconditioned (Weight $=0.31$ ) } \\
\hline 8.88 & 0.91 & 4.57 & 0.00 & 11.49 & 0.37 & 0.07 & 0.00 & 0.00 & 0.00 & 26.29 \\
\hline \multicolumn{11}{|c|}{ Weighted Average } \\
\hline 8.88 & 0.91 & 4.57 & 0.00 & 11.49 & 0.37 & 0.07 & 0.00 & 1.64 & 1.86 & 29.79 \\
\hline \multicolumn{11}{|l|}{ Reconciled } \\
\hline 13.97 & 1.29 & 6.40 & 0.06 & 15.15 & 0.50 & 0.11 & 0.00 & 4.43 & 4.61 & 46.52 \\
\hline
\end{tabular}


Figure 4-13a. Food Store Simulated Average Standard Day LS - Coastal

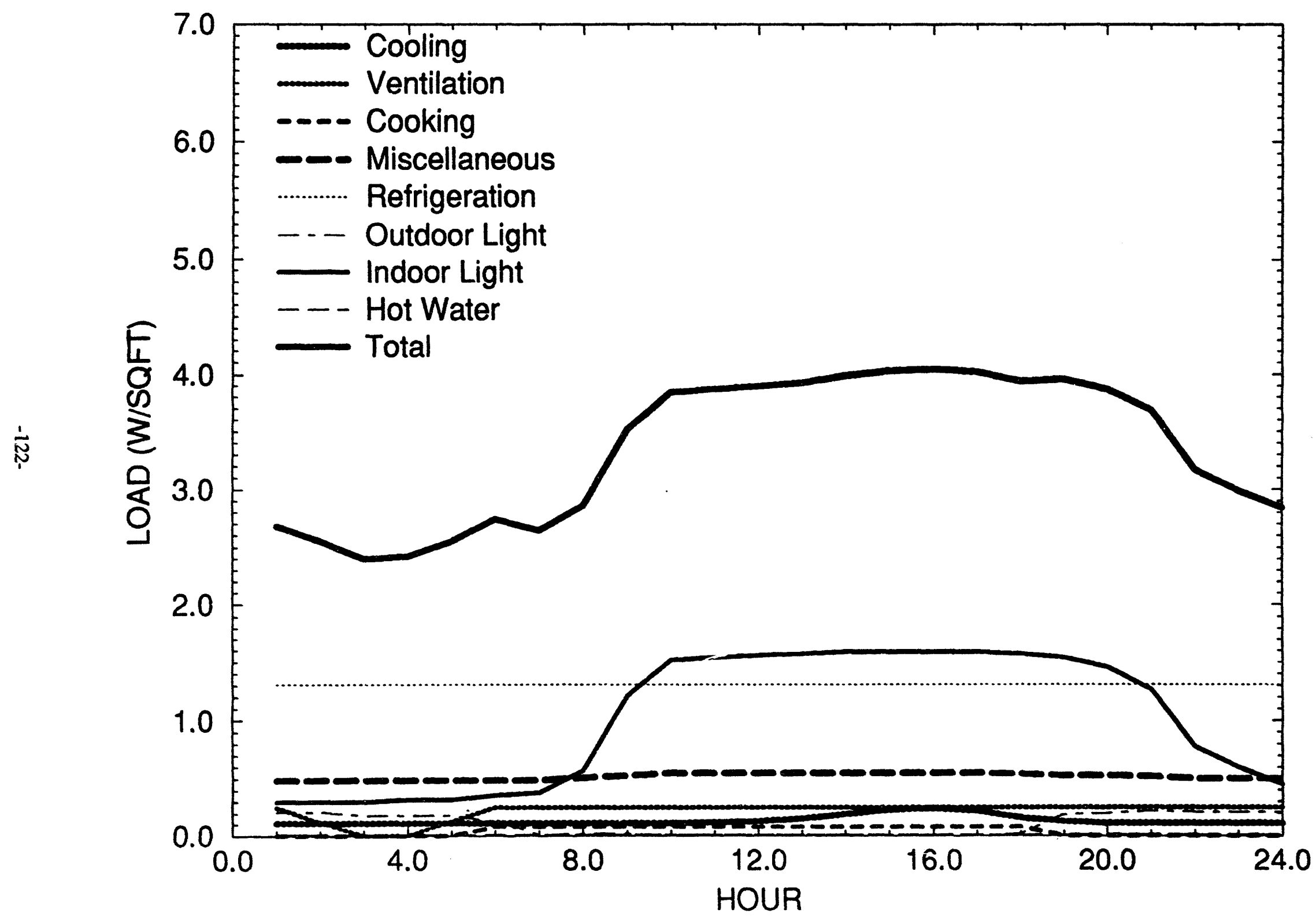


Figure 4-13b. Food Store Simulated Average Standard Day LS - Inland

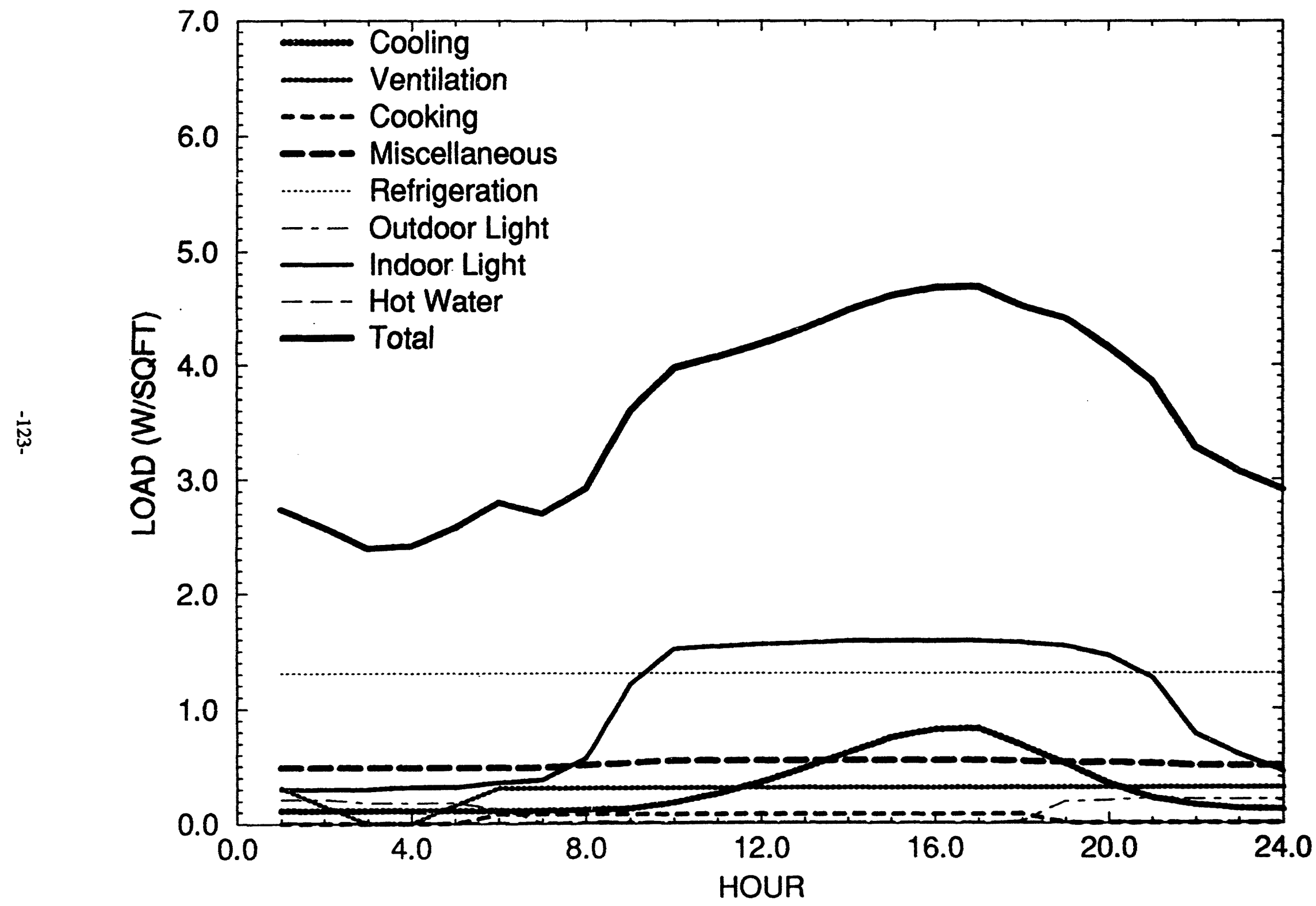




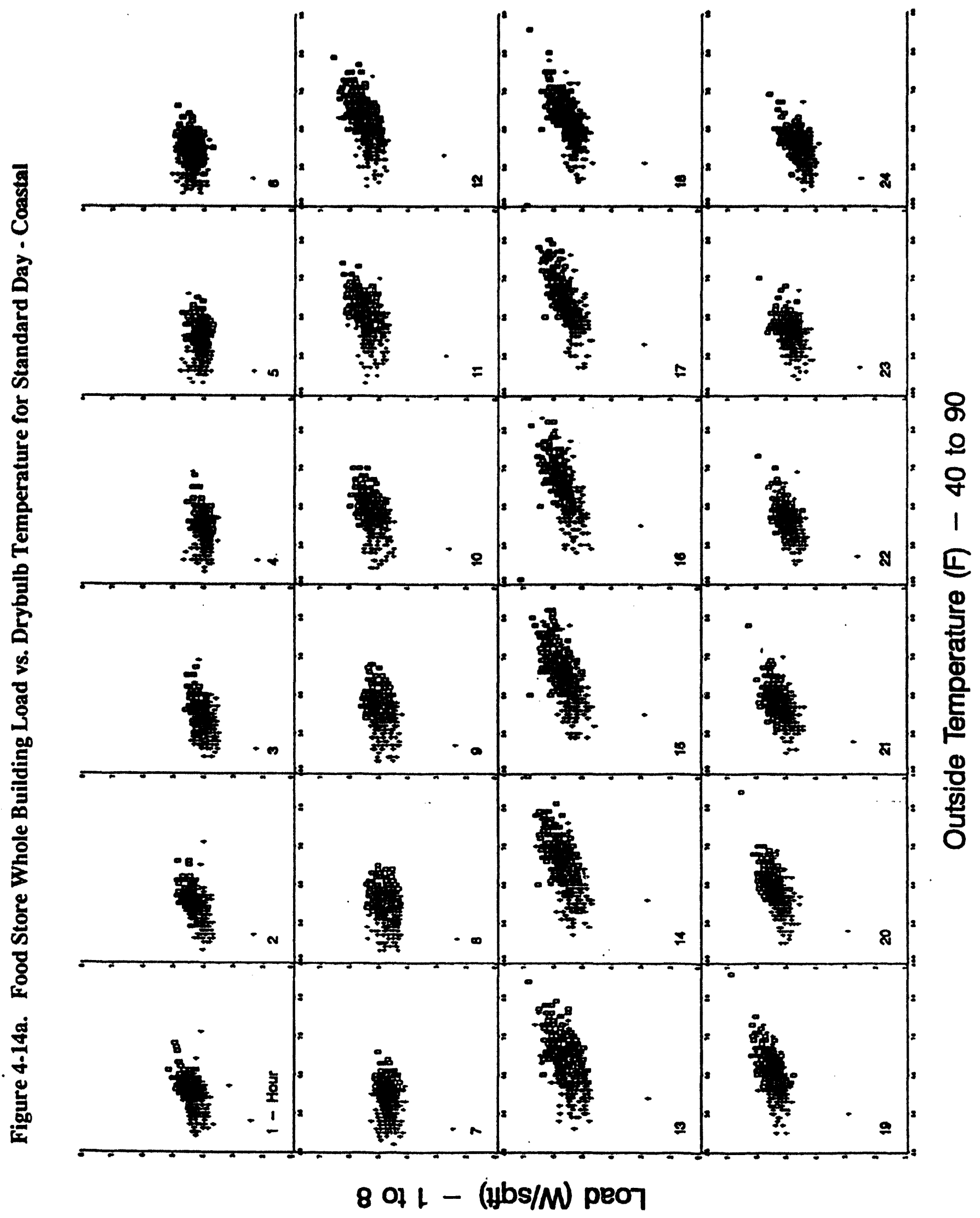


Figure 4-14b. Food Store Whole Building Load vs. Drybulb Temperature for Standard Day - Inland

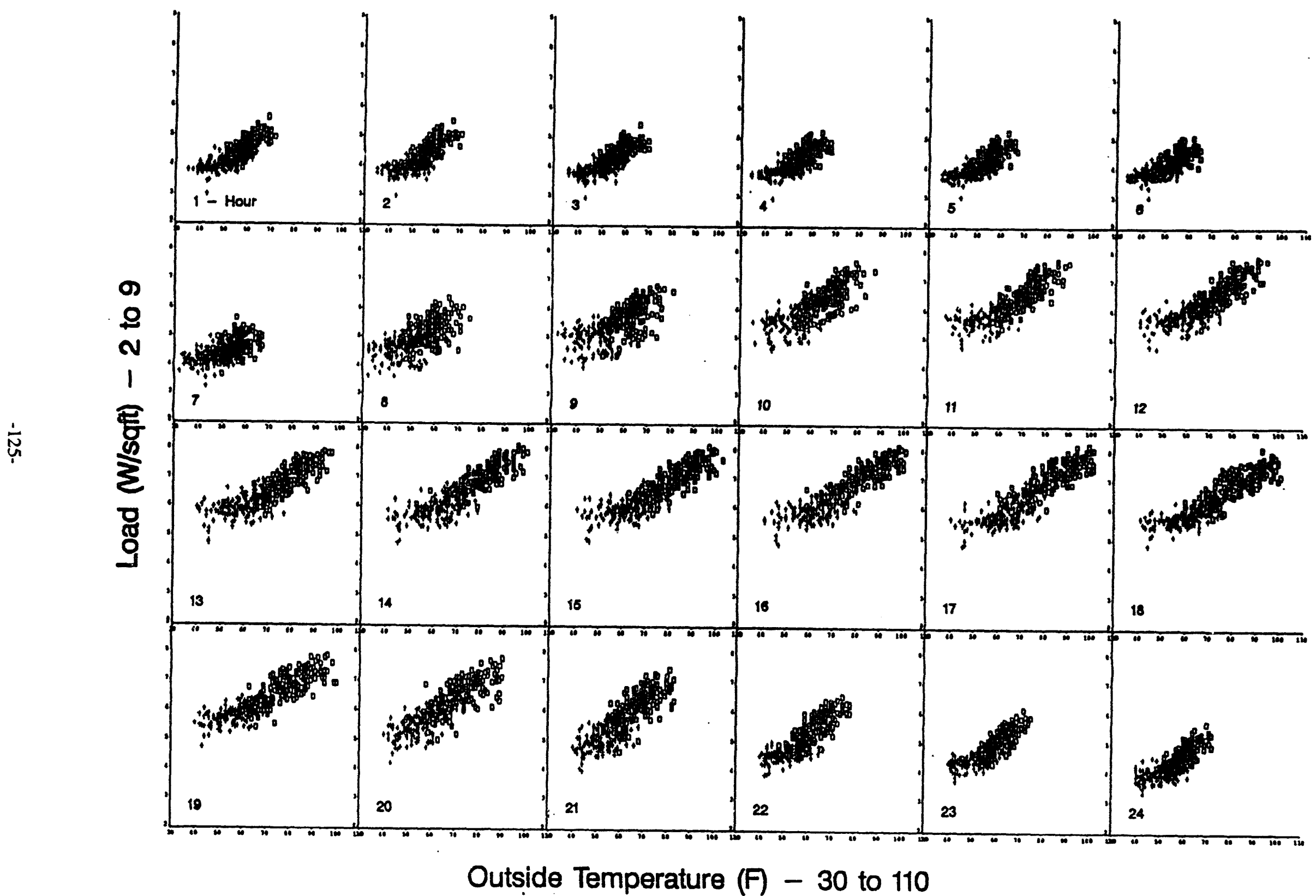


Figure 4-15a. Food Store Reconciled Standard Day Annual End-Use LS - Coastal

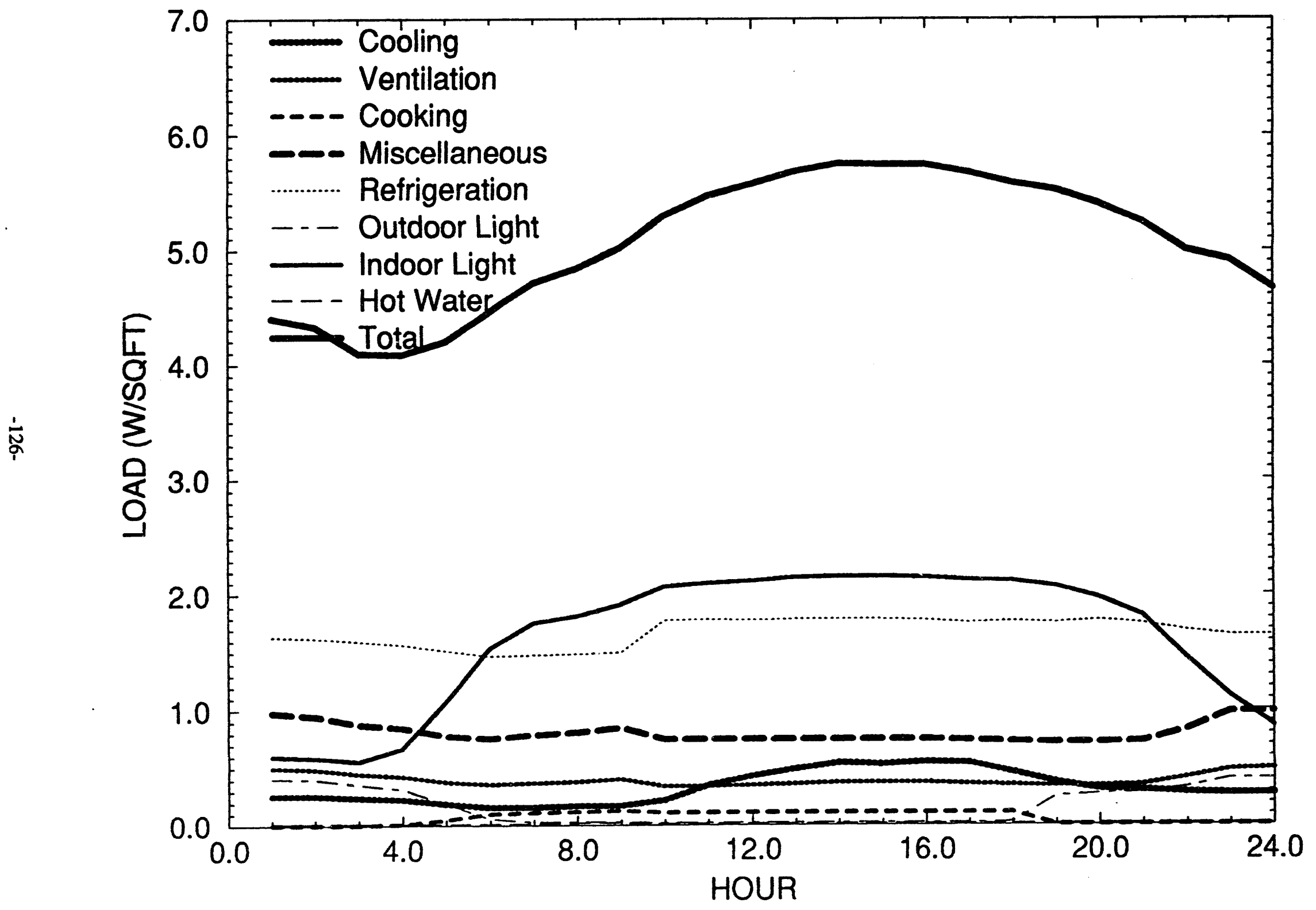




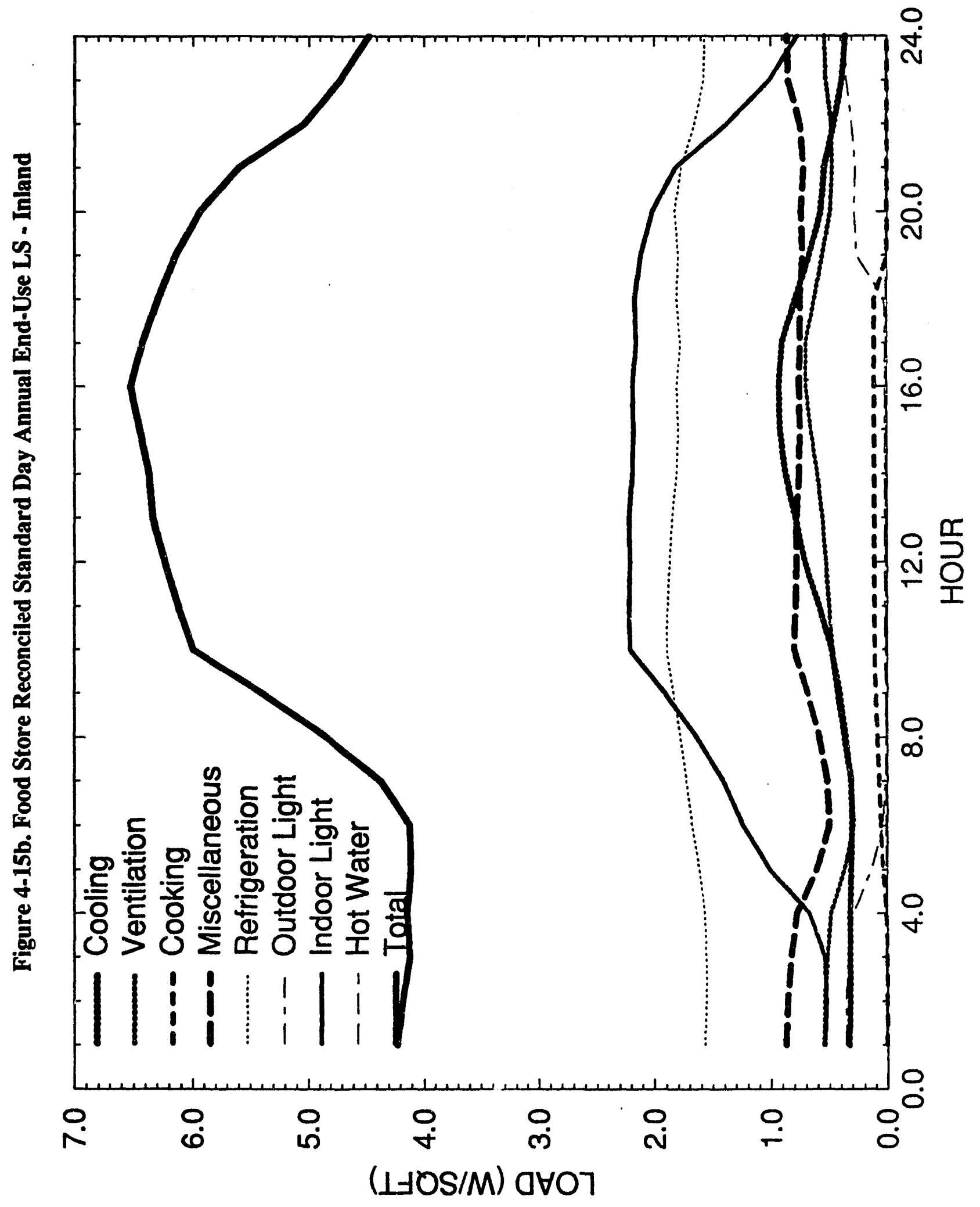




\section{Warehouse}

The Warehouse prototype is a combination of nonrefrigerated and refrigerated types.

\section{Nonrefrigerated Warehouse}

The nonrefrigerated warehouse prototype is a $6,000 \mathrm{ft}^{2}$ single story building modeled with a single zone, which is conditioned with a Packaged Single Zone system. Hot water and heating are provided by a gas furnace.

Major characteristics of the prototypical building are summarized in Table 4-20a and Table 420b. The vintage and technology options are summarized in Table 4-21.

\section{Refrigerated Warehouse}

The refrigerated warehouse prototype is a 53,200 $\mathrm{ft}^{2}$ single story building modeled with a single zone, which is conditioned with a Packaged Single Zone system. Hot water and heat are provided with a gas furnace.

Major characteristics of the prototypical building are summarized in Table 4-22a and Table 422b. The vintage and technology options are summarized in Table 4-23.

\section{Warehouse}

Table 4-24 shows the DOE-2 simulation and EDA-reconciled end-use EUI summaries for the Warehouse category of the coastal and inland climate regions. DOE-2 simulated average standard day end-use LSs for the coastal and inland climate zones are shown in Figure 4-16. Scatter plots of hourly whole-building EUIs against drybulb temperature for annual standard days of coastal and inland climates are shown in Figure 4-17. Both plots depict no correlation between whole-building-load and dry bulb temperature. EDA reconciled average standard and nonstandard day end-use LSs for coastal and inland climates are shown in Figure 4-18. The coastal LSs illustrate that refrigeration is the major end-use, miscellaneous equipment and indoor lighting are the next greatest energy consumers, ventilation consumes yet a smaller percentage, and cooling and outdoor lighting are of the smallest order. The inland LSs show that refrigeration, miscellaneous equipment and indoor lighting are the largest demand, cooling and ventilation require a smaller percentage, and outdoor lighting represents the least load. Peak operation occurs on weekdays during 8 am to $5 \mathrm{pm}$.

Note: $\quad$ Packaged Single Zone (PSZ) 
Table 4-20a. Nonrefrigerated Warehouse Building Prototype Characteristics

\begin{tabular}{|l|r|}
\hline Shell & \\
Floor Area $\left(1000 \mathrm{ft}^{2}\right)$ & 6.0 \\
Number of Floors & 1 \\
Ceiling Insulation R-value & 8.2 \\
Wall Insulation R-value & 5.5 \\
Window shading coefficient & 0.72 \\
Window/wall ratio & 0.05 \\
Loads & \\
Refrigeration $\left(\mathrm{W}^{2} / \mathrm{ft}^{2}\right)$ & 0.1 \\
Cooking (W/ $\left.\mathrm{ft}^{2}\right)$ & - \\
Hot Water (Btu/hr/ $\left.\mathrm{ft}^{2}\right)$ & 0.5 \\
Schedule & \\
Standard Days & 5 \\
Start & 6 \\
Stop & 22 \\
Non-Standard Days & 2 \\
Start & 6 \\
Stop & 22 \\
System & \\
System Type & PSZ \\
COP & 2.3 \\
Supply Air (cfim/ $\mathrm{ft}^{2}$ ) & 0.7 \\
Economizer Limit Temperature & $65^{\circ} \mathrm{F}$ \\
Thermostat Type & Proportional \\
Outside Air Control & Temperature \\
Outside Air / Person (CFM) & 15 \\
Heat Setpoint & $70^{\circ} \mathrm{F}$ \\
Cool Setpoint & $74^{\circ} \mathrm{F}$ \\
Plant & \\
Heating & Gas Furnace \\
Cooling & Gas Furnace \\
Hot Water & \\
\hline
\end{tabular}

Table 4-20b. Nonrefrigerated Warehouse Building Prototype Zone Description

\begin{tabular}{|c|c|c|}
\hline & Office & Storage \\
\hline Floor Area (\% total) & 30 & 70 \\
\hline Occupancy ( $\mathrm{ft}^{2} /$ person) & 180 & 1150 \\
\hline Indoor Lighting (W/ $\left.\mathrm{ft}^{2}\right)$ & 1.0 & 0.9 \\
\hline Equipment $\left(\mathrm{W} / \mathrm{ft}^{2}\right)$ & 1.0 & 1.4 \\
\hline
\end{tabular}


Table 4-21. Nonrefrigerated Warehouse Building Vintage Characteristics

\begin{tabular}{|l|rr|}
\hline Technology & Pre-1978 & \multicolumn{1}{c|}{ Post-1978 } \\
\hline Ceiling Insulation R-value & 7.9 & 17.3 \\
Wall Insulation R-value & 5.3 & 6.6 \\
Indoor Lighting (W/ft ${ }^{2}$ ) & 1.0 & 1.0 \\
Equipment (W/ft ${ }^{2}$ ) & 1.0 & 1.1 \\
Refrigeration & 0.1 & 0.1 \\
Thermostat Type & Proportional & Reverse Action \\
Outside Air Control & Fixed & Temperature \\
System Type & PSZ & PSZ \\
\hline
\end{tabular}


Table 4-22a. Refrigerated Warehouse Building Prototype Characteristics

\begin{tabular}{|l|r|}
\hline Shell & \\
Floor Area (1000 $\mathrm{ft}^{2}$ ) & 53.2 \\
Number of Floors & 1 \\
Ceiling Insulation R-value & 8.2 \\
Wall Insulation R-value & 5.5 \\
Window shading coefficient & 0.73 \\
Window/wall ratio & 0.01 \\
Loads & \\
Refrigeration $\left(\mathrm{W}^{\prime} / \mathrm{ft}^{2}\right.$ ) & 8.5 \\
Cooking (W/ $\left.\mathrm{ft}^{2}\right)$ & - \\
Hot Water (Btu/hr/ft $\left.{ }^{2}\right)$ & 0.5 \\
Schedule & \\
Standard Days & 5 \\
Start & 6 \\
Stop & 22 \\
Non-Standard Days & 2 \\
Start & 6 \\
Stop & 22 \\
System & \\
System Type & PSZ \\
COP & 2.3 \\
Supply Air (cfm/ $\mathrm{ft}^{2}$ ) & 0.7 \\
Economizer Limit Temperature & $65^{\circ} \mathrm{F}$ \\
Thermostat Type & Proportional \\
Outside Air Control & Temperature \\
Outside Air / Person (CFM) & 15 \\
Heat Setpoint & $69^{\circ} \mathrm{F}$ \\
Cool Setpoint & $74^{\circ} \mathrm{F}$ \\
Plant & \\
Heating & Gas Furnace \\
Cooling & Gas Furnace \\
Hot Water & \\
\hline & Direct Expansion \\
\hline
\end{tabular}

Table 4-22b. Refrigerated Warehouse Building Prototype Zone Description

\begin{tabular}{|l|rr|}
\hline & Office & Refrigerated Storage \\
\hline Floor Area (\% total) & 5 & 95 \\
Occupancy $\left(\mathrm{ft}^{2} /\right.$ person) & 250 & 1426 \\
Indoor Lighting $\left(\mathrm{W} / \mathrm{ft}^{2}\right)$ & 1.0 & 0.5 \\
Equipment $\left(\mathrm{W} / \mathrm{ft}^{2}\right)$ & 1.0 & 0.5 \\
\hline
\end{tabular}


Table 4-23. Refrigerated Warehouse Building Vintage Characteristics

\begin{tabular}{|l|rr|}
\hline Technology & \multicolumn{1}{|c|}{ Pre-1978 } & \multicolumn{1}{c|}{ Post-1978 } \\
\hline Ceiling Insulation R-value & 8.2 & 17.3 \\
Wall Insulation R-value & 5.5 & 6.6 \\
Indoor Lighting (W/ft ${ }^{2}$ ) & 0.4 & 0.5 \\
Equipment (W/ft ${ }^{2}$ ) & 0.4 & 0.5 \\
Refrigeration & 6.8 & 7.6 \\
Thermostat Type & Proportional & Reverse Action \\
Outside Air Control & Fixed & Temperature \\
System Type & PSZ & PSZ \\
\hline
\end{tabular}


Table 4-24a. Warehouse Simulated and EDA-Reconciled EUIs-Coastal (kWh/ft $\left.{ }^{2} / \mathbf{y r}\right)$

\begin{tabular}{|c|c|c|c|c|c|c|c|c|c|c|}
\hline \multicolumn{7}{|c|}{ Non-HVAC End Uses } & \multicolumn{3}{|c|}{ HVAC } & \multirow[t]{2}{*}{ Total } \\
\hline $\begin{array}{l}\text { Indoor } \\
\text { Lighting }\end{array}$ & $\begin{array}{l}\text { Outdoor } \\
\text { Lighting }\end{array}$ & $\begin{array}{l}\text { Misc. } \\
\text { Equip. }\end{array}$ & $\begin{array}{l}\text { Office } \\
\text { Equip. }\end{array}$ & Refrig & Cooking & $\begin{array}{l}\text { Water } \\
\text { Heating }\end{array}$ & Heating & Fans & Cooling & \\
\hline \multicolumn{11}{|l|}{ Simulation } \\
\hline \multicolumn{11}{|c|}{ Conditioned (Weight $=0.48)$} \\
\hline 2.06 & 0.36 & 2.16 & 0.00 & 11.98 & 0.00 & 0.01 & 0.00 & 1.37 & 0.41 & 18.35 \\
\hline \multicolumn{11}{|c|}{ Unconditioned (Weight $=0.52$ ) } \\
\hline 2.06 & 0.36 & 2.16 & 0.00 & 11.98 & 0.00 & 0.01 & 0.00 & 0.00 & 0.00 & 16.57 \\
\hline \multicolumn{11}{|c|}{ Weighted Average } \\
\hline 2.06 & 0.36 & 2.16 & 0.00 & 11.98 & 0.00 & 0.01 & 0.00 & 0.66 & 0.20 & 17.43 \\
\hline \multicolumn{11}{|l|}{ Reconciled } \\
\hline 2.26 & 0.39 & 2.80 & 0.22 & 11.52 & 0.00 & 0.01 & 0.00 & 1.09 & 0.11 & 18.40 \\
\hline
\end{tabular}

Table 4-24b. Warehouse Simulated and EDA-Reconciled EUIs-Inland (kWh/fit $\left.\mathbf{t}^{2} / \mathrm{yr}\right)$

\begin{tabular}{|c|c|c|c|c|c|c|c|c|c|c|}
\hline \multicolumn{7}{|c|}{ Non-HVAC End Uses } & \multicolumn{3}{|c|}{ HVAC } & \multirow[t]{2}{*}{ Total } \\
\hline $\begin{array}{c}\text { Indoor } \\
\text { Lighting } \\
\end{array}$ & $\begin{array}{l}\text { Outdoor } \\
\text { Lighting }\end{array}$ & $\begin{array}{l}\text { Misc. } \\
\text { Equip. }\end{array}$ & $\begin{array}{l}\text { Office } \\
\text { Equip. }\end{array}$ & Refrig & Cooking & $\begin{array}{l}\text { Water } \\
\text { Heating }\end{array}$ & Heating & Fans & Cooling & \\
\hline \multicolumn{11}{|l|}{ Simulation } \\
\hline \multicolumn{11}{|c|}{ Conditioned (Weight $=0.51)$} \\
\hline 2.14 & 0.35 & 2.39 & 0.00 & 7.18 & 0.00 & 0.01 & 0.00 & 1.50 & 1.31 & 14.88 \\
\hline \multicolumn{11}{|c|}{ Unconditioned (Weight $=0.49$ ) } \\
\hline 2.14 & 0.35 & 2.39 & 0.00 & 7.18 & 0.00 & 0.01 & 0.00 & 0.00 & 0.00 & 12.07 \\
\hline \multicolumn{11}{|c|}{ Weighted Average } \\
\hline 2.14 & 0.35 & 2.39 & 0.00 & 7.18 & 0.00 & 0.01 & 0.00 & 0.77 & 0.67 & 13.51 \\
\hline \multicolumn{11}{|l|}{ Reconciled } \\
\hline 1.81 & 0.52 & 2.31 & 0.22 & 6.97 & 0.00 & 0.01 & 0.00 & 0.92 & 0.74 & 13.50 \\
\hline
\end{tabular}


Figure 4-16a. Warehouse Simulated Average Standard Day LS - Coastal

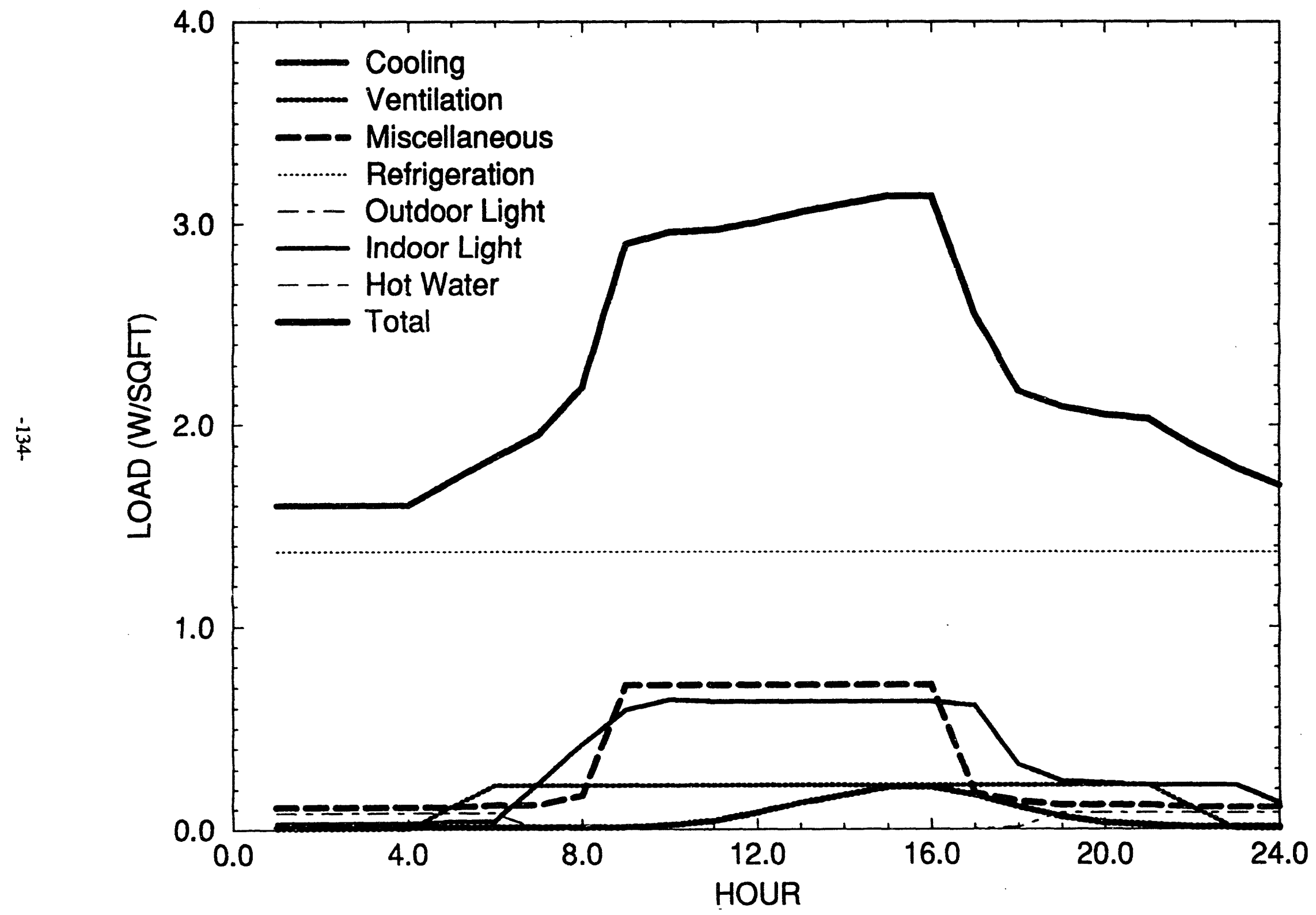


Figure 4-16b. Warehouse Simulated Average Standard Day LS - Inland

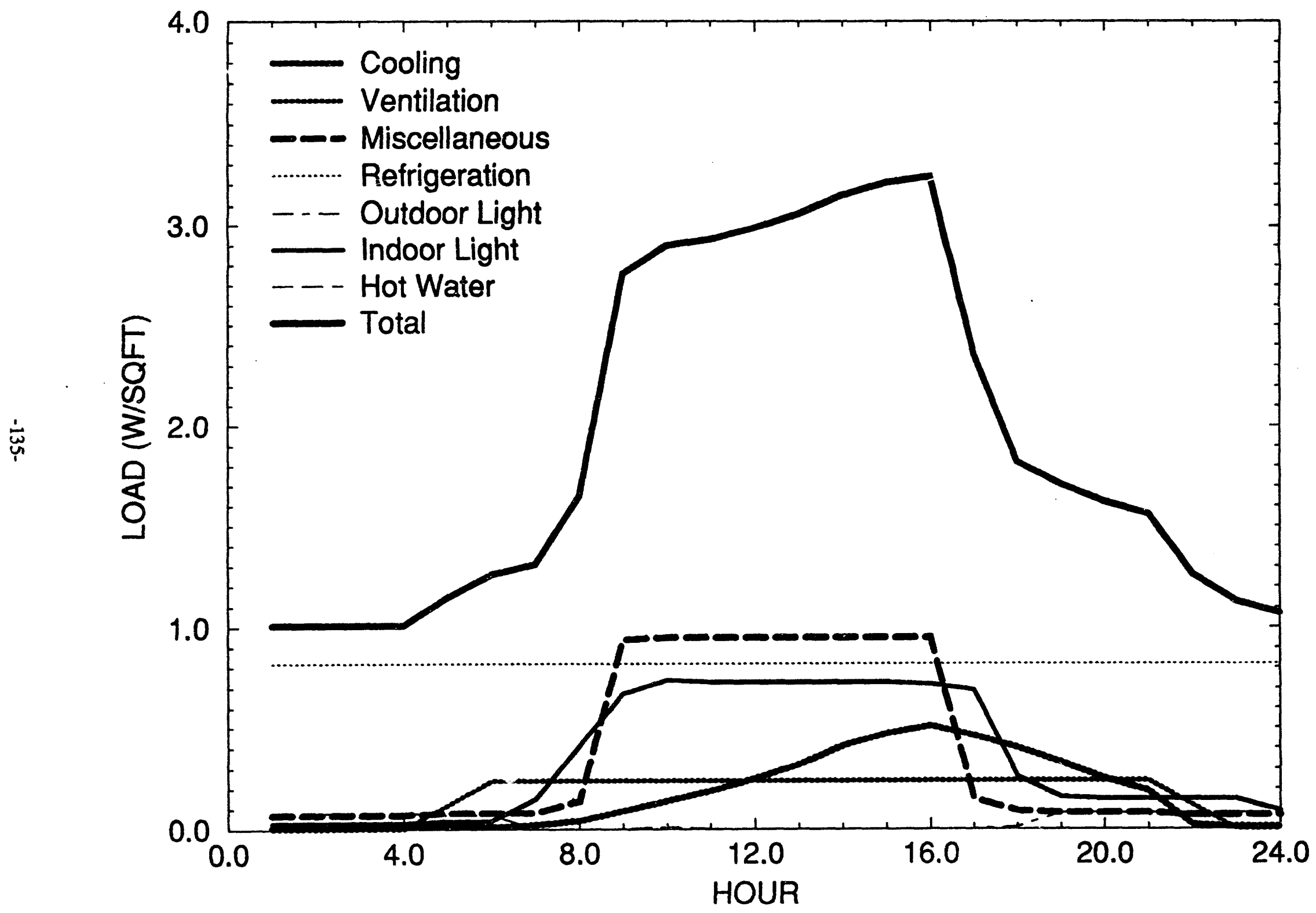


Figure 4-17a. Warehouse Whole Building Load vs. Drybulb Temperature for Standard Day - Coastal

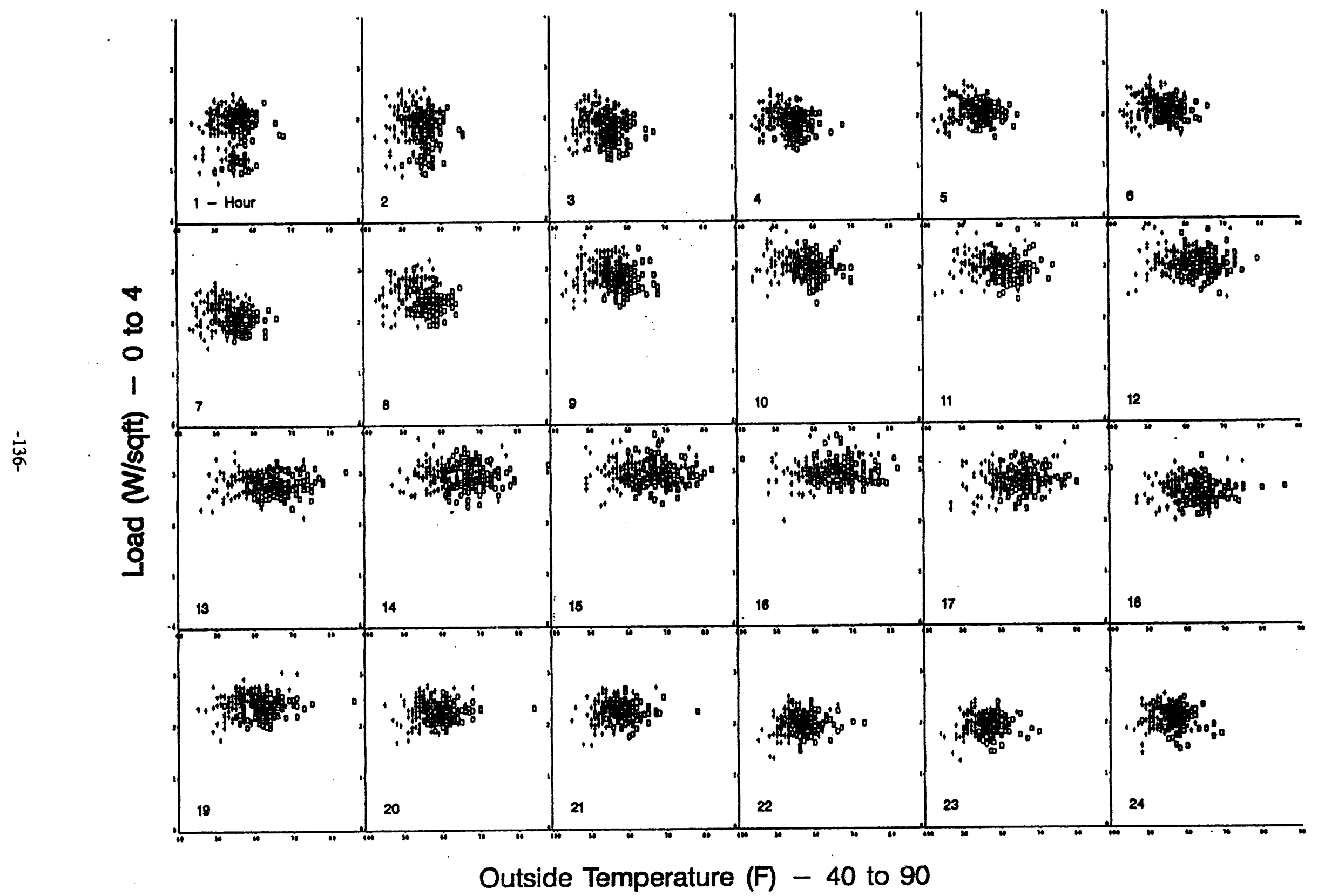


Figure 4-17b. Warehouse Whcle Building Load vs. Drybulb Temperature for Standard Day - Inland

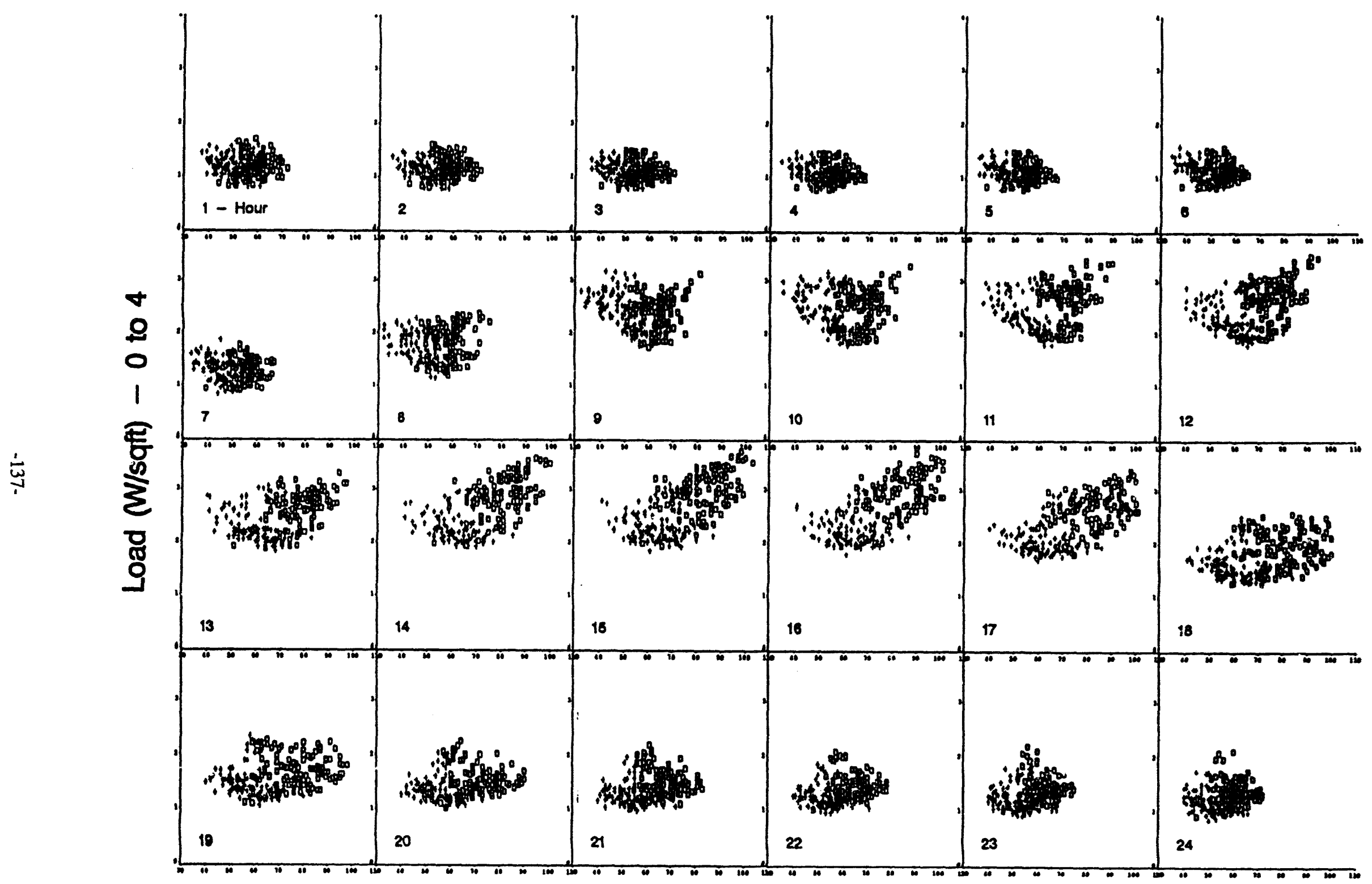

Outside Temperature (F) -30 to 110 
Figure 4-18a. Warehouse Reconciled Standard Day Annual End-Use LS - Coastal

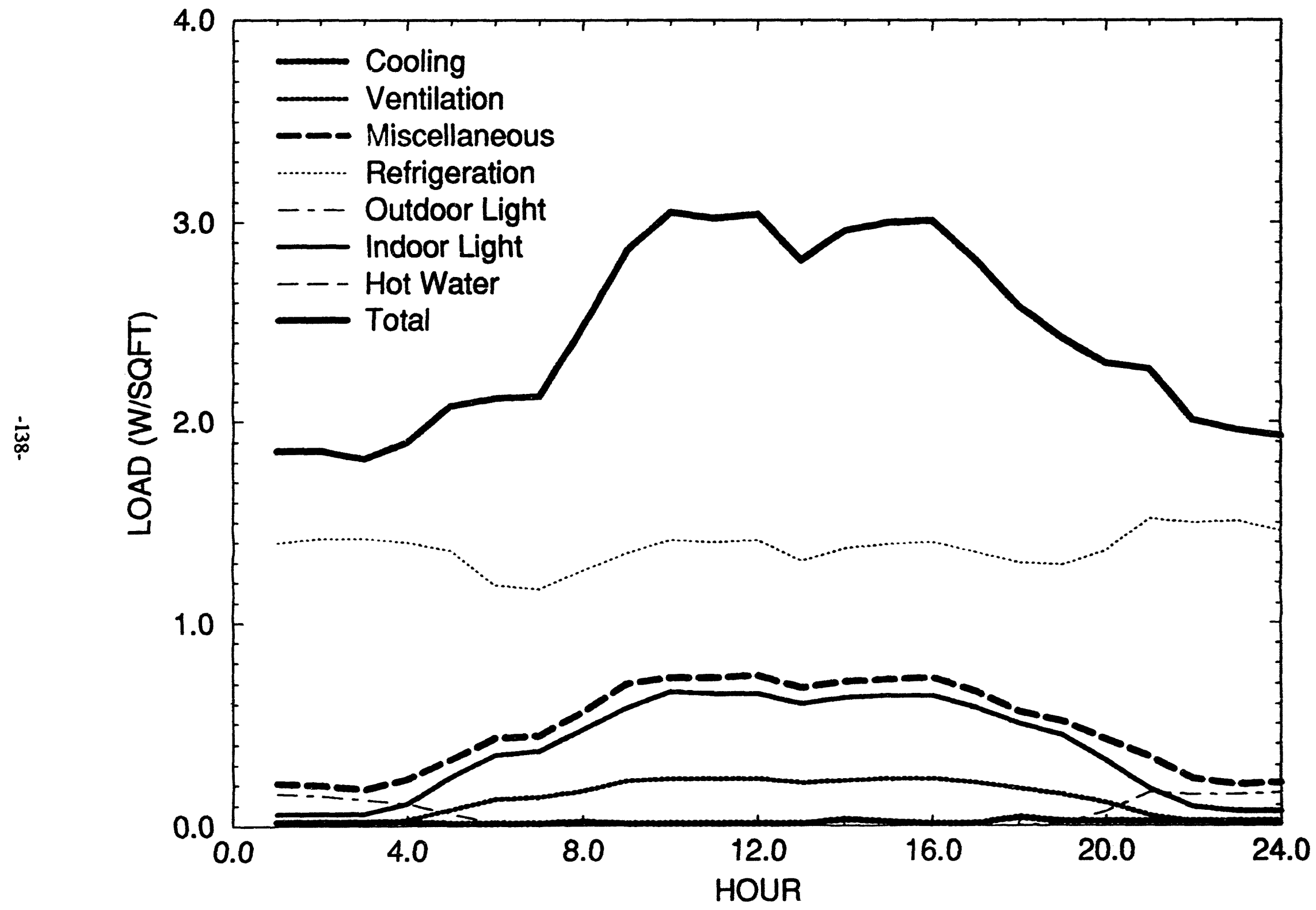


Figure 4-18b. Warehouse Reconciled Standard Day Annual End-Use LS - Inland

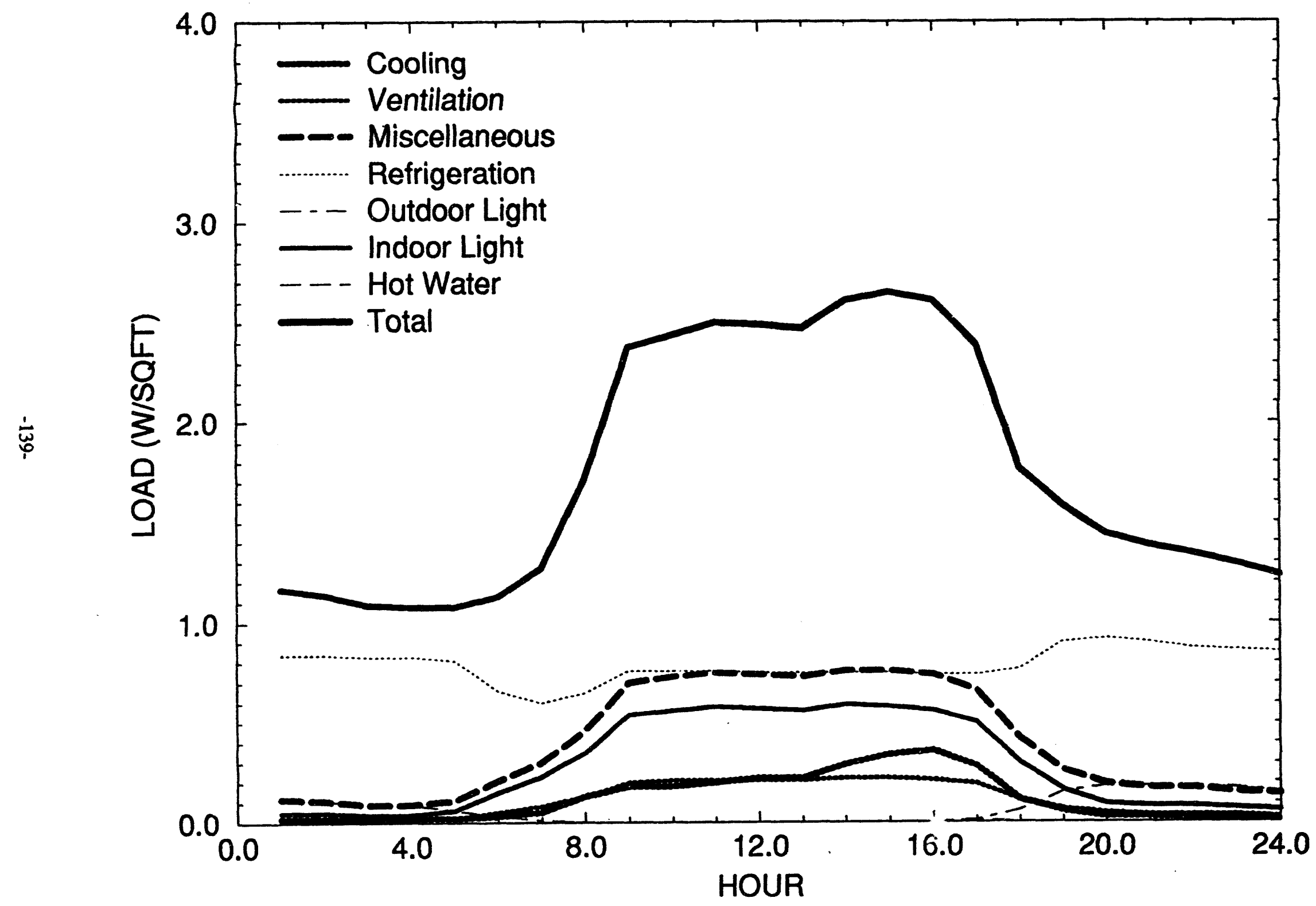


Figure 4-18c. Warehouse Reconciled Nonstandard Day Annual End-Use LS - Coastal

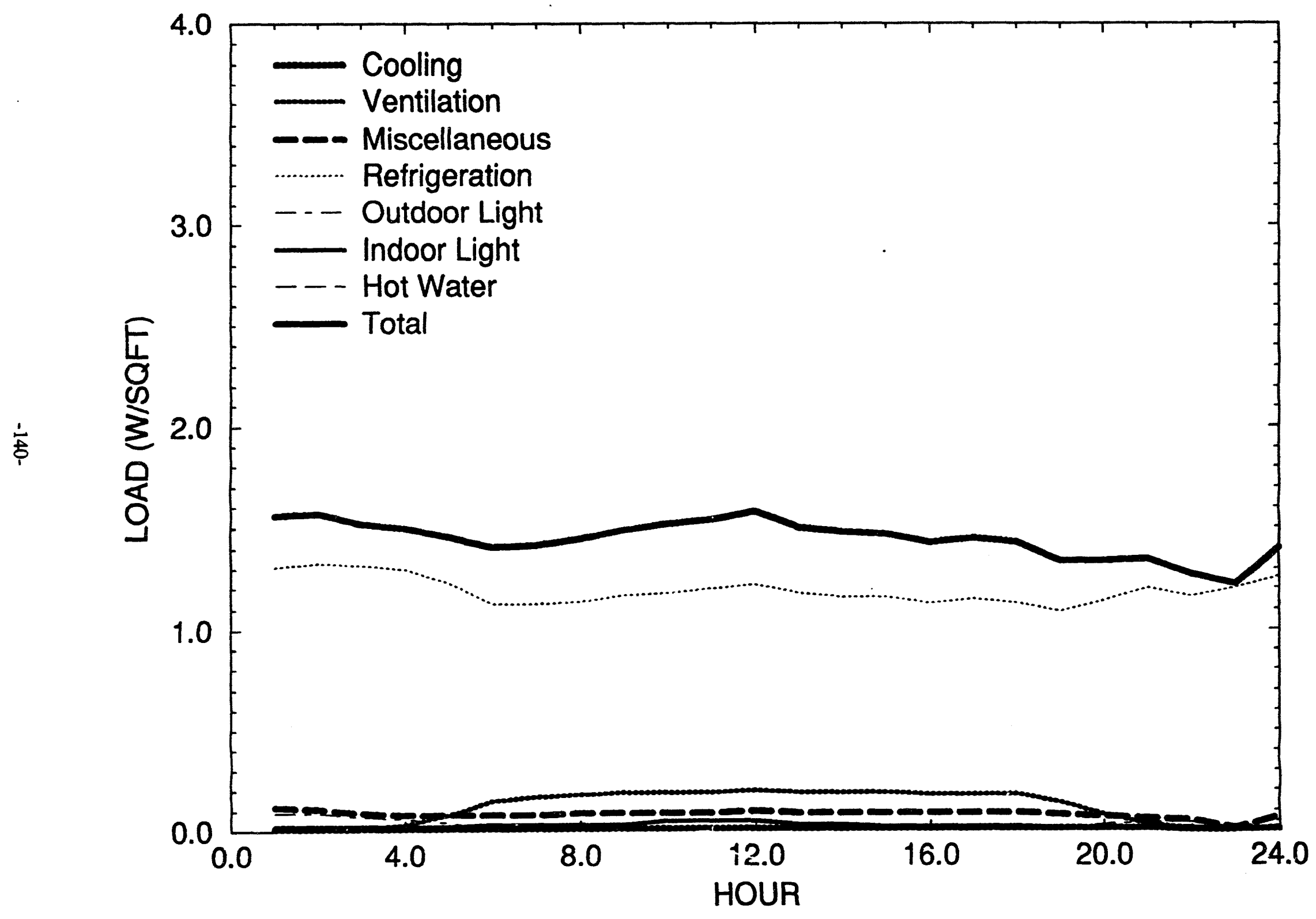


Figure 4-18d. Warehouse Reconciled Nonstandard Day Annual End-Use LS - Inland

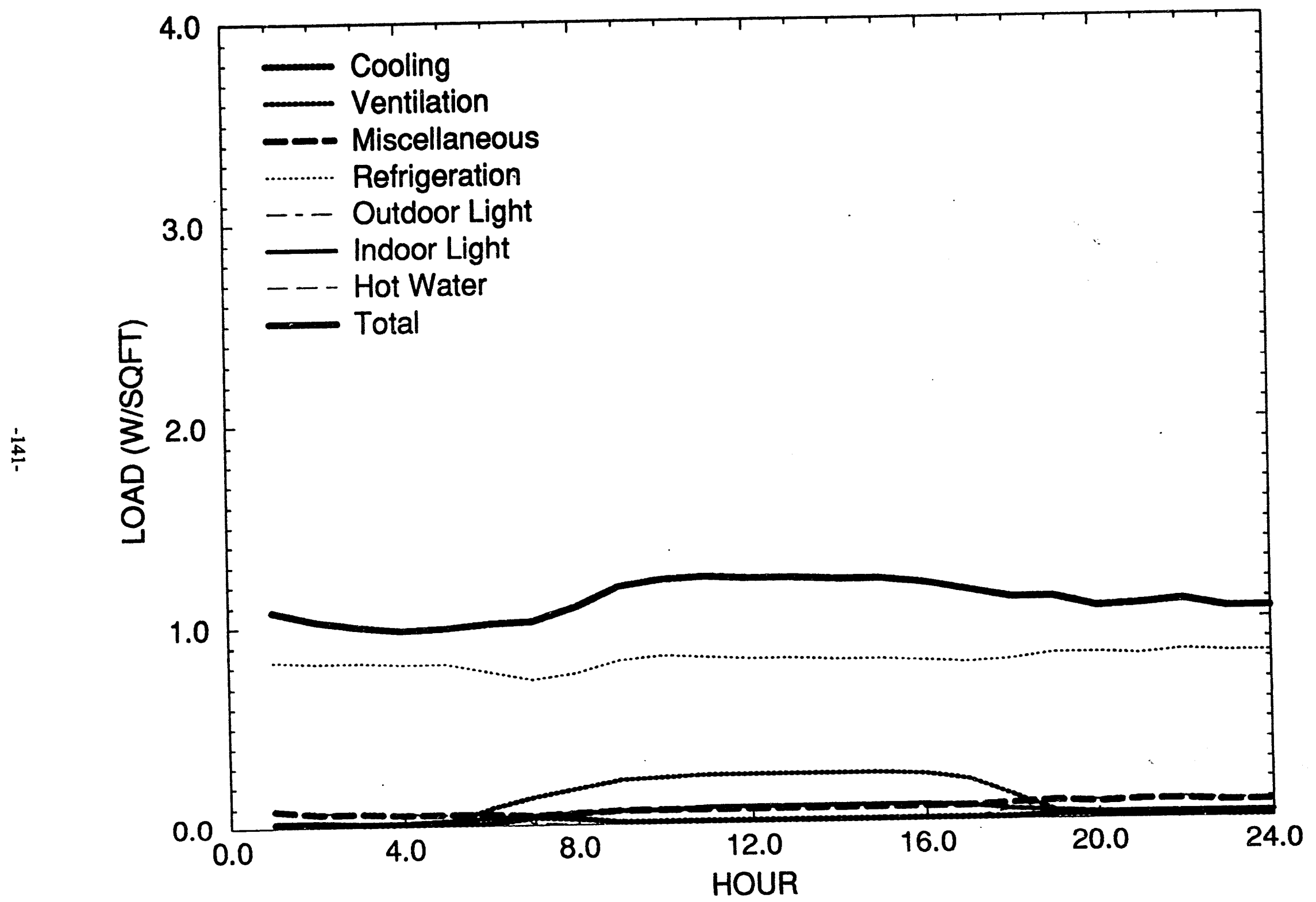




\section{School}

The school category consists of primary schools (grades $\mathrm{K}$ through 6 ) and secondary schools (junior and senior highs).

\section{Primary}

The primary school prototype is a $35,000 \mathrm{ft}^{2}$, single story building consisting of fifteen $1,800 \mathrm{ft}^{2}$ classrooms, a 4,900 $\mathrm{ft}^{2}$ library/multipurpose room, and a 3,200 $\mathrm{ft}^{2}$ kitchen. The zones are conditioned with a Packaged Single Zone system. Heating and hot water are provided by a gas furnace.

Major characteristics of the prototypical building are summarized in Table 4-25a and Table 425b. The onsite survey reported an average floor area of $6,400 \mathrm{ft}^{2}$ within a range of $700 \mathrm{ft}^{2}$ to $46,500 \mathrm{ft}^{2}$, and the mail survey reports $35,000 \mathrm{ft}^{2}$. We felt that the mail survey result more accurately represented the floor area of the primary school. The mail survey does not provide numbers on lighting, equipment, and occupancy loads, so onsite data was used for consistency. The vintage and technology options are summarized in Table 4-26.

\section{Secondary}

The secondary school is a three-story, $100,000 \mathrm{ft}^{2}$ building consisting of six zones: thirty-three $1,800 \mathrm{ft}^{2}$ classrooms, a $13,000 \mathrm{ft}^{2}$ library, a $13,000 \mathrm{ft}^{2}$ gymnasium, a $8,000 \mathrm{ft}^{2}$ auditorium, a $2,000 \mathrm{ft}^{2}$ kitchen, and a 4,000 $\mathrm{ft}^{2}$ dining room. The zones are conditioned with a Packaged Single Zone system. Heating is provided with a gas furnace and hot water through a gas boiler.

Major characteristics of the prototypical building are summarized in Table 4-27a and Table 427b. There was no onsite survey data for the secondary school, therefore mail survey data was used. The vintage and technology options are summarized in Table 4-28.

\section{School}

Table 4-29 shows the DOE-2 simulation and EDA-reconciled end-use EUI summaries for the School category of the coastal and inland climate regions. DOE-2 simulated average standard day end-use LSs for the coastal and inland climate zones are shown in Figure 4-19. Scatter plots of hourly whole-building EUIs against drybulb temperature for annual standard days of coastal and inland climates are shown in Figure 4-20. The coastal plots depict no correlation between whole-building-load and dry bulb temperature, however the inland plots illustrate some correlation during summer from late morning through the afternoon. EDA reconciled average standard and nonstandard day end-use LSs for coastal and inland climate regions are shown in Figure 4-21. The LSs indicate that indoor lighting constitutes the majority of the load, and lesser loads are ventilation, miscellaneous equipment, and hot water heating, and cooking, refrigeration, cooling, and outdoor lighting are the smallest consumers of electricity. Peak operation occurs on weekdays during 8 am to $5 \mathrm{pm}$. 
Table 4-25a. Primary School Building Prototype Characteristics

\begin{tabular}{|l|r|}
\hline Shell & \\
Floor Area (1000 $\mathrm{ft}^{2}$ ) & 35.0 \\
Number of Floors & 1 \\
Ceiling Insulation R-value & 12.1 \\
Wall Insulation R-value & 8.4 \\
Window shading coefficient & 0.79 \\
Window/wall ratio & 0.13 \\
Loads & \\
Refrigeration $\left(\mathrm{W} / \mathrm{ft}^{2}\right)$ & 0.3 \\
Schedule & \\
Standard Days & \\
Start & 5 \\
Stop & 6 \\
Non-Standard Days & 24 \\
Start & 2 \\
Stop & 6 \\
System & 24 \\
System Type & \\
COP & PSZ \\
Supply Air (cfm/ $\mathrm{ft}^{2}$ ) & 2.3 \\
Economizer Limit Temperature & 0.7 \\
Thermostat Type & $65^{\circ} \mathrm{F}$ \\
Outside Air Control & Proportional \\
Heat Setpoint & Temperature \\
Cool Setpoint & $71^{\circ} \mathrm{F}$ \\
Plant & $74^{\circ} \mathrm{F}$ \\
Heating & \\
Cooling & Gas Furnace \\
Hot Water & Gas Furnace \\
\hline & \\
\hline & Direct Expansion \\
\hline
\end{tabular}

Table 4-25b. Primary School Building Prototype Zone Description

\begin{tabular}{|c|c|c|c|}
\hline & Class & Library & Kitchen \\
\hline Floor Area (\% total) & 77 & 17 & 6 \\
\hline Occupancy $\left(\mathrm{ft}^{2} /\right.$ person) & 90 & 78 & 208 \\
\hline Outside Air (ACH) & - & - & 2.9 \\
\hline Outside Air / Person (ÇFM) & 15 & 15 & - \\
\hline Indoor Lighting $\left(\mathrm{W} / \mathrm{ft}^{2}\right)$ & 1.8 & 1.2 & 1.4 \\
\hline Equipment $\left(\mathrm{W} / \mathrm{ft}^{2}\right)$ & 0.5 & 0.5 & 38 \\
\hline Cooking $\left(\mathrm{W} / \mathrm{ft}^{2}\right)$ & 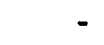 & 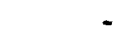 & 11.7 \\
\hline Hot Water $\left(\mathrm{Btu} / \mathrm{hr} / \mathrm{ft}^{2}\right)$ & - & - & 150 \\
\hline
\end{tabular}


Table 4-26. Primary School Building Vintage Characteristics

\begin{tabular}{|l|rr|}
\hline Technology & Pre-1978 & \multicolumn{1}{c|}{ Post-1978 } \\
\hline Ceiling Insulation R-value & 12.1 & 12.1 \\
Wall Insulation R-value & 8.4 & 8.7 \\
Indoor Lighting (W/ft ${ }^{2}$ ) & 1.7 & 1.7 \\
Equipment $\left(W / \mathrm{ft}^{2}\right.$ ) & 2.8 & 2.8 \\
Thermostat Type & Proportional & Reverse Action \\
Outside Air Control & Fixed & Temperature \\
System Type & PMZ & PSZ \\
\hline
\end{tabular}

Note: Packaged Single Zone (PSZ)

Packaged Multi Zone (PMZ) 
Table 4-27a. Secondary School Building Prototype Characteristics

\begin{tabular}{|l|r|}
\hline Shell & \\
Floor Area $\left(1000 \mathrm{ft}^{2}\right)$ & 100 \\
Number of Floors & 3 \\
Ceiling Insulation R-value & 11.0 \\
Wall Insulation R-value & 7.0 \\
Window shading coefficient & 0.85 \\
Window/wall ratio & 0.29 \\
Loads & \\
Refrigeration (W/ $\mathrm{ft}^{2}$ ) & 0.5 \\
Schedule & \\
Standard Days & 5 \\
Start & 6 \\
Stop & 24 \\
Non-Standard Days & 2 \\
Start & 6 \\
Stop & 24 \\
System & \\
System Type & PSZ \\
COP & 2.3 \\
Supply Air (cfm/ft ${ }^{2}$ ) & 0.7 \\
Economizer Limit Temperature & $65^{\circ} \mathrm{F}$ \\
Thermostat Type & Proportional \\
Outside Air Control & Temperature \\
Heat Setpoint & $75^{\circ} \mathrm{F}$ \\
Cool Setpoint & $78^{\circ} \mathrm{F}$ \\
Plant & \\
Heating & Gas Furnace \\
Cooling & Boiler \\
Hot Water & \\
\hline
\end{tabular}

Table 4-27b. Secondary School Building Prototype Zone Description

\begin{tabular}{|c|c|c|c|c|c|c|}
\hline & Library & Class & Gym & Auditorium & Kitchen & Dining \\
\hline Floor Area (\% total) & 13 & 60 & 13 & 8 & 2 & 4 \\
\hline Occupancy $\left(\mathrm{ft}^{2} /\right.$ person) & 100 & 90 & 180 & 100 & 300 & 20 \\
\hline Outside Air (ACH) & - & - & - & - & 3.0 & 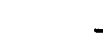 \\
\hline Outside Air / Person (CFM) & 15 & 15 & 15 & 15 & - & 15 \\
\hline Indoor Lighting $\left(\mathrm{W} / \mathrm{ft}^{2}\right)$ & 1.5 & 2.2 & 0.7 & 0.8 & 1.7 & 1.7 \\
\hline Equipment (W/ft $\left.{ }^{2}\right)$ & 0.5 & 0.5 & 0.5 & 0.5 & 38 & 0.5 \\
\hline Cooking $\left(\mathrm{W} / \mathrm{ft}^{2}\right)$ & - & - & - & - & 12.0 & \\
\hline Hot Water $\left(\mathrm{Btu} / \mathrm{hr} / \mathrm{ft}^{2}\right.$, & - & - & - & - & 150 & . \\
\hline
\end{tabular}


Table 4-28. Secondary School Building Vintage Characteristics

\begin{tabular}{|l|rr|}
\hline Technology & Pre-1978 & \multicolumn{1}{c|}{ Post-1978 } \\
\hline Ceiling Insulation R-value & 4.9 & 11.0 \\
Wall Insulation R-value & 1.0 & 7.0 \\
Indoor Lighting $\left(\mathrm{W} / \mathrm{ft}^{2}\right.$ ) & 1.8 & 1.8 \\
Equipment $\left(\mathrm{W} / \mathrm{ft}^{2}\right.$ ) & 1.3 & 1.3 \\
Cooking $\left(W / \mathrm{ft}^{2}\right)$ & 0.2 & 0.2 \\
Thermostat Type & Proportional & Reverse Action \\
Outside Air Control & Fixed & Temperature \\
System Type & PMZ & PSZ \\
\hline
\end{tabular}


Table 4-29a. School Simulated and EDA-Reconciled EUIs-Coastal (kWh/fit $/ \mathbf{y r})$

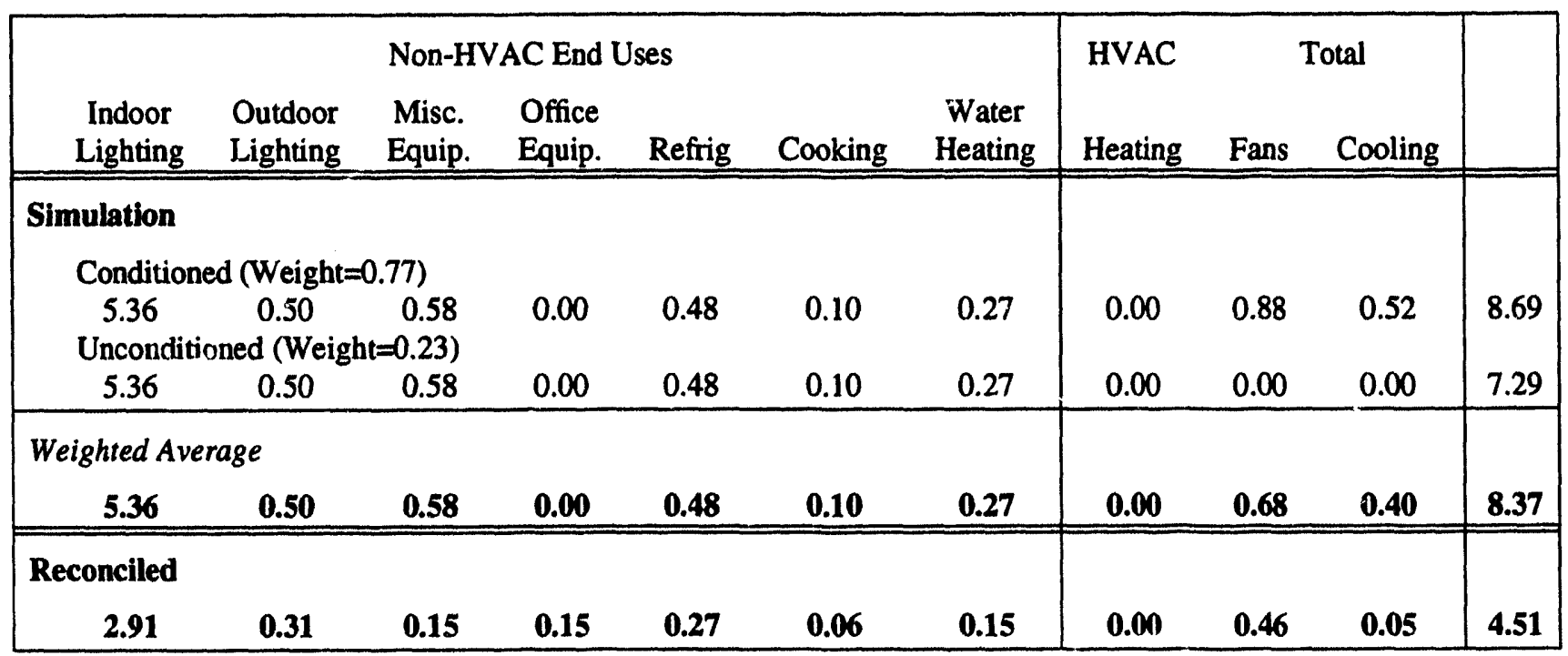

Table 4-29b. School Simulated and EDA-Reconciled EUIs-Inland $\left(\mathrm{kWh} / \mathrm{ft}^{2} / \mathrm{yr}\right)$

\begin{tabular}{|c|c|c|c|c|c|c|c|c|c|c|}
\hline \multicolumn{7}{|c|}{ Non-HVAC End Uses } & \multicolumn{3}{|c|}{ HVAC } & \multirow[t]{2}{*}{ Total } \\
\hline $\begin{array}{c}\text { Indoor } \\
\text { Lighting } \\
\end{array}$ & $\begin{array}{l}\text { Outdoor } \\
\text { Lighting }\end{array}$ & $\begin{array}{l}\text { Misc. } \\
\text { Equip. }\end{array}$ & $\begin{array}{l}\text { Office } \\
\text { Equip. }\end{array}$ & Refrig & Cooking & $\begin{array}{l}\text { Water } \\
\text { Heating }\end{array}$ & Heating & Fans & Cooling & \\
\hline \multicolumn{11}{|l|}{ Simulation } \\
\hline \multicolumn{11}{|c|}{ Conditioned (Weight $=0.83$ ) } \\
\hline 5.38 & 0.50 & 0.58 & 0.00 & 0.48 & 0.11 & 0.27 & 0.00 & 0.95 & 1.37 & 9.64 \\
\hline \multicolumn{11}{|c|}{ Unconditioned (Weight $=0.17$ ) } \\
\hline 5.38 & 0.50 & 0.58 & 0.00 & 0.48 & 0.11 & 0.27 & 0.00 & 0.00 & 0.00 & 7.32 \\
\hline \multicolumn{11}{|c|}{ Weighted Average } \\
\hline 5.38 & 0.50 & 0.58 & 0.00 & 0.48 & 0.11 & 0.27 & 0.00 & 0.79 & 1.14 & 9.25 \\
\hline \multicolumn{11}{|l|}{ Reconciled } \\
\hline 3.06 & 0.28 & 0.17 & 0.15 & 0.25 & 0.07 & 0.16 & 0.00 & 0.62 & 0.05 & 4.81 \\
\hline
\end{tabular}


Figure 4-19a. School Simulated Average Standard Day LS - Coastal

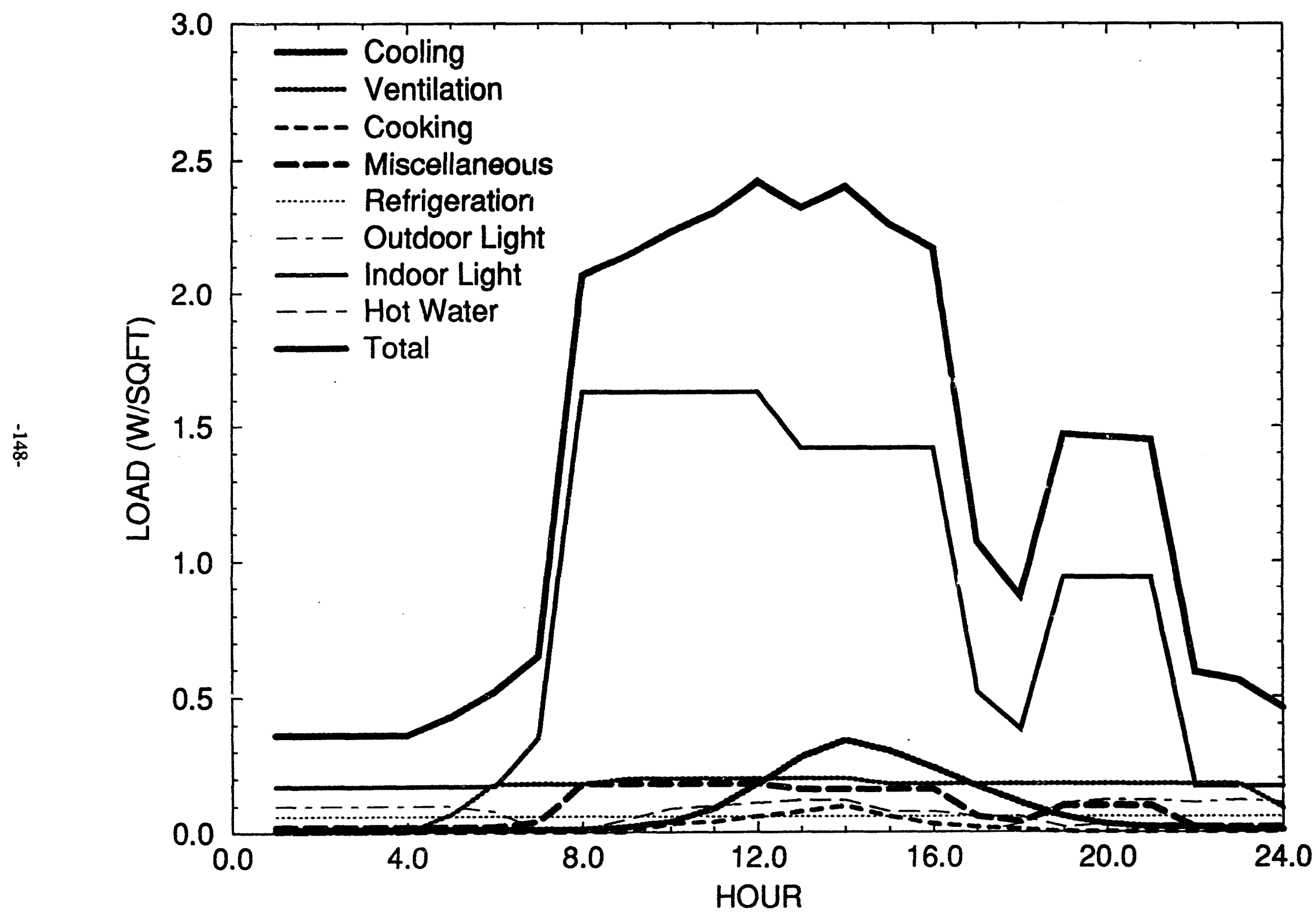


Figure 4-19b. School Simulated Average Standard Day LS - Inland

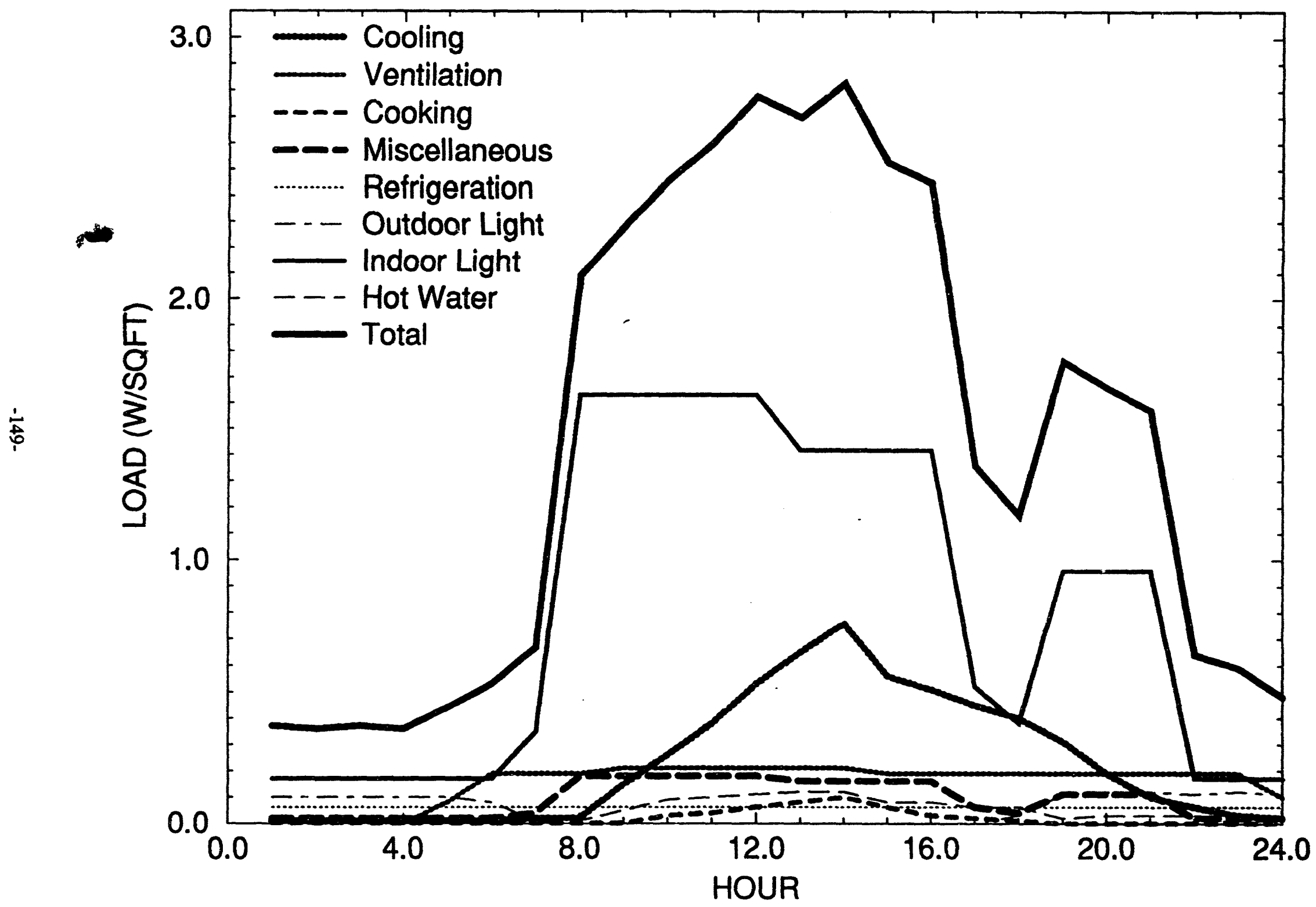


Figure 4-20a. School Whole Building Load vs. Drybulb Temperature for Standard Day - Coastal

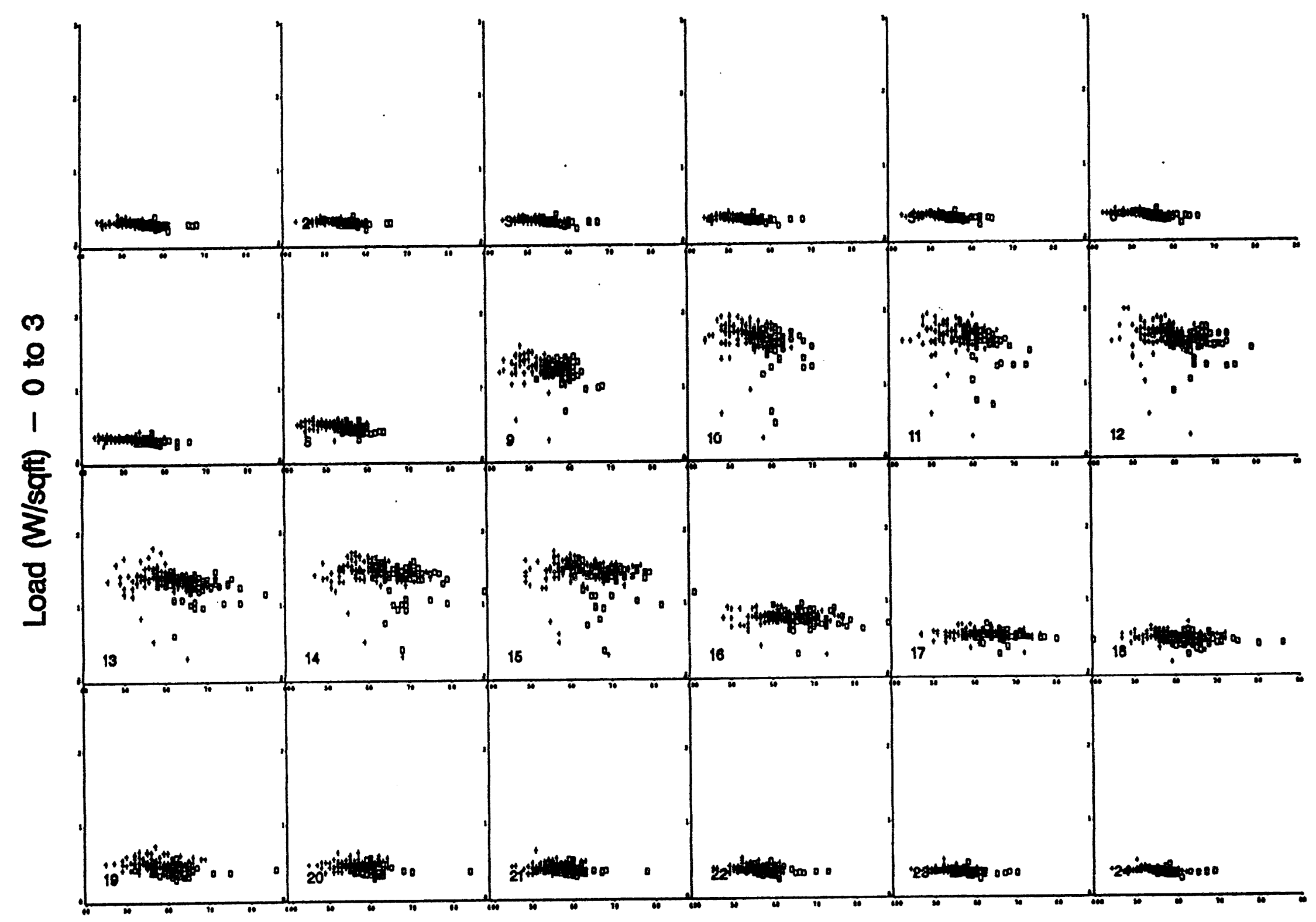

Outside Temperature (F) - 40 to 90 
Figure 4-20b. School Whole Building Load vs. Drybulb Temperature for Standard Day - Inland

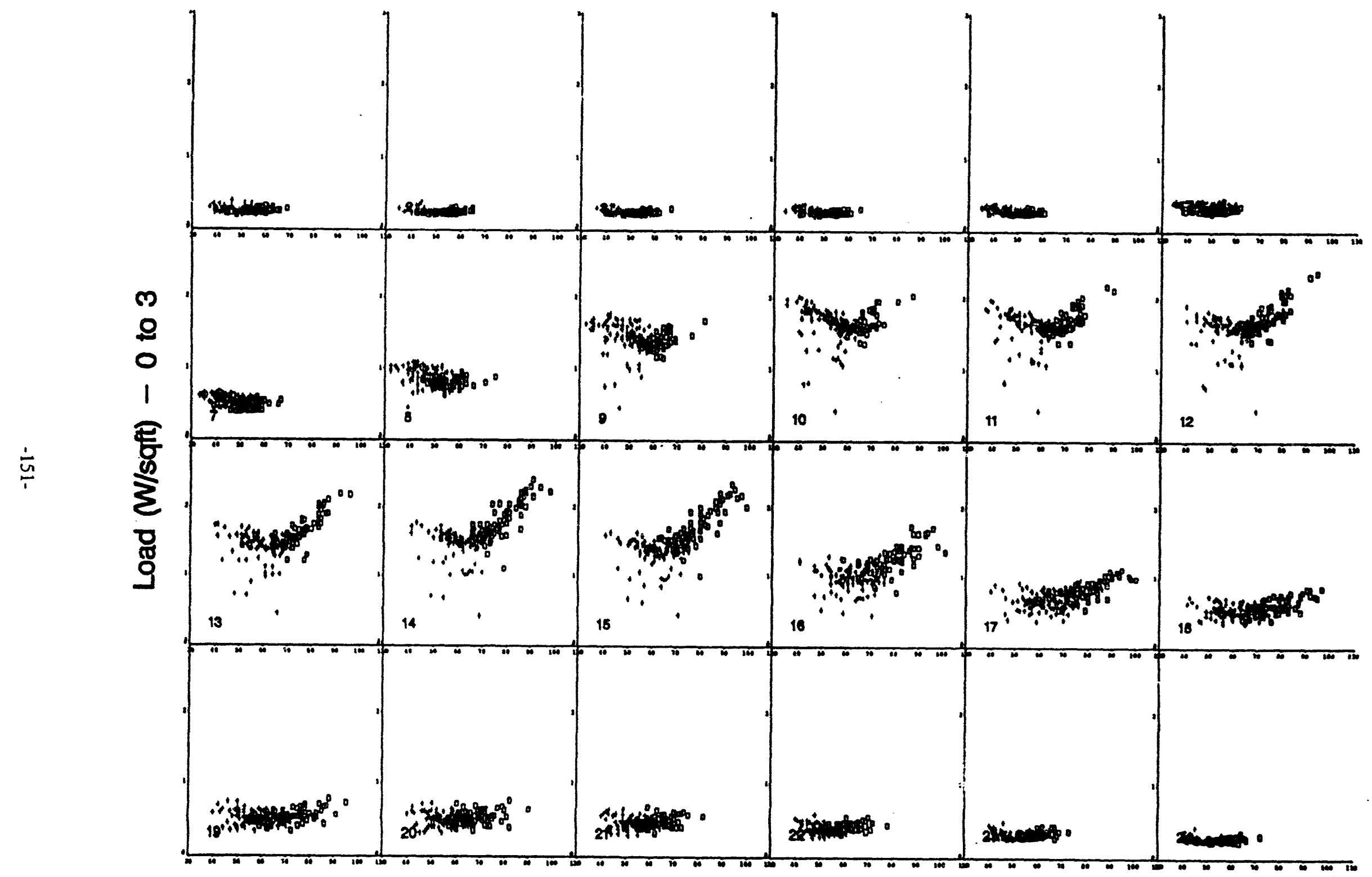

Outside Temperature $(\boldsymbol{F})-30$ to 110 
Figure 4-21a. School Reconciled Standard Day Annual End-Use LS - Coastal

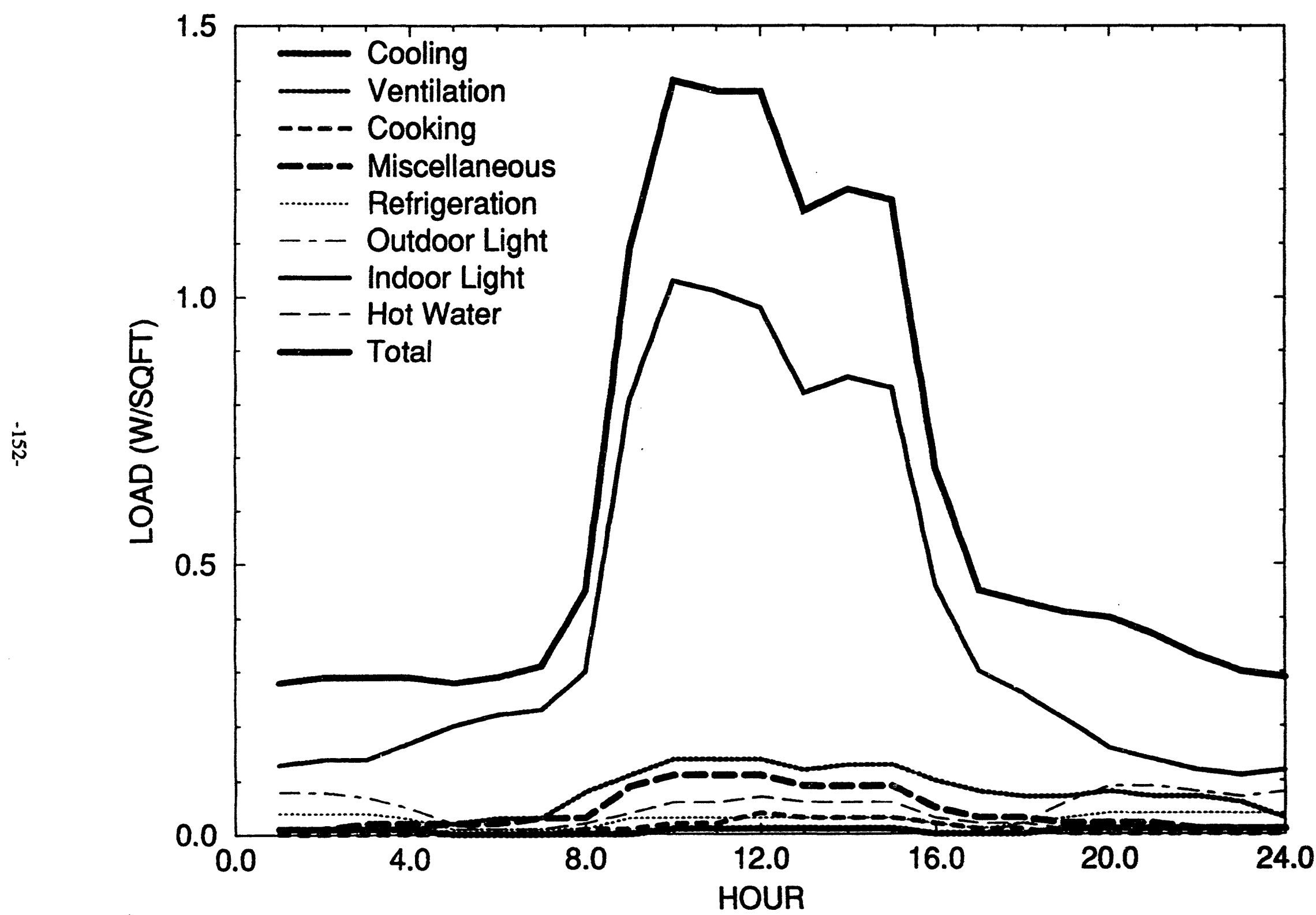


Figure 4-21b. School Reconciled Standard Day Annual End-Use LS - Inland

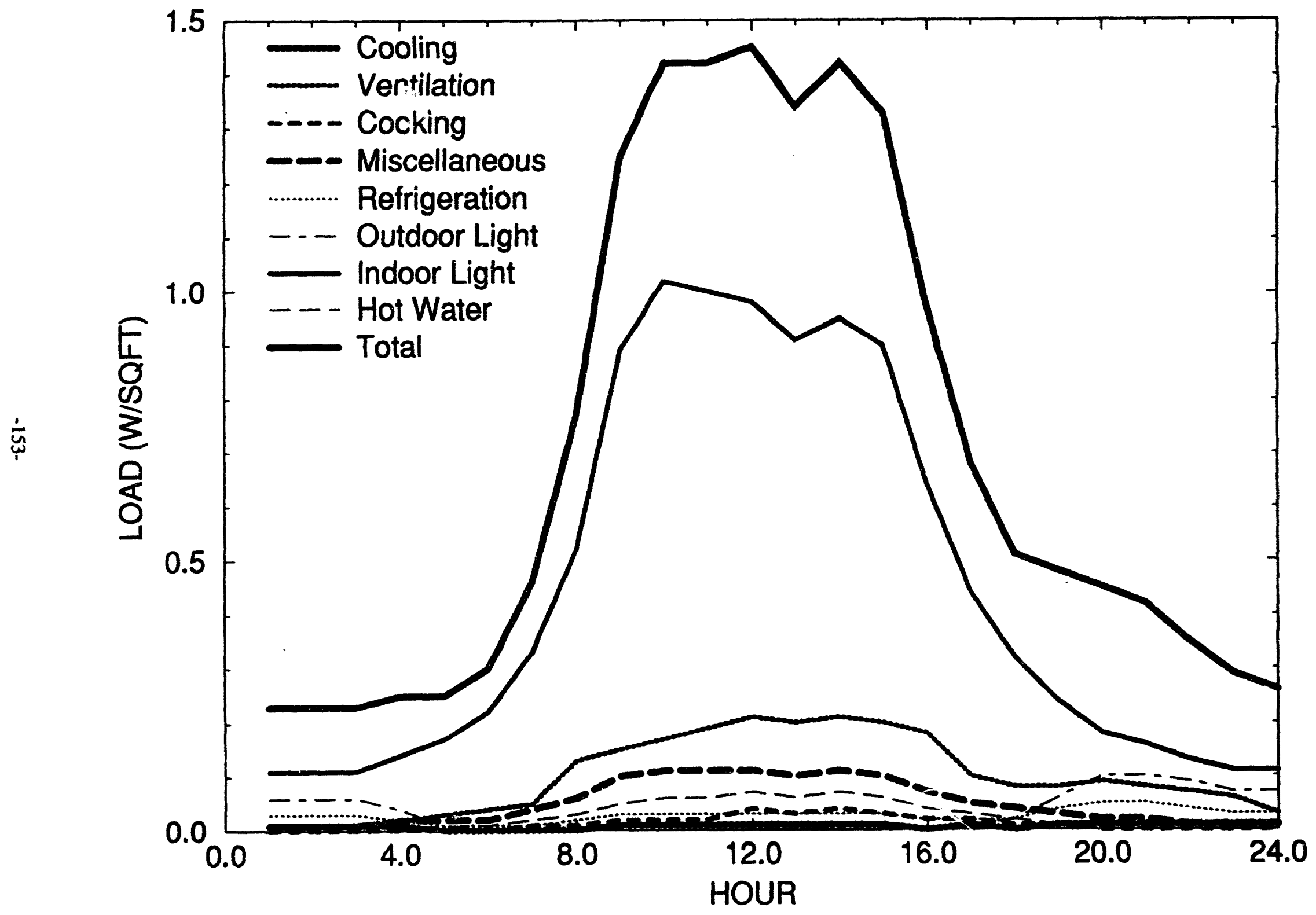


Figure 4-21c. School Reconciled Nonstandard Day Annual End-Use LS - Coastal

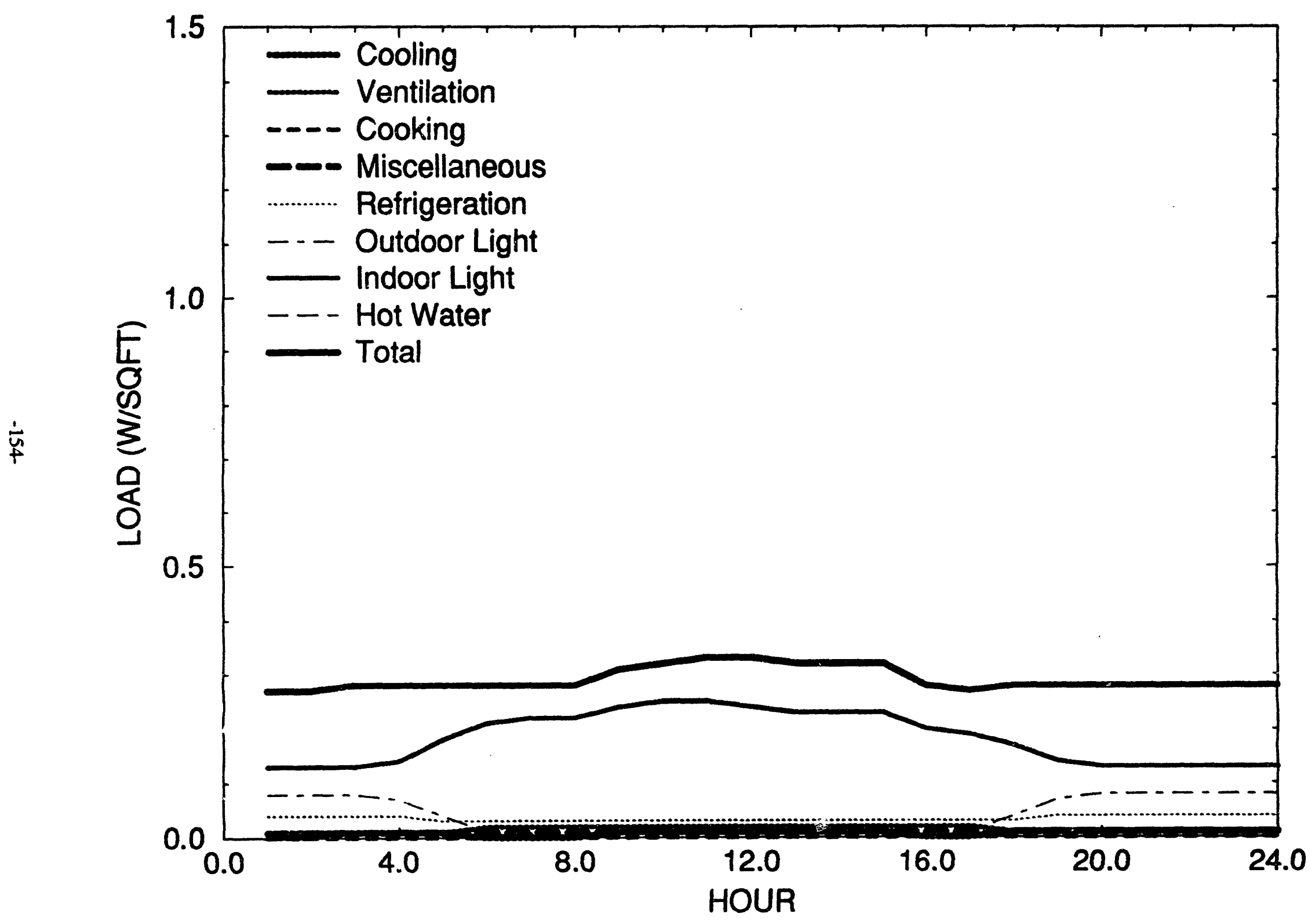


Figure 4-21d. School Reconciled Nonstandard Day Annual End-Use LS - Inland

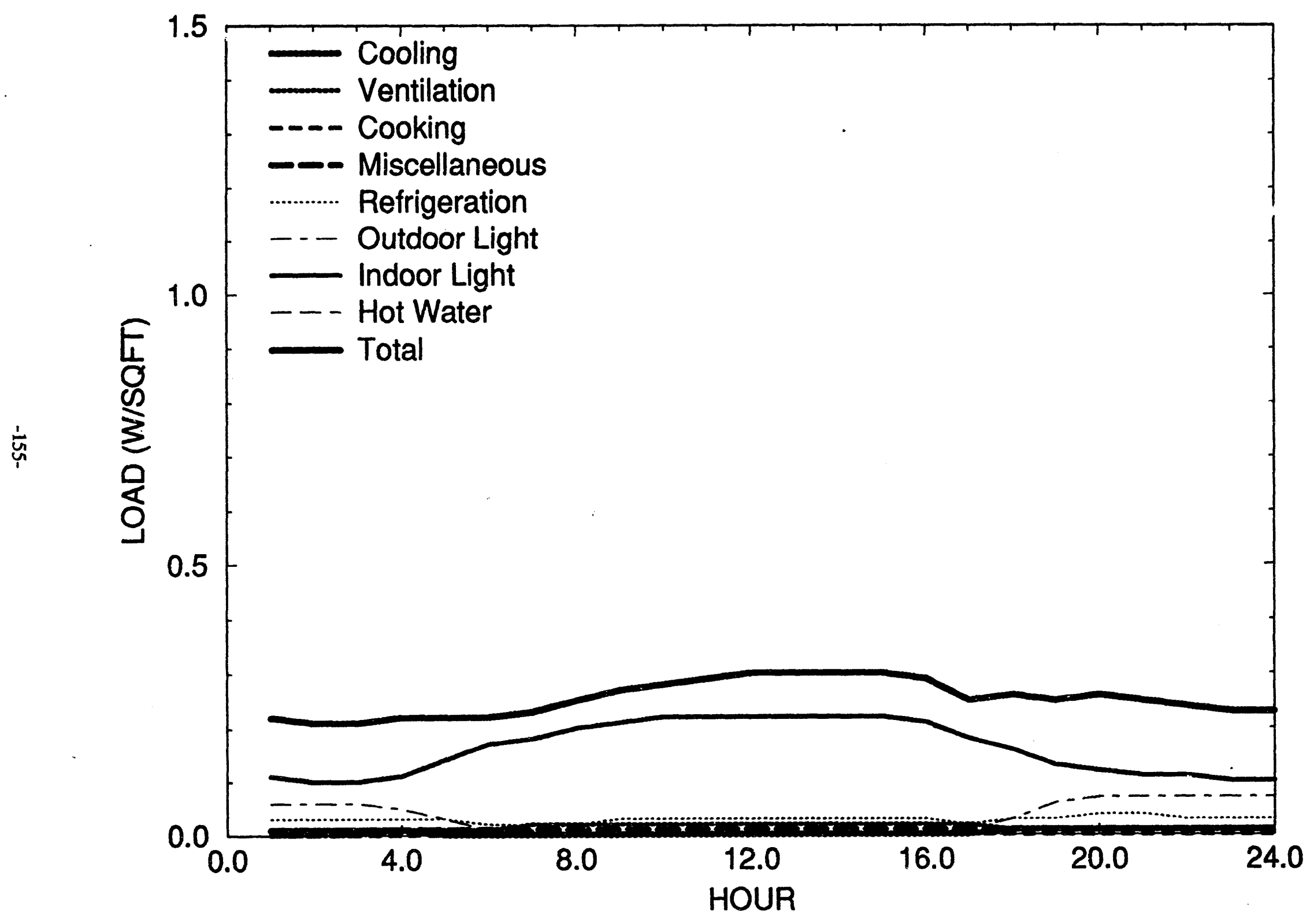




\section{College}

The college prototype is modeled with three buildings, which are classroom/lab/office, dormitory, and library. The mail survey data does not provide any information of the fraction of college buildings that are dormitories and libraries. We have reviewed available sources of information such as CBECS (EIA 1989) for this data. The rather scarce data sources suggest that about 20 percent of college campus floor area consists of dormitories and 5 percent consists of libraries. The remaining 75 percent is made up of classrooms, labs and offices.

\section{Classrooms/Labs/Offices}

The Classrooms/Labs/Offices are modeled with two conditioned zones and an unconditioned basement zone as a four story concrete building with $205,600 \mathrm{ft}^{2}$ of floor area. The bottom floor consists of $110,000 \mathrm{ft}^{2}$ of classrooms and lecture halls served by a Single Zone Reheat system. Beneath the bottom floor is an unconditioned basement space. The upper floors contain onehundred-ninety-two $500 \mathrm{ft}^{2}$ individual offices served by a Reheat Fan system. Both systems are supplied with heating and cooling by a central gas boiler and a hermetic centrifugal chiller with cooling tower.

Major characteristics of the prototypical building are summarized in Table 4-30a and Table 430b. The onsite survey includes only one sample for college, therefore mail survey data was used for the floor area. The mail survey does not provide numbers on lighting, equipment, and occupancy loads, so onsite data was used for consistency. The vintage and technology options are summarized in Table 4-31.

\section{Dormitory}

The dormitory building is modeled with four zones as a five story concrete building with 52,000 $\mathrm{ft}^{2}$ of floor area. The bottom floor consists of a $2,600 \mathrm{ft}^{2}$ kitchen, and a 7,000 $\mathrm{ft}^{2}$ dining area, and is conditioned with a Single Zone Reheat system. The fifty $500 \mathrm{ft}^{2}$ rooms are on the upper floors with a common bath room and shower facilities, and are only heated with a Two Pipe Fan Coil system. Corridors on the upper floors represent $2,400 \mathrm{ft}^{2}$ and are conditioned with a Single Zone Reheat system. Both heating and hot water energy source is a gas boiler.

Major characteristics of the prototypical building are summarized in Table 4-32a and Table 432b. There was no onsite or mail survey data available for the dorm prototype. The vintage and technology options are summarized in Table 4-33.

\section{Library}

The library building is modeled as a single story concrete building with $40,000 \mathrm{ft}^{2}$ of floor area divided into four equally sized zones. The building is heated and cooled with a Reheat Fan system. The heating energy source is $s$ gas boiler and the cooling energy s ource is a hermetic 
centrifugal chiller. There is no hot water.

Major characteristics of the prototypical building are summarized in Table 4-34. There was no onsite or mail survey data available for the library prototype. The vintage and technology options are summarized in Table 4-35.

\section{College}

Table 4-36 shows the DOE-2 simulation and EDA-reconciled end-use EUI summaries for the College category of the coastal and inland climate regions. DOE-2 simulated average standard day end-use LSs for the coastal and inland climate zones are shown in Figure 4-22. Scatter plots of hourly whole-building EUIs against drybulb temperature for annual standard days of coastal and inland climates are shown in Figure 4-23. Both sets of plots depict no correlation between whole-building-load and dry bulb temperature. EDA reconciled average standard and nonstandard day end-use LSs for coastal and inland climates are shown in Figure 4-24. The LSs indicate that indoor lighting constitutes the majority of the load, and ventilation, cooling, and miscellaneous equipment create a lesser demand, and cooking, refrigeration, and outdoor lighting demand a very small portion of electricity. Peak operation occurs on weekdays during 9 am to $6 \mathrm{pm}$.

Note: Reheat Fan (RHF)

Single Zone Reheat (SZRH)

Two Pipe Fan Coil (TPFC)

Variable Air Volume (VAV) 
Table 4-30a. Classroom/Lab/Office Building Prototype Characteristics

\begin{tabular}{|l|r|}
\hline Shell & \\
Floor Area (1000 $\mathrm{ft}^{2}$ ) & 205.6 \\
Number of Floors & 4 \\
Ceiling Insulation R-value & 5.8 \\
Wall Insulation R-value & 2.6 \\
Window shading coefficient & 0.6 \\
Window/wall ratio & 0.32 \\
Loads & \\
Refrigeration $\left(\mathrm{W}^{2} / \mathrm{ft}^{2}\right)$ & - \\
Cooking (W/ft & \\
Hot Water (Btu/hr/ft $\left.{ }^{2}\right)$ & - \\
Schedule & 1.2 \\
Standard Days & \\
Start & 5 \\
Stop & 5 \\
Non-Standard Days & 24 \\
Start & 2 \\
Stop & 5 \\
System & 24 \\
Supply Air (cfm/ $\mathrm{ft}^{2}$ ) & \\
Economizer Limit Temperature & 0.7 \\
Thermostat Type & $65^{\circ} \mathrm{F}$ \\
Outside Air Control & Proportional \\
Outside Air / Person (CFM) & Temperature \\
Heat Setpoint & 15 \\
Cool Setpoint & $72^{\circ} \mathrm{F}$ \\
Plant & $76^{\circ} \mathrm{F}$ \\
Heating & \\
Cooling & Gas Boiler \\
Hot Water & Gas Boiler \\
\hline
\end{tabular}

Table 4-30b. Classroom/Lab/Office Building Prototype Zone Description

\begin{tabular}{|l|rr|}
\hline & Office & Classroom \\
\hline Floor Area (\% total) & 47 & 53 \\
Occupancy $\left(\mathrm{ft}^{2} /\right.$ person) & 250 & 81 \\
Indoor Lighting (W/ft $\left.{ }^{2}\right)$ & 1.0 & 1.5 \\
Equipment $\left(\mathrm{W} / \mathrm{ft}^{2}\right)$ & 0.6 & - \\
System Tyəe & RHF & SZRH \\
\hline
\end{tabular}


Table 4-31. Classroom/Lab/Office Building Vintage Characteristics

\begin{tabular}{|l|rr|}
\hline Technology & \multicolumn{1}{|c|}{ Pre-1978 } & \multicolumn{1}{c|}{ Post-1978 } \\
\hline Ceiling Insulation R-value & 5.8 & 9.0 \\
Wall Insulation R-value & 2.6 & 4.0 \\
Indoor Lighting (W/ $/ \mathrm{ft}^{2}$ ) & 1.3 & 1.3 \\
Equipment (W/ft ${ }^{2}$ ) & 0.3 & 0.3 \\
Thermostat Type & Proportional & Reverse Action \\
Outside Air Control & Fixed & Temperature \\
System Type & & \\
Office & RHF & VAV \\
Class & SZRH & VAV \\
\hline
\end{tabular}


Table 4-32a. Dormitory Building Prototype Characteristics

\begin{tabular}{|l|r|}
\hline Shell & \\
Floor Area (1000 $\mathrm{ft}^{2}$ ) & 52.0 \\
Number of Floors & 5 \\
Ceiling Insulation R-value & 5.8 \\
Wall Insulation R-value & 2.6 \\
Window shading coefficient & 0.6 \\
Window/wall ratio & 0.2 \\
Loads & \\
Refrigeration (W/ft ${ }^{2}$ ) & 0.3 \\
Schedule & \\
Standard Days & 5 \\
Start & 5 \\
Stop & 24 \\
Non-Standard Days & 2 \\
Start & 5 \\
Stop & 24 \\
System & \\
Supply Air (cfm/ $\mathrm{ft}^{2}$ ) & 0.7 \\
Economizer Limit Temperature & $65^{\circ} \mathrm{F}$ \\
Thermostat Type & Proportional \\
Outside Air Control & Temperature \\
Heat Setpoint & $72^{\circ} \mathrm{F}$ \\
Cool Setpoint & $85^{\circ} \mathrm{F}$ \\
Plant & \\
Heating & Gas Boiler \\
Cooling & - \\
Hot Water & Gas Boiler \\
\hline
\end{tabular}

Table 4-32b. Dormitory Building Prototype Zone Description

\begin{tabular}{|l|rrrr|}
\hline & Corridor & Kitchen & Dining & Room \\
\hline Floor Area (\% total) & 5 & 5 & 13 & 77 \\
Occupancy $\left(\mathrm{ft}^{2} /\right.$ person) & 240 & 260 & 17.5 & 100 \\
Outside Air (ACH) & - & 2.9 & - & - \\
Outside Air / Person (CFM) & 15 & - & 15 & 15 \\
Indoor Lighting (W/ $\left./ \mathrm{ft}^{2}\right)$ & 1.5 & 2.0 & 1.5 & 1.0 \\
Equipment $\left(\mathrm{W} / \mathrm{ft}^{2}\right.$ ) & - & 3.0 & - & 0.6 \\
Cooking $\left(\mathrm{W} / \mathrm{ft}^{2}\right.$ ) & - & 5.0 & - & - \\
Hot Water $\left(\mathrm{Btu} / \mathrm{hr}^{\prime} / \mathrm{ft}^{2}\right.$ ) & - & 50 & - & - \\
System Type & TPFC & SZRH & SZRH & TPFC \\
\hline
\end{tabular}


Table 4-33. Dormitory Building Vintage Characteristics

\begin{tabular}{|l|rr|}
\hline Technology & Pre-1978 & \multicolumn{1}{c|}{ Post-1978 } \\
\hline Ceiling Insulation R-value & 5.8 & 9.0 \\
Wall Insulation R-value & 2.6 & 4.0 \\
Indoor Lighting (W/ $\left./ \mathrm{ft}^{2}\right)$ & 1.1 & 1.1 \\
${\text { Equipment }\left(W / \mathrm{ft}^{2}\right)}^{\text {Thermostat Type }}$ & 0.6 & 0.6 \\
Outside Air Control & Proportional & Reverse Action \\
System Type & Fixed & Temperature \\
Room/Corridor & & \\
Kitchen/Dining & TPFC & VAV \\
\hline
\end{tabular}


Table 4-34. Library Building Prototype Characteristics

\begin{tabular}{|c|c|}
\hline Shell & \\
\hline Floor Area $\left(1000 \mathrm{ft}^{2}\right)$ & 40.0 \\
\hline Number of Floors & 1 \\
\hline Ceiling Insulation $\mathbf{R}$-value & 4.9 \\
\hline Wall Insulation R-value & 1.0 \\
\hline Window shading coefficient & 0.6 \\
\hline Window/wall ratio & 0.1 \\
\hline \multicolumn{2}{|l|}{ Loads } \\
\hline Occupancy ( $\mathrm{ft}^{2} /$ person) & 333 \\
\hline Indoor Lighting $\left(\mathrm{W} / \mathrm{ft}^{2}\right)$ & 1.7 \\
\hline Equipment $\left(\mathrm{W} / \mathrm{ft}^{2}\right)$ & 0.5 \\
\hline Refrigeration $\left(\mathrm{W} / \mathrm{ft}^{2}\right)$ & \\
\hline Cooking $\left(\mathrm{W} / \mathrm{ft}^{2}\right)$ & - \\
\hline Hot Water $\left(\mathrm{Btu} / \mathrm{hr} / \mathrm{ft}^{2}\right)$ & - \\
\hline \multicolumn{2}{|l|}{ Schedule } \\
\hline Standard Days & 5 \\
\hline Start & 5 \\
\hline Stop & 24 \\
\hline Non-Standard Days & 2 \\
\hline Start & 5 \\
\hline Strn & 24 \\
\hline \multicolumn{2}{|l|}{ System } \\
\hline System Type & RHF \\
\hline Supply Air $\left(\mathrm{cfm} / \mathrm{ft}^{2}\right)$ & 0.7 \\
\hline Economizer Limit Temperature & $65^{\circ} \mathrm{F}$ \\
\hline Thermostat Type & Proportional \\
\hline Outside Air Control & Temperature \\
\hline Outside Air / Person (CFM) & 15 \\
\hline Heat Setpoint & $72^{\circ} \mathrm{F}$ \\
\hline Cool Setpoint & $78^{\circ} \mathrm{F}$ \\
\hline \multicolumn{2}{|l|}{ Plant } \\
\hline Heating & Gas Boiler \\
\hline Cooling & Hermetic Centrifugal Chiller \\
\hline Hot Water & \\
\hline
\end{tabular}

Table 4-35. Library Building Vintage Characteristics

\begin{tabular}{|l|rr|}
\hline Technology & Pre-1978 & \multicolumn{1}{|c|}{ Post-1978 } \\
\hline Ceiling Insulation R-value & 4.9 & 9.0 \\
Wall Insulation R-value & 1.0 & 4.0 \\
Indoor Lighting (W/ $\mathrm{ft}^{2}$ ) & 1.7 & 1.7 \\
Equipment $\left(W / \mathrm{ft}^{2}\right)$ & 0.5 & 0.5 \\
Thermostat Type & Proportional & Reverse Action \\
Outside Air Control & Fixed & Temperature \\
System Type & RHF & VAV \\
\hline
\end{tabular}


Table 4-36a. College Simulated and EDA-Reconciled EUIs-Coastal $\left(\mathrm{kWh} / \mathrm{rt}^{2} / \mathrm{yr}\right)$

\begin{tabular}{|c|c|c|c|c|c|c|c|c|c|c|}
\hline \multicolumn{7}{|c|}{ Non-HVAC End Uses } & \multicolumn{3}{|c|}{ HVAC } & \multirow[t]{2}{*}{ Total } \\
\hline $\begin{array}{c}\text { Indoor } \\
\text { Lighting } \\
\end{array}$ & $\begin{array}{r}\text { Outdoor } \\
\text { Lighting } \\
\end{array}$ & $\begin{array}{l}\text { Misc. } \\
\text { Equip. } \\
\end{array}$ & $\begin{array}{l}\text { Office } \\
\text { Equip. } \\
\end{array}$ & Refrig & Cooking & $\begin{array}{c}\text { Water } \\
\text { Heating }\end{array}$ & Heating & Fans & Cooling & \\
\hline \multicolumn{11}{|l|}{ Simulation } \\
\hline \multicolumn{11}{|c|}{ Conditioned (Weight $=0.52)$} \\
\hline 4.30 & 0.11 & 0.50 & 0.00 & 0.02 & 0.06 & 0.06 & 0.00 & 1.92 & 1.76 & 8.73 \\
\hline \multicolumn{11}{|c|}{ Unconditioned (Weight $=0.48$ ) } \\
\hline 4.30 & 0.11 & 0.50 & 0.00 & 0.02 & 0.06 & 0.06 & 0.00 & 0.00 & 0.00 & 5.05 \\
\hline \multicolumn{11}{|c|}{ Weighted Average } \\
\hline 4.30 & 0.11 & 0.50 & 0.00 & 0.02 & 0.06 & 0.06 & 0.00 & 1.00 & 0.92 & 6.97 \\
\hline \multicolumn{11}{|l|}{ Reconciled } \\
\hline 2.90 & 0.15 & 0.20 & 0.22 & 0.06 & 0.04 & 0.04 & 0.00 & 1.06 & 0.63 & 5.30 \\
\hline
\end{tabular}

Table 4-36b. College Simulated and EDA-Reconciled EUIs-Inland $\left(\mathrm{kWh} / \mathrm{ft}^{2} / \mathrm{yr}\right)$

\begin{tabular}{|c|c|c|c|c|c|c|c|c|c|c|}
\hline \multicolumn{7}{|c|}{ Non-HVAC End Uses } & \multicolumn{3}{|c|}{ HVAC } & \multirow[t]{2}{*}{ Total } \\
\hline $\begin{array}{c}\text { Indoor } \\
\text { Lighting }\end{array}$ & $\begin{array}{l}\text { Outdoor } \\
\text { Lighting }\end{array}$ & $\begin{array}{l}\text { Misc. } \\
\text { Equip. }\end{array}$ & $\begin{array}{l}\text { Office } \\
\text { Equip. }\end{array}$ & Refrig & Cooking & $\begin{array}{c}\text { Water } \\
\text { Heating }\end{array}$ & Heating & Fans & Cooling & \\
\hline \multicolumn{11}{|l|}{ Simulation } \\
\hline \multicolumn{11}{|c|}{ Conditioned (Weight $=0.95$ ) } \\
\hline 4.30 & 0.11 & 0.50 & 0.00 & 0.02 & 0.06 & 0.06 & 0.00 & 1.93 & 2.63 & 9.61 \\
\hline \multicolumn{11}{|c|}{ Unconditioned (Weight $=0.05$ ) } \\
\hline 4.30 & 0.11 & 0.50 & 0.00 & 0.02 & 0.06 & 0.06 & 0.00 & 0.00 & 0.00 & 5.05 \\
\hline \multicolumn{11}{|c|}{ Weighted Average } \\
\hline 4.30 & 0.11 & 0.50 & 0.00 & 0.02 & 0.06 & 0.06 & 0.00 & 1.83 & 2.50 & 9.38 \\
\hline \multicolumn{11}{|l|}{ Reconciled } \\
\hline 3.59 & 0.11 & 0.23 & 0.22 & 0.04 & 0.04 & 0.05 & 0.00 & 1.43 & 1.29 & .00 \\
\hline
\end{tabular}


Figure 4-22a. College Simulated Average Standard Day LS - Coastal

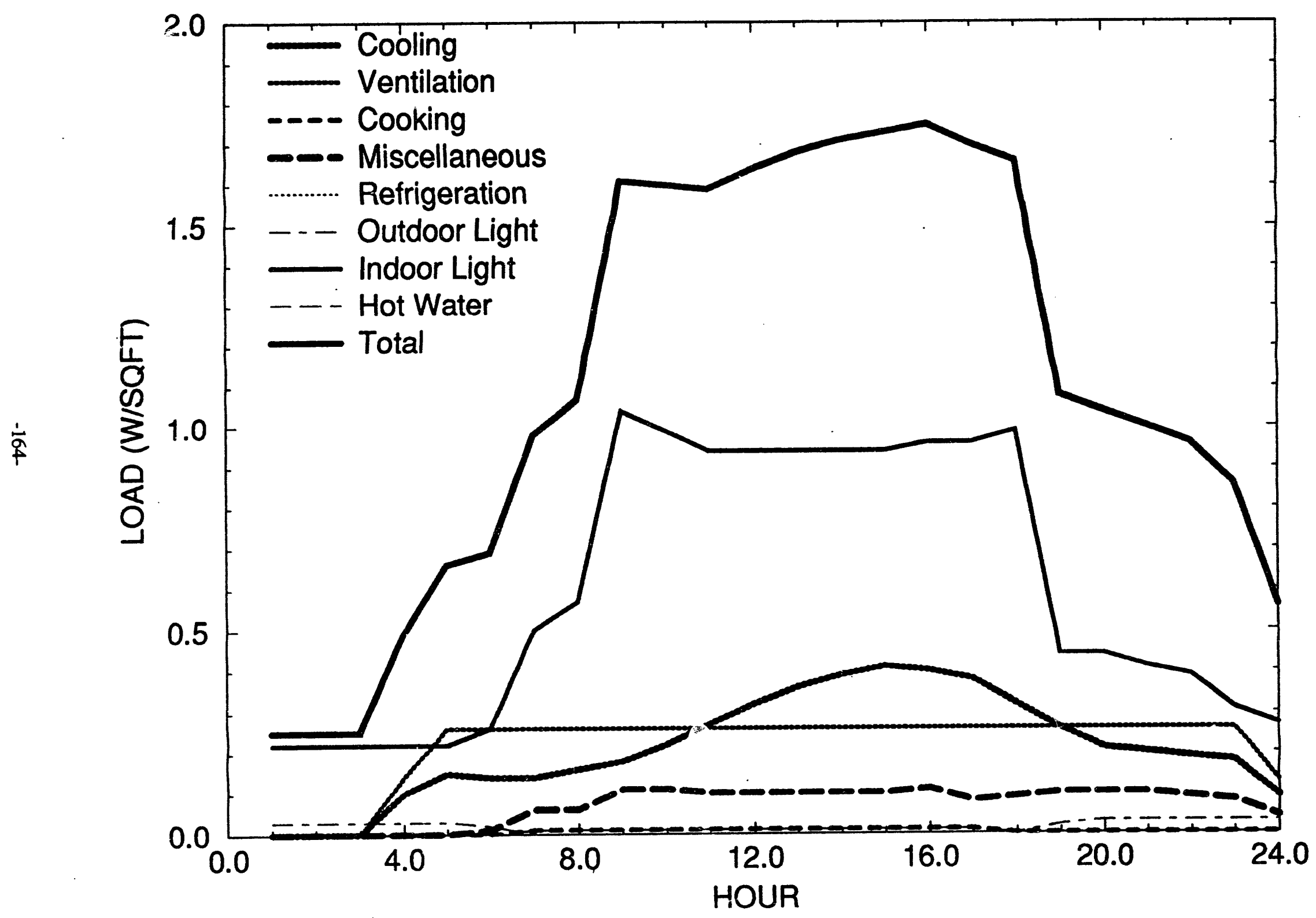


Figure 4-22b. College Simulated Average Standard Day LS - Inland

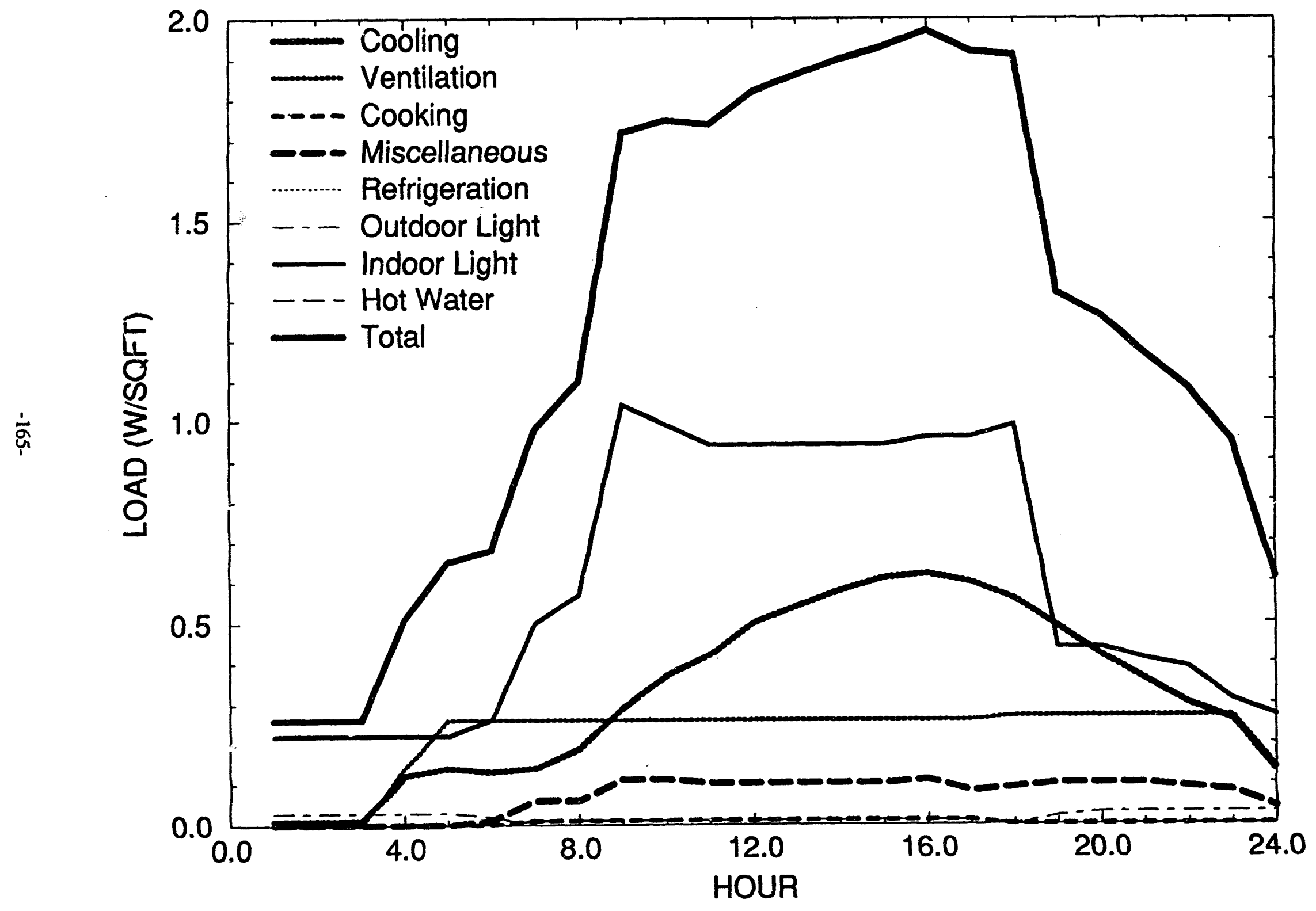


Figure 4-23a. College Whole Building Load vs. Drybulb Temperature for Standard Day - Coastal

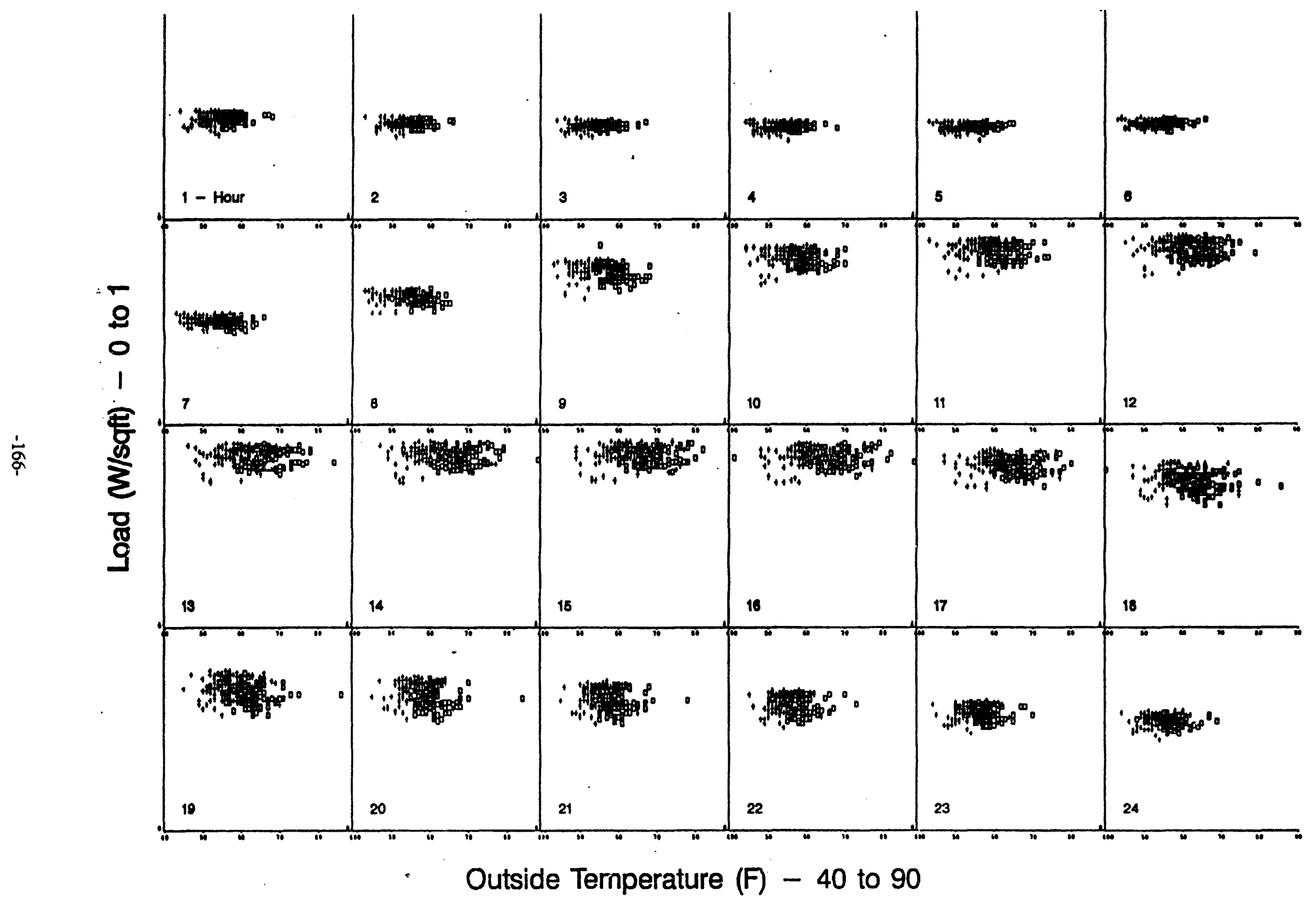


Figure 4-23b. College Whole Building Load vs. Drybulb Temperature for Standard Day - Inland

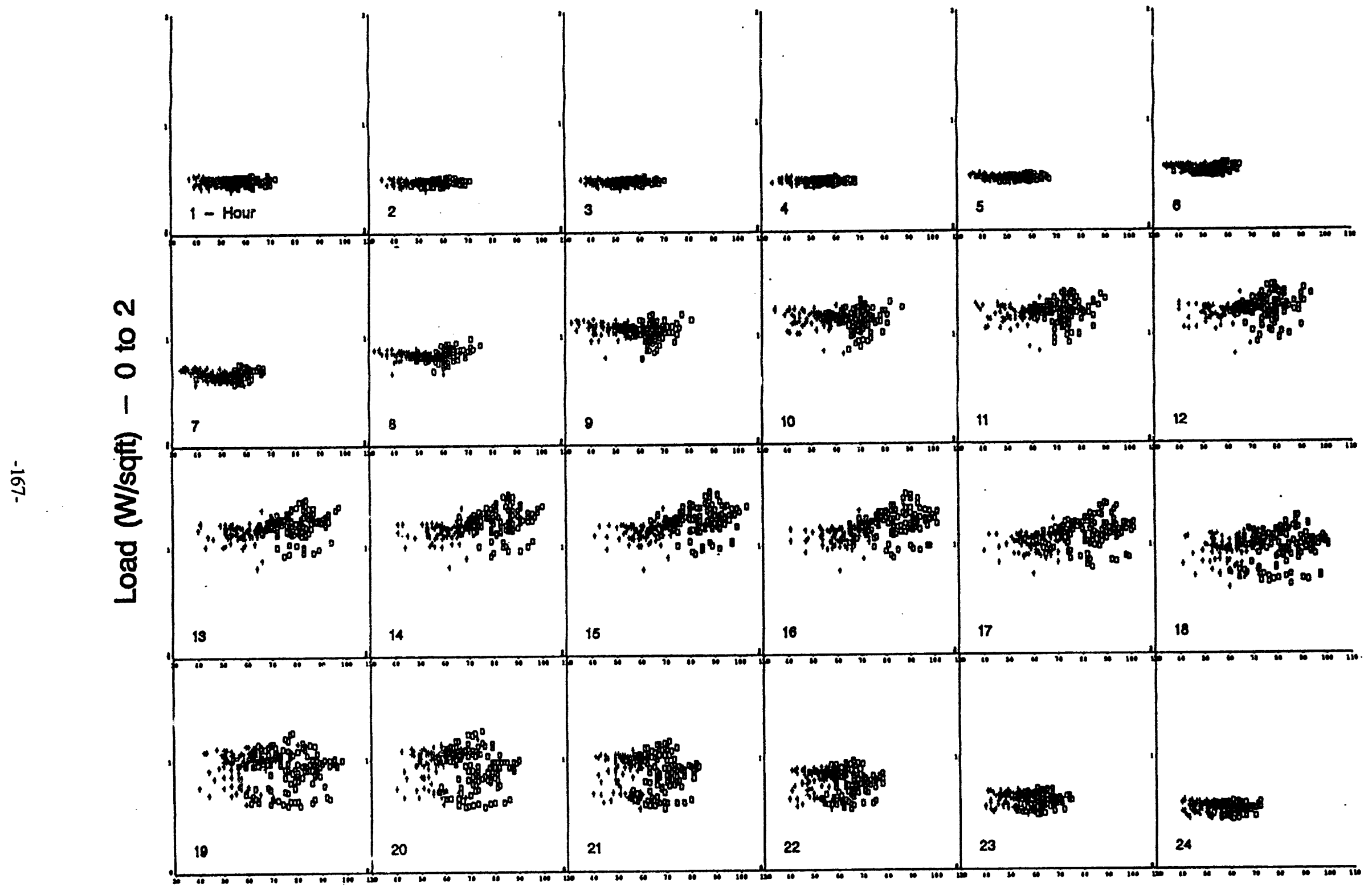

Outside Temperature $(F)-30$ to 110 
Figure 4-24a. College Reconciled Standard Day Annual End-Use LS - Coastal

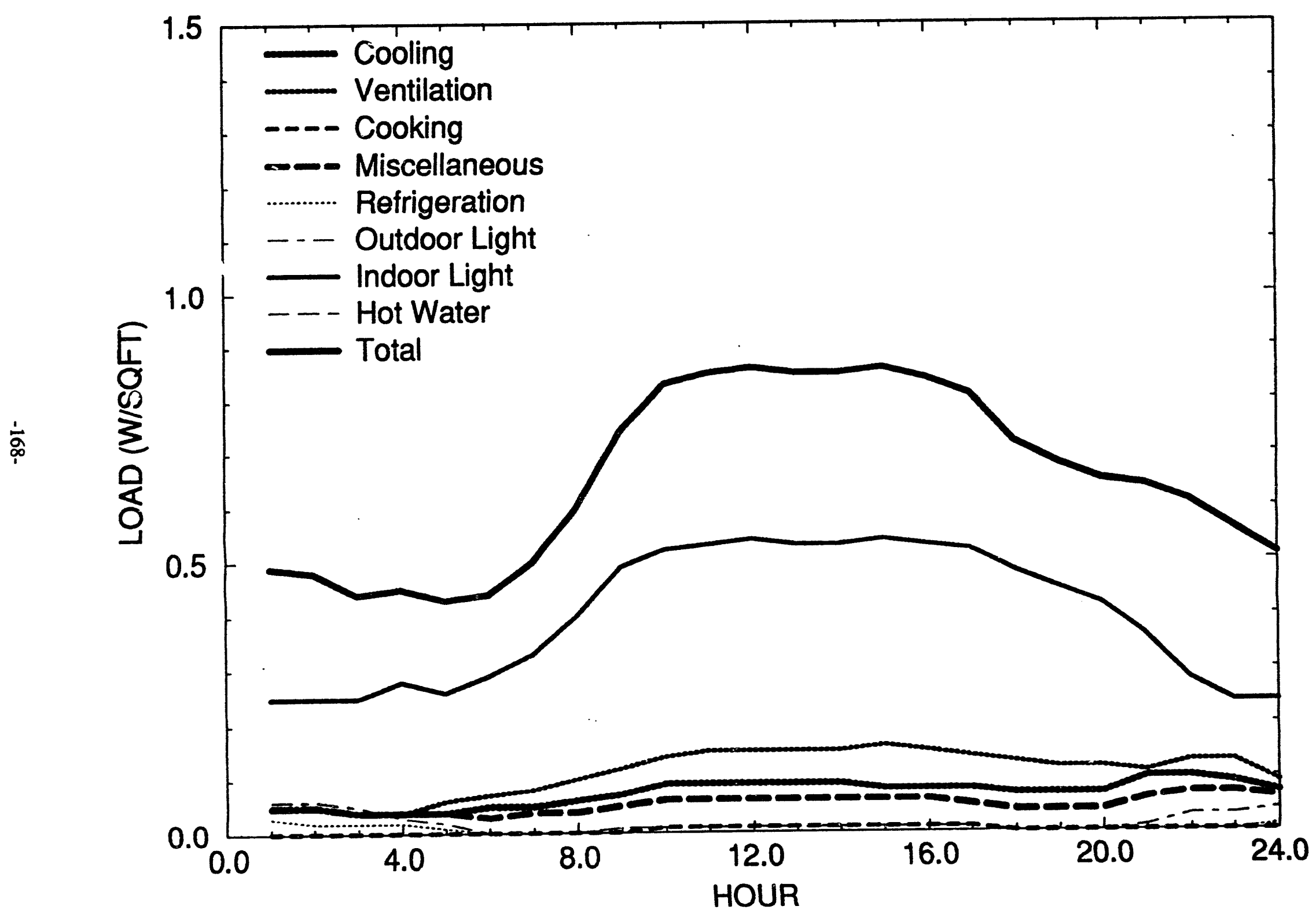




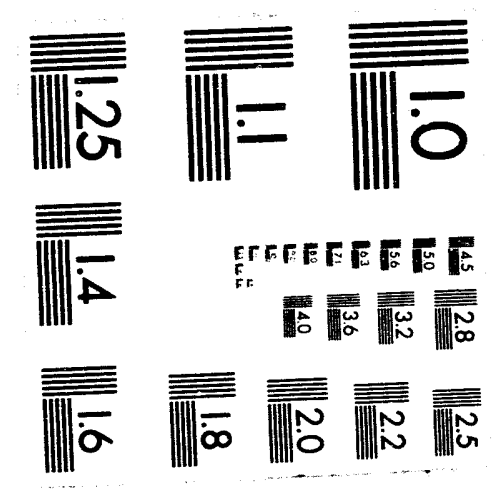



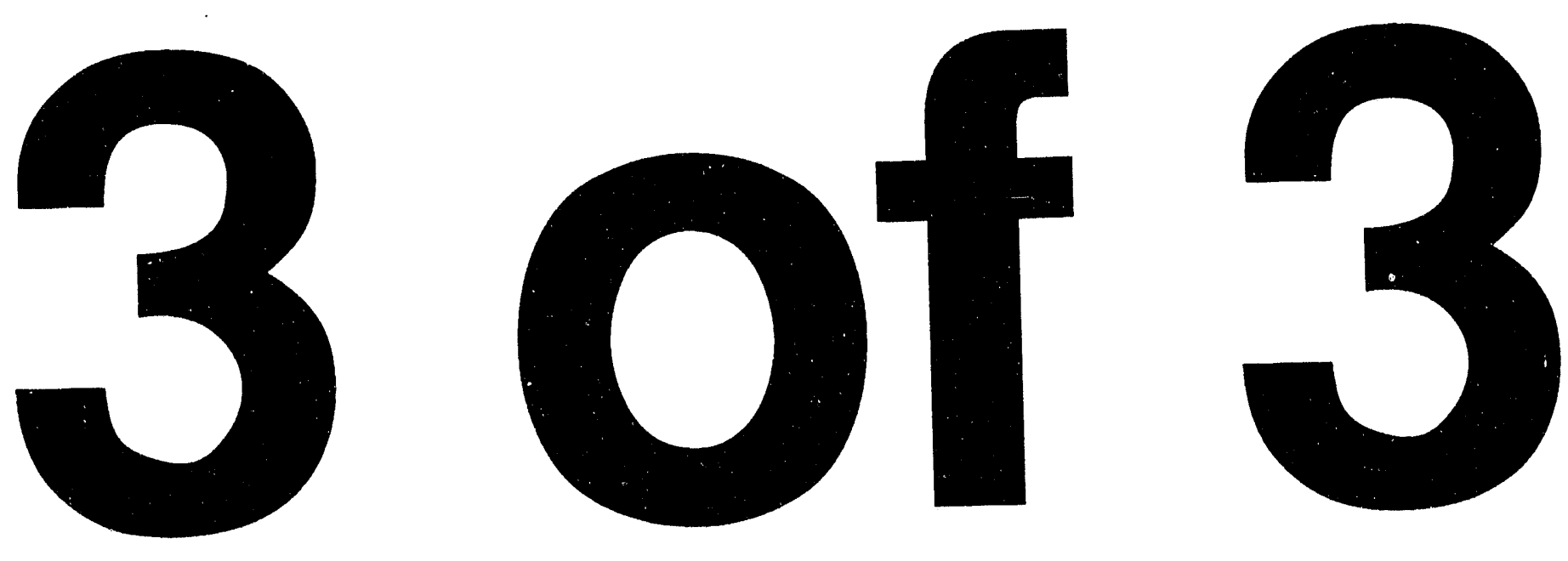
Figure 4-24b. College Reconciled Standard Day Annual End-Use LS - Inland

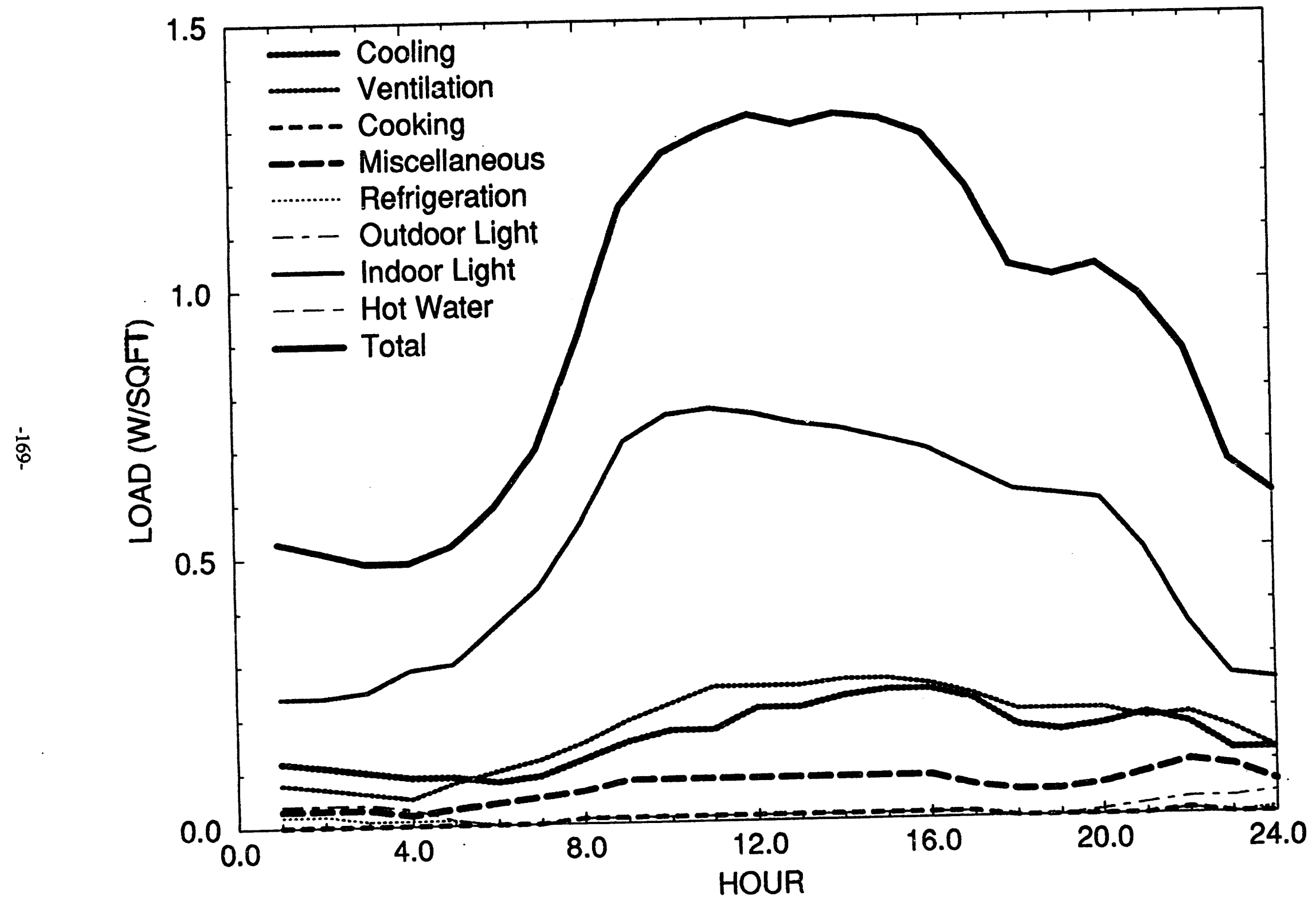


Figure 4-24c. Cr llege Reconciled Nonstandard Day Annual End-Use LS - Coastal

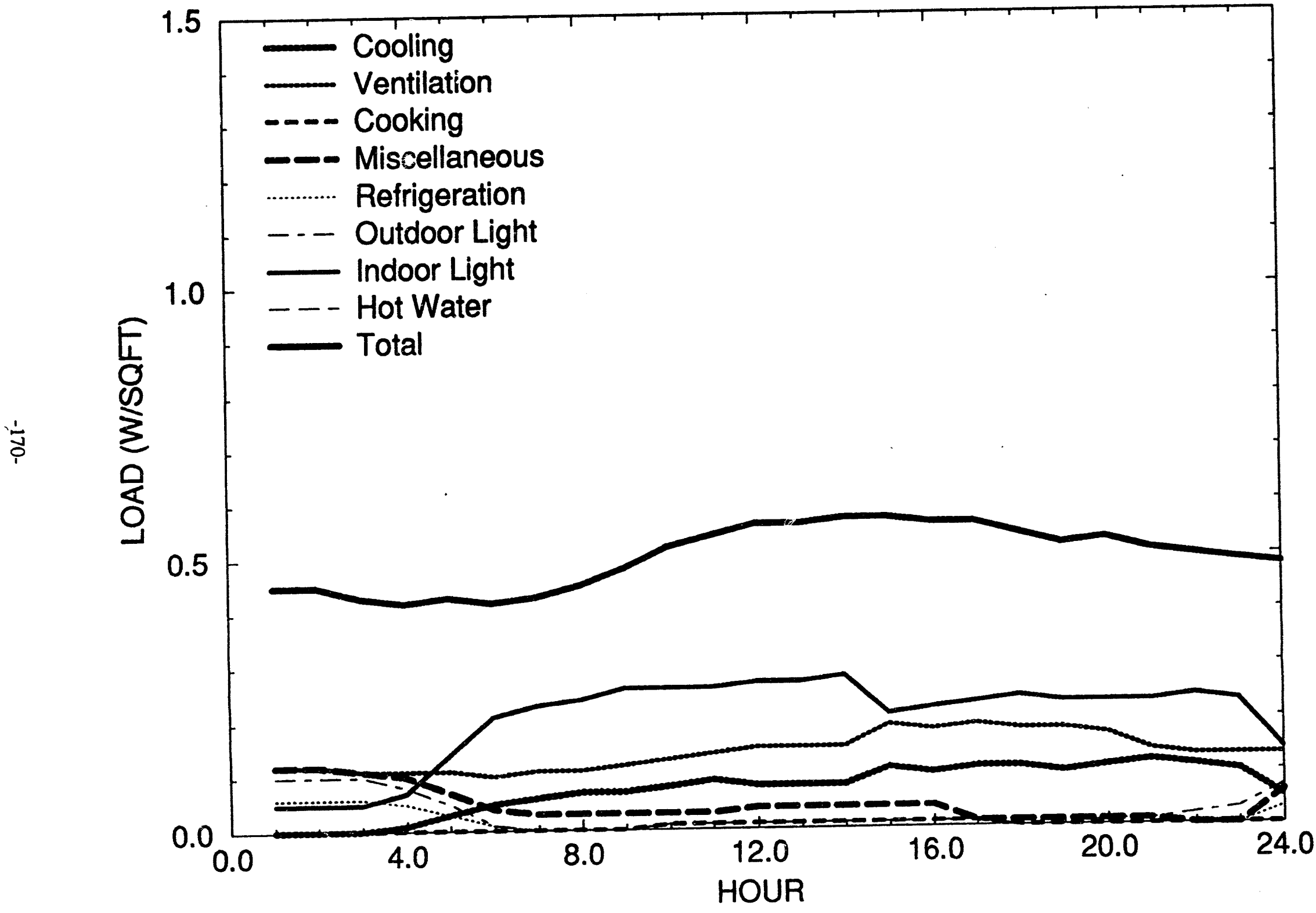


Figure 4-24d. College Reconciled Nonstandard Day Annual End-Use LS - Inland

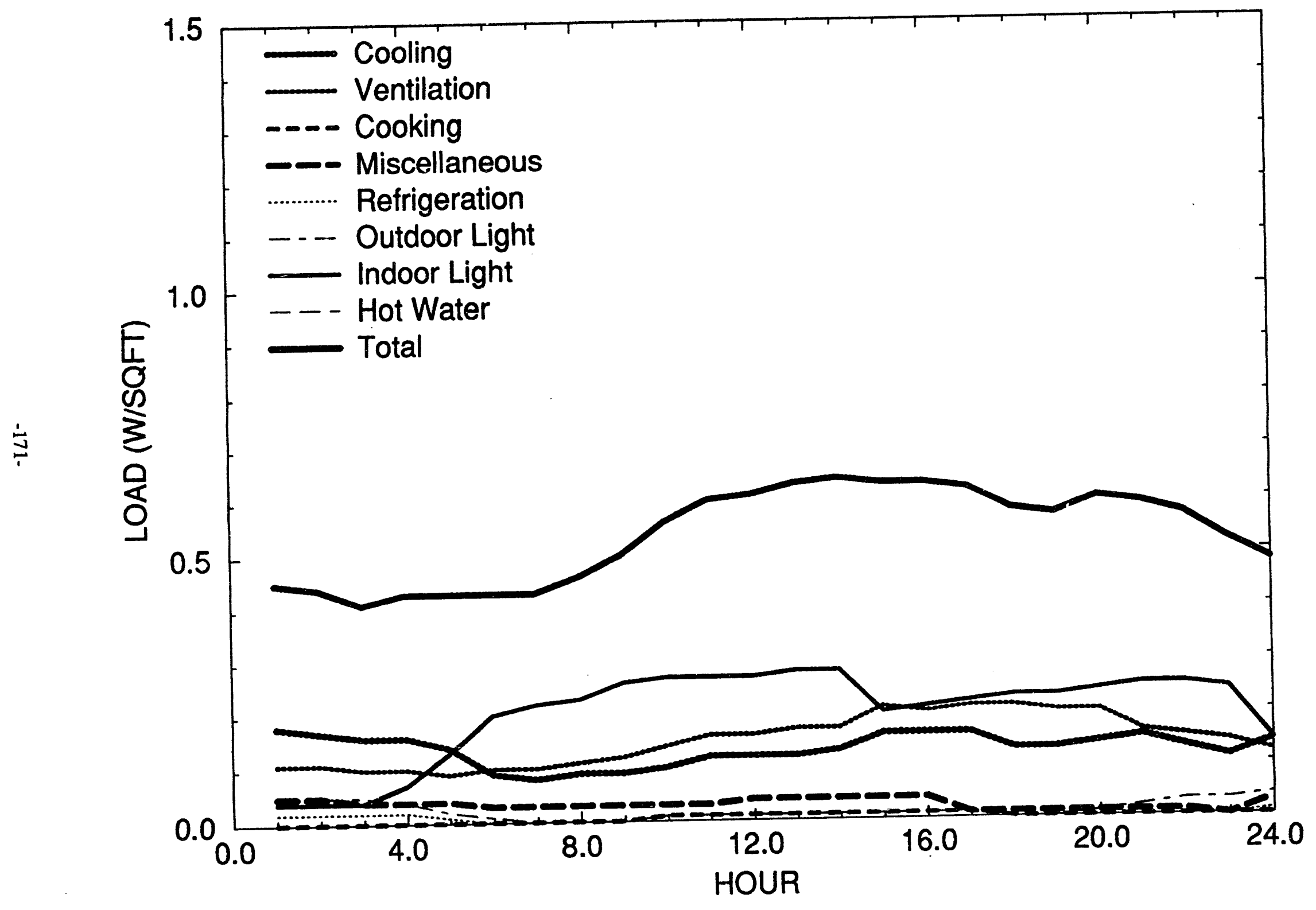




\section{Health}

The Health classification is made up of acute care hospitals and skilled nursing homes/residential care. Some studies also place medical offices in this category while others place medical offices in with conventional offices. The only difference between medical office and conventional office should be the equipment intensities and possibly some added ventilation.

\section{Hospital}

The hospital prototype is a $132,000 \mathrm{ft}^{2}$, seven story building modeled with five conditioned zones and an unconditioned basement zone. The conditioned zones are a 33,000 $\mathrm{ft}^{2}$ clinic, a $46,000 \mathrm{ft}^{2}$ core/public zone, a $20,000 \mathrm{ft}^{2}$ perimeter, a $6,600 \mathrm{ft}^{2}$ kitchen, and a $26,400 \mathrm{ft}^{2}$ hallway; conditioned with Dual Duct, Variable Air Volume, Four Pipe Fan Coil, Single Zone Reheat, and Four Pipe Fan Coil systems respectively. Hot water and heating are provided by gas boilers and cooling is provided by hermetic centrifugal chillers.

Major characteristics of the prototypical building are summarized in Table 4-37a and Table 437b. The vintage and technology options are summarized in Table 4-38.

\section{Nursing Home}

The nursing home prototype is a $38,400 \mathrm{ft}^{2}$, modeled with three zones as a single story building with 96 beds. The zones consists of forty-eight, $600 \mathrm{ft}^{2}$ rooms, a $1,900 \mathrm{ft}^{2}$ kitchen, and a 7,700 $\mathrm{ft}^{2}$ multipurpose room. The rooms have Packaged Air Conditioning units with gas heaters. The kitchen and multipurpose room are conditioned by a Packaged Single Zone system, where heating is provided by a gas furnace. Hot water for the entire building is provided by a gas furnace.

Major characteristics of the prototypical building are summarized in Table 4-39a and Table 439b. The vintage and technology options are summarized in Table 4-40.

\section{Health}

Table 4-41 shows the DOE-2 simulation and EDA-reconciled end-use EUI summaries for the Health category of the coastal and inland climate regions. DOE-2 simulated average standard day end-use LSs for the coastal and inland climate zones are shown in Figure 4-25. Scatter plots of hourly whole-building EUIs against drybulb temperature for annual standard days of coastal and inland climates are shown in Figure 4-26. Both sets of plots depict no correlation between whole-building-load and dry bulb temperature. EDA reconciled average standard and nonstandard day end-use LSs for coastal and inland climates are shown in Figure 4-27. These graphs show that indoor lighting, ventilation, cooling, and miscellaneous equinment are the major end-uses. 
Table 4-37a. Hospital Building Prototype Characteristics

\begin{tabular}{|l|r|}
\hline Shell & \\
Floor Area $\left(1000 \mathrm{ft}^{2}\right.$ ) & 132.0 \\
Number of Floors & 7 \\
Ceiling Insulation R-value & 11.4 \\
Wall Insulation R-value & 6.6 \\
Window shading coefficient & 0.65 \\
Window/wall ratio & 0.28 \\
Loads & \\
Refrigeration $\left(\mathrm{W} / \mathrm{ft}^{2}{ }^{2}\right.$ & \\
Hot Water (Btu/hr $\mathrm{ft}^{2}$ ) & 0.1 \\
Schedule & 7.0 \\
Standard Days & \\
Start & \\
Stop & 5 \\
Non-Standard Days & 1 \\
Start & 24 \\
Stop & 2 \\
System & 1 \\
Supply Air (cfm/ $\mathrm{ft}^{2}$ ) & 24 \\
Economizer Limit Temperature & \\
Thermostat Type & 0.7 \\
Outside Air Control & $65^{\circ} \mathrm{F}$ \\
Heat Setpoint & \\
Cool Setpoint & Proportional \\
Plant & Temperature \\
Heating & $73^{\circ} \mathrm{F}$ \\
Cooling & $73^{\circ} \mathrm{F}$ \\
Hot Water & \\
\hline
\end{tabular}

Table 4-37b. Hospital Building Prototype Zone Description

\begin{tabular}{|l|rrrrr|}
\hline & Clinic & Core & Perimeter & Kitchen & Hallway \\
\hline Floor Area (\% total) & 25 & 35 & 15 & 5 & 20 \\
Occupancy $\left(\mathrm{ft}^{2}\right.$ /person) & 289 & 289 & 150 & 321 & 578 \\
Outside Air (ACH) & - & - & - & 1.8 & - \\
Outside Air / Person (CFM) & 15 & 15 & 15 & - & 15 \\
Indoor Lighting (W/ft ${ }^{2}$ ) & 2.1 & 1.6 & 1.6 & 2.1 & 0.8 \\
Equipment $\left(\mathrm{W} / \mathrm{ft}^{2}\right.$ ) & 4.0 & 1.3 & 1.3 & 9.0 & \\
Cooking $\left(\mathrm{W} / \mathrm{ft}^{2}\right.$ ) & - & - & - & 4.0 & - \\
System Type & DD & VAV & FPFC & SZRH & VAV \\
\hline
\end{tabular}


Table 4-38. Hospital Building Vintage Characteristics

\begin{tabular}{|l|rr|}
\hline Technology & Pre-1978 & Post-1978 \\
\hline Ceiling Insulation R-value & 11.3 & 17.21 \\
Wall Insulation R-value & 6.5 & 6.6 \\
Indoor Lighting $\left(\mathrm{W} / \mathrm{ft}^{2}\right)$ & 1.6 & 1.1 \\
Equipment $\left(\mathrm{W} / \mathrm{ft}^{2}\right.$ ) & 2.1 & 2.1 \\
Thermostat Type & Proportional & Reverse Action \\
Outside Air Control & Fixed & Temperature \\
System Type & & $\cdot$ \\
Clinic & DD & DD \\
Core & RHF & VAV \\
Perimeter & FPFC & FPFC \\
Kitchen & SZRH & SZRH \\
Hallway & RHF & VAV \\
\hline
\end{tabular}

Note: Packaged Single Zone (PSZ)

Single Zone Reheat (SZRH)

Reheat Fan (RHF)

Dual Duct (DD)

Four Pipe Fan Coil (FPFC)

Variable Air Volume (VAV)

Packaged Variable Air Volume (PVAV)

Packaged Terminal Air Conditioner (PTAC) 
Table 4-39a. Nursing Home Building Prototype Characteristics

\begin{tabular}{|l|r|}
\hline Shell & \\
Floor Area (1000 $\mathrm{ft}^{2}$ ) & 38.4 \\
Number of Floors & 1 \\
Ceiling Insulation R-value & 21.8 \\
Wall Insulation R-value & 9.1 \\
Window shading coefficient & 0.51 \\
Window/wall ratio & 0.17 \\
Loads & \\
Refrigeration $\left(\mathrm{W} / \mathrm{ft}^{2}{ }^{2}\right.$ & 0.1 \\
Hot Water (Btu/hr/ft $\left.{ }^{2}\right)$ & 3.0 \\
Schedule & \\
Standard Days & 7 \\
Start & 1 \\
Stop & 24 \\
Non-Standard Days & - \\
Start & - \\
Stop & - \\
System & \\
COP & 2.3 \\
Supply Air (cfm/ $\mathrm{ft}^{2}$ ) & 0.7 \\
Economizer Limit Temperature & $65^{\circ} \mathrm{F}$ \\
Thermostat Type & Proportional \\
Outside Air Control & Temperature \\
Heat Setpoint & $70^{\circ} \mathrm{F}$ \\
Cool Setpoint & $75^{\circ} \mathrm{F}$ \\
Plant & \\
Heating & Gas Furnace \\
Cooling & Gas Furnace \\
Hot Water & \\
\hline
\end{tabular}

Table 4-39b. Nursing Home Building Prototype Zone Description

\begin{tabular}{|l|rrr|}
\hline & Multiple & Room & Kitchen \\
\hline Floor Area (\% total) & 20 & 75 & 5 \\
Occupancy $\left(\mathrm{ft}^{2} /\right.$ person) & 50 & 300 & 190 \\
Outside Air (ACH) & - & - & 3.9 \\
Outside Air / Person (CFM) & 15 & 15 & - \\
Indoor Lighting (W/f $\mathrm{ft}^{2}$ ) & 1.2 & 0.8 & 1.3 \\
Equipment $\left(\mathrm{W} / \mathrm{ft}^{2}\right)$ & - & 1.3 & 6.5 \\
Cooking $\left(\mathrm{W} / \mathrm{ft}^{2}\right.$ ) & - & - & 32.0 \\
System Type & PSZ & PTAC & PSZ \\
\hline
\end{tabular}


Table 4-40. Nursing Home Building Vintage Characteristics

\begin{tabular}{|l|rr|}
\hline Technology & Pre-1978 & Post-1978 \\
\hline Ceiling Insulation R-value & 21.8 & 21.8 \\
Wall Insulation R-value & 9.1 & 9.1 \\
Indoor Lighting (W/ $\mathrm{ft}^{2}$ ) & 0.9 & 0.9 \\
Equipment (W/ft ${ }^{2}$ ) & 1.3 & 1.3 \\
Thermostat Type & Proportional & Reverse Action \\
Outside Air Control & Fixed & Temperature \\
System Type & & \\
Multiple & PSZ & PVAV \\
Room & PTAC & PTAC \\
Kitchen & PSZ & PVAV \\
\hline
\end{tabular}


Table 4-41a. Health Simulated and EDA-Reconciled EUls-Coastal (kWh/ $\left.\mathrm{ft}^{2} / \mathrm{yr}\right)$

\begin{tabular}{|c|c|c|c|c|c|c|c|c|c|c|}
\hline \multicolumn{7}{|c|}{ Non-HVAC End Uses } & \multicolumn{3}{|c|}{ HVAC } & \multirow[t]{2}{*}{ Total } \\
\hline $\begin{array}{c}\text { Indoor } \\
\text { Lighting } \\
\end{array}$ & $\begin{array}{l}\text { Outdoor } \\
\text { Lighting }\end{array}$ & $\begin{array}{l}\text { Misc. } \\
\text { Equip. }\end{array}$ & $\begin{array}{l}\text { Office } \\
\text { Equip. } \\
\end{array}$ & Kefrig & Cooking & $\begin{array}{c}\text { Water } \\
\text { Heating } \\
\end{array}$ & Heating & Fans & Cooling & \\
\hline \multicolumn{11}{|l|}{ Simulation } \\
\hline \multicolumn{11}{|c|}{ Conditioned (Weight $=0.85$ ) } \\
\hline 12.57 & 0.43 & 9.22 & 0.00 & 0.29 & 0.19 & 0.01 & 0.00 & 1.92 & 3.62 & 28.25 \\
\hline \multicolumn{11}{|c|}{ Unconditioned (Weight $=0.15$ ) } \\
\hline 12.57 & 0.43 & 9.22 & 0.00 & 0.29 & 0.19 & 0.01 & 0.00 & 0.00 & 0.00 & 22.71 \\
\hline \multicolumn{11}{|c|}{ Weighted Average } \\
\hline 12.57 & 0.43 & 9.22 & 0.00 & 0.29 & 0.19 & 0.01 & 0.00 & 1.65 & 3.11 & 27.47 \\
\hline \multicolumn{11}{|l|}{ Reconciled } \\
\hline 11.15 & 0.36 & 7.28 & 0.90 & 0.26 & 0.17 & 0.01 & 0.00 & 2.02 & $\mathbf{3 . 3 4}$ & 25.49 \\
\hline
\end{tabular}

Table 4-41b. Health Simulated and EDA-Reconciled EUIs-Inland $\left(\mathrm{kWh} / \mathrm{ft}^{2} / \mathrm{yr}\right)$

\begin{tabular}{|c|c|c|c|c|c|c|c|c|c|c|}
\hline \multicolumn{7}{|c|}{ Non-HVAC End Uses } & \multicolumn{3}{|c|}{ HVAC } & \multirow[t]{2}{*}{ Total } \\
\hline $\begin{array}{c}\text { Indoor } \\
\text { Lighting }\end{array}$ & $\begin{array}{l}\text { Outdoor } \\
\text { Lighting }\end{array}$ & $\begin{array}{l}\text { Misc. } \\
\text { Equip. }\end{array}$ & $\begin{array}{l}\text { Office } \\
\text { Equip. }\end{array}$ & Refrig & Cooking & $\begin{array}{c}\text { Water } \\
\text { Heating }\end{array}$ & Heating & Fans & Cooling & \\
\hline \multicolumn{11}{|l|}{ Simulation } \\
\hline \multicolumn{11}{|c|}{ Conditioned (Weight $=0.78$ ) } \\
\hline 12.98 & 0.44 & 9.61 & 0.00 & 0.28 & 0.19 & 0.01 & 0.00 & 2.15 & 4.91 & 30.57 \\
\hline \multicolumn{11}{|c|}{ Unconditioned (Weight $=0.22$ ) } \\
\hline 12.98 & 0.44 & 9.61 & 0.00 & 0.29 & 0.19 & 0.01 & 0.00 & 0.00 & 0.00 & 23.51 \\
\hline \multicolumn{11}{|c|}{ Weighted Average } \\
\hline 12.98 & 0.44 & 9.61 & 0.00 & 0.29 & 0.19 & 0.01 & 0.00 & 1.68 & 3.83 & 29.02 \\
\hline \multicolumn{11}{|l|}{ Reconciled } \\
\hline 10.98 & 0.36 & 7.23 & 0.90 & 0.24 & 0.16 & 0.01 & 0.00 & 2.49 & 4.74 & 27.11 \\
\hline
\end{tabular}


Figure 4-25a. Health Simulated Average Standard Day LS - Coastal

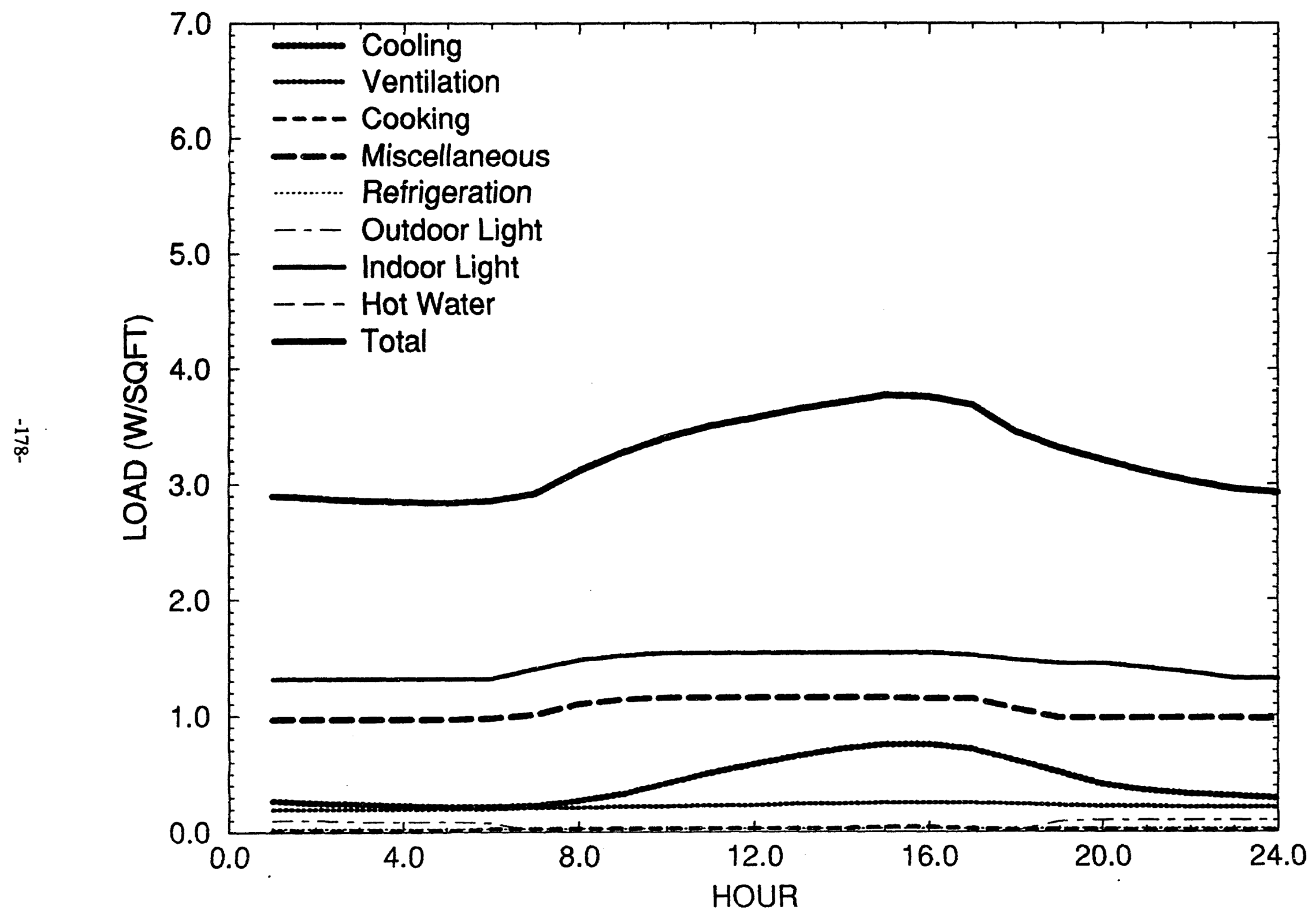


Figure 4-25b. Health Simulated Average Standard Day LS - Inland

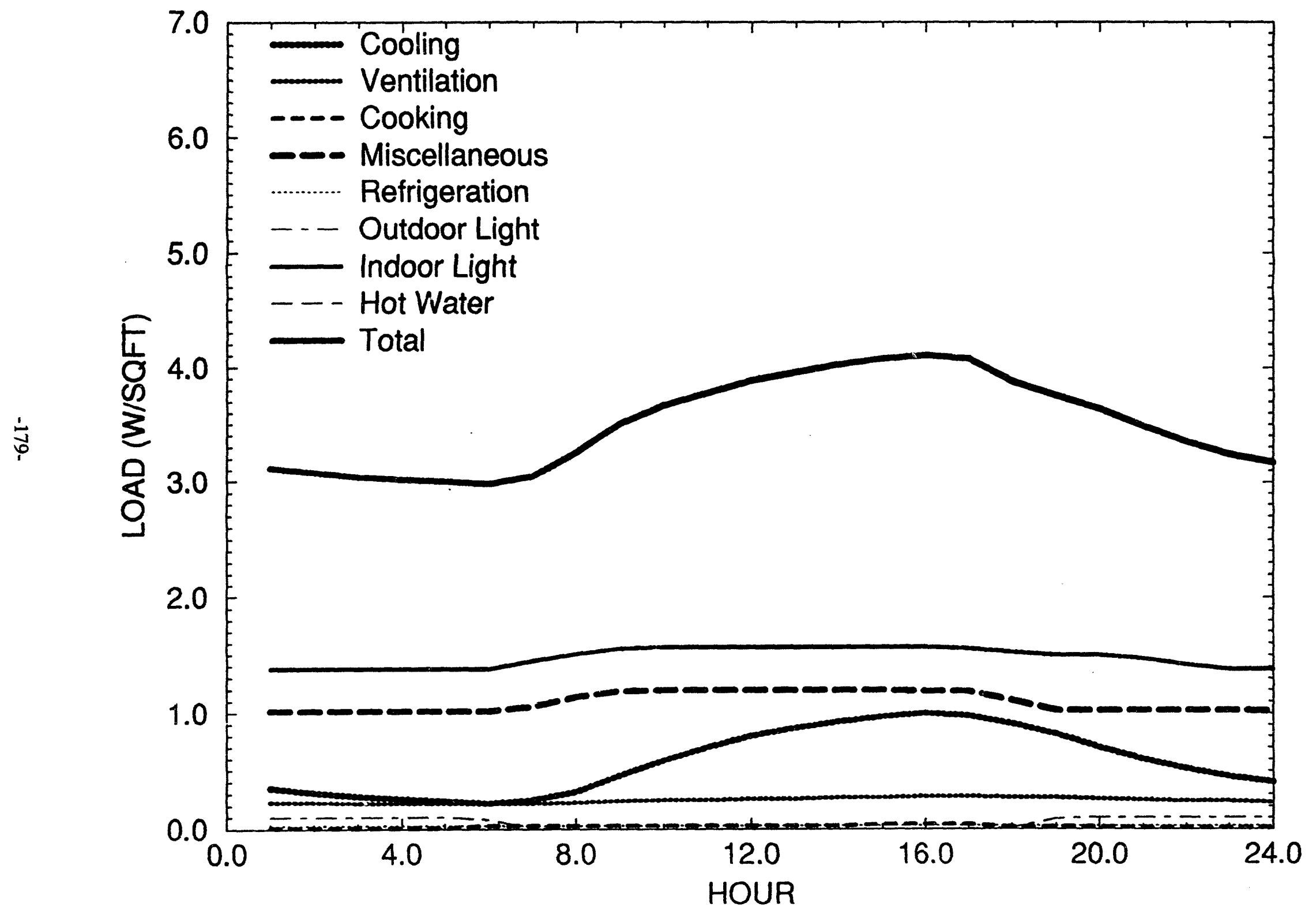


Figure 4-26a. Health Whole Building Load vs. Drybulb Temperature for Standard

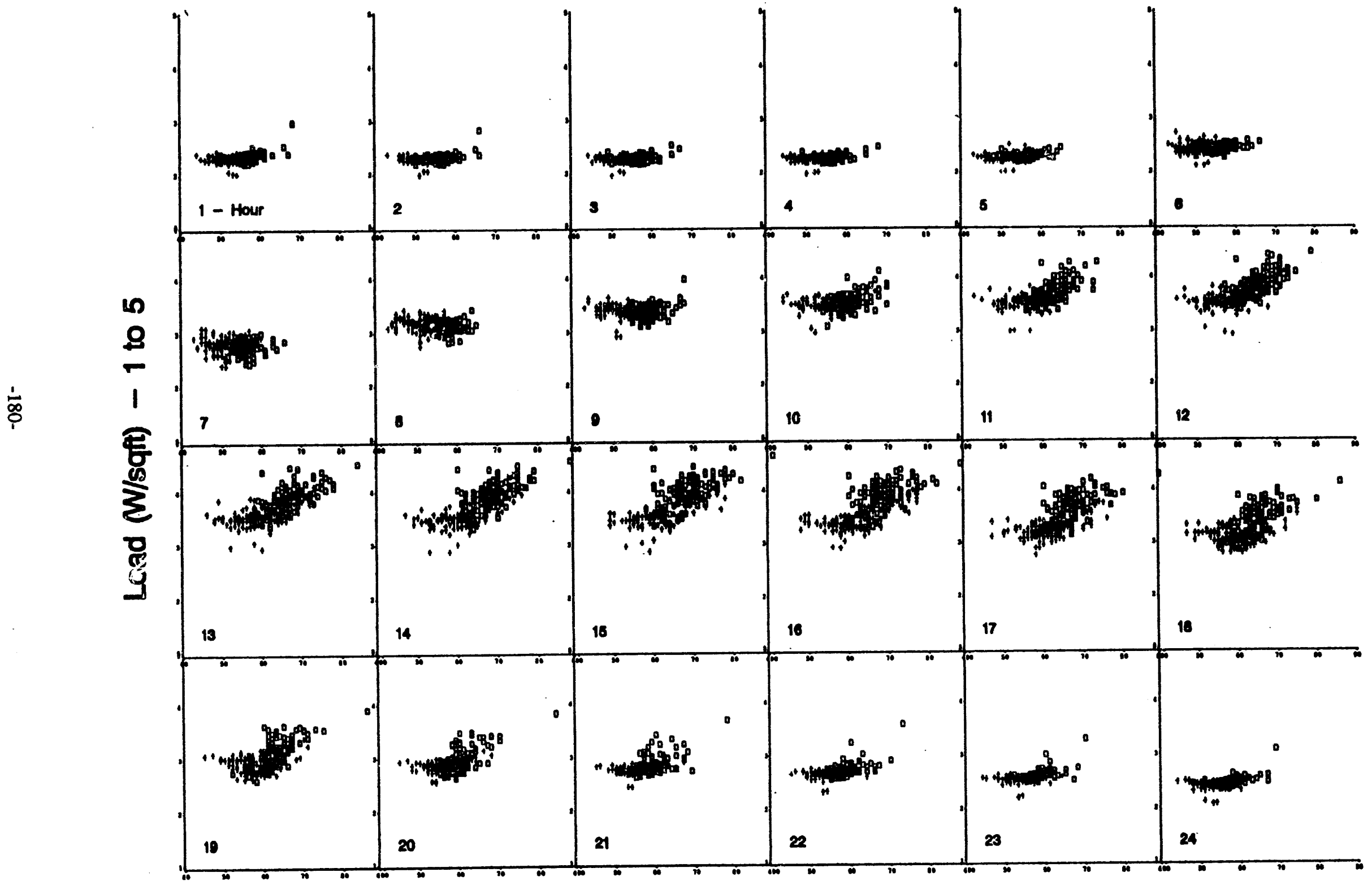

Outside Temperature $(F)-40$ to 90 


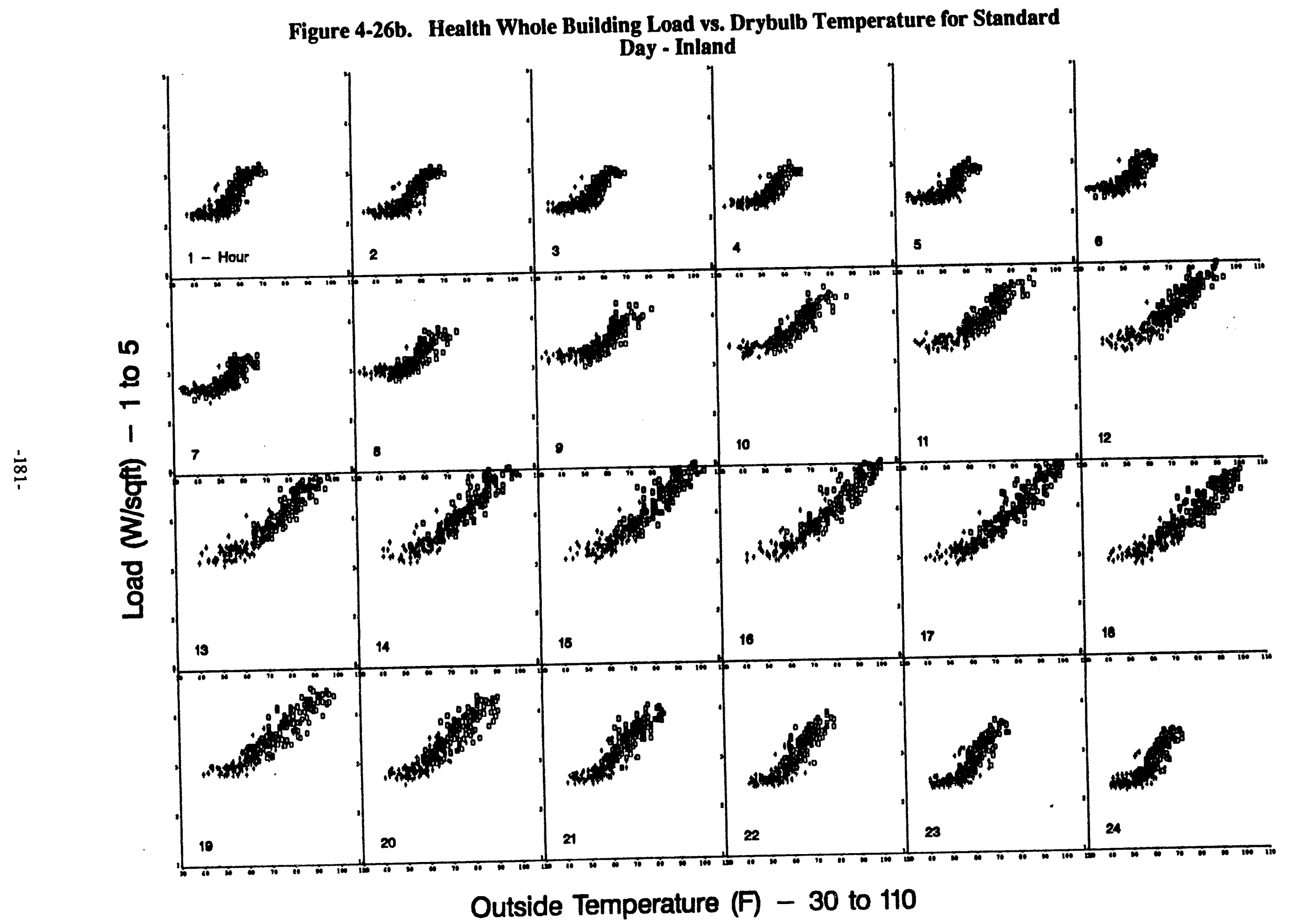


Figure 4-27a. Health Reconciled Standard Day Annual End-Use LS - Coastal

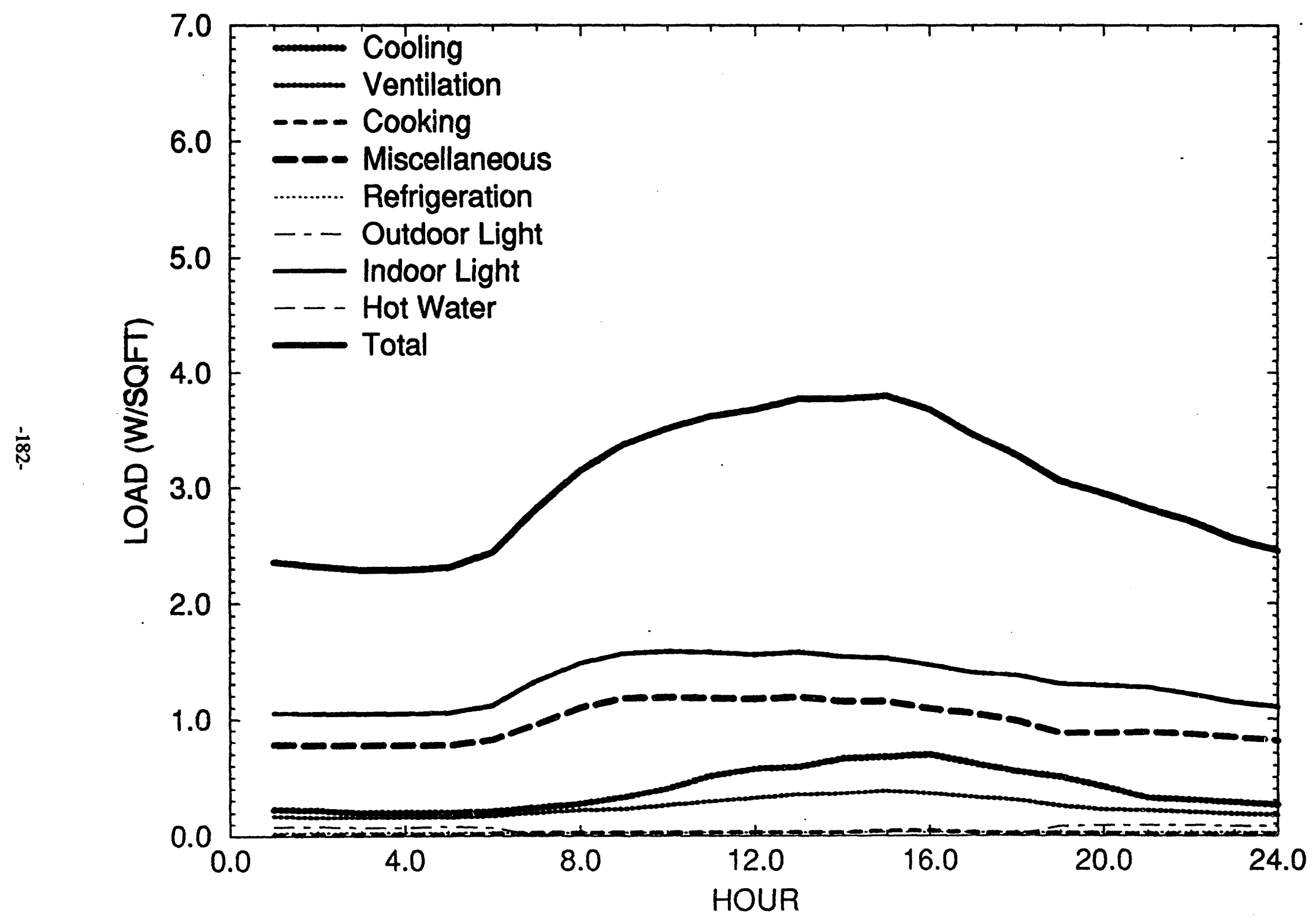


Figure 4-27b. Health Reconciled Standard Day Annual End-Use LS - Inland

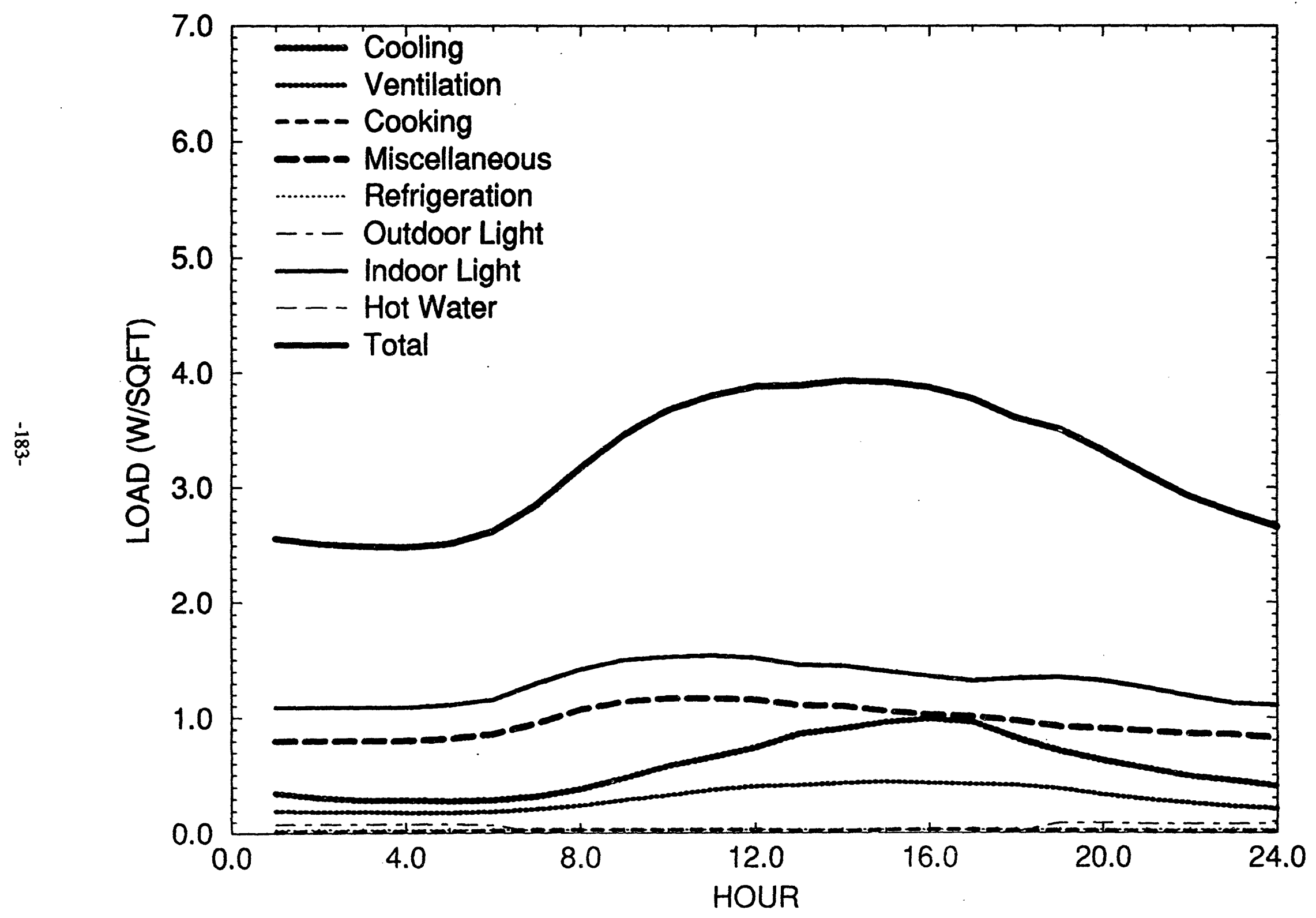


Figure 4-27c. Health Reconciled Nonstandard Day Annual End-Use LS - Coastal

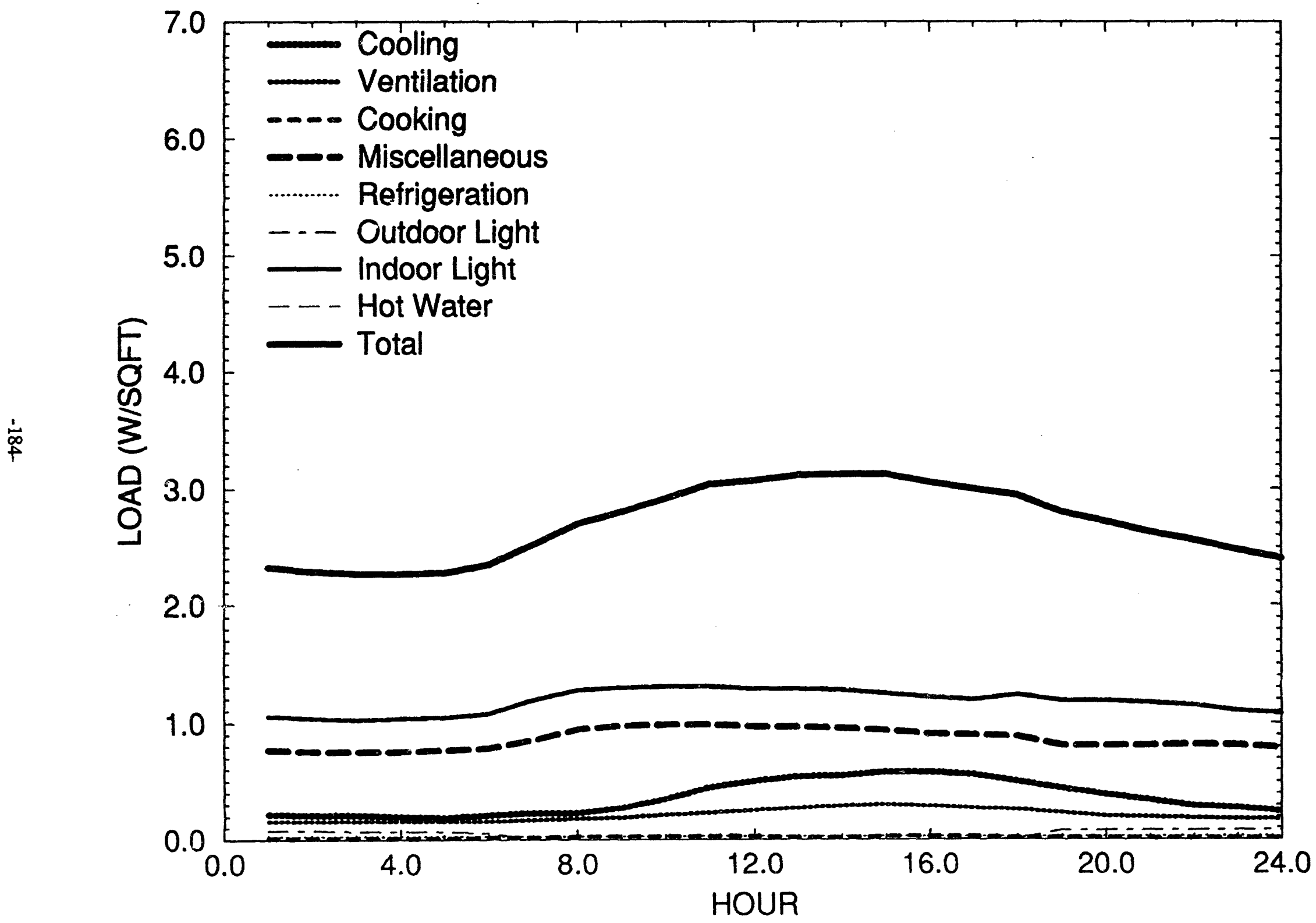


Figure 4-27d. Health Reconciled Nonstandard Day Annual End-Use LS - Inland

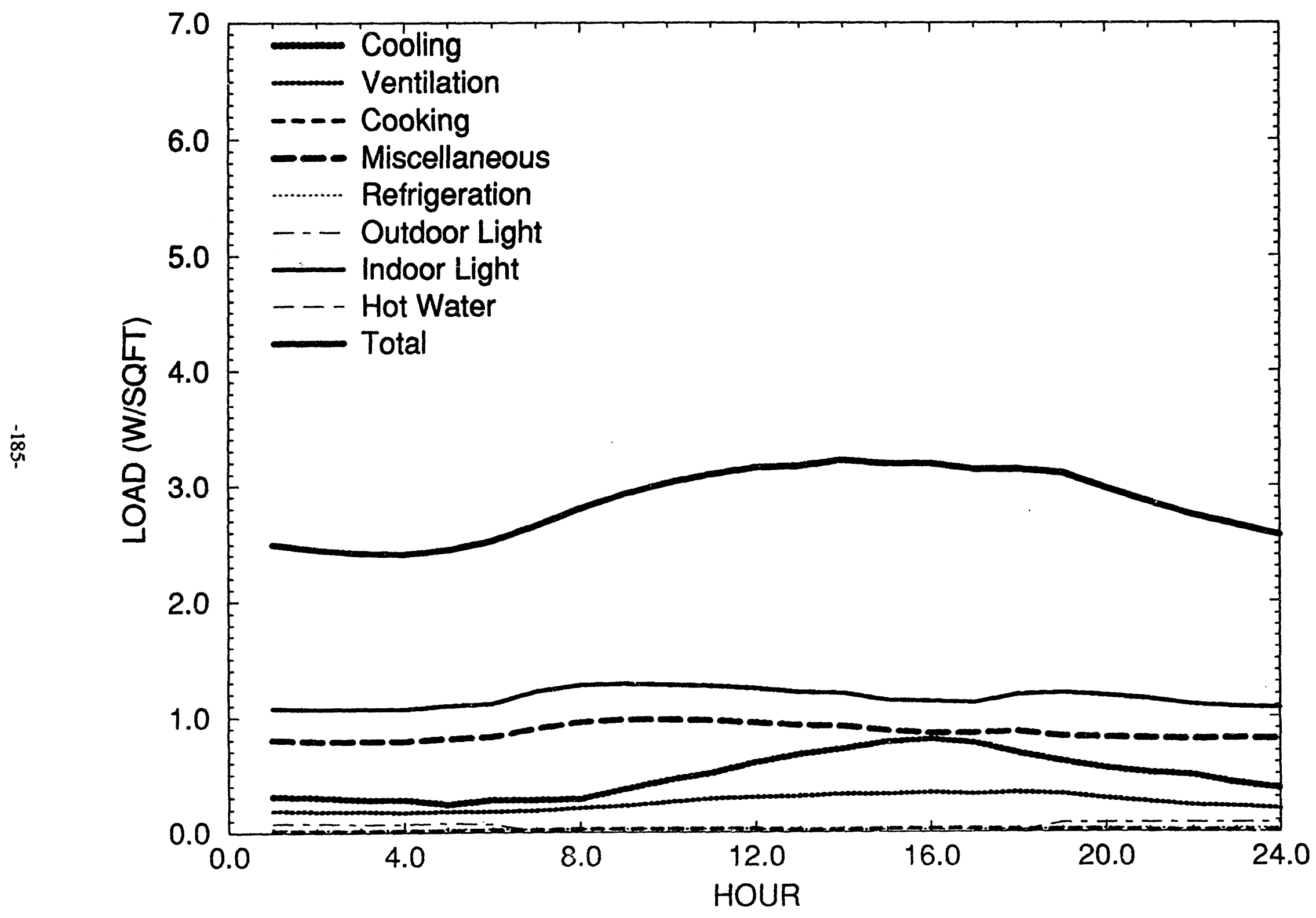




\section{Lodging}

The Lodging category consists of large hotels and small hotels as described below.

\section{Large Hotel}

The large hotel is a seven story, $205,000 \mathrm{ft}^{2}$ building modeled using three conditioned zones; three hundred sixty $400 \mathrm{ft}^{2}$ guest rooms, $51,000 \mathrm{ft}^{2}$ of lobby/conference rooms, and $10,000 \mathrm{ft}^{2}$ of kitchen/laundry, and an unconditioned basement zone. Guest rooms are heated and cooled with Four Pipe Fan Coil system. The other zones are conditioned by Variable Air Volume systems. Heating is supplied by gas boilers, cooling by hermetic centrifugal chillers, and hot water by a gas furnace.

Major characteristics of the prototypical building are summarized in Table 4-42a and Table 442b. The vintage and technology options are summarized in Table 4-43.

\section{Small Hotel}

The small hotel is a two story, $20,000 \mathrm{ft}^{2}$ building modeled with three zones: one hundred twenty $150 \mathrm{ft}^{2}$ guest rooms, a 1,000 $\mathrm{ft}^{2}$ lobby, and a $1,000 \mathrm{ft}^{2}$ laundry. The guest rooms are cooled with Packaged Air Conditioning units and heated with unit heaters. The lobby and laundry are conditioned with Packaged Single Zone units, with heating provided by a gas furnace. Hot water is provided by a gas furnace.

Major characteristics of the prototypical building are summarized in Table 4-44a and Table 444b. The onsite survey reported an average floor area of $8,300 \mathrm{ft}^{2}$ within a range of $1,500 \mathrm{ft}^{2}$ to $50,900 \mathrm{ft}^{2}$, and the mail survey reports $20,000 \mathrm{ft}^{2}$. We felt that the mail survey result more accurately represented the floor area of the small hotel. The mail survey does not provide numbers on lighting, equipment, and occupancy loads, so onsite data was used for consistency. The vintage and technology options are summarized in Table 4-45.

\section{Lodging}

Table 4-46 shows the DOE-2 simulation and EDA-reconciled end-use EUI summaries for the Lodging category of the coastai and inland climate regions. DOE-2 simulated average standard day end-use LSs for the coastal and inland climate zones are shown in Figure 4-28. Scatter plots of hourly whole-building EUIs against drybulb temperature for annual standard days of coastal and inland climates are shown in Figure 4-29. Inland Lodging plots for winter depict strong correlation between whole-building-load and dry bulb temperature from 6:00 pm. to 9:00 am. EDA reconciled average standard and nonstandard day end-use L ss for coastal and inland climates are shown in Figure 4-30. These graphs show that indoor lighting, ventilation, cooling, and miscellaneous equipment are the major end-uses. 
Table 4-42a. Large Hotel Building Prototype Characteristics

\begin{tabular}{|l|r|}
\hline Shell & \\
Floor Area $\left(1000 \mathrm{ft}^{2}\right.$ ) & 205.0 \\
Number of Floors & 7 \\
Ceiling Insulation R-value & 20.6 \\
Wall Insulation R-value & 6.3 \\
Window shading coefficient & 0.63 \\
Window/wall ratio & 0.52 \\
Loads & \\
Refrigeration (W/ $\mathrm{ft}^{2}$ ) & 0.3 \\
Schedule & \\
Standard Days & \\
Start & 7 \\
Stop & 1 \\
Non-Standard Days & 24 \\
Start & - \\
Stop & - \\
System & - \\
Supply Air (cfm/ $\mathrm{ft}^{2}$ ) & \\
Economizer Limit Tempe: ature & \\
Thermostat Type & 0.7 \\
Outside Air Control & $65^{\circ} \mathrm{F}$ \\
Heat Setpoint & Proportional \\
Cool Setpoint & Temperature \\
Plant & $70^{\circ} \mathrm{F}$ \\
Heating & $75^{\circ} \mathrm{F}$ \\
Cooling & \\
Hot Water & Gas Boiler \\
\hline
\end{tabular}

Table 4-42b. Large Hotel Building Prototype Zone Description

\begin{tabular}{|l|rrr|}
\hline & Lobby & Room & Kitchen/Laundry \\
\hline Floor Area (\% total) & 25 & 70 & 5 \\
Occupancy $\left(\mathrm{ft}^{2} /\right.$ person) & 1000 & 600 & 400 \\
Outside Air (ACH) & - & - & 1.8 \\
Outside Air / Person (CFM) & 15 & 15 & - \\
Indoor Lighting (W/ $\left./ \mathrm{ft}^{2}\right)$ & 0.8 & 0.6 & 1.1 \\
Equipment $\left(\mathrm{W} / \mathrm{ft}^{2}\right.$ ) & - & 0.9 & 4.5 \\
Cooking $\left(\mathrm{W} / \mathrm{ft}^{2}\right)$ & - & - & 2.0 \\
Hot Water $\left(\mathrm{Btu} / \mathrm{hr}^{2} / \mathrm{ft}^{2}\right.$ ) & - & 10 & 20 \\
System Type & VAV & FPFC & SZRH \\
\hline
\end{tabular}


Table 4-43. Large Hotel Building Vintage Characteristics

\begin{tabular}{|l|rr|}
\hline Technology & Pre-1978 & \multicolumn{1}{c|}{ Pos"-1978 } \\
\hline Ceiling Insulation R-value & 16.6 & 26.3 \\
Wall Insulation R-value & 5.6 & 9.8 \\
Indoor Lighting (W/ft ${ }^{2}$ ) & 0.7 & 0.7 \\
Equipment (W/ft') & 0.9 & 0.9 \\
Thermostat Type & Proportional & Reverse Action \\
Outside Air Control & Fixed & Temperature \\
System Type & & \\
Lobby & SZRH & VAV \\
Room & FPFC & FPFC \\
Kitchen & SZRH & SZRH \\
\hline
\end{tabular}

Note: Packaged Single Zone (PSZ)

Single Zone Reheat (SZRH)

Four Pipe Fan Coil (FPFC)

Variable Air Volume (VAV)

Packaged Variable Air Volume (PVAV)

Packaged Terminal Air Conditioner (PTAC) 
Table 4-44a. Small Hotel Building Prototype Characteristics

\begin{tabular}{|l|r|}
\hline Shell & \\
Floor Area (1000 $\mathrm{ft}^{2}$ ) & 20.0 \\
Number of Floors & 2 \\
Ceiling Insulation R-value & 13.2 \\
Wall Insulation R-value & 7.8 \\
Window shading coefficient & 0.66 \\
Window/wall ratio & 0.1 \\
Loads & \\
Refrigeration (W/ $\mathrm{ft}^{2}$ ) & 0.5 \\
Schedule & \\
Standard Days & 7 \\
Start & 1 \\
Stop & 24 \\
Non-Standard Days & - \\
Start & - \\
Stop & - \\
System & \\
COP & 2.3 \\
Supply Air (cfm/ $\mathrm{ft}^{2}$ ) & 0.7 \\
Economizer Limit Temperature & $65^{\circ} \mathrm{F}$ \\
Thermostat Type & Proportional \\
Outside Air Control & Temperature \\
Heat Setpoint & $70^{\circ} \mathrm{F}$ \\
Cool Setpoint & $75^{\circ} \mathrm{F}$ \\
Plant & \\
Heating & Gas Furnace \\
Cooling & Gas Furnace \\
Hot Water & \\
\hline
\end{tabular}

Table 4-44b. Small Hotel Building Prototype Zone Description

\begin{tabular}{|c|c|c|c|}
\hline & Lobby & Room & Laundry \\
\hline Floor Area (\% total) & 5 & 90 & 5 \\
\hline Occupancy ( $\mathrm{ft}^{2} /$ person) & 104 & 300 & 140 \\
\hline Outside Air (ACH) & & & 1.0 \\
\hline Outside Air / Person (CֵFM) & 15 & 15 & \\
\hline Indoor Lighting (W/ft $\left.{ }^{2}\right)$ & 1.0 & 0.7 & 1.2 \\
\hline Equipment $\left(\mathrm{W} / \mathrm{ft}^{2}\right)$ & & 1.0 & .8 \\
\hline Cooking $\left(\mathrm{W} / \mathrm{ft}^{2}\right)$ & - & & 4.0 \\
\hline Hot Water $\left(\mathrm{Btu} / \mathrm{hr} / \mathrm{ft}^{2}\right)$ & - & e & 20 \\
\hline System Type & PSZ & PTAC & PSZ \\
\hline
\end{tabular}


Table 4-45. Small Hotel Building Vintage Characteristics

\begin{tabular}{|l|rr|}
\hline Technology & \multicolumn{1}{|c|}{ Pre-1978 } & \multicolumn{1}{c|}{ Post-1978 } \\
\hline Ceiling Insulation R-value & 13.2 & 13.2 \\
Wall Insulation R-value & 7.7 & 9.8 \\
Indoor Lighting (W/ $\mathrm{ft}^{2}$ ) & 0.7 & 0.7 \\
Equipment (W/ft' & 1.1 \\
Thermostat Type & 1.1 & 1 \\
Outside Air Control & Proportional & Reverse Action \\
System Type & Fixed & Temperature \\
Lobby & & \\
Room & PSZ & PVAV \\
Laundry & PTAC & PTAC \\
\hline
\end{tabular}


Table 4-46a. Lodging Simulated and EDA-Reconciled EUIs-Coastal $\left(\mathrm{kWh} / \mathrm{ft}^{2} / \mathrm{yr}\right)$

\begin{tabular}{|c|c|c|c|c|c|c|c|c|c|c|}
\hline \multicolumn{7}{|c|}{ Non-HVAC End Uses } & \multicolumn{3}{|c|}{ HVAC } & \multirow[t]{2}{*}{ Total } \\
\hline $\begin{array}{c}\text { Indoor } \\
\text { Lighting }\end{array}$ & $\begin{array}{l}\text { Outdoor } \\
\text { Lighting }\end{array}$ & $\begin{array}{l}\text { Misc. } \\
\text { Equip. }\end{array}$ & $\begin{array}{l}\text { Office } \\
\text { Equip. }\end{array}$ & Refrig & Cooking & $\begin{array}{l}\text { Water } \\
\text { Heating }\end{array}$ & Heating & Fans & Cooling & \\
\hline \multicolumn{11}{|l|}{ Simuls:ion } \\
\hline \multicolumn{11}{|c|}{ Conditioned (Weight=0.69) } \\
\hline 4.43 & 0.30 & 2.01 & 0.00 & 0.44 & 0.10 & 0.02 & 0.00 & 0.71 & 1.55 & 9.56 \\
\hline \multicolumn{11}{|c|}{ Unconditioned (Weight $=0.31$ ) } \\
\hline 4.43 & 0.30 & 2.01 & 0.00 & 0.44 & 0.10 & 0.02 & 0.00 & 0.00 & 0.00 & 7.30 \\
\hline \multicolumn{11}{|c|}{ Weighted Average } \\
\hline 4.43 & 0.30 & 2.01 & 0.00 & 0.44 & 0.10 & 0.02 & 0.00 & 0.49 & 1.07 & 8.86 \\
\hline \multicolumn{11}{|l|}{ Reconciled } \\
\hline 2.76 & 0.21 & 1.18 & 0.05 & 0.30 & 0.06 & 0.01 & 0.32 & 0.60 & 0.90 & 6.39 \\
\hline
\end{tabular}

Table 4-46b. Lodging Simulated and EDA-Reconciled EUIs-Inland (kWh/ft $\left.{ }^{2} / \mathrm{yr}\right)$

\begin{tabular}{|c|c|c|c|c|c|c|c|c|c|c|}
\hline \multicolumn{7}{|c|}{ Non-HVAC End Uses } & \multicolumn{3}{|c|}{ HVAC } & \multirow[t]{2}{*}{ Total } \\
\hline $\begin{array}{c}\text { Indoor } \\
\text { Lighting } \\
\end{array}$ & $\begin{array}{l}\text { Outdoor } \\
\text { Lighting } \\
\end{array}$ & $\begin{array}{l}\text { Misc. } \\
\text { Equip. }\end{array}$ & $\begin{array}{l}\text { Office } \\
\text { Equip. }\end{array}$ & Refrig & Cooking & $\begin{array}{c}\text { Water } \\
\text { Heating }\end{array}$ & Heating & Fans & Cooling & \\
\hline \multicolumn{11}{|l|}{ Simulation } \\
\hline \multicolumn{11}{|c|}{ Conditioned (Weight=0.96) } \\
\hline 3.85 & 0.45 & 1.48 & 0.00 & 0.64 & 0.08 & 0.02 & 0.00 & 0.82 & 4.15 & 11.49 \\
\hline \multicolumn{11}{|c|}{ Unconditioned (Weight $=0.04$ ) } \\
\hline 3.85 & 0.45 & 1.48 & 0.00 & 0.64 & 0.08 & 0.02 & 0.00 & 0.00 & 0.00 & 6.52 \\
\hline \multicolumn{11}{|c|}{ Weighted Average } \\
\hline $\mathbf{3 . 8 5}$ & 0.45 & 1.48 & 0.00 & 0.64 & 0.08 & 0.02 & 0.00 & 0.79 & 3.98 & 11.29 \\
\hline \multicolumn{11}{|l|}{ Reconciled } \\
\hline 2.78 & 0.41 & 0.98 & 0.05 & 0.53 & 0.04 & 0.00 & 0.43 & 1.27 & 1.33 & 7.82 \\
\hline
\end{tabular}


Figure 4-28a. Lodging Simulated Average Standard Day LS - Coastal

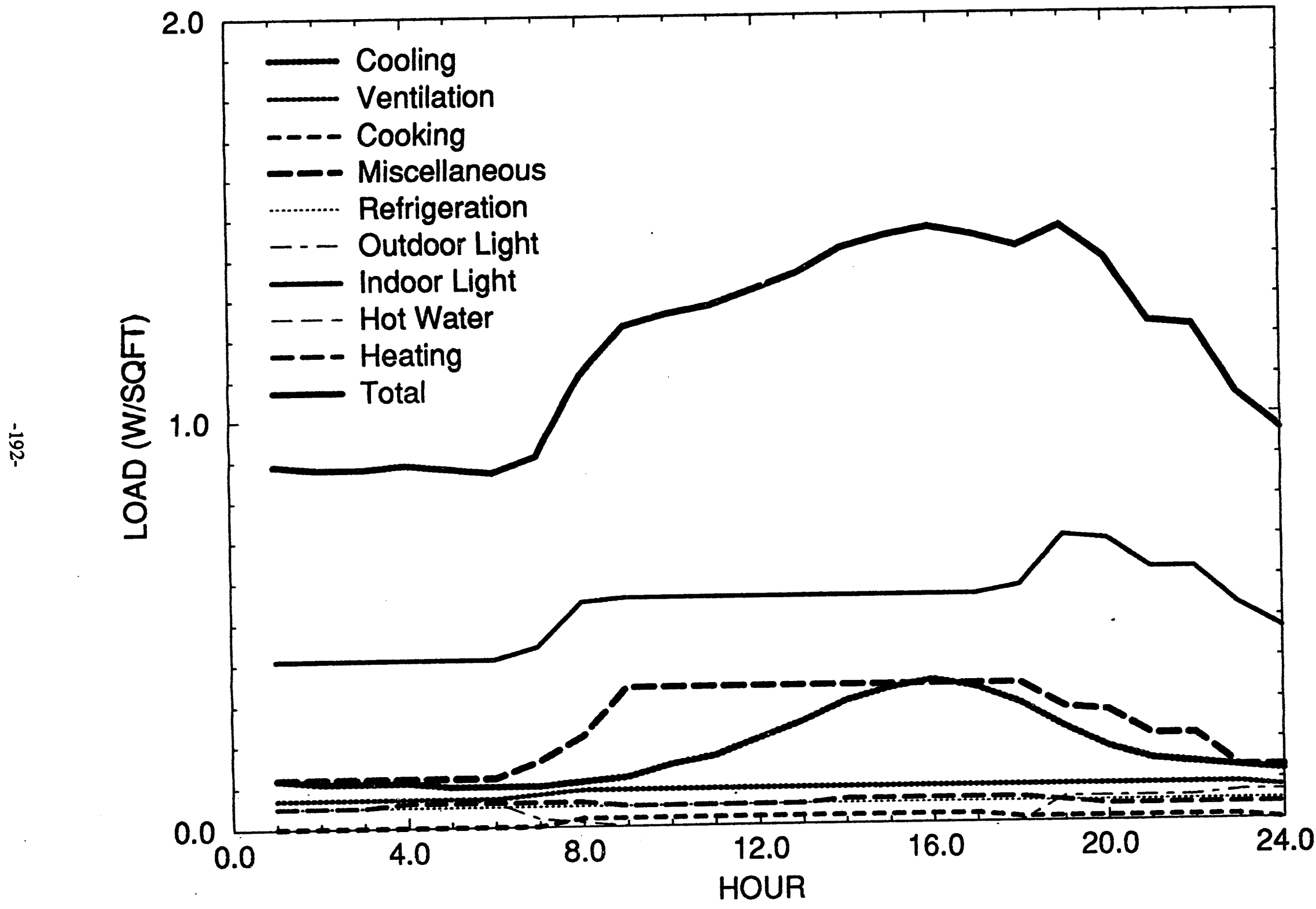


Figure 4-28b. Lodging Simulated Average Standard Day LS - Inland

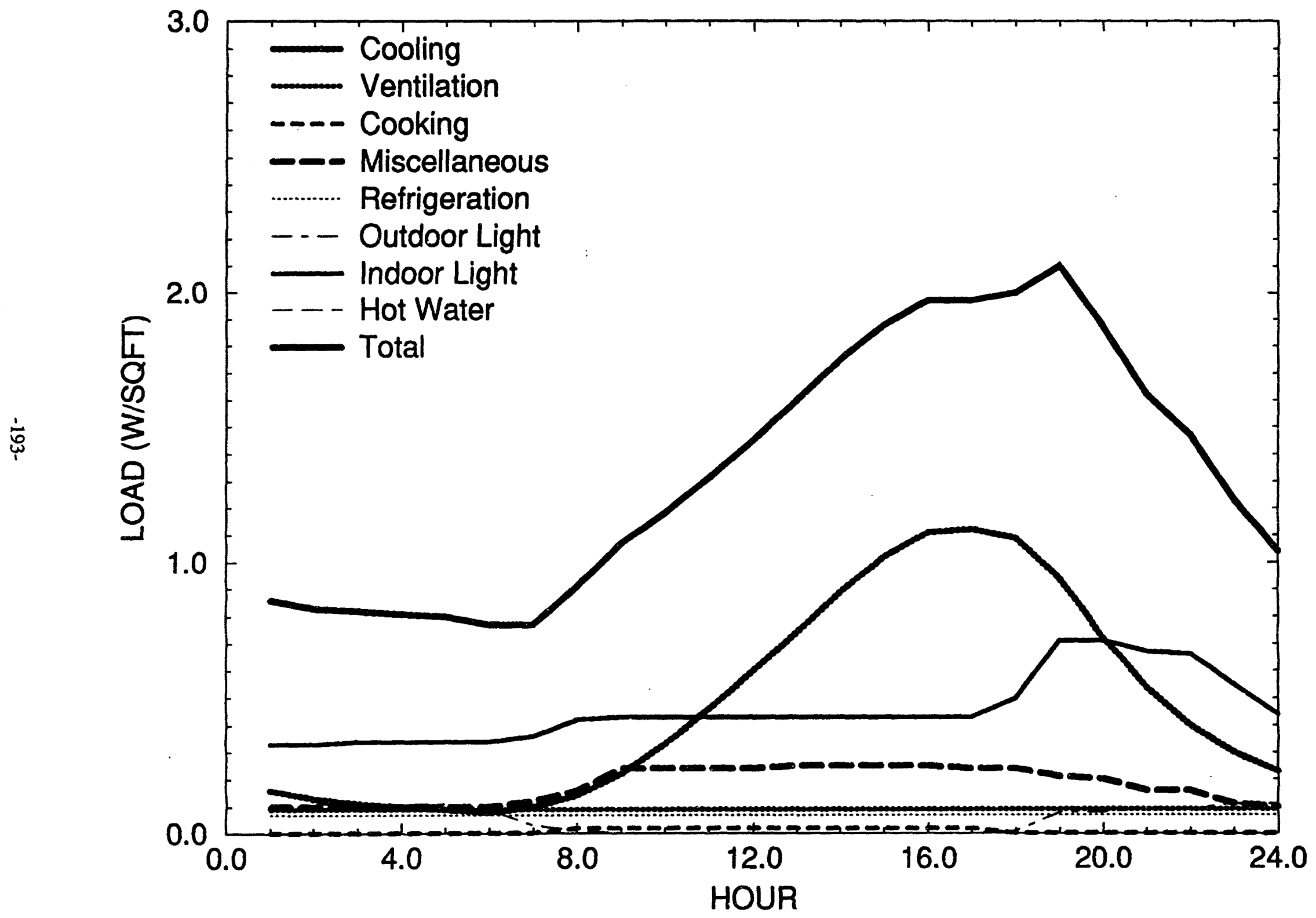


Figure 4-29a. Lodging Whole Building Load vs. Drybulb Temperature for Standard

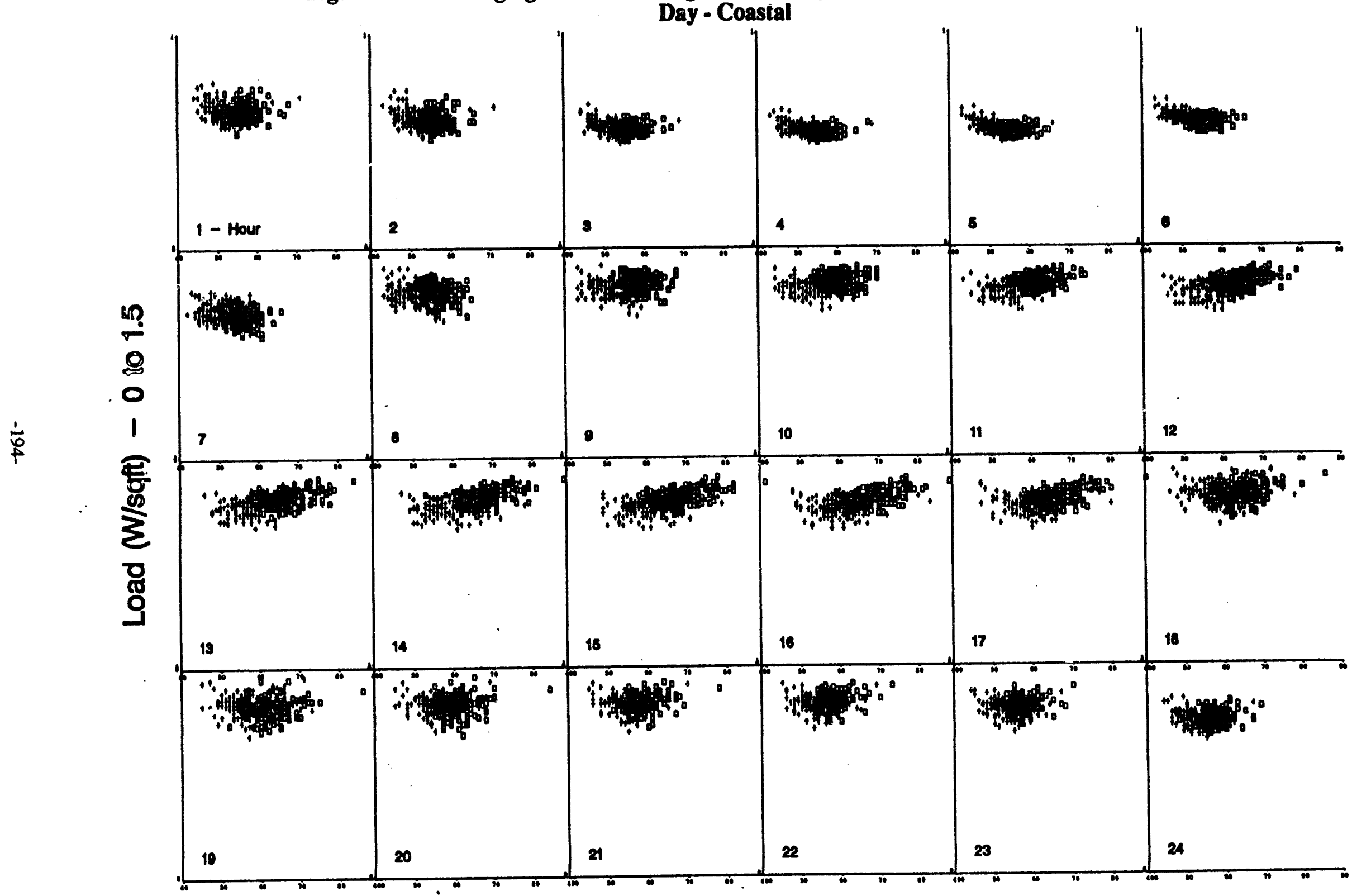

Outside Temperature $(F)-40$ to 90 


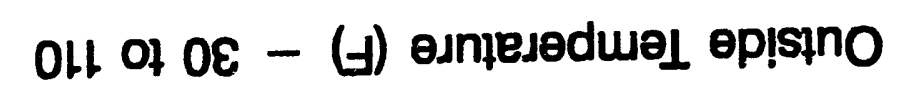

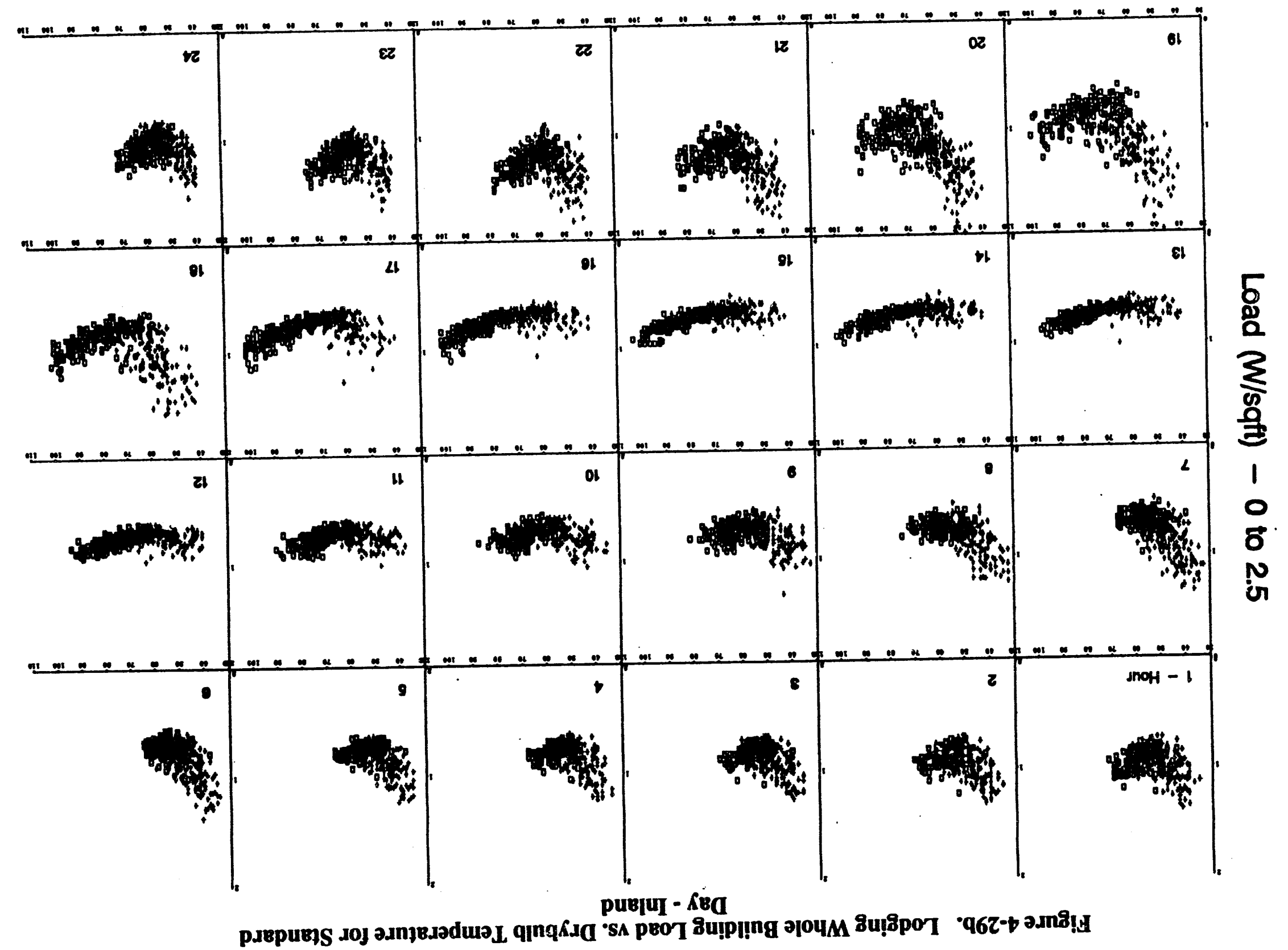


Figure 4-30a. Lodging Reconciled Standard Day Annual End-Use LS - Coastal

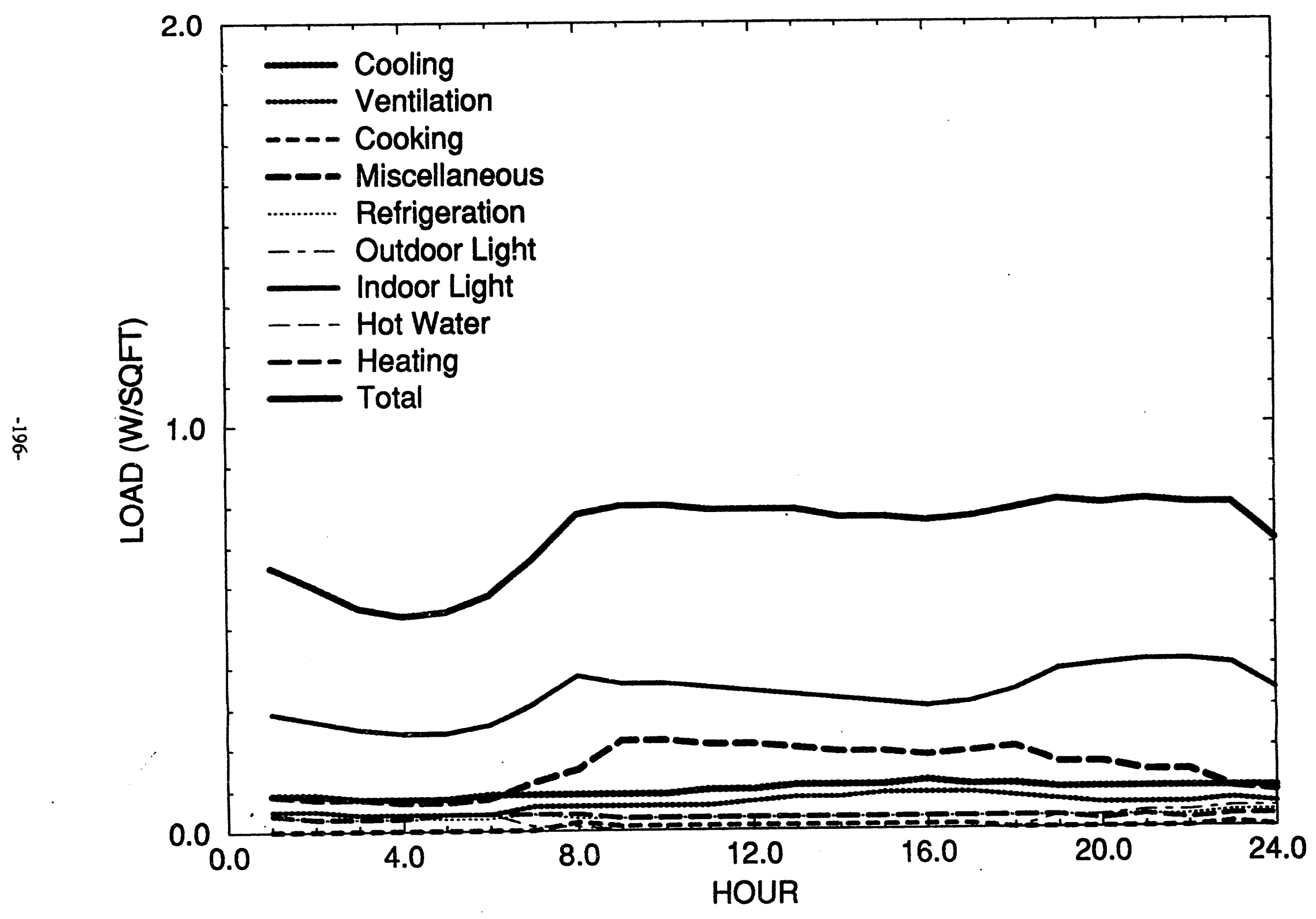


Figure 4-30b. Lodging Reconciled Standard Day Annual End-Use LS - Inland

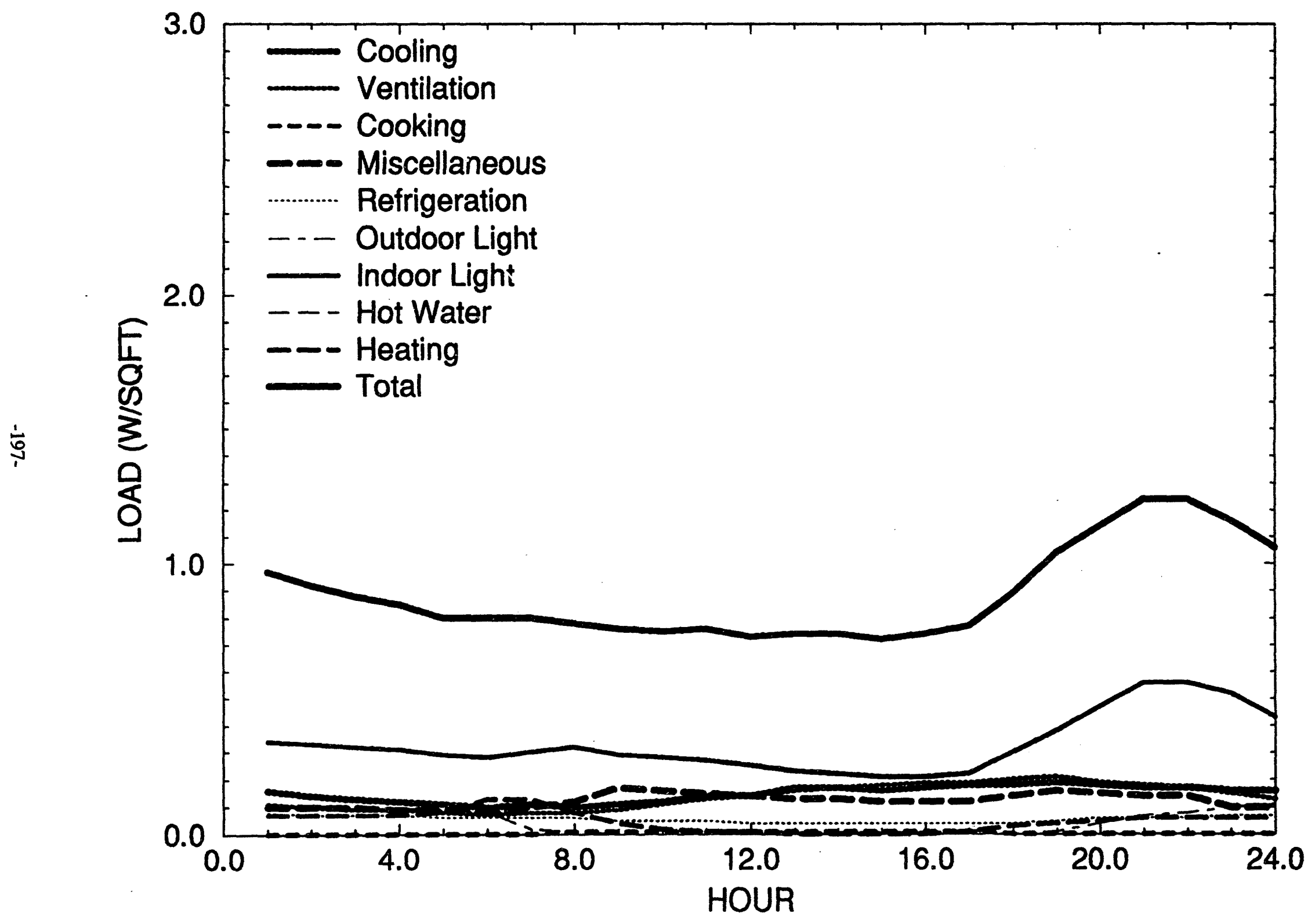




\section{Miscellaneous}

The miscellaneous prototype is a $8,800 \mathrm{ft}^{2}$ single story building modeled with a single zone and conditioned with a Packaged Single Zone system. Hot water and heating are provided by gas furnaces.

Major characteristics of the prototypical building are summarized in Table 4-47. The vintage and technology options are summarized in Table 4-48.

Table 4-49 shows the DOE-2 simulation and EDA-reconciled end-use EUI summaries for the Miscellaneous category of the coastal and inland climate regions. DOE-2 simulated average standard day end-use LSs for the coastal and inland climate zones are shown in Figure 4-31. Indoor lighting, miscellaneous equipment, ventilation and refrigeration are the dominant loads in coastal buildings while inland ones have high cooling loads in addition to these. Scatter plots of hourly whole-building EUIs against drybulb temperature for annual standard days of coastal and inland climates are shown in Figure 4-32. Both sets of plots depict no correlation between whole-building-load and dry bulb temperature. EDA reconciled average standard and nonstandard day end-use LSs for coastal and inland climates are shown in Figure 4-33. These graphs show that indoor lighting, ventilation, cooling, and miscellaneous equipment are the major enduses.

Note: $\quad$ Packaged Single Zone (PSZ) 
Table 4-47. Miscellaneous Building Prototype Characteristics

\begin{tabular}{|c|c|}
\hline $\begin{array}{l}\text { Shell } \\
\left.\text { Floor Area (1000 } \mathrm{ft}^{2}\right) \\
\text { Number of Floors } \\
\text { Ceiling Insulation } \mathrm{R} \text {-value } \\
\text { Wall Insulation } \mathrm{R} \text {-value } \\
\text { Window shading coefficient } \\
\text { Window/wall ratio }\end{array}$ & $\begin{array}{r}8.8 \\
1 \\
8.6 \\
6.1 \\
0.78 \\
0.02\end{array}$ \\
\hline $\begin{array}{l}\text { Loads } \\
\text { Refrigeration }\left(\mathrm{W} / \mathrm{ft}^{2}\right) \\
\text { Occupancy }\left(\mathrm{ft}^{2} / \mathrm{person}^{2}\right) \\
\text { Indoor Lighting }\left(\mathrm{W} / \mathrm{ft}^{2}\right) \\
\text { Equipment }\left(\mathrm{W} / \mathrm{ft}^{2}\right) \\
\text { Cooking }\left(\mathrm{W} / \mathrm{ft}^{2}\right) \\
\text { Hot Water }\left(\mathrm{Btu} / \mathrm{hr} / \mathrm{ft}^{2}\right)\end{array}$ & $\begin{array}{r}0.2 \\
606 \\
0.6 \\
2.5 \\
0.2 \\
1.0\end{array}$ \\
\hline $\begin{array}{l}\text { Schedule } \\
\text { Standard Days } \\
\text { Start } \\
\text { Stop } \\
\text { Non-Standard Days } \\
\text { Start } \\
\text { Stop }\end{array}$ & $\begin{array}{r}5 \\
6 \\
24 \\
2 \\
6 \\
24\end{array}$ \\
\hline $\begin{array}{l}\text { System } \\
\text { System Type } \\
\text { COP } \\
\text { Supply Air }\left(\mathrm{cfm} / \mathrm{ft}^{2}\right) \\
\text { Economizer Limit Temperature } \\
\text { Thermostat Type } \\
\text { Outside Air Control } \\
\text { Outside Air / Person (CFM) } \\
\text { Heat Setpoint } \\
\text { Cool Setpoint }\end{array}$ & $\begin{array}{r}\text { PSZ } \\
2.3 \\
0.7 \\
65^{\circ} \mathrm{F} \\
\text { Proportional } \\
\text { Temperature } \\
15 \\
70^{\circ} \mathrm{F} \\
75^{\circ} \mathrm{F}\end{array}$ \\
\hline $\begin{array}{l}\text { Plant } \\
\text { Heating } \\
\text { Cooling } \\
\text { Hot Water }\end{array}$ & $\begin{array}{r}\text { Gas Furnace } \\
\text { Direct Expansion } \\
\text { Gas Furnace }\end{array}$ \\
\hline
\end{tabular}

Table 4-48. Miscellaneous Building Vintage Characteristics

\begin{tabular}{|l|rr|}
\hline Technology & Pre-1978 & Post-1978 \\
\hline Ceiling Insulation R-value & 8.4 & 12.5 \\
Wall Insulation R-value & 6.1 & 6.6 \\
${\text { Indoor Lighting }\left(W / \mathrm{ft}^{2}\right)}$ ) & 0.6 & 0.7 \\
${\text { Equipment }\left(W / \mathrm{ft}^{2}\right)}^{\text {Cooking }\left(W / \mathrm{ft}^{2}\right)}$ & 2.0 & 2.2 \\
Thermostat Type & 0.2 & 0.2 \\
Outside Air Control & Proportional & Reverse Action \\
System Type & Fixed & Temperature \\
\hline
\end{tabular}


Table 4-49a. Miscellaneous Simulated and EDA-Reconciled EUIs-Coastal (kWh/ $\left.\mathrm{ft}^{2} / \mathrm{yr}\right)$

\begin{tabular}{|c|c|c|c|c|c|c|c|c|c|c|}
\hline \multicolumn{7}{|c|}{ Non-HVAC End Uses } & \multicolumn{3}{|c|}{ HVAC } & \multirow[t]{2}{*}{ Total } \\
\hline $\begin{array}{c}\text { Indoor } \\
\text { Lighting } \\
\end{array}$ & $\begin{array}{l}\text { Outdoor } \\
\text { Lighting } \\
\end{array}$ & $\begin{array}{l}\text { Misc. } \\
\text { Equip. } \\
\end{array}$ & $\begin{array}{l}\text { Office } \\
\text { Equip. }\end{array}$ & Refrig & Cooking & $\begin{array}{l}\text { Water } \\
\text { Heating }\end{array}$ & Heating & Fans & Cooling & \\
\hline \multicolumn{11}{|l|}{ Simulation } \\
\hline \multicolumn{11}{|c|}{ Conditioned (Weight $=0.27$ ) } \\
\hline 2.48 & 0.55 & 3.39 & 0.00 & 0.31 & 0.00 & 0.03 & 0.00 & 1.46 & 0.32 & 8.54 \\
\hline \multicolumn{11}{|c|}{ Unconditioned (Weight $=0.73$ ) } \\
\hline 2.48 & 0.55 & 3.39 & 0.00 & 0.31 & 0.00 & 0.03 & 0.00 & 0.00 & 0.00 & 6.76 \\
\hline \multicolumn{11}{|c|}{ Weighted Average } \\
\hline 2.48 & 0.55 & 3.39 & 0.00 & 0.31 & 0.00 & 0.03 & 0.00 & 0.40 & 0.09 & 7.25 \\
\hline \multicolumn{11}{|l|}{ Reconciled } \\
\hline 1.46 & 0.42 & 1.90 & 0.16 & 0.45 & 0.00 & 0.00 & 0.00 & 1.07 & 0.53 & 5.99 \\
\hline
\end{tabular}

Table 4-49b. Miscellaneous Simulated and EDA-Reconciled EUls—-Inland (kWh/ $\left./ \mathrm{ft}^{2} / \mathrm{yr}\right)$

\begin{tabular}{|c|c|c|c|c|c|c|c|c|c|c|}
\hline \multicolumn{7}{|c|}{ Non-HVAC End Uses } & \multicolumn{3}{|c|}{ HVAC } & \multirow[t]{2}{*}{ Total } \\
\hline $\begin{array}{c}\text { Indoor } \\
\text { Lighting } \\
\end{array}$ & $\begin{array}{l}\text { Outdoor } \\
\text { Lighting } \\
\end{array}$ & $\begin{array}{l}\text { Misc. } \\
\text { Equip. }\end{array}$ & $\begin{array}{l}\text { Office } \\
\text { Equip. }\end{array}$ & Refrig & Cooking & $\begin{array}{c}\text { Water } \\
\text { Heating }\end{array}$ & Heating & Fans & Cooling & \\
\hline \multicolumn{11}{|l|}{ Simulation } \\
\hline \multicolumn{11}{|c|}{ Conditioned (Weight=0.77) } \\
\hline 2.82 & 0.55 & 3.76 & 0.00 & 0.31 & 0.00 & 0.03 & 0.00 & 1.46 & 0.85 & 9.78 \\
\hline \multicolumn{11}{|c|}{ Unconditioned (Weight $=0.23$ ) } \\
\hline 2.82 & 0.55 & 3.76 & 0.00 & 0.31 & 0.00 & 0.03 & 0.00 & 0.00 & 0.00 & 7.47 \\
\hline \multicolumn{11}{|c|}{ Weighted Average } \\
\hline 2.82 & 0.55 & 3.76 & 0.00 & 0.31 & 0.00 & 0.03 & 0.00 & 1.12 & 0.65 & 9.24 \\
\hline \multicolumn{11}{|l|}{ Reconciled } \\
\hline 1.84 & 0.39 & 2.45 & 0.16 & 0.43 & 0.00 & 0.00 & 0.00 & 1.13 & 1.10 & $\mathbf{7 . 5 0}$ \\
\hline
\end{tabular}


Figure 4-31a. Miscellaneous Simulated Average Standard Day LS - Coastal

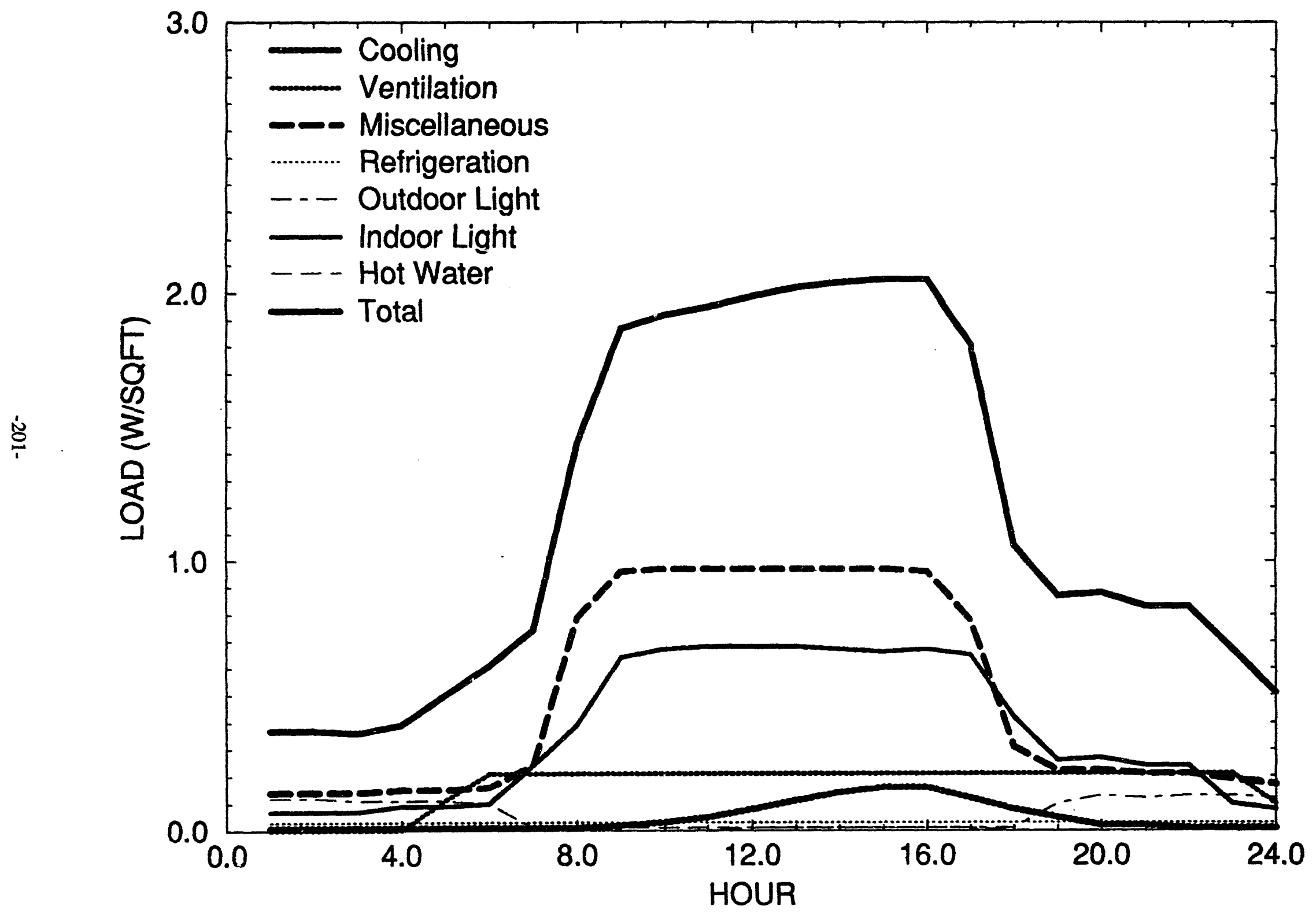


Figure 4-31b. Miscellaneous Simulated Average Standard Day LS - Inland

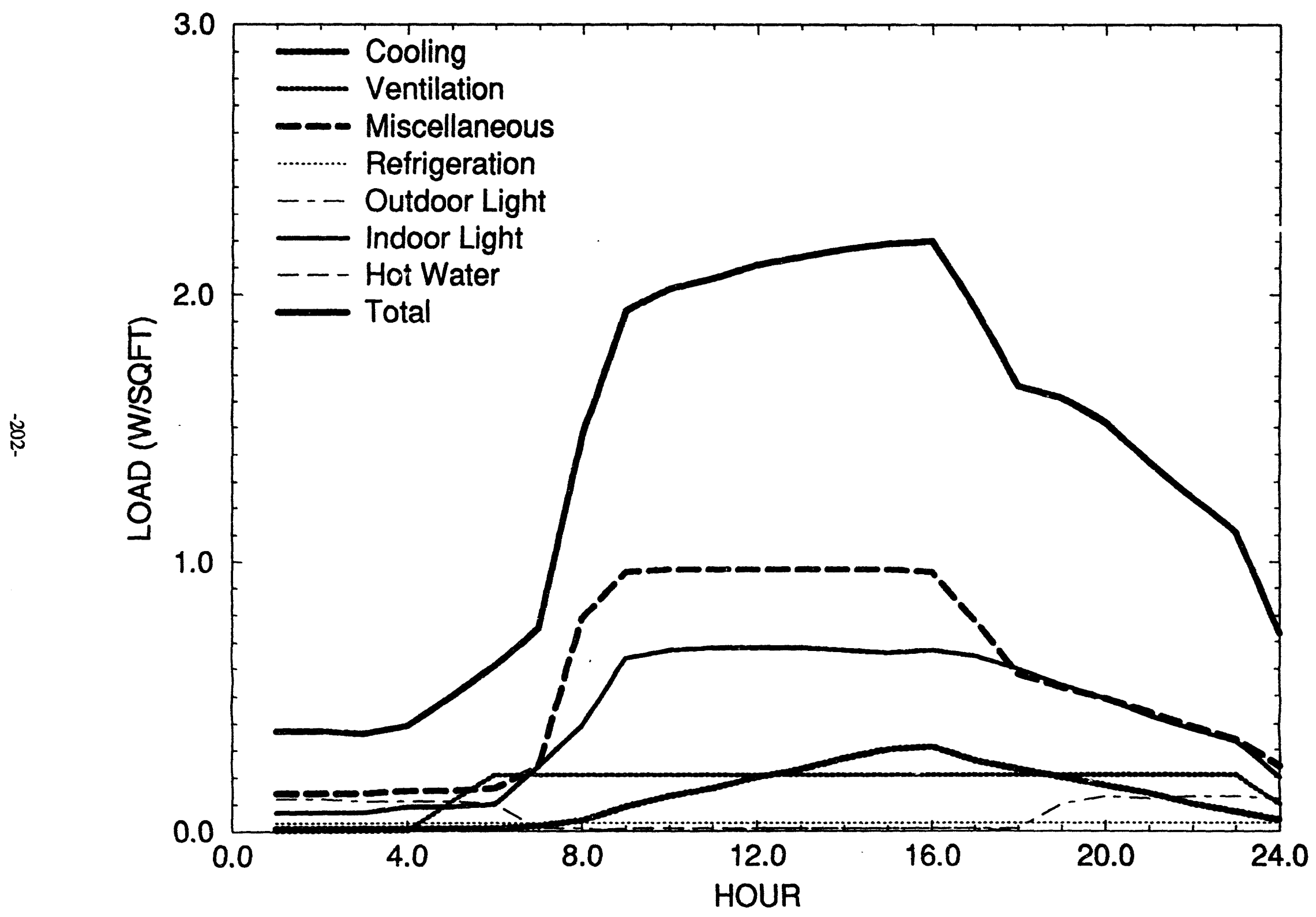




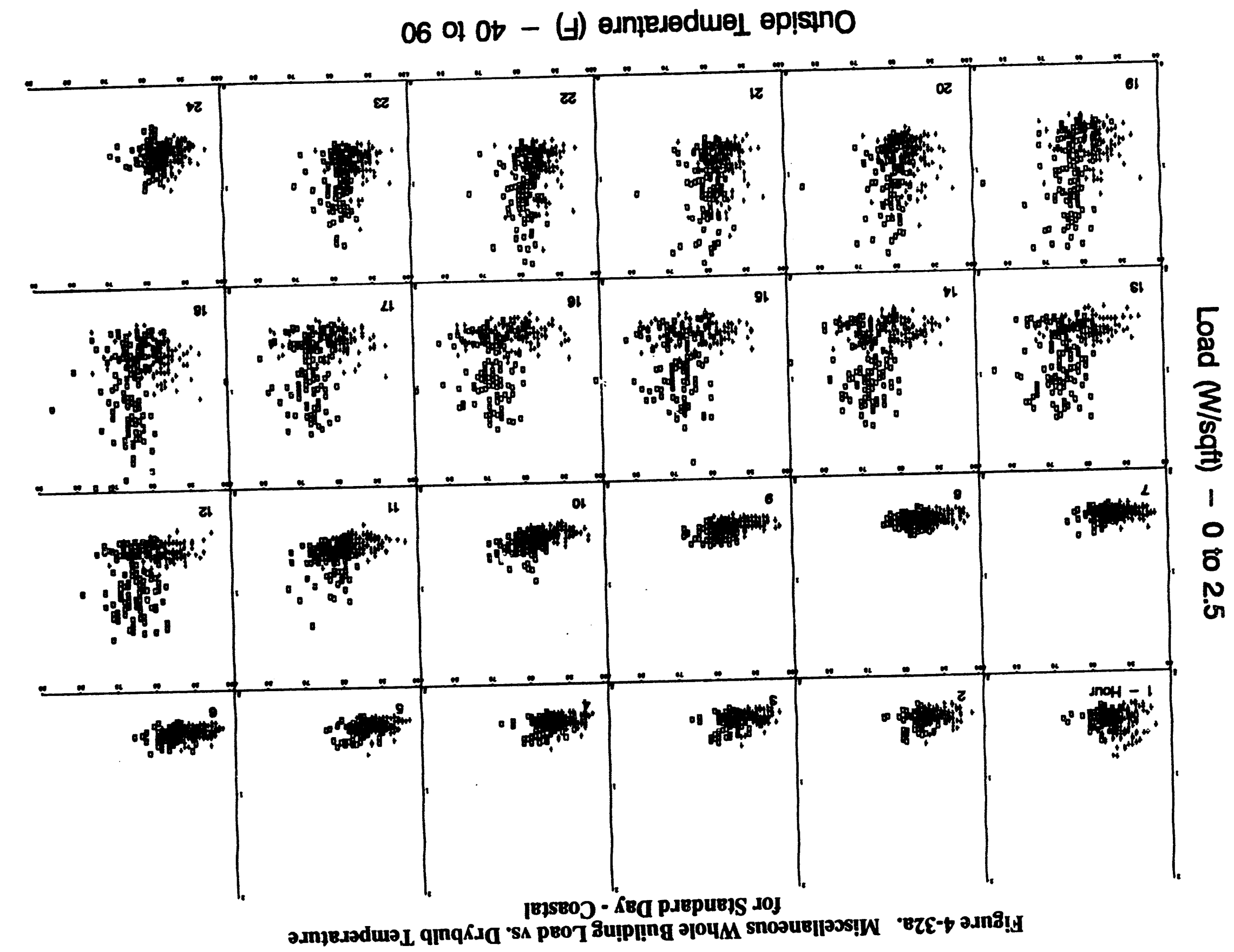


Figure 4-32b. Miscellaneous Whole Building Losd vs. Drybulb Temperature

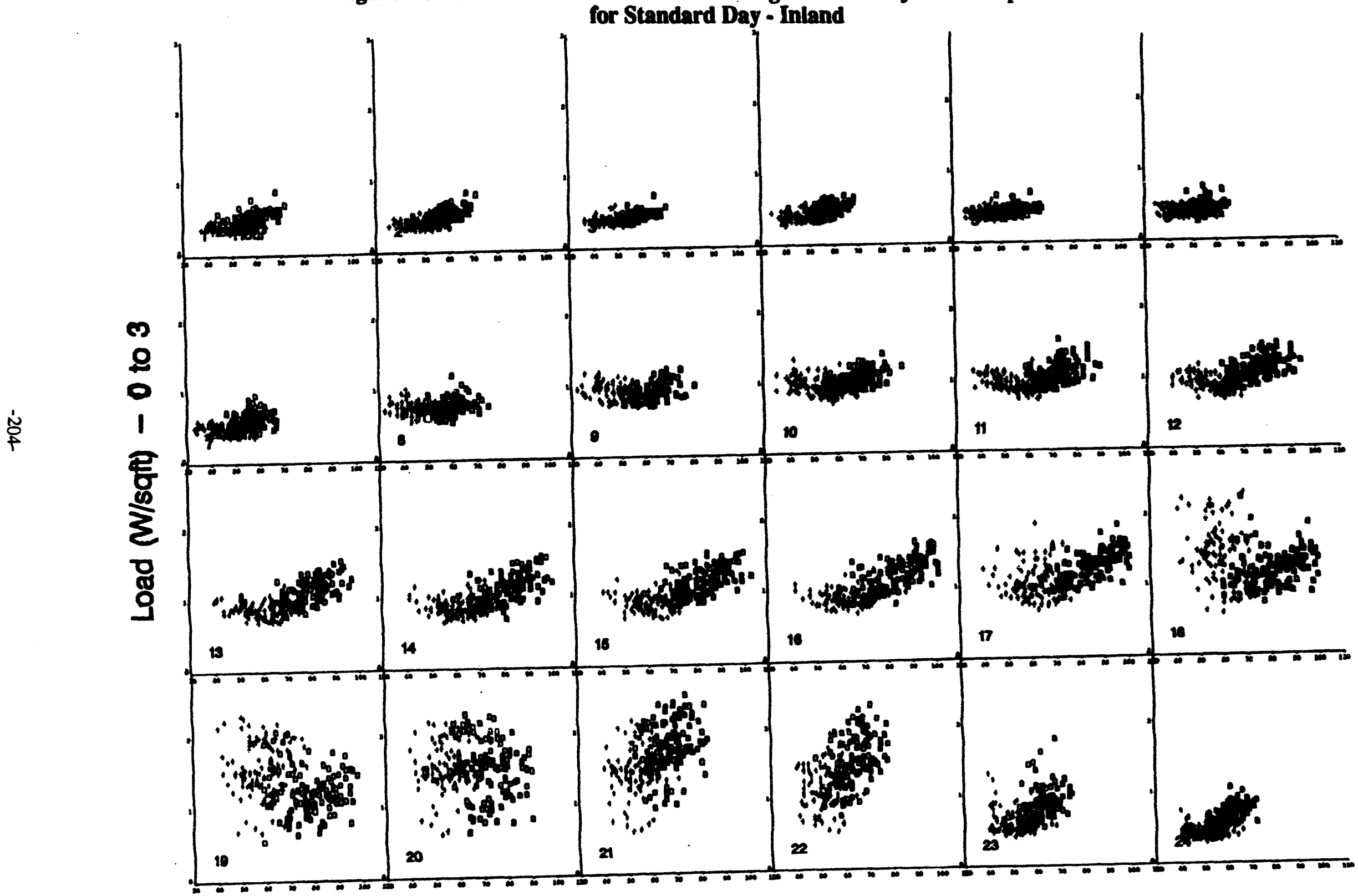

Outside Temperature (F) - $\mathbf{3 0}$ to 110 
Figure 4-33a. Miscellaneous Reconciled Standard Day Annual End-Use LS - Coastal

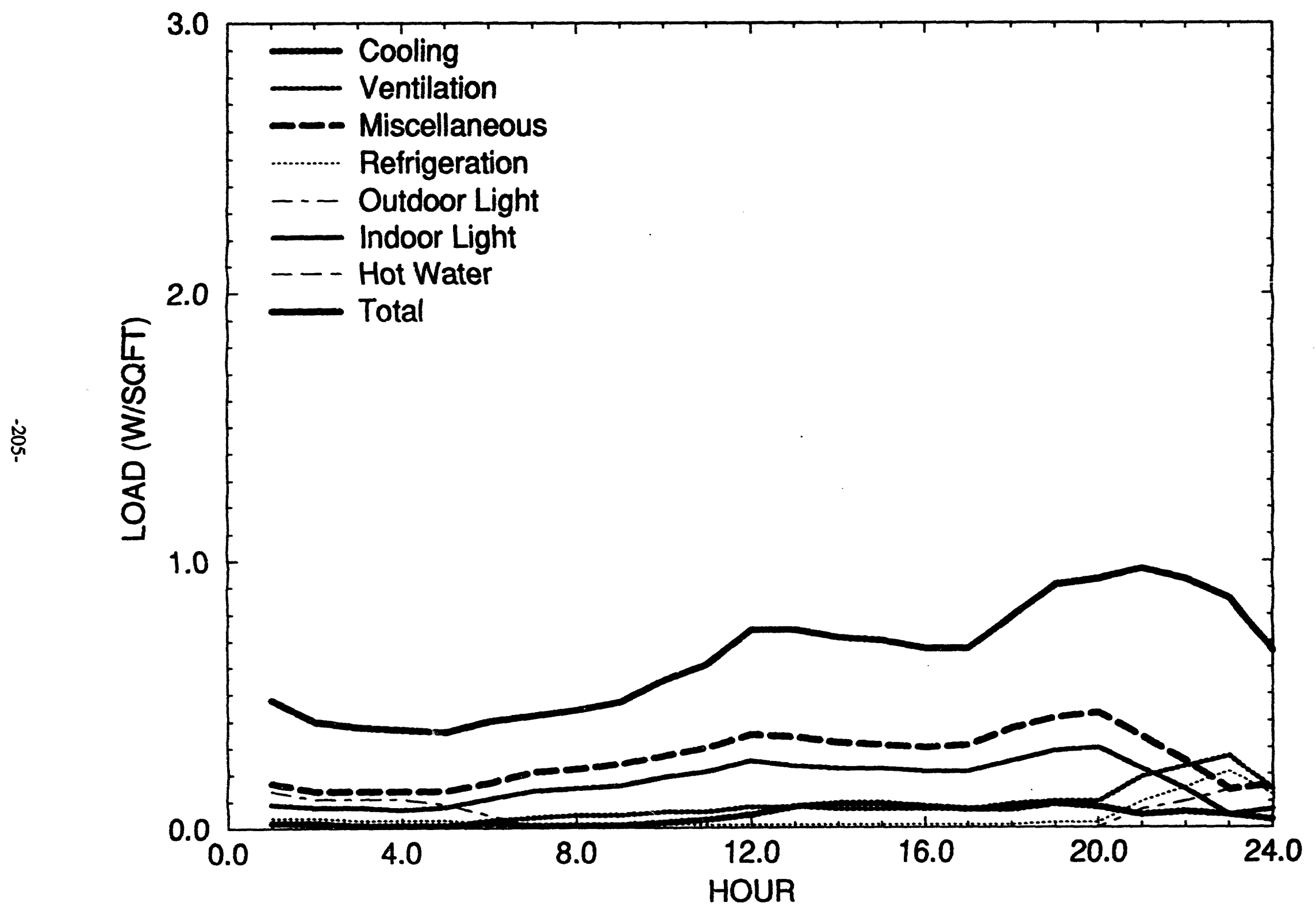


Figure 4-33b. Miscellaneous Reconciled Standard Day Annual End-Use LS - Inland

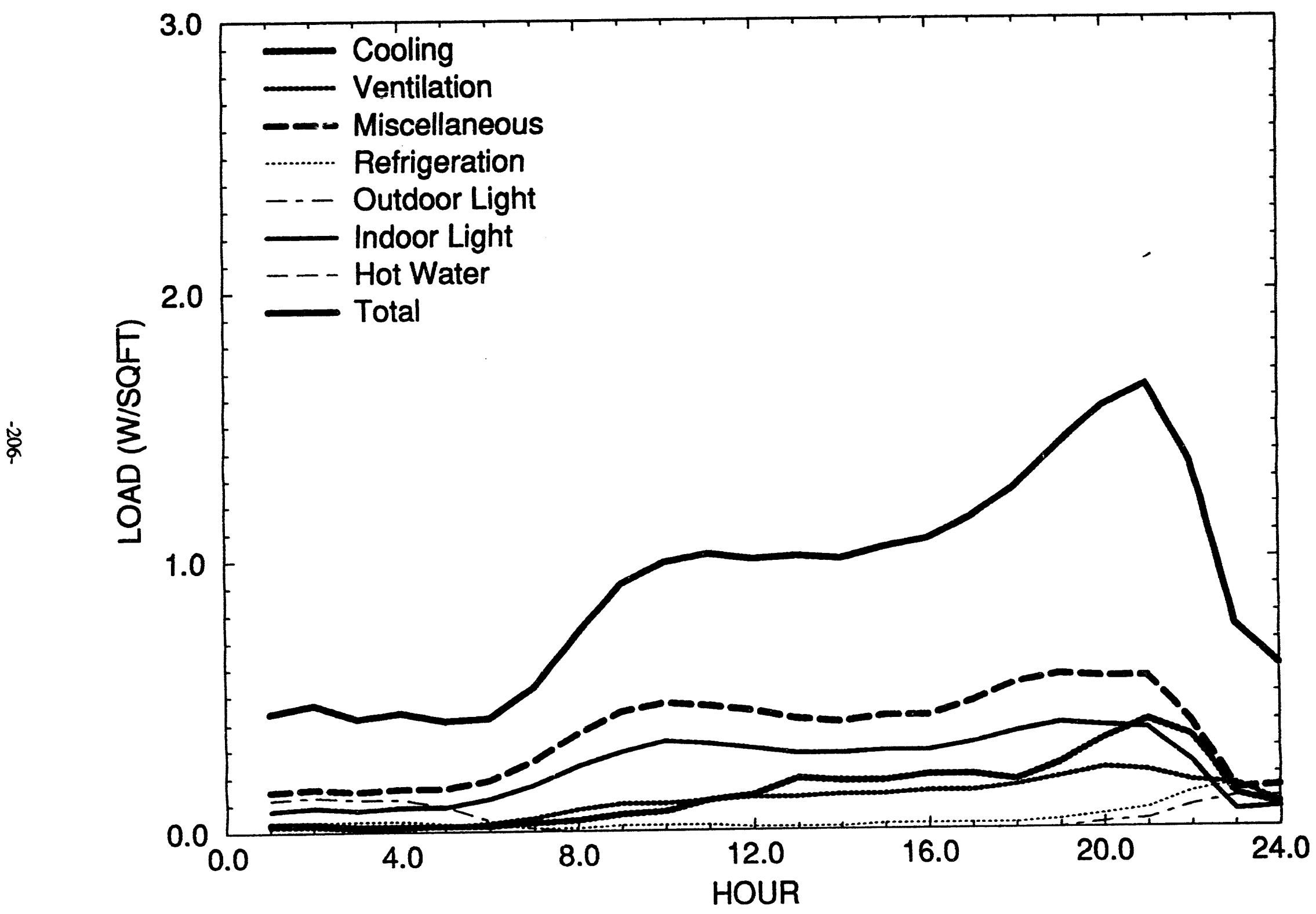


Figure 4-33c. Miscellaneous Reconciled Nonstandard Day Annual End-Use LS-Coastal

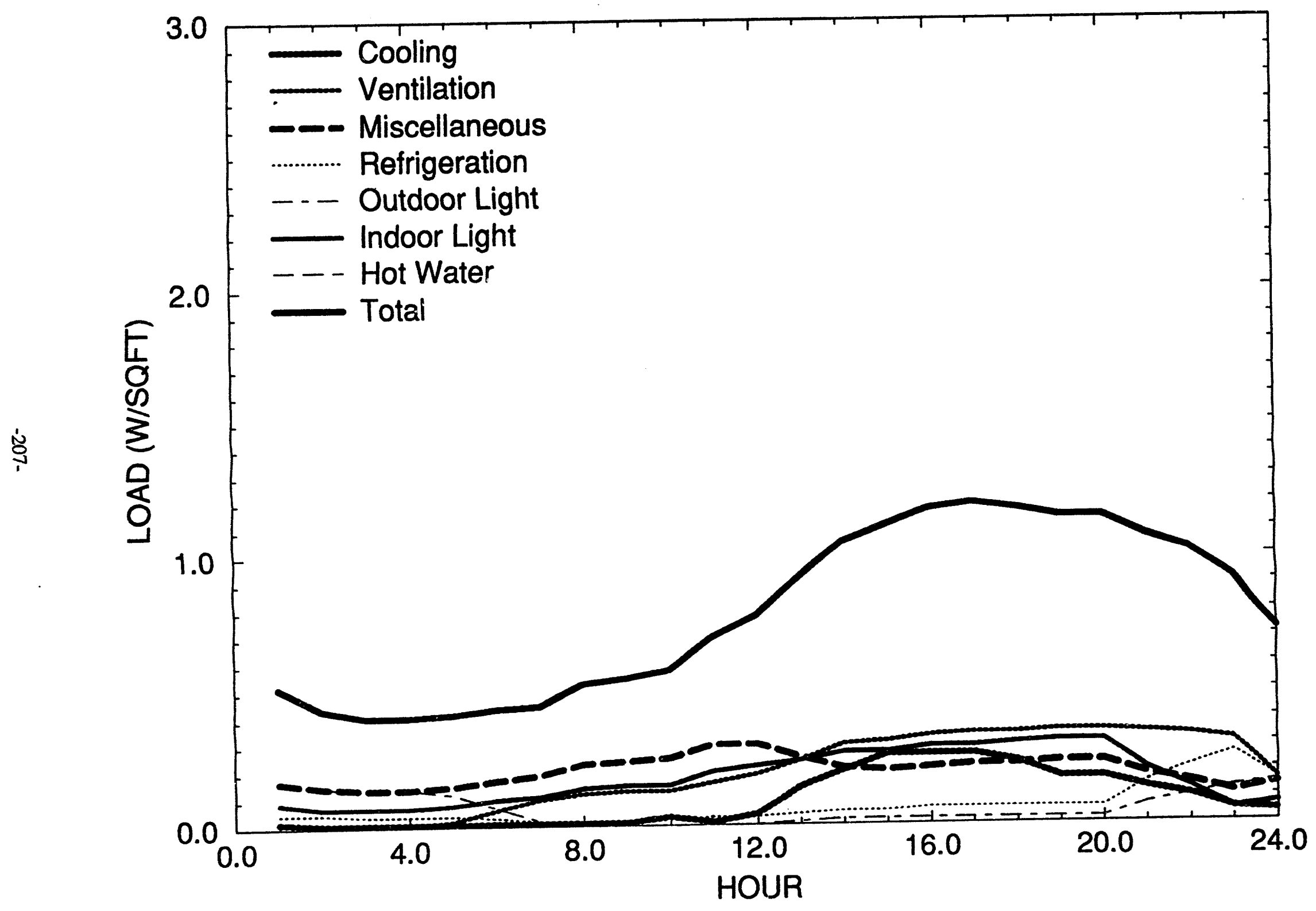


Figure 4-33d. Miscellaneous Reconciled Nonstandard Day Annzal End-Use LS-Inland

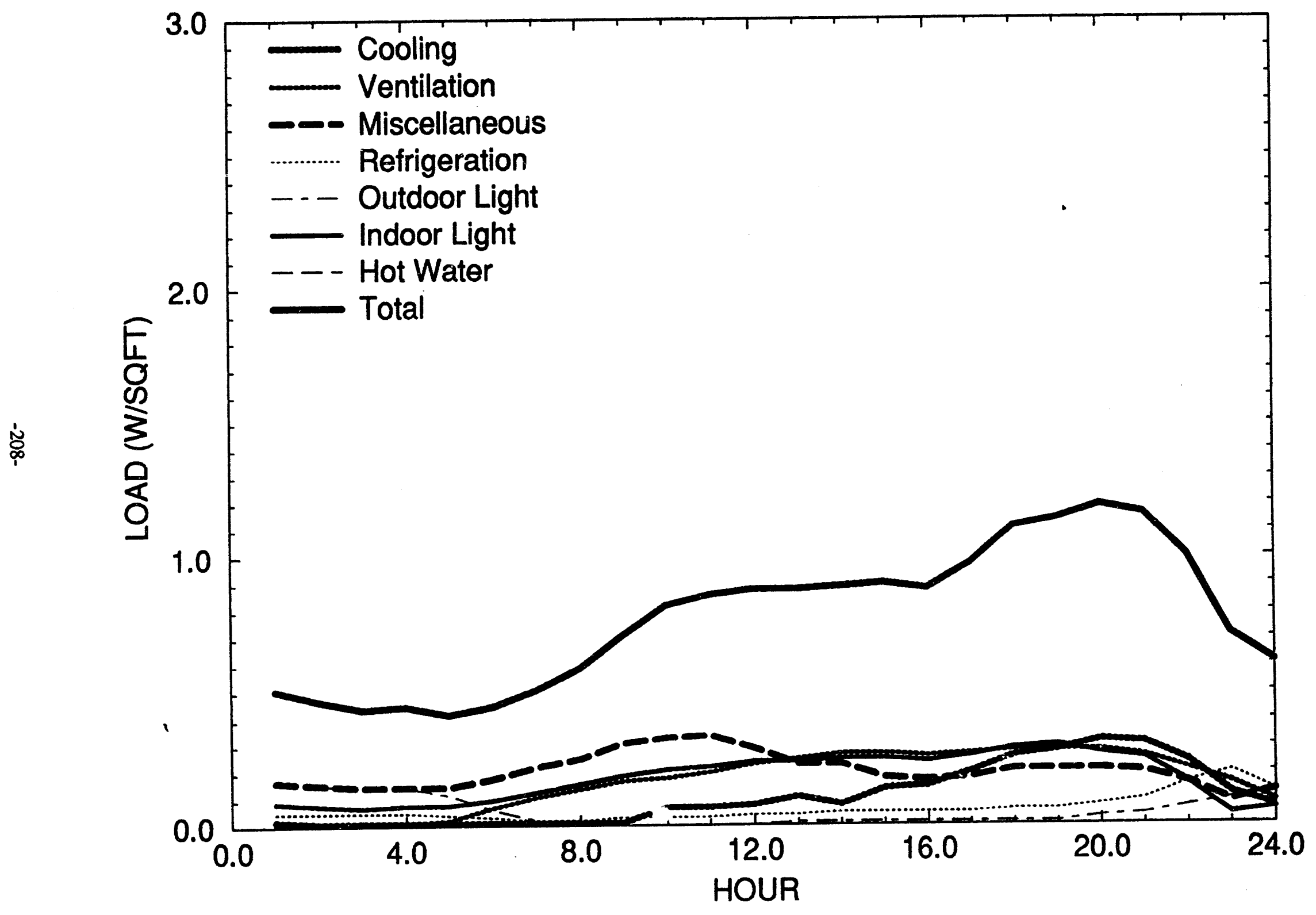




\section{Chapter 5 \\ Forecasting Model Energy Inputs}

This chapter describes the implementation of the methods developed to create a complete set of revised energy inputs for commercial forecasting models used by CEC and PG\&E. The method, which was described in Chapter 2, relies on the reconciled EUIs described in the previous chapter and additional information from the mail and on-site surveys. Based on our current understanding of the CEC and PG\&E models, ine revised model inputs we develop, which have also been formatted in tables according to the specifications of the CEC and PG\&E forecasting models, can be used to replace the current set of CEC and PG\&E model inputs.

Recall that the end-use LSs and EUIs developed through the reconciliation procedures represent a snap-shot of 1986 electricity use by building type and end-use for two regions of the PG\&E service territory. For each building type, this snap-shot represents an aggregation over important distinctions that are explicitly represented within CEC and PG\&E forecasting models. These distinctions include price effects between 1986 and the 1975 model base year, office equipment energy use as a distinct element of miscellaneous electricity use, fuel saturations, and, for space conditioning end uses, the effects of different eras of building and equipment minimum energy efficiency standards. The CEC, in addition, models five distinct climate regions within the PG\&E service territory, rather than the two we have examined. Finally for both models, there are several EUIs that could not be estimated with our reconciliation methodology, including electric space heating (except for lodging) and all non-electric end uses (space heating, water heating, cooking, and miscellaneous).

Chapter 2 described our seven step approach for developing new energy inputs for the CEC and PG\&E model: 1) Development of 1986 EUIs for end-uses not estimated through application of EDA (electric heating, and all non-electric end uses); 2) Re-specification of all 1986 EUIs to a 1975 base year through application of the short price elasticity of demand and the historical prices of energy; 3) Removal of fuel saturation effects for all reconciled electric end uses, except those for which, by definition, the saturation is $100 \%$ (indoor and outdoor lighting, and miscellaneous); 4) Incorporation of previous LBL work to further disaggregate the electric miscellaneous EUI into office equipment and other miscellaneous; 5) For the space conditioning end uses, accounting explicitly for the effects of the first generation of mandatory minimum building energy efficiency standards; 6) For the space conditioning end use specification used by the CEC model, accounting separately for the impacts of equipment energy efficiency; and 7) Finally, for the space conditioning end use specification used by the CEC model, accounting separately for the additional variations in energy use for the 5 sub-regions represented in aggregate by the 2 regions for which explicit reconciliations were performed. 
Intermediate Results for Space Conditioning End Uses

The final three steps of the method address the treatment of space conditioning end uses by the CEC and PG\&E models.

For the CEC model, Tables 5-1, 5-2, and 5-3 show the development of U75 and EUI79-CEC for the two primary climate regions (additional climate regions are treated separately) for the space cooling, space heating, and ventilation end uses, respectively. Table 5-4 shows the DOE-2 simulation adjusted HVAC EUIs for the additional climate regions represented in the CEC model.

For the PG\&E model, Tables 5-5, 5-6, and 5-7 show the development of 1975 and 1979 EUIs for the two PG\&E climate regions for the space cooling, space heating, and ventilation end uses, respectively.

As seen in Tables 5-1 and 5-5 the cooling EUI for the school prototype is the same for both coastal and inland climate regions. The DOE-2 simulations predict more cooling inland than coastal, however the EDA whole-building-load vs dry-bulb-temperature regression correlations indicate that the cooling EUIs for this building is small.

Final Results for Non-Space Conditioning End Uses

Non-hvac electric EUIs and U75s for CEC are shown in Tables 5-8, 5-9, 5-10, 5-11, 5-12, and 5-13 for cooking, hot water, indoor lighting, outdoor lighting, miscellaneous equipment, and refrigeration, respectively. Non-hvac gas EUIs and U75s for CEC are shown in Tables 5-14, 515, and 5-16 for cooking, hot water, and miscellaneous equipment, respectively. Non-hvac electric EUIs for PG\&E are shown in Tables 5-17, 5-18, 5-19, 5-20, 5-21, and 5-22 for cooking, hot water, indoor lighting, outdoor lighting, miscellaneous equipment, and refrigeration, respectively. Non-hvac gas EUIs for PG\&E are shown in Tables 5-23, 5-24, and 5-25 for cooking, hot water, and miscellaneous equipment, respectively.

Note that all non-space conditioning EUIs are the same for the two climate regions with one exception, the warehouse refrigeration end-use, which reflects differences in the proportion of refrigerated versus non-refrigerated warehouses in these regions.

Note in Tables 5-1 through 5-25 the following abbreviations are utilized. Sat: Electricity Saturation, Eff: Equipment Efficiency, A/P: Ratio of Simulated Loads 1975 Vintage to 1986 Prototype, CECe: Weighted Average Energy Conversion Efficiency 1975 Vintage, PrEf: Price Effect, C/A: Ratio of Simulated Loads 1979 Vintage to 1986 Prototype, EffR: Ratio of Weighted Average Energy Conversion Efficiency 1975 Vintage to Weighted Average Energy Conversion Efficiency 1979 Vintage (not used for CEC). 
Revised CEC and PG\&E Forecasting Model Inputs

A final set of tables summarize all project results in the formats used to specify input files for the CEC and PG\&E forecasting models.

Tables 5-26, 5-27, 5-28, 5-29, and 5-30 summarize CEC Vintage 1975 EUIs (U75) for climate regions 1 (Blue Canyon), 2 (Sacramento), 3 (Fresno), 4 (San Jose), and 5 (Oakland), respectively. Tables 5-31, 5-32, 5-33, 5-34, and 5-35 summarize CEC Vintage 1979 EUIs (EUI79CEC) for climate regions 1 (Blue Canyon), 2 (Sacramento), 3 (Fresno), 4 (San Jose), and 5 (Oakland), respectively. Tables 5-36 and 5-37 summarize PG\&E Vintage 1975 EUIs for climate regions Coastal (Oakland) and Inland (Sacramento), respectively. Tables 5-38 and 5-39 summarize PG\&E Vintage 1979 EUIs for climate regions Coastal (Oakland) and Inland (Sacramento), respectively.

CEC U75 and PG\&E 1975 EUIs are in units of [kBtu/sqft/yr]. EUI79-CEC does not include equipment conversion efficiencies and is expressed as a percentage. PG\&E 1979 EUIs include the equipment conversion efficiencies and is expressed in [kBtu/sqft/yr]. Refer to Chapter 2 for definitions of U75, EUI79-CEC, and PG\&E 1975 and 1979 EUIs. 
Table 5-1. CEC Cooling EUIs for 1975 and 1979 Vintages [kBtu/sqft/yr]

\begin{tabular}{|c|c|c|c|c|c|c|c|c|c|c|c|c|}
\hline Building & Region & Fuel & EUI & Sat & Eff & $\bar{A} / \mathbf{P}$ & CECe & PrEf & U75 & $\mathrm{C} / \mathrm{A}$ & EffR & EU179 \\
\hline \multirow[t]{3}{*}{ SmOffice } & OAK & elec & 2.80 & 0.699 & 2.34 & 1.08 & 2.43 & 1.28 & 5.32 & 0.51 & 0.90 & 0.51 \\
\hline & & ngas & ne & 1.000 & 2.34 & 1.08 & 0.53 & 1.09 & 14.46 & 0.51 & 0.74 & 0.51 \\
\hline & & othr & ne & 1.000 & 2.34 & 1.08 & 0.53 & 0.99 & 13.13 & 0.51 & 0.74 & 0.51 \\
\hline \multirow{3}{*}{ SmOffice } & SAC & elec & 10.68 & 0.800 & 2.30 & 1.04 & 2.43 & 1.28 & 16.80 & 0.82 & 0.90 & 0.82 \\
\hline & & ngas & ne & 1.000 & 2.30 & 1.04 & 0.53 & 1.09 & 52.24 & 0.82 & 0.74 & 0.82 \\
\hline & & othr & ne & 1.000 & 2.30 & 1.04 & 0.53 & 0.99 & 47.45 & 0.82 & 0.74 & 0.82 \\
\hline \multirow[t]{3}{*}{ Lg Jffice } & OAK & elec & 13.24 & 0.866 & 3.13 & 1.56 & 3.96 & 1.28 & 24.13 & 0.28 & 0.98 & 0.28 \\
\hline & & ngas & ne & 1.000 & 3.13 & 1.56 & 0.56 & 1.09 & 126.50 & 0.28 & 0.78 & 0.28 \\
\hline & & othr & ne & 1.000 & 3.13 & 1.56 & 0.56 & 0.99 & 114.89 & 0.28 & 0.78 & 0.28 \\
\hline \multirow[t]{3}{*}{ LgOffice } & SAC & elec & 19.48 & 0.917 & 2.90 & 1.45 & 3.96 & 1.28 & 28.38 & 0.45 & 0.98 & 0.45 \\
\hline & & ngas & ne & 1.000 & 2.90 & 1.45 & 0.56 & 1.09 & 160.32 & 0.45 & 0.78 & 0.45 \\
\hline & & othr & ne & 1.000 & 2.90 & 1.45 & 0.56 & 0.99 & 145.61 & 0.45 & 0.78 & 0.45 \\
\hline \multirow[t]{3}{*}{ Retail } & OAK & elec & 2.87 & 0.590 & 1.78 & 1.10 & 3.25 & 1.29 & 3.78 & 0.93 & 0.95 & 0.93 \\
\hline & & ngas & ne & 1.000 & 1.78 & 1.10 & 0.59 & 1.09 & 10.37 & 0.93 & 0.79 & 0.93 \\
\hline & & othr & ne & 1.000 & 1.78 & 1.10 & 0.59 & 0.99 & 9.42 & 0.93 & 0.79 & 0.93 \\
\hline \multirow[t]{3}{*}{ Retail } & SAC & elec & 7.64 & 0.764 & 2.22 & 1.04 & 3.25 & 1.29 & 9.17 & 0.79 & 0.95 & 0.79 \\
\hline & & ngas & ne & 1.000 & 2.22 & 1.04 & 0.59 & 1.09 & 32.60 & 0.79 & 0.79 & 0.79 \\
\hline & & othr & ne & 1.000 & 2.22 & 1.04 & 0.59 & 0.99 & 29.61 & 0.79 & 0.79 & $0.7 y$ \\
\hline \multirow[t]{3}{*}{ Restrnt } & OAK & elec & 8.56 & 0.689 & 2.20 & 1.16 & 2.19 & 1.18 & 17.12 & 0.53 & 0.88 & 0.53 \\
\hline & & ngas & ne & 1.000 & 2.20 & 1.16 & 0.45 & 1.09 & 53.53 & 0.53 & 0.65 & 0.53 \\
\hline & & othr & ne & 1.000 & 2.20 & 1.16 & 0.45 & 0.99 & 48.62 & 0.53 & 0.65 & 0.53 \\
\hline \multirow[t]{3}{*}{ Restrnt } & SAC & elec & 17.64 & 0.843 & 2.21 & 0.83 & 2.19 & 1.18 & 20.72 & 0.67 & 0.88 & 0.67 \\
\hline & & ngas & ne & 1.000 & 2.21 & 0.83 & 0.45 & 1.09 & 79.26 & 0.67 & 0.65 & 0.67 \\
\hline & & Ouir & ne & 1.000 & 2.21 & 0.83 & 0.45 & 0.99 & 71.99 & 0.67 & 0.65 & 0.67 \\
\hline \multirow[t]{3}{*}{ FoodStr } & OAK & elec & 9.42 & 0.760 & 1.43 & 1.31 & 2.03 & 1.33 & 15.21 & 0.84 & 0.87 & 0.84 \\
\hline & & ngas & ne & 1.000 & 1.43 & 1.31 & 0.36 & 1.09 & 53.43 & 0.84 & 0.55 & 0.84 \\
\hline & & othr & ne & 1.000 & 1.43 & 1.31 & 0.36 & 0.99 & 48.53 & 0.84 & 0.55 & 0.84 \\
\hline \multirow[t]{3}{*}{ FoodStr } & SAC & elec & 15.73 & 0.695 & 1.46 & 1.10 & 2.03 & 1.33 & 23.81 & 0.91 & 0.87 & 0.91 \\
\hline & & ngas & ne & 1.000 & 1.46 & 1.10 & 0.36 & 1.09 & 76.49 & 0.91 & 0.55 & 0.91 \\
\hline & & othr & ne & 1.000 & 1.46 & 1.10 & 0.36 & 0.99 & 69.47 & 0.91 & 0.55 & 0.91 \\
\hline \multirow[t]{3}{*}{ Warehse } & OAK & elec & 0.38 & 0.478 & 2.20 & 1.53 & 2.19 & 1.15 & 1.39 & 0.61 & 0.89 & 0.61 \\
\hline & & ngas & ne & 1.000 & 2.20 & 1.53 & 0.43 & 1.09 & 3.21 & 0.61 & 0.63 & 0.61 \\
\hline & & othr & ne & 1.000 & 2.20 & 1.53 & 0.43 & 0.99 & 2.92 & 0.61 & 0.63 & 0.61 \\
\hline \multirow[t]{3}{*}{ Warehse } & SAC & elec & 2.52 & 0.511 & 2.14 & 1.24 & 2.19 & 1.15 & 6.89 & 0.84 & 0.89 & 0.84 \\
\hline & & ngas & ne & 1.000 & 2.14 & 1.24 & 0.43 & 1.09 & 17.02 & 0.84 & 0.63 & 0.84 \\
\hline & & othr & ne & 1.000 & 2.14 & 1.24 & 0.43 & 0.99 & 15.46 & 0.84 & 0.63 & 0.84 \\
\hline \multirow[t]{3}{*}{ School } & OAK & elec & 0.17 & 0.772 & 2.25 & 10.33 & 2.03 & 1.16 & 2.93 & 0.10 & 0.87 & 0.10 \\
\hline & & ngas & ne & 1.000 & 2.25 & 10.33 & 0.30 & 1.09 & 14.22 & 0.10 & 0.62 & 0.10 \\
\hline & & othr & ne & 1.000 & 2.25 & 10.33 & 0.36 & 0.99 & 10.90 & 0.10 & 0.55 & 0.10 \\
\hline \multirow[t]{3}{*}{ School } & SAC & elec & 0.17 & 0.828 & 2.34 & 4.65 & 2.03 & 1.16 & 1.28 & 0.22 & 0.87 & 0.22 \\
\hline & & ngas & ne & 1.000 & 2.34 & 4.65 & 0.30 & 1.09 & 6.66 & 0.22 & 0.62 & 0.22 \\
\hline & & othr & ne & 1.000 & 2.34 & 4.65 & 0.36 & 0.99 & 5.10 & 0.22 & 0.55 & 0.22 \\
\hline
\end{tabular}


Table 5-1. CEC Cooling EUIs for 1975 and 1979 Vintages [kBtu/sqft/yr] (Continued)

\begin{tabular}{|c|c|c|c|c|c|c|c|c|c|c|c|c|}
\hline Building & Region & Fuel & EUI & Sat & Eff & $\bar{A} / \mathrm{P}$ & CECe & PrEf & U75 & CIA & EffR & EUI79 \\
\hline College & $\overline{O A K}$ & $\begin{array}{l}\text { elec } \\
\text { ngas } \\
\text { othr }\end{array}$ & $\begin{array}{c}2.15 \\
\text { ne } \\
\text { ne }\end{array}$ & $\begin{array}{l}0.523 \\
1.000 \\
1.000\end{array}$ & $\begin{array}{l}3.60 \\
3.60 \\
3.60\end{array}$ & $\begin{array}{l}1.60 \\
1.60 \\
1.60\end{array}$ & $\begin{array}{l}2.82 \\
0.49 \\
0.49\end{array}$ & $\begin{array}{l}1.23 \\
1.09 \\
0.99\end{array}$ & $\begin{array}{l}10.31 \\
27.60 \\
25.07\end{array}$ & $\begin{array}{l}0.21 \\
0.21 \\
0.21\end{array}$ & $\begin{array}{l}0.90 \\
0.69 \\
0.69\end{array}$ & $\begin{array}{l}0.21 \\
0.21 \\
0.21\end{array}$ \\
\hline College & SAC & $\begin{array}{l}\text { elec } \\
\text { ngas } \\
\text { othr }\end{array}$ & $\begin{array}{c}4.40 \\
\text { ne } \\
\text { ne }\end{array}$ & $\begin{array}{l}0.946 \\
1.000 \\
1.000\end{array}$ & $\begin{array}{l}3.45 \\
3.45 \\
3.45\end{array}$ & $\begin{array}{l}1.30 \\
1.30 \\
1.30\end{array}$ & $\begin{array}{l}2.82 \\
0.49 \\
0.49\end{array}$ & $\begin{array}{l}1.23 \\
1.09 \\
0.99\end{array}$ & $\begin{array}{c}9.09 \\
44.00 \\
39.97\end{array}$ & $\begin{array}{l}0.28 \\
0.28 \\
0.28\end{array}$ & $\begin{array}{l}0.90 \\
0.69 \\
0.69\end{array}$ & $\begin{array}{l}0.28 \\
0.28 \\
0.28\end{array}$ \\
\hline Health & OAK & $\begin{array}{l}\text { elec } \\
\text { ngas } \\
\text { othr }\end{array}$ & $\begin{array}{c}11.40 \\
\text { ne } \\
\text { ne }\end{array}$ & $\begin{array}{l}0.854 \\
1.000 \\
1.000\end{array}$ & $\begin{array}{l}3.51 \\
3.51 \\
3.51\end{array}$ & $\begin{array}{l}2.20 \\
2.20 \\
2.20\end{array}$ & $\begin{array}{l}3.97 \\
0.56 \\
0.56\end{array}$ & $\begin{array}{l}1.24 \\
1.09 \\
0.99\end{array}$ & $\begin{array}{c}32.20 \\
169.77 \\
154.20\end{array}$ & $\begin{array}{l}0.52 \\
0.52 \\
0.52\end{array}$ & $\begin{array}{l}0.98 \\
0.77 \\
0.77\end{array}$ & $\begin{array}{l}0.52 \\
0.52 \\
0.52\end{array}$ \\
\hline Health & SAC & $\begin{array}{l}\text { elec } \\
\text { ngas } \\
\text { othr }\end{array}$ & $\begin{array}{c}16.17 \\
\text { ne } \\
\text { ne }\end{array}$ & $\begin{array}{l}0.783 \\
1.000 \\
1.000\end{array}$ & $\begin{array}{l}3.60 \\
3.60 \\
3.60\end{array}$ & $\begin{array}{l}1.88 \\
1.88 \\
1.88\end{array}$ & $\begin{array}{l}3.97 \\
0.56 \\
0.56\end{array}$ & $\begin{array}{l}1.24 \\
1.09 \\
0.99\end{array}$ & $\begin{array}{c}43.69 \\
211.17 \\
191.79\end{array}$ & $\begin{array}{l}0.55 \\
0.55 \\
0.55\end{array}$ & $\begin{array}{l}0.98 \\
0.77 \\
0.77\end{array}$ & $\begin{array}{l}0.55 \\
0.55 \\
0.55\end{array}$ \\
\hline Lodging & OAK & $\begin{array}{l}\text { elec } \\
\text { ngas } \\
\text { othr }\end{array}$ & $\begin{array}{c}3.07 \\
\text { ne } \\
\text { ne }\end{array}$ & $\begin{array}{l}0.694 \\
1.000 \\
1.000\end{array}$ & $\begin{array}{l}2.33 \\
2.33 \\
2.33\end{array}$ & $\begin{array}{l}1.69 \\
1.69 \\
1.69\end{array}$ & $\begin{array}{l}4.09 \\
0.59 \\
0.59\end{array}$ & $\begin{array}{l}1.14 \\
1.09 \\
0.99\end{array}$ & $\begin{array}{c}4.85 \\
22.34 \\
20.29\end{array}$ & $\begin{array}{l}0.40 \\
0.40 \\
0.40\end{array}$ & $\begin{array}{l}0.98 \\
0.79 \\
0.79\end{array}$ & $\begin{array}{l}0.40 \\
0.40 \\
0.40\end{array}$ \\
\hline Lodging & SAC & $\begin{array}{l}\text { elec } \\
\text { ngas } \\
\text { othr }\end{array}$ & $\begin{array}{c}4.54 \\
\text { ne } \\
\text { ne }\end{array}$ & $\begin{array}{l}0.957 \\
1.000 \\
1.000\end{array}$ & $\begin{array}{l}2.03 \\
2.03 \\
2.03\end{array}$ & $\begin{array}{l}0.75 \\
0.75 \\
0.75\end{array}$ & $\begin{array}{l}4.09 \\
0.59 \\
0.59\end{array}$ & $\begin{array}{l}1.14 \\
1.09 \\
0.99\end{array}$ & $\begin{array}{c}2.01 \\
12.76 \\
11.59\end{array}$ & $\begin{array}{l}0.31 \\
0.31 \\
0.31\end{array}$ & $\begin{array}{l}0.98 \\
0.79 \\
0.79\end{array}$ & $\begin{array}{l}0.31 \\
0.31 \\
0.31\end{array}$ \\
\hline Miscellns & OAK & $\begin{array}{l}\text { elec } \\
\text { ngas } \\
\text { othr }\end{array}$ & $\begin{array}{c}1.81 \\
\text { ne } \\
\text { ne }\end{array}$ & $\begin{array}{l}0.272 \\
1.000 \\
1.000\end{array}$ & $\begin{array}{l}1.75 \\
1.75 \\
1.75\end{array}$ & $\begin{array}{l}2.74 \\
2.74 \\
2.74\end{array}$ & $\begin{array}{l}2.47 \\
0.38 \\
0.38\end{array}$ & $\begin{array}{l}1.16 \\
1.09 \\
0.99\end{array}$ & $\begin{array}{l}14.97 \\
24.81 \\
22.53\end{array}$ & $\begin{array}{l}0.58 \\
0.58 \\
0.58\end{array}$ & $\begin{array}{l}0.89 \\
0.65 \\
0.65\end{array}$ & $\begin{array}{l}0.58 \\
0.58 \\
0.58\end{array}$ \\
\hline Miscellns & SAC & $\begin{array}{c}\text { elec } \\
\text { ngas } \\
\text { othr }\end{array}$ & $\begin{array}{c}3.75 \\
\text { ne } \\
\text { ne }\end{array}$ & $\begin{array}{l}0.773 \\
1.000 \\
1.000\end{array}$ & $\begin{array}{l}2.01 \\
2.01 \\
2.01\end{array}$ & $\begin{array}{l}1.75 \\
1.75 \\
1.75\end{array}$ & $\begin{array}{l}2.47 \\
0.38 \\
0.38\end{array}$ & $\begin{array}{l}1.16 \\
1.09 \\
0.99\end{array}$ & $\begin{array}{c}8.02 \\
37.77 \\
34.30\end{array}$ & $\begin{array}{l}0.82 \\
0.82 \\
0.82\end{array}$ & $\begin{array}{l}0.89 \\
0.65 \\
0.65\end{array}$ & $\begin{array}{l}0.82 \\
0.82 \\
0.82\end{array}$ \\
\hline
\end{tabular}


Table 5-2. CEC Heating EUIs for 1975 and 1979 Vintages [kBtu/sqft/yr]

\begin{tabular}{|c|c|c|c|c|c|c|c|c|c|c|c|}
\hline Building & Region & Fuel & EUI & Eff & $\bar{A} \sqrt{P}$ & CECe & PrEf & U75 & C/A & EffR & EUT79 \\
\hline SmOffice & OAK & $\begin{array}{l}\text { elec } \\
\text { ngas } \\
\text { othr }\end{array}$ & $\begin{array}{c}\text { ne } \\
9.11 \\
\text { ne }\end{array}$ & $\begin{array}{l}0.52 \\
0.52 \\
0.52\end{array}$ & $\begin{array}{l}0.97 \\
0.97 \\
0.97\end{array}$ & $\begin{array}{l}1.27 \\
0.66 \\
0.66\end{array}$ & $\begin{array}{l}1.28 \\
1.09 \\
0.99\end{array}$ & $\begin{array}{l}4.65 \\
7.60 \\
6.89\end{array}$ & $\begin{array}{l}0.75 \\
0.75 \\
0.75\end{array}$ & $\begin{array}{l}0.88 \\
0.89 \\
0.90\end{array}$ & $\begin{array}{l}0.75 \\
0.75 \\
0.75\end{array}$ \\
\hline SmOffice & SAC & $\begin{array}{l}\text { elec } \\
\text { ngas } \\
\text { othr }\end{array}$ & $\begin{array}{c}\text { ne } \\
13.38 \\
\text { ne }\end{array}$ & $\begin{array}{l}0.57 \\
0.57 \\
0.57\end{array}$ & $\begin{array}{l}0.99 \\
0.99 \\
0.99\end{array}$ & $\begin{array}{l}1.27 \\
0.66 \\
0.66\end{array}$ & $\begin{array}{l}1.28 \\
1.09 \\
0.99\end{array}$ & $\begin{array}{c}7.63 \\
12.49 \\
11.33\end{array}$ & $\begin{array}{l}0.76 \\
0.76 \\
0.76\end{array}$ & $\begin{array}{l}0.88 \\
0.89 \\
0.90\end{array}$ & $\begin{array}{l}0.76 \\
0.76 \\
0.76\end{array}$ \\
\hline LgOffice & OAK & $\begin{array}{l}\text { elec } \\
\text { ngas } \\
\text { othr }\end{array}$ & $\begin{array}{c}\text { ne } \\
2.14 \\
\text { ne }\end{array}$ & $\begin{array}{l}0.80 \\
0.80 \\
0.80\end{array}$ & $\begin{array}{l}5.83 \\
5.83 \\
5.83\end{array}$ & $\begin{array}{l}0.95 \\
0.66 \\
0.66\end{array}$ & $\begin{array}{l}1.28 \\
1.09 \\
0.99\end{array}$ & $\begin{array}{l}13.45 \\
16.48 \\
14.97\end{array}$ & $\begin{array}{l}0.75 \\
0.75 \\
0.75\end{array}$ & $\begin{array}{l}1.00 \\
0.88 \\
0.88\end{array}$ & $\begin{array}{l}0.75 \\
0.75 \\
0.75\end{array}$ \\
\hline LgOffice & SAC & $\begin{array}{l}\text { elec } \\
\text { ngas } \\
\text { othr }\end{array}$ & $\begin{array}{c}\text { ne } \\
3.80 \\
\text { ne }\end{array}$ & $\begin{array}{l}0.73 \\
0.73 \\
0.73\end{array}$ & $\begin{array}{l}4.23 \\
4.23 \\
4.23\end{array}$ & $\begin{array}{l}0.95 \\
0.66 \\
0.66\end{array}$ & $\begin{array}{l}1.28 \\
1.09 \\
0.99\end{array}$ & $\begin{array}{l}15.81 \\
19.38 \\
17.60\end{array}$ & $\begin{array}{l}0.77 \\
0.77 \\
0.77\end{array}$ & $\begin{array}{l}1.00 \\
0.88 \\
0.88\end{array}$ & $\begin{array}{l}0.77 \\
0.77 \\
0.77\end{array}$ \\
\hline Retail & OAK & $\begin{array}{l}\text { elec } \\
\text { ngas } \\
\text { othr }\end{array}$ & $\begin{array}{c}\text { ne } \\
11.42 \\
\text { ne }\end{array}$ & $\begin{array}{l}0.59 \\
0.59 \\
0.59\end{array}$ & $\begin{array}{l}0.96 \\
0.96 \\
0.96\end{array}$ & $\begin{array}{l}1.47 \\
0.66 \\
0.66\end{array}$ & $\begin{array}{l}1.29 \\
1.09 \\
0.99\end{array}$ & $\begin{array}{c}5.68 \\
10.68 \\
9.70\end{array}$ & $\begin{array}{l}0.56 \\
0.56 \\
0.56\end{array}$ & $\begin{array}{l}0.84 \\
0.88 \\
0.94\end{array}$ & $\begin{array}{l}0.56 \\
0.56 \\
0.56\end{array}$ \\
\hline Retail & SAC & $\begin{array}{l}\text { elec } \\
\text { ngas } \\
\text { othr }\end{array}$ & $\begin{array}{c}\text { ne } \\
17.29 \\
\text { ne }\end{array}$ & $\begin{array}{l}0.60 \\
0.60 \\
0.60\end{array}$ & $\begin{array}{l}0.96 \\
0.96 \\
0.96\end{array}$ & $\begin{array}{l}1.47 \\
0.66 \\
0.66\end{array}$ & $\begin{array}{l}1.29 \\
1.09 \\
0.99\end{array}$ & $\begin{array}{c}8.75 \\
16.45 \\
14.94\end{array}$ & $\begin{array}{l}0.57 \\
0.57 \\
0.57\end{array}$ & $\begin{array}{l}0.84 \\
0.88 \\
0.94\end{array}$ & $\begin{array}{l}0.57 \\
0.57 \\
0.57\end{array}$ \\
\hline Restrnt & OAK & $\begin{array}{l}\text { elec } \\
\text { ngas } \\
\text { othr }\end{array}$ & $\begin{array}{c}\text { ne } \\
24.42 \\
\text { ne }\end{array}$ & $\begin{array}{l}0.46 \\
0.46 \\
0.46\end{array}$ & $\begin{array}{l}0.89 \\
0.89 \\
0.89\end{array}$ & $\begin{array}{l}1.07 \\
0.66 \\
0.66\end{array}$ & $\begin{array}{l}1.18 \\
1.09 \\
0.99\end{array}$ & $\begin{array}{l}11.04 \\
16.51 \\
15.00\end{array}$ & $\begin{array}{l}0.54 \\
0.54 \\
0.54\end{array}$ & $\begin{array}{l}0.95 \\
0.89 \\
1.00\end{array}$ & $\begin{array}{l}0.54 \\
0.54 \\
0.54\end{array}$ \\
\hline Restrnt & SAC & $\begin{array}{l}\text { elec } \\
\text { ngas } \\
\text { othr }\end{array}$ & $\begin{array}{c}\text { ne } \\
33.55 \\
\text { ne }\end{array}$ & $\begin{array}{l}0.52 \\
0.52 \\
0.52\end{array}$ & $\begin{array}{l}0.86 \\
0.86 \\
0.86\end{array}$ & $\begin{array}{l}1.07 \\
0.66 \\
0.66\end{array}$ & $\begin{array}{l}1.18 \\
1.09 \\
0.99\end{array}$ & $\begin{array}{l}16.56 \\
24.78 \\
22.51\end{array}$ & $\begin{array}{l}0.56 \\
0.56 \\
0.56\end{array}$ & $\begin{array}{l}0.95 \\
0.89 \\
1.00\end{array}$ & $\begin{array}{l}0.56 \\
0.57 \\
0.56\end{array}$ \\
\hline FoodStr & OAK & $\begin{array}{l}\text { elec } \\
\text { ngas } \\
\text { othr }\end{array}$ & $\begin{array}{c}\text { ne } \\
46.54 \\
\text { ne }\end{array}$ & $\begin{array}{l}0.54 \\
0.54 \\
0.54\end{array}$ & $\begin{array}{l}0.98 \\
0.98 \\
0.98\end{array}$ & $\begin{array}{l}1.15 \\
0.66 \\
0.66\end{array}$ & $\begin{array}{l}1.33 \\
1.09 \\
0.99\end{array}$ & $\begin{array}{l}28.48 \\
40.68 \\
36.94\end{array}$ & $\begin{array}{l}0.96 \\
0.96 \\
0.96\end{array}$ & $\begin{array}{l}0.92 \\
0.93 \\
1.00\end{array}$ & $\begin{array}{l}0.96 \\
0.96 \\
0.96\end{array}$ \\
\hline FoodStr & SAC & $\begin{array}{l}\text { elec } \\
\text { ngas } \\
\text { othr }\end{array}$ & $\begin{array}{c}\text { ne } \\
46.65 \\
\text { ne }\end{array}$ & $\begin{array}{l}0.44 \\
0.44 \\
0.44\end{array}$ & $\begin{array}{l}0.98 \\
0.98 \\
0.98\end{array}$ & $\begin{array}{l}1.15 \\
0.66 \\
0.66\end{array}$ & $\begin{array}{l}1.33 \\
1.09 \\
0.99\end{array}$ & $\begin{array}{l}23.26 \\
33.22 \\
30.17\end{array}$ & $\begin{array}{l}0.96 \\
0.96 \\
0.96\end{array}$ & $\begin{array}{l}0.92 \\
0.93 \\
1.00\end{array}$ & $\begin{array}{l}0.96 \\
0.96 \\
0.96\end{array}$ \\
\hline Warehse & OAK & $\begin{array}{l}\text { elec } \\
\text { ngas } \\
\text { othr }\end{array}$ & $\begin{array}{c}\text { ne } \\
14.71 \\
\text { ne }\end{array}$ & $\begin{array}{l}0.53 \\
0.53 \\
0.53\end{array}$ & $\begin{array}{l}1.46 \\
1.46 \\
1.46\end{array}$ & $\begin{array}{l}1.00 \\
0.66 \\
0.66\end{array}$ & $\begin{array}{l}1.15 \\
1.09 \\
0.99\end{array}$ & $\begin{array}{l}13.09 \\
18.80 \\
17.07\end{array}$ & $\begin{array}{l}0.79 \\
0.79 \\
0.79\end{array}$ & $\begin{array}{l}1.00 \\
0.92 \\
0.92\end{array}$ & $\begin{array}{l}0.79 \\
0.79 \\
0.79\end{array}$ \\
\hline Warehse & SAC & $\begin{array}{l}\text { elec } \\
\text { ngas } \\
\text { othr }\end{array}$ & $\begin{array}{c}\text { ne } \\
17.78 \\
\text { ne }\end{array}$ & $\begin{array}{l}0.55 \\
0.55 \\
0.55\end{array}$ & $\begin{array}{l}1.53 \\
1.53 \\
1.53\end{array}$ & $\begin{array}{l}1.00 \\
0.66 \\
0.66\end{array}$ & $\begin{array}{l}1.15 \\
1.09 \\
0.99\end{array}$ & $\begin{array}{l}17.21 \\
24.71 \\
22.44\end{array}$ & $\begin{array}{l}0.80 \\
0.80 \\
0.80\end{array}$ & $\begin{array}{l}1.00 \\
0.92 \\
0.92\end{array}$ & $\begin{array}{l}0.80 \\
0.80 \\
0.80\end{array}$ \\
\hline School & OAK & $\begin{array}{l}\text { elec } \\
\text { ngas } \\
\text { othr }\end{array}$ & $\begin{array}{c}\text { ne } \\
15.21 \\
\text { ne }\end{array}$ & $\begin{array}{l}0.60 \\
0.60 \\
0.60\end{array}$ & $\begin{array}{l}5.25 \\
5.25 \\
5.25\end{array}$ & $\begin{array}{l}1.04 \\
0.66 \\
0.66\end{array}$ & $\begin{array}{l}1.16 \\
1.09 \\
0.99\end{array}$ & $\begin{array}{l}53.49 \\
79.13 \\
71.87\end{array}$ & $\begin{array}{l}0.20 \\
0.20 \\
0.20\end{array}$ & $\begin{array}{l}0.96 \\
0.88 \\
0.88\end{array}$ & $\begin{array}{l}0.20 \\
0.20 \\
0.20\end{array}$ \\
\hline School & SAC & $\begin{array}{l}\text { elec } \\
\text { ngas } \\
\text { othr }\end{array}$ & $\begin{array}{c}\text { ne } \\
17.19 \\
\text { ne }\end{array}$ & $\begin{array}{l}0.61 \\
0.61 \\
0.61\end{array}$ & $\begin{array}{l}5.00 \\
5.00 \\
5.00\end{array}$ & $\begin{array}{l}1.04 \\
0.66 \\
0.66\end{array}$ & $\begin{array}{l}1.16 \\
1.09 \\
0.99\end{array}$ & $\begin{array}{l}58.54 \\
86.59 \\
78.64\end{array}$ & $\begin{array}{l}0.20 \\
0.20 \\
0.20\end{array}$ & $\begin{array}{l}0.96 \\
0.88 \\
0.88\end{array}$ & $\begin{array}{l}0.20 \\
0.20 \\
0.20\end{array}$ \\
\hline
\end{tabular}


Table 5-2. CEC Heating EUIs for 1975 and 1979 Vintages [kBtu/sqft/yr] (Continued)

\begin{tabular}{|c|c|c|c|c|c|c|c|c|c|c|c|}
\hline Building & Region & Fuel & EUI & Eff & $\mathrm{A} \sqrt{\mathrm{P}}$ & CECe & PrEf & U75 & C/A & EffR & EUI79 \\
\hline College & OAK & $\begin{array}{l}\text { elec } \\
\text { ngas } \\
\text { othr }\end{array}$ & $\begin{array}{c}\text { ne } \\
14.62 \\
\text { ne }\end{array}$ & $\begin{array}{l}0.74 \\
0.74 \\
0.74\end{array}$ & $\begin{array}{l}0.69 \\
0.69 \\
0.69\end{array}$ & $\begin{array}{l}1.02 \\
0.66 \\
0.66\end{array}$ & $\begin{array}{l}1.23 \\
1.09 \\
0.99\end{array}$ & $\begin{array}{c}9.02 \\
12.33 \\
11.20\end{array}$ & $\begin{array}{l}0.20 \\
0.20 \\
0.20\end{array}$ & $\begin{array}{l}0.97 \\
0.88 \\
0.88\end{array}$ & $\begin{array}{l}0.20 \\
0.20 \\
0.20\end{array}$ \\
\hline College & SAC & $\begin{array}{c}\text { elec } \\
\text { ngas } \\
\text { othr }\end{array}$ & $\begin{array}{c}\text { ne } \\
14.46 \\
\text { ne }\end{array}$ & $\begin{array}{l}0.73 \\
0.73 \\
0.73\end{array}$ & $\begin{array}{l}0.71 \\
0.71 \\
0.71\end{array}$ & $\begin{array}{l}1.02 \\
0.66 \\
0.66\end{array}$ & $\begin{array}{l}1.23 \\
1.09 \\
0.99\end{array}$ & $\begin{array}{c}9.06 \\
12.38 \\
11.24\end{array}$ & $\begin{array}{l}0.20 \\
0.20 \\
0.20\end{array}$ & $\begin{array}{l}0.97 \\
0.88 \\
0.88\end{array}$ & $\begin{array}{l}0.20 \\
0.20 \\
0.20\end{array}$ \\
\hline Health & OAK & $\begin{array}{l}\text { elec } \\
\text { ngas } \\
\text { othr }\end{array}$ & $\begin{array}{c}\text { ne } \\
3.66 \\
\text { ne }\end{array}$ & $\begin{array}{l}0.67 \\
0.67 \\
0.67\end{array}$ & $\begin{array}{l}8.06 \\
8.06 \\
8.06\end{array}$ & $\begin{array}{l}1.90 \\
0.66 \\
0.66\end{array}$ & $\begin{array}{l}1.24 \\
1.09 \\
0.99\end{array}$ & $\begin{array}{l}12.90 \\
32.64 \\
29.65\end{array}$ & $\begin{array}{l}0.15 \\
0.15 \\
0.15\end{array}$ & $\begin{array}{l}0.79 \\
0.88 \\
0.88\end{array}$ & $\begin{array}{l}0.15 \\
0.15 \\
0.15\end{array}$ \\
\hline Health & SAC & $\begin{array}{c}\text { elec } \\
\text { ngas } \\
\text { othr }\end{array}$ & $\begin{array}{c}\text { ne } \\
5.54 \\
\text { ne }\end{array}$ & $\begin{array}{l}0.71 \\
0.71 \\
0.71\end{array}$ & $\begin{array}{l}5.16 \\
5.16 \\
5.16\end{array}$ & $\begin{array}{l}1.90 \\
0.66 \\
0.66\end{array}$ & $\begin{array}{l}1.24 \\
1.09 \\
0.99\end{array}$ & $\begin{array}{l}13.25 \\
33.52 \\
30.44\end{array}$ & $\begin{array}{l}0.21 \\
0.21 \\
0.21\end{array}$ & $\begin{array}{l}0.79 \\
0.88 \\
0.88\end{array}$ & $\begin{array}{l}0.21 \\
0.21 \\
0.21\end{array}$ \\
\hline Lodging & OAK & $\begin{array}{c}\text { elec } \\
\text { ngas } \\
\text { othr }\end{array}$ & $\begin{array}{c}5.83 \\
23.50 \\
\text { ne }\end{array}$ & $\begin{array}{l}0.55 \\
0.55 \\
0.55\end{array}$ & $\begin{array}{l}1.19 \\
1.19 \\
1.19\end{array}$ & $\begin{array}{l}1.76 \\
0.66 \\
0.66\end{array}$ & $\begin{array}{l}1.14 \\
1.09 \\
0.99\end{array}$ & $\begin{array}{r}2.47 \\
25.40 \\
23.07\end{array}$ & $\begin{array}{l}0.57 \\
0.57 \\
0.57\end{array}$ & $\begin{array}{l}0.81 \\
0.88 \\
0.96\end{array}$ & $\begin{array}{l}0.57 \\
0.57 \\
0.57\end{array}$ \\
\hline Lodging & SAC & $\begin{array}{l}\text { elec } \\
\text { ngas } \\
\text { othr }\end{array}$ & $\begin{array}{c}8.15 \\
37.54 \\
\text { ne }\end{array}$ & $\begin{array}{l}0.61 \\
0.61 \\
0.61\end{array}$ & $\begin{array}{l}0.69 \\
0.69 \\
0.69\end{array}$ & $\begin{array}{l}1.76 \\
0.66 \\
0.66\end{array}$ & $\begin{array}{l}1.14 \\
1.09 \\
0.99\end{array}$ & $\begin{array}{c}2.22 \\
26.09 \\
23.70\end{array}$ & $\begin{array}{l}0.33 \\
0.33 \\
0.33\end{array}$ & $\begin{array}{l}0.81 \\
0.88 \\
0.96\end{array}$ & $\begin{array}{l}0.33 \\
0.33 \\
0.33\end{array}$ \\
\hline Miscellns & OAK & $\begin{array}{l}\text { elec } \\
\text { ngas } \\
\text { othr }\end{array}$ & $\begin{array}{c}\text { ne } \\
7.55 \\
\text { ne }\end{array}$ & $\begin{array}{l}0.44 \\
0.44 \\
0.44\end{array}$ & $\begin{array}{l}2.38 \\
2.38 \\
2.38\end{array}$ & $\begin{array}{l}1.49 \\
0.66 \\
0.66\end{array}$ & $\begin{array}{l}1.16 \\
1.09 \\
0.99\end{array}$ & $\begin{array}{c}6.18 \\
13.06 \\
11.86\end{array}$ & $\begin{array}{l}0.31 \\
0.31 \\
0.31\end{array}$ & $\begin{array}{l}0.85 \\
0.90 \\
0.93\end{array}$ & $\begin{array}{l}0.31 \\
0.31 \\
0.31\end{array}$ \\
\hline Miscellns & SAC & $\begin{array}{l}\text { elec } \\
\text { ngas } \\
\text { othr }\end{array}$ & $\begin{array}{c}\text { ne } \\
8.16 \\
\text { ne }\end{array}$ & $\begin{array}{l}0.48 \\
0.48 \\
0.48\end{array}$ & $\begin{array}{l}2.29 \\
2.29 \\
2.29\end{array}$ & $\begin{array}{l}1.49 \\
0.66 \\
0.66\end{array}$ & $\begin{array}{l}1.16 \\
1.09 \\
0.99\end{array}$ & $\begin{array}{c}7.01 \\
14.81 \\
13.45\end{array}$ & $\begin{array}{l}0.35 \\
0.35 \\
0.35\end{array}$ & $\begin{array}{l}0.85 \\
0.90 \\
0.93\end{array}$ & $\begin{array}{l}0.35 \\
0.35 \\
0.35\end{array}$ \\
\hline
\end{tabular}


Table 5-3. CEC Ventilation EUIs for 1975 and 1979 Vintages [kBtu/sqft/yr]

\begin{tabular}{|ll|rrrrrr|}
\hline Building & Region & EUI & Sat & A/P & PrEf & U75 & EUI79 \\
\hline SmOffice & OAK & 0.75 & 0.699 & 1.00 & 1.28 & 1.37 & 1.00 \\
& SAC & 1.94 & 0.800 & 1.05 & 1.28 & 3.27 & 0.89 \\
LgOffice & OAK & 10.17 & 0.866 & 1.09 & 1.28 & 16.38 & 0.64 \\
& SAC & 13.75 & 0.917 & 1.10 & 1.28 & 21.11 & 0.64 \\
Retail & OAK & 1.16 & 0.590 & 1.00 & 1.29 & 2.54 & 0.96 \\
& SAC & 2.73 & 0.764 & 1.01 & 1.29 & 4.65 & 0.87 \\
Restrnt & OAK & 14.84 & 0.689 & 0.77 & 1.18 & 19.57 & 0.73 \\
& SAC & 19.55 & 0.843 & 0.75 & 1.18 & 20.52 & 0.70 \\
FoodStr & OAK & 11.63 & 0.760 & 1.03 & 1.33 & 20.97 & 0.97 \\
& SAC & 15.12 & 0.695 & 1.03 & 1.33 & 29.79 & 0.95 \\
Warehse & OAK & 3.72 & 0.478 & 0.98 & 1.15 & 8.77 & 0.95 \\
& SAC & 3.14 & 0.511 & 1.08 & 1.15 & 7.63 & 0.92 \\
School & OAK & 1.57 & 0.772 & 1.23 & 1.16 & 2.90 & 0.82 \\
& SAC & 2.12 & 0.828 & 1.36 & 1.16 & 4.03 & 0.75 \\
College & OAK & 3.62 & 0.523 & 0.80 & 1.23 & 6.80 & 0.25 \\
& SAC & 4.88 & 0.946 & 0.82 & 1.23 & 5.20 & 0.29 \\
Health & OAK & 6.89 & 0.854 & 1.22 & 1.24 & 12.21 & 0.80 \\
& SAC & 8.50 & 0.783 & 1.23 & 1.24 & 16.55 & 0.80 \\
Lodging & OAK & 2.05 & 0.694 & 1.19 & 1.14 & 4.00 & 0.56 \\
& SAC & 4.33 & 0.957 & 0.68 & 1.14 & 3.51 & 0.34 \\
Miscellns & OAK & 3.65 & 0.272 & 1.00 & 1.16 & 15.57 & 1.00 \\
& SAC & 3.86 & 0.773 & 1.00 & 1.16 & 5.79 & 1.00 \\
\hline
\end{tabular}


Table 5-4. CEC Regional 1986 HVAC EUIs [kBtu/sqft/yr]

\begin{tabular}{|c|c|c|c|c|c|c|c|c|c|}
\hline Building & Region & End-Use & EUI & DOE- & Simula & Ratio & & gional E & \\
\hline & & & & $1 / 5$ & $3 / 2$ & $4 / 2$ & $\operatorname{Reg}_{1} 1$ & $\operatorname{Reg} 3$ & $\operatorname{Reg}_{4} 4$ \\
\hline SMALLOFFICE & Coastal & Cool & 2.80 & 0.26 & $\cdot$ & - & 0.72 & - & - \\
\hline & (Reg_5) & Heat & 9.11 & 2.00 & - & - & 18.24 & - & - \\
\hline & & Vent & 0.75 & 1.00 & - & $\cdot$ & 0.75 & - & - \\
\hline & Inland & Cool & 10.68 & - & 1.43 & 0.57 & - & 15.28 & 6.08 \\
\hline & (Reg_2) & Heat & 13.38 & - & 1.44 & 0.96 & - & 19.27 & 12.82 \\
\hline & & Vent & 1.94 & $\therefore$ & 1.09 & 0.93 & - & 2.13 & 1.82 \\
\hline LARGEOFFICE & Coastal & Cool & 13.24 & 0.64 & - & - & 8.47 & $\cdot$ & - \\
\hline & (Reg_5) & Heat & 2.14 & 2.78 & - & - & 5.95 & - & - \\
\hline & & Vent & 10.17 & 0.96 & $\cdot$ & - & 9.81 & - & - \\
\hline & Inland & Cool & 19.48 & - & 1.11 & 0.76 & - & 21.56 & 14.88 \\
\hline & (Reg_2) & Heat & 3.80 & - & 1.76 & 0.97 & - & 6.70 & 3.68 \\
\hline & & Vent & 13.75 & $\therefore$ & 1.02 & 0.96 & $\therefore$ & 13.97 & 13.24 \\
\hline RETAII & Coastal & Cool & 2.87 & 0.45 & - & - & 1.30 & - & - \\
\hline & $(\operatorname{Reg}[5)$ & Heat & 11.42 & 1.79 & - & - & 20.48 & - & - \\
\hline & & Vent & 1.16 & 1.00 & - & - & 1.16 & - & - \\
\hline & Inland & Cool & 7.64 & - & 1.49 & 0.42 & - & 11.42 & 3.24 \\
\hline & (Reg_2) & Heat & 17.29 & - & 1.35 & 0.93 & - & 23.39 & 16.01 \\
\hline & & Vent & 2.73 & - & 1.05 & 0.85 & - & 2.86 & 2.32 \\
\hline RESTAURANT & Coastal & Cool & 8.56 & 0.28 & - & - & 2.36 & - & - \\
\hline & (Reg_5) & Heat & 24.42 & 2.48 & - & - & 60.63 & - & - \\
\hline & & Vent & 14.84 & 0.91 & $\cdot$ & - & 13.55 & - & - \\
\hline & Inland & Cool & 17.64 & - & 1.35 & 0.55 & - & 23.90 & 9.74 \\
\hline & (Reg_2) & Heat & 33.55 & - & 1.20 & 0.96 & - & 40.18 & 32.09 \\
\hline & & Vent & 19.55 & - & 1.13 & 0.96 & - & 22.05 & 18.85 \\
\hline GROCERY & Coastal & Cool & 9.42 & 0.84 & - & - & 7.91 & - & - \\
\hline & (Reg_5) & Heat & 46.54 & 1.86 & - & - & 86.39 & - & - \\
\hline & & Vent & 11.63 & 1.15 & - & - & 13.42 & - & - \\
\hline & Inland & Cool & 15.73 & - & 1.83 & 0.58 & - & 28.74 & 9.08 \\
\hline & (Reg_2) & Heat & 46.65 & - & 1.12 & 1.07 & - & 52.33 & 49.99 \\
\hline & & Vent & 15.12 & - & 1.18 & 0.97 & - & 17.89 & 14.60 \\
\hline WAREHOUSE & Coastal & Cool & 0.38 & 0.22 & - & $\cdot$ & 0.08 & - & - \\
\hline & (Reg_5) & Heat & 14.71 & 2.33 & - & - & 34.28 & - & - \\
\hline & & Vent & 3.72 & 0.93 & - & - & 3.45 & - & - \\
\hline & Inland & Cool & 2.52 & - & 1.89 & 0.58 & - & 4.78 & 1.46 \\
\hline & (Reg_2) & Heat & 17.78 & - & 0.99 & 1.07 & - & 17.53 & 19.07 \\
\hline & & Vent & 3.14 & - & 1.19 & 0.94 & - & 3.75 & 2.95 \\
\hline SCHOOL & Coastal & Cool & 0.17 & 0.22 & - & - & 0.04 & - & - \\
\hline & (Reg_5) & Heat & 15.21 & 2.24 & - & - & 34.08 & - & - \\
\hline & & Vent & 1.57 & 1.00 & - & - & 1.57 & - & - \\
\hline & Inland & Cool & 0.17 & - & 1.71 & 0.49 & - & 0.29 & 0.08 \\
\hline & (Reg_2) & Heat & 17.19 & - & 1.25 & 1.10 & - & 21.48 & 18.83 \\
\hline & & Vent & 2.12 & - & 1.10 & 0.95 & - & 2.32 & 2.00 \\
\hline
\end{tabular}


Table 5-4. CEC Regional 1986 HVAC EUIs [kBtu/sqft/yr] (Continued)

\begin{tabular}{|c|c|c|c|c|c|c|c|c|c|}
\hline Building & Region & End-Use & EUI & $\overline{\mathrm{DOE}}$ & imula & Ratio & & gional E & \\
\hline & & & & $1 / 5$ & $3 / 2$ & $4 / 2$ & $\operatorname{Reg}_{1}$ & $\operatorname{Reg}_{3}$ & $\operatorname{Reg} 4$ \\
\hline COLLEGE & Coastal & Cool & 2.15 & 0.45 & - & $\cdot$ & 0.96 & - & 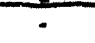 \\
\hline & (Reg_5) & Heat & 14.62 & 1.53 & - & - & 22.39 & - & - \\
\hline & & Vent & 3.62 & 0.99 & - & - & 3.59 & - & - \\
\hline & Inland & Cool & 4.40 & 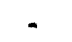 & 1.05 & 0.76 & - & 4.64 & 3.33 \\
\hline & (Reg_2) & Heat & 14.46 & - & 1.03 & 1.06 & - & 14.94 & 15.38 \\
\hline & & Vent & 4.88 & - & 1.01 & 0.93 & - & 4.93 & 4.52 \\
\hline HEALTH & Coastal & Cool & 11.40 & 0.47 & - & - & 5.32 & - & - \\
\hline & (Reg_5) & Heat & 3.66 & 2.55 & - & - & 9.33 & - & - \\
\hline & & Vent & 6.89 & 0.87 & - & - & 5.97 & - & • \\
\hline & Inland & Cool & 16.17 & - & 1.13 & 0.85 & - & 18.25 & 13.70 \\
\hline & (Reg 2) & Heat & 5.54 & - & 1.52 & 1.02 & - & 8.41 & 5.65 \\
\hline & & Vent & 8.50 & - & 1.04 & 0.97 & - & 8.80 & 8.22 \\
\hline LODGING & Coastal & Cool & 3.07 & 0.35 & - & - & 1.07 & - & - \\
\hline & (Reg_5) & Heat & 23.50 & 1.81 & - & - & 42.54 & - & . \\
\hline & & Heat_e & 5.83 & 1.81 & - & - & 10.55 & - & - \\
\hline & & Vent & 2.05 & 0.84 & - & - & 1.72 & - & . \\
\hline & Inland & Cool & 4.54 & - & 1.30 & 0.56 & - & 5.89 & 2.52 \\
\hline & $(\operatorname{Reg} 2)$ & Heat & 37.54 & - & 1.08 & 1.08 & - & 40.54 & 40.54 \\
\hline & & Heat_e & 8.15 & - & 1.08 & 1.08 & - & 8.80 & 8.80 \\
\hline & & Vent & 4.33 & - & 0.86 & 0.83 & - & 3.72 & 3.59 \\
\hline MISCELLNS & Coastal & Cool & 1.81 & 0.33 & 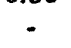 & - & 0.60 & - & - \\
\hline & (Reg_5) & Heat & 7.55 & 2.66 & - & - & 20.05 & - & - \\
\hline & & Vent & 3.65 & 1.00 & - & - & 3.65 & - & - \\
\hline & Inland & Cool & 3.75 & - & 2.17 & 0.66 & 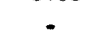 & 8.16 & 2.49 \\
\hline & (Reg_2) & Heat & 8.16 & - & 1.09 & 0.99 & - & 8.88 & 8.04 \\
\hline & & Vent & 3.86 & - & 1.00 & 1.00 & - & 3.86 & 3.86 \\
\hline
\end{tabular}


Table 5-5. PG\&E Cooling EUls for 1975 and 1979 Vintages [kBtu/sqft/yr]

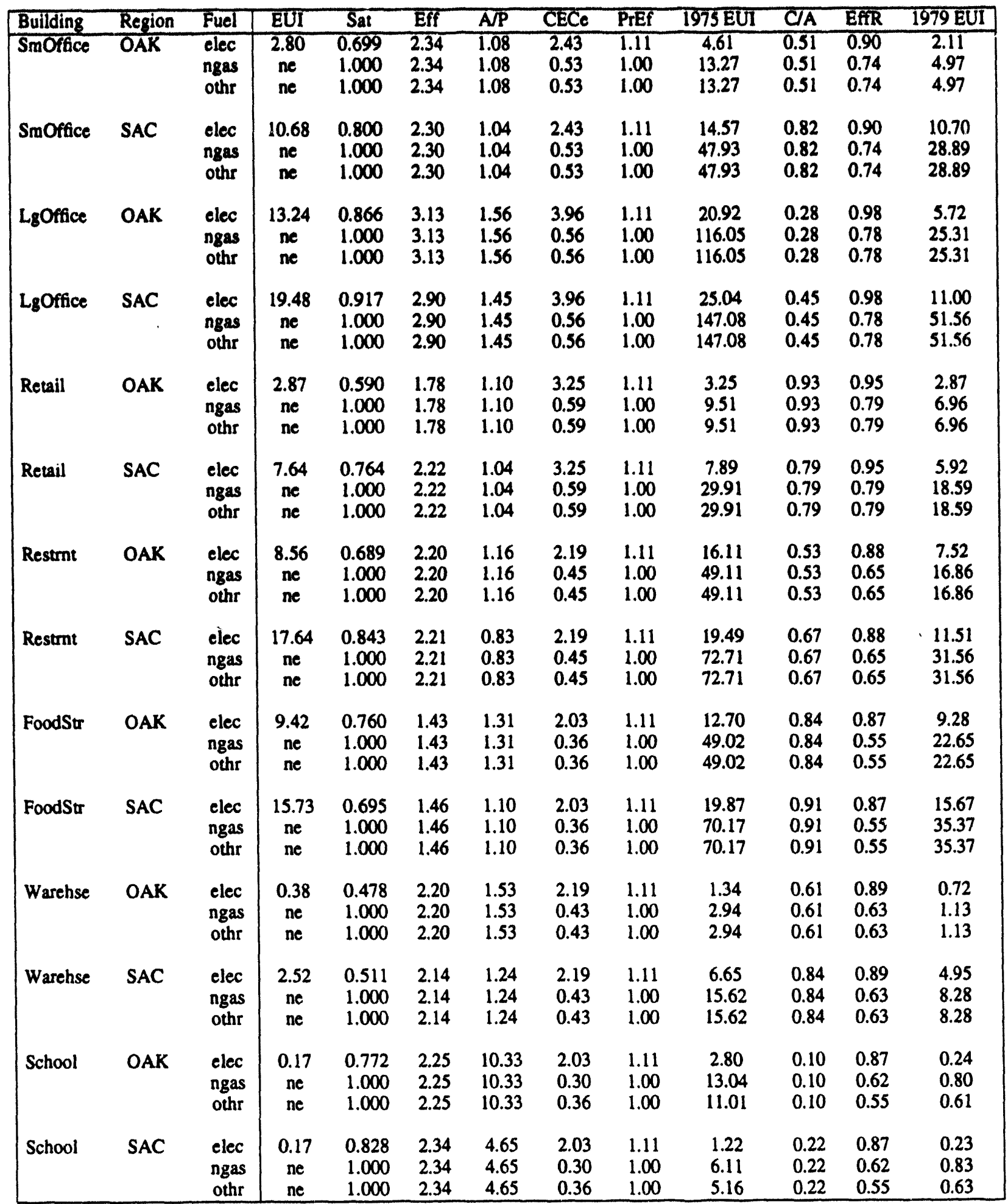


Table 5-5. PG\&E Cooling EUIs for 1975 and 1979 Vintages [kBtw/sqft/yr] (Continued)

\begin{tabular}{|c|c|c|c|c|c|c|c|c|c|c|c|c|}
\hline Building & Region & Fuel & EUI & Sat & Eff & $\bar{A} \mathbf{P}$ & CECe & PrEf & 1975 EUI & C/A & EffR & 1979 EUI \\
\hline College & OAK & $\begin{array}{l}\text { elec } \\
\text { ngas } \\
\text { othr }\end{array}$ & $\begin{array}{l}2.15 \\
\text { ne } \\
\text { ne }\end{array}$ & $\begin{array}{l}0.523 \\
1.000 \\
1.000\end{array}$ & $\begin{array}{l}3.60 \\
3.60 \\
3.60\end{array}$ & $\begin{array}{l}1.60 \\
1.60 \\
1.60\end{array}$ & $\begin{array}{l}2.82 \\
0.49 \\
0.49\end{array}$ & $\begin{array}{l}1.11 \\
1.00 \\
1.00\end{array}$ & $\begin{array}{c}9.31 \\
25.32 \\
25.32\end{array}$ & $\begin{array}{l}0.21 \\
0.21 \\
0.21\end{array}$ & $\begin{array}{l}0.90 \\
0.69 \\
0.69\end{array}$ & $\begin{array}{l}1.76 \\
3.68 \\
3.68\end{array}$ \\
\hline College & SAC & $\begin{array}{l}\text { elec } \\
\text { ngas } \\
\text { othr }\end{array}$ & $\begin{array}{l}4.40 \\
\text { ne } \\
\text { ne }\end{array}$ & $\begin{array}{l}0.946 \\
1.000 \\
1.000\end{array}$ & $\begin{array}{l}3.45 \\
3.45 \\
3.45\end{array}$ & $\begin{array}{l}1.30 \\
1.30 \\
1.30\end{array}$ & $\begin{array}{l}2.82 \\
0.49 \\
0.49\end{array}$ & $\begin{array}{l}1.11 \\
1.00 \\
1.00\end{array}$ & $\begin{array}{c}8.21 \\
40.37 \\
40.37\end{array}$ & $\begin{array}{l}0.28 \\
0.28 \\
0.28\end{array}$ & $\begin{array}{l}0.90 \\
0.69 \\
0.69\end{array}$ & $\begin{array}{l}2.07 \\
7.83 \\
7.83\end{array}$ \\
\hline Health & OAK & $\begin{array}{l}\text { elec } \\
\text { ngas } \\
\text { othr }\end{array}$ & $\begin{array}{c}11.40 \\
\text { ne } \\
\text { ne }\end{array}$ & $\begin{array}{l}0.854 \\
1.000 \\
1.000\end{array}$ & $\begin{array}{l}3.51 \\
3.51 \\
3.51\end{array}$ & $\begin{array}{l}2.20 \\
2.20 \\
2.20\end{array}$ & $\begin{array}{l}3.97 \\
0.56 \\
0.56\end{array}$ & $\begin{array}{l}1.11 \\
1.00 \\
1.00\end{array}$ & $\begin{array}{l}28.83 \\
155.75 \\
155.75\end{array}$ & $\begin{array}{l}0.52 \\
0.52 \\
0.52\end{array}$ & $\begin{array}{l}0.98 \\
0.77 \\
0.77\end{array}$ & $\begin{array}{l}14.70 \\
62.01 \\
62.01\end{array}$ \\
\hline Health & SAC & $\begin{array}{l}\text { elec } \\
\text { ngas } \\
\text { othr }\end{array}$ & $\begin{array}{c}16.17 \\
\text { ne } \\
\text { ne }\end{array}$ & $\begin{array}{l}0.783 \\
1.000 \\
1.000\end{array}$ & $\begin{array}{l}3.60 \\
3.60 \\
3.60\end{array}$ & $\begin{array}{l}1.88 \\
1.88 \\
1.88\end{array}$ & $\begin{array}{l}3.97 \\
0.56 \\
0.56\end{array}$ & $\begin{array}{l}1.11 \\
1.00 \\
1.00\end{array}$ & $\begin{array}{c}39.11 \\
193.73 \\
193.73\end{array}$ & $\begin{array}{l}0.55 \\
0.55 \\
0.55\end{array}$ & $\begin{array}{l}0.98 \\
0.77 \\
0.77\end{array}$ & $\begin{array}{l}21.09 \\
81.57 \\
81.57\end{array}$ \\
\hline Lodging & OAK & $\begin{array}{l}\text { elec } \\
\text { ngas } \\
\text { othr }\end{array}$ & $\begin{array}{l}3.07 \\
\text { ne } \\
\text { ne }\end{array}$ & $\begin{array}{l}0.694 \\
1.000 \\
1.000\end{array}$ & $\begin{array}{l}2.33 \\
2.33 \\
2.33\end{array}$ & $\begin{array}{l}1.69 \\
1.69 \\
1.69\end{array}$ & $\begin{array}{l}4.09 \\
0.59 \\
0.59\end{array}$ & $\begin{array}{l}1.11 \\
1.00 \\
1.00\end{array}$ & $\begin{array}{c}4.73 \\
20.49 \\
20.49\end{array}$ & $\begin{array}{l}0.40 \\
0.40 \\
0.40\end{array}$ & $\begin{array}{l}0.98 \\
0.79 \\
0.79\end{array}$ & $\begin{array}{l}1.86 \\
6.45 \\
6.45\end{array}$ \\
\hline Lodging & SAC & $\begin{array}{l}\text { elec } \\
\text { ngas } \\
\text { othr }\end{array}$ & $\begin{array}{l}4.54 \\
\text { ne } \\
\text { ne }\end{array}$ & $\begin{array}{l}0.957 \\
1.000 \\
1.000\end{array}$ & $\begin{array}{l}2.03 \\
2.03 \\
2.03\end{array}$ & $\begin{array}{l}0.75 \\
0.75 \\
0.75\end{array}$ & $\begin{array}{l}4.09 \\
0.59 \\
0.59\end{array}$ & $\begin{array}{l}1.11 \\
1.00 \\
1.00\end{array}$ & $\begin{array}{c}1.96 \\
11.71 \\
11.71\end{array}$ & $\begin{array}{l}0.31 \\
0.31 \\
0.31\end{array}$ & $\begin{array}{l}0.98 \\
0.79 \\
0.79\end{array}$ & $\begin{array}{l}0.60 \\
2.86 \\
2.86\end{array}$ \\
\hline Miscellns & OAK & $\begin{array}{l}\text { elec } \\
\text { ngas } \\
\text { othr }\end{array}$ & $\begin{array}{c}1.81 \\
\text { ne } \\
\text { ne }\end{array}$ & $\begin{array}{l}0.272 \\
1.000 \\
1.000\end{array}$ & $\begin{array}{l}1.75 \\
1.75 \\
1.75\end{array}$ & $\begin{array}{l}2.74 \\
2.74 \\
2.74\end{array}$ & $\begin{array}{l}2.47 \\
0.38 \\
0.38\end{array}$ & $\begin{array}{l}1.11 \\
1.00 \\
1.00\end{array}$ & $\begin{array}{l}14.33 \\
22.76 \\
22.76\end{array}$ & $\begin{array}{l}0.58 \\
0.58 \\
0.58\end{array}$ & $\begin{array}{l}0.89 \\
0.65 \\
0.65\end{array}$ & $\begin{array}{l}7.38 \\
8.55 \\
8.55\end{array}$ \\
\hline Miscellns & SAC & $\begin{array}{c}\text { elec } \\
\text { ngas } \\
\text { othr } \\
\end{array}$ & $\begin{array}{c}3.75 \\
\text { ne } \\
\text { ne }\end{array}$ & $\begin{array}{l}0.773 \\
1.000 \\
1.000 \\
\end{array}$ & $\begin{array}{l}2.01 \\
2.01 \\
2.01\end{array}$ & $\begin{array}{l}1.75 \\
1.75 \\
1.75 \\
\end{array}$ & $\begin{array}{l}2.47 \\
0.38 \\
0.38 \\
\end{array}$ & $\begin{array}{l}1.11 \\
1.00 \\
1.00 \\
\end{array}$ & $\begin{array}{c}7.68 \\
34.65 \\
34.65\end{array}$ & $\begin{array}{l}0.82 \\
0.82 \\
0.82 \\
\end{array}$ & $\begin{array}{l}0.89 \\
0.65 \\
0.65 \\
\end{array}$ & $\begin{array}{c}5.59 \\
18.41 \\
18.41 \\
\end{array}$ \\
\hline
\end{tabular}


Table 5-6. PG\&E Heating EUIs for 1975 and 1979 Vintages [kBtu/sqft/yr]

\begin{tabular}{|c|c|c|c|c|c|c|c|c|c|c|c|}
\hline Building & Region & Fuel & EUI & Eff & $\bar{A} \sqrt{P}$ & CECe & PrEf & 1975 EUI & $\mathbf{C} / \mathbf{A}$ & EffR & $1979 \mathrm{EUI}$ \\
\hline \multirow[t]{3}{*}{ SmOffice } & OAK & elec & ne & 0.52 & 0.97 & 1.27 & 1.14 & 4.14 & 0.75 & 0.88 & 2.74 \\
\hline & & ngas & 9.11 & 0.52 & 0.97 & 0.66 & 1.32 & 9.20 & 0.75 & 0.89 & 6.11 \\
\hline & & othr & ne & 0.52 & 0.97 & 0.66 & 1.00 & 6.96 & 0.75 & 0.90 & 4.70 \\
\hline \multirow[t]{3}{*}{ SmOffice } & SAC & elec & ne & 0.57 & 0.99 & 1.27 & 1.14 & 6.80 & 0.76 & 0.88 & 4.57 \\
\hline & & ngas & 13.38 & 0.57 & 0.99 & 0.66 & 1.32 & 15.12 & 0.76 & 0.89 & 10.18 \\
\hline & & othr & ne & 0.57 & 0.99 & 0.66 & 1.00 & 11.44 & 0.76 & 0.90 & 7.83 \\
\hline \multirow[t]{3}{*}{ LgOffice } & OAK & elec & ne & 0.80 & 5.83 & 0.95 & 1.14 & 11.98 & 0.75 & 1.00 & 8.98 \\
\hline & & ngas & 2.14 & $\begin{array}{l}0.80 \\
0.80\end{array}$ & $\begin{array}{l}5.83 \\
5.83\end{array}$ & 0.66 & 1.32 & $\begin{array}{l}19.96 \\
15.12\end{array}$ & $\begin{array}{l}0.75 \\
075\end{array}$ & $\begin{array}{l}0.88 \\
0.88\end{array}$ & $\begin{array}{c}13.17 \\
9.98\end{array}$ \\
\hline & & & & & & & & & & & \\
\hline \multirow[t]{3}{*}{ LgOffice } & SAC & elec & ne & 0.73 & 4.23 & 0.95 & 1.14 & 14.08 & 0.77 & 1.00 & 10.84 \\
\hline & & ngas & 3.80 & 0.73 & 4.23 & 0.66 & 1.32 & 23.47 & 0.77 & 0.88 & 15.90 \\
\hline & & othr & ne & 0.73 & 4.23 & 0.66 & 1.00 & 17.78 & 0.77 & 0.88 & 12.05 \\
\hline \multirow{3}{*}{ Retail } & OAK & elec & ne & 0.59 & 0.96 & 1.47 & 1.14 & 5.02 & 0.56 & 0.84 & 2.37 \\
\hline & & ngas & 11.42 & 0.59 & 0.96 & 0.66 & 1.32 & 12.94 & 0.56 & 0.88 & 6.40 \\
\hline & & othr & ne & 0.59 & 0.96 & 0.66 & 1.00 & 9.80 & 0.56 & 0.94 & 5.14 \\
\hline \multirow[t]{3}{*}{ Retail } & SAC & elec & ne & 0.60 & 0.96 & 1.47 & 1.14 & 7.73 & 0.57 & 0.84 & 3.72 \\
\hline & & ngas & 17.29 & 0.60 & 0.96 & 0.66 & 1.32 & 19.92 & 0.57 & 0.88 & 10.03 \\
\hline & & othr & ne & 0.60 & 0.96 & 0.66 & 1.00 & 15.09 & 0.57 & 0.94 & 8.05 \\
\hline \multirow[t]{3}{*}{ Restrnt } & OAK & elec & ne & 0.46 & 0.89 & 1.07 & 1.14 & 10.66 & 0.54 & 0.95 & 5.47 \\
\hline & & ngas & 24.42 & 0.46 & 0.89 & 0.66 & 1.32 & 20.00 & 0.54 & 0.89 & 9.60 \\
\hline & & othr & ne & 0.46 & 0.89 & 0.66 & 1.00 & 15.15 & 0.54 & 1.00 & 8.18 \\
\hline \multirow[t]{3}{*}{ Restrnt } & SAC & elec & ne & 0.52 & 0.86 & 1.07 & 1.14 & 16.00 & 0.56 & 0.95 & 8.51 \\
\hline & & ngas & 33.55 & 0.52 & 0.86 & 0.66 & 1.32 & 30.01 & 0.56 & 0.89 & 15.21 \\
\hline & & othr & ne & 0.52 & 0.86 & 0.66 & 1.00 & 22.73 & 0.56 & 1.00 & 12.73 \\
\hline \multirow[t]{3}{*}{ FoodStr } & OAK & elec & ne & 0.54 & 0.98 & 1.15 & 1.14 & 24.46 & 0.96 & 0.92 & 21.60 \\
\hline & & ngas & 46.54 & 0.54 & 0.98 & 0.66 & 1.32 & 49.26 & 0.96 & 0.93 & 45.40 \\
\hline & & othr & ne & 0.54 & 0.98 & 0.66 & 1.00 & 37.32 & 0.96 & 1.00 & 35.83 \\
\hline \multirow[t]{3}{*}{ FoodStr } & SAC & elec & ne & 0.44 & 0.98 & 1.15 & 1.14 & 19.97 & 0.96 & 0.92 & 17.64 \\
\hline & & ngas & 46.65 & 0.44 & 0.98 & 0.66 & 1.32 & 40.23 & 0.96 & 0.93 & 35.92 \\
\hline & & othr & ne & 0.44 & 0.98 & 0.66 & 1.00 & 30.48 & 0.96 & 1.00 & 29.26 \\
\hline \multirow[t]{3}{*}{ Warehse } & OAK & elec & ne & 0.53 & 1.46 & 1.00 & 1.14 & 12.98 & 0.79 & 1.00 & 10.25 \\
\hline & & ngas & 14.71 & 0.53 & 1.46 & 0.66 & 1.32 & 22.77 & 0.79 & 0.92 & 16.58 \\
\hline & & othr & ne & 0.53 & 1.46 & 0.66 & 1.00 & 17.25 & 0.79 & 0.92 & 12.56 \\
\hline \multirow[t]{3}{*}{ Warehse } & SAC & elec & ne & 0.55 & 1.53 & 1.00 & 1.14 & 17.06 & 0.80 & 1.00 & 13.65 \\
\hline & & ngas & 17.78 & 0.55 & 1.53 & 0.66 & 1.32 & 29.92 & 0.80 & 0.92 & 22.07 \\
\hline & & othr & ne & 0.55 & 1.53 & 0.66 & 1.00 & 22.67 & 0.80 & 0.92 & 16.72 \\
\hline \multirow[t]{3}{*}{ School } & OAK & elec & ne & 0.60 & 5.25 & 1.04 & 1.14 & 52.57 & 0.20 & 0.96 & 10.06 \\
\hline & & ngas & 15.21 & 0.60 & 5.25 & 0.66 & 1.32 & 95.82 & 0.20 & 0.88 & 16.86 \\
\hline & & othr & ne & 0.60 & 5.25 & 0.66 & 1.00 & 72.59 & 0.20 & 0.88 & 12.79 \\
\hline \multirow[t]{3}{*}{ School } & SAC & elec & ne & 0.61 & 5.00 & 1.04 & 1.14 & 57.53 & 0.20 & 0.96 & 11.01 \\
\hline & & ngas & 17.19 & 0.61 & 5.00 & 0.66 & 1.32 & 104.86 & 0.20 & 0.88 & 18.46 \\
\hline & & othr & ne & 0.61 & 5.00 & 0.66 & 1.00 & 79.44 & 0.20 & 0.88 & 14.00 \\
\hline
\end{tabular}


Table 5-6. PG\&E Heating EUIs for 1975 and 1979 Vintages [kBtu/sqft/yr] (Continued)

\begin{tabular}{|c|c|c|c|c|c|c|c|c|c|c|c|}
\hline Building & Region & Fuel & EUI & Eff & $\bar{A} \mathbf{P}$ & CECe & PrEf & 1975 EUI & $\mathrm{C} / \mathrm{A}$ & EffR & $1979 \mathrm{EUI}$ \\
\hline College & $\overline{\text { OAK }}$ & $\begin{array}{l}\text { clec } \\
\text { ngas } \\
\text { othr }\end{array}$ & $\begin{array}{c}\text { ne } \\
14.62 \\
\text { ne }\end{array}$ & $\begin{array}{l}0.74 \\
0.74 \\
0.74\end{array}$ & $\begin{array}{l}0.69 \\
0.69 \\
0.69\end{array}$ & $\begin{array}{l}1.02 \\
0.66 \\
0.66\end{array}$ & $\begin{array}{l}1.14 \\
1.32 \\
1.00\end{array}$ & $\begin{array}{c}8.36 \\
14.93 \\
11.31\end{array}$ & $\begin{array}{l}0.20 \\
0.20 \\
0.20\end{array}$ & $\begin{array}{l}0.97 \\
0.88 \\
0.88\end{array}$ & $\begin{array}{l}1.62 \\
2.63 \\
1.99\end{array}$ \\
\hline College & SAC & $\begin{array}{l}\text { elec } \\
\text { ngas } \\
\text { othr }\end{array}$ & $\begin{array}{c}\text { ne } \\
14.46 \\
\text { ne }\end{array}$ & $\begin{array}{l}0.73 \\
0.73 \\
0.73\end{array}$ & $\begin{array}{l}0.71 \\
0.71 \\
0.71\end{array}$ & $\begin{array}{l}1.02 \\
0.66 \\
0.66\end{array}$ & $\begin{array}{l}1.14 \\
1.32 \\
1.00\end{array}$ & $\begin{array}{c}8.39 \\
14.99 \\
11.36\end{array}$ & $\begin{array}{l}0.20 \\
0.20 \\
0.20\end{array}$ & $\begin{array}{l}0.97 \\
0.88 \\
0.88\end{array}$ & $\begin{array}{l}1.63 \\
2.64 \\
2.00\end{array}$ \\
\hline Health & OAK & $\begin{array}{c}\text { elec } \\
\text { ngas } \\
\text { othr }\end{array}$ & $\begin{array}{c}\text { ne } \\
3.66 \\
\text { ne }\end{array}$ & $\begin{array}{l}0.67 \\
0.67 \\
0.67\end{array}$ & $\begin{array}{l}8.06 \\
8.06 \\
8.06\end{array}$ & $\begin{array}{l}1.90 \\
0.66 \\
0.66\end{array}$ & $\begin{array}{l}1.14 \\
1.32 \\
1.00\end{array}$ & $\begin{array}{l}11.86 \\
39.53 \\
29.95\end{array}$ & $\begin{array}{l}0.15 \\
0.15 \\
0.15\end{array}$ & $\begin{array}{l}0.79 \\
0.88 \\
0.88\end{array}$ & $\begin{array}{l}1.41 \\
5.22 \\
3.95\end{array}$ \\
\hline Health & SAC & $\begin{array}{l}\text { elec } \\
\text { ngas } \\
\text { othr }\end{array}$ & $\begin{array}{c}\text { ne } \\
5.54 \\
\text { ne }\end{array}$ & $\begin{array}{l}0.71 \\
0.71 \\
0.71\end{array}$ & $\begin{array}{l}5.16 \\
5.16 \\
5.16\end{array}$ & $\begin{array}{l}1.90 \\
0.66 \\
0.66\end{array}$ & $\begin{array}{l}1.14 \\
1.32 \\
1.00\end{array}$ & $\begin{array}{l}12.18 \\
40.59 \\
30.75\end{array}$ & $\begin{array}{l}0.21 \\
0.21 \\
0.21\end{array}$ & $\begin{array}{l}0.79 \\
0.88 \\
0.88\end{array}$ & $\begin{array}{l}2.02 \\
7.50 \\
5.68\end{array}$ \\
\hline Lodging & OAK & $\begin{array}{l}\text { elec } \\
\text { ngas } \\
\text { othr }\end{array}$ & $\begin{array}{c}5.83 \\
23.50 \\
\text { ne }\end{array}$ & $\begin{array}{l}0.55 \\
0.55 \\
0.55\end{array}$ & $\begin{array}{l}1.19 \\
1.19 \\
1.19\end{array}$ & $\begin{array}{l}1.76 \\
0.66 \\
0.66\end{array}$ & $\begin{array}{l}1.14 \\
1.32 \\
1.00\end{array}$ & $\begin{array}{c}2.47 \\
30.76 \\
23.30\end{array}$ & $\begin{array}{l}0.57 \\
0.57 \\
0.57\end{array}$ & $\begin{array}{l}0.81 \\
0.88 \\
0.96\end{array}$ & $\begin{array}{c}1.14 \\
15.43 \\
12.75\end{array}$ \\
\hline Lodging & SAC & $\begin{array}{l}\text { elec } \\
\text { ngas } \\
\text { othr }\end{array}$ & $\begin{array}{c}8.15 \\
37.54 \\
\text { ne }\end{array}$ & $\begin{array}{l}0.61 \\
0.61 \\
0.61\end{array}$ & $\begin{array}{l}0.69 \\
0.69 \\
0.69\end{array}$ & $\begin{array}{l}1.76 \\
0.66 \\
0.66\end{array}$ & $\begin{array}{l}1.14 \\
1.32 \\
1.00\end{array}$ & $\begin{array}{c}2.22 \\
31.60 \\
23.94\end{array}$ & $\begin{array}{l}0.33 \\
0.33 \\
0.33\end{array}$ & $\begin{array}{l}0.81 \\
0.88 \\
0.96\end{array}$ & $\begin{array}{l}0.59 \\
9.18 \\
7.58\end{array}$ \\
\hline Miscellns & OAK & $\begin{array}{l}\text { elec } \\
\text { ngas } \\
\text { othr }\end{array}$ & $\begin{array}{c}\text { ne } \\
7.55 \\
\text { ne }\end{array}$ & $\begin{array}{l}0.44 \\
0.44 \\
0.44\end{array}$ & $\begin{array}{l}2.38 \\
2.38 \\
2.38\end{array}$ & $\begin{array}{l}1.49 \\
0.66 \\
0.66\end{array}$ & $\begin{array}{l}1.14 \\
1.32 \\
1.00\end{array}$ & $\begin{array}{c}6.07 \\
15.81 \\
11.98\end{array}$ & $\begin{array}{l}0.31 \\
0.31 \\
0.31\end{array}$ & $\begin{array}{l}0.85 \\
0.90 \\
0.93\end{array}$ & $\begin{array}{l}1.59 \\
4.39 \\
3.45\end{array}$ \\
\hline Miscellns & SAC & $\begin{array}{l}\text { elec } \\
\text { ngas } \\
\text { othr }\end{array}$ & $\begin{array}{c}\text { ne } \\
8.16 \\
\text { ne }\end{array}$ & $\begin{array}{l}0.48 \\
0.48 \\
0.48\end{array}$ & $\begin{array}{l}2.29 \\
2.29 \\
2.29\end{array}$ & $\begin{array}{l}1.49 \\
0.66 \\
0.66\end{array}$ & $\begin{array}{l}1.14 \\
1.32 \\
1.00\end{array}$ & $\begin{array}{c}6.89 \\
17.94 \\
13.59\end{array}$ & $\begin{array}{l}0.35 \\
0.35 \\
0.35\end{array}$ & $\begin{array}{l}0.85 \\
0.90 \\
0.93\end{array}$ & $\begin{array}{l}2.04 \\
5.62 \\
4.42\end{array}$ \\
\hline
\end{tabular}


Table 5-7. PG\&E Ventilation EUIs for 1975 and 1979 Vintages [kBtu/sqft/yr]

\begin{tabular}{|lc|rrrrrr|}
\hline Building & Region & \multicolumn{1}{|c|}{ EUI } & \multicolumn{1}{c}{ Sat } & A/P & PrEf & 1975 EUI & 1979 EUI \\
\hline SmOffice & OAK & 0.75 & 0.699 & 1.00 & 1.01 & 1.08 & 1.00 \\
& SAC & 1.94 & 0.800 & 1.05 & 1.01 & 2.58 & 0.89 \\
LgOffice & OAK & 10.17 & 0.866 & 1.09 & 1.01 & 12.93 & 0.64 \\
& SAC & 13.75 & 0.917 & 1.10 & 1.01 & 16.66 & 0.64 \\
Retail & OAK & 1.16 & 0.590 & 1.00 & 1.01 & 1.99 & 0.96 \\
& SAC & 2.73 & 0.764 & 1.01 & 1.01 & 3.64 & 0.87 \\
Restrnt & OAK & 14.84 & 0.689 & 0.77 & 1.01 & 16.75 & 0.73 \\
& SAC & 19.55 & 0.843 & 0.75 & 1.01 & 17.57 & 0.70 \\
FoodStr & OAK & 11.63 & 0.760 & 1.03 & 1.01 & 15.93 & 0.97 \\
& SAC & 15.12 & 0.695 & 1.03 & 1.01 & 22.62 & 0.95 \\
Warehse & OAK & 3.72 & 0.478 & 0.98 & 1.01 & 7.70 & 0.95 \\
& SAC & 3.14 & 0.511 & 1.08 & 1.01 & 6.70 & 0.92 \\
School & OAK & 1.57 & 0.772 & 1.23 & 1.01 & 2.53 & 0.82 \\
& SAC & 2.12 & 0.828 & 1.36 & 1.01 & 3.51 & 0.75 \\
College & OAK & 3.62 & 0.523 & 0.80 & 1.01 & 5.59 & 0.25 \\
& SAC & 4.88 & 0.946 & 0.82 & 1.01 & 4.27 & 0.29 \\
Health & OAK & 6.89 & 0.854 & 1.22 & 1.01 & 9.94 & 0.80 \\
& SAC & 8.50 & 0.783 & 1.23 & 1.01 & 13.48 & 0.80 \\
Lodging & OAK & 2.05 & 0.694 & 1.19 & 1.01 & 3.55 & 0.56 \\
& SAC & 4.33 & 0.957 & 0.68 & 1.01 & 3.11 & 0.34 \\
Miscellns & OAK & 3.65 & 0.272 & 1.00 & 1.01 & 13.56 & 1.00 \\
& SAC & 3.86 & 0.773 & 1.00 & 1.01 & 5.04 & 1.00 \\
\hline
\end{tabular}


Table 5-8. CEC Electric Cooking EUIs for 1975 Vintage [kBtu/sqft/yr]

\begin{tabular}{|lc|rrrr|}
\hline Building & Region & EUI & Sat. & PrEff. & U75 \\
\hline SmOffice & OAK & 0.10 & 0.526 & 1.28 & 0.25 \\
& SAC & 0.10 & 0.526 & 1.28 & 0.25 \\
LgOffice & OAK & 0.51 & 0.617 & 1.28 & 1.06 \\
& SAC & 0.51 & 0.617 & 1.28 & 1.06 \\
Retail & OAK & 0.10 & 0.600 & 1.29 & 0.22 \\
& SAC & 0.10 & 0.600 & 1.29 & 0.22 \\
Restaurant & OAK & 13.55 & 0.449 & 1.18 & 35.60 \\
& SAC & 13.55 & 0.449 & 1.18 & 35.60 \\
FoodStr & OAK & 1.77 & 0.675 & 1.33 & 3.50 \\
& SAC & 1.77 & 0.675 & 1.33 & 3.50 \\
Warehouse & OAK & 0.00 & 0.665 & 1.15 & 0.00 \\
& SAC & 0.00 & 0.665 & 1.15 & 0.00 \\
School & OAK & 0.24 & 0.533 & 1.16 & 0.52 \\
& SAC & 0.24 & 0.533 & 1.16 & 0.52 \\
College & OAK & 0.14 & 0.768 & 1.23 & 0.22 \\
& SAC & 0.14 & 0.768 & 1.23 & 0.22 \\
Health & OAK & 0.55 & 0.528 & 1.24 & 1.28 \\
& SAC & 0.55 & 0.528 & 1.24 & 1.28 \\
Lodging & OAK & 0.17 & 0.733 & 1.14 & 0.27 \\
& SAC & 0.17 & 0.733 & 1.14 & 0.27 \\
Miscellns & OAK & 0.00 & 0.703 & 1.16 & 0.00 \\
& SAC & 0.00 & 0.703 & 1.16 & 0.00 \\
\hline \multicolumn{4}{|l}{}
\end{tabular}


f3Table 5-9. CEC Electric Hot Water EUIs for 1975 Vintage [kBtu/sqft/yr]

\begin{tabular}{|lc|cccc|}
\hline Building & Region & EUI & Sat. & PrEff. & U75 \\
\hline SmOffice & OAK & 0.41 & 0.457 & 1.28 & 1.15 \\
& SAC & 0.41 & 0.457 & 1.28 & 1.15 \\
LgOffice & OAK & 0.17 & 0.203 & 1.28 & 1.08 \\
& SAC & 0.17 & 0.203 & 1.28 & 1.08 \\
Retail & OAK & 0.10 & 0.246 & 1.29 & 0.54 \\
& SAC & 0.10 & 0.246 & 1.29 & 0.54 \\
Restaurant & OAK & 0.96 & 0.153 & 1.18 & 7.37 \\
& SAC & 0.96 & 0.153 & 1.18 & 7.37 \\
FoodStr & OAK & 0.38 & 0.145 & 1.33 & 3.44 \\
& SAC & 0.38 & 0.145 & 1.33 & 3.44 \\
Warehouse & OAK & 0.03 & 0.528 & 1.15 & 0.07 \\
& SAC & 0.03 & 0.528 & 1.15 & 0.07 \\
School & OAK & 0.55 & 0.140 & 1.16 & 4.52 \\
& SAC & 0.55 & 0.140 & 1.16 & 4.52 \\
College & OAK & 0.17 & 0.082 & 1.23 & 2.56 \\
& SAC & 0.17 & 0.082 & 1.23 & 2.56 \\
Health & OAK & 0.03 & 0.009 & 1.24 & 4.70 \\
& SAC & 0.03 & 0.009 & 1.24 & 4.70 \\
Lodging & OAK & 0.03 & 0.027 & 1.14 & 1.44 \\
& SAC & 0.03 & 0.027 & 1.14 & 1.44 \\
Miscellns & OAK & 0.00 & 0.210 & 1.16 & 0.00 \\
& SAC & 0.00 & 0.210 & 1.16 & 0.00 \\
\hline
\end{tabular}


Table 5-10. CEC Electric Indoor Lighting EUIs for 1975 Vintage [kBtu/sqft/yr]

\begin{tabular}{|lc|rrrr|}
\hline Building & Region & EUI & Sat. & PrEff. & U75 \\
\hline SmOffice & OAK & 15.76 & 1.000 & 1.28 & 20.18 \\
& SAC & 15.76 & 1.000 & 1.28 & 20.18 \\
LgOffice & OAK & 35.76 & 1.000 & 1.28 & 45.77 \\
& SAC & 35.76 & 1.000 & 1.28 & 45.77 \\
Retail & OAK & 20.78 & 1.000 & 1.29 & 26.81 \\
& SAC & 20.78 & 1.000 & 1.29 & 26.81 \\
Restaurant & OAK & 27.64 & 1.000 & 1.18 & 32.61 \\
& SAC & 27.64 & 1.000 & 1.18 & 32.61 \\
FoodStr & OAK & 48.18 & 1.000 & 1.33 & 64.08 \\
& SAC & 48.18 & 1.000 & 1.33 & 64.08 \\
Warehouse & OAK & 6.96 & 1.000 & 1.15 & 8.00 \\
& SAC & 6.96 & 1.000 & 1.15 & 8.00 \\
School & OAK & 10.20 & 1.000 & 1.16 & 11.83 \\
& SAC & 10.20 & 1.000 & 1.16 & 11.83 \\
College & OAK & 11.09 & 1.000 & 1.23 & 13.64 \\
& SAC & 11.09 & 1.000 & 1.23 & 13.64 \\
Health & OAK & 37.77 & 1.000 & 1.24 & 46.84 \\
& SAC & 37.77 & 1.000 & 1.24 & 46.84 \\
Lodging & OAK & 9.45 & 1.000 & 1.14 & 10.77 \\
& SAC & 9.45 & 1.000 & 1.14 & 10.77 \\
Miscellns & OAK & 5.63 & 1.000 & 1.16 & 6.53 \\
& SAC & 5.63 & 1.000 & 1.16 & 6.53 \\
\hline
\end{tabular}


Table 5-11. CEC Electric Outdoor Lighting EUIs for 1975 Vintage [kBtu/sqft/yr]

\begin{tabular}{|lc|cccc|}
\hline Building & Region & EUI & Sat. & PrEff. & U75 \\
\hline SmOffice & OAK & 5.25 & 1.000 & 1.28 & 6.73 \\
& SAC & 5.25 & 1.000 & 1.28 & 6.73 \\
LgOffice & OAK & 1.50 & 1.000 & 1.28 & 1.92 \\
& SAC & 1.50 & 1.000 & 1.28 & 1.92 \\
Retail & OAK & 2.73 & 1.000 & 1.29 & 3.52 \\
& SAC & 2.73 & 1.000 & 1.29 & 3.52 \\
Restaurant & OAK & 7.06 & 1.000 & 1.18 & 8.33 \\
FoodStr & SAC & 7.06 & 1.000 & 1.18 & 8.33 \\
& OAK & 4.64 & 1.000 & 1.33 & 6.17 \\
Warehouse & SAC & 4.64 & 1.000 & 1.33 & 6.17 \\
& OAK & 1.57 & 1.000 & 1.15 & 1.80 \\
School & SAC & 1.57 & 1.000 & 1.15 & 1.80 \\
& OAK & 0.99 & 1.000 & 1.16 & 1.15 \\
College & SAC & 0.99 & 1.000 & 1.16 & 1.15 \\
& OAK & 0.44 & 1.000 & 1.23 & 0.55 \\
Health & SAC & 0.44 & 1.000 & 1.23 & 0.55 \\
& OAK & 1.23 & 1.000 & 1.24 & 1.52 \\
Lodging & SAC & 1.23 & 1.000 & 1.24 & 1.52 \\
& OAK & 1.06 & 1.000 & 1.14 & 1.21 \\
Miscellns & SAC & 1.06 & 1.000 & 1.14 & 1.21 \\
& OAK & 1.36 & 1.000 & 1.16 & 1.58 \\
& SAC & 1.36 & 1.000 & 1.16 & 1.58 \\
\hline
\end{tabular}


Table 5-12. CEC Electric Miscellaneous Equipment EUIs for 1975 Vintage [kBtu/sqft/yr]

\begin{tabular}{|lc|rrrr|}
\hline Building & Region & EUI & Sat. & PrEff. & U75 \\
\hline SmOffice & OAK & 4.74 & 1.000 & 1.28 & 6.07 \\
& SAC & 4.74 & 1.000 & 1.28 & 6.07 \\
LgOffice & OAK & 7.30 & 1.000 & 1.28 & 9.35 \\
& SAC & 7.30 & 1.000 & 1.28 & 9.35 \\
Retail & OAK & 2.22 & 1.000 & 1.29 & 2.86 \\
& SAC & 2.22 & 1.000 & 1.29 & 2.86 \\
Restaurant & OAK & 21.50 & 1.000 & 1.18 & 25.36 \\
& SAC & 21.50 & 1.000 & 1.18 & 25.36 \\
FoodStr & OAK & 22.83 & 1.000 & 1.33 & 30.36 \\
& SAC & 22.83 & 1.000 & 1.33 & 30.36 \\
Warehouse & OAK & 8.73 & 1.000 & 1.15 & 10.04 \\
& SAC & 8.73 & 1.000 & 1.15 & 10.04 \\
School & OAK & 0.55 & 1.000 & 1.16 & 0.63 \\
& SAC & 0.55 & 1.000 & 1.16 & 0.63 \\
College & OAK & 0.75 & 1.000 & 1.23 & 0.92 \\
& SAC & 0.75 & 1.000 & 1.23 & 0.92 \\
Health & OAK & 24.74 & 1.000 & 1.24 & 30.67 \\
& SAC & 24.74 & 1.000 & 1.24 & 30.67 \\
Lodging & OAK & 3.68 & 1.000 & 1.14 & 4.20 \\
& SAC & 3.68 & 1.000 & 1.14 & 4.20 \\
Miscellns & OAK & 7.44 & 1.000 & 1.16 & 8.63 \\
& SAC & 7.44 & 1.000 & 1.16 & 8.63 \\
\hline
\end{tabular}


Table 5-13. CEC Electric Refrigeration EUIs for 1975 Vintage [kBtu/sqft/yr]

\begin{tabular}{|lc|rrrr|}
\hline Building & Region & EUI & \multicolumn{1}{c|}{ Sat. } & PrEff. & U75 \\
\hline SmOffice & OAK & 0.58 & 0.734 & 1.28 & 1.01 \\
& SAC & 0.58 & 0.734 & 1.28 & 1.01 \\
LgOffice & OAK & 0.31 & 0.792 & 1.28 & 0.50 \\
& SAC & 0.31 & 0.792 & 1.28 & 0.50 \\
Retail & OAK & 1.54 & 0.754 & 1.29 & 2.63 \\
& SAC & 1.54 & 0.754 & 1.29 & 2.63 \\
Restaurant & OAK & 24.53 & 0.985 & 1.18 & 29.39 \\
& SAC & 24.53 & 0.985 & 1.18 & 29.39 \\
FoodStr & OAK & 50.87 & 0.978 & 1.33 & 69.18 \\
& SAC & 50.87 & 0.978 & 1.33 & 69.18 \\
Warehouse & OAK & 39.31 & 0.893 & 1.15 & 50.62 \\
& SAC & 23.78 & 0.922 & 1.15 & 29.66 \\
School & OAK & 0.89 & 0.955 & 1.16 & 1.08 \\
& SAC & 0.89 & 0.955 & 1.16 & 1.08 \\
College & OAK & 0.17 & 1.000 & 1.23 & 0.21 \\
& SAC & 0.17 & 1.000 & 1.23 & 0.21 \\
Health & OAK & 0.85 & 0.998 & 1.24 & 1.06 \\
& SAC & 0.85 & 0.998 & 1.24 & 1.06 \\
Lodging & OAK & 1.43 & 0.891 & 1.14 & 1.83 \\
& SAC & 1.43 & 0.891 & 1.14 & 1.83 \\
Miscellns & OAK & 1.50 & 0.967 & 1.16 & 1.80 \\
& SAC & 1.50 & 0.967 & 1.16 & 1.80 \\
\hline
\end{tabular}


Table 5-14. CEC Gas Cooking EUIs for 1975 Vintage [kBtu/sqft/yr]

\begin{tabular}{|lc|rrr|}
\hline Building & Region & EUI & PrEff. & U75 \\
\hline SmOffice & OAK & 0.01 & 1.09 & 0.01 \\
& SAC & 0.01 & 1.09 & 0.01 \\
LgOffice & OAK & 0.30 & 1.09 & 0.33 \\
& SAC & 0.30 & 1.09 & 0.33 \\
Retail & OAK & 0.04 & 1.09 & 0.04 \\
& SAC & 0.04 & 1.09 & 0.04 \\
Restaurant & OAK & 23.77 & 1.09 & 25.91 \\
& SAC & 23.77 & 1.09 & 25.91 \\
FoodStr & OAK & 1.27 & 1.09 & 1.38 \\
& SAC & 1.27 & 1.09 & 1.38 \\
Warehouse & OAK & 0.00 & 1.09 & 0.00 \\
& SAC & 0.00 & 1.09 & 0.00 \\
School & OAK & 1.00 & 1.09 & 1.09 \\
& SAC & 1.00 & 1.09 & 1.09 \\
College & OAK & 0.00 & 1.09 & 0.00 \\
& SAC & 0.00 & 1.09 & 0.00 \\
Health & OAK & 0.47 & 1.09 & 0.51 \\
& SAC & 0.47 & 1.09 & 0.51 \\
Lodging & OAK & 0.80 & 1.09 & 0.87 \\
& SAC & 0.80 & 1.09 & 0.87 \\
Miscellns & OAK & 0.20 & 1.09 & 0.22 \\
& SAC & 0.20 & 1.09 & 0.22 \\
\hline \multirow{2}{*}{ S } & & & & \\
& & &
\end{tabular}


Table 5-15. CEC Gas Water Heating EUIs for 1975 Vintage [kBtu/sqft/yr]

\begin{tabular}{|lc|ccc|}
\hline Building & Region & EUI & PrEff. & U75 \\
\hline SmOffice & OAK & 0.21 & 1.09 & 0.23 \\
& SAC & 0.21 & 1.09 & 0.23 \\
LgOffice & OAK & 0.25 & 1.09 & 0.27 \\
& SAC & 0.25 & 1.09 & 0.27 \\
Retail & OAK & 0.18 & 1.09 & 0.20 \\
& SAC & 0.18 & 1.09 & 0.20 \\
Restaurant & OAK & 8.76 & 1.09 & 9.55 \\
& SAC & 8.76 & 1.09 & 9.55 \\
FoodStr & OAK & 4.38 & 1.09 & 4.77 \\
& SAC & 4.38 & 1.09 & 4.77 \\
Warehouse & OAK & 0.09 & 1.09 & 0.10 \\
& SAC & 0.09 & 1.09 & 0.10 \\
School & OAK & 5.63 & 1.09 & 6.14 \\
& SAC & 5.63 & 1.09 & 6.14 \\
College & OAK & 2.26 & 1.09 & 2.46 \\
& SAC & 2.26 & 1.09 & 2.46 \\
Health & OAK & 1.92 & 1.09 & 2.09 \\
& SAC & 1.92 & 1.09 & 2.09 \\
Lodging & OAK & 1.80 & 1.09 & 1.96 \\
\multirow{4}{*}{ Miscellns } & SAC & 1.80 & 1.09 & 1.96 \\
& OAK & 0.00 & 1.09 & 0.00 \\
& SAC & 0.00 & 1.09 & 0.00 \\
\hline \multirow{2}{*}{ S } & & & &
\end{tabular}


Table 5-16. CEC Gas Miscellaneous Equipment for 1975 Vintage [kBtu/sqft/yr]

\begin{tabular}{|lc|rrr|}
\hline Building & Region & EUI & PrEff. & U75 \\
\hline SmOffice & OAK & 0.00 & 1.09 & 0.00 \\
& SAC & 0.00 & 1.09 & 0.00 \\
LgOffice & OAK & 0.31 & 1.09 & 0.34 \\
& SAC & 0.31 & 1.09 & 0.34 \\
Retail & OAK & 0.24 & 1.09 & 0.26 \\
& SAC & 0.24 & 1.09 & 0.26 \\
Restaurant & OAK & 0.00 & 1.09 & 0.00 \\
& SAC & 0.00 & 1.09 & 0.00 \\
FoodStr & OAK & 14.00 & 1.09 & 15.26 \\
& SAC & 14.00 & 1.09 & 15.26 \\
Warehouse & OAK & 1.96 & 1.09 & 2.14 \\
& SAC & 1.96 & 1.09 & 2.14 \\
School & OAK & 0.00 & 1.09 & 0.00 \\
& SAC & 0.00 & 1.09 & 0.00 \\
College & OAK & 3.04 & 1.09 & 3.31 \\
& SAC & 3.04 & 1.09 & 3.31 \\
Health & OAK & 4.20 & 1.09 & 4.58 \\
& SAC & 4.20 & 1.09 & 4.58 \\
Lodging & OAK & 3.68 & 1.09 & 4.01 \\
& SAC & 3.68 & 1.09 & 4.01 \\
Miscellns & OAK & 5.00 & 1.09 & 5.45 \\
& SAC & 5.00 & 1.09 & 5.45 \\
\hline
\end{tabular}


Table 5-17. PG\&E Electric Cooking EUIs for 1975 Vintage [kBtu/sqft/yr]

\begin{tabular}{|lc|cccc|}
\hline Building & Region & EUI & Sat. & PrEff. & 1975 EUI \\
\hline SmOffice & OAK & 0.10 & 0.526 & 1.01 & 0.20 \\
& SAC & 0.10 & 0.526 & 1.01 & 0.20 \\
LgOffice & OAK & 0.51 & 0.617 & 1.01 & 0.84 \\
& SAC & 0.51 & 0.617 & 1.01 & 0.84 \\
Retail & OAK & 0.10 & 0.600 & 1.01 & 0.17 \\
& SAC & 0.10 & 0.600 & 1.01 & 0.17 \\
Restaurant & OAK & 13.55 & 0.449 & 1.01 & 30.47 \\
FoodStr & SAC & 13.55 & 0.449 & 1.01 & 30.47 \\
& OAK & 1.77 & 0.675 & 1.01 & 2.65 \\
Warehouse & SAC & 1.77 & 0.675 & 1.01 & 2.65 \\
& OAK & 0.00 & 0.665 & 1.01 & 0.00 \\
School & SAC & 0.00 & 0.665 & 1.01 & 0.00 \\
& OAK & 0.24 & 0.533 & 1.01 & 0.45 \\
College & SAC & 0.24 & 0.533 & 1.01 & 0.45 \\
& OAK & 0.14 & 0.768 & 1.01 & 0.18 \\
Health & SAC & 0.14 & 0.768 & 1.01 & 0.18 \\
& OAK & 0.55 & 0.528 & 1.01 & 1.04 \\
Lodging & SAC & 0.55 & 0.528 & 1.01 & 1.04 \\
& OAK & 0.17 & 0.733 & 1.01 & 0.24 \\
Miscellns & SAC & 0.17 & 0.733 & 1.01 & 0.24 \\
& OAK & 0.00 & 0.703 & 1.01 & 0.00 \\
& SAC & 0.00 & 0.703 & 1.01 & 0.00 \\
\hline \multirow{4}{*}{ Fon } & & & & & \\
& & & & &
\end{tabular}


Table 5-18. PG\&E Electric Hot Water EUIs for 1975 Vintage [kBtu/sqft/yr]

\begin{tabular}{|lc|cccc|}
\hline Building & Region & EUI & Sat. & PrEff. & 1975 EUI \\
\hline SmOffice & OAK & 0.41 & 0.457 & 1.20 & 1.08 \\
& SAC & 0.41 & 0.457 & 1.20 & 1.08 \\
LgOffice & OAK & 0.17 & 0.203 & 1.20 & 1.01 \\
& SAC & 0.17 & 0.203 & 1.20 & 1.01 \\
Retail & OAK & 0.10 & 0.246 & 1.20 & 0.50 \\
& SAC & 0.10 & 0.246 & 1.20 & 0.50 \\
Restaurant & OAK & 0.96 & 0.153 & 1.20 & 7.49 \\
& SAC & 0.96 & 0.153 & 1.20 & 7.49 \\
FoodStr & OAK & 0.38 & 0.145 & 1.20 & 3.11 \\
& SAC & 0.38 & 0.145 & 1.20 & 3.11 \\
Warehouse & OAK & 0.03 & 0.528 & 1.20 & 0.08 \\
& SAC & 0.03 & 0.528 & 1.20 & 0.08 \\
School & OAK & 0.55 & 0.140 & 1.20 & 4.68 \\
& SAC & 0.55 & 0.140 & 1.20 & 4.68 \\
College & OAK & 0.17 & 0.082 & 1.20 & 2.50 \\
& SAC & 0.17 & 0.082 & 1.20 & 2.50 \\
Health & OAK & 0.03 & 0.009 & 1.20 & 4.55 \\
& SAC & 0.03 & 0.009 & 1.20 & 4.55 \\
Lodging & OAK & 0.03 & 0.027 & 1.20 & 1.52 \\
Miscellns & SAC & 0.03 & 0.027 & 1.20 & 1.52 \\
& OAK & 0.00 & 0.210 & 1.20 & 0.00 \\
& SAC & 0.00 & 0.210 & 1.20 & 0.00 \\
\hline
\end{tabular}


Table 5-19. PG\&E Electric Indoor Lighting EUIs for 1975 Vintage [kBtu/sqft/yr]

\begin{tabular}{|lc|rrrr|}
\hline Building & Region & EUI & Sat. & PrEff. & 1975 EUI \\
\hline SmOffice & OAK & 15.76 & 1.000 & 1.01 & 15.92 \\
& SAC & 15.76 & 1.000 & 1.01 & 15.92 \\
LgOffice & OAK & 35.76 & 1.000 & 1.01 & 36.12 \\
& SAC & 35.76 & 1.000 & 1.01 & 36.12 \\
Retail & OAK & 20.78 & 1.000 & 1.01 & 20.99 \\
& SAC & 20.78 & 1.000 & 1.01 & 20.99 \\
Restaurant & OAK & 27.64 & 1.000 & 1.01 & 27.91 \\
& SAC & 27.64 & 1.000 & 1.01 & 27.91 \\
FoodStr & OAK & 48.18 & 1.000 & 1.01 & 48.66 \\
& SAC & 48.18 & 1.000 & 1.01 & 48.66 \\
Warehouse & OAK & 6.96 & 1.000 & 1.01 & 7.03 \\
& SAC & 6.96 & 1.000 & 1.01 & 7.03 \\
School & OAK & 10.20 & 1.000 & 1.01 & 10.30 \\
& SAC & 10.20 & 1.000 & 1.01 & 10.30 \\
College & OAK & 11.09 & 1.000 & 1.01 & 11.20 \\
& SAC & 11.09 & 1.000 & 1.01 & 11.20 \\
Health & OAK & 37.77 & 1.000 & 1.01 & 38.15 \\
& SAC & 37.77 & 1.000 & 1.01 & 38.15 \\
Lodging & OAK & 9.45 & 1.000 & 1.01 & 9.55 \\
& SAC & 9.45 & 1.000 & 1.01 & 9.55 \\
Miscelins & OAK & 5.63 & 1.000 & 1.01 & 5.69 \\
& SAC & 5.63 & 1.000 & 1.01 & 5.69 \\
\hline
\end{tabular}


Table 5-20. PG\&E Electric Outdoor Lighting EUIs for 1975 Vintage [kBtu/sqft/yr]

\begin{tabular}{|lc|cccc|}
\hline Building & Region & EUI & Sat. & PrEff. & 1975 EUI \\
\hline SmOffice & OAK & 5.25 & 1.000 & 1.01 & 5.31 \\
& SAC & 5.25 & 1.000 & 1.01 & 5.31 \\
LgOffice & OAK & 1.50 & 1.000 & 1.01 & 1.52 \\
& SAC & 1.50 & 1.000 & 1.01 & 1.52 \\
Retail & OAK & 2.73 & 1.000 & 1.01 & 2.76 \\
& SAC & 2.73 & 1.000 & 1.01 & 2.76 \\
Restaurant & OAK & 7.06 & 1.000 & 1.01 & 7.13 \\
& SAC & 7.06 & 1.000 & 1.01 & 7.13 \\
FoodStr & OAK & 4.64 & 1.000 & 1.01 & 4.69 \\
& SAC & 4.64 & 1.000 & 1.01 & 4.69 \\
Warehouse & OAK & 1.57 & 1.000 & 1.01 & 1.59 \\
& SAC & 1.57 & 1.000 & 1.01 & 1.59 \\
School & OAK & 0.99 & 1.000 & 1.01 & 1.00 \\
& SAC & 0.99 & 1.000 & 1.01 & 1.00 \\
College & OAK & 0.44 & 1.000 & 1.01 & 0.45 \\
& SAC & 0.44 & 1.000 & 1.01 & 0.45 \\
Health & OAK & 1.23 & 1.000 & 1.01 & 1.24 \\
& SAC & 1.23 & 1.000 & 1.01 & 1.24 \\
Lodging & OAK & 1.06 & 1.000 & 1.01 & 1.07 \\
& SAC & 1.06 & 1.000 & 1.01 & 1.07 \\
Miscellns & OAK & 1.36 & 1.000 & 1.01 & 1.38 \\
& SAC & 1.36 & 1.000 & 1.01 & 1.38 \\
\hline
\end{tabular}


Table 5-21. PG\&E Electric Miscellaneous Equipment EUIs for 1975 Vintage [kBtu/sqft/yr]

\begin{tabular}{|lc|rrrr|}
\hline Building & Region & EUI & Sat. & PrEff. & 1975 EUI \\
\hline SmOffice & OAK & 4.74 & 1.000 & 1.01 & 4.79 \\
& SAC & 4.74 & 1.000 & 1.01 & 4.79 \\
LgOffice & OAK & 7.30 & 1.000 & 1.01 & 7.37 \\
& SAC & 7.30 & 1.000 & 1.01 & 7.37 \\
Retail & OAK & 2.22 & 1.000 & 1.01 & 2.24 \\
& SAC & 2.22 & 1.000 & 1.01 & 2.24 \\
Restaurant & OAK & 21.50 & 1.000 & 1.01 & 21.71 \\
& SAC & 21.50 & 1.000 & 1.01 & 21.71 \\
FoodStr & OAK & 22.83 & 1.000 & 1.01 & 23.05 \\
& SAC & 22.83 & 1.000 & 1.01 & 23.05 \\
Warehouse & OAK & 8.73 & 1.000 & 1.01 & 8.82 \\
\multirow{4}{*}{ School } & SAC & 8.73 & 1.000 & 1.01 & 8.82 \\
& OAK & 0.55 & 1.000 & 1.01 & 0.55 \\
College & SAC & 0.55 & 1.000 & 1.01 & 0.55 \\
& OAK & 0.75 & 1.000 & 1.01 & 0.76 \\
Health & SAC & 0.75 & 1.000 & 1.01 & 0.76 \\
& OAK & 24.74 & 1.000 & 1.01 & 24.98 \\
Lodging & SAC & 24.74 & 1.000 & 1.01 & 24.98 \\
& OAK & 3.68 & 1.000 & 1.01 & 3.72 \\
Miscellns & SAC & 3.68 & 1.000 & 1.01 & 3.72 \\
& OAK & 7.44 & 1.000 & 1.01 & 7.51 \\
& SAC & 7.44 & 1.000 & 1.01 & 7.51 \\
\hline
\end{tabular}


Table 5-22. PG\&E Electric Refrigeration EUIs for 1975 Vintage [kBtu/sqft/yr]

\begin{tabular}{|lc|rccc|}
\hline Building & Region & EUI & Sat. & PrEff. & 1975 EUI \\
\hline SmOffice & OAK & 0.58 & 0.734 & 1.01 & 0.80 \\
& SAC & 0.58 & 0.734 & 1.01 & 0.80 \\
LgOffice & OAK & 0.31 & 0.792 & 1.01 & 0.39 \\
& SAC & 0.31 & 0.792 & 1.01 & 0.39 \\
Retail & OAK & 1.54 & 0.754 & 1.01 & 2.06 \\
& SAC & 1.54 & 0.754 & 1.01 & 2.06 \\
Restaurant & OAK & 24.53 & 0.985 & 1.01 & 25.15 \\
& SAC & 24.53 & 0.985 & 1.01 & 25.15 \\
FoodStr & OAK & 50.87 & 0.978 & 1.01 & 52.54 \\
& SAC & 50.87 & 0.978 & 1.01 & 52.54 \\
Warehouse & OAK & 39.31 & 0.893 & 1.01 & 44.46 \\
& SAC & 23.78 & 0.922 & 1.01 & 26.05 \\
School & OAK & 0.89 & 0.955 & 1.01 & 0.94 \\
& SAC & 0.89 & 0.955 & 1.01 & 0.94 \\
College & OAK & $C .17$ & 1.000 & 1.01 & 0.17 \\
& SAC & 0.17 & 1.000 & 1.01 & 0.17 \\
Health & OAK & 0.85 & 0.998 & 1.01 & 0.86 \\
& SAC & 0.85 & 0.998 & 1.01 & 0.86 \\
Lodging & OAK & 1.43 & 0.891 & 1.01 & 1.62 \\
\multirow{4}{*}{ Miscellns } & SAC & 1.43 & 0.891 & 1.01 & 1.62 \\
& OAK & 1.50 & 0.967 & 1.01 & 1.57 \\
& SAC & 1.50 & 0.967 & 1.01 & 1.57 \\
\hline \multirow{2}{*}{} & & & & &
\end{tabular}


Table 5-23. PG\&E Gas Cooking EUIs for 1975 Vintage [kBtu/sqft/yr]

\begin{tabular}{|c|c|c|c|c|}
\hline Building & Region & EUI & PrEff. & $1975 \mathrm{EUI}$ \\
\hline \multirow[t]{2}{*}{ SmOffice } & OAK & 0.01 & 1.01 & 0.01 \\
\hline & SAC & 0.01 & 1.01 & 0.01 \\
\hline \multirow[t]{2}{*}{ LgOffice } & OAK & 0.30 & 1.01 & 0.30 \\
\hline & SAC & 0.30 & 1.01 & 0.30 \\
\hline \multirow[t]{2}{*}{ Retail } & OAK & 0.04 & 1.01 & 0.04 \\
\hline & SAC & 0.04 & 1.01 & 0.04 \\
\hline \multirow[t]{2}{*}{ Restaurant } & OAK & 23.77 & 1.01 & 24.01 \\
\hline & SAC & 23.77 & 1.01 & 24.01 \\
\hline \multirow[t]{2}{*}{ FoodStr } & OAK & 1.27 & 1.01 & 1.28 \\
\hline & SAC & 1.27 & 1.01 & 1.28 \\
\hline \multirow[t]{2}{*}{ Warehouse } & OAK & 0.00 & 1.01 & 0.00 \\
\hline & SAC & 0.00 & 1.01 & 0.00 \\
\hline \multirow[t]{2}{*}{ School } & OAK & 1.00 & 1.01 & 1.01 \\
\hline & SAC & 1.00 & 1.01 & 1.01 \\
\hline \multirow[t]{2}{*}{ College } & OAK & 0.00 & 1.01 & 0.00 \\
\hline & SAC & 0.00 & 1.01 & 0.00 \\
\hline \multirow[t]{2}{*}{ Health } & OAK & 0.47 & 1.01 & 0.47 \\
\hline & SAC & 0.47 & 1.01 & 0.47 \\
\hline \multirow[t]{2}{*}{ Lodging } & OAK & 0.80 & 1.01 & 0.81 \\
\hline & SAC & 0.80 & 1.01 & 0.81 \\
\hline \multirow[t]{2}{*}{ Miscellns } & OAK & 0.20 & 1.01 & 0.20 \\
\hline & SAC & 0.20 & 1.01 & 0.20 \\
\hline
\end{tabular}


Table 5-24. PG\&E Gas Water Heating EUIs for 1975 Vintage [kBtu/sqft/yr]

\begin{tabular}{|lc|ccc|}
\hline Building & Region & EUI & PrEff. & 1975 EUI \\
\hline SmOffice & OAK & 0.21 & 1.37 & 0.29 \\
& SAC & 0.21 & 1.37 & 0.29 \\
LgOffice & OAK & 0.25 & 1.37 & 0.34 \\
& SAC & 0.25 & 1.37 & 0.34 \\
Retail & OAK & 0.18 & 1.37 & 0.25 \\
& SAC & 0.18 & 1.37 & 0.25 \\
Restaurant & OAK & 8.76 & 1.37 & 12.00 \\
& SAC & 8.76 & 1.37 & 12.00 \\
FoodStr & OAK & 4.38 & 1.37 & 6.00 \\
& SAC & 4.38 & 1.37 & 6.00 \\
Warehouse & OAK & 0.09 & 1.37 & 0.12 \\
& SAC & 0.09 & 1.37 & 0.12 \\
School & OAK & 5.63 & 1.37 & 7.71 \\
& SAC & 5.63 & 1.37 & 7.71 \\
College & OAK & 2.26 & 1.37 & 3.10 \\
& SAC & 2.26 & 1.37 & 3.10 \\
Health & OAK & 1.92 & 1.37 & 2.63 \\
& SAC & 1.92 & 1.37 & 2.63 \\
Lodging & OAK & 1.80 & 1.37 & 2.47 \\
& SAC & 1.80 & 1.37 & 2.47 \\
Miscellns & OAK & 0.00 & 1.37 & 0.00 \\
& SAC & 0.00 & 1.37 & 0.00 \\
\hline
\end{tabular}


Table 5-25. PG\&E Gas Miscellaneous Equipment for 1975 Vintage [kBtu/sqft/yr]

\begin{tabular}{|lc|ccc|}
\hline Building & Region & EUI & PrEff. & 1975 EUI \\
\hline SmOffice & OAK & 0.00 & 1.37 & 0.00 \\
& SAC & 0.00 & 1.37 & 0.00 \\
LgOffice & OAK & 0.31 & 1.37 & 0.42 \\
& SAC & 0.31 & 1.37 & 0.42 \\
Retail & OAK & 0.24 & 1.37 & 0.33 \\
& SAC & 0.24 & 1.37 & 0.33 \\
Restaurant & OAK & 0.00 & 1.37 & 0.00 \\
& SAC & 0.00 & 1.37 & 0.00 \\
FoodStr & OAK & 14.00 & 1.37 & 19.18 \\
& SAC & 14.00 & 1.37 & 19.18 \\
Warehouse & OAK & 1.96 & 1.37 & 2.69 \\
& SAC & 1.96 & 1.37 & 2.69 \\
School & OAK & 0.00 & 1.37 & 0.00 \\
& SAC & 0.00 & 1.37 & 0.00 \\
College & OAK & 3.04 & 1.37 & 4.16 \\
& SAC & 3.04 & 1.37 & 4.16 \\
Health & OAK & 4.20 & 1.37 & 5.75 \\
& SAC & 4.20 & 1.37 & 5.75 \\
Lodging & OAK & 3.68 & 1.37 & 5.04 \\
& SAC & 3.68 & 1.37 & 5.04 \\
Miscellns & OAK & 5.00 & 1.37 & 6.85 \\
& SAC & 5.00 & 1.37 & 6.85 \\
\hline
\end{tabular}


Table 5-26. CEC 1975 EUIs for Region 1 (Blue Canyon) Climate Zone [kBtu/sqft/yr] - U75

\begin{tabular}{|c|c|c|c|c|c|c|c|c|c|c|c|}
\hline Building & Fuel & Heat & Cool & Vent & HotW & Cook & Refr & OtLt & InLt & OfEq & Misc \\
\hline \multirow[t]{3}{*}{ SmOffice } & Elec & 10.84 & 0.79 & 1.37 & 1.15 & 0.25 & 1.01 & 6.73 & 20.18 & 0.72 & 6.07 \\
\hline & NGas & 17.74 & 2.16 & ne & 0.23 & 0.01 & ne & ne & ne & ne & 0.00 \\
\hline & Othr & 16.09 & 1.96 & ne & ne & ne & ne & ne & ne & ne & ne \\
\hline \multirow[t]{3}{*}{ LgOffice } & Elec & 16.93 & 18.42 & 15,80 & 1.08 & 1.06 & 0.50 & 1.92 & 45.77 & 1.13 & 9.35 \\
\hline & NGas & 20.75 & 96.59 & ne & 0.27 & 0.33 & ne & ne & ne & ne & 0.34 \\
\hline & Othr & 18.84 & 87.73 & ne & ne & ne & ne & ne & ne & ne & ne \\
\hline \multirow[t]{3}{*}{ Retail } & Elec & 10.60 & 0.74 & 2.54 & 0.54 & 0.22 & 2.63 & 3.52 & 26.81 & 0.14 & 2.86 \\
\hline & NGas & 19.92 & 2.04 & ne & 0.20 & 0.04 & ne & ne & ne & ne & 0.26 \\
\hline & Othr & 18.09 & 1.86 & ne & ne & ne & ne & ne & ne & ne & ne \\
\hline \multirow[t]{3}{*}{ Restaurant } & Elec & 33.57 & 4.64 & $\overline{17.64}$ & 7.37 & 35.60 & 29.39 & 8.33 & 32.61 & 0.10 & 25.36 \\
\hline & NGas & 50.23 & 14.52 & ne & 9.55 & 25.91 & ne & ne & ne & ne & 0.00 \\
\hline & Othr & 45.62 & 13.19 & ne & ne & ne & ne & ne & ne & ne & ne \\
\hline \multirow[t]{3}{*}{ FoodStr } & Elec & 52.87 & 12.77 & 23.49 & 3.44 & 3.50 & 69.18 & 6.17 & 64.08 & 0.07 & 30.36 \\
\hline & NGas & 75.51 & 44.87 & ne & 4.77 & 1.38 & ne & ne & ne & ne & 15.26 \\
\hline & Othr & 68.58 & 40.75 & ne & ne & ne & ne & ne & ne & ne & ne \\
\hline \multirow[t]{3}{*}{ Warehouse } & Elec & 31.86 & 0.31 & 8.30 & 0.07 & 0.00 & 50.62 & 1.80 & 8.00 & 0.07 & 10.04 \\
\hline & NGas & 45.76 & 0.72 & ne & 0.10 & 0.00 & ne & ne & ne & ne & 2.14 \\
\hline & Othr & 41.56 & 0.66 & ne & ne & ne & ne & ne & ne & ne & ne \\
\hline \multirow[t]{3}{*}{ School } & Elec & 69.40 & 2.32 & 2.83 & 4.52 & 0.52 & 1.08 & 1.15 & 11.83 & 0.10 & 0.63 \\
\hline & NGas & 102.66 & 11.24 & ne & 6.14 & 1.09 & ne & ne & ne & ne & 0.00 \\
\hline & Othr & 93.24 & 8.62 & ne & ne & ne & ne & ne & ne & ne & ne \\
\hline \multirow[t]{3}{*}{ College } & $\overline{\text { Elec }}$ & 13.61 & 8.78 & 6.92 & 2.56 & 0.22 & 0.21 & 0.55 & 13.64 & 0.14 & 0.92 \\
\hline & NGas & 18.61 & 23.48 & ne & 2.46 & 0.00 & ne & ne & ne & ne & 3.31 \\
\hline & Othr & 16.90 & 21.33 & ne & ne & ne & ne & ne & ne & ne & ne \\
\hline \multirow[t]{3}{*}{ Health } & Elec & 20.63 & 26.84 & 11.79 & 4.70 & 1.28 & 1.06 & 1.52 & $\overline{46.84}$ & 0.68 & 30.67 \\
\hline & NGas & 52.20 & 141.48 & ne & 2.09 & 0.51 & ne & ne & ne & ne & 4.58 \\
\hline & Othr & 47.42 & 128.50 & ne & ne & ne & ne & ne & ne & ne & ne \\
\hline \multirow[t]{3}{*}{ Lodging } & Elec & 4.47 & 2.83 & 3.67 & 1.44 & 0.27 & 1.83 & 1.21 & 10.77 & 0.03 & 4.20 \\
\hline & NGas & 45.98 & 13.02 & ne & 1.96 & 0.87 & ne & ne & ne & ne & 4.01 \\
\hline & Othr & 41.76 & 11.82 & ne & ne & ne & ne & ne & ne & ne & ne \\
\hline \multirow[t]{3}{*}{ Miscellns } & Elec & 16.15 & 3.11 & 15.57 & 0.00 & 0.00 & 1.80 & 1.58 & 6.53 & 0.14 & 8.63 \\
\hline & NGas & 34.15 & 5.15 & ne & 0.00 & 0.22 & ne & ne & ne & ne & 5.45 \\
\hline & Othr & 31.02 & 4.68 & ne & ne & ne & ne & ne & ne & ne & ne \\
\hline
\end{tabular}


Table 5-27. CEC 1975 EUIs for Region 2 (Sacramento) Climate Zone [kBtu/sqft/yr] - U75

\begin{tabular}{|c|c|c|c|c|c|c|c|c|c|c|c|}
\hline Building & Fuel & Heat & Cool & Vent & HotW & Cook & Refr & OtLt & InLt & OfEq & Misc \\
\hline \multirow[t]{3}{*}{ SmOffice } & Elec & 7.63 & 16.80 & 3.27 & 1.15 & 0.25 & 1.01 & 6.73 & 20.18 & 0.72 & 6.07 \\
\hline & NGas & 12.49 & 52.24 & ne & 0.23 & 0.01 & ne & ne & ne & ne & 0.00 \\
\hline & Othr & 11.33 & 47.45 & ne & ne & ne & ne & ne & ne & ne & ne \\
\hline \multirow[t]{3}{*}{ LgOffice } & Elec & 15.81 & 28.88 & 21.11 & 1.08 & 1.06 & 0.50 & 1.92 & 45.77 & 1.13 & 9.35 \\
\hline & NGas & 19.38 & 160.32 & ne & 0.27 & 0.33 & ne & ne & ne & ne & 0.34 \\
\hline & Othr & 17.60 & 145.61 & ne & ne & ne & ne & ne & ne & ne & ne \\
\hline \multirow[t]{3}{*}{ Retail } & Elec & 8.75 & 9.17 & 4.65 & 0.54 & 0.22 & 2.63 & 3.52 & 26.81 & 0.14 & 2.86 \\
\hline & NGas & 16.45 & 32.60 & ne & 0.20 & 0.04 & ne & ne & ne & ne & 0.26 \\
\hline & Othr & 14.94 & 29.61 & ne & ne & ne & ne & ne & ne & ne & ne \\
\hline \multirow[t]{3}{*}{ Restaurant } & Elec & 16.56 & 20.72 & 20.52 & 7.37 & 35.60 & 29.39 & 8.33 & 32.61 & 0.10 & 25.36 \\
\hline & NGas & 24.78 & 79.26 & ne & 9.55 & 25.91 & ne & ne & ne & ne & 0.00 \\
\hline & Othr & 22.51 & 71.99 & ne & ne & ne & ne & ne & ne & ne & ne \\
\hline \multirow[t]{3}{*}{ FoodStr } & Elec & 23.26 & 23.81 & 29.79 & 3.44 & 3.50 & 69.18 & 6.17 & 64.08 & 0.07 & 30.36 \\
\hline & NGas & 33.22 & 76.49 & ne & 4.77 & 1.38 & ne & ne & ne & ne & 15.26 \\
\hline & Othr & 30.17 & 69.47 & ne & ne & ne & ne & ne & ne & ne & ne \\
\hline \multirow[t]{3}{*}{ Warehouse } & Elec & 17.21 & 6.89 & 7.63 & 0.07 & 0.00 & 29.66 & 1.80 & 8.00 & 0.07 & 10.04 \\
\hline & NGas & 24.71 & 17.02 & ne & 0.10 & $0 . M$ & ne & ne & ne & ne & 2.14 \\
\hline & Othr & 22.44 & $15.4 n$ & ne & ne & ne & ne & ne & ne & ne & ne \\
\hline \multirow[t]{3}{*}{ School } & Elec & 58.54 & 1.28 & 4.03 & 4.52 & 0.52 & 1.08 & 1.15 & 11.83 & 0.10 & 0.63 \\
\hline & NGas & 86.59 & 6.66 & ne & 6.14 & 109 & ne & ne & ne & ne & 0.00 \\
\hline & Othr & 78.64 & 5.10 & ne & ne & ne & ne & ne & ne & ne & ne \\
\hline \multirow[t]{3}{*}{ College } & Elec & 9.06 & 9.09 & 5.20 & 2.56 & 0.22 & 0.21 & $\overline{0.5^{\prime} / 3}$ & 13.64 & 0.14 & 0.92 \\
\hline & NGas & 12.38 & 44.00 & ne & 2.46 & 0.00 & ne & ne & ne & ne & 3.31 \\
\hline & Othr & 11.24 & 39.97 & ne & ne & ne & ne & ne & ne & ne & ne \\
\hline \multirow[t]{3}{*}{ Health } & Elec & 13.25 & 43.69 & 16.55 & 4.70 & 1.28 & 1.06 & 1.52 & 46.84 & 0.68 & 30.67 \\
\hline & NGas & 33.52 & 211.17 & ne & 2.09 & 0.51 & ne & ne & ne & ne & 4.58 \\
\hline & Othr & 30.44 & 191.79 & ne & ne & ne & ne & ne & ne & ne & ne \\
\hline \multirow[t]{3}{*}{ Lodging } & Elec & 2.22 & 2.01 & 3.51 & 1.44 & 0.27 & 1.83 & 1.21 & 10.77 & 0.03 & 4.20 \\
\hline & NGas & 26.09 & 12.76 & ne & 1.96 & 0.87 & ne & ne & ne & ne & 4.01 \\
\hline & Othr & 23.70 & 11.59 & ne & ne & ne & ne & ne & ne & ne & ne \\
\hline \multirow[t]{3}{*}{ Miscellns } & Elec & 7.01 & 8.02 & 5.79 & 0.00 & 0.00 & 1.80 & 1.58 & 6.53 & 0.14 & 8.63 \\
\hline & NGas & 14.81 & 37.77 & ne & 0.00 & 0.22 & ne & ne & ne & ne & 5.45 \\
\hline & Othr & 13.45 & 34.30 & ne & ne & ne & ne & ne & ne & ne & ne \\
\hline
\end{tabular}


Table 5-28. CEC 1975 EUIs for Region 3 (Fresno) Climate Zone [kBtu/sqft/yr] - U75

\begin{tabular}{|c|c|c|c|c|c|c|c|c|c|c|c|}
\hline Building & Fuel & Heat & Cool & Vent & $\overline{\text { HotW }}$ & Cook & Refr & OtLt & $\ln L t$ & OfEq & Misc \\
\hline \multirow[t]{3}{*}{ SmOffice } & Elec & 11.57 & 23.29 & 3.58 & 1.15 & 0.25 & 1.01 & 6.73 & 20.18 & 0.72 & 6.07 \\
\hline & NGas & 18.93 & 72.42 & ne & 0.23 & 0.01 & ne & ne & ne & ne & 0.00 \\
\hline & Othr & 17.17 & 65.77 & ne & ne & ne & ne & ne & ne & ne & ne \\
\hline \multirow[t]{3}{*}{ LgOffice } & Elec & 18.57 & 31.04 & 21.45 & 1.08 & 1.06 & 0.50 & 1.92 & 45.77 & 1.13 & 9.35 \\
\hline & NGas & 22.76 & 172.34 & ne & 0.27 & 0.33 & ne & ne & ne & ne & 0.34 \\
\hline & Othr & 20.67 & 156.53 & ne & ne & ne & ne & ne & ne & ne & ne \\
\hline \multirow[t]{3}{*}{ Retail } & Elec & 12.23 & 14.00 & 4.88 & 0.54 & 0.22 & 2.63 & 3.52 & 26.81 & 0.14 & 2.86 \\
\hline & NGas & 22.99 & 49.76 & ne & 0.20 & 0.04 & ne & ne & ne & ne & 0.26 \\
\hline & Othr & 20.88 & 45.20 & ne & ne & ne & ne & ne & ne & ne & ne \\
\hline \multirow[t]{3}{*}{ Restaurant } & Elec & 19.98 & 27.77 & 23.46 & 7.37 & 35.60 & 29.39 & 8.33 & 32.61 & 0.10 & 25.36 \\
\hline & NGas & 29.89 & 106.22 & ne & 9.55 & 25.91 & ne & ne & ne & ne & 0.00 \\
\hline & Othr & 27.15 & 96.47 & ne & ne & ne & ne & ne & ne & ne & ne \\
\hline \multirow[t]{3}{*}{ FoodStr } & Elec & 26.10 & 54.73 & 35.26 & 3.44 & 3.50 & 69.18 & 6.17 & 64.08 & 0.07 & 30.36 \\
\hline & NGas & 37.27 & 175.79 & ne & 4.77 & 1.38 & ne & ne & ne & ne & 15.26 \\
\hline & Othr & 33.85 & 159.67 & ne & ne & ne & ne & ne & ne & ne & ne \\
\hline \multirow[t]{3}{*}{ Warehouse } & Elec & 16.96 & 13.31 & 9.28 & 0.07 & 0.00 & 49.03 & 1.80 & 8.00 & 0.07 & 10.04 \\
\hline & NGas & 24.36 & 32.86 & ne & 0.10 & 0.00 & ne & ne & ne & ne & 2.14 \\
\hline & Othr & 22.13 & 29.85 & ne & ne & ne & ne & ne & ne & ne & ne \\
\hline \multirow[t]{3}{*}{ School } & Elec & 59.92 & 1.44 & 4.42 & 4.52 & 0.52 & 1.08 & 1.15 & 11.83 & 0.10 & 0.63 \\
\hline & NGas & 88.64 & 7.51 & ne & 6.14 & 1.09 & ne & ne & ne & ne & 0.00 \\
\hline & Othr & 80.50 & 5.76 & ne & ne & ne & ne & ne & ne & ne & ne \\
\hline \multirow[t]{3}{*}{ College } & Ele: & 9.23 & 9.96 & 5.32 & 2.56 & 0.22 & 0.21 & 0.55 & 13.64 & 0.14 & 0.92 \\
\hline & NGas & 12.61 & 48.21 & ne & 2.46 & 0.00 & ne & ne & ne & ne & 3.31 \\
\hline & Othr & 11.46 & 43.79 & ne & ne & ne & ne & ne & ne & ne & ne \\
\hline \multirow[t]{3}{*}{ Health } & Elec & 13.75 & 45.87 & 17.00 & 4.70 & 1.28 & 1.06 & 1.52 & 46.84 & 0.68 & 30.67 \\
\hline & NGas & 34.80 & 226.54 & ne & 2.09 & 0.51 & ne & ne & ne & ne & 4.58 \\
\hline & Othr & 31.61 & 205.76 & ne & ne & ne & ne & ne & ne & ne & ne \\
\hline \multirow[t]{3}{*}{ Lodging } & Elec & 2.40 & 2.79 & 3.19 & 1.44 & 0.27 & 1.83 & 1.21 & 10.77 & 0.03 & 4.20 \\
\hline & NGas & 28.18 & 17.74 & ne & 1.96 & 0.87 & ne & ne & ne & ne & 4.01 \\
\hline & Othr & 25.59 & 16.11 & ne & ne & ne & ne & ne & ne & ne & ne \\
\hline \multirow[t]{3}{*}{ Miscellns } & Elec & 8.00 & 15.73 & 5.79 & 0.00 & 0.00 & 1.80 & 1.58 & 6.53 & 0.14 & 8.63 \\
\hline & NGas & 16.90 & 74.09 & ne & 0.00 & 0.22 & ne & ne & ne & ne & 5.45 \\
\hline & Othr & 15.35 & 67.29 & ne & ne & ne & ne & ne & ne & ne & ne \\
\hline
\end{tabular}


Table 5-29. CEC 1975 EUIs for Region 4 (San Jose) Climate Zone [kBtu/sqft/yr] - U75

\begin{tabular}{|c|c|c|c|c|c|c|c|c|c|c|c|}
\hline Building & Fuel & Heat & Cool & Vent & HotW & Cook & Refr & OtLt & InLt & $\overline{\text { OfEq }}$ & Misc \\
\hline \multirow[t]{3}{*}{ SmOffice } & Elec & 7.11 & 10.09 & 2.91 & 1.15 & 0.25 & 1.01 & 6.73 & 20.18 & 0.72 & 6.07 \\
\hline & NGas & 11.64 & 31.37 & ne & 0.23 & 0.01 & ne & ne & ne & ne & 0.00 \\
\hline & Othr & 10.55 & 28.49 & ne & ne & ne & ne & ne & ne & ne & ne \\
\hline \multirow[t]{3}{*}{ LgOffice } & Elec & 15.21 & 25.28 & 20.14 & 1.08 & 1.06 & 0.50 & 1.92 & 45.77 & 1.13 & 9.35 \\
\hline & NGas & 18.64 & 140.35 & ne & 0.27 & 0.33 & ne & ne & ne & ne & 0.34 \\
\hline & Othr & 16.93 & 127.47 & ne & ne & ne & ne & ne & ne & ne & ne \\
\hline \multirow[t]{3}{*}{ Retail } & Elec & 8.10 & 3.71 & 3.92 & 0.54 & 0.22 & 2.63 & 3.52 & 26.81 & 0.14 & 2.86 \\
\hline & NGas & 15.23 & 13.19 & ne & 0.20 & 0.04 & ne & ne & ne & ne & 0.26 \\
\hline & Othr & 13.83 & 11.98 & ne & ne & ne & ne & ne & ne & ne & ne \\
\hline \multirow[t]{3}{*}{ Restaurant } & Elec & 15.23 & 14.14 & 19.79 & 7.37 & 35.60 & 29.39 & 8.33 & 32.61 & 0.10 & 25.36 \\
\hline & NGas & 22.79 & 54.09 & ne & 9.55 & 25.91 & ne & ne & ne & ne & 0.00 \\
\hline & Othr & 20.70 & 49.13 & ne & ne & ne & ne & ne & ne & ne & ne \\
\hline \multirow[t]{3}{*}{ FoodStr } & Elec & 24.93 & 9.61 & 28.78 & 3.44 & 3.50 & 69.18 & 6.17 & 64.08 & 0.07 & 30.36 \\
\hline & NGas & 35.60 & 30.86 & ne & 4.77 & 1.38 & ne & ne & ne & ne & 15.26 \\
\hline & Othr & 32.33 & 28.03 & ne & ne & ne & ne & ne & ne & ne & ne \\
\hline \multirow[t]{3}{*}{ Warehouse } & Elec & 19.28 & 4.59 & 6.97 & 0.07 & 0.00 & 49.03 & 1.80 & 8.00 & 0.07 & 10.04 \\
\hline & NGas & 27.69 & 11.33 & ne & 0.10 & 0.00 & ne & ne & ne & ne & 2.14 \\
\hline & Othr & 25.15 & 10.29 & ne & ne & ne & ne & ne & ne & ne & ne \\
\hline \multirow[t]{3}{*}{ School } & Elec & 57.09 & 0.99 & 3.47 & 4.52 & 0.52 & 1.08 & 1.15 & 11.83 & 0.10 & 0.63 \\
\hline & NGas & 84.45 & 5.14 & ne & 6.14 & 1.09 & ne & ne & ne & ne & 0.00 \\
\hline & Othr & 76.70 & 3.94 & ne & ne & ne & ne & ne & ne & ne & ne \\
\hline \multirow[t]{3}{*}{ College } & Elec & 9.50 & 8.14 & 4.76 & 2.56 & 0.22 & 0.21 & 0.55 & 13.64 & 0.14 & 0.92 \\
\hline & NGas & 12.98 & 39.38 & ne & 2.46 & 0.00 & ne & ne & ne & ne & 3.31 \\
\hline & Othr & 11.79 & 35.76 & ne & ne & ne & ne & ne & ne & ne & ne \\
\hline \multirow[t]{3}{*}{ Health } & $\overline{\text { Elec }}$ & 13.23 & 41.48 & 16.01 & 4.70 & 1.28 & 1.06 & 1.52 & 46.84 & 0.68 & 30.67 \\
\hline & NGas & 33.48 & 200.52 & ne & 2.09 & 0.51 & ne & ne & ne & ne & 4.58 \\
\hline & Othr & 30.41 & 182.12 & ne & ne & ne & ne & ne & ne & ne & ne \\
\hline \multirow[t]{3}{*}{ Lodging } & Elec & 2.40 & 1.33 & 2.95 & 1.44 & 0.27 & 1.83 & 1.21 & 10.77 & $\overline{0.03}$ & 4.20 \\
\hline & NGas & 28.18 & 8.47 & ne & 1.96 & 0.87 & ne & ne & ne & ne & 4.01 \\
\hline & Othr & 25.59 & 7.70 & ne & ne & ne & ne & ne & ne & ne & ne \\
\hline \multirow[t]{3}{*}{ Miscellns } & Elec & 7.17 & 5.99 & 5.79 & 0.00 & 0.00 & 1.80 & 1.58 & 6.53 & 0.14 & 8.63 \\
\hline & NGas & 15.17 & 28.18 & ne & 0.00 & 0.22 & ne & ne & ne & ne & 5.45 \\
\hline & Othr & 13.77 & 25.60 & ne & ne & ne & ne & ne & ne & ne & ne \\
\hline
\end{tabular}


Table 5-30. CEC 1975 EUIs for Region 5 (Oakland) Climate Zone [kBtu/sqft/yr] - U75

\begin{tabular}{|c|c|c|c|c|c|c|c|c|c|c|c|}
\hline Building & Fuel & Heat & Cool & Vent & HotW & Cook & Refr & OtLt & InLt & OfEq & Misc \\
\hline \multirow[t]{3}{*}{ SmOffice } & Elec & 4.65 & 5.32 & 1.37 & 1.15 & 0.25 & 1.01 & 6.73 & 20.18 & 0.72 & 6.07 \\
\hline & NGas & 7.60 & 14.46 & ne & 0.23 & 0.01 & ne & ne & ne & ne & 0.00 \\
\hline & Othr & 6.89 & 13.13 & ne & ne & ne & ne & ne & ne & ne & ne \\
\hline \multirow[t]{3}{*}{ LgOffice } & Elec & 13.45 & 24.13 & 16.38 & 1.08 & 1.06 & 0.50 & 1.92 & 45.77 & 1.13 & 9.35 \\
\hline & NGas & 16.48 & 126.50 & ne & 0.27 & 0.33 & ne & ne & ne & ne & 0.34 \\
\hline & Othr & 14.97 & 114.89 & ne & ne & ne & ne & ne & ne & ne & ne \\
\hline \multirow[t]{3}{*}{ Retail } & Elec & 5.68 & 3.78 & 2.54 & 0.54 & 0.22 & 2.63 & 3.52 & 26.81 & 0.14 & 2.86 \\
\hline & NGas & 10.68 & 10.37 & ne & 0.20 & 0.04 & ne & ne & ne & ne & 0.26 \\
\hline & Othr & 9.70 & 9.42 & ne & ne & ne & ne & ne & ne & ne & ne \\
\hline \multirow[t]{3}{*}{ Restaurant } & Elec & 11.04 & 17.12 & 19.57 & 7.37 & 35.60 & 29.39 & 8.33 & 32.61 & 0.10 & 25.36 \\
\hline & NGas & 16.51 & 53.53 & ne & 9.55 & 25.91 & ne & ne & ne & ne & 0.00 \\
\hline & Othr & 15.00 & 48.62 & ne & ne & ne & ne & ne & ne & ne & ne \\
\hline \multirow[t]{3}{*}{ FoodStr } & Elec & 28.48 & 15.21 & 20.97 & 3.44 & 3.50 & 69.18 & 6.17 & 64.08 & 0.07 & 30.36 \\
\hline & NGas & 40.68 & 53.43 & ne & 4.77 & 1.38 & ne & ne & ne & ne & 15.26 \\
\hline & Othr & 36.94 & 48.53 & ne & ne & ne & ne & ne & ne & ne & ne \\
\hline \multirow[t]{3}{*}{ Warehouse } & Elec & 13.09 & 1.39 & 8.77 & 0.07 & 0.00 & 50.62 & 1.80 & 8.00 & 0.07 & 10.04 \\
\hline & NGas & 18.80 & 3.21 & ne & 0.10 & 0.00 & ne & ne & ne & ne & 2.14 \\
\hline & Othr & 17.07 & 2.92 & ne & ne & ne & ne & ne & ne & ne & ne \\
\hline \multirow[t]{3}{*}{ School } & Elec & 53.49 & 2.93 & 2.90 & 4.52 & 0.52 & 1.08 & 1.15 & 11.83 & 0.10 & 0.63 \\
\hline & NGas & 79.13 & 14.22 & ne & 6.14 & 1.09 & ne & ne & ne & ne & 0.00 \\
\hline & Othr & 71.87 & 10.90 & ne & ne & ne & ne & ne & ne & ne & ne \\
\hline \multirow[t]{3}{*}{ College } & Elec & 9.02 & 10.31 & 6.80 & 2.56 & 0.22 & 0.21 & 0.55 & 13.64 & 0.14 & 0.92 \\
\hline & NGas & 12.33 & 27.60 & ne & 2.46 & 0.00 & ne & ne & ne & ne & 3.31 \\
\hline & Othr & 11.20 & 25.07 & ne & ne & ne & ne & ne & ne & ne & ne \\
\hline \multirow[t]{3}{*}{ Health } & Elec & 12.90 & 32.20 & 12.21 & 4.70 & 1.28 & 1.06 & 1.52 & 46.84 & 0.68 & 30.67 \\
\hline & NGas & 32.64 & 169.77 & ne & 2.09 & 0.51 & ne & ne & ne & ne & 4.58 \\
\hline & Othr & 29.65 & 154.20 & ne & ne & ne & ne & ne & ne & ne & ne \\
\hline \multirow[t]{3}{*}{ Lodging } & Elec & 2.47 & 4.85 & 4.00 & 1.44 & 0.27 & 1.83 & 1.21 & 10.77 & 0.03 & 4.20 \\
\hline & NGas & 25.40 & 22.34 & ne & 1.96 & 0.87 & ne & ne & ne & ne & 4.01 \\
\hline & Othr & 23.07 & 20.29 & ne & ne & ne & ne & ne & ne & ne & ne \\
\hline \multirow[t]{3}{*}{ Miscellns } & Elec & 6.18 & 14.97 & 15.57 & 0.00 & 0.00 & 1.80 & 1.58 & 6.53 & 0.14 & 8.63 \\
\hline & NGas & 13.06 & 24.81 & ne & 0.00 & 0.22 & ne & ne & ne & ne & 5.45 \\
\hline & Othr & 11.86 & 22.53 & ne & ne & ne & ne & ne & ne & ne & ne \\
\hline
\end{tabular}


Table 5:31. CEC 1979 EUIs for Region 1 (Blue Canyon) Climate Zone [Ratio] - EUI79

\begin{tabular}{|c|c|c|c|c|c|c|c|c|c|c|c|}
\hline Building & Fuel & Heat & $\mathrm{CoOl}$ & Vent & HotW & Cook & $\overline{R e f r}$ & OLt & $\operatorname{lnLt}$ & $\overline{\mathrm{OfEq}}$ & Misc \\
\hline SmOffice & $\begin{array}{l}\text { Elec } \\
\text { NGas } \\
\text { Othr }\end{array}$ & $\begin{array}{l}0.81 \\
0.81 \\
0.81\end{array}$ & $\begin{array}{l}0.08 \\
0.08 \\
0.08\end{array}$ & $\begin{array}{c}1.00 \\
\text { ne } \\
\text { ne }\end{array}$ & $\begin{array}{l}\text { ne } \\
\text { ne } \\
\text { ne }\end{array}$ & $\begin{array}{l}\text { ne } \\
\text { ne } \\
\text { ne }\end{array}$ & $\begin{array}{l}\text { ne } \\
\text { ne } \\
\text { ne }\end{array}$ & $\begin{array}{l}\text { ne } \\
\text { ne } \\
\text { ne }\end{array}$ & $\begin{array}{l}\text { ne } \\
\text { ne } \\
\text { ne } \\
\end{array}$ & $\begin{array}{l}\text { ne } \\
\text { ne } \\
\text { ne }\end{array}$ & $\begin{array}{l}\text { ne } \\
\text { ne } \\
\text { ne }\end{array}$ \\
\hline LgOffice & $\begin{array}{l}\text { Elec } \\
\text { NGas } \\
\text { Othr }\end{array}$ & $\begin{array}{l}0.80 \\
0.80 \\
0.80\end{array}$ & $\begin{array}{l}0.11 \\
0.11 \\
0.11\end{array}$ & $\begin{array}{c}0.64 \\
\text { ne } \\
\text { ne }\end{array}$ & $\begin{array}{l}\text { ne } \\
\text { ne } \\
\text { ne }\end{array}$ & $\begin{array}{l}\text { ne } \\
\text { ne } \\
\text { ne }\end{array}$ & $\begin{array}{l}\text { ne } \\
\text { ne } \\
\text { ne }\end{array}$ & $\begin{array}{l}\text { ne } \\
\text { ne } \\
\text { ne }\end{array}$ & $\begin{array}{l}\text { ne } \\
\text { ne } \\
\text { ne }\end{array}$ & $\begin{array}{l}\text { ne } \\
\text { ne } \\
\text { ne }\end{array}$ & $\begin{array}{l}\text { ne } \\
\text { ne } \\
\text { ne }\end{array}$ \\
\hline Retail & $\begin{array}{l}\text { Elec } \\
\text { NGas } \\
\text { Othr }\end{array}$ & $\begin{array}{l}0.66 \\
0.66 \\
0.66\end{array}$ & $\begin{array}{l}0.80 \\
0.80 \\
0.80\end{array}$ & $\begin{array}{l}0.96 \\
\text { ne } \\
\text { ne }\end{array}$ & $\begin{array}{l}\text { ne } \\
\text { ne } \\
\text { ne }\end{array}$ & $\begin{array}{l}\text { ne } \\
\text { ne } \\
\text { ne }\end{array}$ & $\begin{array}{l}\text { ne } \\
\text { ne } \\
\text { ne }\end{array}$ & $\begin{array}{l}\text { ne } \\
\text { ne } \\
\text { ne }\end{array}$ & $\begin{array}{l}\text { ne } \\
\text { ne } \\
\text { ne }\end{array}$ & $\begin{array}{l}\text { ne } \\
\text { ne } \\
\text { ne }\end{array}$ & $\begin{array}{l}\text { ne } \\
\text { ne } \\
\text { ne }\end{array}$ \\
\hline Restaurant & $\begin{array}{l}\text { Elec } \\
\text { NGas } \\
\text { Othr }\end{array}$ & $\begin{array}{l}0.58 \\
0.58 \\
0.58 \\
\end{array}$ & $\begin{array}{l}0.22 \\
0.22 \\
0.22 \\
\end{array}$ & $\begin{array}{c}0.77 \\
\text { ne } \\
\text { ne }\end{array}$ & $\begin{array}{l}\text { ne } \\
\text { ne } \\
\text { ne }\end{array}$ & $\begin{array}{l}\text { ne } \\
\text { ne } \\
\text { ne }\end{array}$ & $\begin{array}{l}\text { ne } \\
\text { ne } \\
\text { ne }\end{array}$ & $\begin{array}{l}\text { ne } \\
\text { ne } \\
\text { ne }\end{array}$ & $\begin{array}{l}\text { ne } \\
\text { ne } \\
\text { ne }\end{array}$ & $\begin{array}{l}\text { ne } \\
\text { ne } \\
\text { ne }\end{array}$ & $\begin{array}{l}\text { ne } \\
\text { ne } \\
\text { ne }\end{array}$ \\
\hline FoodStr & $\begin{array}{l}\text { Elec } \\
\text { NGas } \\
\text { Othr } \\
\end{array}$ & $\begin{array}{l}0.96 \\
0.96 \\
0.96 \\
\end{array}$ & $\begin{array}{l}0.40 \\
0.40 \\
0.40 \\
\end{array}$ & $\begin{array}{c}0.97 \\
\text { ne } \\
\text { ne }\end{array}$ & $\begin{array}{l}\text { ne } \\
\text { ne } \\
\text { ne }\end{array}$ & $\begin{array}{l}\text { ne } \\
\text { ne } \\
\text { ne }\end{array}$ & $\begin{array}{l}\text { ne } \\
\text { ne } \\
\text { ne }\end{array}$ & $\begin{array}{l}\text { ne } \\
\text { ne } \\
\text { ne }\end{array}$ & $\begin{array}{l}\text { ne } \\
\text { ne } \\
\text { ne }\end{array}$ & $\begin{array}{l}\text { ne } \\
\text { ne } \\
\text { ne }\end{array}$ & $\begin{array}{l}\text { ne } \\
\text { ne } \\
\text { ne }\end{array}$ \\
\hline Warehouse & $\begin{array}{l}\text { Elec } \\
\text { NGas } \\
\text { Othr }\end{array}$ & $\begin{array}{l}0.81 \\
0.81 \\
0.81 \\
\end{array}$ & $\begin{array}{l}0.18 \\
0.18 \\
0.18 \\
\end{array}$ & $\begin{array}{c}1.00 \\
\text { ne } \\
\text { ne }\end{array}$ & $\begin{array}{l}\text { ne } \\
\text { ne } \\
\text { ne }\end{array}$ & $\begin{array}{l}\text { ne } \\
\text { ne } \\
\text { ne }\end{array}$ & $\begin{array}{l}\text { ne } \\
\text { ne } \\
\text { ne }\end{array}$ & $\begin{array}{l}\text { ne } \\
\text { ne } \\
\text { ne } \\
\end{array}$ & $\begin{array}{l}\text { ne } \\
\text { ne } \\
\text { ne } \\
\end{array}$ & $\begin{array}{l}\text { ne } \\
\text { ne } \\
\text { ne }\end{array}$ & $\begin{array}{l}\text { ne } \\
\text { ne } \\
\text { ne }\end{array}$ \\
\hline School & $\begin{array}{l}\text { Elec } \\
\text { NGas } \\
\text { Othr }\end{array}$ & $\begin{array}{l}0.35 \\
0.35 \\
0.35 \\
\end{array}$ & $\begin{array}{l}0.01 \\
0.01 \\
0.01 \\
\end{array}$ & $\begin{array}{c}0.83 \\
\text { ne } \\
\text { ne } \\
\end{array}$ & $\begin{array}{l}\text { ne } \\
\text { ne } \\
\text { ne }\end{array}$ & $\begin{array}{l}\text { ne } \\
\text { ne } \\
\text { ne }\end{array}$ & $\begin{array}{l}\text { ne } \\
\text { ne } \\
\text { ne }\end{array}$ & $\begin{array}{l}\text { ne } \\
\text { ne } \\
\text { ne }\end{array}$ & $\begin{array}{l}\text { ne } \\
\text { ne } \\
\text { ne }\end{array}$ & $\begin{array}{l}\text { ne } \\
\text { ne } \\
\text { ne }\end{array}$ & $\begin{array}{l}\text { ne } \\
\text { ne } \\
\text { ne }\end{array}$ \\
\hline College & $\begin{array}{l}\text { Elec } \\
\text { NGas } \\
\text { Othr }\end{array}$ & $\begin{array}{l}0.28 \\
0.28 \\
0.28\end{array}$ & $\begin{array}{l}0.42 \\
0.42 \\
0.42\end{array}$ & $\begin{array}{c}0.22 \\
\text { ne } \\
\text { ne }\end{array}$ & $\begin{array}{l}\text { ne } \\
\text { ne } \\
\text { ne }\end{array}$ & $\begin{array}{l}\text { ne } \\
\text { ne } \\
\text { ne }\end{array}$ & $\begin{array}{l}\text { ne } \\
\text { ne } \\
\text { ne }\end{array}$ & $\begin{array}{l}\text { ne } \\
\text { ne } \\
\text { ne }\end{array}$ & $\begin{array}{l}\text { ne } \\
\text { ne } \\
\text { ne }\end{array}$ & $\begin{array}{l}\text { ne } \\
\text { ne } \\
\text { ne }\end{array}$ & $\begin{array}{l}\text { ne } \\
\text { ne } \\
\text { ne }\end{array}$ \\
\hline Health & $\begin{array}{l}\text { Elec } \\
\text { NGas } \\
\text { Othr }\end{array}$ & $\begin{array}{l}0.24 \\
0.24 \\
0.24\end{array}$ & $\begin{array}{l}0.33 \\
0.33 \\
0.33 \\
\end{array}$ & $\begin{array}{c}0.73 \\
\text { ne } \\
\text { ne }\end{array}$ & $\begin{array}{l}\text { ne } \\
\text { ne } \\
\text { ne }\end{array}$ & $\begin{array}{l}\text { ne } \\
\text { ne } \\
\text { ne }\end{array}$ & $\begin{array}{l}\text { ne } \\
\text { ne } \\
\text { ne }\end{array}$ & $\begin{array}{l}\text { ne } \\
\text { ne } \\
\text { ne }\end{array}$ & $\begin{array}{l}\text { ne } \\
\text { ne } \\
\text { ne }\end{array}$ & $\begin{array}{l}\text { ne } \\
\text { ne } \\
\text { ne }\end{array}$ & $\begin{array}{l}\text { ne } \\
\text { ne } \\
\text { ne }\end{array}$ \\
\hline Lodging & $\begin{array}{l}\text { Elec } \\
\text { NGas } \\
\text { Othr }\end{array}$ & $\begin{array}{l}0.65 \\
0.65 \\
0.65 \\
\end{array}$ & $\begin{array}{l}0.18 \\
0.18 \\
0.18 \\
\end{array}$ & $\begin{array}{c}0.52 \\
\text { ne } \\
\text { ne } \\
\end{array}$ & $\begin{array}{l}\text { ne } \\
\text { ne } \\
\text { ne }\end{array}$ & $\begin{array}{l}\text { ne } \\
\text { ne } \\
\text { ne }\end{array}$ & $\begin{array}{l}\text { ne } \\
\text { ne } \\
\text { ne }\end{array}$ & $\begin{array}{l}\text { ne } \\
\text { ne } \\
\text { ne }\end{array}$ & $\begin{array}{l}\text { ne } \\
\text { ne } \\
\text { ne }\end{array}$ & $\begin{array}{l}\text { ne } \\
\text { ne } \\
\text { ne }\end{array}$ & $\begin{array}{l}\text { ne } \\
\text { ne } \\
\text { ne }\end{array}$ \\
\hline Miscellns & $\begin{array}{l}\text { Elec } \\
\text { NGas } \\
\text { Othr }\end{array}$ & $\begin{array}{l}0.43 \\
0.43 \\
0.43\end{array}$ & $\begin{array}{l}0.20 \\
0.20 \\
0.20\end{array}$ & $\begin{array}{c}1.00 \\
\text { ne } \\
\text { ne }\end{array}$ & $\begin{array}{l}\text { ne } \\
\text { ne } \\
\text { ne }\end{array}$ & $\begin{array}{l}\text { ne } \\
\text { ne } \\
\text { ne }\end{array}$ & $\begin{array}{l}\text { ne } \\
\text { ne } \\
\text { ne }\end{array}$ & $\begin{array}{l}\text { ne } \\
\text { ne } \\
\text { ne }\end{array}$ & $\begin{array}{l}\text { ne } \\
\text { ne } \\
\text { ne }\end{array}$ & $\begin{array}{l}\text { ne } \\
\text { ne } \\
\text { ne }\end{array}$ & $\begin{array}{l}\text { ne } \\
\text { ne } \\
\text { ne }\end{array}$ \\
\hline
\end{tabular}


Table 5-32. CEC 1979 EUIs for Region 2 (Sacramento) Climate Zone [Ratio] - EUI79

\begin{tabular}{|c|c|c|c|c|c|c|c|c|c|c|c|}
\hline Building & Fuel & Heat & $\mathrm{CoOl}$ & Vent & HotW & Cook & Refr & OLt & InLt & OfEq & Misc \\
\hline SmOffice & $\begin{array}{l}\text { Elec } \\
\text { NGas } \\
\text { Othr }\end{array}$ & $\begin{array}{l}0.76 \\
0.76 \\
0.76\end{array}$ & $\begin{array}{l}0.82 \\
0.82 \\
0.82 \\
\end{array}$ & $\begin{array}{c}0.89 \\
\text { ne } \\
\text { ne }\end{array}$ & $\begin{array}{l}\text { ne } \\
\text { ne } \\
\text { ne }\end{array}$ & $\begin{array}{l}\text { ne } \\
\text { ne } \\
\text { ne }\end{array}$ & $\begin{array}{l}\text { ne } \\
\text { ne } \\
\text { ne }\end{array}$ & $\begin{array}{l}\text { ne } \\
\text { ne } \\
\text { ne }\end{array}$ & $\begin{array}{l}\text { ne } \\
\text { ne } \\
\text { ne }\end{array}$ & $\begin{array}{l}\text { ne } \\
\text { ne } \\
\text { ne }\end{array}$ & $\begin{array}{l}\text { ne } \\
\text { ne } \\
\text { ne }\end{array}$ \\
\hline LgOffice & $\begin{array}{l}\text { Elec } \\
\text { NGas } \\
\text { Othr }\end{array}$ & $\begin{array}{l}0.77 \\
0.77 \\
0.77\end{array}$ & $\begin{array}{l}0.45 \\
0.45 \\
0.45 \\
\end{array}$ & $\begin{array}{c}0.64 \\
\text { ne } \\
\text { ne }\end{array}$ & $\begin{array}{l}\text { ne } \\
\text { ne } \\
\text { ne }\end{array}$ & $\begin{array}{l}\text { ne } \\
\text { ne } \\
\text { ne }\end{array}$ & $\begin{array}{l}\text { ne } \\
\text { ne } \\
\text { ne }\end{array}$ & $\begin{array}{l}\text { ne } \\
\text { ne } \\
\text { ne }\end{array}$ & $\begin{array}{l}\text { ne } \\
\text { ne } \\
\text { ne }\end{array}$ & $\begin{array}{l}\text { ne } \\
\text { ne } \\
\text { ne }\end{array}$ & $\begin{array}{l}\text { ne } \\
\text { ne } \\
\text { ne }\end{array}$ \\
\hline Retail & $\begin{array}{l}\text { Elec } \\
\text { NGas } \\
\text { Othr } \\
\end{array}$ & $\begin{array}{l}0.57 \\
0.57 \\
0.57 \\
\end{array}$ & $\begin{array}{l}0.79 \\
0.79 \\
0.79 \\
\end{array}$ & $\begin{array}{c}0.87 \\
\text { ne } \\
\text { ne } \\
\end{array}$ & $\begin{array}{l}\text { ne } \\
\text { ne } \\
\text { ne }\end{array}$ & $\begin{array}{l}\text { ne } \\
\text { ne } \\
\text { ne }\end{array}$ & $\begin{array}{l}\text { ne } \\
\text { ne } \\
\text { ne }\end{array}$ & $\begin{array}{l}\text { ne } \\
\text { ne } \\
\text { ne }\end{array}$ & $\begin{array}{l}\text { ne } \\
\text { ne } \\
\text { ne }\end{array}$ & $\begin{array}{l}\text { ne } \\
\text { ne } \\
\text { ne }\end{array}$ & $\begin{array}{l}\text { ne } \\
\text { ne } \\
\text { ne }\end{array}$ \\
\hline Restaurant & $\begin{array}{l}\text { Elec } \\
\text { NGas } \\
\text { Othr }\end{array}$ & $\begin{array}{l}0.56 \\
0.57 \\
0.56 \\
\end{array}$ & $\begin{array}{l}0.67 \\
0.67 \\
0.67 \\
\end{array}$ & $\begin{array}{c}0.70 \\
\text { ne } \\
\text { ne } \\
\end{array}$ & $\begin{array}{l}\text { ne } \\
\text { ne } \\
\text { ne }\end{array}$ & $\begin{array}{l}\text { ne } \\
\text { ne } \\
\text { ne }\end{array}$ & $\begin{array}{l}\text { ne } \\
\text { ne } \\
\text { ne }\end{array}$ & $\begin{array}{l}\text { ne } \\
\text { ne } \\
\text { ne }\end{array}$ & $\begin{array}{l}\text { ne } \\
\text { ne } \\
\text { ne }\end{array}$ & $\begin{array}{l}\text { ne } \\
\text { ne } \\
\text { ne } \\
\end{array}$ & $\begin{array}{l}\text { ne } \\
\text { ne } \\
\text { ne }\end{array}$ \\
\hline FoodStr & $\begin{array}{l}\text { Elec } \\
\text { NGas } \\
\text { Othr }\end{array}$ & $\begin{array}{l}0.96 \\
0.96 \\
0.96\end{array}$ & $\begin{array}{l}0.91 \\
0.91 \\
0.91 \\
\end{array}$ & $\begin{array}{c}0.95 \\
\text { ne } \\
\text { ne }\end{array}$ & $\begin{array}{l}\text { ne } \\
\text { ne } \\
\text { ne }\end{array}$ & $\begin{array}{l}\text { ne } \\
\text { ne } \\
\text { ne }\end{array}$ & $\begin{array}{l}\text { ne } \\
\text { ne } \\
\text { ne }\end{array}$ & $\begin{array}{l}\text { ne } \\
\text { ne } \\
\text { ne }\end{array}$ & $\begin{array}{l}\text { ne } \\
\text { ne } \\
\text { ne }\end{array}$ & $\begin{array}{l}\text { ne } \\
\text { ne } \\
\text { ne }\end{array}$ & $\begin{array}{l}\text { ne } \\
\text { ne } \\
\text { ne }\end{array}$ \\
\hline Warehouse & $\begin{array}{l}\text { Elec } \\
\text { NGas } \\
\text { Othr } \\
\end{array}$ & $\begin{array}{l}0.80 \\
0.80 \\
0.80 \\
\end{array}$ & $\begin{array}{l}0.84 \\
0.84 \\
0.84 \\
\end{array}$ & $\begin{array}{c}0.92 \\
\text { ne } \\
\text { ne } \\
\end{array}$ & $\begin{array}{l}\text { ne } \\
\text { ne } \\
\text { ne }\end{array}$ & $\begin{array}{l}\text { ne } \\
\text { ne } \\
\text { ne }\end{array}$ & $\begin{array}{l}\text { ne } \\
\text { ne } \\
\text { ne }\end{array}$ & $\begin{array}{l}\text { ne } \\
\text { ne } \\
\text { ne }\end{array}$ & $\begin{array}{l}\text { ne } \\
\text { ne } \\
\text { ne }\end{array}$ & $\begin{array}{l}\text { ne } \\
\text { ne } \\
\text { ne }\end{array}$ & $\begin{array}{l}\text { ne } \\
\text { ne } \\
\text { ne }\end{array}$ \\
\hline School & $\begin{array}{l}\text { Elec } \\
\text { NGas } \\
\text { Othr }\end{array}$ & $\begin{array}{l}0.20 \\
0.20 \\
0.20 \\
\end{array}$ & $\begin{array}{l}0.22 \\
0.22 \\
0.22 \\
\end{array}$ & $\begin{array}{c}0.75 \\
\text { ne } \\
\text { ne }\end{array}$ & $\begin{array}{l}\text { ne } \\
\text { ne } \\
\text { ne }\end{array}$ & $\begin{array}{l}\text { ne } \\
\text { ne } \\
\text { ne }\end{array}$ & $\begin{array}{l}\text { ne } \\
\text { ne } \\
\text { ne }\end{array}$ & $\begin{array}{l}\text { ne } \\
\text { ne } \\
\text { ne }\end{array}$ & $\begin{array}{l}\text { ne } \\
\text { ne } \\
\text { ne }\end{array}$ & $\begin{array}{l}\text { ne } \\
\text { ne } \\
\text { ne }\end{array}$ & $\begin{array}{l}\text { ne } \\
\text { ne } \\
\text { ne }\end{array}$ \\
\hline College & $\begin{array}{l}\text { Elec } \\
\text { NGas } \\
\text { Othr }\end{array}$ & $\begin{array}{l}0.20 \\
0.20 \\
0.20 \\
\end{array}$ & $\begin{array}{l}0.28 \\
0.28 \\
0.28 \\
\end{array}$ & $\begin{array}{c}0.29 \\
\text { ne } \\
\text { ne }\end{array}$ & $\begin{array}{l}\text { ne } \\
\text { ne } \\
\text { ne }\end{array}$ & $\begin{array}{l}\text { ne } \\
\text { ne } \\
\text { ne }\end{array}$ & $\begin{array}{l}\text { ne } \\
\text { ne } \\
\text { ne }\end{array}$ & $\begin{array}{l}\text { ne } \\
\text { ne } \\
\text { ne }\end{array}$ & $\begin{array}{l}\text { ne } \\
\text { ne } \\
\text { ne }\end{array}$ & $\begin{array}{l}\text { ne } \\
\text { ne } \\
\text { ne }\end{array}$ & $\begin{array}{l}\text { ne } \\
\text { ne } \\
\text { ne }\end{array}$ \\
\hline Health & $\begin{array}{l}\text { Elec } \\
\text { NGas } \\
\text { Othr } \\
\end{array}$ & $\begin{array}{l}0.21 \\
0.21 \\
0.21 \\
\end{array}$ & $\begin{array}{l}0.55 \\
0.55 \\
0.55 \\
\end{array}$ & $\begin{array}{c}0.80 \\
\text { ne } \\
\text { ne } \\
\end{array}$ & $\begin{array}{l}\text { ne } \\
\text { ne } \\
\text { ne }\end{array}$ & $\begin{array}{l}\text { ne } \\
\text { ne } \\
\text { ne }\end{array}$ & $\begin{array}{l}\text { ne } \\
\text { ne } \\
\text { ne }\end{array}$ & $\begin{array}{l}\text { ne } \\
\text { ne } \\
\text { ne }\end{array}$ & $\begin{array}{l}\text { ne } \\
\text { ne } \\
\text { ne }\end{array}$ & $\begin{array}{l}\text { ne } \\
\text { ne } \\
\text { ne }\end{array}$ & $\begin{array}{l}\text { ne } \\
\text { ne } \\
\text { ne }\end{array}$ \\
\hline Lodging & $\begin{array}{l}\text { Elec } \\
\text { NGas } \\
\text { Othr } \\
\end{array}$ & $\begin{array}{l}0.33 \\
0.33 \\
0.33 \\
\end{array}$ & $\begin{array}{l}0.31 \\
0.31 \\
0.31 \\
\end{array}$ & $\begin{array}{c}0.34 \\
\text { ne } \\
\text { ne } \\
\end{array}$ & $\begin{array}{l}\text { ne } \\
\text { ne } \\
\text { ne }\end{array}$ & $\begin{array}{l}\text { ne } \\
\text { ne } \\
\text { ne }\end{array}$ & $\begin{array}{l}\text { ne } \\
\text { ne } \\
\text { ne }\end{array}$ & $\begin{array}{l}\text { ne } \\
\text { ne } \\
\text { ne }\end{array}$ & $\begin{array}{l}\text { ne } \\
\text { ne } \\
\text { ne }\end{array}$ & $\begin{array}{l}\text { ne } \\
\text { ne } \\
\text { ne }\end{array}$ & $\begin{array}{l}\text { ne } \\
\text { ne } \\
\text { ne }\end{array}$ \\
\hline Miscellns & $\begin{array}{l}\text { Elec } \\
\text { NGas } \\
\text { Othr }\end{array}$ & $\begin{array}{l}0.35 \\
0.35 \\
0.35 \\
\end{array}$ & $\begin{array}{l}0.82 \\
0.82 \\
0.82 \\
\end{array}$ & $\begin{array}{c}1.00 \\
\text { ne } \\
\text { ne } \\
\end{array}$ & $\begin{array}{l}\text { ne } \\
\text { ne } \\
\text { ne }\end{array}$ & $\begin{array}{l}\text { ne } \\
\text { ne } \\
\text { ne }\end{array}$ & $\begin{array}{l}\text { ne } \\
\text { ne } \\
\text { ne }\end{array}$ & $\begin{array}{l}\text { ne } \\
\text { ne } \\
\text { ne }\end{array}$ & $\begin{array}{l}\text { ne } \\
\text { ne } \\
\text { ne }\end{array}$ & $\begin{array}{l}\text { ne } \\
\text { ne } \\
\text { ne }\end{array}$ & $\begin{array}{l}\text { ne } \\
\text { ne } \\
\text { ne }\end{array}$ \\
\hline
\end{tabular}


Table 5-33. CEC 1979 EUIs for Region 3 (Fresno) Climate Zone [Ratio] - EUI79

\begin{tabular}{|c|c|c|c|c|c|c|c|c|c|c|c|}
\hline Building & Fuel & Heat & Cool & Vent & HotW & Cook & Refr & OtLt & InLt & $\mathrm{OfEq}$ & Misc \\
\hline \multirow[t]{3}{*}{ SmOffice } & Elec & 0.78 & 0.86 & 0.89 & ne & ne & ne & ne & ne & ne & ne \\
\hline & NGas & 0.78 & 0.86 & ne & ne & ne & ne & ne & ne & ne & ne \\
\hline & Othr & 0.78 & 0.86 & ne & ne & ne & ne & ne & ne & ne & ne \\
\hline \multirow[t]{3}{*}{ LgOffice } & Elec & 0.79 & 0.52 & 0.64 & ne & ne & ne & ne & ne & ne & ne \\
\hline & NGas & 0.79 & 0.52 & ne & ne & ne & ne & ne & ne & ne & ne \\
\hline & Othr & 0.79 & 0.52 & ne & ne & ne & ne & ne & ne & ne & ne \\
\hline \multirow[t]{3}{*}{ Retail } & Elec & 0.60 & 0.77 & 0.87 & ne & ne & ne & ne & ne & ne & ne \\
\hline & NGas & 0.60 & 0.77 & ne & ne & ne & ne & ne & ne & ne & ne \\
\hline & Othr & 0.60 & 0.77 & ne & ne & ne & ne & ne & ne & ne & ne \\
\hline \multirow[t]{3}{*}{ Restaurant } & Elec & 0.58 & 0.69 & 0.69 & ne & ne & ne & ne & ne & ne & ne \\
\hline & NGas & 0.60 & 0.69 & ne & ne & ne & ne & ne & ne & ne & ne \\
\hline & Othr & 0.58 & 0.69 & ne & ne & ne & ne & ne & ne & ne & ne \\
\hline \multirow[t]{3}{*}{ FoodStr } & Elec & 0.96 & $0 . \overline{91}$ & 0.94 & ne & ne & ne & ne & ne & ne & ne \\
\hline & NGas & 0.96 & 0.91 & ne & ne & ne & ne & ne & ne & ne & ne \\
\hline & Othr & 0.96 & 0.91 & ne & ne & ne & ne & ne & ne & ne & ne \\
\hline \multirow[t]{3}{*}{ Warehouse } & Elec & 0.80 & 0.85 & 0.93 & ne & ne & ne & ne & ne & ne & ne \\
\hline & NGas & 0.80 & 0.85 & ne & ne & ne & ne & ne & ne & ne & ne \\
\hline & Othr & 0.80 & 0.85 & ne & ne & ne & ne & ne & ne & ne & ne \\
\hline \multirow[t]{3}{*}{ School } & Elec & 0.25 & 0.32 & 0.75 & ne & ne & ne & ne & ne & ne & ne \\
\hline & NGas & 0.25 & 0.32 & ne & ne & ne & ne & ne & ne & ne & ne \\
\hline & Othr & 0.25 & 0.32 & ne & ne & ne & ne & ne & ne & ne & ne \\
\hline \multirow[t]{3}{*}{ College } & Elec & 0.23 & 0.33 & 0.31 & ne & ne & ne & ne & ne & ne & ne \\
\hline & NGas & 0.23 & 0.33 & ne & ne & ne & ne & ne & ne & ne & ne \\
\hline & Othr & 0.23 & 0.33 & ne & ne & ne & ne & ne & ne & ne & ne \\
\hline \multirow[t]{3}{*}{ Health } & Elec & 0.29 & 0.61 & 0.80 & ne & ne & ne & ne & ne & ne & ne \\
\hline & NGas & 0.29 & 0.61 & ne & ne & ne & ne & ne & ne & ne & ne \\
\hline & Othr & 0.29 & 0.61 & ne & ne & ne & ne & ne & ne & ne & ne \\
\hline \multirow[t]{3}{*}{ Lodging } & Elec & 0.36 & 0.35 & 0.32 & ne & ne & ne & ne & ne & ne & ne \\
\hline & NGas & 0.36 & 0.35 & ne & ne & ne & ne & ne & ne & ne & ne \\
\hline & Othr & 0.36 & 0.35 & ne & ne & ne & ne & ne & ne & ne & ne \\
\hline \multirow[t]{3}{*}{ Miscellns } & Elec & 0.37 & 0.83 & 1.00 & ne & ne & ne & ne & ne & ne & ne \\
\hline & NGas & 0.37 & 0.83 & ne & ne & ne & ne & ne & ne & ne & ne \\
\hline & Othr & 0.37 & 0.83 & ne & ne & ne & ne & ne & ne & ne & ne \\
\hline
\end{tabular}


Table 5-34. CEC 1979 EUIs for Region 4 (San Jose) Climate Zone [Ratio] - EUI79

\begin{tabular}{|c|c|c|c|c|c|c|c|c|c|c|c|}
\hline Building & Fuel & Heat & Cool & Vent & HotW & Cook & Refr & OtLt & InLt & OfEq & Misc \\
\hline \multirow[t]{3}{*}{ SmOffice } & Elec & 0.78 & 0.67 & 1.00 & ne & ne & ne & ne & ne & ne & ne \\
\hline & NGas & 0.78 & 0.67 & ne & ne & ne & ne & ne & ne & ne & ne \\
\hline & Othr & 0.78 & 0.67 & ne & ne & ne & ne & ne & ne & ne & ne \\
\hline \multirow[t]{3}{*}{ LgOffice } & Elec & 0.77 & 0.34 & 0.64 & ne & ne & ne & ne & ne & ne & ne \\
\hline & NGas & 0.77 & 0.34 & ne & ne & ne & ne & ne & ne & ne & ne \\
\hline & Othr & 0.77 & 0.34 & ne & ne & ne & ne & ne & ne & ne & ne \\
\hline \multirow[t]{3}{*}{ Retail } & Elec & 0.60 & 0.87 & 0.97 & ne & ne & ne & ne & ne & ne & ne \\
\hline & NGas & 0.60 & 0.87 & ne & ne & ne & ne & ne & ne & ne & ne \\
\hline & Othr & 0.60 & 0.87 & ne & ne & ne & ne & ne & ne & ne & ne \\
\hline \multirow[t]{3}{*}{ Restaurant } & Elec & 0.55 & 0.58 & 0.70 & ne & ne & ne & ne & ne & ne & ne \\
\hline & NGas & 0.60 & 0.58 & ne & ne & ne & ne & ne & ne & ne & ne \\
\hline & Othr & 0.55 & 0.58 & ne & ne & ne & ne & ne & ne & ne & ne \\
\hline \multirow[t]{3}{*}{ FoodStr } & Elec & 0.96 & 0.85 & 0.95 & ne & ne & ne & ne & ne & ne & ne \\
\hline & NGas & 0.96 & 0.85 & ne & ne & ne & ne & ne & ne & ne & ne \\
\hline & Othr & 0.96 & 0.85 & ne & ne & ne & ne & ne & ne & ne & ne \\
\hline \multirow[t]{3}{*}{ Warehouse } & Elec & 0.79 & 0.73 & 0.95 & $\overline{\text { ne }}$ & ne & ne & ne & ne & ne & ne \\
\hline & NGas & 0.79 & 0.73 & ne & ne & ne & ne & ne & ne & ne & ne \\
\hline & Othr & 0.79 & 0.73 & ne & ne & ne & ne & ne & ne & ne & ne \\
\hline \multirow[t]{3}{*}{ School } & Elec & 0.23 & 0.13 & 0.81 & $\overline{\text { ne }}$ & ne & ne & ne & ne & ne & ne \\
\hline & NGas & 0.23 & 0.13 & ne & ne & ne & ne & ne & ne & ne & ne \\
\hline & Othr & 0.23 & 0.13 & ne & ne & ne & ne & ne & ne & ne & ne \\
\hline \multirow[t]{3}{*}{ College } & Elec & 0.20 & 0.23 & 0.26 & ne & ne & ne & $\overline{\text { ne }}$ & ne & ne & ne \\
\hline & NGas & 0.20 & 0.23 & ne & ne & ne & ne & ne & ne & ne & ne \\
\hline & Othr & 0.20 & 0.23 & ne & ne & ne & ne & ne & ne & ne & ne \\
\hline \multirow[t]{3}{*}{ Health } & Elec & 0.20 & 0.51 & 0.80 & ne & ne & ne & ne & ne & ne & ne \\
\hline & NGas & 0.20 & 0.51 & ne & ne & ne & ne & ne & ne & ne & ne \\
\hline & Othr & 0.20 & 0.51 & ne & ne & ne & ne & ne & ne & ne & ne \\
\hline \multirow[t]{3}{*}{ Lodging } & Elec & 0.34 & 0.7 & 3 & ne & ne & ne & ne & ne & ne & ne \\
\hline & NGas & 0.34 & 0 & & ne & ne & ne & ne & ne & ne & ne \\
\hline & Othr & 0.34 & C & & ne & ne & ne & ne & ne & ne & ne \\
\hline \multirow[t]{3}{*}{ Miscellns } & Elec & 0.33 & $\overline{0}$ & J & ne & ne & ne & ne & ne & ne & ne \\
\hline & NGas & 0.33 & 0.73 & ne & ne & ne & ne & ne & ne & ne & ne \\
\hline & Othr & 0.33 & 0.73 & ne & ne & ne & ne & ne & ne & ne & ne \\
\hline
\end{tabular}


Table 5-35. CEC 1979 EUIs for Region 5 (Oakland) Climate Zone [Ratio] - EUI79

\begin{tabular}{|c|c|c|c|c|c|c|c|c|c|c|c|}
\hline Building & Fuel & Heat & Cool & Vent & HotW & Cook & Refr & OtLt & InLt & OfEg & Misc \\
\hline SmOffice & $\begin{array}{l}\text { Elec } \\
\text { NGas } \\
\text { Othr }\end{array}$ & $\begin{array}{l}0.75 \\
0.75 \\
0.75\end{array}$ & $\begin{array}{l}0.51 \\
0.51 \\
0.51\end{array}$ & $\begin{array}{c}1.00 \\
\text { ne } \\
\text { ne }\end{array}$ & $\begin{array}{l}\text { ne } \\
\text { ne } \\
\text { ne }\end{array}$ & $\begin{array}{l}\text { ne } \\
\text { ne } \\
\text { ne }\end{array}$ & $\begin{array}{l}\text { ne } \\
\text { ne } \\
\text { ne }\end{array}$ & $\begin{array}{l}\text { ne } \\
\text { ne } \\
\text { ne }\end{array}$ & $\begin{array}{l}\text { ne } \\
\text { ne } \\
\text { ne }\end{array}$ & $\begin{array}{l}\text { ne } \\
\text { ne } \\
\text { ne }\end{array}$ & $\begin{array}{l}\text { ne } \\
\text { ne } \\
\text { ne }\end{array}$ \\
\hline LgOffice & $\begin{array}{l}\text { Elec } \\
\text { NGas } \\
\text { Othr }\end{array}$ & $\begin{array}{l}0.75 \\
0.75 \\
0.75 \\
\end{array}$ & $\begin{array}{l}0.28 \\
0.28 \\
0.28 \\
\end{array}$ & $\begin{array}{c}0.64 \\
\text { ne } \\
\text { ne }\end{array}$ & $\begin{array}{l}\text { ne } \\
\text { ne } \\
\text { ne }\end{array}$ & $\begin{array}{l}\text { ne } \\
\text { ne } \\
\text { ne }\end{array}$ & $\begin{array}{l}\text { ne } \\
\text { ne } \\
\text { ne }\end{array}$ & $\begin{array}{l}\text { ne } \\
\text { ne } \\
\text { ne }\end{array}$ & $\begin{array}{l}\text { ne } \\
\text { ne } \\
\text { ne }\end{array}$ & $\begin{array}{l}\text { ne } \\
\text { ne } \\
\text { ne }\end{array}$ & $\begin{array}{l}\text { ne } \\
\text { ne } \\
\text { ne }\end{array}$ \\
\hline Retail & $\begin{array}{l}\text { Elec } \\
\text { NGas } \\
\text { Othr }\end{array}$ & $\begin{array}{l}0.56 \\
0.56 \\
0.56\end{array}$ & $\begin{array}{l}0.93 \\
0.93 \\
0.93\end{array}$ & $\begin{array}{c}0.96 \\
\text { ne } \\
\text { ne }\end{array}$ & $\begin{array}{l}\text { ne } \\
\text { ne } \\
\text { ne }\end{array}$ & $\begin{array}{l}\text { ne } \\
\text { ne } \\
\text { ne }\end{array}$ & $\begin{array}{l}\text { ne } \\
\text { ne } \\
\text { ne }\end{array}$ & $\begin{array}{l}\text { ne } \\
\text { ne } \\
\text { ne }\end{array}$ & $\begin{array}{l}\text { ne } \\
\text { ne } \\
\text { ne }\end{array}$ & $\begin{array}{l}\text { ne } \\
\text { ne } \\
\text { ne }\end{array}$ & $\begin{array}{l}\text { ne } \\
\text { ne } \\
\text { ne }\end{array}$ \\
\hline Restaurant & $\begin{array}{l}\text { Elec } \\
\text { NGas } \\
\text { Othr }\end{array}$ & $\begin{array}{l}0.54 \\
0.54 \\
0.54\end{array}$ & $\begin{array}{l}0.53 \\
0.53 \\
0.53\end{array}$ & $\begin{array}{c}0.73 \\
\text { ne } \\
\text { ne }\end{array}$ & $\begin{array}{l}\text { ne } \\
\text { ne } \\
\text { ne }\end{array}$ & $\begin{array}{l}\text { ne } \\
\text { ne } \\
\text { ne }\end{array}$ & $\begin{array}{l}\text { ne } \\
\text { ne } \\
\text { ne }\end{array}$ & $\begin{array}{l}\text { ne } \\
\text { ne } \\
\text { ne }\end{array}$ & $\begin{array}{l}\text { ne } \\
\text { ne } \\
\text { ne }\end{array}$ & $\begin{array}{l}\text { ne } \\
\text { ne } \\
\text { ne }\end{array}$ & $\begin{array}{l}\text { ne } \\
\text { ne } \\
\text { ne }\end{array}$ \\
\hline FoodStr & $\begin{array}{l}\text { Elec } \\
\text { NGas } \\
\text { Othr } \\
\end{array}$ & $\begin{array}{l}0.96 \\
0.96 \\
0.96 \\
\end{array}$ & $\begin{array}{l}0.84 \\
0.84 \\
0.84 \\
\end{array}$ & $\begin{array}{c}0.97 \\
\text { ne } \\
\text { ne } \\
\end{array}$ & $\begin{array}{l}\text { ne } \\
\text { ne } \\
\text { ne }\end{array}$ & $\begin{array}{l}\text { ne } \\
\text { ne } \\
\text { ne }\end{array}$ & $\begin{array}{l}\text { ne } \\
\text { ne } \\
\text { ne }\end{array}$ & $\begin{array}{l}\text { ne } \\
\text { ne } \\
\text { ne }\end{array}$ & $\begin{array}{l}\text { ne } \\
\text { ne } \\
\text { ne }\end{array}$ & $\begin{array}{l}\text { ne } \\
\text { ne } \\
\text { ne }\end{array}$ & $\begin{array}{l}\text { ne } \\
\text { ne } \\
\text { ne }\end{array}$ \\
\hline Warehouse & $\begin{array}{l}\text { Elec } \\
\text { NGas } \\
\text { Othr } \\
\end{array}$ & $\begin{array}{l}0.79 \\
0.79 \\
0.79 \\
\end{array}$ & $\begin{array}{l}0.61 \\
0.61 \\
0.61 \\
\end{array}$ & $\begin{array}{c}0.95 \\
\text { ne } \\
\text { ne } \\
\end{array}$ & $\begin{array}{l}\text { ne } \\
\text { ne } \\
\text { ne }\end{array}$ & $\begin{array}{l}\text { ne } \\
\text { ne } \\
\text { ne }\end{array}$ & $\begin{array}{l}\text { ne } \\
\text { ne } \\
\text { ne }\end{array}$ & $\begin{array}{l}\text { ne } \\
\text { ne } \\
\text { ne }\end{array}$ & $\begin{array}{l}\text { ne } \\
\text { ne } \\
\text { ne }\end{array}$ & $\begin{array}{l}\text { ne } \\
\text { ne } \\
\text { ne }\end{array}$ & $\begin{array}{l}\text { ne } \\
\text { ne } \\
\text { ne }\end{array}$ \\
\hline School & $\begin{array}{l}\text { Elec } \\
\text { NGas } \\
\text { Othr }\end{array}$ & $\begin{array}{l}0.20 \\
0.20 \\
0.20 \\
\end{array}$ & $\begin{array}{l}0.10 \\
0.10 \\
0.10 \\
\end{array}$ & $\begin{array}{c}0.82 \\
\text { ne } \\
\text { ne } \\
\end{array}$ & $\begin{array}{l}\text { ne } \\
\text { ne } \\
\text { ne }\end{array}$ & $\begin{array}{l}\text { ne } \\
\text { ne } \\
\text { ne }\end{array}$ & $\begin{array}{l}\text { ne } \\
\text { ne } \\
\text { ne }\end{array}$ & $\begin{array}{l}\text { ne } \\
\text { ne } \\
\text { ne }\end{array}$ & $\begin{array}{l}\text { ne } \\
\text { ne } \\
\text { ne }\end{array}$ & $\begin{array}{l}\text { ne } \\
\text { ne } \\
\text { ne } \\
\end{array}$ & $\begin{array}{l}\text { ne } \\
\text { ne } \\
\text { ne }\end{array}$ \\
\hline College & $\begin{array}{l}\text { Elec } \\
\text { NGas } \\
\text { Othr }\end{array}$ & $\begin{array}{l}0.20 \\
0.20 \\
0.20 \\
\end{array}$ & $\begin{array}{l}0.21 \\
0.21 \\
0.21 \\
\end{array}$ & $\begin{array}{c}0.25 \\
\text { ne } \\
\text { ne }\end{array}$ & $\begin{array}{l}\text { ne } \\
\text { ne } \\
\text { ne }\end{array}$ & $\begin{array}{l}\text { ne } \\
\text { ne } \\
\text { ne }\end{array}$ & $\begin{array}{l}\text { ne } \\
\text { ne } \\
\text { ne }\end{array}$ & $\begin{array}{l}\text { ne } \\
\text { ne } \\
\text { ne }\end{array}$ & $\begin{array}{l}\text { ne } \\
\text { ne } \\
\text { ne }\end{array}$ & $\begin{array}{l}\text { ne } \\
\text { ne } \\
\text { ne }\end{array}$ & $\begin{array}{l}\text { ne } \\
\text { ne } \\
\text { ne }\end{array}$ \\
\hline Health & $\begin{array}{l}\text { Elec } \\
\text { NGas } \\
\text { Othr }\end{array}$ & $\begin{array}{l}0.15 \\
0.15 \\
0.15 \\
\end{array}$ & $\begin{array}{l}0.52 \\
0.52 \\
0.52 \\
\end{array}$ & $\begin{array}{c}0.80 \\
\text { ne } \\
\text { ne }\end{array}$ & $\begin{array}{l}\text { ne } \\
\text { ne } \\
\text { ne }\end{array}$ & $\begin{array}{l}\text { ne } \\
\text { ne } \\
\text { ne }\end{array}$ & $\begin{array}{l}\text { ne } \\
\text { ne } \\
\text { ne }\end{array}$ & $\begin{array}{l}\text { ne } \\
\text { ne } \\
\text { ne }\end{array}$ & $\begin{array}{l}\text { ne } \\
\text { ne } \\
\text { ne }\end{array}$ & $\begin{array}{l}\text { ne } \\
\text { ne } \\
\text { ne }\end{array}$ & $\begin{array}{l}\text { ne } \\
\text { ne } \\
\text { ne }\end{array}$ \\
\hline Lodging & $\begin{array}{l}\text { Elec } \\
\text { NGas } \\
\text { Othr } \\
\end{array}$ & $\begin{array}{l}0.57 \\
0.57 \\
0.57 \\
\end{array}$ & $\begin{array}{l}0.40 \\
0.40 \\
0.40 \\
\end{array}$ & $\begin{array}{c}0.56 \\
\text { ne } \\
\text { ne } \\
\end{array}$ & $\begin{array}{l}\text { ne } \\
\text { ne } \\
\text { ne }\end{array}$ & $\begin{array}{l}\text { ne } \\
\text { ne } \\
\text { ne }\end{array}$ & $\begin{array}{l}\text { ne } \\
\text { ne } \\
\text { ne }\end{array}$ & $\begin{array}{l}\text { ne } \\
\text { ne } \\
\text { ne }\end{array}$ & $\begin{array}{l}\text { ne } \\
\text { ne } \\
\text { ne }\end{array}$ & $\begin{array}{l}\text { ne } \\
\text { ne } \\
\text { ne }\end{array}$ & $\begin{array}{l}\text { ne } \\
\text { ne } \\
\text { ne }\end{array}$ \\
\hline Miscellns & $\begin{array}{l}\text { Elec } \\
\text { NGas } \\
\text { Othr }\end{array}$ & $\begin{array}{l}0.31 \\
0.31 \\
0.31 \\
\end{array}$ & $\begin{array}{l}0.58 \\
0.58 \\
0.58 \\
\end{array}$ & $\begin{array}{c}1.00 \\
\text { ne } \\
\text { ne }\end{array}$ & $\begin{array}{l}\text { ne } \\
\text { ne } \\
\text { ne }\end{array}$ & $\begin{array}{l}\text { ne } \\
\text { ne } \\
\text { ne }\end{array}$ & $\begin{array}{l}\text { ne } \\
\text { ne } \\
\text { ne }\end{array}$ & $\begin{array}{l}\text { ne } \\
\text { ne } \\
\text { ne }\end{array}$ & $\begin{array}{l}\text { ne } \\
\text { ne } \\
\text { ne }\end{array}$ & $\begin{array}{l}\text { ne } \\
\text { ne } \\
\text { ne }\end{array}$ & $\begin{array}{l}\text { ne } \\
\text { ne } \\
\text { ne }\end{array}$ \\
\hline
\end{tabular}


Table 5-36. PG\&E 1975 EUIs for Coastal (Oakland) Climate Zone [kBtu/sqft/yr]

\begin{tabular}{|c|c|c|c|c|c|c|c|c|c|c|c|}
\hline Building & Fuel & Heat & Cool & Vent & HotW & Cook & Refr & $\overline{\mathrm{OtLt}}$ & InLt & OfEq & Misc \\
\hline \multirow[t]{3}{*}{ SmOffice } & Elec & 4.14 & 4.61 & 1.08 & 1.08 & 0.20 & 0.80 & 5.31 & 15.92 & 0.72 & 4.79 \\
\hline & NGas & 9.20 & 13.27 & ne & 0.29 & 0.01 & ne & ne & ne & ne & 0.00 \\
\hline & Othr & 6.96 & 13.27 & ne & ne & ne & ne & ne & ne & ne & ne \\
\hline \multirow[t]{3}{*}{ LgOffice } & Elec & 11.98 & 20.92 & 12.93 & 1.01 & 0.84 & 0.39 & 1.52 & 36.12 & 1.13 & 7.37 \\
\hline & NGas & 19.96 & 116.05 & ne & 0.34 & 0.30 & ne & ne & ne & ne & 0.42 \\
\hline & Othr & 15.12 & 116.05 & ne & ne & ne & ne & ne & ne & ne & ne \\
\hline \multirow[t]{3}{*}{ Retail } & Elec & 5.02 & 3.25 & 1.99 & 0.50 & 0.17 & 2.06 & 2.76 & 20.99 & 0.14 & 2.24 \\
\hline & NGas & 12.94 & 9.51 & ne & 0.25 & 0.04 & ne & ne & ne & ne & 0.33 \\
\hline & Othr & 9.80 & 9.51 & ne & ne & ne & ne & ne & ne & ne & ne \\
\hline \multirow[t]{3}{*}{ Restaurant } & Elec & 10.66 & 16.11 & 16.75 & 7.49 & 30.47 & 25.15 & 7.13 & 27.91 & 0.10 & 21.71 \\
\hline & NGas & 20.00 & 49.11 & ne & 12.00 & 24.01 & ne & ne & ne & ne & 0.00 \\
\hline & Othr & 15.15 & 49.11 & ne & ne & ne & ne & ne & ne & ne & ne \\
\hline \multirow[t]{3}{*}{ FoodStr } & Elec & 24.46 & 12.70 & 15.93 & 3.11 & 2.65 & 52.54 & 4.69 & $\overline{48.66}$ & 0.07 & 23.05 \\
\hline & NGas & 49.26 & 49.02 & ne & 6.00 & 1.28 & ne & ne & ne & ne & 19.18 \\
\hline & Othr & 37.32 & 49.02 & ne & ne & ne & ne & ne & ne & ne & ne \\
\hline \multirow[t]{3}{*}{ Warehouse } & Elec & 12.98 & 1.34 & 7.70 & 0.08 & 0.00 & $\overline{44.46}$ & 1.59 & 7.03 & 0.07 & 8.82 \\
\hline & NGas & 22.77 & 2.94 & ne & 0.12 & 0.00 & ne & ne & ne & ne & 2.69 \\
\hline & Othr & 17.25 & 2.94 & ne & ne & ne & ne & ne & ne & ne & ne \\
\hline \multirow[t]{3}{*}{ School } & Elec & 52.57 & 2.80 & 2.53 & 4.68 & $\overline{0.45}$ & 0.94 & 1.00 & 10.30 & 0.10 & 0.55 \\
\hline & NGas & 95.82 & 13.04 & ne & 7.71 & 1.01 & ne & ne & ne & ne & 0.00 \\
\hline & Othr & 72.59 & 11.01 & ne & ne & ne & ne & ne & ne & ne & ne \\
\hline \multirow[t]{3}{*}{ College } & Elec & 8.36 & 9.31 & 5.59 & 2.50 & 0.18 & 0.17 & 0.45 & 11.20 & 0.14 & 0.76 \\
\hline & NGas & 14.93 & 25.32 & ne & 3.10 & 0.00 & ne & ne & ne & ne & 4.16 \\
\hline & Othr & 11.31 & 25.32 & ne & ne & ne & ne & ne & ne & ne & ne \\
\hline \multirow[t]{3}{*}{ Health } & Elec & 11.86 & 28.83 & 9.94 & 4.55 & 1.04 & $\overline{0.86}$ & 1.24 & 38.15 & 0.68 & 24.98 \\
\hline & NGas & 39.53 & 155.75 & ne & 2.63 & 0.47 & ne & ne & ne & ne & 5.75 \\
\hline & Othr & 29.95 & 155.75 & ne & ne & ne & ne & ne & ne & ne & ne \\
\hline \multirow[t]{3}{*}{ Lodging } & Elec & 2.47 & 4.73 & 3.55 & 1.52 & 0.24 & 1.62 & 1.07 & 9.55 & 0.03 & 3.72 \\
\hline & NGas & 30.76 & 20.49 & ne & 2.47 & 0.81 & ne & ne & ne & ne & 5.04 \\
\hline & Othr & 23.30 & 20.49 & ne & ne & ne & ne & ne & ne & ne & ne \\
\hline \multirow[t]{3}{*}{ Miscellns } & Elec & 6.07 & $\overline{14.33}$ & 13.56 & 0.00 & 0.00 & 1.57 & 1.38 & 5.69 & 0.14 & 7.51 \\
\hline & NGas & 15.81 & 22.76 & ne & 0.00 & 0.20 & ne & ne & ne & ne & 6.85 \\
\hline & Othr & 11.98 & 22.76 & ne & ne & ne & ne & ne & ne & ne & ne \\
\hline
\end{tabular}


Table 5-37. PG\&E 1975 EUIs for Inland (Sacramento) Climate Zone [kBtu/sqft/yr]

\begin{tabular}{|c|c|c|c|c|c|c|c|c|c|c|c|}
\hline Building & Fuel & Heat & Cool & Vent & HotW & Cook & Refr & OtLt & InLt & OfEq & Misc \\
\hline \multirow[t]{3}{*}{ SmOffice } & Elec & 6.80 & 14.57 & 2.58 & 1.08 & 0.20 & 0.80 & 5.31 & 15.92 & 0.72 & 4.79 \\
\hline & NGas & 15.12 & 47.93 & ne & 0.29 & 0.01 & ne & ne & ne & ne & 0.00 \\
\hline & Othr & 11.44 & 47.93 & ne & ne & ne & ne & ne & ne & ne & ne \\
\hline \multirow[t]{3}{*}{ LgOffice } & Elec & 14.08 & 25.04 & 16.66 & 1.01 & 0.84 & 0.39 & 1.52 & 36.12 & 1.13 & 7.37 \\
\hline & NGas & 23.47 & 147.08 & ne & 0.34 & 0.30 & ne & ne & ne & ne & 0.42 \\
\hline & Othr & 17.78 & 147.08 & ne & ne & ne & ne & ne & ne & ne & ne \\
\hline \multirow[t]{3}{*}{ Retail } & Elec & 7.73 & 7.89 & 3.64 & 0.50 & 0.17 & 2.06 & 2.76 & 20.99 & 0.14 & 2.24 \\
\hline & NGas & 19.92 & 29.91 & ne & 0.25 & 0.04 & ne & ne & ne & ne & 0.33 \\
\hline & Othr & 15.09 & 29.91 & ne & ne & ne & ne & ne & ne & ne & ne \\
\hline \multirow[t]{3}{*}{ Restaurant } & Elec & 16.00 & 19.49 & 17.57 & 7.49 & 30.47 & 25.15 & 7.13 & 27.91 & 0.10 & 21.71 \\
\hline & NGas & 30.01 & 72.71 & ne & 12.00 & 24.01 & ne & ne & ne & ne & 0.00 \\
\hline & Othr & 22.73 & 72.71 & ne & ne & ne & ne & ne & ne & ne & ne \\
\hline \multirow[t]{3}{*}{ FoodStr } & Elec & 19.97 & 19.87 & 22.62 & 3.11 & 2.65 & 52.54 & 4.69 & 48.66 & 0.07 & 23.05 \\
\hline & NGas & 40.23 & 70.17 & ne & 6.00 & 1.28 & ne & ne & ne & ne & 19.18 \\
\hline & Othr & 30.48 & 70.17 & ne & ne & ne & ne & ne & ne & ne & ne \\
\hline \multirow[t]{3}{*}{ Warehouse } & Elec & 17.06 & 6.65 & 6.70 & 0.08 & 0.00 & 26.05 & 1.59 & 7.03 & 0.07 & 8.82 \\
\hline & NGas & 29.92 & 15.62 & ne & 0.12 & 0.00 & ne & ne & ne & ne & 2.69 \\
\hline & Othr & 22.67 & 15.62 & ne & ne & ne & ne & ne & ne & ne & ne \\
\hline \multirow[t]{3}{*}{ School } & Elec & 57.53 & 1.22 & 3.51 & 4.68 & 0.45 & 0.94 & 1.00 & 10.30 & 0.10 & 0.55 \\
\hline & NGas & 104.86 & 6.11 & ne & 7.71 & 1.01 & ne & ne & ne & ne & 0.00 \\
\hline & Othr & 79.44 & 5.16 & ne & ne & ne & ne & ne & ne & ne & ne \\
\hline \multirow[t]{3}{*}{ College } & Elec & 8.39 & 8.21 & 4.27 & 2.50 & 0.18 & 0.17 & 0.45 & 11.20 & 0.14 & 0.76 \\
\hline & NGas & 14.99 & 40.37 & ne & 3.10 & 0.00 & ne & ne & ne & ne & 4.16 \\
\hline & Othr & 11.36 & 40.37 & ne & ne & ne & ne & ne & ne & ne & ne \\
\hline \multirow[t]{3}{*}{ Health } & Elec & 12.18 & 39.11 & 13.48 & 4.55 & 1.04 & 0.86 & 1.24 & 38.15 & 0.68 & 24.98 \\
\hline & NGas & 40.59 & 193.73 & ne & 2.63 & 0.47 & ne & ne & ne & ne & 5.75 \\
\hline & Othr & 30.75 & 193.73 & ne & ne & ne & ne & ne & ne & ne & ne \\
\hline \multirow[t]{3}{*}{ Lodging } & Elec & 2.22 & 1.96 & 3.11 & 1.52 & 0.24 & 1.62 & 1.07 & 9.55 & 0.03 & 3.72 \\
\hline & NGas & 31.60 & 11.71 & ne & 2.47 & 0.81 & ne & ne & ne & ne & 5.04 \\
\hline & Othr & 23.94 & 11.71 & ne & ne & ne & ne & ne & ne & ne & ne \\
\hline \multirow[t]{3}{*}{ Miscellns } & Elec & 6.89 & 7.68 & 5.04 & 0.00 & 0.00 & 1.57 & 1.38 & 5.69 & 0.14 & 7.51 \\
\hline & NGas & 17.94 & 34.65 & ne & 0.00 & 0.20 & ne & ne & ne & ne & 6.85 \\
\hline & Othr & 13.59 & 34.65 & ne & ne & ne & ne & ne & ne & ne & ne \\
\hline
\end{tabular}


Table 5-38. PG\&E 1979 EUIs for Coastal (Oakland) Climate Zone [kBtu/sqft/yr]

\begin{tabular}{|c|c|c|c|c|c|c|c|c|c|c|c|}
\hline Building & Fuel & Heat & Cool & Vent & HotW & Cook & Refr & OtLt & $\ln L t$ & OfEq & Misc \\
\hline SmOffice & $\begin{array}{l}\text { Elec } \\
\text { NGas } \\
\text { Othr }\end{array}$ & $\begin{array}{l}2.74 \\
6.11 \\
4.70 \\
\end{array}$ & $\begin{array}{l}2.11 \\
4.97 \\
4.97 \\
\end{array}$ & $\begin{array}{c}1.08 \\
\text { ne } \\
\text { ne }\end{array}$ & $\begin{array}{l}\text { ne } \\
\text { ne } \\
\text { ne }\end{array}$ & $\begin{array}{l}\text { ne } \\
\text { ne } \\
\text { ne }\end{array}$ & $\begin{array}{l}\text { ne } \\
\text { ne } \\
\text { ne }\end{array}$ & $\begin{array}{l}\text { ne } \\
\text { ne } \\
\text { ne }\end{array}$ & $\begin{array}{l}\text { ne } \\
\text { ne } \\
\text { ne }\end{array}$ & $\begin{array}{l}\text { ne } \\
\text { ne } \\
\text { ne }\end{array}$ & $\begin{array}{l}\text { ne } \\
\text { ne } \\
\text { ne }\end{array}$ \\
\hline LgOffice & $\begin{array}{l}\text { Elec } \\
\text { NGas } \\
\text { Othr }\end{array}$ & $\begin{array}{c}8.98 \\
13.17 \\
9.98\end{array}$ & $\begin{array}{c}5.72 \\
25.31 \\
25.31\end{array}$ & $\begin{array}{c}8.27 \\
\text { ne } \\
\text { ne }\end{array}$ & $\begin{array}{l}\text { ne } \\
\text { ne } \\
\text { ne }\end{array}$ & $\begin{array}{l}\text { ne } \\
\text { ne } \\
\text { ne }\end{array}$ & $\begin{array}{l}\text { ne } \\
\text { ne } \\
\text { ne }\end{array}$ & $\begin{array}{l}\text { ne } \\
\text { ne } \\
\text { ne }\end{array}$ & $\begin{array}{l}\text { ne } \\
\text { ne } \\
\text { ne }\end{array}$ & $\begin{array}{l}\text { ne } \\
\text { ne } \\
\text { ne }\end{array}$ & $\begin{array}{l}\text { ne } \\
\text { ne } \\
\text { ne }\end{array}$ \\
\hline Retail & $\begin{array}{l}\text { Elec } \\
\text { NGas } \\
\text { Othr }\end{array}$ & $\begin{array}{l}2.37 \\
6.40 \\
5.14 \\
\end{array}$ & $\begin{array}{l}2.87 \\
6.96 \\
6.96 \\
\end{array}$ & $\begin{array}{c}1.91 \\
\text { ne } \\
\text { ne }\end{array}$ & $\begin{array}{l}\text { ne } \\
\text { ne } \\
\text { ne }\end{array}$ & $\begin{array}{l}\text { ne } \\
\text { ne } \\
\text { ne }\end{array}$ & $\begin{array}{l}\text { ne } \\
\text { ne } \\
\text { ne }\end{array}$ & $\begin{array}{l}\text { ne } \\
\text { ne } \\
\text { ne }\end{array}$ & $\begin{array}{l}\text { ne } \\
\text { ne } \\
\text { ne }\end{array}$ & $\begin{array}{l}\text { ne } \\
\text { ne } \\
\text { ne }\end{array}$ & $\begin{array}{l}\text { ne } \\
\text { ne } \\
\text { ne }\end{array}$ \\
\hline Restaurant & $\begin{array}{l}\text { Elec } \\
\text { NGas } \\
\text { Othr } \\
\end{array}$ & $\begin{array}{l}5.47 \\
9.60 \\
8.18 \\
\end{array}$ & $\begin{array}{c}7.52 \\
16.86 \\
16.86 \\
\end{array}$ & $\begin{array}{c}12.23 \\
\text { ne } \\
\text { ne }\end{array}$ & $\begin{array}{l}\text { ne } \\
\text { ne } \\
\text { ne }\end{array}$ & $\begin{array}{l}\text { ne } \\
\text { ne } \\
\text { ne }\end{array}$ & $\begin{array}{l}\text { ne } \\
\text { ne } \\
\text { ne }\end{array}$ & $\begin{array}{l}\text { ne } \\
\text { ne } \\
\text { ne }\end{array}$ & $\begin{array}{l}\text { ne } \\
\text { ne } \\
\text { ne }\end{array}$ & $\begin{array}{l}\text { ne } \\
\text { ne } \\
\text { ne }\end{array}$ & $\begin{array}{l}\text { ne } \\
\text { ne } \\
\text { ne }\end{array}$ \\
\hline FoodStr & $\begin{array}{l}\text { Elec } \\
\text { NGas } \\
\text { Othr } \\
\end{array}$ & $\begin{array}{l}21.60 \\
45.40 \\
35.83 \\
\end{array}$ & $\begin{array}{c}9.28 \\
22.65 \\
22.65 \\
\end{array}$ & $\begin{array}{l}15.45 \\
\text { ne } \\
\text { ne }\end{array}$ & $\begin{array}{l}\text { ne } \\
\text { ne } \\
\text { ne }\end{array}$ & $\begin{array}{l}\text { ne } \\
\text { ne } \\
\text { ne }\end{array}$ & $\begin{array}{l}\text { ne } \\
\text { ne } \\
\text { ne }\end{array}$ & $\begin{array}{l}\text { ne } \\
\text { ne } \\
\text { ne }\end{array}$ & $\begin{array}{l}\text { ne } \\
\text { ne } \\
\text { ne }\end{array}$ & $\begin{array}{l}\text { ne } \\
\text { ne } \\
\text { ne }\end{array}$ & $\begin{array}{l}\text { ne } \\
\text { ne } \\
\text { ne }\end{array}$ \\
\hline Warehouse & $\begin{array}{l}\text { Elec } \\
\text { NGas } \\
\text { Othr } \\
\end{array}$ & $\begin{array}{l}10.25 \\
16.58 \\
12.56 \\
\end{array}$ & $\begin{array}{l}0.72 \\
1.13 \\
1.13 \\
\end{array}$ & $\begin{array}{c}7.32 \\
\text { ne } \\
\text { ne }\end{array}$ & $\begin{array}{l}\text { ne } \\
\text { ne } \\
\text { ne }\end{array}$ & $\begin{array}{l}\text { ne } \\
\text { ne } \\
\text { ne }\end{array}$ & $\begin{array}{l}\text { ne } \\
\text { ne } \\
\text { ne }\end{array}$ & $\begin{array}{l}\text { ne } \\
\text { ne } \\
\text { ne }\end{array}$ & $\begin{array}{l}\text { ne } \\
\text { ne } \\
\text { ne }\end{array}$ & $\begin{array}{l}\text { ne } \\
\text { ne } \\
\text { ne }\end{array}$ & $\begin{array}{l}\text { ne } \\
\text { ne } \\
\text { ne }\end{array}$ \\
\hline School & $\begin{array}{l}\text { Elec } \\
\text { NGas } \\
\text { Othr } \\
\end{array}$ & $\begin{array}{l}10.06 \\
16.86 \\
12.79 \\
\end{array}$ & $\begin{array}{l}0.24 \\
0.80 \\
0.61 \\
\end{array}$ & $\begin{array}{c}2.07 \\
\text { ne } \\
\text { ne }\end{array}$ & $\begin{array}{l}\text { ne } \\
\text { ne } \\
\text { ne }\end{array}$ & $\begin{array}{l}\text { ne } \\
\text { ne } \\
\text { ne }\end{array}$ & $\begin{array}{l}\text { ne } \\
\text { ne } \\
\text { ne } \\
\end{array}$ & $\begin{array}{l}\text { ne } \\
\text { ne } \\
\text { ne }\end{array}$ & $\begin{array}{l}\text { ne } \\
\text { ne } \\
\text { ne }\end{array}$ & $\begin{array}{l}\text { ne } \\
\text { ne } \\
\text { ne }\end{array}$ & $\begin{array}{l}\text { ne } \\
\text { ne } \\
\text { ne }\end{array}$ \\
\hline College & $\begin{array}{l}\text { Elec } \\
\text { NGas } \\
\text { Othr }\end{array}$ & $\begin{array}{l}1.62 \\
2.63 \\
1.99\end{array}$ & $\begin{array}{l}1.76 \\
3.68 \\
3.68\end{array}$ & $\begin{array}{l}1.40 \\
\text { ne } \\
\text { ne }\end{array}$ & $\begin{array}{l}\text { ne } \\
\text { ne } \\
\text { ne }\end{array}$ & $\begin{array}{l}\text { ne } \\
\text { ne } \\
\text { ne }\end{array}$ & $\begin{array}{l}\text { ne } \\
\text { ne } \\
\text { ne }\end{array}$ & $\begin{array}{l}\text { ne } \\
\text { ne } \\
\text { ne }\end{array}$ & $\begin{array}{l}\text { ne } \\
\text { ne } \\
\text { ne }\end{array}$ & $\begin{array}{l}\text { ne } \\
\text { ne } \\
\text { ne }\end{array}$ & $\begin{array}{l}\text { ne } \\
\text { ne } \\
\text { ne }\end{array}$ \\
\hline Health & $\begin{array}{l}\text { Elec } \\
\text { NGas } \\
\text { Othr } \\
\end{array}$ & $\begin{array}{l}1.41 \\
5.22 \\
3.95 \\
\end{array}$ & $\begin{array}{l}14.70 \\
62.01 \\
62.01 \\
\end{array}$ & $\begin{array}{c}7.96 \\
\text { ne } \\
\text { ne }\end{array}$ & $\begin{array}{l}\text { ne } \\
\text { ne } \\
\text { ne }\end{array}$ & $\begin{array}{l}\text { ne } \\
\text { ne } \\
\text { ne }\end{array}$ & $\begin{array}{l}\text { ne } \\
\text { ne } \\
\text { ne }\end{array}$ & $\begin{array}{l}\text { ne } \\
\text { ne } \\
\text { ne }\end{array}$ & $\begin{array}{l}\text { ne } \\
\text { ne } \\
\text { ne }\end{array}$ & $\begin{array}{l}\text { ne } \\
\text { ne } \\
\text { ne }\end{array}$ & $\begin{array}{l}\text { ne } \\
\text { ne } \\
\text { ne }\end{array}$ \\
\hline Lodging & $\begin{array}{l}\text { Elec } \\
\text { NGas } \\
\text { Othr } \\
\end{array}$ & $\begin{array}{c}1.14 \\
15.43 \\
12.75 \\
\end{array}$ & $\begin{array}{l}1.86 \\
6.45 \\
6.45 \\
\end{array}$ & $\begin{array}{c}1.99 \\
\text { ne } \\
\text { ne }\end{array}$ & $\begin{array}{l}\text { ne } \\
\text { ne } \\
\text { ne }\end{array}$ & $\begin{array}{l}\text { ne } \\
\text { ne } \\
\text { ne }\end{array}$ & $\begin{array}{l}\text { ne } \\
\text { ne } \\
\text { ne }\end{array}$ & $\begin{array}{l}\text { ne } \\
\text { ne } \\
\text { ne }\end{array}$ & $\begin{array}{l}\text { ne } \\
\text { ne } \\
\text { ne }\end{array}$ & $\begin{array}{l}\text { ne } \\
\text { ne } \\
\text { ne }\end{array}$ & $\begin{array}{l}\text { ne } \\
\text { ne } \\
\text { ne }\end{array}$ \\
\hline Miscellns & $\begin{array}{l}\text { Elec } \\
\text { NGas } \\
\text { Othr }\end{array}$ & $\begin{array}{l}1.59 \\
4.39 \\
3.45 \\
\end{array}$ & $\begin{array}{l}7.38 \\
8.55 \\
8.55 \\
\end{array}$ & $\begin{array}{c}13.56 \\
\text { ne } \\
\text { ne } \\
\end{array}$ & $\begin{array}{l}\text { ne } \\
\text { ne } \\
\text { ne } \\
\end{array}$ & $\begin{array}{l}\text { ne } \\
\text { ne } \\
\text { ne }\end{array}$ & $\begin{array}{l}\text { ne } \\
\text { ne } \\
\text { ne }\end{array}$ & $\begin{array}{l}\text { ne } \\
\text { ne } \\
\text { ne }\end{array}$ & $\begin{array}{l}\text { ne } \\
\text { ne } \\
\text { ne }\end{array}$ & $\begin{array}{l}\text { ne } \\
\text { ne } \\
\text { ne }\end{array}$ & $\begin{array}{l}\text { ne } \\
\text { ne } \\
\text { ne }\end{array}$ \\
\hline
\end{tabular}


Table 5-39. PG\&E 1979 EUIs for Inland (Sacramento) Climate Zone [kBtu/sqft/yr]

\begin{tabular}{|c|c|c|c|c|c|c|c|c|c|c|c|}
\hline Building & Fuel & Heat & Cool & Vent & HotW & Cook & $\overline{R e f r}$ & OtLt & InLt & $\overline{O f E q}$ & Misc \\
\hline SmOffice & $\begin{array}{l}\text { Elec } \\
\text { NGas } \\
\text { Othr }\end{array}$ & $\begin{array}{c}4.57 \\
10.18 \\
7.83\end{array}$ & $\begin{array}{l}10.70 \\
28.89 \\
28.89\end{array}$ & $\begin{array}{c}2.29 \\
\text { ne } \\
\text { ne }\end{array}$ & $\begin{array}{l}\text { ne } \\
\text { ne } \\
\text { ne }\end{array}$ & $\begin{array}{l}\text { ne } \\
\text { ne } \\
\text { ne }\end{array}$ & $\begin{array}{l}\text { ne } \\
\text { ne } \\
\text { ne }\end{array}$ & $\begin{array}{l}\text { ne } \\
\text { ne } \\
\text { ne }\end{array}$ & $\begin{array}{l}\text { ne } \\
\text { ne } \\
\text { ne }\end{array}$ & $\begin{array}{l}\text { ne } \\
\text { ne } \\
\text { ne }\end{array}$ & $\begin{array}{l}\text { ne } \\
\text { ne } \\
\text { ne }\end{array}$ \\
\hline LgOffice & $\begin{array}{l}\text { Elec } \\
\text { NGas } \\
\text { Othr }\end{array}$ & $\begin{array}{l}10.84 \\
15.90 \\
12.05\end{array}$ & $\begin{array}{l}11.00 \\
51.56 \\
51.56\end{array}$ & $\begin{array}{c}10.66 \\
\text { ne } \\
\text { ne }\end{array}$ & $\begin{array}{l}\text { ne } \\
\text { ne } \\
\text { ne }\end{array}$ & $\begin{array}{l}\text { ne } \\
\text { ne } \\
\text { ne }\end{array}$ & $\begin{array}{l}\text { ne } \\
\text { ne } \\
\text { ne }\end{array}$ & $\begin{array}{l}\text { ne } \\
\text { ne } \\
\text { ne }\end{array}$ & $\begin{array}{l}\text { ne } \\
\text { ne } \\
\text { ne }\end{array}$ & $\begin{array}{l}\text { ne } \\
\text { ne } \\
\text { ne }\end{array}$ & $\begin{array}{l}\text { ne } \\
\text { ne } \\
\text { ne }\end{array}$ \\
\hline Retail & $\begin{array}{l}\text { Elec } \\
\text { NGas } \\
\text { Othr }\end{array}$ & $\begin{array}{c}3.72 \\
10.03 \\
8.05 \\
\end{array}$ & $\begin{array}{c}5.92 \\
18.59 \\
18.59 \\
\end{array}$ & $\begin{array}{c}3.17 \\
\text { ne } \\
\text { ne }\end{array}$ & $\begin{array}{l}\text { ne } \\
\text { ne } \\
\text { ne }\end{array}$ & $\begin{array}{l}\text { ne } \\
\text { ne } \\
\text { ne }\end{array}$ & $\begin{array}{l}\text { ne } \\
\text { ne } \\
\text { ne }\end{array}$ & $\begin{array}{l}\text { ne } \\
\text { ne } \\
\text { ne }\end{array}$ & $\begin{array}{l}\text { ne } \\
\text { ne } \\
\text { ne }\end{array}$ & $\begin{array}{l}\text { ne } \\
\text { ne } \\
\text { ne }\end{array}$ & $\begin{array}{l}\text { ne } \\
\text { ne } \\
\text { ne }\end{array}$ \\
\hline Restaurant & $\begin{array}{l}\text { Elec } \\
\text { NGas } \\
\text { Othr }\end{array}$ & $\begin{array}{c}8.51 \\
15.21 \\
12.73\end{array}$ & $\begin{array}{l}11.51 \\
31.56 \\
31.56\end{array}$ & $\begin{array}{c}12.30 \\
\text { ne } \\
\text { ne }\end{array}$ & $\begin{array}{l}\text { ne } \\
\text { ne } \\
\text { ne }\end{array}$ & $\begin{array}{l}\text { ne } \\
\text { ne } \\
\text { ne }\end{array}$ & $\begin{array}{l}\text { ne } \\
\text { ne } \\
\text { ne }\end{array}$ & $\begin{array}{l}\text { ne } \\
\text { ne } \\
\text { ne }\end{array}$ & $\begin{array}{l}\text { ne } \\
\text { ne } \\
\text { ne }\end{array}$ & $\begin{array}{l}\text { ne } \\
\text { ne } \\
\text { ne }\end{array}$ & $\begin{array}{l}\text { ne } \\
\text { ne } \\
\text { ne }\end{array}$ \\
\hline FoodStr & $\begin{array}{l}\text { Elec } \\
\text { NGas } \\
\text { Othr }\end{array}$ & $\begin{array}{l}17.64 \\
35.92 \\
29.26\end{array}$ & $\begin{array}{l}15.67 \\
35.37 \\
35.37\end{array}$ & $\begin{array}{c}21.49 \\
\text { ne } \\
\text { ne }\end{array}$ & $\begin{array}{l}\text { ne } \\
\text { ne } \\
\text { ne }\end{array}$ & $\begin{array}{l}\text { ne } \\
\text { ne } \\
\text { ne }\end{array}$ & $\begin{array}{l}\text { ne } \\
\text { ne } \\
\text { ne }\end{array}$ & $\begin{array}{l}\text { ne } \\
\text { ne } \\
\text { ne }\end{array}$ & $\begin{array}{l}\text { ne } \\
\text { ne } \\
\text { ne }\end{array}$ & $\begin{array}{l}\text { ne } \\
\text { ne } \\
\text { ne }\end{array}$ & $\begin{array}{l}\text { ne } \\
\text { ne } \\
\text { ne }\end{array}$ \\
\hline Warehouse & $\begin{array}{l}\text { Elec } \\
\text { NGas } \\
\text { Othr }\end{array}$ & $\begin{array}{l}13.65 \\
22.07 \\
16.72\end{array}$ & $\begin{array}{l}4.95 \\
8.28 \\
8.28 \\
\end{array}$ & $\begin{array}{c}6.16 \\
\text { ne } \\
\text { ne }\end{array}$ & $\begin{array}{l}\text { ne } \\
\text { ne } \\
\text { ne }\end{array}$ & $\begin{array}{l}\text { ne } \\
\text { ne } \\
\text { ne }\end{array}$ & $\begin{array}{l}\text { ne } \\
\text { ne } \\
\text { ne }\end{array}$ & $\begin{array}{l}\text { ne } \\
\text { ne } \\
\text { ne }\end{array}$ & $\begin{array}{l}\text { ne } \\
\text { ne } \\
\text { ne }\end{array}$ & $\begin{array}{l}\text { ne } \\
\text { ne } \\
\text { ne }\end{array}$ & $\begin{array}{l}\text { ne } \\
\text { ne } \\
\text { ne }\end{array}$ \\
\hline School & $\begin{array}{l}\text { Elec } \\
\text { NGas } \\
\text { Othr }\end{array}$ & $\begin{array}{l}11.01 \\
18.46 \\
14.00\end{array}$ & $\begin{array}{l}0.23 \\
0.83 \\
0.63\end{array}$ & $\begin{array}{c}2.63 \\
\text { ne } \\
\text { ne }\end{array}$ & $\begin{array}{l}\text { ne } \\
\text { ne } \\
\text { ne }\end{array}$ & $\begin{array}{l}\text { ne } \\
\text { ne } \\
\text { ne }\end{array}$ & $\begin{array}{l}\text { ne } \\
\text { ne } \\
\text { ne }\end{array}$ & $\begin{array}{l}\text { ne } \\
\text { ne } \\
\text { ne }\end{array}$ & $\begin{array}{l}\text { ne } \\
\text { ne } \\
\text { ne }\end{array}$ & $\begin{array}{l}\text { ne } \\
\text { ne } \\
\text { ne }\end{array}$ & $\begin{array}{l}\text { ne } \\
\text { ne } \\
\text { ne }\end{array}$ \\
\hline College & $\begin{array}{l}\text { Elec } \\
\text { NGas } \\
\text { Othr }\end{array}$ & $\begin{array}{l}1.63 \\
2.64 \\
2.00 \\
\end{array}$ & $\begin{array}{l}2.07 \\
7.83 \\
7.83 \\
\end{array}$ & $\begin{array}{c}1.24 \\
\text { ne } \\
\text { ne }\end{array}$ & $\begin{array}{l}\text { ne } \\
\text { ne } \\
\text { ne }\end{array}$ & $\begin{array}{l}\text { ne } \\
\text { ne } \\
\text { ne }\end{array}$ & $\begin{array}{l}\text { ne } \\
\text { ne } \\
\text { ne }\end{array}$ & $\begin{array}{l}\text { ne } \\
\text { ne } \\
\text { ne }\end{array}$ & $\begin{array}{l}\text { ne } \\
\text { ne } \\
\text { ne }\end{array}$ & $\begin{array}{l}\text { ne } \\
\text { ne } \\
\text { ne }\end{array}$ & $\begin{array}{l}\text { ne } \\
\text { ne } \\
\text { ne }\end{array}$ \\
\hline Health & $\begin{array}{l}\text { Elec } \\
\text { NGas } \\
\text { Othr }\end{array}$ & $\begin{array}{l}2.02 \\
7.50 \\
5.68\end{array}$ & $\begin{array}{l}21.09 \\
81.57 \\
81.57\end{array}$ & $\begin{array}{c}10.78 \\
\text { ne } \\
\text { ne }\end{array}$ & $\begin{array}{l}\text { ne } \\
\text { is } \\
\text { ne }\end{array}$ & $\begin{array}{l}\text { ne } \\
\text { ne } \\
\text { ne }\end{array}$ & $\begin{array}{l}\text { ne } \\
\text { ne } \\
\text { ne }\end{array}$ & $\begin{array}{l}\text { ne } \\
\text { ne } \\
\text { ne }\end{array}$ & $\begin{array}{l}\text { ne } \\
\text { ne } \\
\text { ne }\end{array}$ & $\begin{array}{l}\text { ne } \\
\text { ne } \\
\text { ne }\end{array}$ & $\begin{array}{l}\text { ne } \\
\text { ne } \\
\text { ne }\end{array}$ \\
\hline Lodging & $\begin{array}{l}\text { Elec } \\
\text { NGas } \\
\text { Othr }\end{array}$ & $\begin{array}{l}0.59 \\
9.18 \\
7.58 \\
\end{array}$ & $\begin{array}{l}0.60 \\
2.86 \\
2.86 \\
\end{array}$ & $\begin{array}{c}1.06 \\
\text { ne } \\
\text { ne } \\
\end{array}$ & $\begin{array}{l}\text { ne } \\
\text { ne } \\
\text { ne }\end{array}$ & $\begin{array}{l}\text { ne } \\
\text { ne } \\
\text { ne }\end{array}$ & $\begin{array}{l}\text { ne } \\
\text { ne } \\
\text { ne }\end{array}$ & $\begin{array}{l}\text { ne } \\
\text { ne } \\
\text { ne }\end{array}$ & $\begin{array}{l}\text { ne } \\
\text { ne } \\
\text { ne }\end{array}$ & $\begin{array}{l}\text { ne } \\
\text { ne } \\
\text { ne }\end{array}$ & $\begin{array}{l}\text { ne } \\
\text { ne } \\
\text { ne }\end{array}$ \\
\hline Miscellns & $\begin{array}{l}\text { Elec } \\
\text { NGas } \\
\text { Othr }\end{array}$ & $\begin{array}{l}2.04 \\
5.62 \\
4.42\end{array}$ & $\begin{array}{c}5.59 \\
18.41 \\
18.41\end{array}$ & $\begin{array}{c}5.04 \\
\text { ne } \\
\text { ne }\end{array}$ & $\begin{array}{l}\text { ne } \\
\text { ne } \\
\text { ne }\end{array}$ & $\begin{array}{l}\text { ne } \\
\text { ne } \\
\text { ne }\end{array}$ & $\begin{array}{l}\text { ne } \\
\text { ne } \\
\text { ne }\end{array}$ & $\begin{array}{l}\text { ne } \\
\text { ne } \\
\text { ne }\end{array}$ & $\begin{array}{l}\text { ne } \\
\text { ne } \\
\text { ne }\end{array}$ & $\begin{array}{l}\text { ne } \\
\text { ne } \\
\text { ne }\end{array}$ & $\begin{array}{l}\text { ne } \\
\text { ne } \\
\text { ne }\end{array}$ \\
\hline
\end{tabular}




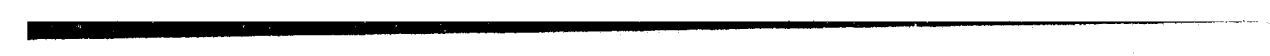

.

$-256$ 


\section{Bibliography}

\section{Documents Referenced in Report}

ADM Associates, Inc., "PG\&E Commercial On-Site Survey Data Base," California Energy Commission, 1987.

Akbari, H., Heinemeier, K., Le Coniac, P., and Flora, D., "An Algorithm to Disaggregate Commercial Whole-Building Electric Hourly Load into End Uses," Proceedings of ACEEE 1988 Summer Study on Energy Efficiency in Buildings, Vol 10, pp 13-26, Asilomar, CA, August, 1988.

Building Energy Simulation Group (BESG), "Overview of the DOE-2 Building Energy Analysis Program, Version 2.1D," Lawrence Berkeley Laboratory Report LBL-19735, Rev.1, Berkeley, CA, 1990.

Energy Information Agency (EIA), "Commmercial Buildings Energy Consumption Survey: 1989 Consumption and Expenditures," US Department of Energy DOE/ELA-0318(89), 1989.

Piette, M. A., Eto, J. H., and Harris, J. P., "Office Equipment Energy Use and Trends," Lawrence Berkeley Laboratory Report LBL-31308, Berkeley, CA, September, 1991.

\section{Other Relevant Documents}

Akbari, H., Eto, J. H., Turiel, I., Heinemeier, K., Lebot, B., Nordman, B., and Rainer, L., "Integrated Estimation of Commercial Sector End-Use Load Shapes and Energy Use Intensities," Final Report, Submitted to SCE and CEC, LBL-27512, April 1989.

Akbari, H., Heinemeier, K., Flora, D., and Le Coniac, P., "Analysis of Commercial WholeBuilding 15-Minute Electric Load Data," ASHRAE Transactions, 94(2), pp 855 - 871, 1988.

Akbari, H., Rainer, L., and Eto, J. H., "Integrated estimation of commercial sector end-use load shapes and energy use intensities in PG\&E service ared," An Interim Report, Submitted to CIEE/PG\&E, October 1991.

Akbari, H., Rainer, L., and Eto, J. H., "Integrated estimation of commericial sector end-use load shapes and energy use intensities, Phase II," Final Report Submitted to CEC, January 1991, LBL-30401.

Akbari, H., Turiel, I., Eto, J. H., Heinemeier, K., Lebot, B., and Rainer, L., "A Review of Existing Commercial Energy Use Intensity and Load-Shapes Studies," Proceedings of the ACEEE 1990 Summer Study on Energy Efficiency in Buildings, Volume 3, p. 7, Asilomar, CA, August 1990. also Lawrence Berkeley Laboratory Report LBL-29209, 1990. 


\section{Bibliography (Continued)}

\section{Other Relevant Documents}

Eto, J. H., Akbari, H., Pratt, R., and Braithwait, "End-use load shape data application, estimation, and collection," Chapter 4, State of the Art of Energy Efficiency, Vine, E. and Crawly, D. (Editors), American Council for an Energy Efficient Economy, Washington, D.C., 1991.

Eto, J. H., Akbari, H., Pratt, R., and Braithwail, "End-Use Load Shape Data: Application, Estimation, and Collection," Proceedings of the ACEEE 1990 Summer Study on Energy Efficiency in Buildings, Volume 10, p.39, Asilomar, CA, August 1990.

Eto, J. H., Turiel, I., Akbari, H., Lebot, B., and Heinemeier, K., "An Investigation of the Use of Prototypes for Commercial Sector EUI Analysis," Proceedings of the ACEEE 1990 Summer Study on Energy Efficiency in Buildings, Volume 10, p. 29, Asilomar, CA, August 1990. 
11
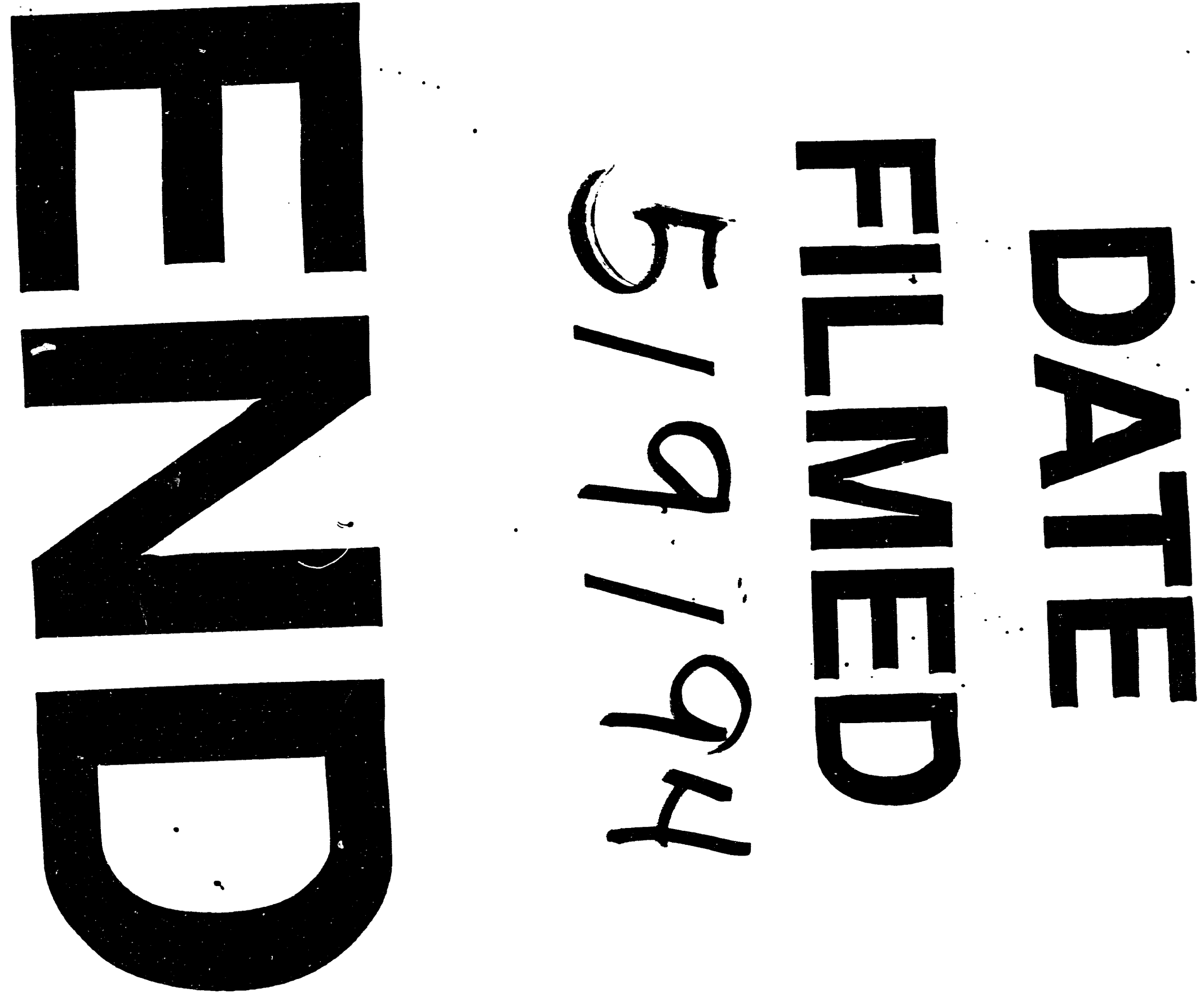
